UC-NRLF

||||||||||||-|||||||||||||||||||||||||||||

|||||||||||||||||||||||||||||||||||||||||||||||||||||

\$B $542 \quad 233$

MHW + IISHMRMINS
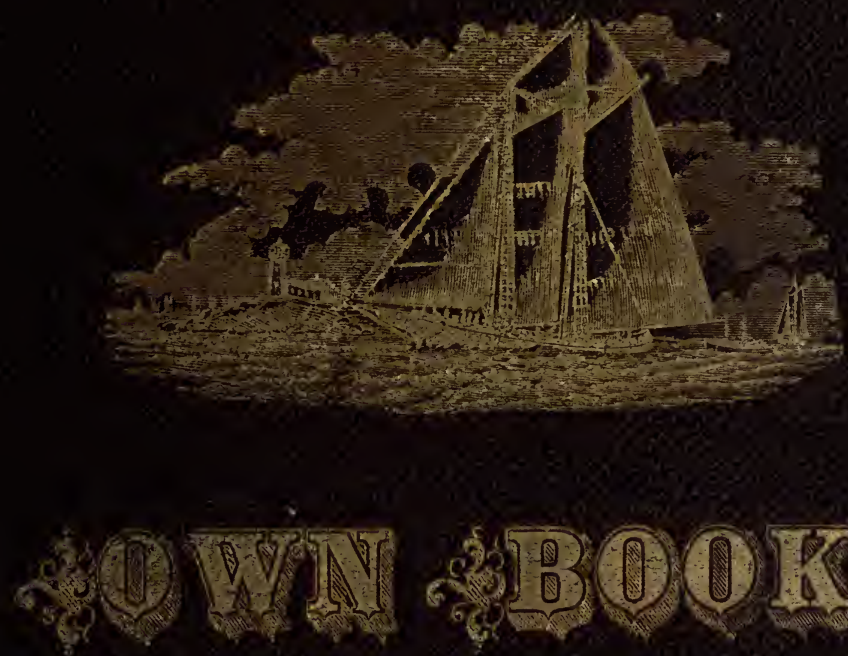

G 


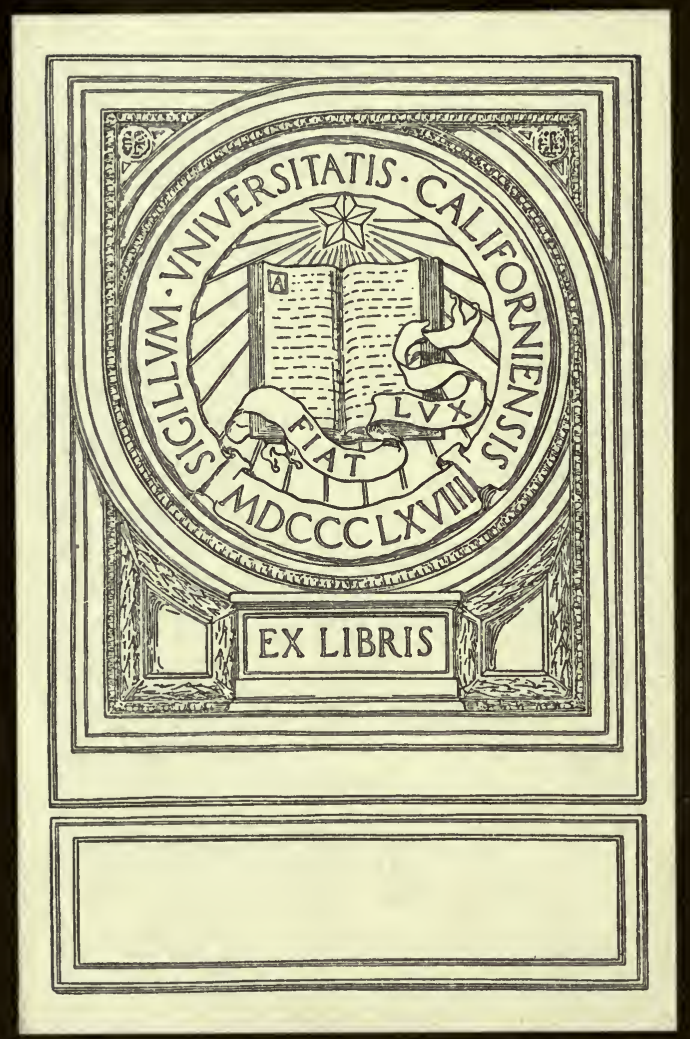






\section{THE}

\section{Fishermen's Own Book,}

11

COMPRISING

THE LIST OF MEN AND VESSELS LOST FROM THE PORT OF GLOUCESTER, MASS., FROM 1874 TO APRIL I, 1882.

AND

A TABLE OF LOSSES FROM 1830,

TOGETHER WITH

\section{VALUABLE STATISTICS OF THE FISHERIES,}

ALso

NOTABLE FARES, NARROW ESCAPES, STAR'LLING ADVENTURES, FISHERMEN'S OFF-HAND SKETCHES, BALLADS, DESCRIPTIONS OF FISHING TRIPS

AND

OTHER INTERESTING FACTS AND INCIDENTS CONNECTED WITH THIS BRANCH OF MARITIME INDUSTRY.

GLOUCESTER :

PROCTER BROTHERS, Publishers, CAPE ANN ADVERTISER OFFICE. - 


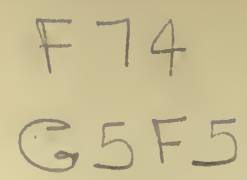

Entered according to Act of Congress, in the year 188z, by PROCTER. BROTHERS,

'Ii cthe office of the tibrarian of Congress, at Washington.

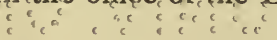




\section{TABLE OF CONTENTS.}

PAGE,

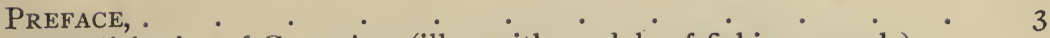

Early Fisheries of Cape Ann (illus. with models of fishing vessels), . $\quad 5$

A Remarkable Escape on Board Sch. Codseeker, . . . . . 8

Gloucester Harbor in 1806 (illustrated with map), . . . . . 9

A Winter's Trip to Georges (illlustrated), . . . . . 12

Table, giving Prices of Mackerel for the Past 52 Years, . . . $\quad$ I9

Leaves from a Log-Book-Remarkable Adventures, etc. (illustrated), 20

Notable Fishing Fares (illustrated), . $\quad$ • . . . . $\quad$. 28

The Old-Time Fishery at 'Squam, • • • • • . $\quad$. 36

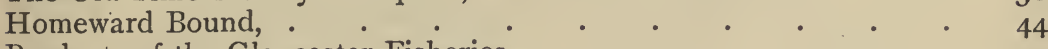

Products of the Gloucester Fisheries, . . . . . . 45

Return of the Dories (illustrated), . $\quad$. $\quad . \quad$. $\quad . \quad$. 47

Quick Passages (illustrated), . $\quad$. . . . . . . . . 48

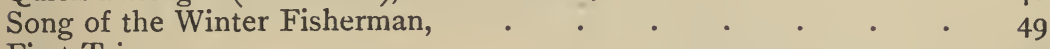

First Trips, . $\quad . \quad$. $\quad . \quad$. . . . . . 50

Large Fish (illustrated), • . . . . . . . . 5 . 5 I

Gloucester Harbor in 1830 (illustrated), . . . . . . . 53

U. S. Fish Commission-Summer Headquarters in Gloucester, 54

Around Cape Ann, . • • • • • • . . . 55

Sch. Sultana Towed by a Whale (illustrated), . $\quad$. $\quad$. $\quad$. $\quad 5^{8}$

Loss of Sch. Henrietta Greenleaf, . • • • • . 59

Gill-Net Codfishing in Ipswich Bay (illustrated), . . . . . $\quad 6$ I

A Day at the Beach (illustrated), . • • • • . . 64

In Memoriam. List of Lost Men and Vessels of the Port of Gloucester from 1874 to $188 \mathrm{r}$, inclusive, . . . . . . 66

Table, giving the Losses for 52 Years, . . . . . . $\quad 85$

Welcome Home-A Romance in a Fisherman's Life (illustrated), . 86

The Fisher-Boy in the Storm (illustrated),.$\quad$. $\quad . \quad$. 92

Halibut Fishing among the Ice Floes, . $\quad$ : 93

List of Vessels Belonging to the Port of Gloucester in 1850 (illus.), . $\quad$ I 00

The Phantom Boat, . . . . . . . . 102

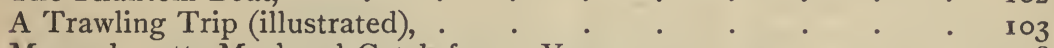

Massachusetts Mackerel Catch for 74 Years, . . . . . . Io8

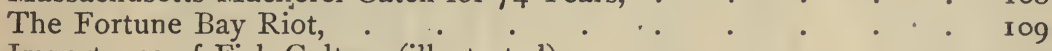

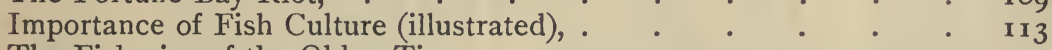

The Fisheries of the Olden Time, . . . . . . Ir5

Salmon Fishing at the Mouth of the Columbia River, Oregon (illus.), II

On the Beach in a Storm (illustrated), . . . . . I20

Narrow Escape of Sch. David A. Story (illustrated), . . . I2I

Hammerhead Shark-The Shark's Mouth-Shark Fishing (illus.), . $\quad$ I 53

No More Sea, . . . . . . . . 125 
Fishermen's Superstitions,

The Old Fort and Gloucester Harbor in 1837 (illustrated),

Foreign Commerce of Gloucester (illustrated),

Fishermen Coming into Port. From the Home of the Fish to the

Table of the Consumer (illustrated),

The Regatta (illustrated),

A Night in Boston Bay,

Truthful and Startling Accounts of Tough Times, etc. (illustrated),

The Frenchman's Stew and the Disgusted Irishmen,

Dory Voyages across the Atlantic (illustrated),

On Board a Mackerel Catcher,

The Merry, Merry Mackerel Catchers (illustrated), .

Saving the Cable,

A Summer Trip to Georges (illustrated), .

Rob's First Cruise (illustrated),

Lost in the Fog (illustrated),

Crippled on the "Home Stretch" (illustrated),

The December Gales of 1876 (illustrated),

Fearful Experience on Board Sch. Howard,

Thacher's Island,

Foundering of Sch. Almon Bird,

The Harbor Bar (illustrated),

Ninety-Three Voyages to Surinam (illustrated),

Recollections of a Veteran Fisherman,

Making a Harbor in a Snow Storm,

An Old Boat (illustrated),

Hand-Line Mackerel Fishing, .

"Setting Under Sail,"

In a Fog on the Banks (illustrated),

Lines on the Loss of Sch. Guy Cunningham and in Memory of her

Master, Capt. Daniel O'Brien, .

Around the Wharves of Old Gloucester Half a Century Ago, .

'The Jolly Yachtsman (illustrated),

'The Haddock Fisheries-Then and Now,

A Mackerel Catcher Dressing Her Fare by Moonlight (illustrated), .

Frightened by the Moon,

Gloucester Harbor (illustrated),

Adventures of Capt. Richard Murphy,

133

135

× 36

137

159

I 6 I

165

169

170

I 7 I

I 75

I 79

I 80

I 84

187

I9r

192

195

r96

197

ז99

201

202

204

206

'The Open Sea,

(Yloucester's Exhibition at the Centennial,

'The Widow's Appeal to the Winds and Sea (illustrated),

- 'icking the Nets and Trawls (illustrated),

206

208

212

213

2 I 5

215

216

217

226

227

228

229

255

256

"Not a Bene,"

'I'he Mackerel Pocket, or "Spiller,"

(1) the Loss of the "Royal George,"

257

$25^{8}$

A Banker Discharging Her Fare (illustrated), . . . . . 259

I oss of Life and Vessel Property from January r to April I, 1882, . 260

List of Vessels Comprising the Gloucester Fishing Fleet, and their

Owners or Fitters, 

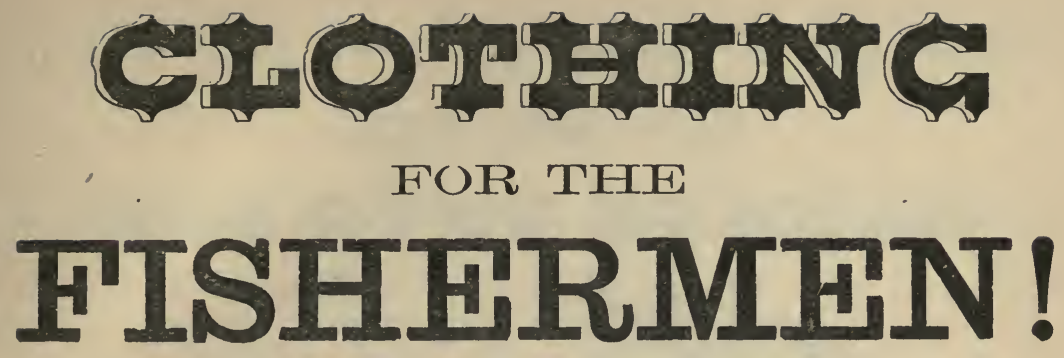

Consisting of the largest variety of

Double-Breasted Sack Suits,

Double-Breasted Vests, with

Peg-Top Pants to match,

Large Leg Pants, small bottoms,

Short Reefing Jackets,

Rubber Overcoats, long,

Rubber Suits,

Mittens and Leggings.

AISO

Woolen Goods,

sxamatx:

Jumpers, Shirts, outside and inside, Socks, Drawers, Mittens,

SGARIS, GARDIGAN JAGKITS, GAPS,

In fact, everything in the line for Business or Dress up, at the lowest prices for quality of goods. All are cordially invited.

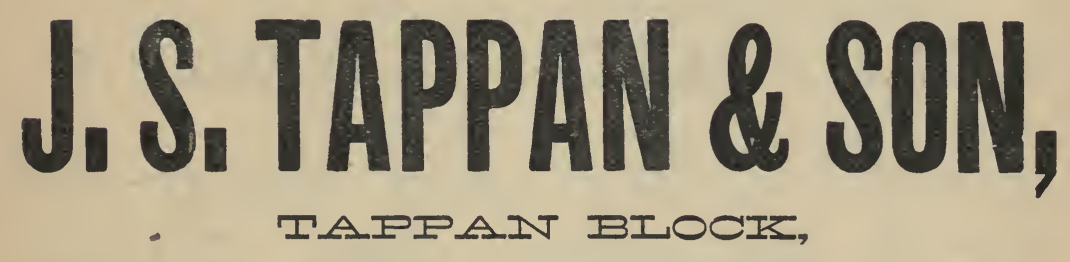

$112,114,116$ Main St., GLOUCESTER. 


\section{Ye Jolly Fishermen who Sail from old Cape Ann,}

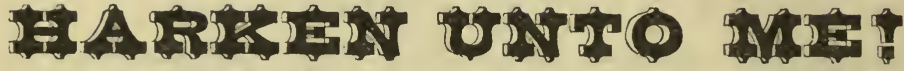

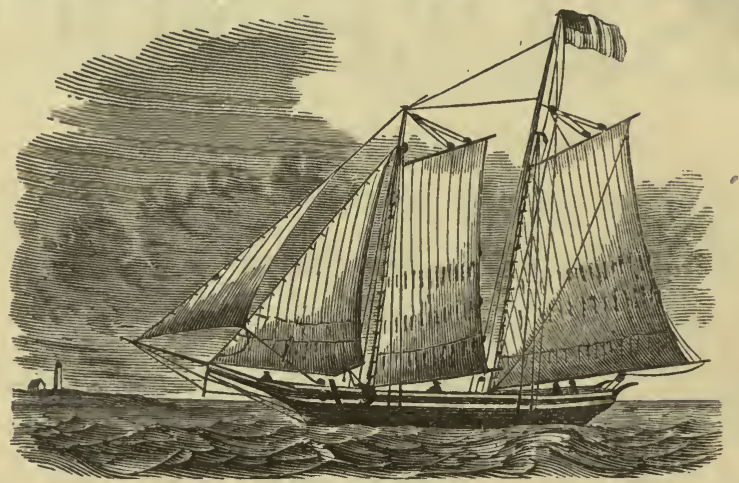

The fisher's life 1s the life you love,

And you love the sparkling wave;

And hence you glide o'er the stormy tide In far pursuit of the finny tribe,

With hearts so light and brave.
On Georges Bank, at Newfoundland, On the coast of Labrador,

The lines you fling, and you laugh and sing, And make your merry voices ring

'Round Nova Scotia's shore.

Pnd when in port you will come to

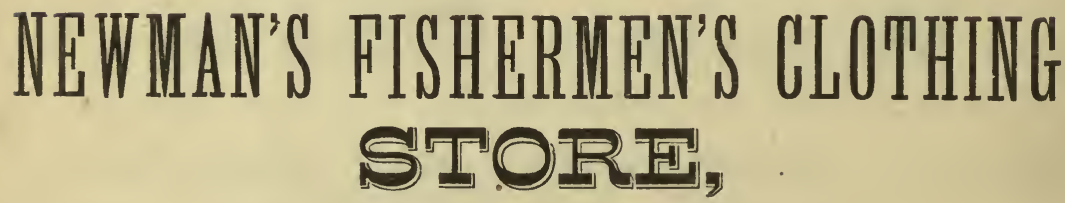

where there is no need of these constant "MARK Downs" advertised by other Clothing stores, as I mark my goods low enough the first going off, as " the Sons of the Cape" know well.

None can undersell me, as I buy for cash, have no big rents or big interest account, and but very little old stock to carry. Everything on board my craft is snug and trim. Always ready to show my goods, and always having the new styles.

I don't sell less than cost-neither does any other establishment; and when they advertise in this manner, it is all moonshine, and "the Sons of the Cape" know this to be true. These markdowns of about fifty cents on a dollar don't pan out well either, as people are not fond of this style of ding business, and if they are, they couldn't stand it a great while; hence it is inferred that they don't do it, and the people won't swallow such taffy.

Every customer gets the full value of his money in good honest

\section{READY-MADE CIOTHING, Hats, Caps and Gents' Furnishing Goods.}

45 I lon't sell at cost or less than cost, but a fair living profit, which enables me to "live and let live," and I cordially invite those who believe in Square Dealing to visit my establishment,
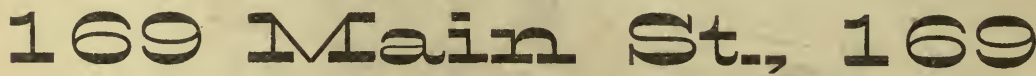


\section{OIIS S. FEARS,}

Manufacturer of

\section{Standard Black \& Yellow Cape Ann Oil Clothing}

Lincoln and Cape Ann Sou' Westers, Fancy and Cape Anin Long Coats, Fishermen's Outfits, dic.

OFFICE and FACTORT,

P. O. Box 448. 68 Rogers St., GLOUCESTER, Mass.

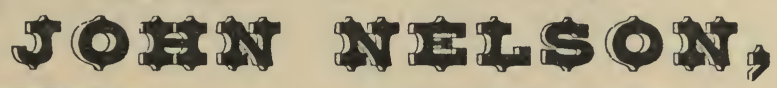

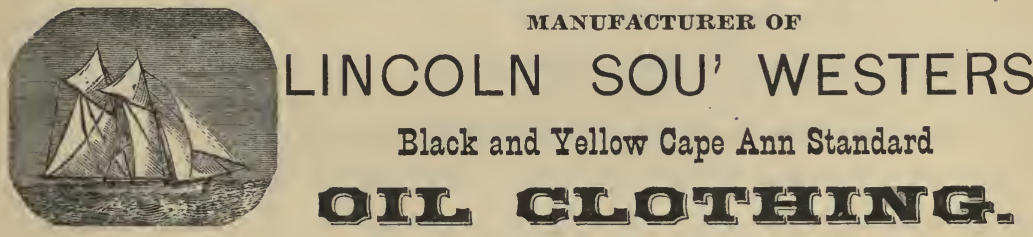

Dealer in Rubber Goods, Jackets, Pants, Boots, Mittens, \&c., and Fishermen's Outfits.

285 MAIN ST., GLOUCESTER.

\section{HOWARD F. INGERSOLL,}

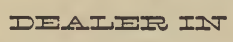

Beef, Pork, Mutton, Poultry, Vegetables, Butter, CHEese, LARd, Ham, CANNEd GOOdS, \&C. WASHINGTON ST., COR. WASHINGTON SQ., Gloucester, - = - = = Mass.

\section{C \& B BSON}

Receivers and Wholesale Dealers in

Dry P1ckled Fish Fish OILS AND VESSELS' OUTFITS,

GLOUCESTER, MASS. 


\section{The Direct United States Cable Co., \\ (IIMIIIEI.)}

\section{Notice to Owners and Masters of Fishing Vessels.}

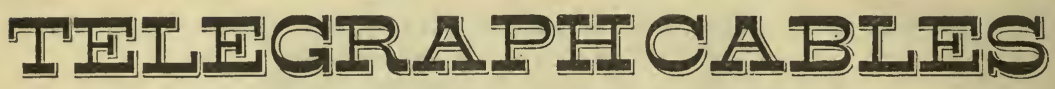

In order to avoid the danger of losing their tackle, and also of damaging the Cables of this Company, captains are requested to give them a wide berth.

Should any vessel, however, lose her anchor or tackle by reason of coming in contact with the Telegraph Cable, and will use every endeavor to save the same from damage, the Company will-subject to immediate notice being given at either of the Company's stations named below, and full particulars furnished of the circumstances,-reimburse the loss, subject to adjustment, upon being satisfied of the bona-fides of the claim.

The directors in adopting this course confidently believe that masters of vessels will do everything in their power to protect the Cables from injury.

As a means of verification, and to enable the tackle to be cleared from the Cable by the Company's repairing ship if considered necessary, it is important (weather permitting) that the slipped anchor should be buoyed by means of a light hawser and wooden spar.

For the guidance and information of Fishermen, CHARTS showing the location of the Direct United States Cable Company's Cables, with the depths of water, have been placed as follows:

BEVERLY, MASS., John Picket's Store.

GLOUCESTER, MASS., Reading Room on Main St., Custom House, and at the Stores of John Pew \& Son, and Clark \& Somes.

HALIFAX, N. S., Shipping Officer's Office, Anglo-French Steamship Company's Office, and J. S. Maclean \& Co.'s Uffice.

NEWBURYPORT, MASS., Custom House.

PLYMOUTH, MASS., Custom House.

PORTSMOUTH, N. H., Custom House.

PROVINCETOWN, CAPE COD, Custom House, Post Office, and at the Office of the "Advocate."

SHELBOURNE, N. S., Mr. G. Robertson's.

SYDNEY, C. B., Messrs. Archibald \& Co.'s.

ST. PIERRE, MIQUELON, The American House (U. S. Consulate.)

NEW YORK (16 Broad St.)

BOSTON (122 State St.) The Stations of the Direct United States Cable

RYE BEACH, N. H.

TORBAY, N. S. Company.

By Order of the Board of Directors.

Head Office of the Company, 52 OLD BROAD ST., London, England.

February, 1882. 


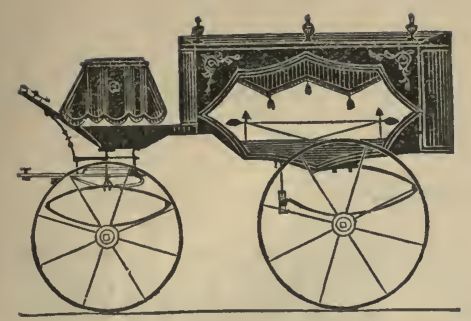

\section{JOHN LLOYD'S \\ Undertaker's Wareroom, \\ NO. 2 WESTERN AVENUE, \\ Gloucester, Mass.}

Coffins, Caskets, Robes, Habits, Caps, \&c., constantly on hand. Children's Robes and Dresses made to order. Personal attention given to attending Funerals, and also to laying-out and preparing the dead for burial.

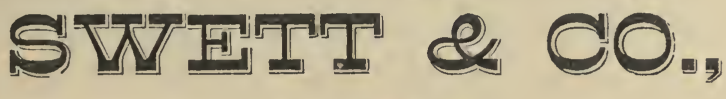
- 6 DEAIERS IN

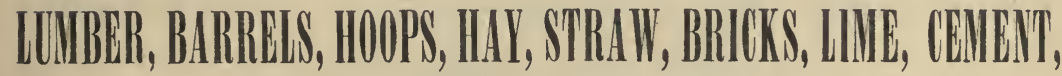
POTATOES, BEANS, \&C.

Wharf on Commercial St.; Gloucester, Mass.

\section{A. W. DODD \& CO,}

IMPORTERS AND DEALERS IN
Pure Cod Liver Oil,

For Medicinal Purposes.

\section{D. LOTHROP,}

Manufacturer and Dealẹ in

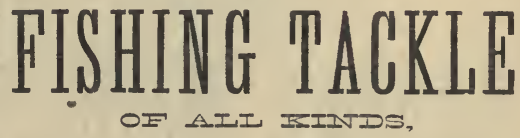

HOOKS, LINES, SINKERS, BRASS AND HORN SWIVELS, HAWSES, SPREADERS, \&C.

Gloucester, . Mass. 33 DUNCAN ST., GLOUCESTER.

\section{BENJAMIN \& WEST,}

\section{WHOLFSALE FISH DEALFTS}

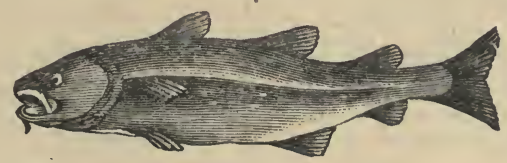

No. 1 Fulton Fish Mrarlzet,

P. BEN.JAMIN,

B. W. WEST.

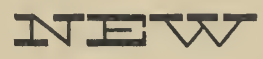

TOERE. 


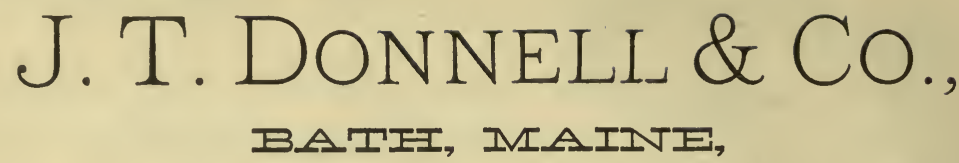

\section{Manufacturers of CORDAGE}

\section{OF EVERY DESCRIPTION,}

The undersigned, our Agents at GLOUCESTER, Mass., keep constantly in store a large assortment of Cables and Manila Cordage, and will take orders for Gangs of Russia or American Hemp Rope, which will be of best quality, and sold at lowest market rates.

Orders solicited, and filled with promptness.

\section{PETTINGELL \& CUNNINGHAM.}
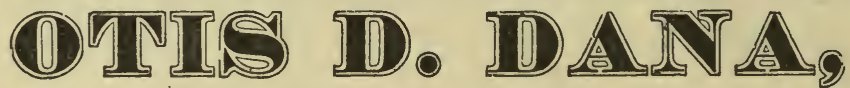

Wholesale Deàler in

\section{Hardware, Manila and Hemp Cordage,}

Gangs of Rigging and a Full Line of Fishing Supplies.

\section{2 to 32 Pear1 St., \\ SAVE YOUR MONEY}

BY HAVING YOUR

Clothing Dyed,

\section{Oleansed,}

Iépairea.

and put in the best of order at a trifling ex-

pense. Second-hand Clothing made to look as good as new, by

\section{A. A. ROBINSON,}

BOSTON.

\section{DAVID G. ALLEN,}

DEALER IN ALI KINDS OF

Iramber,

IIaraware, Bricks, Iime,

Cement, Hair, Doors, Blinds, Windows, Window Frames, Nails, Lead, Zinc, Sinks, dec.

Basement Belmont llouse, Main St., Gloucester. 35 ROGERS ST., GLOUCESTER, MASS. 


\section{SLADE GORTON \& CO.,}

GLOUCESTER, MASS.,

\section{Wholesale Fish Dealers.}

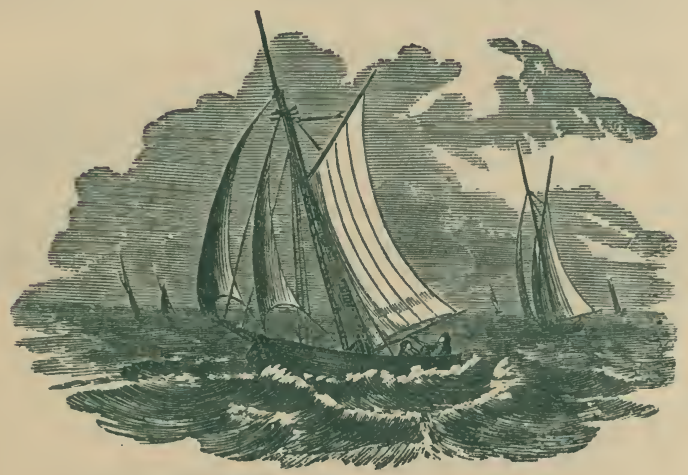

DEALERS IN

\section{ALL KINDS OF SALT WATER FISH,}

FORT WHARF。

Slade Gorton.

Charles C. Cressy. 


\section{TARR \& WONSON'S}

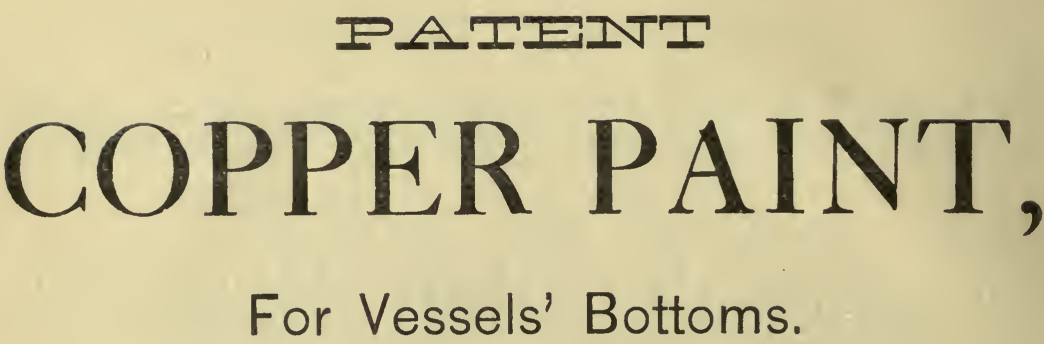

A test of 18 years proves this Paint to be the best in the market.

\section{MANUFACTURED at GLOUCESTER, MASS.}

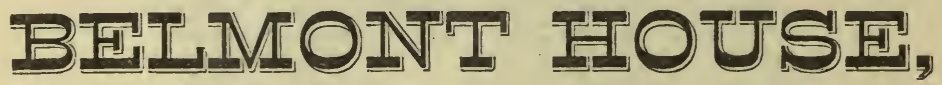

149 Main Street, GLOUCESTER, Mass.

This House has been newly fitted, and has all the modern improvements for the accommodation of permanent and transient Boarders. It is heated by steam in Winter, and well ventilated for Summer. Rates per day to suit every customer.

This House is within two minutes' walk of the Post Office, with a full view of the Harbor.

If you want a Summer or Winter home, go to the BELMONT HOUSE, 149 Main Street, Gloucester, Mass.

A First-Class Restaurant connected with the House.

\section{S. A. LATTER, Prop'r.}

ALEX. MCCURDY,

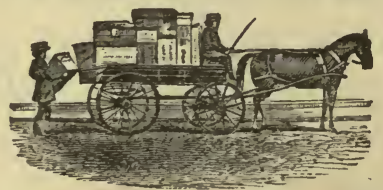

Carriage Manufacturer and Shipsmith,

SHOP NEAR CLAY COVE, EAST GLOUCESTER.

Vessel work, Carriage Repairing, and Horse Shoeing. Edge Tools and Fishermen's Knives a specialty.

\section{East Gloucester Steam Ferry}

Leaves E. GLOdCEsTER at 6.30 A. M. and thrice hourly at ten minutes past, half-past and ten minutes of the hour until 9.10 P. M. Saturdays until 9.50 .

Leave DUNCAN STREET, on the hour and twenty minutes past and twenty minutes of.

The SAIL FERR Y BOAT will run Sundays from 9 A. M. till 7 P. M.

\section{Sail and Row Boats}

to let by the day, week or hour, during the boating season.

DOUGLASS BROTHERS. 


\section{JAMES CLARK, Dealer in all kinds of \\ HARD AND SOFT \\ WOOD,}

Rear 7 and 9 Middle St., GLOUCESTER, Mass.

\section{GEO. D. GARNIER \& SON,}

\section{Carriage Repair Shop,}

PARSONS STREET,

GLOUCESTER, MASS.

Wood delivered in any part of the city free of expense.

\section{A. J. IEOTF \& SOIT,}

HACK, BOARDING, LIVERY AND SALE STABLE, MIDDLE ST., junction WESTERN AVE.

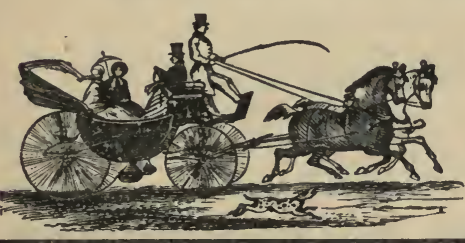

H. C. L. HASKELL,

Insurance

97 Main Street,

Gloroester. - Mass.

Only First-class Stock and Insurance Companies represented.

LOSSES PROMPTLY ADJUSTED.
Boarding and Livery Stable $\triangle T M A G N O L I A$.

Hacks furnished for Weddings, Parties, Balls, Funerals, \&c. Wagons furnished for Picnic and Pleasure Parties. Coaches connect with Railroad and Steamboat.

Order Boxes at Burnham's Block, 179 Main Street, and J. C. Overbeck's, 58 Maln Street, Gloucester.

\section{on Georges in a Storm.}

THIS BEAUTIFUL PAINTING has been photographed, and copies may now be obtained at the store of $P R O C T E R \boldsymbol{B R}$. It is a fine picture, showing two schooners riding at anchor, and another jogging under a double-reefed foresail. Just such a picture as every fishing owner and fisherman wants.

Selling for $\$ 2.00$ and upwards, according to style of frame. Without frame, 75 cents. Call and see this picture. Sent by mail on reception of 75 cents.

Send 75 cents to Procter Bros., Gloucester, Mass., and receive by return mail one of the above pictures. 


\section{WILLIAM P. DOLLIVER,}

\section{Auctioneer and Appraiser,}

INSURHNGE HGENT FND REFIS ESTI $/$ JE BROKER,

At DOLLIVER BROS. GROCERY STORE,

NO. 32 MAIN STREET, GLOUCESTER, MASS.

\section{GAITWIN S. GROWEII \& GO.,}

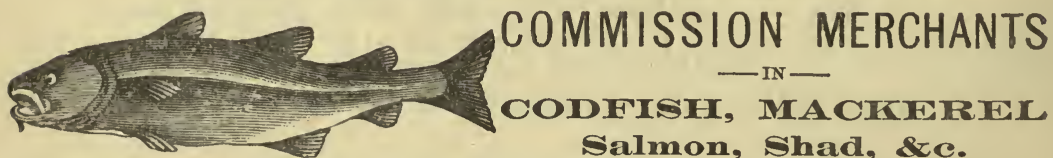

Salmon, Shad, \&ce.

124 North Delaware Ave., PHILADELPHIA, Pa.

References :-Messrs. B. S. Snow \& Co., Boston, Geo. Perkins \& Son, Gloucester, Geo. Trefethern \& Co., Portland, Me.

\section{P. ALDERMAN, - DEALER IN -

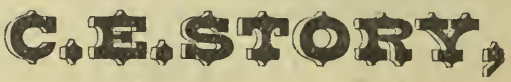 GROCER,}

SEIWING + MHGHINES

\section{AGENT FOR THE}

NEW DAVIS, WHITE, AND DOMESTIC.

AG- Machines of all kinds Repaired.

114 MAIN ST., TAPPAN BLOCK.
Cor. School \& Prospect Streets, GLOUCESTER.

ACT First-class GROCERIES, BREAD, MULK, CROCKERY, CHINA and WOODEN WARE, and articles usually found in a Family Furnishing Store, cheap for cash.
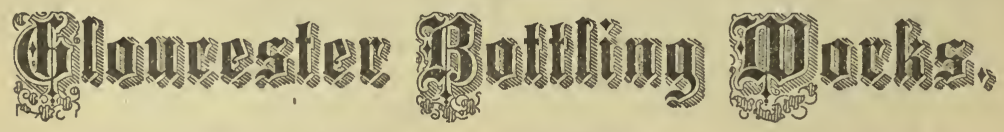

\section{IAITE \& IIEAIIFI,}

MANUFACTURERS OF

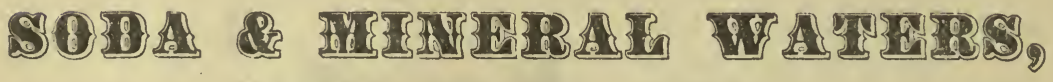
GINTGIE AIJ, MONTIE EDIE, \&o.

Bottlers of ATe, Lager Beer, Porter and Cider. Also, Agents for MrLWAUkEe LAGER.

65 Duncan Street, Gloucester, Mass. 


\section{WARRANTED THE BEST!

For Vessels' Bottoms. MANUEACTUEED IY

JAMIPS II. TAIR, Glorcester, MIass.

एक्ष For sale in all of the principal ports on the Atlantic and Pacific coast.

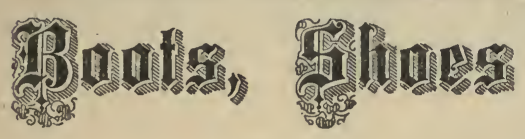

$\longrightarrow$ AND -

RUBBERS.

A Full Line of Seasonable Goods Always in Stock.

\section{LADILS: GOODS}

Made to Measure, and

Warranted to Fit.

C. 0. HOWARD,

64 Main Street,

GLOUCESTER, - Mass.

\section{WHITE'S}

\section{GROCERY,}

$-\mathrm{IN}$

‘TIBBETS' NEW BLOCK,

No. 98 Main St,

Is the Largest, Most Spacious and Finest Arranged in the City. First-Class Goods, accommodating Clerks, and goods delivered to any part of the Cape. All are cordially invited to visit this establishment.

\section{Augustus White, PROPRIETOR.}

\section{F. S. THOMPSON,}

(Successor to J. J. BURNS,

Has the Largest and Best Selected Stock of Watches, Clocks, \$ewelty Silver and Silver Plated Ware, FAncy Goods, ETC.,

IO BE FOUIVD IN ESSEX COUIVIY Particular Attention Given to Repairing. Also, Plain and. Ornamental Engraving. All goods bought of me will be Engraved Free of Charge.

164 Main Street, Gloucester, Mass. 


\section{Established 1849.}

John PEW \& Son,

Producers of and Wholesale Dealers in
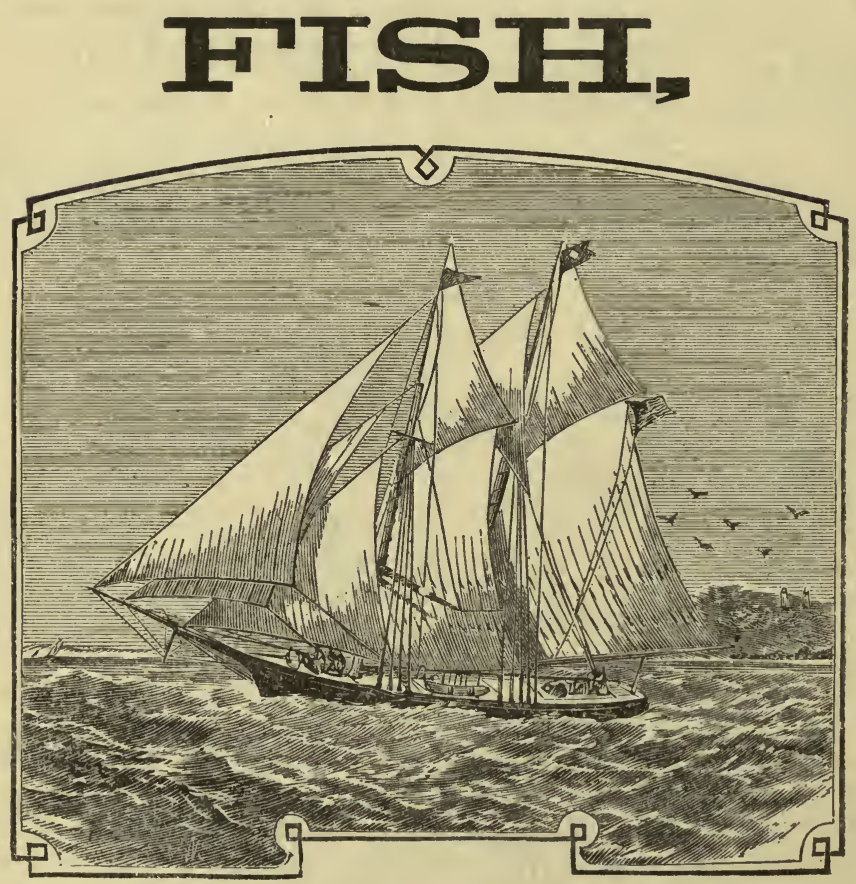

And Importers of

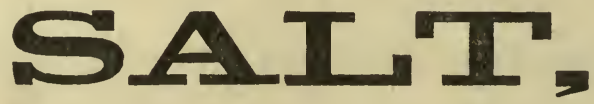

33I Main Street, : : : Gloucester, Mass.

JOHN PEW. CHARLES H. PEW. JOHN J. PEW. JOHN K. DUSTIN, JR. 


\section{SEWALL \& DAY}

\section{Coporge Company}

MANUFACTURERS OF

CORDAGE and OAKUM,

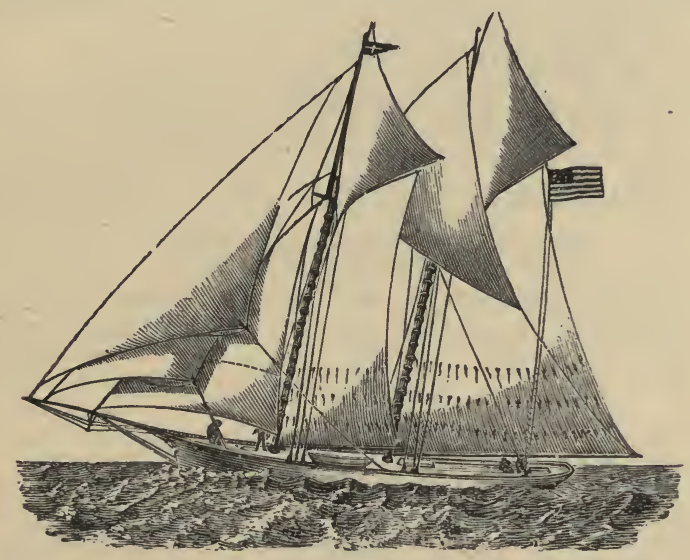

SPECIAL ATTENTION GIVEN TO

FISHERMEN'S OUTEITS,

OABIFS,

NET ROPES, TRAWL LINES, \&C., \&C.

Gangs of Rigging made to order at short notice.

83 \& 85 COMMERCIILL ST, BCSTON, 


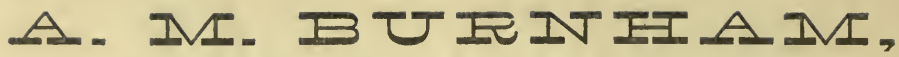
Importer, Wholesale and Retail Dealer in

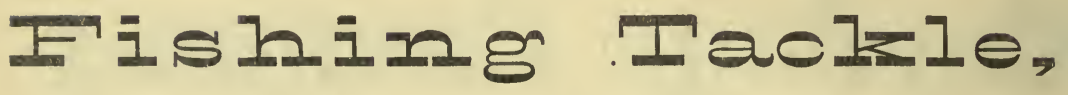
SHIP STORES, CHANDLERY AND PRODUCE.

Opposite the Custom House, Gloucester, Mass.

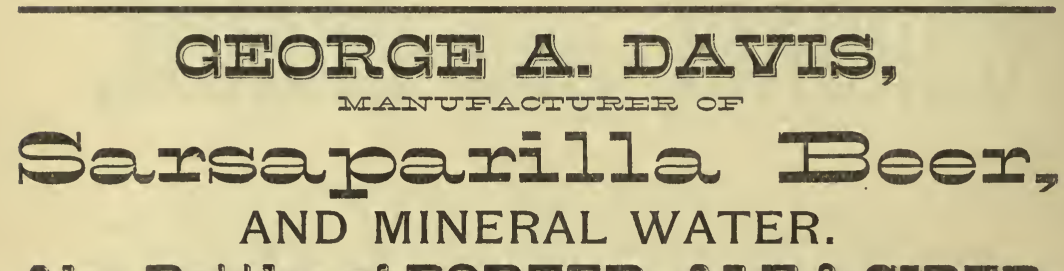

Also Bottlex of PORTER, AIE \& CIDER. PARTIES FURNISHED AT SHORT NOTICE.

SAWYER BLOCK, (Basement, 95 MAIN ST., Gloucester, IMass.

\section{$\rightarrow$ HENJHMIIN P. CHSWELL, \%t BAIEER OF \\ Vienna Bread, Cake and Pastry.} WEDDING CAKE A SPECTALTY.

I am prepared to furnish any description of Cake and Pastry, and of a quality that has no equal in the city. When in want of goods in this line please give me a call.

BAKERY AND STORE 29 DUNCAN ST.

W. F. HILTON,

HORSE SHOER,

FOOT OF MANSFIELD ST., Gloucester, : Mass.

Horses Shod in a Superior Manner.
CROWELL \& PATTANGALL,

COMHISSION MERCHANTS

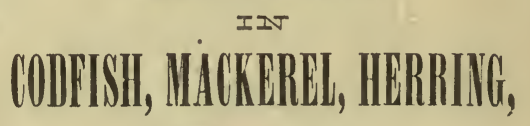

\section{OIIS, \&U.}

No. 46 Water St., New York. A. L. CROWELL.

L. O. PATTANGALL.

Particular attention paid to Eastern Produce. 
Fire, Life, Accident, - AND -

MHRINE:IIUSUIRHICE

In Sound Companies, $-\mathrm{BY}-$

H. L. Follansbee, Ins. Agent and Broker.

\section{T, H, FULLER \& $\mathrm{CO}_{\text {, }}$} - DEALERS IN -

Dry and Pickled Fish,

PREPARED FND BONELESS COD. SMOKED HALIBUT, \&C.

GITOUCHSTER,... MASS.

Boneless Fish a specialty. The Trade supplied at the lowest market rates.

Proprietors of the "Boss" and "Neptune" Brands of Boneless Fish.

\section{Fitz J. Babson, Jr. DEAIIE INT}

LUMBER

Of Every Description,

lapboards,

Shingles,

Cedar Posts,

Iuths,

DOORS, WINDOW FRHMES,

Black Walnut, Whitewood,

Pickets, Lime, Cement,

Brick, Hair, Hardware, de.

WHFRH HND SJORE,

275 Main Street, Gloucester, Mass.

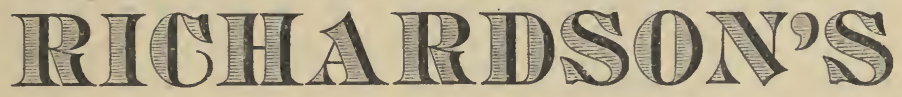

GPATHIJI 20

Streting Apptotion.

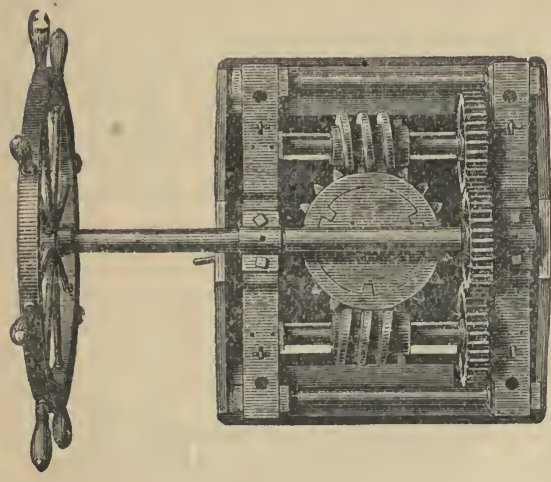

MANUFACTURED BY

NATHAN RICHARDSON

104 Washington St.,

GLOUCESter, Mass.

PRICES:-4, 41.2 and 5 in., $30 \mathrm{in.} \mathrm{Hand}$ Wheel, $\$ 30.00 ; 6,61-2,7$ and $71-2$ in. 36 in. Hand Wheel, $\$ 40.00 ; 8,8$ 1-2 and 9 in., 42 in. Hand Wheel, $\$ 50.00 ; 10$ in. Hand Wheel, $\$ 60$. Address all orders to NATHAN RICHARD. SON, Gloucester, Mass.

P. O. Box 338 . 


\section{SeABURY \& ChASE,}

$\rightarrow$ THE *

Merehant

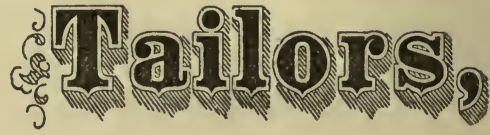

OF GLOUCESTER.

$\rightarrow$ H6 REFDY-MHDE GLOIHIING

- AND - -

FURNISHING GOODS.

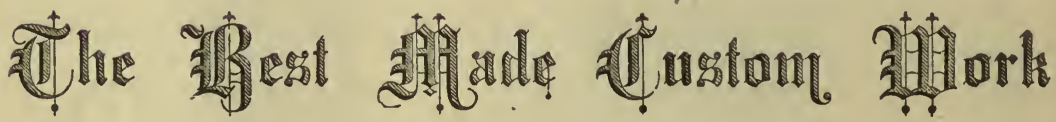
IN ESSEX COUNTY.

No. 136 Main Street, Corner of Hancock. 


\section{PREFACE.}

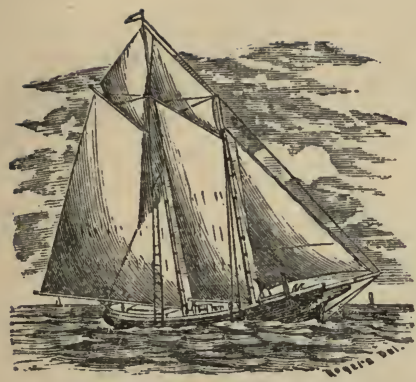

Nine years ago we published "The FisherMeN's Memorial aND Record BooK." It at once met with popular favor, and the two editions of 3500 copies have nearly all been sold. Orders have been received from Nova Scotia to California from those who once pulled a line on board a Cape Ann fisherman, -and from this class, especially, the work has received a most flattering reception.

For the past two years we have been importuned by the fishermen to publish another similar work, which would prove a companion volume, carrying the record of lost vessels and men to the date of publication, thus finishing the list to date, and adding such matter in relation to the fisheries as we had gathered in the interim.

This volume is in answer to oft-repeated requests. W'e have endeavored to make it reliable and of special interest to that class of men whom we have known from childhood-the hardy fishermen, who man the fleet and earn their livelihood amidst constant peril; the men who have done so much toward building up Gloucester ; the producers from old ocean's harvest fields, who draw deposits from Banks which have never yet refused to honor their drafts, who go forth at all seasons and brave the dangers of the sea in order to obtain an honest livelihood for themselves and those dependent upon them.

Through the labors of the fishermen mainly, Gloucester has grown from a population of $635^{\circ}$ and a valuation of one million dollars in 1840 , to a present population of 19,288 and a valuation exceeding nine millions, showing an increase in the brief period of $4 \mathrm{I}$ years of upwards of 200 per cent. in population and over 800 per cent. in valuation. Through his skilled operations and the advantages taken of his labors, the fishing business of Gloucester has grown from an enterprise of secondary importance to rank among the valuable producing interests of the country. In 1847 , thirty-five years ago, the total valuation of the fishing product from this port was $\$ 589,354$, and now, in round numbers, it exceeds $\$ 4,000,000$ yearly.

To this class Gloucester owes much, and they are entitled to the kindly consideration of every good citizen. Around them should be thrown every 
safeguard, morally and physically, and they should receive every encouragement possible.

" Long may their white sails dot the sea, In sunshine or in rain;

And welcome home their comings be From off the changing main.

Long may the clippers make their way

i With gallant hearts to man

As those who tread the decks to-dayThe fishers of Cape Ann.

"Their sharp prows cut the billows blue, On Georges Bank away-

Their white sails fav'ring breezes woo

In fair St. Lawrence Bay,

Or glide along New England's shore,

Or where cool breezes fan

The icy line of Labrador-

The fishers of Cape Ann."

We therefore send forth this our second volume with the hope that its contents may be instructive and pleasing to the class for whom it is intended, and bespeak from the fishermen everywhere a widely extended patronage.

\section{PROCTER BROTHERS.}

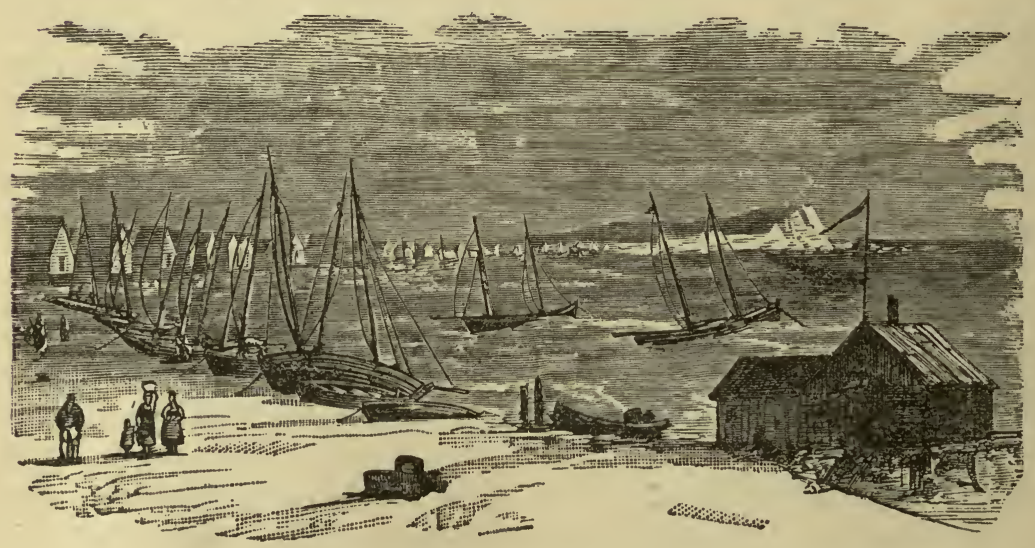




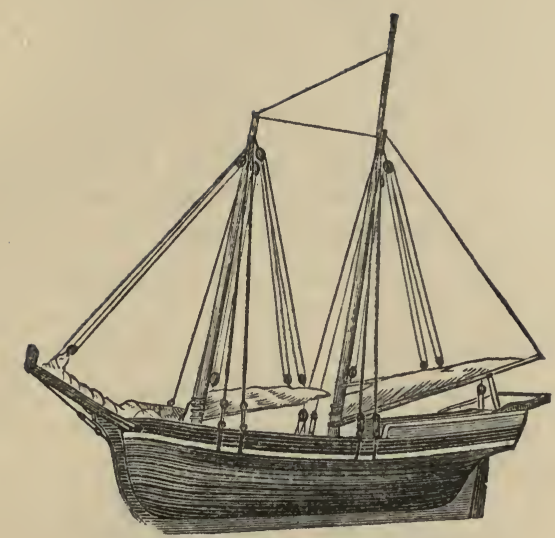

[MODEL OF A GRAND GANKER, 1741.]

\section{The Early Fisheries of Cape Ann}

Antedate the permanent settlement of her territory. In 1623 a fishing vessel from England, having completed her cargo in "Mattahusetts Bay," sailed for Spain, leaving fourteen men "in the country at Cape Anne," to await her return. Early in the next year the same ship, with a consort, came to Cape Ann, and after an unsuccessful fishing season set sail for England, leaving thirty-two men here. The following year three vessels came from England, and an effort was made to establish a colony here under the governorship of Roger Conant, but the attempt was abandoned in the course of the year, Mr. Conant and some of his companions removing to Salem, and founding the Colony of Massachusetts Bay. Fishing was also carried on at Cape Ann in 1624 and 1625 by the Plymouth people, who had two vessels fishing on our coast in the latter year. The permanent settlement of the territory was commenced prior to 1633 , and something was again done in the way of fishing as early as 1639 , although it does not appear that the early settlers of the Cape were fishermen.

The fisheries of Cape Ann, as a considerable and permanent industry, seem to have become firmly established about 1722 , when the business was conducted on a somewhat extensive scale at Annisquam, and also, in a lesser degree, in the harbor parish. Heretofore the business had been carried on in small sloops, built in the town, but in 1720 a few schooners were added, and this class of vessels soon became popular. Many of these schooners were of a burthen of fifty tons or more, and were therefore suitable for the prosecution of the fisheries on the Grand Bank and other distant fishing grounds. They were of a nearly uniform model, with square bows and high 
stern, and presented the strongest possible contrast to the swift clipper fleet of our own day. The model on the preceding page of a Grand Banker of I 74I will give a good idea of the appearance of these old-time craft.

There was one of these craft in existence in 1878 , the Manchester, which was then owned in York, Me., and was nearly one hundred years old. She was formerly of this port, being owned by Mr. Daniel Gaffney and others. She was 63.95 tons, built in Duxbury, Mass., in 1784 . We do not know whether she is in existence now or not.

About seventy of these vessels were owned in Gloucester in $174 \mathrm{I}$, nearly all of which were probably employed in the Grand Bank fishery for codfish. Each of the crew kept an account of the number of fish he caught, and the proceeds of the voyage were distributed accordingly. That their earnings were far from uniform is shown by an account of three trips of sch. Abigail, Capt. Paul Hughes, to Grand Bank in 1757 ; the three trips occupied about six months, in which were included sixty-seven days fishing, the skipper being "high line" with a catch of 6643 fish, the "low line" taking 3435, the average catch of the crew of six men being 4506 . From 1770 to 1775 between seventy and eighty Gloucester vessels resorted yearly to the Grand Bank, and about seventy boats fished for cod, hake and pollock on the ledges near our own coast. These latter boats were mostly built at Essex, then the Chebacco parish of Ipswich, and from that fact received the name of "Chebacco boats," their model being shown in the following engraving. There was a large fleet of them owned here and in Rockport at the commencement of the present century, but they have all disappeared.

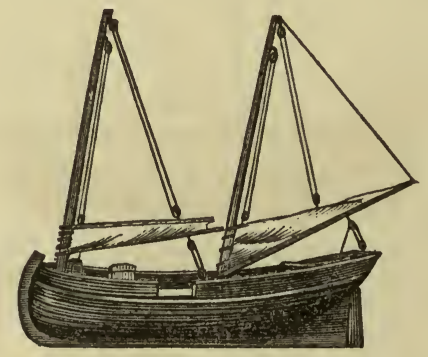

The tonnage employed in the Cape Ann Fisheries at the outbreak of the Revolution could not have been far from forty-eight hundred tons, represented by one hundred and fifty schooners and boats, and employing about six hundred men. The yearly product may be estimated at forty-eight thousand quintals, of a value of one hundred thousand dollars.

The Revolution, of course, put an embargo on Bank fishing, as well as an end to the exportation of fish, and the business soon divindled to insignificant figures. After peace had been declared the business was resumed, 
and some sixty vessels were sent to the Grand Bank, but in consequence of unsatisfactory returns the business soon languished. In 1804 the whole number of vessels over thirty tons burthen engaged in the Cape Ann fisheries was only eight, and for nearly half a century fishing was almost totally abandoned,

With the decline of the Bank fishery, the Shore fishery commenced to attract increased attention. At the commencement of the present century some two hundred Chebacco boats, averaging about fifteen tons each, and manned by some six hundred men, were engaged in this fishery. The increasing importance of this industry created a demand for an increase in the capacity of the craft engaged in it, and about 1810 the Chebacco boats began to give place to the "jigger" or "pinkey," of which class but a single specimen is now included in the Gloucester enrolment,- -the sch. Senator, built in Essex in $183 \mathrm{I}$, and now owned by Capt. John Parker. The following is a specimen of a pinkey of the model of $x 810$.

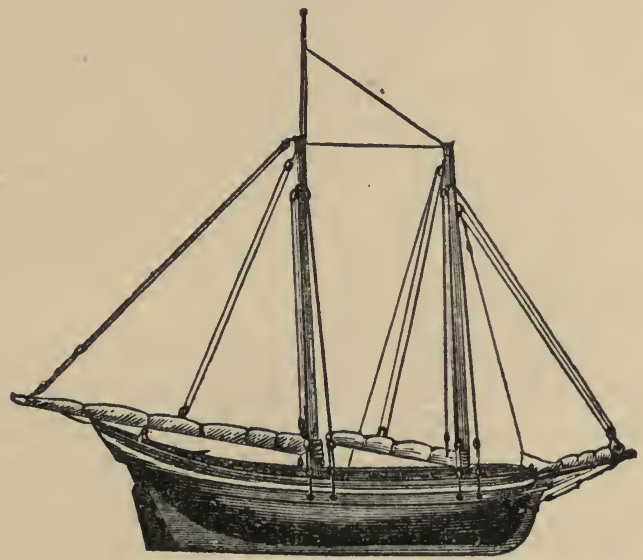

The Shore fishery reached its maximum in 1832 , when it employed a tonnage of 6463 tons, furnishing employment to $799 \mathrm{men}$, and resulting in a catch of 63, I 12 qtls. fish, of a value of $\$ 157,780$, receiving also a bounty of $\$ 25,172$ from the government. From this time, the business, except as a winter industry, began to decline, giving place to the mackerel fishery and other modern branches of the industry. 


\section{A Remarkable Escape.}

Two Fishermen Imprisoned in a Forecastle Eighty-Nine Hours without Light or Water and on Short Allowance of Food-Timely Rescue.

The Nova Scotian schooner Codseeker was capsized off Cape Sable, May 9 th, 1877 , with the supposed loss of all the crew except the captain and two others, who saved themselves in a dory. The schooner was struck under the weather-quarter by a sea at about in o'clock, P. M., and gradually careened over on her beam ends, in which position she remained. It was found impossible to clear the boat, and the three men in the dory, while engaged in bailing to keep her afloat, drifted rapidly to leeward, leaving a part of the crew clinging to the weather-side of the vessel, which they were unable to find again when their frail craft became manageable. After great difficulty and danger they effected a landing in the surf on the south side of Cape Sable Island soon after daylight on the morning of the roth. A schooner was at once fitted away, in the face of a heavy gale, and at II o'clock, A. M., twelve hours after the accident, the Codseeker was sighted on her beam ends, with five of the crew lashed to her side; one of these was washed off and drowned before he could be reached, and the other four were rescued with great difficulty. The rest of the crew were supposed to have been drowned in the cabin or washed overboard, and the wreck was abandoned to her fate. On Sunday afternoon the wrecked schooner was fallen in with off Seal Island by the schooner Ohio, of Bucksport, Me., and was boarded by the captain and two of the crew, who fancied that they heard sounds proceeding from the forecastle, the gangway leading to which was entirely under water. On pounding on the side of the vessel they were answered by faint tappings from within, and came to the conclusion that some of the crew had been caught in the forecastle and imprisoned when the vessel capsized. They at once proceeded to cut a hole in the side of the schooner, by the fore-chains, and ef.ected the rescue of two men who had been confined there without light, water or food, with the exception of a few small cakes, from II o'clock on Wednesday night until 4 o'clock on Sunday afternoon. 'They were landed at their homes on Monday morning, to the great joy of their friends, who had given them up as lost. The feelings of these men in their long and apparently hopeless confinement, their sensations when their comrades were taken from the wreck on Thursday, leaving them without means of making their presence known, the long, weary hours that followed, and the intense anxiety with which they became aware that the vessel was boarded again on Sunday afternoon, and their great joy when they knew their signals were heard and deliverance was at hand, can neither be imagined nor described. 


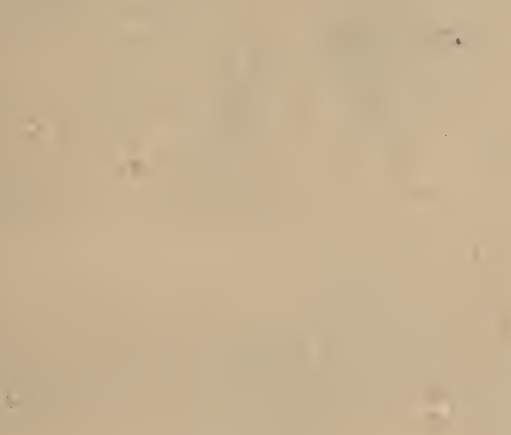




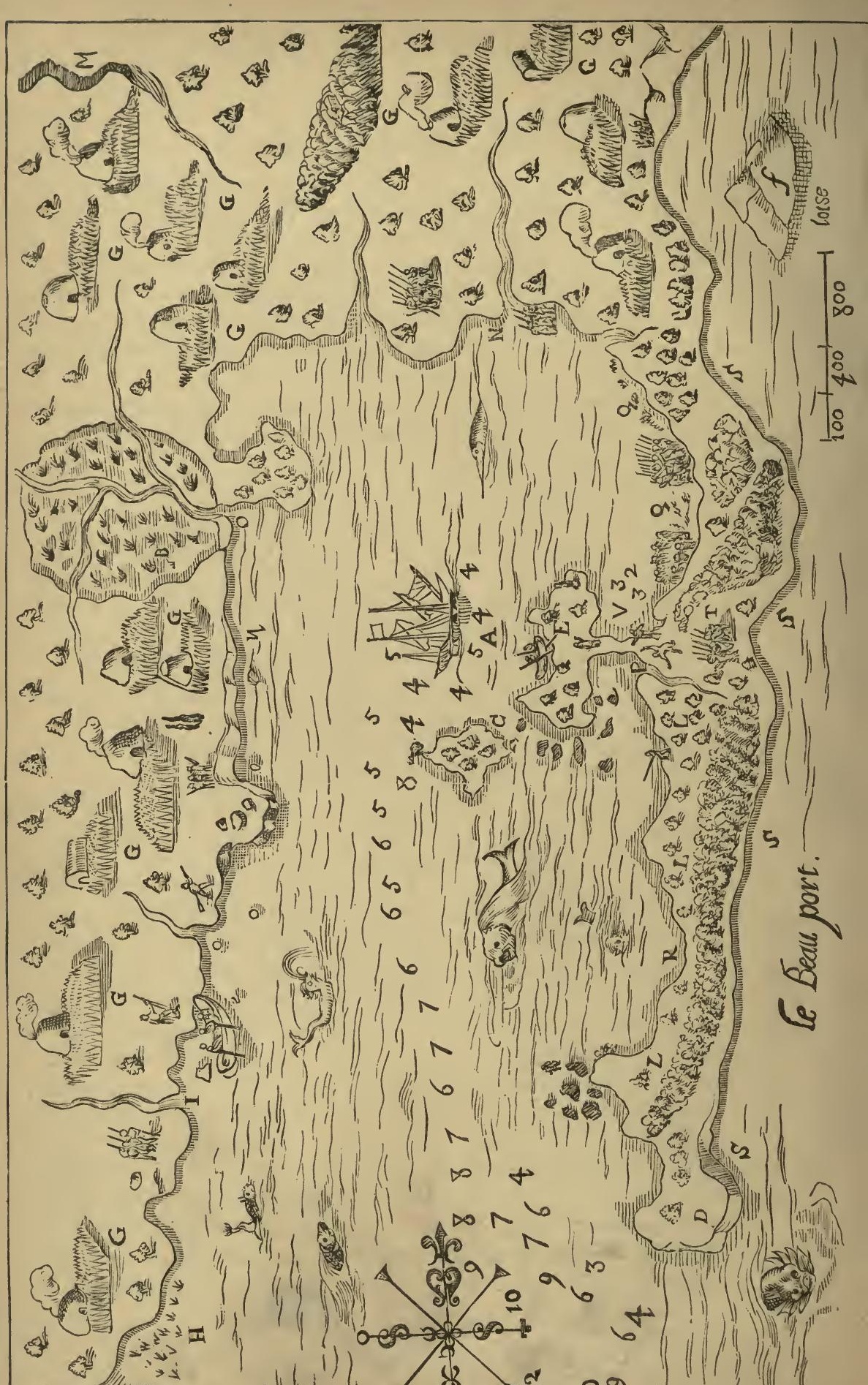




\section{Gloucester Harbor in 1606.}

On the opposite page is presented a map of Gloucester Harbor, as it appeared to some French navigators who sought its shelter in 1606 , reproduced from a map first published in France in 1613 . The accompanying account of this first visit to our harbor was translated from the "Voyages of Champlain," for the columns of the Cape Ann Advertiser, and so far as our knowledge extends has not elsewhere appeared in print in the English language.

The alphabetical references on the map are as follows (the figures denoting the depth of water, probably in French metres, a metre being about three and one-fourth feet):

A, The place where our bark was anchored. B, Meadows. C, Little Island. (Ten Pound Island.) D, Rocky Point. (Eastern Point.) E, The place where we caulked our boat. (Rocky Neck.) $f$, Little Rocky Island. (Salt Island.) G, Wigwams of the savages, where they cultivate the earth. $\mathrm{H}$, Little river, where there are meadows. (Brook and marsh at Fresh Water Cove.) I, Brook. (Brook which enters the sea at Pavilion Beach.) L, Tongue of plain ground, where there are saffrons, nut-trees and vines. (On Eastern Point.) M, The salt water from a place where the Cape of Islands turns. (The creek in the marsh at little good harbor.) $\mathrm{N}$, Little river. (Brook near Clay Cove.) $\mathrm{O}$, Little Brook coming from meadows. (This brook cannot now be exactly located.) P, A little brook where they washed their linen. (At Oakes' Cove, Rocky Neck.) Q, Troop of savages coming to surprise them. (At Rocky Neck.) R, Sand beach. .(Niles' Beach, at Eastern Point.) S, The sea-coast. (Back side of Eastern Point.) $T$, The Sieur de Poutrincourt in ambuscade with seven or eight arquebusiers. $\mathrm{V}$, The Sieur de Champlain perceiving the savages.

In 1603 Samuel de Champlain sailed on a voyage to Canada and ascended the St. Lawrence as far as Cartier went in $\mathbf{r}_{535}$. In $\mathrm{r} 604$ he made a second voyage, as pilot for De Monts, lieutenant-general of L'Acadie. They sailed from Havre April 7, saw Sable Island May x, and fixed the place for their winter residence on St. Croix Island in the St. Croix river. Sept. 2, Champlain left St. Croix for a cruise, sailed up the Penobscot as far as Bangor, and then returned to his winter quarters. June 18,1605 , De Monts and Champlain, with a small company, left St. Croix and cruised along the coast to the southward until July $r 6$, when they reached "a cape, where there were three islands* near the main land, full of trees of different kinds. We named this place," says Champlain, "Cap aux Isles, $†$ near which we perceived a canoe containing five or six savages, who came near our bark and then went

\footnotetext{
*The "Three Turks' Heads" of Capt. John Smith; now Straitsmouth Island, Thacher's Island, and Milk Island. +Now Cape Ann.
} 
away to dance upon the shore. I went ashore to see them, and gave to each a knife and some biscuit, which caused them to dance again better than before. I next made them understand, as well as I could, that they should show me the coast. After having drawn with a piece of charcoal the bay and the cape of islands where we were, they made a figure with the same charcoal of another bay, $\ddagger$ which they represented very large, on which they put six pebbles at equal distances, giving me to understand by so doing that each of these stones denoted the habitation of a chief and his tribe. Then they drew at the said Longue Baie a river§ that we had passed, which extends very far and has sand flats. These savages told us that those who dwelt in this country cultivate the earth as the others whom we had seen before. This place is in the latitude of 43 degrees and some minutes."

On this voyage Champlain did not enter Gloucester harbor, but proceeded to Nauset, Cape Cod, from which place he returned to St. Croix. In r6o6, however, he made another voyage, accompanied by the Sieur de Poutrincourt, sailing from Port Royal, whither the settlers had removed from St. Croix, Aug. 28th. They arrived at Saco Sept. 2 r, and continuing on their course, on arriving at the "Cap aux Isles," came to anchor at the entrance of the harbor. The next day they came up the harbor, and landed. "We saw," says the voyager, "some good ripe grapes, Brazil nuts, gourds, and some roots which the savages cultivate. They gave us some of these in exchange for little trifles we had given to them. They had already gathered their harvest. We saw two hundred savages in the place, the chief of which, Quiouhamenec, came to us with a cousin named Cohonepec, for whom we made good cheer. Onemechin, a Saco chief, also came to see us, to whom we gave a coat, which he soon gave away to another because it did not fit him. We also saw a savage who had been wounded in the heel, while running towards the bark, and had lost so much blood that he fainted. Many others came around him, singing some time before they would touch him; then, making certain gestures with their hands and feet, they moved his head, and, upon their blowing upon him, he came to himself. Our surgeon dressed his wound and he went gaily away; 'but, two hours after, he came again,' adds L. Escarbot, 'the most jocund in the world, having put about his head the binding cloth wherewith his heel was wrapped, for to seem the more gallant.'

"The next day, as some of our men were caulking our shallop, the Sieur de Poutrincourt saw in the woods a number of savages who came with the intention of making us some trouble. They were going to a little brook which is upon the narrow part of a bank which leads to the mainland, where our people wash their linen. As I was walking along this bank, they perceived me, and to put a good face on the matter, because they saw that I

†Massachusetts Bay. §The Merrimac. 
had discovered them, they began to shout and to prepare for dancing. Then they came towards me with their bows, arrows, quivers and other arms, and, as there was a meadow between them and me, I made signs to them that they should dance again, whereupon they formed a circle and put all their arms in the centre of it. They had hardly commenced to dance, when they saw the Sieur de Poutrincourt within the wood, with eight arquebusiers, which astonished them. They stopped dancing, and retired from one side and the other, with apprehension that we should do them some harm. We said no more to them, however, and only made some demonstrations of rejoicing. Then we returned to our boat in order to put to sea and get away from them. They wanted us to stay one day, saying that more than 2000 men would come to see us, but not willing to lose time we would not longer delay. I believe that they wanted to surprise us.

"'They have some cultivated land and are clearing it up all the time. See how they do it! They cut the trees at the height of three feet from the ground; then they burn the branches upon the trunk and sow their corn between the cut wood; and in the course of time they take away the roots. There are also meadows there sufficient for nourishing a number of cattle.

"This port is a.very good one, having -sufficient water for vessels, and affording shelter behind some islands. It is in the latitude of 43 degrees, and we have named it Le Beau Port."

These French explorers next sailed to Cape Cod, leaving Quiohamenec and his tribe in quiet possession of their territory, which is not known to have been again touched by the feet of civilized men till it was occupied by a few English fishermen in 1623 . We should be glad to know something of the doings and adventures of the fourteen men who composed this last company, but no pen has traced the history of the second landing at Le Beau Port.

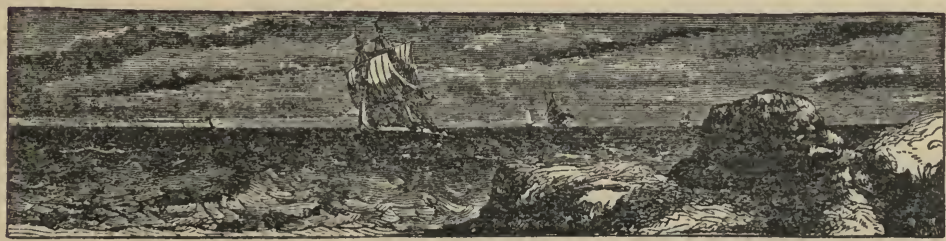




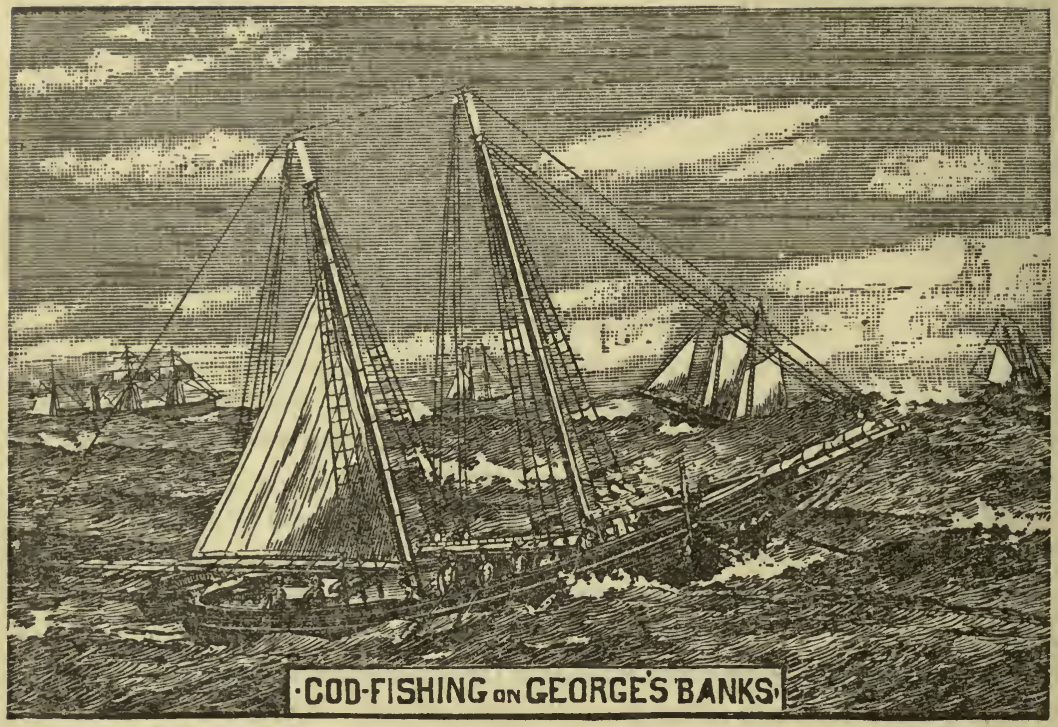

\section{A Winter's Trip to Georges.}

BY WALTER HILL.

Outward Bound-On the Banks-Good Fishing-A Sleeping Giant-Change of Scene-Fishermen's Rations-Eating under Difficulties - The Giant Arouses-To keep our Courage up-Boarded by a Sea-Narrow EscapeA Thrilling Sight-At Daybreak-In their Place-After the Storm-Homeward Bound.

Let us suppose ourselves on board a trim fishing craft, like the above, with a good supply of frozen herring on board, running out from Gloucester harbor, bound to Georges Banks. We are heading E. S. E., with a trip of 140 or 150 miles before us. The wind is N. W., and the sky is cloudless, and we arrive on the grounds the day following our departure, pretty early in the clay, and "bring to" in about 30 fathoms of water, furl the canvas and bend the riding-sai!. The lads are soon at work with their lines. There are several vessels in our vicinity, and the two that we spoke before "bringing to" gave us but litt!e encouragement. But this is not to be depended on, for they would say the same thing, probably, if the fish were "solid" around them. Some skippers direct the crew to stop fishing when a vessel comes along making inquiries of this nature, so as to mislead them. There is some justification for this practice in winter time, since the greatest peril arises from too much crowding, and there are plenty of men in 
charge of vessels who are reckless enough to anchor "right on top" of another vessel if they should see the latter haul in half a dozen fish.

However, we don't find much here, and on the following morning make a "berth" to the eastward and "club her" (i.e. anchor) in about 40 fathoms. Several vessels in sight here too; two or three quite close enough. Here we meet with better fishing, although not anything extra, and by night the boys average about 35 fish each.

The following morning, the wind being brisk from the westward, we are called betimes, and the "morning watch" reports as we sit down to breakfast that he has not had a "bite" yet. This does not disconcert us much, as the fish often refuse to bite for an hour or so after daylight; and so it turns out in this instance, for we soon find ourselves pretty briskly employed, and are able to keep ourselves warm with constant hauling. It is a busy scene, but the reader will readily perceive that the intensity of the cold, even on a moderately fine day in February, precludes much pleasurable emotion warming one's breast, aside from the cold satisfaction that one feels that every fish taken is so much added to the common good.

Well, by night we are all fairly tired out, you may be sure, and no one is sorry to stretch out in his bunk and enjoy a snooze. The "high-line" to-day caught 85 fish, and the "low-line" 60 , a more than average day's fishing.

Two more fine days of glorious fishing weather. The boys have been making good use of the time, too, and some of the "knowing ones" estimate about 35,000 weight of fish in the hold.

We have now reached Thursday evening, and will note the appearance of the weather particularly, as we expect an early change. The "glass" is six or seven-tenths above thirty, and that indicates the approach of an "Easterly." The wind has been light from the S. W. all day, falling at times to a calm ; then light zephyrs spring up and chase each other along. in quick succession. It is one of the few really enjoyable days we get during the winter months in this climate, and some of the sanguine ones have already, in their mind's eye, started for home with a full fare. There is some "swell" on it is true, but no more than would fairly represent the respiration of such a peaceful, sleepy giant as the one on whose bosom we rest. On such occasions this monster becomes to me endowed with speech, and seems to say with a benevolent smile, "Don't be scared of me ; I never harmed anything in the world of my own accord ; it is only when that aggravating brother of mine, Boreas, provokes me to fury with his spiteful whistling and howling that I unwillingly work so much destruction-but I am always sorry for it afterwards." And going on so, the lazy, hulking, good-natured giant half inclines me to believe that he is sincere. I should certainly scout.any other idea but for the recollection of certain slaps he 
has hit me from time to time, which on two or three occasions have wellnigh sent me into "the sweet bye-and-bye."

Darkness has come upon us while we have been musing, and as we may, before many hours, perhaps, be in the midst of a storm, we had better take time by the forelock and secure a nap while we may. The "night-watch" has already been set, the signal light is burning brightly, and even our neighbor, the giant, is breathing less perceptibly, as if inviting us, too, to repose.

Friday morning. Decided change this morning. The wind has sprung up from the N. E. during the night, and the clouds betoken a heavy snowstorm at hand. Our sanguine friends of last night look as if brick walls had sprung up between them and their airy hopes. On the principle of "making hay while the sun shines," every man is doing his utmost to swell his total of fish to a respectable figure while there is still a chance to fish. The cod, too, are biting pretty freely, and the vessel begins to surge and creak to her cable uneasily, like an impatient horse champing the bit and pawing the ground.

The skipper, who was up betimes, is uneasy, also, and now goes forward to inspect the cable, and then below to consult the barometer, which this morning stood almost on 30.80 , but has since commenced to fall, bringin? along occasional spits of snow. He is particularly anxious about the bearings of the three or four vessels in our immediate vicinity,- - one right astern and another on the "starboard quarter" giving him much concern.

The light scattered snowflakes now fall thicker and faster. The neighboring vessels become more and more indistinct, till they fade out of sight altogether, and leave us alone with the increasing wind, the blinding snow and the rising sea! Our giants are evidently about to commence one of their wildest bouts.

There is the skipper's voice. What does he say? "Haul in your lines! Heave in 'strads' and give her cable." The "strads" are strands of rope plaited together, and are bound tightly around the cable to prevent it from chafing in the hawse-pipe. Having taken them off we "pay out" 60 or 70 fathoms, and "strad her up" again as before. We also loose the foresail, put three reefs in it, and roll it up again, so as to have it ready in case the vessel goes adrift from her anchor. (It is usually customary in anchoring on Georges to double-reef the foresail before furling it.) What fish there are on deck we "dress" and heave below, as well as everything else that is loose.

All being made snug some of the crew "stow away" their lines, while the more eager ones heave over again and continue fishing. But one drops off, and another drops off, till the last man fishing calls to those below to "set the watch," and when relieved goes below himself. It is customary 
to have a watch on deck at all times; one in ordinary weather, in very rough weather two in a watch, and in heavy weather the whole crew hold themselves in readiness for a jump at any moment.

About 3 P. M. the cook invites us to supper; for fair weather or foul the inner man has to be taken care of. Let us take this opportunity of observing his hard weather arrangements. He has a kettle each of tea and coffee always on the stove, and one or the other is served with every meal. The provender consists of hash, fish chowder, salt beef, bread and butter, gingerbread, and dried apple or corn starch pies. A good deal depends on the cook however, and his mode of catering. With a good cook everything goes smoothly. There are guards on the table, to keep things from rolling and sliding off; but these are not effectual in very stormy weather.

And now darkness approaches apace. Looking to windward is a painful operation, and one can only snatch a glance. Nothing is to be seen but a blank prospect of snow, which strikes the face with the sharpness of hail.

This is why fishermen so much dread a N. E. storm, it places them so utterly at the mercy of chance. There may be a vessel two seas off bearing down to sweep both to destruction. Like the sword of Damocles, the danger is always hanging over their heads as long as the storm continues. But of its actual approach there is short warning. A careless "lookout" would be inevitable destruction.

The "night watch" being "set," on such occasions as this the rest of the crew usually muster in the cabin, all "oiled up." The "old hands" will be reminded of similar breezes in the past, and entertain us with narrations of narrow escapes, etc. Old Uncle Parsons details the story of his narrow escape in the $2 \mathrm{~d}$ April breeze; also in the 4 th March breeze; and again when he successfully rode out the gale in which 75 other vessels cut their cables and several were lost. Another "old fogy," usually reticent, makes quite a little history of his experience in the Georgesman that "turned over" with them while "lying" on the Bank in a heavy breeze; and, although dismasted, righted herself and fetched them home safely after all.

We begin to be quite oblivious of the present breeze, when a heavy sea strikes us, careens the vessel over, and sends everybody tumbling down to leeward. The skipper, who has been standing in the companion-way, "bobs" down and hauls over the "scuttle," just in time to prevent a drenching sea from pouring down. The watch on deck keeps out of harm's way by getting on the "foregaff," clear of the wildly-rushing water on deck.

This little "flare-up" of excitement has just subsided, when the hands on the lookout give a loud cry. Although none know what was actually said, all recognize the fact that imminent peril was expressed in the manner and tone, and all hands at once rush on deck. The skipper has already placed himself at the cable, with a sharp axe, and every eye is strained into the 
gloom to distinguish the fatal light-for light it is-surely approaching! There is hope yet that the coming craft may drift across our bows without striking us, for the tide is setting over that way somewhat. Yonder she emerges from the gloom, and we can distinguish the dim outline of her spars and hull. It seems as if nothing short of a miracle can prevent the danger from culminating. The skipper has twice lifted his axe to strike the severing blow at the cable, but the remembrance of the vessels to leeward of us causes him to hesitate. But for this we should doubtless have cut at the first alarm. Now she rises on the crest of a sea, right ahead of us, and five seconds more will tell the tale. The suspense which thrills every breast suspends respiration; almost stops circulation. The tongue is powerless, and all the faculties are concentrated in the eyes. Every gaze is riveted on the vessel as she rises, more on the bow this time, and every man draws a great breath of relief, for we know that the danger is past!

She is now abreast of us, but going away slowly on the starboard quarter. So near is she that we feel her cable running up across our own, but we know from its buoyancy that there is no anchor on the end of it, so we have no fear of its hooking hold of us. Away into the gloom, out of sight, drifts the fated vessel, her crew unconscious of the new perils so near at hand, to leeward. The drift she was making when we lost sight of her would take her very, very near the vessel whose bearings we took on the starboard quarter before the storm set in. God help the poor fellows! To be adrift on Georges Bank at such a time, among a fleet of vessels, is a danger only to be realized by those who have been through some experience of the kind.

Is it by chance that the snow shortly after this suddenly ceases? The cessation is of but short duration, but as it clears to leeward all eyes are searching for the lights, and soon one is descried as it rises on the sea. We try to see the other-we know there must be two in that direction. The next sea reveals to all that there are two lights there, TOGETher! A loud and horrified cry announces this discovery, and then every man seems frozen to a statue. The terrible interest centered in those entangled lights seems to suspend every sense but that of sight, which it intensifies.

This scene has scarcely become distinct, when like a vision it fades away. The snow falls again, and the lights disappear, whether behind the curtain of snow, or whether they sink into the embrace of the furious giant who was yesterday so softly enchanting us, we are in doubt. But of the end of the encounter there is, alas! no room even for doubt.

Daylight breaks, or rather, creeps, on us at last. I question if there is a man on board, be he infidel or Christian, who does not feel a sense of thankfulness as he recognizes the long-deferred light slowly spreading over and through the scene. The crests of the breaking seas become visible further and further. The snowflakes show up in relief against the increas- 
ing dawn, and soon all the daylight the storm will permit is ours. The cook does not lay anỹ table for breakfast, and we go down and snatch what we can to eat, and swallow some hot coffee. Several ugly seas boarded us during the night, and bulwarks are stove, gurry-kids smashed, and other damage done, but all thought of this dwarfed into insignificance in the face of the thrilling scene we were going through.

As the morning advances it becomes evident that we have seen the extreme fury of the storm. The "glass" is beginning to rise, and towards noon the snow slowly ceases. The wind is also moderating. We endeavor in the afternoon to snatch a nap. I try hard to sleep, but with poor success. My imagination is excited, and my sleep is fitful and troubled with dreams. I fancy myself on board the lost vessels during the last few hopeless minutes, and appear to have plenty of leisure to observe the effects as shown in the different faces around me. I mark expressions of wild supplication, of cool resignation, of steady bravery, of desperation, and wicked bravado even yet. Here I recognize the face of a young man who has often spoken of his hope of soun going across the ocean to see once more his mother and sisters there, and endeavoring to get them to accompany him back. There is another who has amassed a respectable sum in the savings bank, and has hopes of soon investing in a vessel himself, and of marrying at the same time. In another face I recognize a frank, cheerful young fellow, just beginning the world, full of hope and boisterous merriment, and whose only fault is that he is too free for his own good. And lastly, another familiar face I have often seen; mark the stolid, stupid indifference of expression even now. He is a married man, and has a deserving wife, but he himself is a drunkard, long since lost to all sense of self-respect. It is ever so when a man oversteps the bounds of blessed moderation and allows all his mind, soul and strength to centre on the bottle. What thoughts occupy his mind in this awful moment? Is he consumed with remorse? Has he a thought for that woman he has wronged and made miserable all her life long? Does he think of his neglected children? Or is he merely wishing for a parting grasp and swig of that bottle which should be a comfort, but is so often made a curse?

\footnotetext{
"Over the brink of it,

Picture it, think of it,

Dissolute man."
}

Just as these words are running through my mind somebody shakes me and says I am talking "gibberish." This is somewhat mortifying, for I could have emphatically declared that I was giving expression to the above quotation from Hood.

I go on deck, and find other restless enes fishing. I follow suit and get a few fish. Before dark we "heave in "slack cable." The wind is in the southward now, but it will come round to the westward. I manage to get 
some sleep through the night and rise refreshed. I find the wind is N. W., the air keen, and everything dry and hard with frost. It is freshening, and it is more than we can do to keep warm, hauling all the time. The fish soon freeze stiff after they come on deck, and they are biting briskly. Several good halibut, too, have been secured.

At night we have to "pay out"'more cable again, and the breeze promises to be heavy, but there is only one vessel in our vicinity now, and with good clear weather we do not fear any trouble. It blows heavy through the night, and just about daylight a heavy sea strikes us and makes the vessel tremble. The watch soon after puts his head down the "scuttle" and says, "She's adrift." We all jump out, slip on "oil-skins," and get on deck. The foresail is loosed and set; then we proceed to heave in the cable, which we find has been chafed pretty well through by sawing across a rock on the bottom.

We are now standing with our head to the nor'ard, and as we have received a good deal of damage, the skipper decides to make for home. The wind moderates, so we make sail and pound ice-for forward our vessel is a sheet of ice, and ropes, windlass and cable are all buried in several inches of it. But all hands turn to with a will, and things are soon put to rights. The wind becomes more favorable, and we make all sail and head for Gloucester. Joyful faces are watching for us there; but, alas! for the poor hearts to whom we bring tidings of bereavement-of fathers gone forever; of brothers nevermore to return, and sons whose manly right hands will never earn honorable support for aged parents again.

Few of the affluent have any idea of the dangers encountered and braved to procure those savory dishes of fish which they so highly appreciate; and I am afraid few even stop to enquire whether the fishermen are well or illy paid for their labor. There is one duty, however, which people of fortune ought not to neglect, in my opinion, and that is, to contribute liberally to the support of the widows and orphans of whom this arduous calling makes so many.

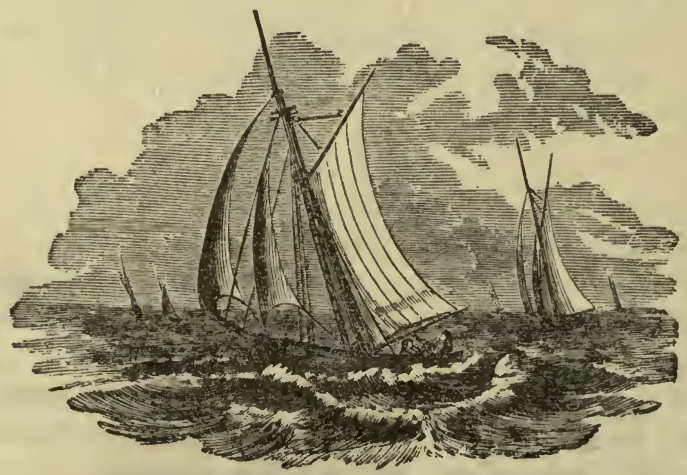


Prices of Mackerel and Codfish in the Gloucester Market Sept. Ist, for the Past 52 Years.

PRICES OF MACKEREL PER BBL.

$$
\text { No. 1. No. 2. No. } 3 .
$$

$\begin{array}{rrrr}1830 & \$ 5.00 & \$ 4.50 & \$ 2.62 \\ 1831 & 5.75 & 4.75 & 2.62 \\ 1832 & 5.00 & 4.00 & 2.75 \\ 1833 & 5.72 & 4.72 & 2.85 \\ 1834 & 5.72 & 4.72 & 3.35 \\ 1835 & 7.00 & 6.00 & 4.00 \\ 1836 & 9.00 & 8.00 & 5.00 \\ 1837 & 7.75 & 6.50 & 4.12 \\ 1838 & 11.00 & 9.25 & 5.50 \\ 1839 & 12.50 & 10.50 & 7.00 \\ 1840 & 12.75 & 10.50 & 5.50 \\ 1841 & 12.00 & 10.00 & 6.00 \\ 1842 & 9.00 & 6.00 & 4.00 \\ 1813 & 10.12 & 8.12 & 6.00 \\ 1844 & 9.50 & 7.50 & 5.50 \\ 1845 & 13.00 & 10.50 & 6.87 \\ 1846 & 9.12 & 6.25 & 3.87 \\ 1847 & 12.75 & 8.25 & 4.25 \\ 1849 & 9.00 & 6.00 & 3.37 \\ 1849 & 12.00 & 7.00 & 3.50 \\ 1850 & 10.12 & 8.12 & 5.00 \\ 1851 & 10.00 & 6.50 & 5.12 \\ 1852 & 9.00 & 7.00 & 5.75 \\ 1853 & 11.50 & 9.50 & 7.50 \\ 1854 & 15.00 & 12.25 & 5.00 \\ 1855 & 19.00 & 11.00 & 6.25 \\ 1856 & 13.00 & 8.00 & 6.00 \\ 1857 & 15.00 & 12.50 & 8.50 \\ 1858 & 15.50 & 12.50 & 8.50 \\ & & & \\ 1859 & 14.50 & 12.50 & 8.50 \\ 1860 & 16.87 & 11.00 & 8.00 \\ 1861 & 7.50 & 4.50 & 3.50 \\ 1862 & 8.25 & 6.00 & 4.50 \\ 1863 & 14.00 & 9.25 & 6.50 \\ 1864 & 30.00 & 20.00 & 9.75 \\ 1865 & 22.00 & 15.00 & 13.25 \\ 1866 & 23.50 & 18.25 & 1.50 \\ 1867 & 19.25 & 12.50 & 9.75 \\ 1868 & 20.50 & 14.00 & 7.50 \\ 1869 & 21.00 & 12.00 & \\ 1870 & 24.00 & 10.00 & \\ & & & \\ 1871 & 11.25 & 7.25 & 6.25 \\ 1872 & 15.00 & 9.50 & 7.25 \\ 1873 & 20.00 & 12.25 & 9.25 \\ 1874 & 13.25 & 9.00 & 7.00 \\ 1875 & 16.25 & 10.25 & 5.50 \\ 1876 & 15.00 & 6.75 & 5.00 \\ 1877 & 16.50 & 12.50 & 8.00 \\ 1878 & 18.00 & 8.00 & 5.00 \\ 1879 & & 5.00 & 3.00 \\ 1880 & 14.00 & 7.00 & 4.00 \\ 1881 & 14.00 & 6.00 & 4.00 \\ & & & \end{array}$

PRICES OF CODFISH PER QTL.

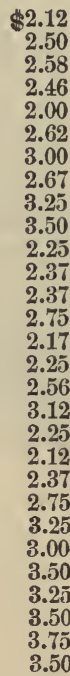

\section{Georges.}

4.25

4.00

3.12

3.80

5.75

8.50

8.00

8.00

6.12

7.37

7.37

6.87

4.50

5.75

5.50

5.25

5.25

5.25

4.75

4.25

4.00

5.50

8.00
Bank. Shore.

$\$ 4.00$

5.00

5.12

5.00

4.75

4.50

4.25

3.50

3.62

4.50

3.87
$\$ 3.75$

3.87

5.00 


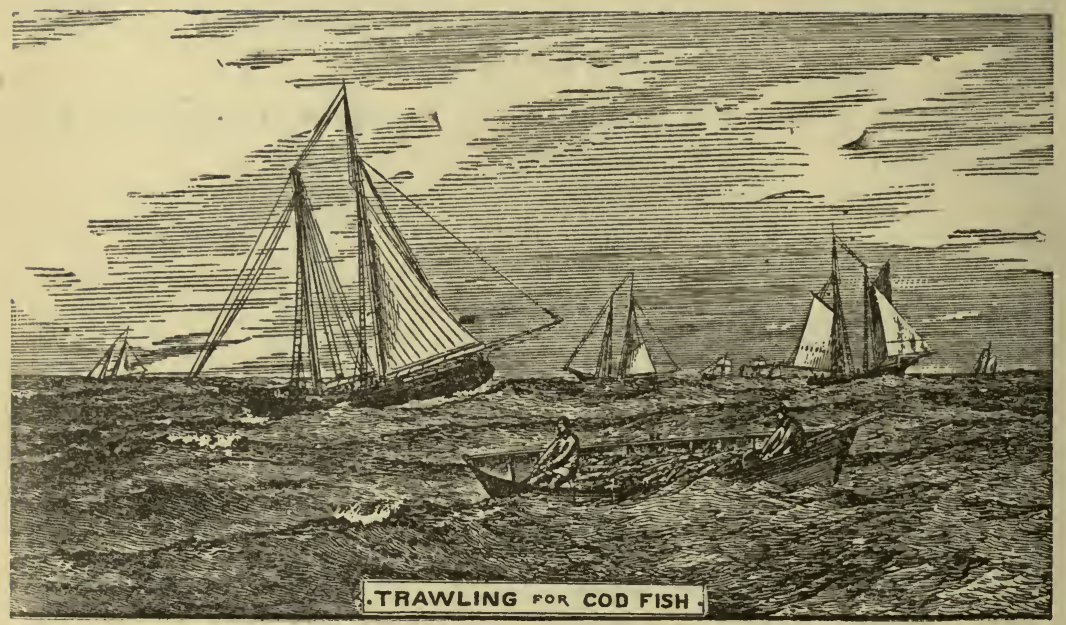

\section{Leaves from a Log-Book-Remarkable Adventures and Hair-Breadth Escapes.}

BY J. W. COLLINS.

The following incidents-extracts from a daily journal kept by the writer while engaged in the fresh halibut fishery, and remarkable and well authenticated personal experiences of others-it is hoped, will convey to the reader some idea of the vicissitudes and perils to which our fishermen are exposed while pursuing their hazardous occupation. At the same time some knowledge may be gained of the daily life of a class of men among whom may be found examples of courageous daring and hardihood unsurpassed by anything which has ever been written. There are few, indeed, among those who have been engaged in the Gloucester fisheries who cannot relate truthful though startling tales of their personal adventures. Though none of our fisheries are exempt from peril, it may be safely said that the winter codfishery on Georges Bank, and the trawl fishery, especially that for haddock and halibut in winter, are the most dangerous of all. The last named -the fresh halibut fishery-from its peculiar nature furnishes much that is interesting, and will be especially considered here, though in quoting from the log-book, much of the writer's own experience must necessarily be given. So sharp is the competition in this business that fearful risks are taken in securing fares and carrying them to market.

The operation of setting and hauling the trawls goes on with all possible 
diligence whenever the weather will permit it. And in this matter of suitable weather the fishermen are not at all fastidious, nor can they afford to be. Thus the boats are often caught out in heavy squalls and driven away to float helplessly for days and nights until their occupants succumb to hunger or succeed in reaching some other vessel. Other dories" are upset on "rough" days, and though the men are sometimes rescued, more frequently they become exhausted and sink in the icy waters. Again, the men will put out in the midst of the dense fogs so characteristic of the Newfoundland Banks, and lose the position of the vessel in spite of loud fog-horns; or, in winter, they will be overtaken by blinding snow-squalls, hiding everything in a thick and turbulent waste of dashing spray and drifting snow.

On idle days, or when, late in the evening, the crew gather in the forecastle for their usual lunch before turning in, you will hear thrilling tales of these adventures, and escapes by only the breadth of a hair from boundless torture or sudden death. Nor are these "yarns"-they are reserved for the gaping crowd around the stove at the corner grocery ashore. When fo'c's'le men compare notes, each one knows the rest are critics, and dares not draw the long bow-at least not beyond the limit of true dramatic effect. Yet whoever heard that these narrations of peril ever deterred a dory's crew from putting off when it seemed necessary? Mr. Stedman, you are right :-

\section{"Brave are the hearts that man}

The fishing smucks of Gloucester, the sea-boats of Cape Ann."

\section{STARTING FOR THE BANK.}

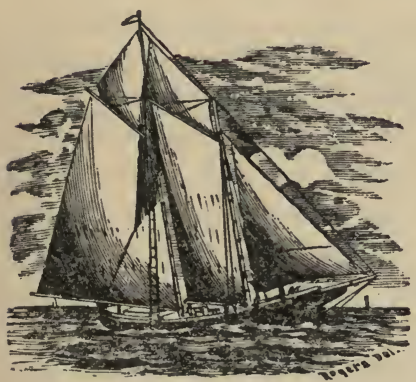

The fittings, including ice, provisions, water, boats, and fishing apparatus, having been taken on board and snugly stowed away, next comes the day of sailing, which oftentimes is quite an episode in the fisherman's life, since he must then part with all he holds dear, knowing full well what dread uncertainties lie between his departure and return. The sailing day may occur at any season, and each time may vary in some particulars, though the general features remain the same. The account of the day of which I now write I find in my journal under date of January $24,1879$.

The men composing our crew came down to the wharf, alongside of which lay our vessel, about half-past eight o'clock in the morning, many of them bringing a small calico bag containing a small supply of clean clothes, and providing themselves at the fitting-out store with pipes and tobacco for the trip. Two of the crew are sent off to the "baiter"-a vessel lying at anchor 
in the harbor with flag flying-and soon return with four or five thousand stiffly frozen herring, which are hastily stored in the hold under straw to prevent their thawing. A little before noon-the tide serving at that timewe got underway and worked out of the harbor with a moderate southwest wind. After passing Eastern Point our course was shaped east by south, and we went skipping away before the wind, leaving Brace's Cove, Bass Rocks, and Thacher's Island with its two tall lighthouses, on our port hand; while astern the snow-covered shores of Magnolia, and the more distant land about Salem and Marblehead soon grew indistinct, and was finally lost to view.

In the meantime the ropes have been coiled, dories turned bottom up and securely lashed, and the vessel pumped out; while our ears have been pleasantly greeted by the ding dong of the cook's dinner bell, calling us away from "straightening up things on deck." The crew is divided into two gangs for meals, the table in the forecastle not being large enough to accommodate all. One of the second gang now came aft saying: "I'll keep her along, skipper, while you get dinner," whereupon I gave up the wheel which I had held since starting, and went with the first gang down to dinner. For dinner we had the usual first meal at sea, which, hastily prepared, consists of boiled salt beef and potatoes, white biscuits, pilot-bread and butter, strong tea and fried beefsteak. This bill of fare is very much changed as soon as the "Doctor" (cook) has time to prepare a greater variety, and though beefsteak or other fresh meat is rarely seen after the first few days out, the table is well provided with plenty of good bread, cakes, pies, \&c., and last, though not least, the finest fish are served up in a manner rarely equalled elsewhere.

After dinner the patent-log is put out, a note made of the bearing and distance of the land, and then everybody is called aft to "thumb the hat," in order that the watch may be set. All hands now stand around an inverted hat, taking hold of it so that the thumbs are on top of the rim. The skipper then turns away his head, and, reaching over, touches one of the thumbs, and then counts around from left to right any number previously decided upon. The first one that the count reaches has the first watch. The counting then begins at the next thumb with "One," and so on until each man knows his watch, and with the injunction from the skipper, "Remember now whom you call," the performance ends, and the one having the first watch takes the wheel.

We now have an opportunity to notice critically the vessel, upon the merits of which we depend not only for the successful issue of the voyage, in a pecuniary sense, but for the preservation of life itself. She is a clipper schooner of 80 tons, with fine lines and broad beam, but "snug-rigged," that is, carrying but one jib, as befits the winter weather. Forward, on the 
larboard side of the foremast, lies coiled a huge pile of manila cable, four hundred fathoms, or nearly a half mile in length. The main deck is divided into small compartments by "checker planks" eight or ten inches wide, set on edge, crossing each other at right angles and securely fastened in their places ; they are to prevent the fish from sliding across the deck, and on top of these are placed the dories, three on each side of the vessel.

The cabin is ten or eleven feet square, tastefully finished in ash and black walnut, and containing four bunks-one for my own use, the others for such members of the crew as have secured them by lot, since there are no underofficers to claim them by right. The furniture of the cabin consists of a stove securely fastened to the floor, a marine clock, looking-glass, barometer, and chronometer, the latter being placed on the seat which runs around the side of the cabin, supplying the place of chairs. The forecastle, also, is nicely finished, and forms the dining-room of the vessel and the sleeping apartment for part of the crew. A door opens from the forecastle into the forehold, where the provisions, water and fuel are stored, and where the cook has his pantry.

Our crew, aside from the cook and myself, number twelve men : stout, hardy and brave fellows, selected for their proficiency as seamen and fishermen. Each one is known to be "a good man on board a vessel," which means that he is an agreeable shipmate and can always be relied on to perform any necessary duty without flinching.

But while we have been looking over the vessel, the wind has increased; the land has sunk below the horizon, and our little schooner is rushing along at a lively rate, occasionally sending her lee rail under, as she lurches in the rising sea; while frequent dashes of spray come flying over the weather-quarter rail. A rival vessel, also bound to the Banks, is close by, and although our topmast bends and seems likely to go over the side, we do not shorten sail until we see a movement for that purpose on board the other. We have already carried our light sails long enough, and the staysail comes fluttering down to the deck, like a great white bird; the gaff-topsail is also clewed up, and away goes a man to furl it, nimbly climbing the rigging to the mainmast head.

A little before seven o'clock, P. M., our vessel took a heavy lurch to leeward, sending her lee rail so far under that, when she straightened up, the deck was nearly full, and several bucketsful came down the companion-way, wetting the bed clothes in the lee bunks, and also the boots lying on the floor. This episode called forth exclamations more forcible than polite from the occupants of the lee bunks, and shouts of laughter from their companions, who could see only the ludicrous sicle of the accident. The sea by this time had risen sharp and choppy, and so frequent were the lurches-the mainboom often going under to the slings-that we soon after double-reefed 
the mainsail. This done, I go below for the night, giving the usual order to "call me if there is any change in the force or direction of the wind."

Thus ends the first day out; and never, perhaps, were words written which so fitly describe the situation of the outward bound fisherman as those of Byron, when he says :

"Once more upon the waters; yet once more, And the waves beneath me as a steed

That knows his rider. Welcome to their roar! Swift be their guidance wheresoe'er it lead; Though the strained mast should quiver as a reed, Still must I on : for $I$ am as a weed

Flung from the rock, on ocean's foam to sail

Where'er the surge may sweep, the tempest's breath prevail."

\section{RUNNING FOR THE BANK IN A GALE.}

Sunday, Jamuary 26 th, 1879.-This day began with a strong breeze, westnor'west, and the barometer, which was on 29.15 , indicated still more wind. The night (or early morning) was intensely dark, and having previously taken in and furled the mainsail and gaff-topsail, we double-reefed the foresail at 1.20 A. M., and took the bonnet out of the jib. At this time the wind was increasing rapidly, blowing in sharp puffs, and hauling to N. N. E., while it grew cold very fast, causing the flying spray to soon congeal into ice on the rigging and such portions of the hull as were not too much under water. At $4.3^{\circ} \mathrm{A}$. M. the wind had freshened to a gale, and the sea ran sharp and high, causing our vessel, which was running with the wind abeam, to occasionally take a heavy lurch to leeward. Fearing the dories might be injured if we continued on our course, we furled the jib and hove to under the reefed foresail until 7 o'clock in the morning, at which time we kept off again, the wind in the interim having changed to N. N. W., which was fair for us, though it was still blowing hard.* It was intensely cold all the morning and ice made rapidly on deck and about the rigging. Notwithstanding this, however, we set the jib and riding-sail soon after breakfast, and a half hour later saw a vessel at anchor ahead, which, as we approached nearer, we knew was the Everett Steele. There was no one to be seen on her deck, and as we passed close to her stern our men, most of whom had gathered aft on the quarter, joined in a general shout. This had the desired effect, and four or five of the Steele's crew rushed up, bare-headed and stocking-footed, to be greeted by the laughter of our fellows as we went dashing by. At ro o'clock, A. M., we passed a brig, which was lying to

*The schooner Howard, of Gloucester, was knocked down and eame near being lost in this gale; the Thresher, of the same port, also had her deck swept, and it is believed by many that the Gwendolen, which was also bound to the Bauks, went down the same day, since she was never seen afterwards. 
under main-staysail. 'She was badly iced up, and appeared to be laboring heavily, rolling her lee yard arms nearly to the surface of the water.

To one standing upon the deck of our little schooner at this time, the scene, though grand and impressive, had a decidedly wintry and dreary look. The ice-covered hull and rigging, the dark masses of snow-laden clouds driven to leeward by the gale, which shrieked and whistled through the ropes, and lashed into the wildest fury the foam-flecked waters, piling them into huge waves, was a sight, that, once seen, could never be forgotten. But on we went, now plunging down the side of a big sea, again lurching heavily, filling the deck with water, which, as the vessel straightened up again, went dashing over to the weather-side, often out over the rail, and through the binnacle into the cabin.

The remark of one of our boys, that "any one who can't swim had better take a back seat," was certainly very apt, but the gravity of the situation, and the damage incident to running in such a gale, with the sea on the quarter, was better expressed by the order frequently shouted to the man at the wheel, "Watch her sharp now! Keep your eye to wind'ard, and if you see a big one* coming swing her off and let her take it stern to."

During the afternoon there was a dangerous and nasty cross sea running, rendering it extremely unsafe to continue on our course during the night. We therefore took in the jib and furled it before dark, and at 5 o'clock, P. M. hove to under double-reefed foresail and riding-sail. At 7 P. M. the gale still continues with undiminished force, but, like a gull with its head under its wing, our litle "sea-boat" rises and falls, safely breasting the foam-crested waves that go seething by, leaving behind them a phosphorescent track, which lights up the surrounding darkness, giving it a peculiarly weird and strange appearance. Thus closes this day, the events of which I now sit down to write before turning in for the night.

\section{WASHED OUT OF:A DORY-A TERRIBLE STRUGGLE FOR LIFE.}

On a breezy day in November, r 880 , the crew of the sch. Grace L. Fears, -a fresh halibut catcher which lay at anchor in the "Deep Water"-started out to haul their trawls. Although it was rough, the waves frequently breaking, and the wind blew in gusty puffs, it was not considered exceptionally dangerous to venture out by the fishermen, since the tide, which ran quite strong to windward, would materially assist them in again reaching the vessel.

In one of the dories were William T. Lee and Jack Devine. When these two had safely hauled the larger part of their trawl, and the boat, which

* A large breaking wave. 
had on board several halibut, lay hawsed up in such a manner that her side was somewhat exposed to the sea, a huge curling wave came tearing along, striking with full force both men and dory, the former being thrown overboard, and the latter nearly filled with water. Devine went over the side, but, fortunately for him, was near enough to grasp the gunwale of the boat and climb into her. With Lee, however, the case was quite different. The sea broke over the dory with such violence as to throw him a distance of a dozen or fifteen feet from her. He was so much encumbered with heavy clothing and sea-boots that he could not prevent himself from sinking. In the meantime his dory-mate fastened the trawl to the bow of the boat so as to keep her as nearly head to the sea as possible, and, frightened for his own safety, made desperate efforts to bail out the nearly filled dory. As good fortune would have it, however, the slacking of the trawl allowed the dory to drop slowly to leeward, and the tide also swept the struggling man slowly to windward, who, as he sank for the second, and, as he thought, last time, felt his hand come in contact with the trawl about two or three fathoms under water. It is said that a drowning man will clutch at a straw, and it requires no great stretch of imagination to understand how eagerly this stout line was grasped by the sinking fisherman. Though quite exhausted by his efforts, he still retained his wits and his indomitable courage, and at once began to haul himself toward the dory, hand over hand, along the line. Almost as soon as he began this process, one of the stout hooks caught in his forefinger and passed completely through it near the end. To an ordinary person this would have been certain death under such circumstances, but, determined not to give up while life lasted, he reached the other hand as far up on the trawl as he could, and, with a desperate pull, tore the hook completely through or out of his finger end, making an ugly wound.* He was now able to proceed, but, just as he got his head above water and caught his breath, just at the very last instant of endurance, with his hand clutching the gunwale of the boat, a second hook caught in the leg of his trousers. Though he shouted to his companion, the man rendered no assistance, fearing that, should he move to the side, the water-logged dory would upset. Lee mustered all of his fast ebbing energies and, by one last and mighty effort, pulled himself over the side of the boat, and fell senseless to the bottom. All of this, though long in the telling, occupied a very short time, but the seconds were eventful ones; and perhaps no better voucher for the invincible pluck of our fishermen could be given than by the statement of the single fact that, after recovering somewhat from his exhaustion, unmindful of his torn and bleeding finger as well as of the breaking waves sweeping

*The mutilated finger was seen by the writer while yet it remained unhealed, and its torn and mangled appearance gave ample proof of the desperate nature of the struggle in which the wound had been received. 
by, Lee would not return to the vessel until he had finished hauling the trawl, thus accomplishing the task he started out to do.

The above is one of the many instances that might be mentioned to show that some men seem endowed with a luck all their own in escaping from perilous positions when their companions, apparently in no worse a scrape, have lost their lives. This is largely due, to be sure, to their indomitable * pluck and perseverance in efforts to save their lives so long as a breath remains, and a presence of mind that enables them to make the most of any fortunate circumstance.

\section{LOSS OF THE FOREST BELLE.}

The schooner Forest Belle was lost on her first trip to the Grand Bank in the latter part of 1868 , and was supposed to have foundered in a furious tornado that swept the western Atlantic in December of that year. She was commanded by Capt. Moses M. Welch, a young man of great promise, who was so much esteemed by those of his own profession that several of his crew were skippers, who, having hauled up their own vessels, chose to make this trip to the Bank with him. In every sense the crew was an excellent one, and the vessel was considered one of the finest that ever sailed from Gloucester. The following comprised the crew : Robert M. Collins, Daniel Lufkin, Randall McLellan, Arthur Ulmer, Sylvanus Gott, Geo. Bartlett, Geo. Kane, John A. Kelly, James McDonald, Wm. Hickman and Wm. B. Rowe.

Come, all you hardy fishermen,

Who winter fishing go;

Who face those northern wintry blasts-

Fierce storms of hail and snow-

Pause here awhile and listen,

While a dreadful tale I tell

Of a winter gale and the sad, sad loss

Of the schooner Forest Belle.

A finer vessel ne'er was launched, Or o'er the wild waves flew;

And braver hearts were never known Than those of her hardy erew.

Twelve sturdy men in prime of life, Daring winter gale and storm,

Left tender wives and mothers dear

To wateh for their return.

'Twas in the Fall of sixty-eight, November, the nineteenth day,

These fearless men, with a nor'west gale, From Cape Ann bore away:

Bound away unto the Grand Bank, O'er the white-capped waves they fly; Ah! little dreamed those seaman bold That so soon they all must die.
With tender words and fond caress

They parted from those dear.

"Cheer up," said they, "we'll soon be back, If God our lives doth spare."

With aching hearts wives, mothers, weepFor none can tell the tale

Of the Belle's sad fate, but all suppose She foundered in a gale.

What those daring men did suffer No one will ever know,

Upon that wild and wintry sea, When howling winds did blow.

The raging waves engulfed their bark-

No hand was there to save

That little band of gallant men

From a cold and watery grave.

God bless the mourning friends they've left, And comfort those who weep

For husbands, sons and brothers dear, Now buried in the deep.

Though parted from their loved ones here, There is a brighter shore,

Where they may meet them once again . There partings are no more 


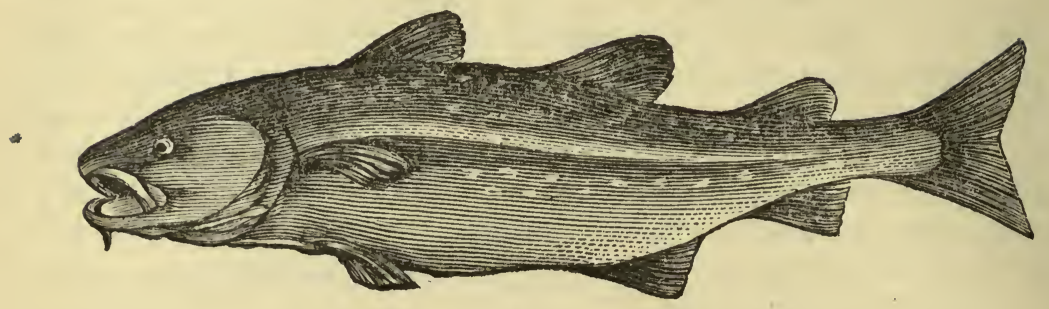

\section{Notable Fishing Fares.}

There is considerable rivalry among the Cape Ann skippers in the matter of bringing in large fares, and this friendly competition not only develops the skill and daring of the fishermen, but keeps them ever on the alert to try experiments and to discover new methods of catching fish and new fishing grounds, thus bringing into play those faculties which tend to promote the fishing interests and add to their productiveness. We have kept a record of many of these big trips, and take much pleasure in publishing them in the pages of the "Fishermen's Own Book."

\section{BANK TRIPS.}

The best codfish fare ever landed at this port was in October, I880, when the Br. sch. Kelso, Capt. Benjamin Hines, arrived here from Grand Bank with $220,000 \mathrm{lbs}$. large codfish, 90,000 to I00,000 lbs. medium and small do., and 1600 lbs. fletched halibut. The next best Bank fare was 300,000 lbs. codfish, in round numbers, landed in 1878 by sch. Herman Babson, Capt. Charles J. Lawson, which schooner also landed $195,000 \mathrm{lbs}$. on one trip in 1880. The five best Bank fares ever landed by a single vessel were received in the sch. Grand Master, Capt. Byron Hines, of Pubnico, N. S., sailing from this port: in 1875 she landed a fare of $240,000 \mathrm{lbs}$; in 1877 , one of $270,770 \mathrm{lbs}$., stocking $\$ 6,5^{80}$; in 1878 , one of $250,000 \mathrm{lbs}$.; in 1880 , one of $250,000 \mathrm{lbs}$; and in $\mathrm{I} 88 \mathrm{I}$, one of $275,000 \mathrm{lbs}$. Among other good codfish fares we notice those of the Centennial, $250,000 \mathrm{lbs}$. in 1878 , and 250,000 lbs. in 1881. Among other good fares in the last named year the Webster Sanborn hailed for 250,000 lbs., the New England for 225,000 lbs., the Shiloh of this port, Hattie L. Newman of Beverly, and Water Lily of Yarmouth, N. S., each 200,000 lbs. ; the Davy Crockett, from a hand line trip to Western Bank, for 2 10,000 lbs., and the Thresher for $190,000 \mathrm{lbs}$. codfish and 10,000 lbs. halibut. For the week ending Sept. 8 six Grand Bank fares were received, aggregating $\mathrm{I}, \mathrm{II}_{5}, 000 \mathrm{lbs}$. codfish, including two fares of 250,000 
and one of $225,000 \mathrm{lbs}$.; from March 8 to October ${ }_{5} 5$ the Josie $M$. Calderwood made five trips to the Western and Grand Banks and Banquereau, taking in round numbers $400,000 \mathrm{lbs}$. codfish and $55,000 \mathrm{lbs}$. halibut, stocking $\$ 10,475$, believed to be the best season's work in the Bank codfishery. The largest amount of Bank codfish ever landed at Gloucester in a single week was 3,620,000 lbs., twenty-five fares, for the week ending July $27, \mathrm{r} 876$, the total codfish receipts for that week being $4,448,000 \mathrm{lbs}$; for the week ending Sept. 16, 1880, fifteen fares of 2,057,000 Bank codfish were landed at Gloucester, and for the week ending Sept. 13, 1877, 2,000,000 lbs. Sch. Plymouth Rock took 225,000 lbs. on one Bank trip in 1878 . On a five months' trip in 1873 sch. Carrie P. Morton, Capt. Charles A. Keene, took $192,000 \mathrm{lbs}$. codfish and $28,050 \mathrm{lbs}$. halibut, stocking $\$ 7,888$, the crew sharing $\$ 326.16$, the best stock on one trip in this fishery of which we have any record. Sch. Knight Templar, Capt. Michael McDonald, stocked \$7,681.25 on one trip in 1873 , being absent only two and one-half months. In 1877 sch. Concord, Capt. John Dago, landed $185,000 \mathrm{lbs}$. codfish and 57,000 lbs. halibut, from a Western Bank trip, stocking $\$ 7,100$ in four months and two days. Sch. Ben: Perley Poore, Capt. Charles H. Nute, landed 180,695 lbs. codfish and $10,597 \mathrm{lbs}$. halibut from a fourteen weeks' trip in 1872 , stocking $\$ 6,345.69$, the crew sharing $\$ 257.29$. In 1879 the Corinna H. Bishop arrived home in August from a seventeen weeks'. Bank trip, with 186,780 lbs. large codfish, 2,315 lbs. small do., and r,214 lbs. fletched halibut, having sold 1 4,000 lbs. in Newfoundland, giving her a catch of 204,309 lbs. fish.

\section{FLETCHED HALIBUT.}

The largest Bank fare of fletched halibut ever landed at Gloucester was 153,044 lbs. in sch. Reunion, Capt. Belcher Torrey, in 1868. She had also 23,875 lbs. codfish, and stocked on a twelve weeks' trip $\$ 8,354$ (the best Bank stock on one trip yet reported), the crew sharing $\$ 286.63$.

\section{FRESH HALIBUT.}

The largest fare of fresh halibut ever landed at Gloucester was 140,000 lbs., by sch. G. P. Whitman, Capt. Jerome McDonald, from a Bank trip in 1877. The next largest fare was landed by sch. Centennial, Capt. Dennis C. Murphy, from a three weeks' trip in 1876 , landing 129,577 lbs. and 5,000 lbs. codfish; on her first ten trips the Centennial took $\mathrm{r}, \mathrm{I} 60,000 \mathrm{lbs}$. halibut. In $1875 \mathrm{sch}$. Chester $R$. Lawerence, Capt. Thomas Hodgdon, took on one trip 126,566 lbs. halibut and 5,480 lbs. codfish. The next year sch. Davy Crockett took 103,000 lbs. on her first trip, which sold at 6 and 3 cts. per lb. for white and gray. Sch. William T. Merchant took ro3,450 lbs. in twentyfive days, in 1868 . The best fare landed in $188 \mathrm{I}$ was brought in by the 
sch. Plymouth Rock; she weighed off 96,539 lbs. halibut and I,500 lbs. codfish, having a sufficient quantity of unsaleable halibut to bring her catch up to $100,000 \mathrm{lbs}$; her stock was $\$ 2,55^{\circ}$, the crew sharing $\$ 85$, on a voyage occupying four weeks and two days. Among the receipts in one week in 1876 were I 4,540 lbs. in sch. Carrie P. Morton, 99,980 in sch. Davy Crockett, 95,000 lbs. in sch. Edwin C. Dolliver, and two other vessels had upwards of $70,000 \mathrm{lbs}$. each the same week. The largest amount of halibut ever received in Gloucester in a single week was for the week ending Feb. ro, 188 I, when the receipts were $740,000 \mathrm{lbs}$. from the Banks and $122,509 \mathrm{lbs}$. from Georges, 862,500 lbs.

The best stock on a single trip in the Bank halibut fishery was made by sch. N. H. Phillips, Capt. William McDonald, in 187 I. She landed $47,65^{\circ}$ lbs. halibut and 9,390 lbs. codfish, stocking in five weeks $\$ 5,36 \mathbf{r}$. Is two successive trips that season she stocked $\$ 9,142$, the crew sharing $\$ 353.42$ for nine weeks' fishing. The same year sch. Mary Carlisle, Capt. William Thompson, stocked $\$ 4,738.75$ on one trip, the crew sharing $\$ 236.25$. In I 879 sch. Thresher stocked $\$ 4,464.82$ on one trip. Sch. Sarah P. Ayer stocked $\$ 4,25$ I on a trip in 1869 . In 1868 sch. Aphrodite, Capt. Randall $\mathrm{McDonald}$, stociked $\$ 4,246.37$, and the previous year the same vessel stocked $\$ 4,126$ on one trip; sch. William T. Merchant, Capt. Nelson McKenney, stocked $\$ 4,200$ on a twenty-six days' trip in 1868. Sch. C. B. Manning, Capt. Charles H. Nute, stocked $\$ 4,033$ on a halibut trip in 1869 . In 1880 the best stock was made by sch. Willie $M$. Stevens, her catch of $81,000 \mathrm{lbs}$. selling for $\$ 3,870$; time about three weeks. The best stock in $188 \mathrm{I}$ was made by the Grace L. Fears, 75,000 lbs., $\$ 3,553$, crew sharing $\$ 121.79$. On one trip in $1876 \mathrm{sch}$. Epes Tarr was absent three weeks, and took in four days' fishing 54,500 lbs. white and 24,442 lbs. gray halibut, whic's s sld for $\$ 3,165$, the crew sharing $\$ 120$.

The best season's stock in this fishery was made by sch. Gertie E. Foster, Capt. Edward Morris, in 1875 . In eleven months she landed $668,517 \mathrm{lbs}$. halibut and $19,220 \mathrm{lbs}$. codfish, stocking $\$ 26,071.56$. The next best stock was that of sch. Willie M. Stevens, Capt. John McInnis, in 1880 ; from Dec. 24,1879 , to Dec. 15,1880 , her gross stock was $\$ 22,107.35$, and her net stock $\$ 20,959.06$, the crew sharing $\$ 706.06$. The best season's stock in this fishery in I88I was made by Capt. Nathaniel Greenleaf in sch. Grace L. Fears, $\$ 20,385$ net. Sch. Racer, Capt. Walter M. Falt, stocked \$22,000 in 1866 ; Capt. William Thompson was high line of the crew, making $\$ \mathbf{I}, 300$. In 187 I Capt. Thompson made nine trips in sch. Mary Carlisle, stocking $\$ 17,275.53$, her crew sharing $\$ 858.62$. In 1869 , ' 70 , ' 7 I , Capt. Thompson stocked $\$ 46,87$ I. In $1873, ' 74,75$, Capt, Edward Morris stocked $\$ 64,769.78$. 


\section{GEORGE'S FARES. ·}

The largest codfish fare ever received from Georges was I23, I I5 lbs., round, with 862 lbs. halibut, by sch. S. R. Lane, Capt. Solomon Jacobs, in I 875 ; the Lane stocked $\$ 2,554$ on this trip, her crew sharing $\$ 90.8 \mathrm{I}$, and the cook making $\$ \mathbf{5} 5.62$. In 188 I the sch. Triton, Capt. Edward Groves, weighed off from one George's trip 54,000 split codfish, 30,000 lbs. round do., (equal to about II I,000 lbs. round), and 3,000 lbs. halibut.* In ${ }^{*} 875$ sch. Carl Schurz, Capt. Neil S. McPhee, landed a Georges fare of 107,200 lbs. codfish and 3,800 lbs. halibut, stocking $\$ 2,580$; crew shared $\$ 105.04$, cook made \$143.95. Sch. Everett Steele, Capt. Joseph Goslin, weighed off 102,075 lbs. on one trip in 1869. In $1868 \mathrm{sch}$. William J. Dale, Capt. David A. Osier, landed a fare of $100,575 \mathrm{lbs}$. On a fourteen days' trip in $1867 \mathrm{sch}$. Montana took $100,162 \mathrm{lbs}$, , and in two successive trips that year landed 183,362 lbs., making a gross stock of $\$ 3,417 \cdot 32$. In 1866 the $\mathrm{Mad}$ ame Roland had a fare of $99,338 \mathrm{lbs}$. In 1877 the Riverdale took 93,378 lbs., and the William J. Dale 91,500 lbs., each on one trip; the Hattie $S$. Clark, Capt. Hiltz, took 172,500 lbs. on two trips in three weeks. In 1879 the Sarah P. Ayer had a trip of 60,000 lbs. split codfish. The best fare in 1880 was $66,000 \mathrm{lbs}$. split codfish and 1,500 lbs. ha!ibut, in sch. Hyperion, and the next best fare $65,000 \mathrm{lbs}$. split codfish and 2,000 lbs. halibut in sch. David M. Hilton. On five Georges trips in the Spring and Summer of 188 I, sch. Procter. Brothers took 2 I, 544 codfish in number, weighing I 7 I, 000 lbs. Of her crew of eleven men Mr. George Williamson was high line, taking $2,4 \mathrm{I} 7$ fish, while the low line caught $\mathrm{r}, 43 \mathrm{I}$.

The best stock on a single Georges trip was $\$ 2,833.29$, by sch. Madame Roland, Capt. James Lunderkin, in 1865 ; in two trips that year she stocked $\$ 5,050.75$. Sch. Everett Steele, Capt. Cash, stocked $\$ 2,824.55$ in 1865 , $\$ 2,760.69$ in 1869 , and $\$ 2,738.95$ in 1866 , on single trips. In $1865 \mathrm{sch}$. Laughing Water, Capt. Joseph Goslin, on eleven Georges trips stocked $\$ 14,843.84$, and afterwards going to the Bay of St. Lawrence for mackerel, stocked \$3, Iro.46, making her season's stock \$17,954.30; the high line made $\$ 1,105.37$, and her cook $\$ 1,402.93$.

\section{GREENLAND TRIPS.}

The largest fare of fletched halibut ever landed at this port was 179,575 lbs., by sch. Bunker Hill, Capt. John McDonald, from a Greenland voyage in I881, stocking $\$ 9,000$. The same year sch. Herman Babson, Capt. Charles J. Lawson, took 178,000 lbs. fletched halibut, and a quantity of other fish, on the coast of Greenland, stocking $\$ 11,734.60$ on a four months' trip; the

*In 1879 the Triton had a trip of 69,012 lbs. split codfish and 1,100 lbs. halibut. 
crew shared $\$ 400.7 \mathrm{I}$ each, and the skipper's share and commission amounted to $\$ 872.07$. In $1870 \mathrm{sch}$. Caleb Eaton, Capt. John S. McQuinn, landed $177,300 \mathrm{lbs}$. fletched halibut, and a quantity of salmon and fins, from a four months' Greenland trip, stocking about $\$ 20,000$.

\section{HIGH PRICES FOR HALIBUT.}

In the Fall of 1865 Capt. L. A. Story, now of Magnolia, caught from a dory while engaged in hand-line fishing in Boston Bay, a halibut weighing 194 lbs., which was sold to Messrs. Parsons \& Co. of Commercial Wharf, Boston, at 28 cents per pound, making the total price $\$ 54 \cdot 32$. The largest price ever received for a fare lot was $2 \mathrm{I}$ cts. per $\mathrm{lb}$. for white and $\mathrm{I} 4 \mathrm{cts}$. for gray, for 9,000 lbs. brought in by sch. T. L. Mayo. In January, I88I, halibut sold at 16 and 12 cts. per lb. for white and gray.

\section{QUICK BANK AND GEORGES TRIPS.}

Sch. Cunard, Capt. Garrett Galvin, made a salt trip to the Banks in $71 / 2$ weeks in 1878 ; sch. Carrie P. Morton, Capt. Charles A. Keene, in $21 / 2$ months in 1873 ; sch. Ben: Perley Poore, Capt. Charles H. Nute, in 14 weeks in 1872 ; sch. Reunion, Capt. Belcher Torrey, a fletched halibut trip to the Banks in 12 weeks in 1868 . In 1877 sch. Augusta H. Johnson, Cápt. George A. Johnson, made a fresh halibut trip to Western Bank in 13 days, and the same year sch. Edward Grover made three such trips inside of 14 days each and another in 16 days. In $188 \mathrm{x}$ sch. Grace L. Fears, Capt. Nathaniel Greenleaf, made a Grand Bank trip for halibut in 14 days, 6 hours, securing 40,000 lbs. halibut, the crew sharing $\$ 9$ I.50. The same year sch. $G$. $P$. Whitman, Capt. Jerome McDonald, made a Grand Bank trip in 16 days, taking $6 \mathrm{r}, 580 \mathrm{lbs}$. halibut; on four trips that year the Whitman averaged 4 weeks each, the crew averaging $\$ 80$ each per trip. The Nathaniel Webster also made a Bank halibut trip in 16 days in $188 \mathrm{I}$; the David $A$. Story, Capt. Joseph Ryan, one in 18 days, stocking $\$ 3,02 \mathrm{I}$, crew sharing $\$ 103.62$; sch. H. A. Duncan, in 17 days, took 80,000 lbs. codfish. Sch. Franklin Snow, Capt. McDonald, stocked $\$ 2,385.47$ on an I 8 days' trip to Western Bank in 1868, and sch. Aphrodite, Capt. McDonald, stocked \$4, I 26 on a 20 days' trip in 1867 , the crew sharing $\$ \mathbf{1} 7$ r.5 r. In 1880 sch. Alice M. Williams, Capt. Dennis C. Murphy, made a Banquereau trip in 16 days, returning with 38,000 lbs. halibut. Sch. Willie Seavy, Capt. Robert White, of Newcastle, N. H., with a crew of eight men, sailed on a Western Bank trip April r6, I88 r, and arrived at Portland May I8, with a fare of 450 qtls. prime codfish, the result of 21 days' fishing. In 1867 sch. Hattie S. Clark, Capt. Hiltz, took 90,000 lbs. codfish in a week's trip to Georges, and made two trips inside of $2 \mathrm{I}$ days, landing 172,500 lbs. cod. In November, 188I, sch. Alice M. Gould, 
of Portland, made a La Have Bank trip in 5 days, securing 45,000 lbs. fish, which sold for $\$ 1,200$, the crew sharing $\$ 80$ each, or $\$$ I 5 per day.*

LONG TRIP.-Sch. Commonwealth arrived home from a Bank halibut trip in April, I88I, having been absent $71 / 2$ weeks. She was 16 days on the passage home.

\section{SHORE FISHING.}

The largest haddock fare ever caught by a Gloucester vessel was landed at Boston in February, 1880 , by sch. Martha C., Capt. Charles Martin. She weighed off $72,000 \mathrm{lbs}$., which sold at $\$ 2.50$ per 100 lbs., stocking $\$ \mathrm{r}, 803$, the result of two days' fishing on a seven days' trip. The expenses of the trip were $\$ 137$, and the crew of fourteen men shared $\$ 86$ each. In I88 I the same vessel and skipper had a very successful season; on a January trip she landed $70,000 \mathrm{lbs}$. fish, about two-thirds haddock and one-third cod; on a February trip to La Have Bank she took $63,000 \mathrm{lbs}$. haddock and 20,250 lbs. codfish, stocking $\$ 1,74^{2} .5^{\circ}$, the crew sharing $\$ 84.3^{8}$; in March she stocked $\$ 1,784$ on one trip, the crew sharing $\$ 94$; in April she struck a good school of fish on the western edge of Western Bank, and in two days' fishing took $80,000 \mathrm{lbs}$. codfish and 12,000 lbs. haddock, the largest "shore" fare yet reported by a Gloucester vessel. Up to the first of May, I $88 \mathrm{I}$, the Martha C. landed about 550,000 fresh fish, stocking more than $\$ 1 \mathrm{I}, \infty 00$, the largest stock for the time employed ever made in the shore fishery.

The largest haddock fare ever landed at Gloucester was 70,380 lbs., taken on Georges in 1878 by sch. E. L. Roze, Capt. Sewall W. Smith, on a five days' trip.

The largest haddock fare ever taken in one day's fishing was $5^{1,700 ~ l b s ., ~}$ with 2,500 lbs. codfish, taken in 1877 by sch. Paul Revere, Capt. John Bentley, who stocked $\$ 10,036.83$ from Oct. 6,1876 , to May I I, 1877. On one trip to Georges in 1877 sch. Cora E. Smith, Capt. Sewall Smith, took 52,679 lbs. haddock; in three trips she landed 124,375 lbs.; during February and March she landed 203,095 lbs., and stocked $\$ 4,500$. In 188 I sch. Edith M. Pere, Capt. William Corliss, landed $60,000 \mathrm{lbs}$. haddock on one trip ; in two trips, occupying three weeks, the crew shared $\$$ roo each. Sch. David J. Adams, Capt. Richard Murphy, stocked $\$ 2, \mathrm{II} 7$ on a ten days' trip, the crew sharing \$107. In three weeks sch. Charles S. Tappan, Capt. John Bentley, stocked $\$ 3,200$. Sch. Aberdeen landed 50,000 lbs., sch. Anable 50,000 lbs., and sch. Paul Revere 40,000 , each on one trip. In 1879 sch. Alice M. Hawkes, of Swampscott, took $49,000 \mathrm{lbs}$. codfish in one day, and sch. George A. Upton took $40,000 \mathrm{lbs}$. on one trip. For the year ending

*In November, 1881, sch. Emma S. Osier made two pollocking trips inside of 5 days, landing $53,000 \mathrm{lbs}$. pollock. 
Feb. 4, I881, sch. Mystic, Capt. John McKennon, stocked \$19,770 shore trawling, the crew sharing $\$ 785.12$ each. In five months in $1872-3 \mathrm{sch}$. Eastern Queen, Capt. William Corliss, stocked \$10,250 net in the haddock fishery, her crew sharing $\$ 560$. The same season sch. Jennie B. Thomas, Capt. Henry Thomas, stocked $\$ 8,000$ in five and a half months. In $1870-1$, sch. Angie S. Friend, Capt. McClain, stocked $\$ 7,700$ in five months, and sch. Maud Muller, Capt. Nathaniel Smith, $\$ 6,600$ in four months. Sch. George H. Hagnet, 32 tons, of Harpswell, Me., stocked $\$ 5,500$ in five months' shore fishing in $\mathrm{r} 88 \mathrm{I}$.

\section{MACKEREL FARES.}

Sch. Edward E. Webster, Capt. Solomon Jacobs, stocked \$24, 466 in the Summer and Fall of $188 \mathrm{I}$ in the mackerel fishery. In the Summer and Fall of 1880 Capt. Jacobs in the Webster, disposed of $\mathrm{r}, 300$ bbls. mackerel fresh, and 2,600 bbls. pickled, stocking $\$ 19,745.76$ gross. The same season sch. Alice, of Swan's Island, Me., took 3,700 bbls., of which 900 bbls. were disposed of fresh, stocking $\$ 19,548.7 .5$.

The season of $188 \mathrm{I}$ was a very favorable one for the mackerel catchers. Sch. Lizzie D. Saunders, Capt. Alfred Saunders, of Pigeon Cove, stocked $\$ 1,700$ in two weeks, the crew sharing $\$ 73$; sch. Ivanhoe made eleven trips for fresh mackerel in seventeen days, being two or three days in port; sch. Wildfire, Capt. George M. McClain, took 1,309 sea-packed barrels in six weeks ; sch. Northern Eagle, Capt. George H. Martin, stocked $\$ 1,85_{2.50}$ in five days ; sch. Isaac Rich, of Swan's Island, Me., took 2,000 bbls. up to the middle of July; sch. Frank Butler, of New London, Conn., caught 762 bbls. in three weeks; sch. David. A. Osier 160 bbls. in forty-seven hours; sch. Col. J. H. French 500 bbls. in eight days, and sch. Piscataqua 400 bbls. in four days; sch. Dreadnaught, of Portland, Me., 205 bbls. in twenty-one hours; sch. Fleetwing 2 ro bbls. at one haul; sch. Madawaska Maid 225 bbls. in one day, and I,000 bbls. in five weeks; sch. William M. Gaffney 900 bbls. in twenty-one days; sch. Alice, of Swan's Island, Me., 4,804 bbls. to Oct. 2 r. Sch. Wildfire stocked $\$ 3,200$ in two weeks. From April 20 to July $26 \mathrm{sch}$. $S$. $R$. Lane landed 2,400 bbls.; for the twenty months ending Aug. $\mathrm{r}, \mathrm{I} 88 \mathrm{r}$, this vessel stocked $\$ 25,000$ fishing. In October, 1876 , sch. Mary Odell, Capt. McLain, made one haul in Barnstable Bay of more than the crew could take care of ; she took 300 bbls., gave away i 10 and lost several hundred through a hole in the seine. The Mary Odell had a crew of 12 men, and up to Sept. 22 stocked $\$$ I r, 0oo, the crew sharing $\$ 436.96$; the next week she landed two good fares, and the week following two more, at Boston. In 1877 sch. James A. Stetson took at one haul, off Block Island, 140 bbls. large fat mackerel, which sold at $\$ 20$ per bbl.; Sch. Moses Adams, 
Capt. Solomon Jacobs, stocked over $\$ 2,400$ in three short trips in one week, in October, 1878 ; in 1876 sch. Herbert $M$. Rogers, Capt. Richard Warren, took at one haul, off Block Island, 165 bbls. fat mackerel, which sold at $\$ 25$ per bbl., stocking $\$ 4,125$; sch. Gen. Grant, Capt. Coas, stocked $\$ 11,254.94$ net on two Bay trips in 1864 ; sch. Nor' Wester, Capt. Daniel Hillier, stocked $\$ 9,721.74$ on one Bay trip in r864. In three months of the same year sch. Gen. Sherman, Capt. George W. Miner, took $6 \mathrm{r}_{2}$ bbls., and stocked $\$ 9,696$; sch. John Bright, Capt. Aaron Riggs, took $63912 / 2$ bbls., and stocked $\$$ I 0,7 I I.2 I gross $(\$ 9,5$ I8.34 net), on one Bay trip in 1866 ; the high line made $\$ 288.73$, low line $\$ 106.06$, cook $\$ 382.78$; she went through Canso after Aug. I, and packed out Nov. 15.

The earliest receipt of new mackerel was in 1881, when the sch. Edward E. Webster, Capt. Solomon Jacobs, sailed from Gloucester March $\mathrm{I}_{5}$, and arrived at New York March 23, with I40 bbls., which sold for $\$ 3,000$. In r878 ro bbls. were taken by sch. Lilian, of Noank, Conn., and landed at Lewes April 5, selling in New York at $20,1_{5}$ and ro cents each. First fare, 150 bbls., sch. J. J. Clark, Capt. Charles Lee, at New York April r3. The first receipts in 1880 were April 4 ; in 1879 , April 14 ; in 1876 , April 24 ; in 1877 , April 25 ; in 1875 , April 30 .

\section{DORY FARES.}

In the Winter of $1877-8$, Leander Godditt of Pigeon Cove took 2,200 lbs. codfish in one day; John E. Woodbury and his son Elbridge, of Folly Cove, took 3,900 lbs.; Albion Knowlton and Howard Parsons, 3,850 lbs.; Warren and Howard Poland, 3,800 lbs.; J. W. Marchant and B. F. Saunders, 3,300 lbs.; John Woodbury and C. Sammis, $3.200 \mathrm{lbs}$. The same Winter a Mr. Taber of Nantucket launched his dory, pulled two miles to the fishing grounds, took 2,rI4 pounds of codfish, and pulled ashore, all on one tide, not exceeding three hours. Feb. 26, I880, Mr. George Woodbury of Folly Cove had three tubs of trawls set, comprising 1,500 hooks. He hauled his trawls and got for his hard day's work five pounds of fish. The next day Mr. Ezra L. Woodbury overhauled six tubs of trawls and did not get a fish. 


\section{The 0ld-Time Fishery at 'Squam.}

BY GIDEON L. DAVIS.

Tradition of the Early Settlement-The Vessels Used and Voyages Pursued-An Interview with "Uncle Ben," Who Tells What He Knowes about the OldTime Fishery - "Uncle Joe's" Narrative- "Uncle 'Bijah's" First TripVarious Kinds of Craft Used in the Fisheries-A Grand Bank Trip in 1816 or 1817-Largest Fishing Fare Ever Landed on Cape Ann.

The business of fishing at 'Squam must have commenced with its settlement, for the not-over-productive soil could have afforded but a scanty livelihood, and the early settlers were doubtless attracted by the products of the sea, which were plentiful and easily obtained. Tradition, documentary evidence and landmarks tend to prove that the fisheries commenced here at a very early period, and flourished for many years. The places which tradition asserts were once the sites of fishing establishments, hardly a trace of which remains, and the fishing stands of a later period, with their wharves and warehouses crumbling to decay, mark two eras of prosperity in the fishing business that have long since passed away.

Could we go back in imagination to that earlier era ; could we bridge over the lapse of years that have intervened ; and tell how the fishermen livedhow they captured their fish-describe their clumsy and ill-contrived crafts -recount the dangers and difficulties they encountered-we might compile a chapter full of interest for the "Fishermen's Own Book."

Of the ancient fishing establishments, which seem to have flourished at an early day, we can hazard but a few conjectures. All record of them, if there ever was any such record, has been lost. Our knowledge of them is therefore merely traditional. The "ketches" and "sloops" spoken of in history as the first vessels employed in the Cape Ann fisheries were doubtless used by them. Of the latter class of fishing craft we learn from history that in I724 several were employed in the Bank fishery, and that one of them, the Squirrel, belonging to 'Squam river, was captured by a pirate; that the crew subsequently rose against their captors, killed some, threw others overboard, retook the sloop and brought her back into the river. The hanging of the bodies of two of the pirates upon "Hangman's Island" may be taken as evidence that the Squirrel belonged to the fishing establishment at "Done Fudging," about which there has been so much conjecture, since the island was but a short distance from it. It is now covered by the Eastern Railroad bridge, which spans the river at this point. I remember seeing 
it when a boy, a small low island, partly washed away by the tide, with a few stunted trees growing upon it. As the captured pirates were tried and executed elsewhere, it is probable that the island took its name from the suspension of the dead bodies of Burroughs and Phillips, who were killed in the recapture of the sloop, upon a mock gallows thereon.

Why the early fishermen should have sought such out-of-the-way placesalways far up some river or creek-in preference to Gloucester harbor, whose convenience of access and adaptability to the business has given birth to a thriving and growing city, is left to conjecture. It may be that in those troublous times they selected them as being more remote from the sea, and affording greater safety from the depredations of piratical craft, which were then quite numerous, and also from the cruisers of the governments with which the mother country was then at war. The location of their dwelling houses-of which forty desolate cellars remain, whose story none can tell-far removed from the shore, and always in some secluded spot, corroborates this view, as does also the tradition that they hauled their fish up on Dogtown Common to cure.

About 1630 a party of men, led by a son of Rev. John Robinson of Puritan fame, seeking a place suitable for a fishing station, landed at Annisquam, and were so well pleased with its harbor and other conveniences that they concluded to set up a fishing stage there, and send for their families. This was the first permanent settlement of Cape Ann. The abandoned cellars were theirs, and the ruined wharves which tradition asserts were once the sites of important fishing establishments, doubtless belonged to and were used by them and their immediate descendants.

What sort of crafts they used, what voyages they made, what success they met with, cannot now be learned. It is probable that the "ketch," a small open boat with two masts and sails, answered every requirement for a long period, since doubtless fish were plentiful and near at hand. Probably no craft of considerable size fitted from these establishments until a much later period. In 1724 , nearly a hundred years after the settlement, we find mention of a vessel of larger proportions, the Squirrel, before alluded to. She must have been a good-sized craft, carrying quite a crew, and bound on a distant voyage, as it is said that the men took their tools along with them to complete her on the outward passage, she being a new vessel. At a later date the old Bankers and Pinkeys were undoubtedly fitted from these establishments.

Wishing to obtain some information in regard to the ancient fishing site at Mill Creek, concerning which there has been so much curiosity and conjecture, and of which a ruined wharf is all that now remains, we sought out "Uncle Ben," who lives near the place, as the one most likely to be able to impart the information we desired "Uncle Ben" is a hale old 
veteran of the sea. We found him open-hearted and free, as we knew him of old, and carrying his eighty and odd years remarkably well.

"Do I know anything about the old fishing establishment just below here on Riggs' Point? Well, I ought to, seeing that I went from there when a boy. Capt. Samuel Riggs carried it on then. I do not know who carried it on before him. Somebody must have done so, for he did not build the wharf or the warehouses; he built only the drying houses that stood further up the hill. They were all pulled down about forty years ago. He owned three vessels, standing-room pinkeys of about twenty-five tons burthen, one called the John, another the Mary Ann, and the third the Sally.

"I was a small boy when I commenced to go. We used to start about the first of May and go down on Tantor, Southeastern Jeffries, Cashes, and sometimes to Wood Island, and would be gone about a week. Fish were plenty enough, and we could catch just as many as we wanted.

"I do not remember anything about the old Banking fleet; that was before I can remember. I have heard say that they used to have them up to Done Fudging. Cod and haddock were all the fish we used to market. Halibut were plenty enough. They would come up alongside and swim with their fins out of water, but we never thought of catching them. Sometimes, though not often, we would catch one and smoke it-for our own eatingin the pinkey's chimney, which made a nice smoke-house. When they got too plenty we would haul up and seek another 'berth.' They used to bother us, as I have heard my father say the pollock used to bother them when he went. They did not know what a pollock was in his day, and used to think it a bad haul when they got one on the hook. At one time he used to go coasting in what would now be thought a small craft, but what they considered a monster, an old-fashioned standing-room pinkey of forty-two tons, with timber heads coming up along her sides six or eight inches, around which a plank was bent to serve as bulwarks-then called a waist. She had fore-and-aft standing rooms, a fore-cuddy with a brick chimney and fireplace, carried fore-and-aft sails, and was without shrouds or bowsprit. She had hemp, or what was then called Raven's duck, sails-cotton duck was then unknown - and carried a scout horn* to wet them down when the wind was moderate. They used to coast along shore, carrying corn and lumber, and once went as far south as Charleston.

"Aaron Hodgkins had a pinkey of twenty tons, called the Willoze. He went in her himself, going from here. Aaron and Vincent Wheeler, brothers, had a square-stern boat whose name I do not remember. They went from Wheeler's Point. Over in Goose Cove, above the mill dam, where

\footnotetext{
*As hemp sails were porous, and had not the wind-holding properties of cotton duck, the "scout horn," a pole about fifteen feet in length with a leather pocket holding about a pint of water to throw on the sails and close them up, was an indispensable instrument.
} 
you can see the remains of an old wharf, Josh. Riggs went in an old pinkey called the Blaney. It is about sixty years since she last left the cove. She went out under her foresail, with a fresh sou'west wind. Uncle Josh., leaning over the mainboom, said, 'Looks dreadful squally, don't it? Guess we had better go back.' Back they went, and there she laid her bones, that being the last cruise of the Blaney."

All this and much more interesting information "Uncle Ben" imparted freely, but we shall omit the rest, as there are other veterans of the fishing grounds to be heard from.

We were desirous of learning something concerning the old Bankers, that are said to have sailed from these ancient fishing establishments, and felt that we should be most likely to obtain the information we desired by interviewing "Uncle Joe." What we gathered from this source will now be given, not as he told it, for that would take a more graphic pen than ours. But we will "puss" it up together, as the fishermen do the schools of mackerel.

"I remember, when a boy, four score years ago, of hearing Capt. William Babson, then an old man, tell about the old Bankers. Capt. Babson, Capt. Gee and Joseph Baker, sometimes called Master Baker, were among the fitters. Capt. Babson's place of business was at Babson's Point. Master Baker's was at Baker's Point, now known as Pleasant Point, and the house in which he resided is the one now occupied by Prof. Hyatt as a Summer residence. The old warehouse, which used to stand so conspicuously on the Point, was owned and used by him. Capt. Gee's place of business was at Gee's Point, now known as Wheeler's Point. His wharf may yet be seen, so far decayed as to be covered at half tide, I think. There were fourteen sail in all. I cannot remember now, even if I ever knew, the names of any other-fitters ; but as there were fourteen vessels, and as it was not usual for one establishment to fit more than one or two Bankers, there were probably other places where they fitted out, and the old sites at Done Fudging, Mill Creek and other places where ruined wharves remain, probably had their share.

"The Revolution put a stop to the business. Some of the vessels were captured and burned, and others sold or otherwise disposed of, as a Bank fishing voyage was deemed hazardous.

"The vessels were for the most part built upon the Merrimac river. They had never heard of a chronometer in those days, and not many of them carried a quadrant. They used to depend on the compass, soundings, and personal judgment. It is probable that as a rule the skippers were acquainted only with the most simple and practical rules of navigation, yet they were very successful on their voyages. It is related of Capt. Babson, that, having secured the services of Capt. David Sargent as skipper, in 
order to badger him he sent some one down while he was getting underway for a fishing voyage, to ask him if he had got his quadrant on board. 'Tell Cap'n Babs'n,' was the reply, 'that I kin find ye way to ye Banks widout a quadrant as weel as he kin wid one.'

"I wish I could tell you something more definite about the old-time fisheries, but even were I able to do so it might be questioned, since I could only speak from hearsay.

"The pinkey fleet, however, were quite numerous in my day. At one time there were more than one hundred on this side of the Cape, including Rockport, then Sandy Bay; Lanesville, then Lane's Cove ; Bay View, then Hodgkins' Cove ; and 'Squam, where about twenty-five were owned and fitted. Those belonging to the first-named places would come around to 'Squam when the weather was bad or threatening, those from Rockport going into Goose Cove as affording a near route to their homes, and those from Lanesville and Bay View into Lobster Cove for the same reason. There were no breakwaters at those places then, and in good weather the pinkeys were moored to a mooring-stump*-a spar with one end driven into a hole made for the purpose in a large flat rock of several tons weight, sunken at a sufficient distance from the shore to allow the pinkeys to swing clear of the rocks. Some of them still remain, and are objects of curiosity.

"They were the old style pinkey, without bowsprit or shrouds, with two masts and hempen sails, and were from twelve to twenty-five tons burthen, and carried a crew of three men. They were built at Chebacco, now Essex, at first, but were afterwards also built at 'Squam. Capt. Epes Davis built the first one there, about the year 1800 , on the Chebacco model. He hired a man from Essex to help him, but for some reason he went away when the pinkey was half completed, and Capt. Davis finished her himself, with the aid of his wife, who held the plank and timbers while he fastened them on. - This pinkey was twenty tons burthen, and named the Dromo. Capt. Davis went to Brown's Bank in her and brought in sixty quintals of split fish. She had the usual features of the pinkey, two open standing rooms, one forward and one aft, to fish in, with hatches to cover them over, and was without shrouds or bowsprit. Capt. Davis continued the building of vessels, and in all built more than one hundred. In 1823 he built the first square stern vessel ever built at 'Squam. Her name was the Chrysanthemum, of sixty-three tons, and she was first sent on a southern mackereling voyage. Others engaged in the business, and it flourished for many years. At one time I have seen ten vessels on the stocks, and sixty sail were owned and fitted here.

"They are all gone, skippers, boats and crews. I can remember the

*A full description of these mooring stumps is given in the "Fishermen's Memorial aud Record Book." 
names of many of them. At the Folly, Walter Woodbury went in the Republican, Epes Woodbury in the Bonaparte, Epes Woodbury, Jr., in the Sea Flower, Caleb Merchant in the Hope, Joel Griffin in the Lion, Nat. Lane in the Sea Foam, John Clovis in the John, and Asa Woodbury in the Essex. At Lane's Cove were the Liberty, Winthrop Sargent; Heron, John Lane; Lily, Reuben Patch; Jefferson, Moses Lane; and William, Andrew and John Langsford owned and went in pinkeys. The last-named was lost overboard in 1826 , in coming from Jeffries, and the crew carried the boat into 'the harbor.'

"There are many others whom I remember-Andrew Bailey, Robert Stevens, William Young, Epes Lane, Joe Lane, David Lane, Fellows Morgan, Harry Sargent, etc., who owned and fished in pinkeys. At 'Squam I remember the Martha, David Chard; Corporal Trim, John Duley; Dove, Joseph Davis ; and many others that I could recall. I remember a trip that Daniel A. Robinson made to Western Bank in April, 1817 , in a pinkey of forty or fifty tons named the Constitution. She was owned and fitted by Epes Davis."

Thanking "Uncle Joe" for his information, we next proceeded to hunt up "Capt. 'Bijah." We found him smoking in a snug corner by a sea-coal fire, and he gave us, between whiffs, the following account of his first trip :

"I was ten years old when I made my first fishing trip. We went to Cashes in a deck boat of twenty tons. Capt. Daniel Robinson was skipper and I was cook. There were six of us, all told. We went at the halves, and all shared alike, the privilege of cooking and the glory of being skipper being considered in those days ample compensation for any extra labor or responsibility. We took about forty barrels of mackerel, saving only the large bloaters, which we slat into the barrels; the smaller fish we slat into the lee scuppers and stamped them up with our boots for bait with which to toll the fish. Afterwards we chopped bait with a hatchet, until Gunnison, of Newburyport, invented the bait mill, a godsend to the fishermen, who could now smoke and spin yarns while on watch, instead of chopping bait. A story is told, on the best of authority, of one skipper, Andrew Burnham, who had been a great 'killer' in his time, that after the bait mill came into use he was unable to sleep without the sound of the hatchet chopping bait, to which he had been so long accustomed. It is said that they tried pounding on the anchor stock, and tramping with their big boots on the deck above his head, but all to no avail. There was an element lacking in the noise they made, and he wooed the somnolent god to no effect, and was obliged to retire to private life on a farm, in the 'Second Parish,' I believe.

"We cooked in the old-fashioned way, in a brick fire place with a brick chimney, and a wooden smoke stack or funnel which was intended to carry 
off the smoke, but did not always do so. The crane, pot-hook, Dutch oven and trencher were all there, and all brought into use, as I well remember. We baked short cakes on the trencher, bread in the Dutch oven, and hung our kettle on the crane, with the pot-hook, to make coffee or tea.

"We had fine weather, and everything passed off finely except the smoke, which refused to pass off at all, and under a less resolute commander than skipper Robinson would doubtless have assumed command altogether. No casualties occurred except the burning of a few short cakes, while 'Bijah (it being his first voyage) paid tribute to father Neptune, and was himself again. We were gone three days. Arriving on the fishing grounds we made but one 'berth,' catching and dressing until everything was full, when we hoisted the foresail, for jib we had none, and bore away for 'Squam, arrived in the channel, dropped anchor, furled the sails, and went home to see the folks."

According to the records the first vessels employed in the Gloucester fisheries were the "ketch" and the "sloop." The ketches were smaller than the sloops, and were doubtless employed in the shore fishery, while the sloops were used for voyages to a greater distance. The ketch was but a miserable shallop, with two masts, one far in the stern and the other far forward in the bows, to obtain all the room possible between. They were little better adapted to the calling than the sloop, which any sailor knows is a poor rig for a fishing trip. At a later day we find the pinkey and the old Banker brought into general use. But the pinkey was only an improvement in some respects upon the ketch, having the same dangerous rig of two unsupported masts, and it is a wonder how they could have performed some of the voyages with which they are credited. Some of the pinkeys were as large as the ordinary fishing schooner, with spars in proportion. With the pinkey to monopolize the shore fishery came the old Banker to take the place of the sloop, a clumsy craft at the best, slow and unwieldly, with short masts, full bow, and high quarter deck, not unlike the vessel in which Columbus discovered the new world, though somewhat improved upon, no doubt. These had their day and generation, and by gradual development, adopting here and there what experience showed to be an improvement, gave to the fisheries and to ocean navigation a new craft, with a new name and characteristics peculiarly its own, the beautifully modelled, swift and graceful "schooner."

With the exception of some disguise in the names of the narrators, the foregoing account of the early fisheries at 'Squam may be regarded as essentially correct, being either matters of history or statements of persons now living.

In conclusion we present a brief account of a trip to Grand Bank in 1816 or 1817 , resulting in the largest fare of fish ever landed on Cape Ann. 
This trip was made from Gloucester in the sch. Mary Elizabeth, one of the old-time Bankers, commanded by Capt. George Davis, of Annisquam. The Mary Elizabeth was owned by Robert Elwell of Gloucester, and was a new topsail schooner of one hundred and thirteen tons, built upon the Merrimac river just above the Haverhill bridge. She carried a crew of twelve men, in addition to the skipper, as follows: Benjamin Marble, Joseph Jones, James Sawyer, all of Fresh Water Cove; Samuel Davis of Ferry Lane; John Wharff, Enoch Center, of Fox Hill ; Samuel Wharf, William Bennett, Benjamin Curtis, near Dodge's Mill, Riverdale; William Marsh, Robert and George Davis of Annisquam, the two latter sons of the skipper, Robert being the cook, and George, now living at Annisquam in the eighty-sixth year of his age, being our informant in regard to the incidents of the trip.

They started about the first of April and were gone ninety days. They fished with hand lines, on board the vessel, and caught seventeen thousand codfish in number.

Having arrived on the Bank they made everything as snug as possible, taking down the topsail and topgallant yards and lashing them across the stern. Halibut were very numerous, and they could have soon loaded with them had they desired. They caught a great many of them, but only saved the fins and napes, which they salted in barrels, and fletched and smoked quite a lot of the best pieces overhead in the cabin. One day they caught a very large one, with a haddock in his mouth, the only haddock they saw during the trip. They had very good weather, met with no disaster, and arrived safely in Gloucester, and landed their fare at Fresh Water Cove, making 2,500 quintals dry fish, the crew realizing as their share $\$ 24$ for each thousand fish caught. Our informant states that the water stood upon her lower deck when she left the Bank, but naturally, from the shrinkage of the fish and the pumping off of the pickle, she was considerable lighter when she reached port. Her outfits were principally ship-bread, beans, rice, a little flour, some beef and pork, molasses, tea and coffee, and some rum. Fish and beans and beef, with ship-bread, were the principal articles of diet, but on Sunday morning they would have fried pancakes-about half a bushel being required to go the rounds-as a sort of holiday treat, as they invariably refrained from fishing on Sunday. The Mary Elizabeth had the high quarter-deck peculiar to the Bankers, divided below into three compartments, the forward part used for the storage of fishing gear, etc., the middle compartment as a pantry and kitchen, in which they cooked and ate, and the after part called the steerage, where they lived and slept. 


\title{
Homeward Bound.
}

\author{
BY JAMES DAVIS.
}

O heave up the anchor, the waist it lies low

With the weight of our good finny freight in the hold;

The wind from the east is beginning to blow,

Now heave up the anchor, my live lions bold;

My eyes they are aching for sight of the land,

My heart it is sighing for sweet home once more;

Now heave 0, my hearties, and landward we'll stand,

To meet the dear friends who are waiting on shore.

\section{CHORUS.}

O heave up the anchor, my good fishers bold,

And homeward we'll steer with our freight good as gold;

Blow, breezes, and waft us the wide waters o'er,

For dear ones are waiting for us on the shore.

Out on the dark waters, for four weeks and more,

We've trawled and we've hauled, boys, day in and day out;

Now dear ones are watching for us on the shore,

And fears for our safety are whispered about;

So heave up the anchor and set every sail,

Blow, breezes, and speed us the wide waters o'er,

Blow steady and strong till the home-port we hail,

And gladden the hearts that are waiting on shore.-Chorus.

O, Love will sail out, and Love will sail in,

For beneath our rough jackets our hearts they beat warm,

And bread and delights for our dear ones to win,

We watch, and we work, and we battle the storm;

But happy the day when the skipper doth say,

"Come, heave up the anchor, men, full is our store,"

And o'er the wide waters we speed on our way,

To meet the dear friends who are waiting on shore.-Chorus.

And so we will sail, boys, blow high or blow low,

Sail landward or seaward, as duty may call,

With a heart for hard fortunes, for never we know,

Bound outward or inward, what luek may befall ;

And we sail and we ride out on Georges' far bauk,

While the winds and the waters they rage and they roar,

And between us and death there is only a plank,

For the sake of the dear ones we've left on the shore.-Chorus.

There's danger on land, and there's danger at sea,

But there's hope at all partings of meeting again,

For Love is around us wherever we be,

And One there goes with us who knows we are men;

So we sail and we ride out upon the rough tide,

Expecting that when our last sea voyage is o'er,

We'll moor our old barks, boys, in port side by side,

And greet our dear friends on the heavenly shore,-Chorus, 


\section{Products of the Gloucester Fisheries.}

The following estimates of the fish productions of Gloucester at different periods during the past thirty-five years will give a good idea of the growth and changes in the business :

Statement of fish products in 1847 , collected by Mr. Addison Winter and furnished the "History of Gloucester," not including the results of the Winter dory fishing: $7,088,376$ lbs. codfish, valued at $\$ 181,703 ; 3,379,776 \mathrm{lbs}$. halibut, $\$ 70,761$; 735,506 lbs. hake, $\$ 12,174 ; 919$, r 88 lbs. pollock, $\$ 16,55^{6}$; 46,779 bbls. mackerel, $\$ 290,055 ; 3371 / 2$ bbls. tongues and sounds, $\$ 1873$; 39,520 gals. oil, $\$ 16,232$. Total value, $\$ 5^{8} 8,354$. Number of vessels employed, 287 , of which 126 were of less than forty tons burthen. Total tonnage, 1 2,354; number of men employed, 168I ; boys, 186.

Fish products for 1859 , exclusive of the herring, shell and shore fisheries : $59,6645 / 8$ bbls. mackerel, valued at $\$ 705,833$; I I 4,047 qtls. codfish, $\$ 416,27$ I ; $4,500,000$ lbs. halibut, $\$ 135,000$; 1,400 bbls. oil, \$19,600. Total value, $\$ 1,276,704$. The other fish products probably brought the value to nearly one and a half million dollars. Number of vessels, 322 ; tonnage, 23,882 ; number of men employed, 3,434 ; boys, 34 .

I 865 -from State Census—value of mackerel catch, I 54,938 bbls., \$2, 190,562 ; codfish, etc., II3,025 qtls., $\$ 706,420$; oil, $\$ 90,420$; fresh fish, $\$ 360$,$\circ 00$; tongues and sounds, 3,000 bbls., $\$ 25,000$; herring, $\$ 200,000$; bait, r, 400 bbls., $\$ 75,000$; lobsters, $\$ 3,450$. Total value, $\$ 3,650,85^{2}$. Number of vessels, 353 ; tonnage, 25,170 ; number of men, 4,700 . Capital invested, $\$ 1,901,700$; value of salt consumed, $\$ 232,275$.

Products for 1873 - Custom House estimate- 86,544 bbls. mackerel, of a value of $\$ 1,125,000 ; 460,000$ qtls. codfish, $\$ 2,070,000 ; 5,000$ bbls. herring, $\$ 23,000 ; 25,000$ qtls. other fish, $\$ 50,000 ; 9,000,000$ lbs. fresh fish, $\$ 310$,000 ; 275,000 gals. oil, $\$ 165,000$; shell fish, $\$ 13,000 ; 7,000$ tons fish manure, $\$ 25,000$; miscellaneous, $\$ 15,000$. Total value, $\$ 3,801,000$, against $\$ 3,437,000$ in 1872 .

Products of 1875 , carefully prepared from actual returns obtained by George H. Procter : I 77,473 qtls. Bank codfish, of a value of $\$ 998,628$; r 85,758 qtls. Georges do., $\$ 1,021,669 ; 2,462,364$ lbs. Georges halibut, $\$ 172,365 ; 7,248,413$ lbs. Bank do., $\$ 507,389 ; 4,257$ qtls. hake, \$12,774; 2,349 qtls. cusk, $\$ 7,047 ; 9,417$ qtls. pollock, $\$ 32,964 ; 38,292$ bbls. herring, $\$ 153$, I 68 ; shore fish, fresh, $\$ 89,738$, cured, $\$ 135,697$, oil, $\$ 8,945 ;$ I $8,1725 / 8$ bbls. No. I mackerel, $\$ 327$, I I $2,7,0651 / 8$ bbls. No. $2, \$ 184,780,21,763$ bbls. No. 3, \$1 74, I04, 4,0393/8 bbls. No. 4, \$24, I05; 3, I 75 bbls. herring, \$1 3,494 ; I 63 bbls. pickled codfish and $401 / 4$ bb!s. swordfish, $\$ 1,097 ; 4105 / 8$ bbls. trout and $753 / 4$ bbls. fins and napes, $\$ 4,042 ; 217 / 8$ bbls. salmon and 205 bbls. 
tongues and sounds, $\$ 2,282$; shell fish, $\$ 10,000$; other fish, $\$ 8,000$; fish oil other than shore, $\$ 100,000$. Total value, $\$ 3,909,500$.

In 1867 there were 220 Gloucester vessels engaged in the Bay St. Lawrence mackerel fishery, and only 50 off shore.

Products since 1875 , excluding hake, pollock, cusk, shell fish and oil :

r 876-Georges codfish, 26,975,000 lbs.; Bank do., 18,62 7,000 lbs.; Bank halibut, II,453,000 lbs.; Georges do., 3,005,100 lbs.; mackerel, 95,422 bbls.; herring, 35,800 bbls.

I877-Georges codfish, 23,755,000 lbs.; Bank do., 16,865,000 lbs.; Bank halibut, I4,319,000 lbs.; Georges do., I,8 14,000 lbs.; Hetched do., 850,000 lbs. ; Greenland do., roo, 000 lbs.; mackerel, 49,044 bbls.; herring, 28,500 bbls. 86 Gloucester vessels fished for mackerel in the Bay St. Lawrence this year.

1878-Georges codfish, 24,158,000 lbs.; Bank do., r2,202,500 lbs.; Bank halibut, 10,914,500 lbs.; Georges do., 524, 100 lbs.; Greenland do., fletched, 120,000 lbs.; mackerel, 55,742 bbls.; herring, 27,000 bbls. This was the year when the herring fleet was driven away from the shores of Newfoundland. I 25 fares, about 30,000 bbls., sea-packed mackerel, were received from the Bay St. Lawrence.

I879-Georges codfish, 23,144,000 lbs.; Bank do., I3,247,000 lbs.; shore do., 3,742,000 lbs.; Bank halibut, II,7 17,400 lbs.; Georges do., 995,500 lbs.; Greenland do., fletched, 500,000 lbs.; mackerel, 48,643 bbls.; herring, 20,000 bbls. 429 vessels were employed, of which $33^{8}$ hailed irom Gloucester ; 104 followed Georges all the season, and 82 the Bank cod and halibut fisheries. 25 vessels made Bay St. Lawrence trips for mackerel.

1880-Georges codfish, 27,51 1, 000 lbs.; Bank do., 20,247,000 lbs.; shore do., 1,721,000 lbs.; Bank halibut, 7,940,000 lbs.; Georges do., I, 125,450 lbs.; Greenland do., fletched 80,000 lbs.; mackerel, I I6,793 bbls.; herring, 30,000 bbls. The fleet numbered $44 \mathrm{r}$ vessels, of which 334 were owned in Gloucester. Io7 followed the Georges fishery exclusively, and 90 confined their operations to the Bank cod and halibut fisheries, and 17 made Bay St. Lawrence trips, bringing some $3,5 \circ 5$ bbls. mackerel.

I 88 I-Georges codfish, 22,5 I0,000 lbs.; Bank do., 20,955,280 lbs.; shore do., 3,245,360 lbs.; Bank halibut, 7,178,800 lbs.; Georges do., 1,087,400 lbs.; fletched do., 25,000 lbs.; Greenland do., fletched, 428,290 lbs.; mackerel, r63,$85^{\mathrm{x}}$ bbls.; frozen herring, $13,318,000$. The fleet numbered 437 vessels, of which 343 were owned in Gloucester. 62 followed the Georges fishery ex. clusively, 26 Western Bank fishery, Io Grand Bank codfishery, 25 Bank halibuting, and 29 shore and Bay of Fundy codfishery. Only 2 vessels visited the Bay St. Lawrence for mackerel, and their catch was less than $50 \mathrm{bbls}$. 


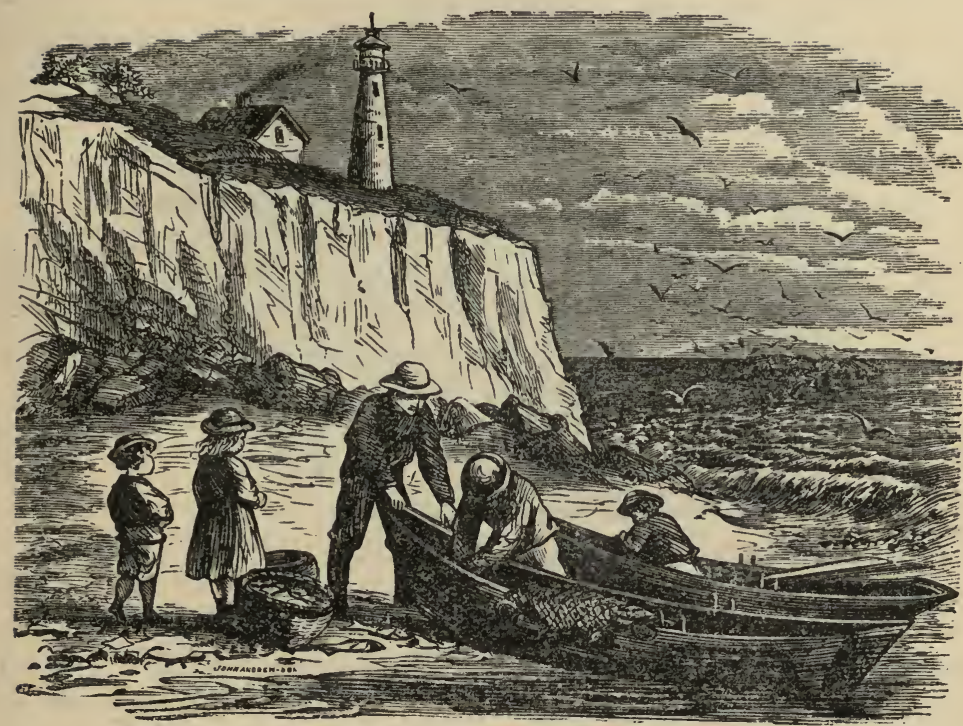

\section{Return of the Dories.}

BY CELLIS.

The above picture shows the return of some of the shore fishermen from a trip off shore, where they have seined a goodly quantity of pogies or mackerel, which they are now about to unload from their dories and take care of. The baskets have been filled all ready to be conveyed to the storehouse. The children are enjoying the sight and are probably asking all the questions which their little brains can conjecture. The vast expanse of water, with the numerous sea birds, add life and beauty to the scene, which is in decided contrast to that presented when the storm-clouds lower and old ocean is lashed into fury. The lighthouse, whose cheerful beams by night guide the mariner on his course over the pathless deep, stands as a faithful sentinel, and the little cottage near by with the smoke rising from its chimney, is suggestive of peace and contentment. Taken as a whole the picture is a cheerful one, and shows the bright side of the fishermen's life. 


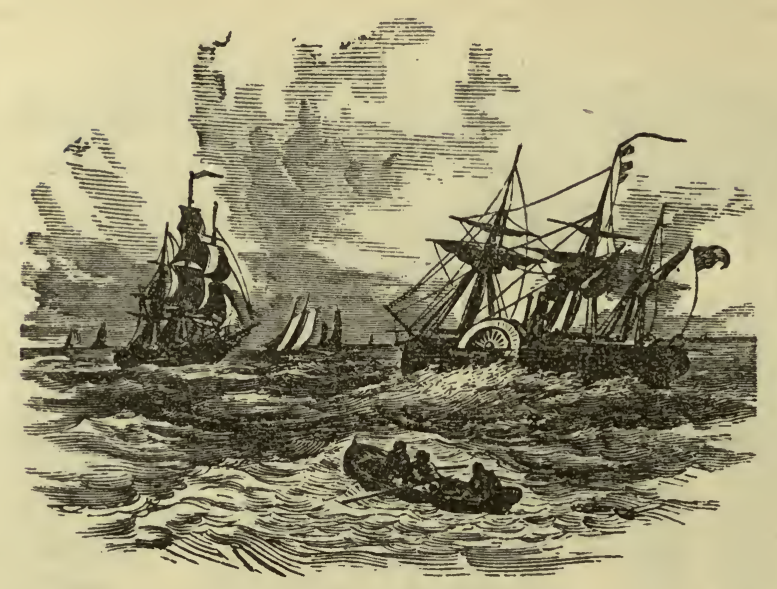

\section{Quick Passages.}

Sch. John D. Griffen, Capt. Gould, left Chatham on Wednesday, Oct. 3 I, 1877, for New York, discharged cargo and was back the following Monday with 6,200 bushels of corn, bound to Danversport. Sch. Anson Stimson, Capt. Sloman, made the passage from Sandy Hook to Matanzas in 18 days, in 1877 . Sch. Tim Pickering, of Salem, made the voyage from New York to Salem and back in 9 days, in 1877,5 days of the time being spent in Salem and Gloucester. Bark Charles Stezext made the passage from Trapani to this port in 43 days, in 1878 , being 33 days from Gibralter. Sch. Herman Babson made the passage from Canso to Gottenberg in a few hours over 16 days, in 1876 . Sch. Centennial, Capt. Philip Johnson, made the passage from Gloucester to Port Mulgrave, a distance of 488 miles, in 1880 in 46 hours. The same year sch. Henry Wilson, Capt. James O. Nauss, made the run from Cape Jack to Georgetown, P. E. I., a distance of 40 miles, in 4 hours, and sch. David A. Story, Capt. Joseph Ryan, made the passage from Gloucester to Grand Menan, a distance of 225 miles, in I 8 hours. In 1860 ship Golden Gate made the pasage from Liverpool, Eng., to San Francisco, in 102 days ; in $1880-1$, ship British General made the same passage in 105 days, being 15 days from the equator into port. In 188 I sch. Alice, of Swan's Island, made the run from Boston to Eastport in 27 hours, and sch. William H. Jordan, of Taunton, made the passage from Baltimore to Providence in $5^{6}$ hours. Steamer Admiral, from New York to Boston, made a run of 9 miles in 27 minutes, and a passage from Gloucester to Boston in I hour, 50 minutes. In November, $188 \mathrm{I}$, sch. Lulu Ammermann, of Perth Amboy, N. J., Capt. John L. Stiles, made the passage 
from Boston to Philadelphia in three days. Sch. Lizzie W. Matheson, Capt. McKay, of Provincetown, in October, I881, made the passage from Boston to Cape Haytien in 8 days, discharged cargo, loaded and returned to Boston, making the round trip inside of 32 days, said to be the quickest time on record. Sch. Jennie A. Stubbs, Capt. Stubbs, made the run from Sandy Hook to Turk's Island, in I88I, in I45 hours, actual time. Sch. Lottie K. Friend, Capt William H. Collins, sailed from New York on Saturday evening, April 30, 1880, at 61/2 o'clock, and arrived at Gloucester at 2 o'clock the following Monday morning, making the passage in $3 \mathrm{I} / 2$ hours; the previous Winter the Lottie $K$. Friend made the passage from Phillips' wharf, Salem, to New York, in $3 \mathrm{I}$ hours.

In the Summer of 1880 several of the Gloucester fishing vessels had an opportunity for a race with crack Boston- yachts, under favorable circumstances: July 27, sch. Alice M. Williams, Capt. Dennis C. Murphy, fell in with the yacht Actae off Cape Sable; the yacht put on all her light sails, and Capt. Murphy spread his riding sail and all the dory sails he could raise, and kept company with the yacht until he reached Eastern Point, when he came into port, the Actae proceeding to Boston. Aug. 5, sch. Isaac A. Chapman, Capt. Chas. R. Crew, fell in with the yacht Tarolinta; both craft spread every inch of canvas, and in an hour and a half beating to windward the yacht was left fully one-half mile to leeward. In September the sch. Mary Odell, Capt. McClain, out-sailed one of the crack Boston yachts, and parties who witnessed the race were so well pleased with her sailing qualities that they made an offer for the Odell on the spot, and she was sold to go to Savannah as a pilot boat.

\section{SONG OF THE WINTER FISHERMAN.}

\section{BY R. CALDFR.}

Up! up with your sails to the bending mast, Sheet them home with a hearty will;

Let the rude caress of the wintry blast Every fold of the canvas fill.

Now sail away o'er the treacherous main, Where the storm-king builds his throne, Where the finny treasures of his domain We will gather and call our own.

Where the towering iceberg's crystal dome Is lost in the drifting snow,

And the waves dash up their milky foam From the gloomy depths below.

Away where the bright Aurora's beams Flash over the starry sky,

Lighting the sea with its golden gleams, Where the daring fishers lie.
Oh, kings and rulers the land may ownWe envy not the great;

The ocean free is our regal throne, The "deck" is our Chair of State.

$\mathrm{Oh}$, here we are free on the ocean's breast As the deer on his native heath;

And when the storm is over we rest On the billows-or underneath.

What matter to us, when the spirit's fled, Where the body finds a tomb-

In the church-yard with our kindred dead, Or 'neath the ocean's foam?

Here's a noble craft to meet the blast Where'er fate bids us roam, And hearts to greet, wheu danger's past, Our loving ones at home. 


\section{First Trips.}

The first codfishing trips to Georges were made in $182 \mathrm{I}$, and the first codfishing trips to the Bay St. Lawrence the same year. The Georges halibut fishery was inaugurated in 1830 .

The first salt herring trip to Newfoundland was made in 1837 or 1838 by Capt. James W. Pattillo, in the pinkey Tiger. The Newfoundland fresh herring fishery was inaugurated in 1854 by sch. Flying Cloud, Capt. Henry O. Smith. The first frozen herring marketed in New York was in 1857 , by sch. E. C. Smith, Capt. Sylvanus Smith. The first cargo of herring ever shipped from Gloucester to a foreign port were sent to Gottenberg in sch. Nulli Secundus, in 1876 .

The first Greenland halibut trip was made in 1866, by sch. John Atwood, of Provincetown, chartered by Messrs. John F. Wonson \& Co., Dodd, Tarr \& Co., and Mr. George J. Marsh. She sailed June 29, commanded by. Capt. G. P. Pomeroy of New London, Conn., with Capt. Averill L. York of this city as fishing master, and arrived home Oct. I4, selling her fletched halibut at 9 cts. per pound, and stocking $\$ 5,500$. Sch. Caleb S. Eaton, Capt. John S. McQuin, made a Greenland trip in 1869 and again in 1870 .

The first and only fishing trip to Iceland from this port was made by Capt. John S. McQuin, in sch. Membrino Chief, in 1873 .

Sch. Notice, Capt. Knud Markuson, made a mackerel-seining trip on the coast of Norway, in 1878 .

The importation of fish to the West Indies was revived by Capt. Charles A. Homans in 1878 .

Mackerel catching was first pursued by small boats about 1800 . The mode of catching by drifting and "throwing bait" did not become general until after 1812. The jig hook was invented by Mr. Abraham Lurvey of Pigeon Cove, in r8r6. Fly lines did not come into use until about r823. Bait mills were not used until 1820 , when they were made of nails driven in straight lines across wooden cylinders and then sharpened. The first bait mill with knives was made by $\mathrm{Mr}$. Gorham Burnham in 1822 , and the knives were first placed in spiral form in $\mathbf{1 8 2 3}$. The first trip for mackerel to cure was made by sch. President, Capt. Simeon Burnham, in 1818. Mackerel were first caught on Georges in 1822 , by Capt. William Marshall. The first mackereling trip from Gloucester to the Bay St. Lawrence was made by Capt. Charles P. Wood in sch. Mariner, in 1830. Sch. Eliza Jane, Capt. Stephen Brown, made a Bay mackereling trip the same season, and two of the crew who made the trip, Messrs. John Hodgkins and John N. Day of Riverdale, are still living. Sch. Clio, of East Salisbury, is said to have 
made a similar trip in 1829 . The first trawl was made and set across Brace's Cove in 1820 , by Mr. John Rowe, still living at East Gloucester at the age of 75 years.

The Fishery Clauses of the Washington Treaty went into effect July $\mathrm{x}$, 1873; notice of a desire to terminate their provision may be given by either side after July $\mathrm{r}, \mathbf{1 8 8 3}$, and they will continue in force two years after such notice is given.

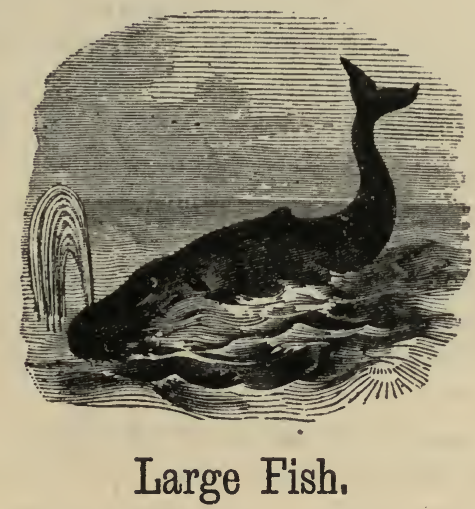

A halibut weighing upwards of $600 \mathrm{lbs}$. is said to have been taken at New Ledge, 60 miles southeast of Portland, Me., in $180 \%$. Twenty years later a dead halibut was picked up by two men near Damask Cove, at Boothbay, Me., that weighed when gutted and gilled, with head on, $637 \mathrm{lbs}$. This is the largest halibut of which we have any record. Dr. Storer mentions one taken off the South Shore three-quarters of a century ago, which weighed $420 \mathrm{lbs}$., dressed; or probably $500 \mathrm{lbs}$. live weight. The largest halibut ever landed at Gloucester was brought in from Georges by sch. Etta $E$. Tanner, in $188 \mathrm{I}$, turning the scales at $380 \mathrm{lbs}$. ; it was purchased by Messrs. Stockbridge \& Co., and attracted considerable attention. The same year sch. Charles Carroll took a Georges halibut weighing $35^{8}$ lbs.; in 1871 sch. John Dove took one weighing 347 lbs., and seven halibut taken on the trip turned the scales at $1,73^{2}$ lbs. The largest Bank halibut of which we have any knowledge weighed 377 lbs., and was taken by sch. Wachusett in 1880. In 1877 sch. City of Gloucester took a Bank halibut weighing $336 \mathrm{lbs}$., and sch. William Thompson one weighing $296 \mathrm{lbs}$. The largest shore halibut on record was taken on Poole's Ledge, about six miles eastsoutheast of Thacher's Island, about 1873 , by J. B. Goldsmith and Peter Leman, two Rockport fishermen; it was as wide as the stern place of the dory, weighed when dressed $347 \mathrm{lbs}$, and sold for $\$ 2$ r.60. In $1877 \mathrm{Mr}$. Elbridge Gerry took off Eastern Point a halibut weighing $320 \mathrm{lbs}$. The 
smallest halibut of which we have heard was brought in by a Gloucester vessel in 1880 , and sent by mail to Mr. E. G. Blackford, the fish culturist, of New York; its weight was 20 ounces.

The Portsmouth fishermen have a tradition of a monster codfish caught by Samuel Haley, of Smutty Nose Island, Isles of Shoals, which weighed when dressed and dried 113 lbs. In 1878 Capt. George H. Martin of Gloucester took off Cape Cod a codfish weighing i i l lbs. dressed, and the next year captured one in Ipswich Bay which measured 5 feet 2 inches in length and weighed $9 \circ \mathrm{lbs}$. when landed, and probably roo lbs. when taken from the water. In 1879 two codfish were received in the Portsmouth market each of which weighed 108 lbs. Storer speaks of a codfish taken in the Spring of 1807 at New Ledge, 60 miles southeast of Portland, Me., which weighed ro7 lbs. The New York "Journal" of April 3, r793, reports a codfish "lately sold in the Newburyport market," which was $5 \frac{1}{2}$ feet in length and weighed $98 \mathrm{lbs}$. One of $97 \mathrm{lbs}$. was caught off Portsmouth in 1827 , and one of 94 lbs., "undressed," by the Swampscott fishermen in 1857 . In February, 1823, the Marblehead fishermen sent to John Q. Adams, Secretary of State, frozen with great care and packed in ice, a codfish weighing 84 lbs. In r881 the sch. Morrill Boy, Capt. Russell Gill, took on one trip net fishing 319 codfish, weighing 9,570 lbs., or averaging $30 \mathrm{lbs}$. each.

A lobster 38 inches in length and weighing ${ }_{5}$ lbs. was taken at New Bedford in the Fall of $188 \mathrm{r}$; a few months earlier a lobster weighing $13 \mathrm{lbs}$. was taken at Liverpool, N. S., and sold for 25 cents. A horse mackerel weighing 545 lbs. was landed at Portland, Me., in the Summer of 1881 . A bass weighing 79 lbs. was taken near Portsmouth, N. H., in August, r88I ; it was two hours from the time it was hooked before it was landed, in a fourteen foot boat, which was half full of water before the fish was secured. A 445 lb. turtle was taken in the weirs at Orleans, Mass., in August, 188r.

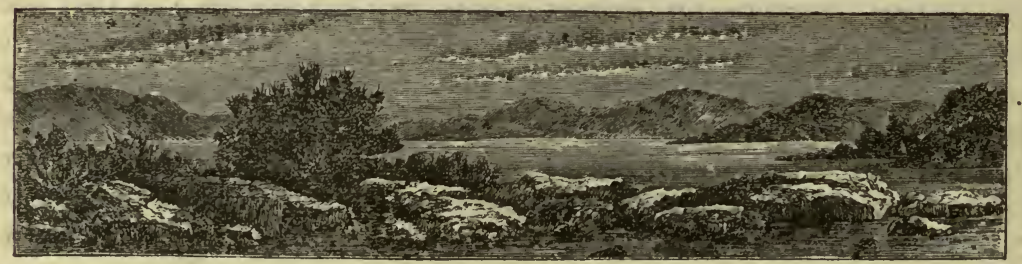




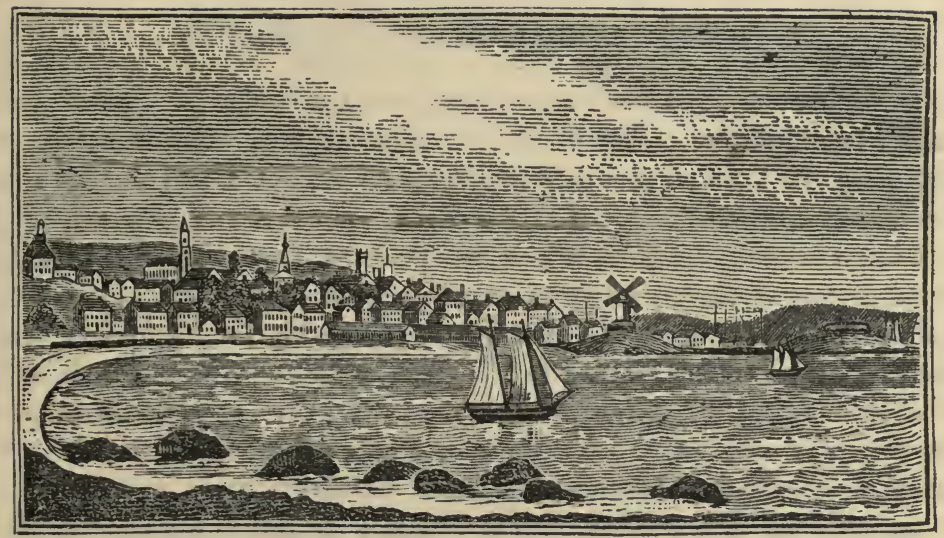

\section{Gloucester Harbor, 1830.}

Above is given a view of the harbor taken from off the beach at the Cut in 1830 , which will be readily recognized by many who peruse these pages. The old windmill which then occupied a position where the Pavilion Hotel now stands, was for many years an important landmark in entering the harbor. It was erected in 1814 by Mr. Ignatius Webber, a successful shipmaster, who retired from seafaring pursuits in 1807 , and for three years subsequently was connected with Messrs. Aaron and Henry Plumer in carrying on the ropewalk on Western avenue, which was built by Capt. Webber and Aaron Plumer in 1803 . The ropewalk was sold at auction about 1810 to Mr. John Somes, Jr., for $\$ 4,55$. The windmill was removed to Commercial street, near the Fort, when the Pavilion was erected, and was so badly injured by fire July $5^{\text {th, }} \mathrm{r} 877$, that it was sold and removed. The ropewalk is plainly discernible in the foreground, and many a fine run, when a lad, have we had barefooted over its smooth floor. There are many noticeable changes in that vicinity, especially on the hill, which now shows some very handsome dwelling houses. 


\section{U. S. Fish Commission,}

SUMMER HEADQUARTERS IN GLOUCESTER.

The Summer of 1878 was memorable for the selection of this city as the Summer headquarters of the U.S. Fish Commission. The scientific corps comprising the Commission arrived here July 9, Prof. Baird and his clerical force taking up their residence at the Kirby cottages on Western avenue, and a large building on Fort Wharf was leased for an office, laboratory, etc. The laboratory work was under the the special charge of Prof. Goode of the Commission and Prof. Verrill of Yale College, with Dr. Bean and Messrs. Richard Rathburn and Warren Upham as assistants. On the 18 th of July the steamer Speedwell, under command of Captain Beardslee, arrived, and from that time until Sept. 30, with a brief interruption for repairs on the steamer, dredging expeditions were made off the coast, Capt. H. C. Chester, formerly of the Polaris, having charge of the dredging machinery. With the departure of the Speedwell, at the end of September, the regular Summer work of the Commission was practically completed.

Aside from the investigations pursued by the scientists, and the valuable collections secured on the dredging expeditions, the visit of the Fish Commission to Gloucester served to create an interest in its field of operations among the Gloucester fishermen, from which great benefit has been derived. Several of the larger fishing vessels were provided with tanks and alcohol for the preservation of such novel specimens as might be brought up on their lines and trawls, and a lively emulation was manifested in forwarding the interests of the Commission. This branch of the work was continued after the departure of Prof. Baird and his corps, the numerous contributions being weekly announced in the columns of the local papers until the middle of November, 1880 , when the number of separate contributions had reached 924, including many thousands of specimens, of which a very large number were either new to science, very rare, or hitherto unheard of in American waters.

During the season a series of investigations was made by Dr. W. G. Farlow, as to the cause of the reddening of codfish cured in Summer, which renders it liable to decomposition and unfit for the market. After a full inquiry Dr. Farlow came to the conclusion that the trouble was occasioned by a minute red alga, specimens of which were found in the Cadiz salt used for curing fish, and in accordance with his recommendation a more general use has since been made of Trapani salt, which was found to be free from this alga.

Through the efforts of Prof. Baird, Gloucester was made a storm signal 
station, during the Summer of 1878 , and the warning signals have proved of great advantage to mariners.

On the $25^{\text {th }}$ of July the Tallapoosa visited Gloucester, having on board the Secretary of the Navy, Hon. R. W. Thompson, the Chief Naval Constructor, Chief Engineer, Paymaster General, and other naval officers. The steamer remained in port two days, the visitors making a dredging trip on the Speedruell.

One of the most valuable results at the Gloucester station was the demonstration of the fact that codfish, haddock, herring, and other deep sea fish could be artificially propagated as readily as shad, whitefish, and other denizens of our rivers and lakes. Assistant Commissioner Milner, Capt. Chester and Messrs. Frank N. Clark and Robert E. Hall had charge of the cod-hatching experiments, which were entered upon after the departure of their associates. Various devices were tried, until the proper conditions were realized, and several millions of codfish were hatched out and turned into the harbor, where they could be readily observed around the wharves the following Summer, having made a good growth. It was also found that herring, haddock, and pollock could be artificially multiplied at will. The results of the experiments were all that could have been expected, and much valuable information was secured that will be of great advantage if the work is ever attempted on a large scale.

The fish-hatching establishment was broken up in the early part of January, 1879 , but the Commission retained its laboratory for the reception and preparation of specimens brought in by Gloucester fishing vessels until the Summer of $188 \mathrm{r}$. Mr. Earle remained in charge of the work in 1879, and was succeeded by Mr. A. Howard Clark in $\mathbf{1 8 8 0}$. Since the laboratory was closed in $188 \mathrm{r}$, Capt. Stephen J. Martin has been the local representative of the Commission, keeping a record of fishing arrivals and securing other information necessary to the prosecution of its work.

\section{Around Cape Ann.}

In 1606 , we have seen, our harbor was named Le Beau Port, and sincerely. Harbors differ as men do. Harbors are human and something like women; they have their own times for dainty and delicate attire. To know them, you must study them, under daylight, under twilight; at sunrise and sunset; under the full harvest moon; at low tide and high tide; in a storm and after it is over; then will you find some mood to admire, new beauty come to sight. Our harbor, like every other, sulks sometimes, one must allow. A dog-day's fog has hung over it, or wrung itself dry into it, to-day. 
Open as the highway to all farers, many kinds of craft share its favor. The deeply laden collier with its sober mien; the lumber-coaster with her deckload suggesting the heart of pine forests in Maine; the stranger ship with salt from Spain; the sloop or schooner yacht with every grace a marvel and every line a picture,- - those lilies of the sea, which toil not, neither do they spin; the tug-boat eying every sail for a summons; the fisherman with her seine-boat ready for action, idle after toil; the ferry-boat going her way so often as to have it by heart; the light, clumsy wood-coaster from the provinces, sturdily maintaining her look of indifference to the finer company around her; a single skiff shooting among the dories and boats; all pointing different ways; some with sails partly set, expectant; some with minds made up, their anchors resolutely down, and all either grieving or sulking over the uncertain weather. One hint of farewell from the setting sun, and what a change! The somber collier and coaster look careless and happy, and the yachts share the gold that falls upon them with every homely sister, till twilight creeps and creeps up every mast, like a miser, for every glint of it. The woods along the western shore grow like a deepening mystery. The tide is down, and the weed-hung rocks seem darkly to desire the night. One gleam is in the western sky, the light of which little pools of tide among the rocks sue for and obtain, by some bridge unseen.

To see the summer day come into the harbor, one must rise early. The early evening most men know ; but the early morning-what is it? How many of us know it? How many love it? One star is skipper and crew of the whole heavens, and, weary with its watch, "turns in," not curious to see what the day is like. The wind is sleeping. A boat here and there puts off to some vessel. "Schooner ahoy!" says a voice from the shore, and she ahoys. Sail and hull and rope and block are duplicated in the tide below. That was a yawn of the awaking wind. Notes of preparation deepen. Sail after sail is swayed up. Anchors break their hold; then comes the quickened clink, clink, of the windlass; the jib is hoisted, and the southwest wind, no longer napping, fills it and a hundred other sails that make their way out of the harbor in the morning sunlight, to and fro.

The first schooner-rigged craft that ever swam, it is claimed, was built by Andrew Robinson, in $\mathrm{I}_{713}$, and named the Schooner. It was a handy craft for rig, but, even down to fifty years ago, a clumsy body. Cape Ann vessels are mostly built at Essex, a few miles from Gloucester; up a river or crooked creek, the builders construct and launch their faithful work for all sorts of weather to try. So they were building thirty years ago, when one, more venturesome, suddenly departed from the models of the day, sharpening the bow and hollowing the run. What talk among the fishermen! Who would go in her? What a of a rake! What a sheer! She was manned, 
though; became successful, and very soon others were on the stocks modeled after the $\operatorname{Romp}$, the pet of the fleet.

Six sloops, one boat and one shallop composed the Cape Ann fleet in r693; now it has nearly five hundred sail, of almost twenty-eight thousand tons, and Gloucester is the largest fishing port in the land. Its fleet is manned by men of every clime. A tide of young men, mainly from the Provinces, sets steadily toward this port. Many have the characteristic recklessness of the sailor, and earnings of weeks are spent between sunset and sunrise. There is among them no sailor cut of clothes, and ashore they follow the prevailing fashions down to lager beer. All haunts are prepared for Jack, and he is prepared for all haunts. As in all other callings thrift follows prudence and industry, though he seems to lie open to the changes and chances of luck. You will see his cottage commanding the finest sea view, for on the heights lie the cheapest lots. Alas! that the waiting wife can look harborward on every coming sail, often to see the flag "half-mast" -for whom?

Here are no labor strikes. The sailor brings in a fare of fish, perhaps all he has caught, by themselves; they are weighed off, the vessel is put to rights, and he goes up to the counting-room for his check. The whole value of the fish is reckoned by the vessel-owner or his clerk; then is deducted cost of ice and bait bought; then one-quarter of one per cent. for the Widows' and Orphans' Fund; one-half the remainder belongs to the owner, the other to him. From his part is then deducted charges for wood-sawing and splitting, for water, medicine-chest, condensed milk, and any charge for labor on the vessel which belonged to him to do, but which has been hired done. His check is then handed him, and he presents it in person, or it finds its devious way to the bank by other-perhaps not cleaner-hands.

One of the most exciting scenes imaginable is that of a fleet of hundreds making the port in a storm. In a northeast gale they must beat in. All day long, by twos and threes, they come. It is luff, bear away, or tack ship to avoid a smash. Crack, snap, goes a jib-boom off. Crack, snap, there is one main-boom the less. Hoarse voices of the skippers howl in entreaty or command above the howling gale, and the shore is lined with listening lookers-on.- "Century Magazine." 


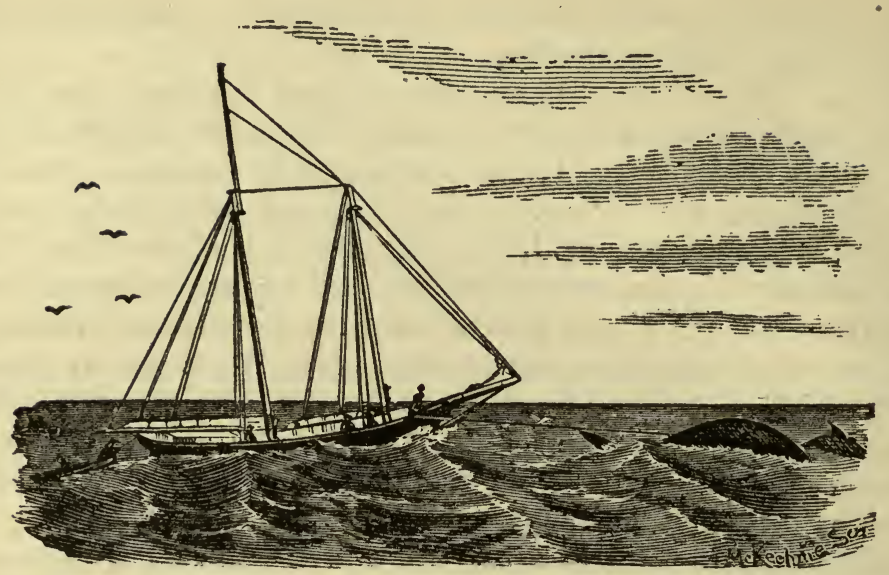

\section{Schooner Sultana Towed by a Whale.}

On the 16 th of December, 1874 , while schooner Sultana, Capt. Peterson, of this port, was at anchor on Grand Bank, there was a sudden motion felt by those on board the vessel, and it was evident that the craft was being carried through the water by some unseen and unknown motive power. Looking forward, it was observed that the cable was drawn taut, and that some "monster of the deep" was attached thereto, and drawing the vessel along at the rate of twelve knots an hour. Soon they. obtained positive evidence, as a mammoth whale came to the surface to blow, having the anchor of the vessel either hooked into his jaw or blow-hole. There was also another whale which swam near, evidently greatly astonished at the predicament of his companion. The men on board of the dories, which had just returned from visiting their trawls, had barely time to make fast their painter ere the vessel started. Another dory, with two men, was at some distance, also visiting their trawls. The captain stood ready with axe in hand, in case of emergency, and allowed the whale to tow them some distance; but not wishing to lose sight of the men in the dory, was obliged to cut the cable-otherwise he might have succeeded in capturing the whale. Whether or not his whaleship succeeded in getting rid of the anchor and tow-line is not known, as no account has yet come to hand of his being fallen in with. It was rather a novel method of being towed. We have heard of but one similar instance among the fishing fleet-that of sch. C. H. Price being towed by a whale a day and a half, some nine years ago, while on Grand Bank, when the fluke of the anchor broke and she was released. The above spirited picture gives a good idea of the Sultana in tow. It was drawn by Rory McDonald, steward of the vessel. 


\section{Loss of the Schooner Henrietta Greenleaf.}

Four Men Drowned in their Berths-The Remainder of the Crew Take to their Dories-Adrift in an Open Dory, with Scanty Clothing, amid Sleet and Cold, without Oars, for Forty-Five Hours-The Dories Part Company -One Rescued by Sch. Lizzie K. Clark-The Other Never Heard From.

The new sch. Henrietta Greenleaf left Gloucester Thursday, April 6, 1876, for a Grand Bank trip; and this was her first and last trip. She was commanded by Capt. William H. Greenleaf, who was also part owner, and from him we obtained the following particulars:

On Friday night was to the southward of La Have Bank, and had fine weather with a six knot south-southwest breeze. The watch on deck were George Olsen and Philip McCloud, and the remainder of the men were below, asleep. Shortly before three o'clock the watch called all hands to handle sail, and all turned out. Capt. Greenleaf was the first one on deck, and when he took the wheel the vessel was masts down in the water. The squall was the most terrific he ever experienced, and came so suddenly that there was no escape from it. All hands were ordered to the weather side, and the rigging was at once cut away in order to let the masts break off, and thus ease the vessel; but of no avail, and it was evident that she was fast sinking, and if they would save their lives they must get out of her as soon as possible. There was no time even to secure oars, water or food, and all the men, except the watch, had only their pants, shirts and stockings on. Thus illy provided, they proceeded to launch the dories, when it was found that four of the crew were missing, and these had been drowned in their berths, having been unable to reach the deck on account of the deluge of water which had overtaken them in their attempt. The names of these unfortunate men were Franklin Greenleaf, brother of the master, 25 years of age; Alfred Short, a native of Olsenburg, Norway, who had followed fishing from this port several years; James Peters, of Prospect, N. S.; George Connors, brother-in-law of Capt. Greenleaf, i 5 years of age.

The loss of these men threw a gloom over the remainder of the crew ; but there was no time for repining; they must work quickly, and at about halfpast three they left the vessel, with the wind blowing hard and a rough sea running. The dories kept company all day Saturday, and the winds were variable, with snow squalls and cold, biting sleet, which made their situation extremely uncomfortable, and they suffered greatly. They were frequently wet with the water shipped by the dories, and it required constant effort 
with a bucket, fortunately on board, to keep them free. Having no oars, they tore the railings off the dories, and were also fortunate enough to pick up the vessel's wheel-box, which they made paddles of, and by dint of almost superhuman exertions, were enabled to keep their frail crafts afloat. At eight o'clock, Saturday evening, the dories parted company, being unable to keep together any longer. The wind was then blowing strong from north-northwest, and continued until Sunday noon, when it moderated gradually until evening. At five in the afternoon, Freeman Crawford, one of the men, succumbed to the terrible fatigue and died, and his companions felt that if not soon rescued, they too must soon follow him. He was a native of Westport, Maine, 25 years of age.

Shortly after midnight, through the dim hazy light, they saw a sail drawing near. They succeeded in attracting attention, and the vessel proved the Lizzie K. Clark, Capt. Thomas Hodgdon, of this port. It was but the work of a few moments for the captain and his crew to respond to the cries of distress, which were borne upon their ears in the midnight, and imagine their surprise when they learned that the sufferers were their own acquaintances. With kindly care they lifted their poor suffering shipmates on board the vessel and did everything possible for men to do for their comfort. The Clark laid to until daylight, in hopes to pick up the other dory, but was unsuccessful, and Capt. Hodgdon cruised all day Monday, leaving no efforts untried in order to save his brother fishermen; but all to no avail, and the condition of the rescued men being such as to require medical skill, he sailed for Halifax, where he arrived on Tuesday. Here the men were the recipients of every attention; money, clothing and kind words were freely offered, and the American Consul, Judge Jackson, was indefatigable in his efforts to benefit them. Capt. Bennett of the steamer Chase offered them a free pass to Portland, and was unremitting in his attentions. Capt. Merrill of the Boston \& Maine Railroad also passed them over his road to Boston, and all whom they met showed none but kindly feelings. The body of Crawford was taken on shore and buried.

The names of the men rescued were Capt. Greenleaf, Lawrence Hardiman, Philip McCloud, George Olsen and Charles Cook. Those in the other dory, which was never heard from, were Joseph Gardner, Liverpool, N. S., 29 years of age; George Rowe, East Gloucester, 28 years ; Bernard Jewett, Westport, 27 years; Charles Pattie, Westport, and John S. Tobbie of Norway, 28 years.

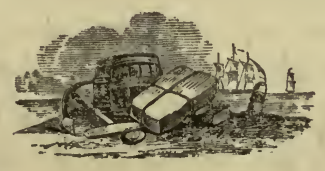




\section{Gill-Net Codfishing in Ipswich Bay,}

The Winter of $1880-8 \mathrm{r}$ will be memorable in local fishing annals as witnessing the first successful attempt at net-fishing for cod in our waters, a method that promises to make as marked a change in the shore fishery as was wrought by the introduction of trawl fishing a few years previously. This method of fishing has long been followed by the Newfoundland fishermen, and it is said that the Norwegians take half the number and two-thirds the weight of their immense catch of codfish in this manner.

Impressed with the importance of the saving made in the cost of bait, and of time consumed in procuring bait, Prof. Baird decided in the Summer of 1878 , when the Summer quarters of the Fish Commission were located in Gloucester, to experiment as to the practicability of introducing the Norwegian methods in our waters. Accordingly, he procured a set of Norwegian gill nets, which attracted considerable attention at the laboratory of the Commission at Fort Wharf, from their novel construction and curious glass floats. When the Winter school of codfish set in, in the Fall of $18 \mathrm{~g} 8$, experiments were made with these nets on the "Old Man's Pasture," but it was found that the nets were too frail for the large cod which frequent our coast in Winter, and for the strong current and rocky bottom along our shores. The result of the experiment, however, was such as to indicate that netfishing might be made practicable, with properly constructed nets, and Prof. Baird continued his investigation of the method, and on the occasion of the International Fisheries Exhibit at Berlin in the Spring of 1880 delegated Capt. Joseph W. Collins of Gloucester to make a careful study of the European methods of deep sea fishing, the result of which has been published by the Government for the information of the American fishermen. Meanwhile the Norwegian seines remained at the Gloucester headquarters of the Fish Commission, with the understanding that they were at the service of any responsible master who desired to experiment with them.

In the Fall of $\mathbf{r} 880$ the scarcity of bait interfered with the successful prosecution of the shore fishery, and at the suggestion of Capt. Stephen J. Martin, an attache of the Commission, his son, Capt. George H. Martin, decided to make a trial of net fishing in the schooner Northern Eagle of Gloucester. Securing the nets belonging to the Commission, and procuring others of improved construction, the Northern Eagle made a thorough trial of this method of fishing for shore cod in Ipswich Bay in the Winter of $1880-8 \mathrm{I}$, with such success that before the season closed quite a number of the shore fleet provided themselves with similar outfits. The Northern Eagle was supplied with three dories, each requiring three nets, which were set at night 
and hauled the next morning. The experiment proved a success from the start. For the first three nights the catch was $4,000,6,000$ and $7,000 \mathrm{lbs}$. respectively, although the weather was unfavorable and the trawl fishermen were securing only about half the amount taken by the Northern Eagle. In eight days' fishing this schooner took 40,000 lbs. of large fish, and on one trip, ending Jan. II, I88 I, she took a fare of 35,000 lbs., of which 8,000 lbs. were taken in one morning. Two trawlers, absent the same length of time, took 4,000 and 8,000 lbs. respectively. The next trip she was absent four days and took 35,000 lbs., of which over one-half were caught in a single day.* From Nov. 27, 1880, to Jan. 20, 1881, Capt. Martin took 110,000 lbs. cod, none of the trawlers exceeding one-third of that amount in the same time. Later in the season three netters arrived at Portsmouth in one day, one with $28,000 \mathrm{lbs}$. and the others with ro, $000 \mathrm{lbs}$. each of large codfish, while the trawlers had much smaller fares. Another day sch. Defiance took with her nets 12,000 lbs. steak codfish, and was high line of a fleet of twenty-seven vessels, one with twenty trawls out securing only fourteen fish, another 800 lbs., and a number of others not exceeding 2,000 lbs. each.

The nets used by the Ipswich Bay fishermen are made of strong Scotch flax twine, twelve-thread, and are of nine-inch mesh ( $4^{\mathrm{T}} / 2$ inches square). Those used by Capt. Martin were 50 fathoms long and 3 fathoms deep, while other vessels, later in the season, used nets roo fathoms long and 2 fathoms deep. The floats were of glass, fifty of them being attached to a fifty-fathom net. Bricks were used as sinkers, one being attached to the foot of the net directly beneath each of the floats. These fifty-fathom nets cost about $\$ \mathrm{r} 8$ each, and a fourteen-pound trawl-anchor was attached to each end of a gang of three nets. They were mostly set in the northern part of the Bay, but a few miles from shore, where the current was not strong, one man in a dory being able to set or "underrun" three nets, fastened together at the top and bottom.

The advantages of this method are found in the larger size of the fish taken, the saving in the cost of bait, the saving of the labor required to bait trawls, etc. Capt. Collins is of the opinion that this method may be profitably employed on the Grand and Western Banks and Banquereau, especially on the shoaler parts of these grounds, where the nets could be easily "underrun." This would obviate the necessity of leaving the Bank before a fare had been secured, as is frequently done, to procure a fresh supply of bait.

We present four plates illustrating the methods of gill-net codfishing: Plate V shows the Norwegian method of setting the nets at the bottom of the sea, 1 being the nets, 2 the rocks used for mooring, 3 the buoy, 4 the buoy-line, 5 glass floats attached to the buoy-line to keep the slack from

\footnotetext{
*On this day sch. Christie Campbell of Portsmouth set ten trawls of 1,000 hooks each close to the nets, and caught about $2,000 \mathrm{lbs}$. of fish to the $18,000 \mathrm{lbs}$. taken in the nets.
} 
PLATE V.

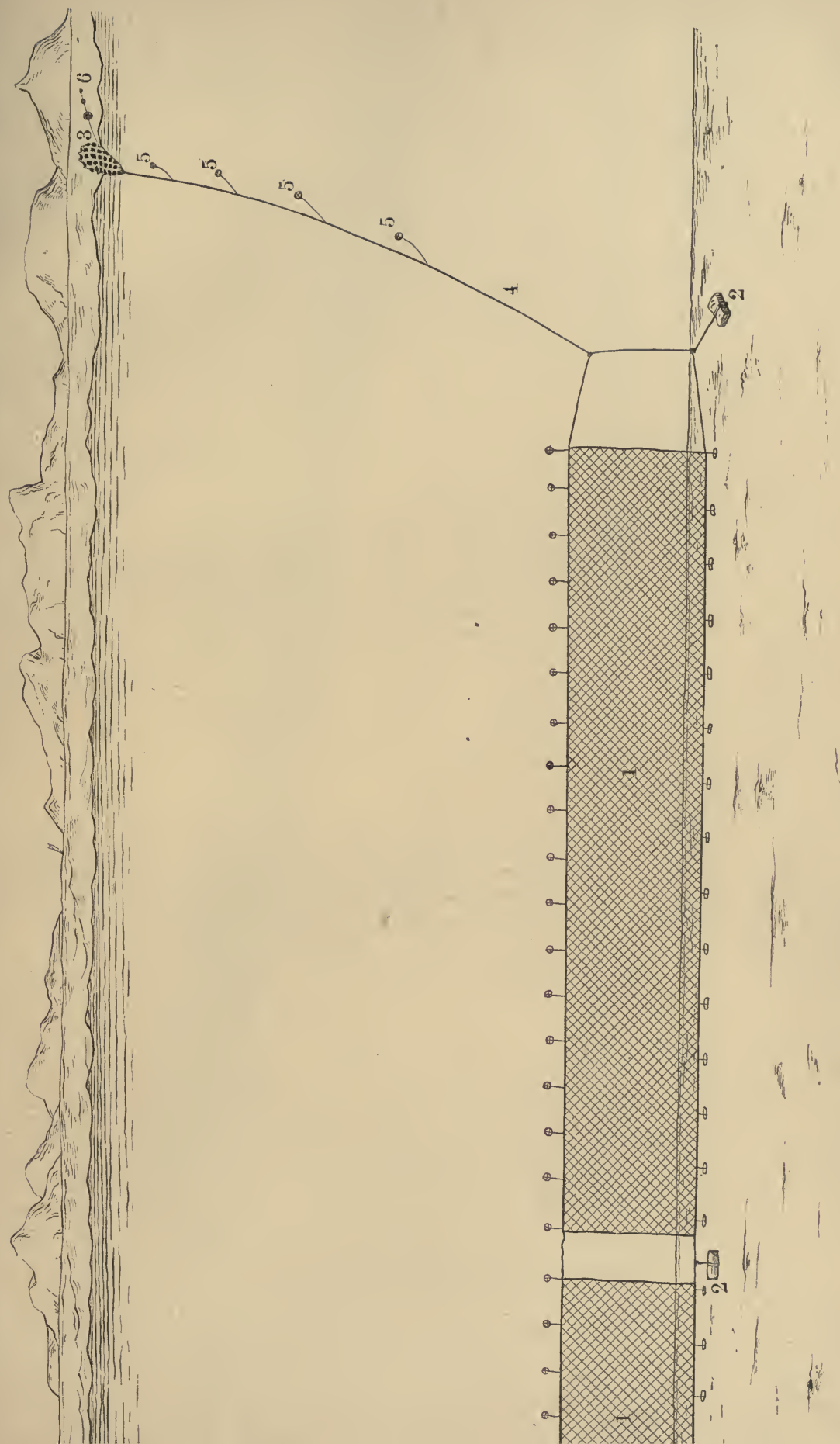


PLATE VI.

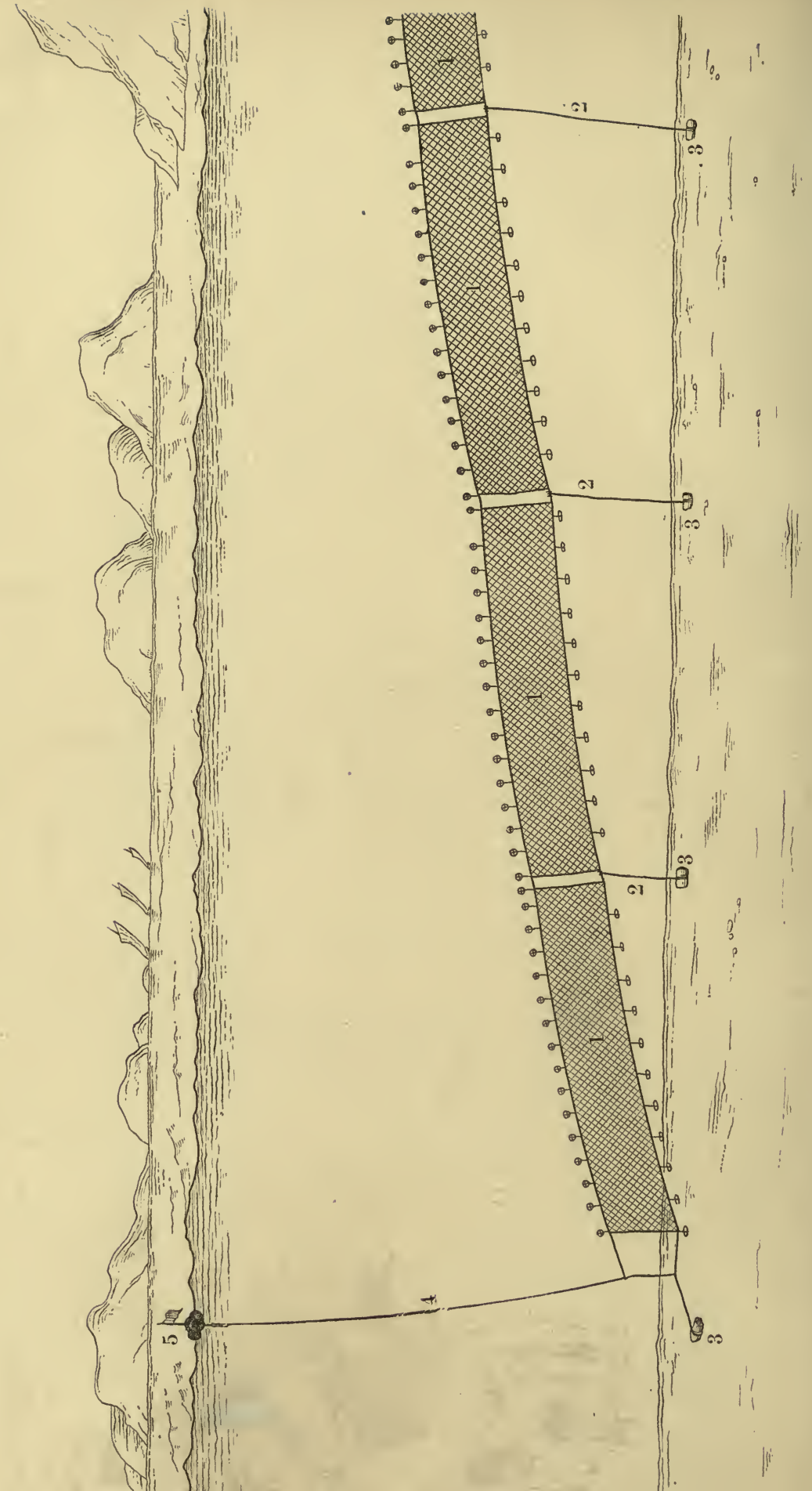


PLATE XI.

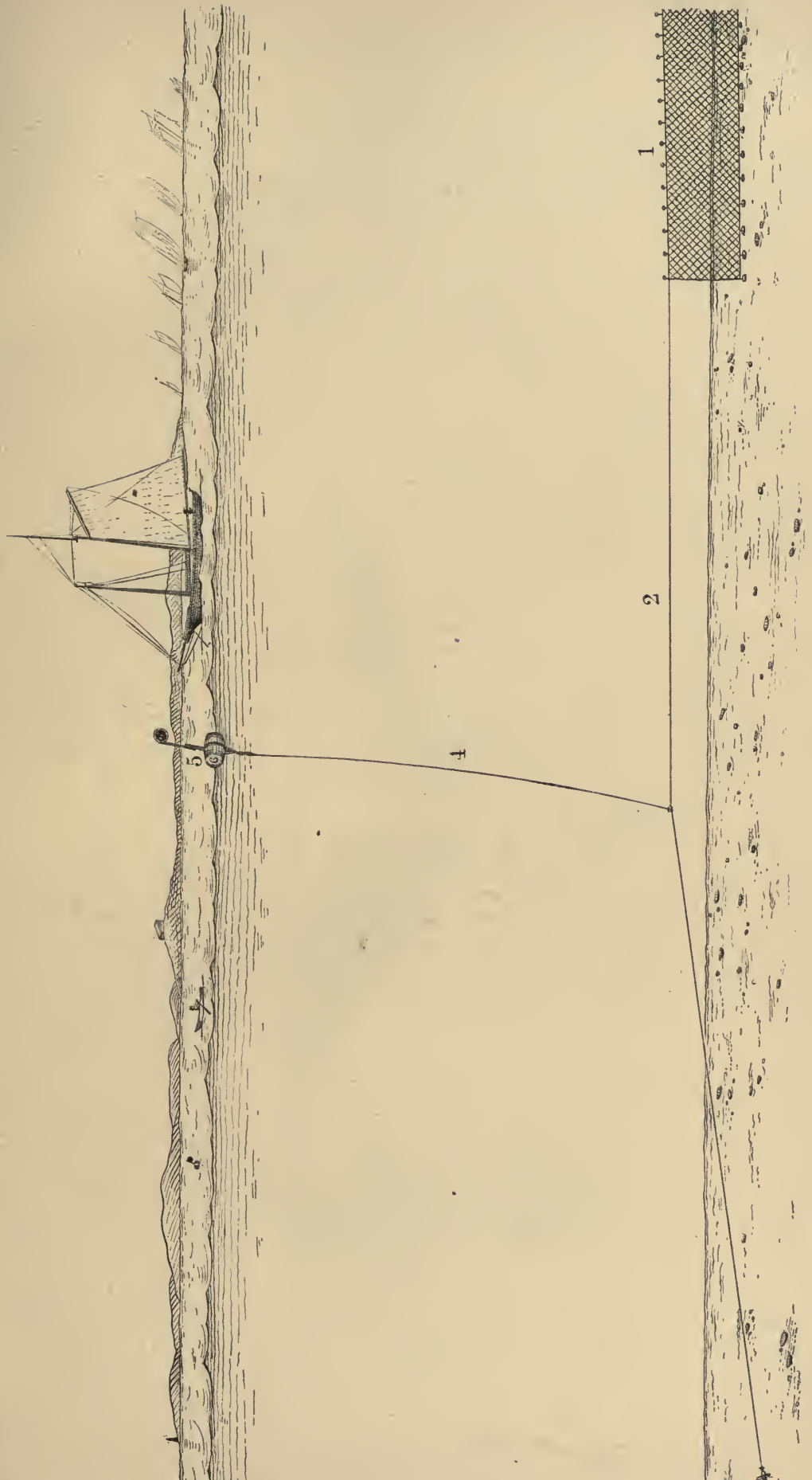




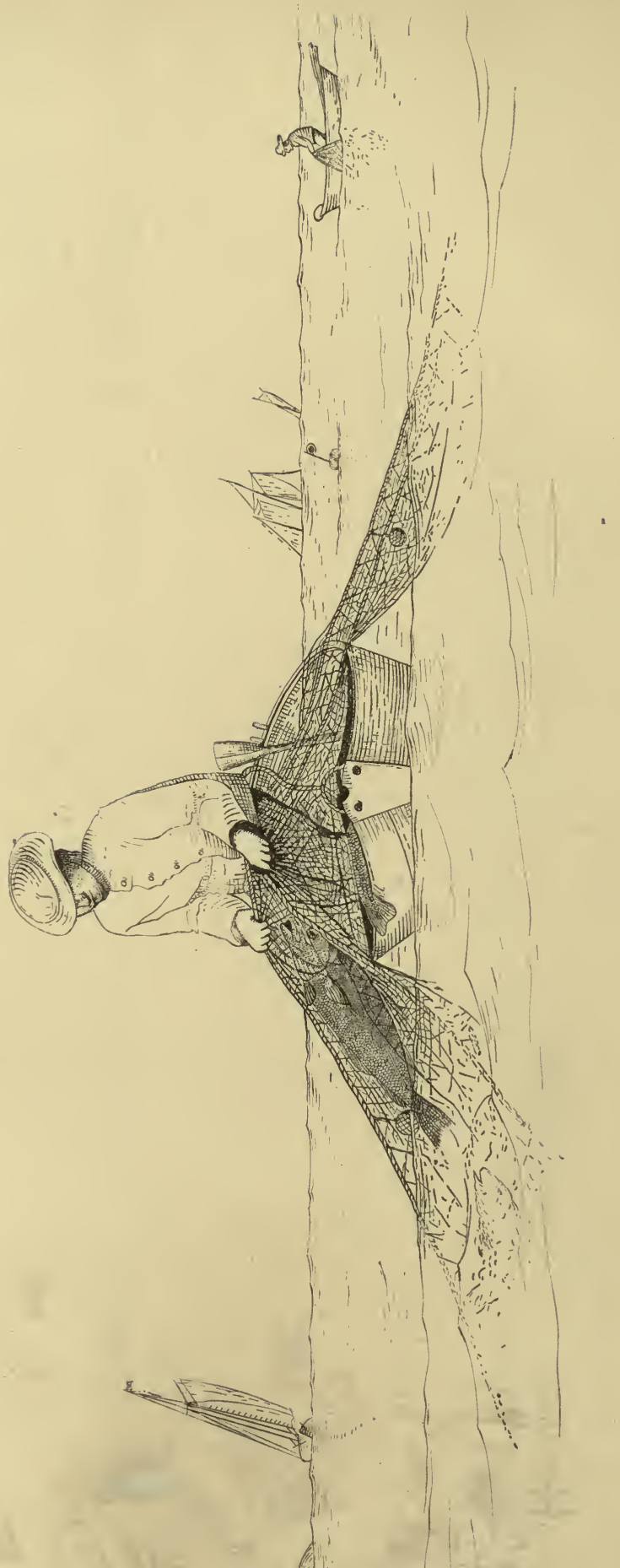


sinking when there is no current, and 6 the watch-floats, to show the position of the buoy when it is drawn under the water by the tide.

Plate VI shows the manner in which the nets are set at different depths to ascertain where the fish may be found, I being the nets, 2 the foot-lines holding the nets to the bottom, 3 the stone moorings, 4 the buoy-line, and 5 the buoy.

Plate XI shows the way in which the gill-nets were set for underrunning in Ipswich Bay. $\quad I$ is the end of a gang of nets, 2 the anchor or underrunning line, 3 the anchor, 4 the buoy-line, 5 the buoy.

In plate XII the fishermen may be seen in their dories underrunning the nets. By this process one man can secure the catch of a gang of nets, for which work an entire boat's crew of six or eight men is required in the Norwegian fishery. Under favorable circumstances one man can set a gang of nets by letting the boat drift with the wind or tide and throwing them over as it moves along, but as a general rule two men can accomplish this much better.

When setting for underrunning the anchor is first thrown over and 25 fathoms of line paid out, when the buoy-line is bent to it. The buoy and line are then thrown over, with the remainder of the anchor line, the end of the latter being made fast to the nets, which are the next to follow. A middle buoy is attached to the center of the gang. When the nets are all out the other anchor-line, with the buoy-line attached, is paid out, and last of all the anchor is thrown over. In underruning, the fisherman goes to one of the buoys on the end of his gang of nets, takes it in his dory, and throws it out on the other side, hauls in the buoy-line, allowing it to run out on the other side, and when the anchor or underrunning line is reached, takes it across the dory and hauls along towards the nets. These are underrun by pulling them in one side of the dory, as seen in plate XII, removing the fish, and allowing the nets to pass over the other side into the water, the anchors, which are not disturbed, holding them in position until the work is accomplished.

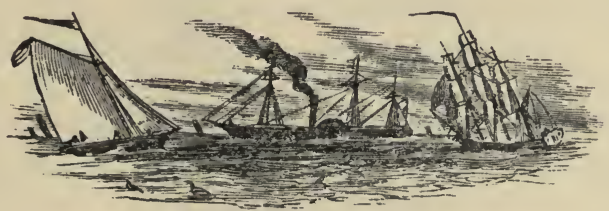




\section{A Day at the Beach.}

The spirited illustration on the opposite page tells its own story, and the scene is an extremely pleasant one to gaze upon. Many who will peruse the "Fishermen's Own Book" will readily call to mind such a festive occasion, in which they were among the happy participants, either at Coffin's Beach, Good Harbor Beach, Half Moon, or Niles'. The first-named is a favorite of ours, and where we have passed many pleasant hours of Summer.

Starting from town in a sail-boat similar to that delineated in the picture, it proves a most delightful trip to sail across the harbor, go through the canal at the Cut, then follow on until the draw at the railroad bridge allows a safe transit, and from thence sail down the Annisquam River, past cozy Summer houses and white tents-the homes of the merry campers, who joyfully greet us as we sail along. With a fair tide and good breeze the passage is quickly made, and we run into Ipswich Bay, coming to anchor off the long white beach, which is so inviting that one longs to wade into the waters which lave the shore and run over the smooth sandy surface spread out for miles. The scene is one of enchanting beauty-the wide expanse of water in the foreground, with the white sails dancing up and down with the billows, and the hillsides dotted with Summer houses-that belonging to Mr. George J. Marsh, so charmingly attractive, commanding particular notice, sitting as it does on the very edge of the water, with its solid rocky foundations, its cool and cozy verandas, and its hospitable and restful appearance.

But let us return to our party. We must get them ashore, just as in the picture. The boys are wild with delight, and the girls not much better. See how one waves his hat as he stands with his trousers stripped up. $\mathrm{He}$ is impatient for the party in the boat to land and join him in his sports. One youngster is fanning the fire with his hat, while another is tugging some wood to keep the blaze agoing. The four girls will have to be brought ashore in the young man's arms-and they are not at all averse to such a landing. The old lobster-trap on the sand looks natural, and the dinner pot, kettle and basket are suggestive of the chowder and lunch a little later. The fishing and rambling, not forgetting the visit to the sand dunes, the bathing, wading, sailing, and that dinner, with the prodigious appetites, are among the pleasing episodes of the day, and when twilight gathers, once more the boat is entered, and with a fair tide and light breeze she skims homeward amid song and mirth from the party who have thus spent a delightful Summer day at the beach. 


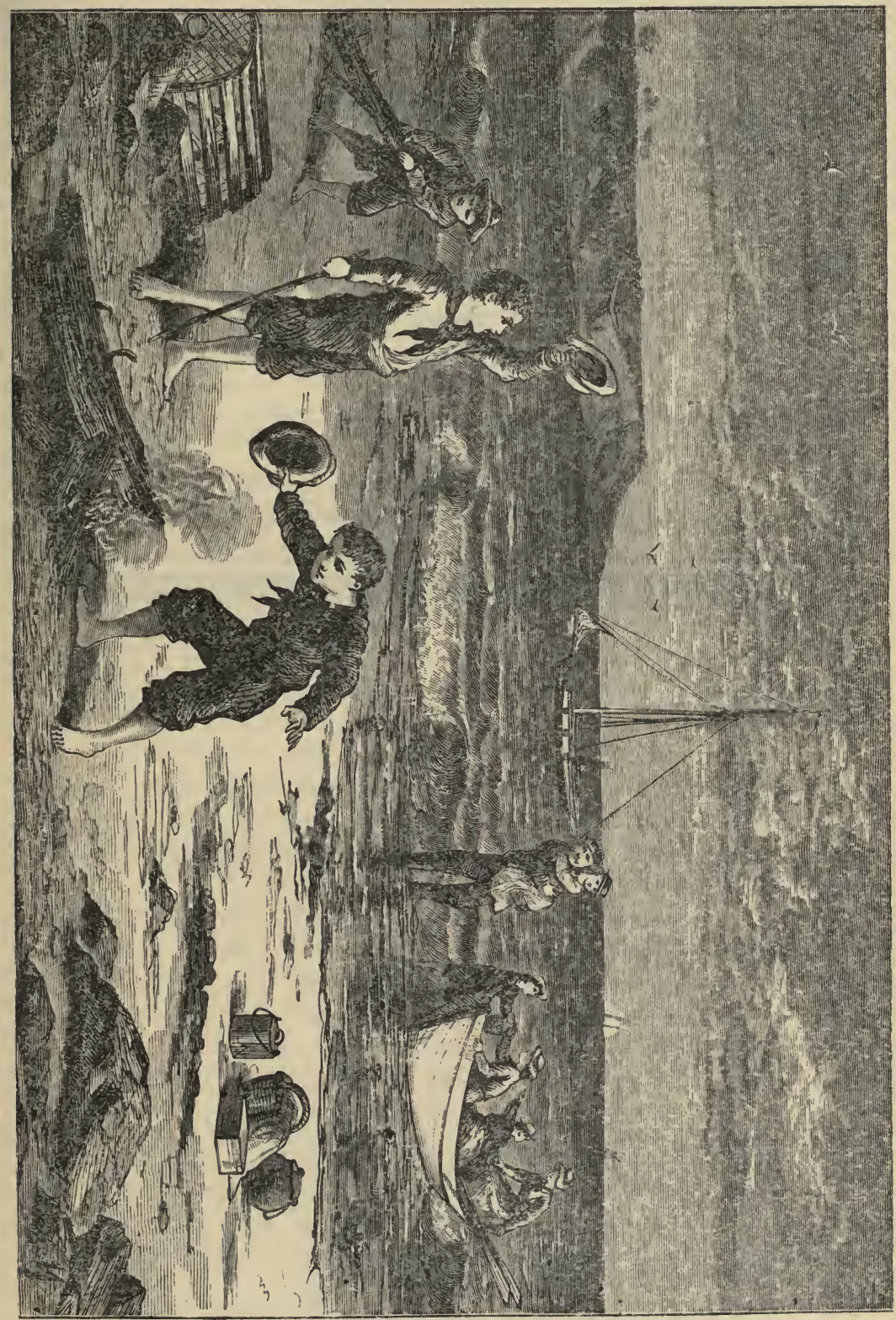




\section{In DJlemoriam.}

List of Lost Men and Vessels of the Port of Gloucester, from 1874 to 1881, Inclusive;

Also, a Table of Losses from 1830 to 1881, Inclusive, Covering a Period of Fifty-Two Years.

The "Fishermen's Memorial and Record Book" contains a detailed report of the losses of vessels and mariners belonging to this port from 1830 to 1873 inclusive. In addition to the losses of 1863 , published therein, there was one vessel which was not recorded, the sch. SUCCESS, Capt. William H. Parsons, lost in the mackerel fishery on the Nova Scotia shore. She was owned by Mr. David G. Allen, 47 tons, and valued at $\$ 2,500$; insured for $\$ \mathbf{I}, 200$ in the Gloucester Mutual Fishing Insurance Co. Crew saved.

Herewith we present a list of the losses since 1873 , completing the record for fifty-two years past. In that time 419 Gloucester vessels, of the value of $\$ \mathrm{I}, 8 \mathrm{I0}, 7 \mathrm{IO}$, and insured for $\$ \mathrm{r}, 355,4 \mathrm{I}$, have been lost, and 2,249 Glouc. ester mariners have perished at sea, making the average annual loss 8 vessels and 43 lives.

$$
1874 \text {. }
$$

Total loss, ro vessels and 68 lives. Lost tonnage, 633.r7. Value, \$49,roo. Insurance, $\$ 44,975$. Eighteen of the lost seamen left widows, and children to the number of 37.2 vessels were lost in the Newfoundland fishery, 4 in the Grand Bank fishery, $\mathbf{I}$ on Western Bank, $\mathbf{I}$ in the Shore Winter fishery, $\mathbf{I}$ in the Bay St. Lawrence, and $\mathbf{I}$ in the Menhaden fishery. Only 2 lives were lost in the Georges fishery this year.

Sch. LAURA A. DODD, 94.36 tons, owned by Leighton \& Co., lost on 
Miquelon Island, in February, on the passage to Newfoundland. Crew saved. Value, $\$ 7,000$; insurance, $\$ 6,000$.

Sch. MARY G. DENNIS, 68 tons, owned by Dennis \& Ayer and Capt. Randall McDonald, lost in Long Island Sound on the passage from Newfoundland for New York. Crew saved. Value, $\$ 6,500$; insurance, $\$ 5,000$.

Sch. B. H. SMITH, 65.26 tons, owned by Clark \& Somes, lost on Grand Bank Feb. 11. Value, $\$ 7,000$; insurance, $\$ 6,000$. Crew list-Charles Johnson, master; David Anderson, Matthew Walker, Lewis Dickson, Chas. Jackson, Samuel Johnson, John Carroll, Robert Nelson, Samuel Peterson, John Nelson, Josiah Howard, and one man name unknown.

Sch. JOHN CORL[SS, 72.54 tons, owned by Walen \& Allen, lost near Barrington, N. S., on the passage home from Grand Bank, March i 7 . Crew saved. Value, $\$ 6,200$; insurance, $\$ 5,800$.

Sch. ROBERT BRUCE, 44 tons, owned by James Mansfield \& Sons, lost at Cape La Have Nov. I2, on the passage home from Grand Bank. Crew saved. Value, $\$ 2,000$; insurance, $\$ 1,75^{\circ}$.

Sch. G. G. KIDDER, $66.3^{2}$ tons, owned by Leonard Walen, lost on Grand Bank in November. Value, $\$ 5,200$; insurance, $\$ 4,550$. Crew listThomas Downie, master; Luke White and his son Thomas, John Coolin, James Merchant, William Jackson, John Vickary, John Smith, George Beattis, John M Donald, James McDonald, Rory J. McDonald, Allan Mehlman.

Sch. WHITE FAWN, 64.49 tons, owned by George Friend \& Co., lost on Western Bank in March. Value, $\$ 6,100$; insurance, $\$ 5,400$. Crew list -Daniel Nickerson, master; Mark Haskell, Henry Perry, Benjamin A. Gray, Woodbury Nickerson, Asa R. Nickerson, Walter Hopps, George Gray, Henry C. Murphy, James Murray, Thomas Monroe, David Commiskey.

Sch. WESTERN LIGHT, 20.53 tons, owned by Peter Bolter, engaged in the Winter shore fishery, lost on the Maine coast in January. Crew saved. Value, $\$ 600$; uninsured.

Sch. CARRIE FRANCES, 88.67 tons, owned by James G. Tarr \& Bro.. engaged in Bay St. Lawrence mackerel fishery, lost on Malpec bar Aug. 6, Crew saved. Value, $\$ 7,500$; insurance; $\$ 6,000$.

Sch. SARAH M. SAUNDERS, 50 tons, owned by Leighton \& Co., engaged in the menhaden fishery, sunk off Dennisport May 20. Value, $\$ 1,000$ insurance, $\$ 875$.

Lost Overboard.-Gamaliel Swain from sch. Shiloh, and Capt. Neil McKenzie and John DeVoh from sch. Giorge B. Loring, on Grand Bank, Nov. 8. Archibald Kennedy from sch. Fitz J. Babson, Jan. I r, and John Carpenter from sch. Oizan Bille, Feb. Iо, on Western Bank. Alexander McDonald from sch. Oceaniss, Nov. 2 I, and Charles McDonald from sch. Enola C., Dec. ${ }_{5}$, in the Winter shore fishery. Frederic Rhodes from sch. Fred $P$. Frye in Gloucester harbor, Oct. 17, in the shore mackerel fishery. George 
M. Bryant from sch. Hattie B. West, March 13, and Joseph H. Bird from sch. Express, Nov. 23, on Georges.

Lost IN DoRies.-Patrick Lynch and James McIntosh from sch. J. $F$. Allen, Jan. 20; Michael McDonald and Harvey Whitman from sch. Carrie P. Morton, June 13 ; Capt. Henry Crowell and Rufus Spinney from sch. William V. Hutehings, in October; Charles Lennox from sch. Hereward, Aug. I 5 ; John Hanley and Stuart Hadley from sch. Everett Steele, Dec. 8 ; Benjamin Griffiths and Neil McLane from sch. Clara B. Chapman, Sept. 14; all on Grand Bank. David Henderson from sch. Edward A. Horton, Feb. 26; Hiram Saunderson and Harry Anderson from sch. Notice, April I7 Murdoch Martell and Thomas White from sch. C. B. Manning, May 30 ;. Alonzo Roberts from sch. Sarah C. Pyle, April 20; William Phalen and Michael Boudrout from sch. Mary Louisa, in May; Charles McPherson and Charles Keefe from sch. Morning Star, Aug. 5 ; all on Western Bank.

1875 .

16 vessels and 123 lives were lost this year. The loss of tonnage was r,050.9 r. Value of vessels lost, $\$ 88,500$. Insurance, $\$ 8$ r,726. ro vessels and $9 \mathrm{I}$ men were lost in the Grand and Western Bank fisheries, 5 vessels and 27 lives in the Georges fishery, $\mathbf{I}$ vessel in the mackerel fishery, 4 lives in the shore fishery and $\mathrm{I}$ in the herring trade.

Sch. DAVID BURNHAM, 2D, 64.57 tons, owned by Brainard Low \& Co., lost on the Banks in January. Value, $\$ 5,600$; insurance, $\$ 5,000$ on vessel and outfits. Crew list-Alfred Daggett, master; William L. Reeves, L. H. Hawson, Patrick Powers, James A. Bushey, Frederic Lindsay, George W. Stuart, Archibald McDonald, William Coolin, Michael Curtiss, Peter H. Miller, Charles Wilson.

Sch. JOSEPH CHANDLER, 69.94 tons, owned by Leonard Walen, lost on the Banks in January. Value, $\$ 6,000$; insurance, $\$ 6,050$ on vessel and outfits. Crew list-Frank McRae, master; Charles Gunnison, Hugh Kennedy, F. A. Beaton, Daniel McDonald, Joel McCaleb, Charles Anderson, Allan McMullen, Alex. Campbell, Henry Mosier, James McDonald, Duncan McIntire.

Sch. SARAH H. CRESSY, 63.03 tons, owned by Leighton \& Co., lost on the Banks in February. Value, $\$ 4,600$; insurance, $\$ 4,525$ on vessel and outfits. Crew list-Daniel McFadden, master; Allen McKinnon, William Freeman, Thomas Joy, Calvin McPhail, K. J. McKenzie, Charles F. Sinclair, Samuel McLean, Malcom Morrison, Alex. Grant, John Maguire, John Kelly.

Sch. J. C. CALL, 78.42 tons, owned by Leighton \& Co., lost on the passage to the Banks in February. Value, $\$ 8,800$; insurance, $\$ 7,700$. Crew list-Robert S. Baker, master; Martin Madison, Pius McPhee, David Dum- 
phy, Joseph Bouchy, Hendrick Jensen, John Donovan, Andrew Peterson, Anthony Cash, Henry O'Neil, Richard Bramble, Christian Peterson.

Sch. PHARSALIA, 76.96 tons, owned by George Steele, lost on the Banks in November. Value, $\$ 12,000$; insurance, \$10,000. Crew listSamuel A. Keene, master; A. W. Getner, J. Peterson, M. Johnson, Oscar Wilson, Charles Smith, Martin Peterson, Theodore Reed, Louis L. Baile, John Lewis, Howard Steele, John W. Strahan.

Sch. BLOOMINGDALE, 59.67 tons, owned by Walen \& Allen and employed in the Bank fishery, lost at Cape Breton, June II. Crew saved. Value, $\$ 2,500$; insurance, $\$ 2,188$, with $\$ 800$ additional on outfits.

Sch. MONADNOCK, 74.49 tons, owned by Poole \& Cunningham, lost at Magdalen Islands in June. Crew saved. Value, $\$ 7,900$; insurance, with outfits, $\$ 8,000$.

Sch. HATTIE M. LYONS, 66.70 tons, owned by D. C. \& H. Babson, lost in Bank fishery at Cape Breton, Aug. 19. Crew saved. Value, $\$ 4,900$; insurance, $\$ 4,200$, with $\$ 800$ on outfits.

Sch. JOHN W. DODGE, 83.07 tons, owned by James A. Stetson, lost near Yarmouth, N. 'S., on the passage home from the Banks, Nov. 6. Crew: saved. Value, $\$ 3,000$; insurance, $\$ 2,200^{\circ}$.

Sch. ABBY M. HEATH, 58.98 tons, owned by Poole \& Cunningham, abandoned or the homeward passage from the Banks in December. Value, $\$ 4,500$; insurance, $\$ 2,875$.

Sch. WILLIAM H. THURSTON, $54.5^{8}$ tons, owned by David Low \& Co., employed in Georges fishery, lost on Gull Island, N. S., in February. Crew saved. Value, $\$ 3,000$; insurance, $\$ 2,500$.

Sch. J. O. FRIEND, JR., $598 \mathrm{I}$ tons, owned by Sayward Brothers, run down and sunk on Georges, May 5. Crew saved. Value, $\$ 5,000$; insur-ance, $\$ 4,375$ on vessel and $\$ 400$ on outfits.

Sch. MONTANA, 62.75 tons, owned by Rowe-\& Jordan, employed in Georges fishery, lost near Cape St. Mary's, May ro. Value, $\$ 4,800$; insurance, $\$ 4,275$, with $\$ 400$ on outfits.

Sch. H. B. STANWOOD, 63.83 tons, owned by Pettingell \& Cunningham, lost on Georges in March. Value, $\$ 4,900$; insurance, $\$ 4,300$. Crew list-Lauchlin McLean, master; Samuel Erickson, David Wooster, Albert Faulk, James McLean, Daniel A. McLeod, John McKay, James McKenzie, Charles McLean. Norman McLean, Neil McDonald, Daniel McLeod.

Sch. WILLIAM C. ENDICOT'T, 6 r.2 r tons, owned by William C. Wonson, lost on Georges in March. Value, $\$ 5,000$; insurance, including outfits, $\$ 4,863$. Crew list-John Jones, master; Frederic Smith, James Johnson, C. Gunderson, E. Hamlin, Frank Nelson, Andrew Johnson, Peter Olsen, James Mahar, John Perow.

Sch. BELLE OF THE BAY, 52.90 tons, owned by Leighton \& Co., em- 
ployed in the Southern mackerel fishery, run down and sunk off Block Island, June 7. Crew saved. Value, $\$ 6,000$; insurance, $\$ 4,875$.

LOST OVERBOARD, ETC.-The following persons were lost overboard on Georges: James Haynes from sch. Mary E. Daniels, March 3; Edmund Coolin from sch. B. F. Somes, March 4; John Wilson from sch. Etta Gott, April 19; Michael Pender from sch. Fïnance, May 14; Harrison T. Clark from sch. John Q. Adams, in October.

August Anderson from sch. El Dorado, on Middle Bank, March I6; Michael Shea from sch. Elisha Crowell, in Provincetown harbor, Oct. 28 ; Charles Anderson from sch. C. P. Thompson, on the passage to Fortune Bay.

The following persons were lost in the Bank fishery, most of them while out in dories to visit their trawls: Angus Harrigan and William Edwards from sch. William Parsons, 2d, Jan. 15 ; Rory McDonald from sch. Knight Templar, Jan. 17 ; Pierce Howard from sch. El Dorado, Feb. 14; William H. Smith from sch. William A. Pew, in Liverpool (N. S.) harbor, in February; Blanchard Campbell from sch. $N$. H. Phillips, March I8; John Marshall and Patrick Manning from sch. Knight Templar, April 6 ; John Wilson from sch. Etta Gott, April 19; Pius McIntire and Hugh Gilmore from sch. Wachusett, May 3 ; John J. Powers and Norman McLeod from sch. Challenge, Sept. 23; George F. Wilson from sch. Gertie E. Foster, Sept. 29; James Greneben from sch. James Bliss, Sept. 22 ; John Johnston and John Peterson, Oct. 2I, and Henry Morine, Nov. 2, from sch. Aberdeen; Morris Bryant from sch. Moro Castle, Oct. 26 ; Joseph Morey, William Gallivan, John McDonald and Henry Stello from sch. Epes Tarr, Oct. 27; Thomas Stevens and Peter Johnson from sch. Alfred Walen, Nov. 7 ; Charles Hymes from sch. Andrew Leighton, Nov. II ; Nicholas Devereaux and Edward McCarty from sch. Peter D. Smith, Nov. 14; Thomas Morrissey and Edward Collins from sch. Fitz J. Babson, in November; Frederic Peterson from sch. Onward, in November; Charles Fogg and John Dennen from sch. Levanter, on Middle Bank, Nov. 23.

$$
1876 .
$$

27 vessels, I fishing boat and 212 men were lost this year. The vessels covered a tonnage of $1,691.44$ tons, and were valued at $\$ 150,000$, with $\$ 116,222$ insurance. Of the lost seaman, 54 left widows, and 122 children were made fatherless. $\quad 167$ men went down in their vessels, 21 were lost overboard, and 24 were lost in dories while visiting their trawls. 9 vessels were lost on Grand Bank, 6 on La Have Bank, 3 on Georges, 3 in the Bay St. Lawrence, 3 in the Winter shore fishery, and $x$ each in the Western Bank, shore mackerel and herring fisheries. 12 vessels and 90 men were lost in a series of gales extending from Dec. 9 to $x 6$. 
Sch. HENRIETTA GREENLEAF, 91.22 tons, owned by Leighton \& Co. and Capt. William H. Greenleaf, capsized and sunk on passage to Grand Bank, April 8. Value, $\$ 10,000$; insurance, $\$ 8,000$. The captain and four of the crew were subsequently picked up in a dory, but the following were lost: Franklin Greenleaf, James Peters, Alfred Short, George Connors, Joseph Gardner, Bernard Jewett, Charles Pattie, John S. Tobie, George S. Rowe and Freeman Crawford. The four first named were drowned in their berths, the last-mentioned died of exposure in the dory which was picked up, and the others were never heard from after the dories parted company the evening after the disaster.

Sch. JANET MIDDLETON, 66.43 tons, owned by Smith \& Oakes, lost on Grand Bank in April or May. Value, $\$ 7,55^{\circ}$; insurance, $\$ 6,057$. Crew list-William Wentzel, master, and his brother, name unknown; Charles Reeves, Caleb Wheaton, John McFadden, Simon Landry, Jerry Saunders, John Russell, Walter S. Williams, Samuel P. Remick, John McFarland.

Sch. JAMES L. SHUTE, I05.57 tons, owned by Shute \& Merchant, also lost on Grand Bank in April or May. Value, $\$ 13,000$; insurance, $\$ 10,275$. Crew list-George H. Norwood, master; Percy H. Norwood, Felix DeCost, Charles B. Turner, Edwin P. Turner, George W. Fyle, Robert S. Mills, John Cody, William Sampson, Michael Trueby, Paul Veno, Henry Cook, William O'Brien, John W. Porter.

Sch. WALTER M. FALT, 67.46 tons, owned by Leighton \& Co., lost on Grand Bank in September. Wreck seen dismasted and water-logged. Crew never heard from. Value, $\$ 8,800$; insurance, $\$ 7$, roo. Crew list-Bennett Perry, master; John P. Colby, James Keyes, John Ginevan, Thomas Davidson, Patrick Dugan, James Wheeler, John Phalan, Charles L. Austin, Thomas Burke, George Williams, Patrick Busteed.

Sch. WILLIAM T. MERCHANT, 76.76 tons, owned by Shute \& Merchant, lost on Grand Bank in December. Value, $\$ 5,800$; insurance, $\$ 5,075$, with $\$ \mathrm{r}, 000$ additional on outfits. Crew list-Angus Anderson, master; Barney Frazier, Charles Frazier, brothers; John Barry, Robert Miles, Alex. Babbin, Samuel Thurber, Charles Anderson, B. W. Alby, John McKay, Joseph Gosby, Moses Stafford.

Sch. D. E. WOODBURY, 65.25 tons, owned by Smith \& Gott, lost on Bank trip, in December. Value, $\$ 5,200$; insurance, $\$ 4,550$, with $\$ 700$ on outfits. Crew list-Franklin D. Pinkham, master; David S. Corson, Andrew M. Anderson, William Oḷsen, Oliver Olsen, Andrew Hanson, John Brant, Edward Sperling, James S. McLeare, and one man name unknown.

Sch. JOB JOHNSON, 64.07 tons, owned by Joseph O. Procter, run down and sunk on Grand Bank in July. Crew saved. Value, $\$ 6,35^{\circ}$; insurance, $\$ 5,182$.

Sch. DANIEL A. BURNHAM, 72.35 tons, owned by Leonard Walen, 
capsized and abandoned in Grand Bank fishery, Dec. ro. Crew taken off. Value, $\$ 6,500$; insurance, $\$ 5,500$.

Sch. GETTYSBURG, 70.32 tons, owned by Cunningham \& Thompson, employed in Bank fishing, abandoned in December. Crew taken off and landed at Plymouth, Eng. Value, $\$ 5,400$; insurance, $\$ 4,35$.

Sch. J. F. ALLEN, 62.63 tons, owned by B. Maddocks \& Co., lost on Western Bank in October. Value, $\$ 4,625$; insurance on vessel and outfits, $\$ 5,025$. Crew list-John Campbell, master; William McNare, Joseph Brown, James Brown, Alpheus Campbell, Woodbury Lewis, Angus McDonald, Smith McDonald, William Rogers, Thomas Russell.

Sch. KEARSARGE, 59.03 tons, owned by John Pew \& Son, lost on Georges in April. Value, $\$ 4,500$; insurance, $\$ 1,500$. Crew list-Solomon Burchell, master; John Haffey, Patrick Dorsey, Joseph Fritz, Frank Hepson, Joseph Fritz, Jr., Joseph Sawyer, John Francis, Joseph Enos, Murdock Smith, Charles King.

Sch. SARATOGA, 74.96 tons, owned by George Steele, lost on Georges in May. Value, $\$ 10,000$; insurance, $\$ 8,800$. Crew list-John McMillan, master; John Hiltz, John D. Carter, William Mackay, Edward McGuire, Albert Walker, Andrew J. Woodman, F. E. Lewis, Jr., John Murphy, Charles Richards, William B. Walker.

Sch. LANCET, 56.76 tons, owned by Joseph O. Procter, engaged in the Georges fishery, abandoned on Georges Dec. ro. One of the crew, John Kirby, washed overboard and drowned. Value, $\$ 3,000$; insurance, $\$ 2,500$.

Sch. HOWARD STEELE, 60.37 tons, owned by George Steele, lost on La Have Bank in December. Value, $\$ 5,15^{\circ}$; insurance, including outfits, $\$ 5$, r25. Crew list-Edward Murphy, master; William Silvey, Patrick Costello, Barnard P. Scanlan, George Melroy, Peter Stapleton, Edward Walsh, Thomas Ready, Peter Collins, James McQuillan, Daniel Curtis.

Sch. JOHN S. TYLER, 63 tons, owned by Sidney Friend \& Bro., lost on La Have Bank in December. Value, $\$ 4,600$; insurance on vessel and outfits, $\$ 4,425$. Crew list-Arthur O’Neal, master; Felix O’Neal, Murdoch McCloud, Alexander McCloud, his son, Edward Berry, William Laney, George Allen, Louis Wilson, William Sullivan, Henry Maddox.

Sch. J. F. HUNTRESS, 63.73 tons, owned by Samuel Haskell, lost on La Have Bank in December. Value, $\$ 5,900$; insurance, $\$ 5,163$ on vessel and $\$ 400$ on outfits. Crew list-Richard Rose, master; George L. Hendrickson, Frank M. Anderson, John M. Johnson, Charles J. Anderson, Andrew Anderson, Harry Beck, Peter J. Olsen, Thomas Thompson, John Beck.

Sch. MODENA B. JERAULD, 70.34 tons, owned by D. C. \& H. Babson, lost on La Have Bank in December. Value, $\$ 5,300$; insurance, $\$ 3,900$. Crew list-Charles P. Mitchell, master; Edward Haines, John C. Haines, brothers; Michael Keefe, Freeman Snow, William Snow, his brother, 
Edward Herring, B. D. Joyce, Lewis D. Martin, Emanuel Rose, Daniel Gardner.

Sch. ROBERT EMMETT, 45.25 tons, owned by Charles Parkhurst, lost on La Have Bank in December. Value, $\$ 4,500$; uninsured. Crew listJoseph Grey, master; John E. Saunders, Seth S. Colby, Samuel Spinney, Alex. Boyd, Edward Dodge, Samuel Tyng, William Michaels, Thomas Tarreo.

Sch. WYOMING, 55.2 I tons, owned by McKenzie, Hardy \& Co., lost on La Have Bank in December. Value, $\$ 5,500$; insurance, $\$ 4,732$. Crew list - Henry Nauss, master, and his brother Arthur; James Jeffrey, Warren Williams, Thomas Haney, Charles Forbes, Alex. Thompson, John Haskins, George Crittenden, Joseph Zink.

Sch. COL. ELLSWORTH, 82.45 tons, owned by Capt. Oliver F. Howard and engaged in the Bay St. Lawrence mackerel fishery, lost at the Magdalen Islands, Aug. 20. Crew saved. Value, $\$ 5,500$; insurance, $\$ 4,800$.

Sch. RELIANCE, 46.49 tons, owned by Walen \& Allen, also employed in Bay mackereling, lost near Canso, Sept. 21. Crew saved. Value, $\$ 3,600$; insurance, $\$ 2,55$.

Sch. TIBER, 44.70 tons, also owned by Walen \& Allen, another of the Bay St. Lawrence fleet, wrecked at Louisburg, Sept. 29. Crew saved. Value, $\$ 1,775$; insurance, $\$ 850$.

Sch. CHALLENGE, 36.16 tons, owned by Eben H. and Franklin Griffin, wrecked on the Maine coast in the shore mackerel fishery, July 6 . Crew saved. Value, $\$ \mathrm{r}, 000$; uninsured.

Sch. JOHN STORY, JR., 27.48 tons, owned by Capt. Charles H. Orne and engaged in the Winter shore fishery, run down and sunk off Eastern Point, Jan. 27. Crew saved. Value, $\$ 800$; insurance, $\$ 700$.

Sch. GLENWOOD, 62.44 tons, owned by Rowe \& Jordan, also employed in the shore fishery, run into and sunk off Highland Light, Feb. 19. Crew saved. Value, $\$ 6,000$; insurance, $\$ 4$, I I 3 .

Sch. MAZEPPA, 47.57 tons, owned by Capt. Gilman Roberts, lost at Brace's Cove in the shore fishery, Nov. 2. Crew saved. Value, $\$ 1,000$; insurance, $\$ 700$.

Sch. ELLEN FRANCES, 55.44 tons, owned by B. Maddocks \& Co., lost on the passage from Souris, P. E. I., with a load of potatoes, in December. Value, $\$ 2,45^{\circ}$; insurance, $\$ 2,144$ on vessel and $\$ 1,000$ on cargo. Crew lost. Commanded by Capt. John Lunergan of Beverly, with a crew of four men, names unknown.

Boat BONANZA, owned by Capt. John Carter, was wrecked in the offshore fishery, off Plymouth, May 23. Crew saved. Value, $\$ 600$; uninsured. Sch. GEORGE PEABODY, of Salem, chartered by Capt. George W. 
Plumer of this city, was wrecked in the Bay St. Lawrence in October, and sold for $\$ \mathrm{I}, 500$. She is not included in our figures.

Lost Overboard.-Louis Beck from sch. Sarah C. Pyle, Jan. 4 ; Capt. Maurice Walen from sch. Marathon, on Georges, Feb. 22 ; Capt. Robert N. Mackey on the passage from Fortune Bay, Feb. 4 ; Dennis Lyon from sch. Nathaniel Webster, Feb. 24; Capt. Martin Nelson from sch. Arizona, on Georges, Feb. 24; S. Augustus Webb from sch. John S. Presson, on Grand Bank, Feb. 26 ; Nathaniel Gillis from sch. David Crockett and Nelson Mitchell from sch. Edwin C. Dolliver, on Gránd Bank March II ; John O'Brien from sch. Joseph $O$., on Georges, March 26; George Carpenter from sch. Robert Emmett, on Georges, April ro; N. T. Chatto from sch. Bloomer, off Portsmouth, July 24; Alfred Meyers from sch. Edward E. Webster, on Grand Bank, July 4; Richard Tibbetts from sch. Charles P. Barrett, on Middle Bank, Oct. I2 ; James Sigsworth, Frank Dunn and Daniel McNeil from sch. F. A. Smith, on Grand Bank, Oct. 16 ; Michael Morgan from sch. Victor, on Grand Bank, in December; Joseph Teddy and Charles Cook from sch. Ruth Groves, on Georges, Dec. II ; George Miller from sch. Howard on Grand Bank, Dec. Io.

Lost in Dories.-Charles H. Fisher and Chester W. Denton from sch. Polar Wave, Jan. 19; John G. Smith and John Davis from sch. Restless, in January; all on Western Bank. Herbert Gorman, mate of sch. Flash, at Newfoundland, Feb. 24. Daniel Brynnelson and Stephen Stone from sch. Alfred Walen, on' La Have Bank, March 17 ; Capt. John McCloud from sch. Addison G. Procter, Feb. 8 ; William Norton and Albert Sulkey from sch. Frederic Gerring, Jr., Feb. 28 ; James Horton and Thomas Kennedy from sch. Eltwin C. Dolliver, March 3 ; George Patience and Charles Anderson from sch. Fitz J. Babson and John McMillan and John McAuley from sch. J. F. Allen, April 18 ; David Shearer and William Diggers from sch. Hireward, June 27 ; Charles Olsen and Charles Strimm from sch. Aberdien, in August; Nicholas Surratt from sch. Shiloh, Sept. 20; Angus McKay and George Party from sch. Epes Tarr, Sept. 27 ; Charles Haley from sch. Charles P. Thompson, Oct. 6 ; all on Grand Bank.

\section{I877.}

This was a year of general depression in the fishing industry, but the losses were comparatively light. 7 vessels were lost in the fishing business and $I$ in the coasting trade, their tonnage being 722.33 , and their value about $\$ 45,000$. Insurance about $\$ 22,000$. Number of lives lost in the fisheries, 38 .

Sch. MAY QUEEN, $53.5^{6}$ tons, owned by Capt. Isaac P. Peterson, wrecked in shore fishery on Coney Island, Jan. 2. Crew saved after seven hours' extreme peril and suffering. Value, $\$ 3,400$; insurance, $\$ 2,975$. 
Sch. ELIZA JANE, 46.43 tons, owned by James Mansfield \& Sons, lost near Shelburne, N. S., Jan. 23. Crew saved. Value, $\$ 2,400$; insurance, $\$ 2,400$.

Sch. GEN. GRAN'T, 86.I I tons, owned by John Pew \& Son, lost at Newfoundland in January. Crew saved. Value, $\$ 5,55^{\circ}$; insurance, $\$ 2.500$.

Sch. MARY BURNHAM, 65.7 I tons, owned by Harvey Knowlton, Jr., lost on La Have Bank in January. Value, $\$ 4,712$; insurance, $\$ 4,623$. Crew list-Alexander Lyle, master; James Howard, John Willow; David S. Merchant, Thomas Lauray, Lawrence McVarish, Randall McVarish, Alexander McVarish, James Campbell, Robert King, Edward Martin.

Sch. CLARA B. CHAPMAN, 68.19 tons, owned by Dennis \& Ayer, lost at Sandy Point in May. Crew saved. Value, $\$ 5,114$; insurance, $\$ 4,975$. Wreck sold for $\$ 1,000$,

Sch. ANN MARIA, 4r.78 tons, owned by Gardner K. and Howard Wonson, and employed in the Georges fishery, lost on Newburyport bar July I. Crew saved with considerable difficulty. Value, \$1,050; insurance, $\$ 928$.

Sch. BELLE, 23.I5 tons, owned by George R. Gates and others, lost near Portsmouth, N. H., in the shore fishery, Aug. 17. Crew saved. Value, $\$ 75^{\circ}$; insurance, $\$ 600$.

Three-masted sch G. P. POMEROY, 337.40 tons, lost with all her crew on the passage from Brunswick, Ga., for Bath, Me., with a cargo of ship timber, in an April gale. About two-thirds owned in Gloucester and onethird in Manchester, Beverly, Boston and Salem. Commanded by Capt. Francis A. Bryant of Gloucester. \$1,500 insurance in the Gloucester Fire Insurance Co., and other small amounts elsewhere.

Lost Overboard.-Capt. Daniel M. Gray from sch. B. F. Somes, March I3; John Kennedy from sch. Adelia Hartwell, March 26; Manuel Veada from sch. Dictator, Oct. 6 ; and Hans Antone Olsen from sch. Arizona, Nov. 2, all in Georges fishery. Neil McPhee from sch. Highflyer, in New York harbor, in May. Walter H. Merchant from sch. Etta Gott, in the Bay St. Lawrence, Sept. 22.

Capsized in Dories.-Alphonso Babson and Gorham Parsons in Ipswich Bay, March 13. Andrew Anderson off Eastern Point, May 7. Harry Miller, of sch. Eben B. Phillips, in Gloucester harbor, Oct. хо. George B. Michael and William Burnham from sch. Eben B. Phillips, March 18 ; John Daniels and Edward Spencer, of sch. Frederic Gerring, Jr., March 27 ; Edward Coles and Howard Powers from sch. Edward E. Webster, and James Murphy from sch. Eben Parsons, April 12; Harry Richardson from sch. Lizzie $K$. Clark, May $2 \mathbf{1}$; Lemuel Parsons and John Holmes from sch. Corinna H. Bishop, May 30 ; Neil Johnson and Charles Culvert from sch. Marion, June 3 ; Adolph Jackson and Matthew Huntwell from sch. Andrew 
Leighton, Sept. 26 ; and Daniel McDonald and Albert Mizner from sch. G. $P$. Whitman, Nov. 4 , all on the Banks.

Capt. Joseph Campbell killed by falling from aloft on board sch. Gertie $E$. Foster, on the Banks, Nov. 6.

$$
1878 .
$$

The fishing losses for this year numbered i I vessels, 795.90 tons, valued at $\$ 60,794$ and insured for $\$ 48,767$, and 55 lives. Two Gloucester coasting vessels were lost this year, making the total number of vessels $I_{3}$, tonnage 907.57 , value $\$ 64,794$, insurance $\$ 49,967$, lives 56 .

Sch. CARRIE P. MORTON, 84. I9 tons, owned by Walen \& Allen, lost on Grand Bank in January or February. Value, $\$ 7,200$; insurance, $\$ 6,300$. Crew list-Antone S. Downs, master; Joseph Gay, Angus McLean, Jesse McLoud, Anthony Holthes, Augustus Frazier, Emanuel Enos, Charles Burke, Lawrence Powers, James Lundry, John Rose, David Atwater, Samuel Bragg, — LeVanze.

Sch. JULIA WOOD, 92.89 tons, owned by James Mansfield \& Sons, wrecked near Liverpool, N. S., in April. Crew saved. Value, $\$ 9,000$; insurance, $\$ 7,878$. Wreck sold for $\$ 700$.

Sch. ORONOCO, 48.2 I tons, owned by John Pew \& Son, lost on Straitsmouth Island, July 5. Crew saved. Value, \$2,000; insurance, \$1,050. Wreck sold for \$16.50.

Sch. LILIAN GERTRUDE, $5^{8.06}$ tons, owned by Daniel Sayward and others, lost on Mt. Desert Rock, July 12. Crew saved. Loss, $\$ 5,500$; insurance, $\$ 4,454$.

Sch. LIZZIE \& NAMARI, 94.09 tons, owned by George Laturen, master, and Almon Mason of Pigeon Cove, lost near Matinicus, Aug. 3 I. Crew saved. Value, $\$ 7,000$; insurance, $\$ 6,000$. Wreck sold for $\$ 50$.

Sch. MARY LOUISE, 68.I5 tons, owned by Daniel Sayward and others and employed in the Georges fishery, run down and sunk 60 miles east of Boston Light, Sept. I. Crew saved. Value, $\$ 5,475$; insurance, $\$ 4,59^{2}$.

Sch. RIVAL, 53.88 tons, owned by Sylvanus Smith, lost at the Magdalen Islands, in September. Crew saved. Value, $\$ 2,054$; insurance, $\$ 1,798$. Wreck sold for $\$ 430$.

Sch. RIVERDALE, 6I.4I tons, owned by Maddocks \& Co., run into and sunk off Thacher's Island, Nov. 23. Crew rescued. Value, $\$ 4,240$; insurance, $\$ 3,423$.

Sch. CUNARD, 74.65 tons, owned by James G. Tarr \& Bro., lost on the Banks in November or December. Value, $\$ 6,000$; insurance, $\$ 3,600$. Crew list-Garrett Galvin, master, Philip Hennesy, John H. Reynolds, Joseph Lockwood, Andrew Crowell, James and John Harding, brothers, John Ryan, 
Allen C. Brian, John Drury, Daniel McLeod, James Tobin, and two others shipped at Port Mulgrave, whose names are unknown.

Sch. NIMBUS, 60.30 tons, owned by Leonard Walen, wrecked on Cape Negro, in December. Value, $\$ 4,470$; insurance, $\$ 3,911$, with $\$ 1,000$ additional on outfits. Two of the crew, Augustus Long and Andrew Robinson, were drowned.

Sch. MOSES ADAMS, 99.87 tons, owned by Samuel Lane \& Bro., abandoned at sea, Dec. 2 I. Crew rescued with considerable difficulty. Value, $\$ 5, \mathrm{r} 55$; insurance, $\$ 4,76 \mathrm{r}$.

Sch. MODENA, 6r.48 tons, owned by Bennett Griffin, lost in coasting trade off Cape Cod, June 2 r. Crew saved. Value, \$1,000; uninsured.

Sch. SAM'L WONSON, 50.19 tons, owned by B. Haskell \& Sons and employed in coasting trade, wrecked in Liscomb harbor, N. S., Dec. 20. Crew saved. Value, $\$ 3,000$; insurance, $\$ 1,200$.

Lost Overboard.-James McQuarrie from sch. Moses Adams, on passage from Newfoundland, Jan. 2I. John Manuel from sch. Polar Wave, March 12, and Joseph Smith from sch. Andrew Leighton, Sept. 22, in the Bank fishery. Thomas Smith from sch. Dictator, March 20, and Samuel K. Pearce from sch. Mary Story, Oct. ${ }_{3}$, on Georges. Capt. Philip Conley from sch. Smuggler, on the passage from Grand Menan, Dec. 19. William Martin from sch. Hyperion, off Milk Island, Nov. I8.

Lost Overioard by Collision.-Thomas Kirby from sch. Racer in collision with sch. Electric Flash, in April; Willis Bateman from sch. Edward E. Webster in collision with sch. Hereward, on the Banks, in May; Nelson M. Doane and William Post from sch. Sarah C. Pyle in collision with an unknown bark, off Thacher's Island, June r.

Capsized in Dories.-Alex. McGinnis from sch. Centennial, Jan. 20 ; John Peterson and Augustus Peterson from sch. Andrew Leighton, March 22 ; Judson W. Allen from sch. Knight Templar, April 8; Sylvester Mitchell and Albert Eldridge from sch. Ossipee, Aug. 22; all in the Bank fishery. Thomas King from sch. Annie C. Norwood, and John Dakin from sch. Ellen H. Powers, Dec. 19, in the shore fishery.

LOST in DuRies.-Angtus McKenzie and Allen Grant from sch. John $S$. Presson, Feb. 18, and William Tate and Charles Russell from sch. Josie $M$. Calderwood, Oct. 9, on the Banks; William Cole and Lemuel Hagan from sch. Mary F. Chisholm, on La Have Bank, Dec. r9.

Capt. H. A. Bearse of the coasting schooner Hattie N. Gove was knocked overboard and drowned in New London harbor, Dec. 2.

1879.

This was the most disastrous year ever experienced in the Gloucester fisheries, so far as loss of life is concerned, although the number of vessels lost 
was less than in 1873 . In 1879,249 Gloucester fishermen sailed from port never to return. The number of vessels lost was 29 . Of these, 15 were lost in the terrible gale of Feb. 20 and $2 \mathrm{I}, \mathrm{I} 3$ on Georges and 2 on the Banks, leaving 57 widows and 140 fatherless children to bewail their loss. This terrible calamity appealed forcibly to the sympathies of the benevolent, and contributions for the relief of the destitute were received from all parts of the land to the amount of $\$ 28,216.72$. 4 vessels and 37 lives were lost in an October gale.

The loss of tonnage in 1879 was $1,893.36$. Value, $\$ 111,056$. Insurance, $\$ 90,582$. Besides the losses in the February gale, during the year 5 vessels were lost in the Bank fishery, 3 in the mackerel fishery, 2 on freighting voyages, and I each squiding, shore fishing, baiting, and on La Have Bank.

The losses in the February gale were as follows:

ON THE BANKS.

Sch. EDWIN C. DOLLIVER, 87.07 tons, owned by Walen \& Allen, abandoned Feb. 26. Crew taken off. Value, $\$ 7,000$; insurance, $\$ 5,800$.

Sch. GWENDOLEN, 82.4I tons, owned by Cunningham \& Thompson. Value, $\$ 7,154$; insurance, $\$ 6$, or o. Crew list-Zadock Hawkins, master; Lyman H. Morey, steward; Edward Landry, Richard Hurley, Alex. McKenzie, John McKay, Michael Donahoe, William Nelson, Augustus Crowell, John McGuire, James Calwell, Daniel McDonald, William Chute, William C. Wilson..

\section{ON GEORGES.}

Sch. ANNIE HOOPER, $69.27^{\circ}$ tons, owned by B. Maddocks \& Co. Value, $\$ 3,485$; insurance, $\$ 3$, I I 2. Crew list-Patrick Foley, master; Samuel Shano, steward; Joseph Smith, David Hogan, Manuel Smith, Stephen Halley, Jackson Clark, Fitz E. Oakes, Michael Hart, William Fisher alias Anderson, Peter Peterson.

Sch. ANNIE LINWOOD, 59.09 tons, owned by Rowe \& Jordan. Value, $\$ 3,725$; insurance, $\$ 3,322$. Crew list-Thomas Connell, master; Patrick O’Brien, Frederic J. Knowles, Daniel D. Morrison, John Silva, Frank Ferris, John Smith, John Lawrence, Angus McDonald, August Mitchell and one man whose name is unknown.

Sch. GEORGE B. LORING, $58.5^{\circ}$ tons, owned by George Norwood \& Son. Value, $\$ 2,119$; insurance, $\$ 1,917$. Crew list-George W. Lane, master; Joseph M. Lane, brother to master; Reuben H. Ellis, Morris Riley, Ambrose Thebedo, James M. Boynton, George Whitman, James White, George Yates, Edward P. Townsend.

Sch. JACOB BACON, 66.44 tons, owned by Cunningham \& Thompson. Value, $\$ 5, \mathrm{i} 86$; insurance, $\$ 4,600$. Crew list-Christian Anderson, master; Richard Carroll, James Powers, Charles Fox alias Johnson, Patrick Sulli- 
van, James Bowie, Conrad Carleson, Frank White, John Sherman, Edward F. Jameson, John Wilson, and Hugh Hennan, steward.

Sch. JOHN DOVE, 59.02 tons, owned by Smith \& Oakes. Value, $\$ 3,193$; insurance, $\$ 2,857$. Crew list-Lewis Caliste, master; Alex. Girrior, John Coughlin, Theophilus V. Porter, Samuel West, William Delroy, Joseph Enos, Benjamin Decoste, Charles Campbell, and Edward and Benjamin Levange, brothers.

Sch. JOSHUA S. SANBORN, 63.89 tons, owned by David Low \& Co. Value, $\$ 2,795$; insurance, $\$ 2,008$. Crew list-George Gray, master; William Carter, John H. Holmes, Michael Allen, Edward Walton, John J. Williams, Jaines Burge, Roland D. Blodgett, Bertram Blake, John A. Howard, Charles Claherty.

Sch. LOTTIE F. BABSON, 6r.96 tons, owned by D. C. \& H. Babson. Value, $\$ 2,5 \circ 5$; insurance, $\$ 1,096$. Crew list-Seward Reynolds, master; Robert Reynolds, brother to master; John Graves, Lorenzo Chute, John Batson, Daniel Tatton, George Pooler, Samuel Thompson, Joseph Boone, James Boshey, and Fred. Hall, steward.

Sch. MARY CARLISLE, 66.78 tons, owned by Andrew Leighton. Value, $\$ 3,425$; insurance, $\$ 3,060$. Crew list-Joseph Scott, master; John L. Ingersoll, Ralph Irving, Philip Vibert, Cyrus Young, William Merchant, Alex. Cogill, Oliver Thompson, Alex. McMaster, Peter McKinnon, George Matthews.

Sch. MARY LOW, 63.97 tons, owned by David Low \& Co. Value, $\$ 2,930$; insurance, $\$ 2,126$. Crew list-James F. Dunton, master; John Tarr; Phillippe Deveaux, Elkanah Nason, Ariel P. Burnham, Paul Thebadeau, Joseph King, Fred. Kenniston, Frank Silva, Joseph White, Peter Jennison.

Sch. MAUD \& EFFIE, 85.23 tons, owned by Willard G. Pool. Value, $\$ 5,735$; insurance, $\$ 4,58 \mathrm{r}$. Crew list-John McIsaac, master; Michael McIsaac, his brother, Joseph Nowlan, their brother-in-law; Edward Gordon, Roland McDonald, Allen McDonald of East Boston; Joseph Rogers, Joseph McAskell ; Edward Shearman, the latter's brother-in-law; Andrew Swinson, Neal Beaton, William McMaster, William Frazier, Roderic Steele.

Sch. MORNING STAR, 52.92 tons, owned by Joseph O. Procter, Jr. Value, \$r,895; insurance, \$r,721. Crew list-John B. Spanks, master; David B. Gorman, William W. Shelton, Antone Aveney, David Jones, F. H. Stimpson, John Black, James Roberts, Charles Ibey, Michael Muldoon.

Sch. OTIS D. DANA, 64.28 tons, owned by Pettingell \& Cunningham. Value, $\$ 3,335$; insurance, $\$ 2,98$ I. Crew list-William Willoughby, master; Archibald McCatheren, Boley Bushey, John Garvey, George C. Stearns, Charles Netherwood, John Atwood, Frederic Hill, Paul A. Peterson, and Charles Mason, steward. 
Sch. SEA QUEEN, 6r.47 tons, owned by Andrew Leighton. Value, $\$ 3,242$; insurance, $\$ 2,900$. Crew list-Charles Wilson, master; Nicholas M. Thompson, Peter Trumbull, A. W. Peterson, Olof Jensen, Neils Hanson, Axel Olssen, John Anderson, William Brown, August Peterson.

\section{OTHER LOSSES.}

Sch. IDA E. BAKER, 63.69 tons, owned by George Norwood \& Son, lost on Western Bank in April. Value, $\$ 4,380$; insurance, $\$ 3,783$. Crew list-M. H. Adams, master; John Benson, Robert McInies, Joseph McDonald, George Major, Frank Oscar, William T. Long, Charles Johnson, Charles White, John McNair, Hugh McCormack, John Jerriwa.

Sch. WILLIAM THOMPSON, 84.15 tons, owned by Cunningham \& Thompson, lost on a Bank halibuting trip in April. Value, $\$ 7,200$; insurance, $\$ 6,057$. Crew list-Christian Olsen, master; Dennis Thelning, Chas. Anderson, Chresten Johnson, Samuel Nordahl, John P. Johnson, Andrew Hanson, Martin Soderstrum, Carl Leweau, Martin Anderson alias Johnson, Julius Manguson, Elias Fladen, Martin Johnson, and Charles S. Olsen, brother of the master.

Sch. N. H. PHILLIPS, 66.93 tons, owned by William McDonald and others, lost on Banquereau in October. Value, $\$ 4,500$; insurance, $\$ 3,862$. Crew list-William McDonald, master; John Welch, John McKinnon, Albion Bowden, John McDonald, Charles Crawler, Neal McDonald, Michael McInnis, Jonn Steele, John and Richard Tobin, brothers, Duncan McIsaac, Clifton Thompson.

Sch. HARVEY C. MACKAY, 64.77 tons, owned by William .Parsons, 2d, \& Co., lost on a Bank codfishing trip in October. Value, $\$ 3,595$; insurance, $\$ 3,07$ r. Crew list-Frank Nolan, master; George Holly, W. H. Bartlett, William Higgins, Charles W. Hunt, Everett Campbell, Augustus Campbell, Frank Crowell, Frank Hobbs, and a young man named Morton.

Sch. ANDREW LEIGHTON, $83.5^{6}$ tons, owned by Cunningham \& Thompson, lost on La Have Bank in October. Value, $\$ 6,800$; insurance, $\$ 5,698$. Crew list-Oscar W. Alden, master; Andrew McDonald, Samuel Grassy, Oscar Wistar, Frank Nelson, Martin Hogan, Charles Berg, Martin Strahan, Adolph Nelson, Frank Veaneau, Frank Flake, John Boudrout, Andrew Olsen, Henry Johnson.

Sch. CITY OF GLOUCESTER, 68.64 tons, owned by Rowe \& Jordan, bound on a Bank trip, lost off Chatham, June r. Crew saved. Value, $\$ 4,665$; insurance, $\$ 4,146$.

Sch. ALICE M. LEWIS, 66.82 tons, owned by Capt. Jesse Lewis, lost in the Southern mackerel fishery at 'Townsend Inlet, April i4. Crew saved. Value, $\$ 3,560$; insurance, $\$ 2,678$.

Sch. GEORGE S. LOW, 6r.69 tons, owned by David Low \& Co., lost 
in the Southern mackerel fishery near Townsend Inlet, May ir. Crew saved. Value, $\$ 3,000$; insurance, $\$ 2,200$.

Sch. CARRIE F. BUTLER, 68.35 tons, owned by William Parsons, wrecked at Rustico, Oct. 3 I. Crew saved. Value, $\$ 2,000$; insurance, $\$ 1,500$.

Sch. O. S. BAILEY, $5^{8.22}$ tons, owned by Hardy Brothers and others, abandoned at sea on passage from Dominica for Boston, Nov. 22. Crew rescued. Value, $\$ 6,000$; insurance, $\$ 4,700$.

Sch. TRENTON, 4r.72 tons, owned by David Low \& Co., wrecked near Deer Island, May I r. Crew saved. Value, $\$ \mathbf{1}, 250$; insurance, $\$ 500$.

Sch. CADET, 60.38 tons, owned by B. Haskell \& Sons and employed in the squid fishery, wrecked at Langlaid, N. S., Aug. I4. Crew saved. Value, $\$ 2,500$; insurance, $\$ 1,600$.

Sch. RIVAL, 53.88 tons, owned by Sylvanus Smith, wrecked at Rye Beach in the Winter shore fishery, Feb. 24. Crew saved. Value, $\$ 1,8$ ro; insurance, $\$ \mathrm{r}, 534$.

Sch. SPARKLING WAVE, 48.66 tons, owned by Wonson Brothers,

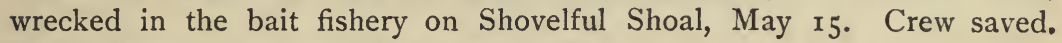
Value, $\$ \mathrm{I}, 475$; insurance, $\$ \mathrm{I}, 253$.

Lost Overboard.-John Clancy knocked overboard from sch. S. R. Lane, Feb. 8, and Michael O'Malley fell overboard from sch. Edward A. Horton, Feb. 19, in Winter shore fishery. Daniel McDougal washed overboard from sch. J.J. Clark about 70 miles off Highland Light, March 6. George Hunson jumped overboard from sch. Jamestozen in the harbor, April r6. Michael .Tobin washed from bowsprit of sch. John Smith, Aug. 29, on Georges.

Capsized in DoRies.-Charles and Clarence Myers, brothers, from sch. Oceanus, in Winter shore fishery, Jan. 28. Andrew Johnson from sch. William H. Oakes, in February; George Ryan from sch. William H. Foye, March 2 ; Lewis Thompson, Gordon Scott and William Nickerson from sch. Herbert $M$. Rogers, March ro; Jámes McDonald, George Perkins, David B. Tinker and Joseph Goslin from sch. Hattie S. Clark, and Thomas Williams of sch. Ernest $F$. Norwood, March 25 (while going ashore at Bliss Harbor, N. B.) ; David Morrison from sch. Mary F. Chisholm, in August; John and Malcom McCloud and James Publicover from sch. Laura Nelson, Dec. 26 ; all in the Bank fisheries. Robert McDonald and Joseph Chisholm from sch. Highflyer, on Jeffrey's, Dec. I.

Lost in Dories.-William Andrews and Nicholas Colberg from sch. Alice G. Wonson, Jan. 29; John Olsen and Charles Hanson from sch. Andreze Leighton, March 18 ; Arthur Hennan and Thomas Davidson from sch. Gatherer, March $3 \mathrm{I}$ all on the Banks. 
I880.

4 schooners and 3 boats, of a tonnage of 300.44 , valued at $\$ 2$ I, 000 and insured for $\$ 15,972$, were lost this year. The number of lives lost was 52 . I schooner was lost in the Bank halibut fishery, I in the Winter shore fishery, I on Georges and I on Cashe's. I fishing boat was lost on Eastern Point, I on the coast of Maine, and $\mathbf{I}$ was run down and sunk in Ipswich Bay.

Sch. ANNIE C. NORWOOD, 60.05 tons, owned by George Norwood \& Son, lost on Cashe's, March 23. Value, \$3,6ro; insurance, \$3,310. Crew list-Joseph M. Hurst, master; Joseph Garrett, William Isaac, William Fardy, David Roberts, Patrick Neal, James Anderson, George Crawford, William Holland, Charles Higgins, Thomas Orne, Lawrence Nelson, Edward W. Wilson, Charles Armstrong.

Sch. NATHANIEL WEBSTER, 76.o4 tons, owned by D. C. \& H. Babson, lost on a Bank halibuting trip, in November. Value, $\$ 6,000$; insurance, $\$ 5,000$. Crew list-Robert C. Grant, master ; Hector McIsaac, Chas. Bennett, Charles Hubley, John Frazier, James Grant, Isaiah Horton, John McDonald, John Peoples, Dominick McIsaac, John I. Wilson, John McMullen, Silas McLellan, and a Mr. Jacobs.

Sch. OCEAN BELLE, 67.02 tons, owned by Sylvanus Smith, sprung aleak and sank on Georges, March 26. Crew taken off. Value, \$3,192; insurance, $\$ 2,992$.

Sch. WINIFRED J. KING, 63.6r tons, owned by Capt. John King, wrecked in the Winter shore fishery at Brace's Cove, Feb. 3. Crew saved. Value, $\$ 4,670$; insurance, $\$ 4,470$.

Boat BEE, 8.13 tons, owned by William Tarr, lost on Eastern Point, Nov. I9. Crew saved. Value, $\$ 300$; insurance, $\$ 200$.

Boat HARP, ro.88 tons, owned by William N. Mace and William P. Dennis, lost on Green Island, Me., March 27. Crew saved. Uninsured.

Boat I TELL YE, I 4.7 I tons, owned by George J. Tarr \& Co., run down and sunk in Boston Bay, Oct. 27. Value, \$2,000; no insurance.

Lost Overboard.-Emery Hooper washed from foreboom of sch. Seth Stockbridge, on Grand Bank, in March; Frank Williams fell overboard from sch. E. L. Rowe, April I7 ; Capt. Daniel Rowe, 2 d, knocked overboard in Boston Bay from sch. Jennie \& Julia (by collision), May 12 ; Edward Day washed overboard from sch. Frederic Gerring, Jr., on the Banks, Sept. 9 ; Thomas Anderson washed overboard from sch. Epes Tarr, on Grand Bank, Nov. 7 .

Capsized in Dories.-Patrick Harrigan and Allen McGinnis from sch. Augusta H. Johnson, Jan. 3 ; William Malloy, John Raymond and Jerry Simmons from sch. Plymouth Rock, Jan. 7 ; Stephen Johnson and Augustus Hendrickson from sch. Isaac A. Chapman, Feb. I I ; Capt. James Nickerson 
and James Downing from sch. Bellerophon, in February; Augustus Anderson from sch. Duvid A. Story, Aug. ro; all in the Bank fisheries.

Died in Dory.-George Nelson from sch. Polar Wave, on Banquereau, March 28.

Lost in Dories in the Fog.-Matthew McDonald and Joseph Merchant from sch. David A. Story, on the Banks, in February; John Higgins and David McDonald from sch. Marion, on Western Bank, March 28; Joseph Coffee and Charles E. Seebloom from sch. Epes Tarr, on Western Bank, April r8; William Geary and John Landry from sch. Schuyler Colfax, on the Banks, Aug. $2 \mathrm{I}$.

I $88 \mathrm{r}$.

8 vessels and $5^{6}$ lives were lost this year. The loss of tonnage was 51r.5r. Value, $\$ 3$ r,ooo. Insurance, $\$ 20,493$. Besides these losses, the ANSON STIMSON of Rockport, a fine schooner of $224.3 \mathrm{I}$ tons burthen, belonging to the Pigeon Hill Granite Company, was wrecked on Brigantine Shoal bar, N. J., Jan. 6, on the passage from San Domingo for New York, her master, Capt. Albion Sloman, having died at sea, and the crew of six men being down with chills and fever, leaving only the mate and cook to work the vessel. The Gloucester losses were : 4 in the Bank fisheries, I in the shore and $\mathrm{I}$ in the mackereling fisheries, and I engaged in coasting, as. follows :

.Sch. CARRIE S. DAGLE, 74.53 tons, owned by William Parsons, 2 d, \& Co., lost on Western Bank, April 15. Value, $\$ 4,000$; insurance, $\$ 3,375$. Crew list-Richard Richardson, master; John F. Deveau, C. A. Bergman, Jeffrey Bushey, Thomas Milford, Edward Jedrey, John McDonald, Asahell Landro, George W. Kinch, Eli Thibadeau, Hugh York, Coleman Jennings.

Sch. GUY CUNNINGHAM, 87.84 tons, owned by Cunningham \& Thompson, lost on Grand Bank in August or September. Value, $\$ 7,000$; insurance, $\$ 5,985$. Crew list-Daniel O'Brien, master; John C. Hanson, Frank Shivrie, John Proctor, Niel Walker, Charles Johnson, John Burns, Andrew Nelson, Peter Peterson, Andrew Serresten, Henry Cushing, Loc: McQuarrie, Chas. Baston.

Sch. CLARA B. WARREN, 5 I.67 tons, owned by Mr. William. J. Nourse, wrecked near Catch Harbor, N. S., Aug. 8, while returning from a Bank. trip. Crew saved. Value, $\$ 3,000$.

Sch. THRESHER, 8o.ro tons, owned by Daniel Allen \& Son, engaged: in the Bank fisheries, stranded and burned at Cape Sable, Sept. 24. Crew. saved. Value, $\$ 6,500$; insurance, $\$ 5,500$. Wreck sold for $\$ 36$.

Sch. HIGHFLYER, 53.73 tons, owned by Benjamin Low, wrecked at Carver's Harbor, Me., with a cargo of frozen herring on. board, Jan. Io. Crew saved. Value, $\$ 2,500$; insurance, $\$ 1,500$. 
Sch. VANGUARD, 40.47 tons, owned by Edward Contillon, Samuel G. Pool and William H. Gardner, engaged in net-codfishing in Ipswich Bay, wrecked off Rye Beach, March 19. Crew saved. Value, $\$ \mathbf{r}, 800$; insurance, $\$ 900$.

Sch. LIZZIE K. CLARK, 72.I9 tons, owned by Clark \& Somes, bound South on a mackereling trip, capsized and sunk about twenty miles southeast of Barnegat, March 25. Crew saved. Value, $\$ 5,000$; insurance, $\$ 3,323$.

Sch. LADY FRANKLIN, 50.98 tons, owned by Capt. Elias Olson and engaged in freighting paving stones, sunk off Stanwood's Point in Annisquam river, July iा. Wreck sold for $\$ 150$.

Lost Overboard.-John White washed overboard from sch. Willie $M$. Stevens, and John Weston from sch. Martha $C$., in January; John Roper from mainboom of sch. Lizzie, Feb. 2, and William Riley, washed overboard from sch. Ocean King, Feb. 22 ; Capt. Robert Ehler of sch. Carthage, caught by foot-rope on mainboom and drawn overboard, off Monhegan, Nov. 27 ; all in the Bank fisheries. Capt. Horace Merry from mainboom of sch. George P. Rust, off the Isle au Haute, April $\mathrm{x}$, and Michael Sampson washed overboard from sch. Mary E. Daniels, April 26, in the Georges fishery. Edward Nickerson fell overboard from sch. Hattie $N$. Reed, in Portland harbor, July $2 \mathrm{I}$, in the mackerel fishery. John A. Johnson from sch. Herman Babson, in September, on the return trip from Greenland. William Rooney, cook of sch. Addie Emma, fell overboard in the Bay of Fundy, Nov. 28.

Capsized in Dories.-Charles Bell from sch. Bellerophon, on Banquereau, Jan. 28. Elias and Peter Landry, brothers, from sch. Fleur de Lis (shore fishing), in attempting to cross Newburyport bar, March 16. Benjamin O'Hara and William L. Grant from sch. Mist, March 8 ; Lewis Dulong and Charles Richards from sch. Webster Sanborn, June 23; John Guthrie and Laughlin Kennedy from sch. Zenobia, Aug. 2 ; George M. Sigsworth from sch. Victor, Aug. I2; John Frost from sch. Plymouth Rock, Nov. I2; Albert McKennon from sch. Wachusett, in November; all on Grand Bank. Joseph Avenue, in November, and Henry Burke, John Hayes, Archie McDonald and Barnard Glenn, Dec. 23, from sch. Smuggler, engaged in the shore fisheries.

Capt. Warren Guptill, of Gloucester, 'master of sch. Ella of Boston, was lost with that vessel on the passage from Boston for Baracoa, in September; William Harrison Card of Newcastle, N. H., engaged for some fifteen years in the Gloucester fisheries, was mate of the Ella. Robert Swain was lost overboard from sch. Orient of Gloucester, on the passage from Baracoa for New York, in January. 
TABLE OF LOSSES FOR 52 YEARS.

\begin{tabular}{|c|c|c|c|c|c|}
\hline Year. & Vessels. & Tonnage. & Value. & Insurance. & Lives. \\
\hline $\begin{array}{l}1830 \\
1832 \\
1833 \\
1834 \\
1836 \\
1837 \\
1838 \\
1839 \\
1840 \\
1841 \\
1842 \\
1843 \\
1844 \\
1845 \\
1846 \\
1847 \\
1849 \\
1850 \\
1851 \\
1852 \\
1853 \\
1854 \\
1855 \\
1856 \\
1857 \\
1858 \\
1859 \\
1860 \\
1861 \\
1862 \\
1863 \\
1864 \\
1865 \\
1866 \\
1867 \\
1868 \\
1869 \\
1870 \\
1871 \\
1872 \\
1873 \\
1874 \\
1875 \\
1876 \\
1877 \\
1878 \\
1879 \\
1880 \\
1881 \\
\end{array}$ & $\begin{array}{r}3 \\
1 \\
1 \\
1 \\
1 \\
5 \\
4 \\
2 \\
2 \\
2 \\
3 \\
3 \\
3 \\
4 \\
3 \\
3 \\
2 \\
4 \\
9 \\
13 \\
3 \\
4 \\
7 \\
6 \\
5 \\
7 \\
6 \\
7 \\
15 \\
19 \\
10 \\
13 \\
8 \\
15 \\
11 \\
4 \\
16 \\
13 \\
20 \\
12 \\
31 \\
10 \\
16 \\
27 \\
8 \\
13 \\
29 \\
7 \\
8\end{array}$ & $\begin{array}{r}504.93 \\
1,055.00 \\
844.57 \\
282.27 \\
858.81 \\
788.15 \\
1,035.93 \\
576.68 \\
1,624.55 \\
633.17 \\
1,050.91 \\
1,075.46 \\
722.33 \\
907.57 \\
1,893.36 \\
300.44 \\
511.51\end{array}$ & $\begin{array}{r}\$ 5,600 \\
1,000 \\
1,000 \\
1,500 \\
1,000 \\
10,100 \\
7,100 \\
3,800 \\
3,800 \\
2,725 \\
2,000 \\
6,000 \\
4,800 \\
4,500 \\
4,900 \\
6,203 \\
3,500 \\
12,500 \\
25,300 \\
41,200 \\
10,000 \\
.14,600 \\
20,900 \\
14,400 \\
11 ; 500 \\
18,700 \\
21,900 \\
26,350 \\
54,250 \\
66,500 \\
40,700 \\
98,900 \\
40,300 \\
114,250 \\
82,675 \\
35,000 \\
83,450 \\
75,200 \\
90,560 \\
55,400 \\
118,700 \\
49,100 \\
96,000 \\
150,000 \\
45,000 \\
64,791 \\
111,056 \\
21,000 \\
31,000\end{array}$ & $\begin{array}{r}\$ 3,100 \\
\\
\\
\\
4,300 \\
3,000 \\
3,150 \\
1,400 \\
150 \\
150 \\
2,000 \\
1,500 \\
2,350 \\
3,600 \\
4,450 \\
2,200 \\
10,300 \\
21,800 \\
37,100 \\
8,800 \\
12,650 \\
16,100 \\
11,475 \\
7,750 \\
8,537 \\
16,475 \\
20,494 \\
43,900 \\
53,225 \\
8,300 \\
59,625 \\
32,400 \\
82,095 \\
59,069 \\
28,150 \\
54,887 \\
59,907 \\
78,253 \\
49,121 \\
100,918 \\
44,975 \\
81,326 \\
116,222 \\
22,000 \\
49,967 \\
90,582 \\
15,972 \\
20,493\end{array}$ & $\begin{array}{r}4 \\
21 \\
\ldots 4 \\
4 \\
6 \\
8 \\
\\
\mid 10 \\
7 \\
8 \\
15 \\
10 \\
31 \\
32 \\
140 \\
\mid 26 \\
21 \\
2 \\
9 \\
142 \\
36 \\
74 \\
44 \\
162 \\
6 \\
84 \\
11 \\
26 \\
66 \\
39 \\
65 \\
97 \\
140 \\
63 \\
174 \\
68 \\
123 \\
212 \\
39 \\
56 \\
249 \\
52 \\
56\end{array}$ \\
\hline $\begin{array}{l}1880 \\
1881\end{array}$ & 419 & & $\$ 1,810,710$ & $\$ \$ 1,355,418$ & 2,249 \\
\hline
\end{tabular}




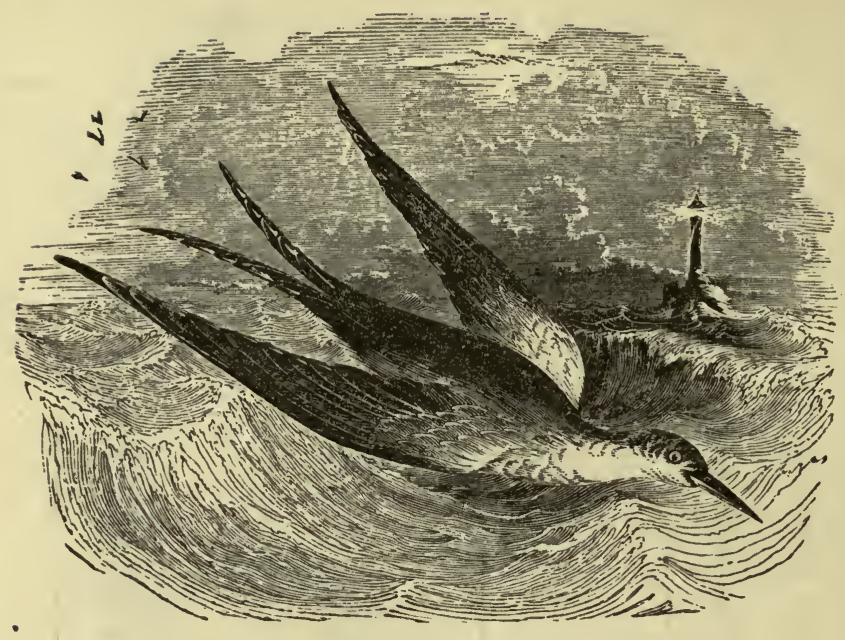

Welcome Home.

A ROMANCE IN A FISHERMAN'S LIFE.

BY M. W. C.

"You will not be angry, dear Janie, if I leave to-night? There's no way out of it for me. I can go with a light enough heart if only you'll tell me you do not mind."

"Nay, I'll not be angry, David, only grieved, deeply grieved. I do mind, for you know I had counted on your being here the $3 \mathrm{~d}-$ "

The sweet voice faltered here; the blue eyes that had been so laughterclear and bright, an hour since, grew blurred with bitter tears under the long curled hazel lashes.

"The $3 \mathrm{~d}$-Wednesday - is the day we wedded six years ago, David; you remember how often we have said we would spend that day together here in our own home."

"Ay, Janet; but you would not have me shirk a trust?" David Colburn's clear soul looked through his shining eyes as he spoke these words. One could see that his resolve was fixed: there would be no more faltering now for him. "The fishing schooner Snow-Bird leaves port to-night; her owners do not believe the master, Bradley, to be trusty, and they want a man on board who can lend a hand, thwart any evil designs on their property, or even take command if need be. That man whom they select in confidence is I. Now, Janet, shall I go? You say the word." 
David Colburn looked his young wife steadily in the face. One could see that he had small doubt what that word would be.

"I say the word? I have this to say, God love thee and keep thee, dear David, wherever thou art. Ay! and He will! He will!"

She put her faithful arms about his neck; her truthful eyes looked into his.

"But now tell me, in plain words, you are not angry; say just the words and I'll go with a lighter heart, Janet."

Again that strong, sure smile.

"Not angry; no! I never shall be angry with you, David, so long as I know. you are doing right. And now," she went on, after a moment's pause, "now let us go and see Dolly, Dora and Davie."

An hour later David Colburn had bade good-bye with "God bless thee" to his wife and his three darling little ones, and his wife's triumphant "God keep thee, my husband," still sounded soothingly in his ears as he walked down to the wharf where the waiting schooner Snow-Bird lay.

And Janet, for all her brave words and her sure faith-for all her stern principle-carried a sore heart that night. She went about her duties calmly, but her step was slow. David was gone. They had counted on living their wedding day over again together, to make that one day's perfect happiness in their newly built cottage give all its sweets to them over again in talk and loving memory-but now David was gone!

She was kneeling at dusk on the hearth, toasting bread for the children's supper. Suddenly a heavy step sounded from the walk, then came a quick knock and the door was flung rudely open.

"Ho! Janet. Janet Colburn! Are ye there?"

With a startled cry the young frightened wife sprang up, letting her toasting fork and her bread fall back upon the fire.

"Kenneth Foster!" she exclaimed, falling back a step as the light fell on and revealed her visitor's face.

"Ay, it is I! Your memory is good, Janet, just as mine is. And you are all alone. I came to see how you look in widow's tears. You'll make a fine widow, Janet. There's many a man will be seeking for your hand when the year's out. The widow Colburn's hand!"

The fair face of the listening woman had grown deadly white during the uttering of this man's wild words. She held her children tight to her, gathering strength from their soft touch as she answered-her voice, too, was gentle, if weak-

"I am alone here with my children, as you see, Mr. Foster. My husband left me to-night. I ask you to leave me till he comes back; you can say what you wish to him then."

"Till he comes back!" Kenneth Foster repeated her words, and then 
he broke into a loud and brutal laugh. "Do you know when your husband will come back to you, Mistress Colburn? It will be when you have finished this life and gone into a different world. There will be other seas and other skies, other men and other women about you in the world where you will meet David Colburn, and you will have to wait long!"

The young wife smiled serenely through the calm pallor of her face.

"Wherever he may be it will be well with him, you may be sure of that," she said.

"Even if it be at the bottom of the sea?" retorted Kenneth. "Well, well, Mistress Janet, I bide my time. You refused me once, when I asked you to be my wife ; be sure I shall not ask you now when you are a widow!"

Before she could interrupt him he went on in a wild whirl of raging words.

"Who was it sent your husband out in that craft? The owners, ay! but $I$ moved them to it. It was my work ; and if, some fine morning, the crew wake to find themselves sinking, with a wild sea rushing in, and no help near, why, that will be my work, too!"

Was the man mad that he should say this thing? What was it he meant? Was it truth-had he meant to scuttle the vessel-or was it only a threat? Most likely only that; a threat to frighten her-her, a helpless, lonely woman.

She pointed to the door. "You have forgotten God!" was her grand reply. "My husband is in the hands of One whom even the seas. obey. God will watch over him. Now go!"

He smiled a wicked smile. "I wish you a good evening, Mistress Colburn. Meanwhile, your bread is burning. You had better take it up, for you know you can't burn your bread and eat it too."

He shut the door and went out into the clear night; too clear and calm and sweet for such a man as he to enjoy, walking among its vines and nodding flowers, looking up into its blue heaven to the far mystery of its stars.

Meanwhile, she who was left in the little consecrated home, holding the darling heads of her children to her breast, watched and waited and prayed through lonely hours. "If that man's story were true-but no! it was not true-it was a threat, a trumped-up story-prompted by jealous rage."

"O David!" she cried, "the very storms are kind to thee; they pass thee by, not harming one so kind and good."

But she watched the sea, the clouds, the heavens, as she had never done before. She waited for news that came not: and then a morning came when she awoke to find the rain pouring, the wind tearing, the sea plunging and the black sky wracked with stormy clouds.

"David," she moaned, falling on her knees, "David, where art thou? my husband, will the sea take thee, leaving me uncomforted?"

But the sea had no answer for her. The husband on whom she called 
was far away. Not drowned; ah, no! Not buried under any mountain wave, cold food for fishes. He had seen lonely hours-night and day when at his work his thoughts were with his dear ones left at home ; in his dreams, too, he was ever with them. His comrades chided him for his lack of sociability; he had no heart for mirth. His greatest pleasure was in the reading of his Bible and in singing the tender songs Janet loved. Those songs were always tender, always telling of love and home. For there have been some stirring sea-songs written-written by men who were never on the sea-but they are not the songs sailors sing. The sea-beaten, homesick sailor does not turn to "A Life on the Ocean Wave" for consolation when he thinks of the faces he leaves behind the curtain of the home window.

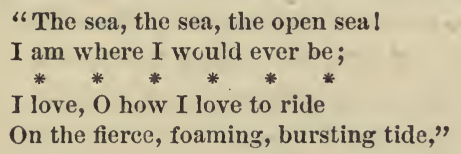

are heartless mockery, an unmeaning gibberish, to the man who has fought for very life, with death behind him, in the sleet and hail and crashing ice on Georges, or in the polar seas. For him the homely ballad of "Wapping Old Stairs" tells a dearer story. Molly, who says she'll be true and promises,

"Your breeches I'll mend, and your grog, too, I'll make,"

is the dearest sweetheart, and her blue eyes shine across the night and storm.

Meanwhile, Janet watched and prayed. With her children she braved the wind and storm, and went to the water-side to be near him. She stretched her arms out, and her hot tears fell on the rocks where she stood.

"O sea!" she sobbed, "Spare him! he loved you always; he has trusted you in your wildest anger, in your darkest moods; spare him now!"

Bye-and-bye came rumors, brought by an old fisherman, of a schooner drifting at the mercy of the storm-a disabled craft, which the gale prevented rendering assistance, and when it was over she was not to be seen, and it was doubtful if she ever returned to port.

Bye-and-bye other news came that it was the Snow-Bird-but there were good men on board of her, and there was hope that she might yet be heard from.

And Janet heard. O God, pity the tortured hearts of woman at such times as these. She went from fisherman to fisherman, as they got into port. They turned away, shivering, from her sad eyes.

"Was there no way to help those drowning men out there? Could nothing be done? Must they stand idle, watching, while vessel and men went down before their eyes?"

Poor wife! And there were others, too, other hearts trembling, other 
eyes of women weeping, other lips of wives and daughters calling on dear names.

The night came on with a gale, and the last that Janet saw or heard was that the vessel supposed to be the Snow-Bird had been blown off and was drifting out of sight.

"She's doomed!" an old fisherman said, turning away from the darkening view. "She'll go down! there's no help for it."

Janet heard; she looked about her with a sickly, piteous smile, as though asking for help for her own misery; then she fell down in a lifeless heap on the wet stones.

Kindly hands lifted her up and strong arms bore her home. On her bed she lay for long hours, her children by her side. She lay in a sort of stupor - she saw the blaze of the fire, she heard voices and footsteps coming and going, through the night. But her mind was torpid-she only realized one fear, that David was lost, and she-

"He called me a widow," she rambled on feebly. "He said I was a widow. What is a widow? Is it a woman whose heart is broken? Then I am one! Oh!"

She put her hand to her brow, and then a merciful sleep came over her, and she dreamed a sweet dream - that David had returned.

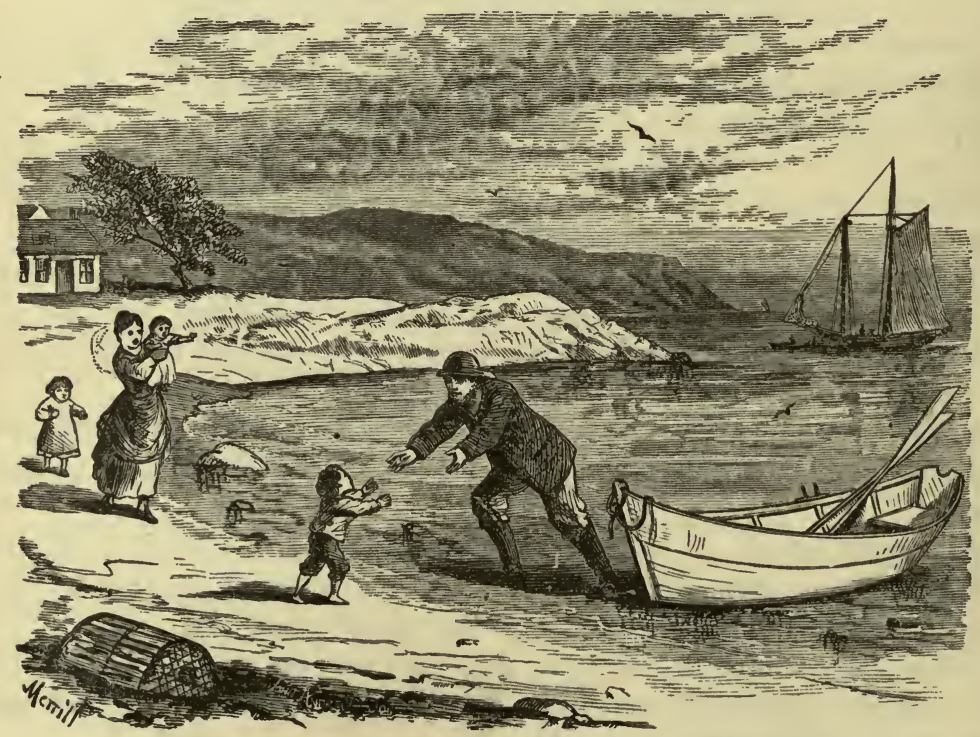

She awoke! The storm had cleared away and the morning sun was stealing into the bed-room window. Some one said the Snow-Bird had just 
come to anchor. Her heart gave one happy rebound, and she arose and soon dressed herself and the children, and looking out, saw the well-known vessel swinging at her anchor off the Point, with her mainsail swaying in the light morning breeze. She also saw a well-known form rowing ashore in a dory which some kind neighbor had tendered him the use of.

Grasping the baby in her arms, with the other little one by her side, and Davie running on ahead, she hastens down the pathway to the beach to meet her husband, for it was he! It seemed to her that he had really come back from another world. He cries out, "Janet, my wife! my good wife!"

And then she knew that it was no dream, for she was in his arms. His dear face was pressed close to hers, and she was so happy.

"David, my husband!" and he answered, "God is good; here are wife and children. What more can I want?"

And they walked up to the little cottage-this united family-and David explained how the Captain and part of the crew put into an out-of-the-way port, and sold most of the trip and nearly all the moveable articles on the vessel and pocketed the money and decamped-how he, in pursuance to instructions from the owner, then took possession and started home; how, when twenty-four hours out from port, during a fresh breeze, they found her leaking badly; how the leak increased as the storm grew worse, and it seemed as if they must go to the bottom; how his faithful men pumped and strove to stop the leak, and when it seemed as if their efforts were fruitless, and they must disappear beneath the seething waters, they found three holes which had been bored through the vessel's bottom and had been partially filled with a substance which the action of the water had set free; how these holes were stopped and the staunch vessel, being freed from the water, was herself again, and they got her safely into port.

The plot had been revealed to Kenneth Foster, and he was hoping that it would be successful, and when he found that it was not, and David Colburn had come back-he left the town and never returned. His cowardly heart failed him-he' could not look honest David Colburn and his faithful wife in the face, after what had transpired.

And David was well remembered by the owners of the Snow-Bird. They reckoned rightly. Without his efforts the vessel would have been lost: They therefore gave him a bill of sale of one-third of her, and remembered the crew with a handsome sum, and David for many years pursued his calling in this vessel, making good returns.

And Janet was one of the happiest little women in all the town. 


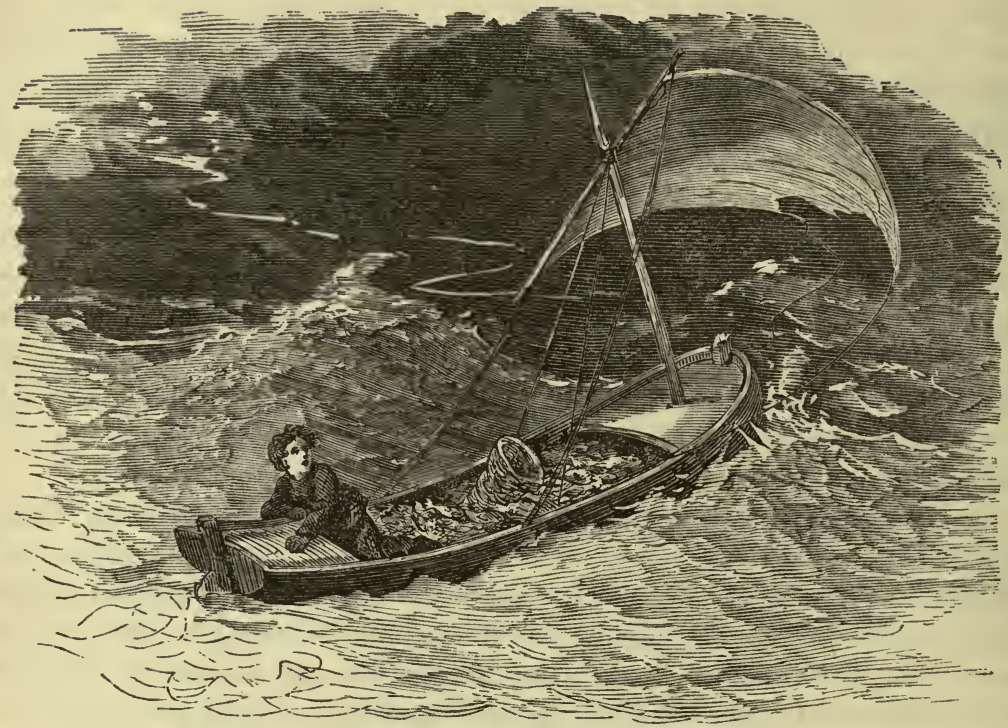

\section{The Fisher-Boy in the Storm.}

The above spirited picture illustrates a narrative given by an English fisherman. At that time he resided in one of the fishing towns on that coast, and the lad, fourteen years of age, the only son of his widowed mother, got so well used to managing his father's boat, that in the event of not being able to get any one to accompany him, he would, in pleasant weather, run off on the grounds alone and catch his fare of fish:

One day he started out with the rest of the boats, and running off farther than most of them, succeeded in catching an extra fare. Just as he was about getting ready to run in, a terrible storm suddenly,came on. The other boats being nearer in, ran for the land and escaped the worst of it; but he, poor fellow, having to get underway alone, was exposed to the full fury of the storm. Anxious eyes watched his coming, and some of the fishermen volunteered to go out after him. The little fellow lost his hat, but not his courage. With a fair wind he kept her well before it, minding well his helm, as his father had taught him. The lightning's livid flashes and the roar of the thunder were not calculated to make his situation very agreeable; but he heeded them not, and carried her bravely in, clearing the bar and running her safely up to the landing place. Here he was met by his anxious mother, who clasped her darling to her breast, thanking God for his safe return. 


\section{Halibut Fishing Among the Ice Floes.}

BY J. W. COLLINS.

It is not unusual, after a Winter of exceptional severity, for large masses of field ice to drift across the eastern fishing banks, especially Banquereau and the Grand Bank. This was especially the case in the Springs of 1875 and 1876 , when, for several weeks, a large portion of the fishing grounds frequented by the halibut fishermen was inaccessible to them. Many singular adventures were experienced by the crews of the ice-beleaguered vessels, which still form the subject of conversation among the fishermen. The inconvenience and peril, which was felt very severely at first by the fishermen, was, however, more than counterbalanced; for there can be no question but what these floes of drifting ice hastened the discovery of the "Deep Water" halibut grounds, which have since that time yielded such a rich harvest. At any rate, the practice of fishing in deep water on the Banks by the halibut fleet dates from the time and circumstances which are here described, though one or two vessels had made previous trials.

The writer was in the sch. Howard in the Spring of 1875 , and the account here given of events connected with the appearance of the immense ice floe, and also of icebergs, upon the Grand Bank, is principally taken from a letter describing some of the incidents of that occasion.

We were detained from sailing on our second trip that winter (1874-5) by easterly winds for two weeks or more, and when we reached the Grand Bank, about the middle of March, the whole of the Bank north of lat. 44 deg. 25 min. N., was covered with heavy masses of field ice. About the time we arrived on the ground the fish left, probably being driven by the ice floes which slowly moved southward, reaching at one time as far south as lat. 43 deg. $40 \mathrm{~min}$. N., in the middle of the Bank, and causing the fishermen much anxiety and more or less loss of gear, by unexpectedly drifting on their anchored vessels during the night. On one occasion a number of vessels tried to skirt the ice and get around it, so as to reach the northwest part of the Bank, but towards night of the day on which the attempt was made, a northeast gale and heavy snowstorm came on, and we all lay to under the lee of the ice, which made the sea quite smooth. The next day we found the floe had been driven so far south by the gale that we did not again attempt to get by to the northwest of it, but eight vessels having met together at the southern edge of the ice, all of the skippers went on board of the sch. Augusta H. Johnson to talk over the situation. After deliberating 
awhile, each returned to his own vessel, and while some of us ran to the southward, others laid by, waiting for the ice to recede to the northward. We ran down to lat. 43 deg. $30 \mathrm{~min}$. N. and long. 50 deg. $30 \mathrm{~min}$. W., but could find no fish. We were there some days before the weather permitted us to try, and after we hauled our gear we got underway, with a southerly wind, and ran for the western edge of the Bank, intending to strike it north of lat. 44 deg. N. A careful lookout for ice was kept. That evening we spoke the sch. Edwin C. Dolliver at anchor in seventy fathoms, and lay by her for the night. The next morning we made sail, spoke the Dolliver again, and also the schs. Chester $R$. Lawrence and Restless. The first two were lying at anchor in sixty to seventy fathoms of water, and the Restless lay in fortynine fathoms. Neither of them caught any halibut.

The ice, driven by the southerly wind, had at this time drifted back to about 45 deg. N. lat., and we worked to the westward in company with several other schooners, among which were the Restless, Edwin C. Dolliver, Alfred Walen, N. H. Phillips and John S. Presson; all of them setting trawls under sail in the day, and anchoring and setting their gear at night. In this manner the fleet beat slowly to the westward against a moderate breeze, for several days, trying for fish in water varying from forty-eight to seventy fathoms in depth, but catching nothing. The water was so intensely cold that the frozen baits on the trawls would scarcely thaw when set in fifty fathoms of water, or less, and we were almost forced to believe that the fish had all been driven entirely off of the Bank by the great ice field, and the straggling icebergs. The latter were occasionally seen in the deep water off the edge of the Bank.

One day we passed by a large berg, about a third of a mile distant from it. On one end of it a sharp pinnacle, resembling the spire of a church, ran up to a height of seventy-five or eighty feet; the middle was quite low, but the other end rose in a bunch or hummock about twenty feet above the water. The sunlight, playing on this huge mass of ice, throwing lights and shadows here and there, causing the peaks to glitter and gleam for a moment, then darken to a greenish tint, and its constantly changing aspect as we sailed by it, made it an interesting and impressive sight. But the thought that it, or some of its fellows, might drive down on us some foggy and windy night, when we were at anchor, caused us to look upon it with a sense of dread and apprehension instead of the admiration we might have felt in watching such an object under different circumstances.*

On the last day of. March we all set our trawls as usual-some of the ves-

*A few weeks later it was a common occurrence for the halibut catchers to shift their position to avoid coming in collision with icebergs. On some occasions the vessels were obliged to move a short distance two or three times in one night. 
sels being at anchor and others under sail-but no fish were caught by any of the fleet, and before dark all of the schooners which had been at anchor got underway. The wind was north-northeast, blowing a fresh breeze, and, knowing the ice was not far off in a northerly direction, no one would have cared to remain anchored, even had there been greater inducement to do so. We were then on nearly the extreme northwest peak of the Grand Bank, and the question was where to go next, for I do not think it occurred to any one then to try in deeper water than we had previously set in. Sch. Edrein C. Dolliver went back to the eastward again, but others of the fleet hung around, speaking with each other, the skippers evidently uncertain in what direction to steer.

Having spoken the sch. Carrie P. Morton, which came driving along from the eastward, just at dark, and learned that no fish had been caught by the vessels farther east, I decided to "hold our ground" till morning. We accordingly hove to alongside of the Alfred Walen, which was also lying to. As day broke on the following morning (All Fools' Day) we saw a schooner at anchor and ran down to her in company with the Walen. Finding the anchored vessel was the Restless, we hove to, and Captain Thompson and I, each of us accompanied by three or four men of our respective crews, went aboard of her for a "gam"* with the skipper and crew. She was anchored in eighty-three fathoms of water, and her crew were just setting their trawls when we ran down to her. The skipper of the Restless said he broke out his anchor the evening before and let her drift until the latter part of the night, when, finding deep water, he let it go again. We stayed on board of the Restless until some of her dories returned from hauling, about ro A. M., when, seeing that they were getting fair fishing on the gear that was in the deepest water, we both returned to our own vessels, and set under sail outside of the Restless.

We were in one hundred and fifteen fathoms, which was then thought to be a great depth to fish in, but the Wulen went still farther out, in one hundred and thirty-five fathoms. We caught about 4,000 pounds of halibut on a short set, and anchored; and the Wixlen, as I afterwards learned, got 8,000 pounds or more, and also came to anchor. In the meantime schs. John S. Presson, William T. Mirchant, Lizzie K. Clark of Gloucester, and the Grorge Prabody of Salem, made their appearance on the scene of action, $\dagger$ and anchored at no great distance to the northwest and southeast of us. The Lizzie $K$. Clark had a fair berth (about two miles) to the north-north-

\footnotetext{
*A term in use among whalemen (and by ex-whaleman on fishing vessels), signifying a chat botween the masters and crews of different vessels. Sometimes a tete- $a$-tete between chums on the same vessel is called "gamming."
}

tOur position was $44 \mathrm{deg} .45 \mathrm{~min}$. N. latitude. and $53 \mathrm{~d} 3 \mathrm{~g} .53 \mathrm{~min}$. W. longitude. 
west. The afternoon was fine, with a moderate and decreasing northeast wind, and current setting to the northwest or north-northwest. Knowing full well that the first vessel arriving home with a trip would be likely to strike a high market, and of course wishing to be the first, we set twenty skates of trawl-the whole string-in the evening, not dreaming that there was any ice in a southerly direction from us.

The next morning was fine and calm, but cool. We had our breakfast before daylight, and just as day was breaking an ice "glin" was noticed in the southern board, and when it grew lighter an immense field of ice could be seen drifting toward us with the current, which still ran north-northwest. Of course, the first thing to be thought of was to get our gear, if possible, or, at least, as much of it as we could. We hoisted the dories out and started at once. One of the crew had had a fainting fit the evening before, which made him quite ill, and I was therefore obliged to go in a dory in his stead. Before leaving the vessel I gave the men orders to get all the gear they could, and if the ice came on them to cut and go aboard. The trawl that we went to haul was off the starboard quarter, four points abaft the beam. We pulled for the outer end, and, on reaching it, began to haul as though our lives depended on our efforts.

We succeeded in getting a skate and a half of trawl-about 500 fathomsin the boat, when we saw the flag in the rigging of our schooner, which we knew was a signal for us to return to the vessel, as the ice was nearing her fast. We instantly cut the trawl, took our oars, and pulled with all our might to reach the vessel before the ice did. Another dory which was near us started about the same time, and we both met the ice about six hundred feet astern of our schooner. When the ice passed the vessel the men on board had the presence of mind to throw a buoy, to which a line was fastened, on one of the leeward cakes of the floe. This buoy we got hold of and made it fast to the bow of the head dory, securing the bow of the other boat close to the stern of the front one. The current was running at least two knots, and the buoy line being under the ice near the buoy, we had a hard struggle for some time to make any progress toward the vessel, and to get the line on top of the ice. The men on the vessel held a strain on the line, while we jumped out of the head dory onto the ice, sometimes hauling the boats over the larger cakes, and again shoving the smaller pieces clear of the dories and line. The ice was broken into sections of all sizes, from a piece of a few pounds weight to one fifty feet in diameter and six to ten feet thick. In this manner we worked, tugged and pulled, never resting for a moment, until at last we had the line clear and above the ice, when it became a comparatively easy matter to reach the vessel.

After getting on deck we found one of the George Peabody's and one of 
the William T. Merchant's dories aboard of our vessel, while one of our dories, which had held on to the trawl too long, had to seek a refuge on board of the Lizzie $K$. Clark. After our dories were taken in we had a better chance to view the scene, which certainly had a decidedly arctic appearance. As far as the eye could extend from aloft, in a southern and eastern direction, an almost unbroken mass of drifting field ice was all that could be seen. Here and there, however, a small streak or pond of water added a little diversity to the otherwise monotonous appearance of the frozen ocean.

All of the forenoon and the first hours of the afternoon the ice kept drifting by us, being carried along with the current. But our anchor held fast, though the strain was great on our cable as the heavy masses of ice came up against the bows and went grinding, gritting and groaning along the vessel's side. After a while a moderately sized open space was seen ahead, and as it approached us the men belonging to the Peabody and Merchant anxiously watched it, being very desirous to reach their respective vessels, which were not far off. In this they succeeded.

A moderate breeze sprang up in the afternoon, and the Lizzie $K$. Clark, getting into one of the clear streaks, got underway and worked up abreast of us, when she forced her way through the ice, passing close alongside, dropping our dory, which came aboard all right.

Meanwhile, we had hove short on our cable, and seeing an open place to windward, were all ready to break out our anchor as soon as the opening came near enough to us. We waited only a short time before we got underway, after which we stood back and forth along the weather edge of the ice, watching for the trawl buoys to make their appearance, and as fast as they did, sent a dory to haul the trawl.

This area of clear water was of considerable extent, and, since the current did not run so swiftly as before, we had a very good chance to work. However, the ice was down on us again before we got all the gear, but the men stuck to it, and, as there was a fine sailing breeze, the vessel could force her way through the floe quite well. It was nine o'clock in the evening when the last dory came aboard-the others had finished hauling their gear before dark. The ice was all around this boat during the evening, but we kept near to her, though it required close calculation to keep the run of her in the darkness. The men in her got the whole of their gear, and, notwithstanding the unfavorable appearance of things in the morning, we lost only one skate of trawl. When, at last, all hands were safely on board, and we were seated at the supper table, the incidents and anxieties of the day became the subjects of an animated conversation, and each one had a yarn to spin in relation to his experience during the day. 
In the meantime, the crews of the other vessels had not been idle, for, taking advantage of any favorable circumstance, they had endeavored, like ourselves, to haul their trawls. Three of the Alfred Walen's crew had a narrow escape from what promised much suffering, if not death. They were Philip Merchant, William Furley and Thomas Olsen. When the area of clear water, that I have before spoken of, came along, they started out to get their trawl, the vessel still remaining at anchor. They were caught in the ice, and although they held on to the trawl, which was the only thing they could do, the floe carried them adrift, and their chances to reach their vessel again were looking slim, when, late in the afternoon, the Lizzie $K$. Clark spoke the Walen, and the skipper of the latter requested Captain Murphy (as his-Murphy's-vessel was under sail) to go to their assistance. The Clark immediately kept off, but as she had to force her way through the ice, it was just growing dark when she reached the drifting boat, and past nine o'clock when she got back to the Walen. The dory was nearly . three miles from the Walen when picked up, and such a timely rescue must have been gratefully appreciated by men fatigued, hungry and chilled to the marrow.

After the Clark reached the Walen she made fast to the stern of the latter with a long warp for the night, the only instance of one vessel lying fast to another on the Grand Bank I ever knew of, and I think the only one on record.*

We kept under sail during the night succeeding the day of which I have been writing, and held our position by observing the riding lights of the other vessels. The following morning we anchored. We had foggy weather after this for the three days we stayed there, which made trawling somewhat dangerous; for, although the main floe had passed by, detached pieces and long narrow streaks of ice kept coming along, and, oftentimes, when the dories were caught to leeward of these, the men had great difficulty in working their way through or over them. Frequently the boats had to be hauled over the ice for a distance of one or two hundred yards. This trouble was increased by the denseness of the fog, which shut out from view all but the nearest objects, and the fisherman leaving the side of his vessel felt that the thick mist, which hung like a pall over the face of the sea, rendered his task more perilous and uncertain than ever before, hiding as it might a vast floe of ice which would carry him away with it to drift helplessly until he succumbed to cold and hunger. Fortunately, however, no more serious adventure occurred than that already mentioned, though the men comprising the crews of the entire fleet did not hesitate to brave the unknown perils incident to the occasion.

*The ice made the water as smooth as a mill pond. 
All of the vessels secured good fares of halibut, and some made large stocks. The rough experience of some of the fleet in the ice was apparent on their return home, when it could be seen that the planking at the water's edge was badly chafed and cut, in some cases necessitating repairs.

A funny incident occurred one evening on board of our vessel, during the fog-mull to which allusion has been made, when a man of undoubted pluck and hardihood literally got scared at his own shadow. Sometime during the day the fog had lifted for a short time, disclosing to our view a number of French brigs and barques slowly working their way along the ice towards St. Pierre. The fog soon shut down again, and the moonless and starless night was as black as pitch. Having obtained a good catch of halibut in the afternoon, we were busily engaged in dressing them until quite late in the evening. Owing to the darkness a light had to be held for each "scrubgang" so that the "scrubber" could be sure that the fish were properly cleaned. I was holding the lantern for one gang, standing inboard and close to the scrubber, who, busily employed in his work, stood in a stooping position facing aft. Suddenly he.straightened up and (possibly with the French vessels in mind) cast a quick look out on the port side into the dense fog, upon which his shadow, reflected from the light behind him, stood out like a huge dark spectre. "Keep off! keep off!" he shouted, with a voice like a Stentor, while the hearty laugh of the rest of the party immediately followed his last cry. We knew at once what he had seen, and he comprehended the situation, too, as soon as he had a chance to think. "What are you hailing your shadow for, Tom?" some one asked. "Did you think it was going to run you down?" "My God!" he exclaimed in reply, "I thought it was a Frenchman, and it seemed to me that the jibboom was going to be run down my throat."

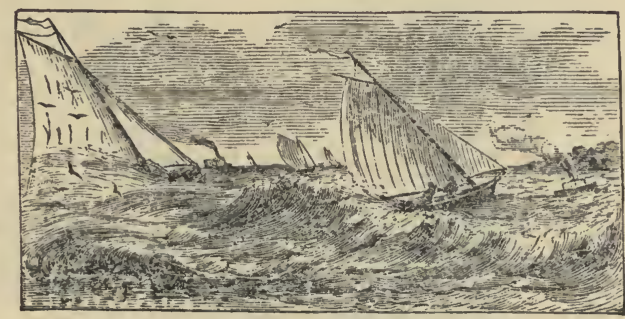




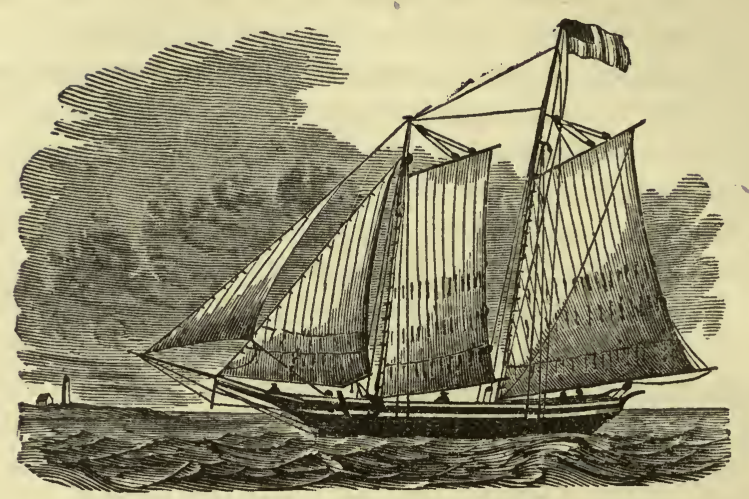

\section{LIST OF VESSELS BELONGING TO THE PORT OF GLOUCESTER IN 1850.}

COMPILED BY WILLIAM BABSON.

\begin{tabular}{|c|c|c|c|c|c|}
\hline \multicolumn{2}{|c|}{ BARQUES. } & Name. & Tons. & \multirow{2}{*}{$\begin{array}{l}\text { Name. } \\
\text { Dolphin }\end{array}$} & \multirow{2}{*}{$\begin{array}{r}\text { Tons. } \\
63\end{array}$} \\
\hline & & Argo & & & \\
\hline Name. & Tons. & Atalanta & 74 & D. P. King & 73 \\
\hline Brenda & 350 & Atlantie & 56 & Eldorado & 60 \\
\hline Galileo & 260 & Augusta & 42 & Eli & 55 \\
\hline Izette & 275 & Augusta Parker & 60 & Eiiza A. Procter & 80 \\
\hline Massasoit & 206 & Avon & 55 & Eliza A. Steele & 77 \\
\hline \multirow{2}{*}{\multicolumn{2}{|c|}{ BRIGS. }} & Avon & 64 & Ellen & \\
\hline & & Baltic & 65 & Emeline & 61 \\
\hline & & Baltimore & 32 & Enterprise & 54 \\
\hline $\begin{array}{l}\text { Amazon } \\
\text { Agenora }\end{array}$ & 202 & Banvard & 62 & Everett & $\begin{array}{l}30 \\
60\end{array}$ \\
\hline Boston & 160 & Bellona & 58 & $\begin{array}{l}\text { Exeelsior } \\
\text { Exehange }\end{array}$ & 61 \\
\hline Carter Braxton & 150 & B. H. Corliss & 78 & Exchange & 40 \\
\hline Eagle & 150 & Bonaventure & 35 & Fair Play & 31 \\
\hline Grampus & 210 & Bonny Boat & 15 & Flag of Truce & 43 \\
\hline Julia Helen & 160 & Brilliant & 52 & Flirt & 80 \\
\hline Niger & 209 & Cape Ann & 64 & Florida & 67 \\
\hline Pleiades & 285 & Capitol & 58 & For & 86 \\
\hline Sarah Ann & 193 & Centurion & 56 & Franklin & 80 \\
\hline Vietorin & 140 & Cera & 30 & Garland & 130 \\
\hline Wellingsley & 212 & Champion & 64 & Gazelle & 72 \\
\hline \multirow{3}{*}{\multicolumn{2}{|c|}{ SLOOPS. }} & Charlotte Ann & 68 & Gazelle & 62 \\
\hline & & Cherokee & 70 & Gem & 30 \\
\hline & & Clarion & 70 & Gen. Washington & 65 \\
\hline Venus & 73 & Clementine D. Stacy & 75 & George Edward & 42 \\
\hline Heröine & 55 & Clinton & 56 & Georgianna & 65 \\
\hline & & Columbia & 65 & Grace Darling & 72 \\
\hline \multirow{2}{*}{\multicolumn{2}{|c|}{ SCHOONERS. }} & Congress & 73 & H. A. Holbrook & 66 \\
\hline & & Constitution & 68 & Haleyon & $\begin{array}{l}37 \\
60\end{array}$ \\
\hline Abigail Brown & 75 & $\begin{array}{l}\text { Convoy } \\
\text { Convoy }\end{array}$ & $\begin{array}{l}00 \\
57\end{array}$ & $\begin{array}{l}\text { Hannibal } \\
\text { Helen Maria }\end{array}$ & $\begin{array}{l}\text { bU } \\
63\end{array}$ \\
\hline Ala & 69 & Cottage & 45 & $\mathrm{He}$ & 80 \\
\hline Alexander & 80 & Cygnet & 64 & Herald & 45 \\
\hline America & 27 & Daniel D. Smith & 49 & Hibernia & 50 \\
\hline Ann Maria & 66 & Diana & 70 & Hosea Ballou & 64 \\
\hline Areola & 62 & Diligent & 48 & Huntress & 59 \\
\hline
\end{tabular}




\section{LIST OF VESSELS-Continued.}

Name.

Imogen

Iowa

James Isaac

Jenny Lind

John

Josephine

J. P. Ober

July

Lanoni

Laurel

Leader

Leona

Lion

Lueinda

Luey Ann

Luey A. Pulcifer

Luey Wharf

Marion

Mary Eliza

Mary Eliza

Mary S. Wonson

Metamora

Miriam

Molly

Montrose

Montezuma

Mount Vernon

Napoleon

Native
Tons. Name.

66 Nautilus

76 Niagara

28 Nile

75 Ocean Queen

100 Oconee

56 Ohio

79 Oregon

54 Orion

66 Orozimbo

56 Pennsylvania

58 Pilot

71 Pocahontas

24 Potomac

55 Premium

67 President

80 Princeton

58 Protector

33 Ranger

70 Reaper

53 Redwing

84 Reliance

57 Richmond

53 Rio del Norte

73 Ripple

62 Robert Bruce

76 Rockaway

68 Romeo

52 Romp

70 Sarah
Tons. Name.

59 Sarah Elwell

Tons.

66 Seienee

5 Signal 37

64 Sisters 44

73 Splendid 48

67 Star of Hope 88

68 St. Lawrence 63

66 Suecess 45

62 Swampscott 38

68 Swan 45

67 Talisnian 68

71 Theory 37

70 Thorn 65

59 Three Sisters 45

49 Tiber 65

60 Traverse 62

62 Tremont 64

43 Trenton 71

50 Union 68

24 Van 30

75 Victory

67 Virgin 62

60 Watehman 60

35 Wave 80

71 Wave 77

61 Welcome Return 29

60 Wm. P. Dolliver 80

76 Wm. Penn 66

67 Yorktown 50

4 barques, 1101 tons, average 275 tons; 12 brigs, 2273 tons, average $189 \frac{1}{2} ; 2$ sloops, $12 \mathrm{~S}$ tons; 166 sehooners, 10,029 tons, average $601 / 3$ tons. Total vessels, 184; tonnage, 13,531; average tonnage, $73 \frac{1}{2}$.

Of these 184 vessels owned in Gloucester 32 years ago, although several are doubtless still in existence, only one, the Lucy Ann, is still owned here. The Lucy Ann is 46.54 tons, new measurement, was built in Essex in r849, and is owned by Mr. Samuel Haskell.

Very many of the readers of this volume will peruse the above list with pleasure, as the recalling of the names of these vessels will awaken many pleasing reminiscences when some of them were the "crack" vessels of their day, and the trips they made and the associations connected therewith, will recall the past with all its wealth of associations connected with the fisheries of that period.

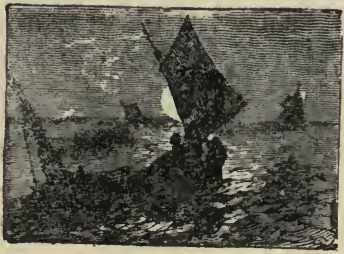




\section{THE PHANTOM BOAT.}

\section{A Legend of Cape Ann.}

\section{BY E. NORMAN GUNNISON.}

The tide comes in and the tide goes out, And the rollers break on the harbor bar,

And up from the distance comes a sail, Gleaming white 'neath the morning star.

Fishing tackle and boats on deck, Running rigging belayed and trim;

Raking spars-' tis no battered wreck Sailing out in the distance dim.

It draws not near, though the wind is fair; The sheets are free, but it comes not nigh, But hangs, a point on the morning air, A pictured sail 'twixt the earth and sky.

Fisherman, tell me why.yonder boat Sails, and no nearer comes to shore; Nor in the distance grows remoteNot a ripple her bow breaks o'er.

"Stranger, I reckon you aren't here long, Many a year has her pennant flewOld is the story - a worn out songBut her deck is trod by no mortal crew.

Look a moment and see the flame Gleaming white over mast and spar-

Here! take my glass, you can read the name Under her starn- 'tis the 'Alice Marr.'

Alice Marr was a fair young girl, Long ago, in Glos'ter town;

Rippling ringlets and sunny curl, Rare red lips and a cheek of brown.

That was Alice, the fisher's pride; Lovers sought her, from near and far; She was John Ackman's promised brideHe named his vessel the 'Alice Marr.'

Thar's nothing sartin, stranger, in life; We're gone to-morrow, though here to-day. Another v'yage she would be his wifeAt least, so I've heard the gossips say.

Pork, potatoes and hard-tack stowed, Water in barrels and water in tanks,
Nicely fixed for a three months' cruise, He sailed away for the fishing banks.

'For mell must work and women must weep,' Men must work for their daily bread; One month out-all well on board, Spoke by the 'Dart' of Marblehead.

Months rolled on, and never a word; Six months, twelve months-on the day That finished the year was a rumor heard Of the 'Alice Marr' in the outer bay.

Boats put out, but they drew not near; Slowly, silently on she steered;

'Skipper Ackman! ho! what cheer?' Sbe had vanished and disappeared.

Ever as rolls the year around, Bringing again her sailing day, Rises her hull from the depths profound, And slowly cruises the outer bay.

Not a word of her master's fate, Only a glimmer of sail and spar; Not a word of her crew or mateThis is the ghost of the 'Alice Marr.'

Still she watched down the peaceful bay, Still her eye scanned each gathering cloud,

Years receded, and worn and gray, Her wedding dress was her fun'r'l shroud."

This is no myth of the poet's pen, This is no mirage upon the blast, The boat $i s$ there, just the same as when Mine own eyes saw in the Summer past.

Only the eye of faith can see,Eyes are blinded-and this in brief-

What is holden from you or me, Is seen by others who have belief.

Still in the morning, cold and gray, Gazing afar the sea to scan,

Looking out from the sheltered bay, See the phantom which haunts Cape Anv 


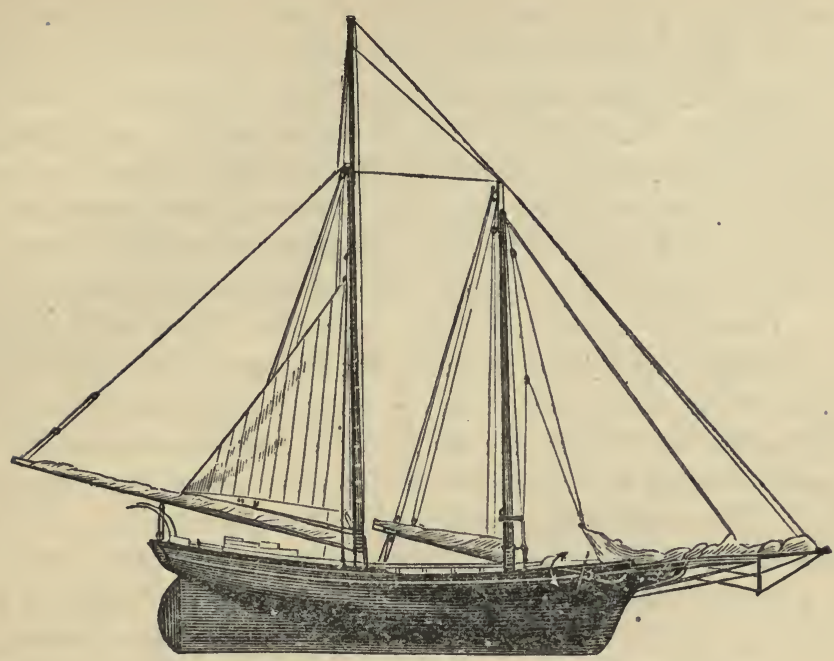

MODEL OF TRAWLER OF $\mathbf{1 8 8 2 .}$

\section{A Trawling Trip.}

BY WALTER HILL.

Gear Used-Porpoises-Frolic at Canso-On the Fishing Grounds-Setting and Hauling the Trawls, and What We Find in Them-Changing Berth -An Uncommon Incident-Putting In for Bait.

Let us imagine ourselves on board a trawler, well outside, and shaping a course E $1 / 2 \mathrm{~S}$ for Cape Sable, a distance of two hundred and fifteen miles.

The lines which compose a trawl are made of cotton, and are in lengths of fifty fathoms, about the size of a lead pencil, and tarred to render them more durable. They are attached at equal distances to a buoy line, and are coiled in tubs or flour barrels cut down, and extend to about three hundred fathoms for each tub. Each dory will "set" about four to six tubs, so that it forms a pretty long string when extended in one direction. For halibut catching the hooks are attached at a distance of two and a half fathoms apart throughout the whole length of the trawl, but for codfishing the hooks are placed a fathom apart. The fishing is done in dories, and two men go in each dory. Our vessel's crew consists of fourteen all told-twelve men, cook, and "skipper" or captain. Müch gear is necessary besides the trawl itself, viz., buoys, buoy-lines, anchors, flags, etc. But you will get a better idea of all this when we come to "make a set," by accompanying one of the dories yourself. 
Meanwhile, take a look at the hold. It is divided off into pens or compartments, in which is stowed the salt necessary to cure the fish. In a fresh halibut catcher these pens would be stowed with ice instead of salt.

Now just step on deck again. Here is something that will interest you. Do you see that splashing far away on the horizon? That is a school of porpoises, and they are coming this way. I'll take the harpoon and go out on the bowsprit, and should they cross our bows, try my luck. I'm not very expert with this weapon, but it may serve to kill time agreeably, if not a porpoise. Here they come, launching themselves along with dazzling rapidity. One might call them the very incarnation of vitality and action. I sometimes think, when I see them evidently enjoying life so intenselylaunching themselves through the air by those magnificent twenty and thirty feet bounds-chasing and racing one another with lightning action-that it is their way of expressing their gratitude for being permitted to inhabit such a beautiful world of waters, and for being so admirably adapted to enjoy it. Whang! I missed that one! Quick! haul in the slack line and give me out the harpoon again. We are in the midst of the school now. Whiz! again. I've struck one this time. Pay out the slack line and heave the helm down! Don't check him till the vessel's way is stopped, or he will snap the line. Now you may try him. There he comes alongside, disputing every inch and making some wicked plunges. We will get a running bowline over his tail and haul him aboard. There he comes in. How he lashes the deck, every nerve quivering with rage and excitement.

The breeze has freshened. We have left Cape Sable behind and are booming along the Nova Scotia shore at a good rate. We shall soon be in Canso, where we shall probably take what bait we require. The bait this time will consist of herring. These are taken by the resident fishermen, in nets, and brought alongside the vessel and sold at so much per hundred or barrel. It is more exciting work when we catch our own bait, especially if that bait happens to be squid.

I shall not say much of the inevitable "frolic" we get upon the night before leaving for the Banks. What pretty girls we-get introduced to. And here, lest the better-halves of the married portion of my compagnons de voyage should become jealous, let me say that $I$ saw no improper flirtations going on on their part. Not one of the benedicts under my eye danced more than twice with the same young lady. An old familiar, just dropped in, suggests I might possibly myself have been too much engrossed to observe all that was passing around me. It is a base insinuation, and were he not a privileged character I should freezingly point him to the door.

Leaving all these open questions behind, let us consider ourselves on the fishing grounds. Having decided on making a set, we round to and anchor in about forty fathoms of water. The hooks being baited up and all ready, 
the dories are rigged out and the tubs of trawl, buoys, buoy-lines, anchors, etc., are put into them. As each dory gets ready she is rowed out in her regular place, which has been drawn for by lot, and the work of setting the trawls commences. Each takes a different direction from the vessel. Thus the vessel forms the centre and the trawls form radii of a circle, being set with a buoy and anchor at each end. A good flag is placed on the buoy at the outer end, which extends about a mile and a half from the vessel, and the dories then row aboard, and the trawls are left out till the following morning.

At daylight all hands are called out to breakfast, immediately after which the dories are hoisted out, and row to the ends of their trawls, being guided by the flags when it is clear; but when it is thick and foggy, which most frequently happens, finding the outer buoy is a matter of much difficulty, and the dories frequently lose themselves. However, being clear, it is all plane sailing to-day. There is some rivalry between the dories, as to which one shall bring most the fish or get done first ; but as the reader is to accompany us, we will proceed leisurely so as to examine all the curios that come up.

We've taken hold of the buoy, then, and having shipped the roller in the bows, commence hauling away. At last the anchor heaves in sight, after what you think a long haul, and here on the first hook is a good codfish, but I don't see much more coming along. There, again, is a haddock. Take notice of those teeth-marks about him. A halibut has been endeavoring to swallow him. See what a scared look he has! When hauling trawls I sometimes liken the expression of different fish to their counterparts on terra-firma. Thus, the haddock bears a strong resemblance to the sheep or lamb. Their large innocent eyes seem to look up appealingly as they come up alongside the dory. They accept their fate, too, with sheepish resignation, and scarcely ever stir after being slatted off the hook into the dory. They are the prey of almost every other fish that swims, and altogether, must have a very hot time of it, indeed, down there.

What have we coming here? A rock which is perfectly honey-combed"Perforated sore and drilled with holes."

This work is accomplished by a species of boring bivalve, whose generic name I am unable to give, but if you could descend and take a submarine stroll, you would scarcely find a rock but was in the same state wherever these curious fellows are found. Curled into some of these holes, and clustered around the rock, in fantastic shapes, you observe numerous sandy tubes. These are inhabited by curious worms, known to the naturalist as annelids. They are widely distributed all over the fishing banks, wherever the bottom can be made available for building their cells. There are vari- 
ous species. One kind does not build a cell at all, and is known as the naked annelid.

But stop! I feel a halibut tugging away below. There he heaves in sight. Keep steady in the dory while I get my gaff in his head, and do not be alarmed when I heel the crank little craft over to take the big fellow in. After I get his head on the gunwale he slides into the bottom of the boat as easily as if he were helping himself in.

I can see two or three codfish coming along next. One of them is a large one. Look how lazily that fifty-pounder rolls up alongside. He seems to accept the situation as if he had been expecting it. If he could speak he might give mouth (what a mouth!) to the following: "Here I come. Whip out your gaff and help me aboard without any fuss. I've been looking for this a long time past. I put all my affairs in order when I reached forty pounds weight, and have been ready to fulfil my destiny at any time since." How differently does that "snapper," or young codfish, appear to act. He darts about, as far as the hook will allow, and seems to have vitality enough for a dozen years to come. After he is unhooked he flutters about and won't be resigned in any place, but seems to protest to the last against the fate which cuts him off in the pride of his youth. And who can believe but his view is the soundest, if it were practicable to let him alone?

But what have we here? As I live, it's a turbot. You will make a delicious meal from this fellow, I'll warrant. We do not save them for market, there being apparently little demand for them in the States. If I were a gourmand, and had the means wherewith to gratify my appetite, I would offer his weight in silver for one of these paragons of all that is delicate and rich among fish flavors.

Passing over numerous codfish, and an occasional halibut, we haul along till we come to a comparative stranger on the Grand Bank-would that he had been a stranger on Georges and some other Banks I've fished on-a dogfish. If you would cultivate angelic patience, or haply sound the depth of wickedness to which it would be possible to goad you, go out on Western Georges in Dog(fish) days and haul a trawl of one thousand hooks with a dogfish on every hook. Whichever course you adopt, if you succeed in fighting it out on that line to the end, will have brought you to the extreme limits of goodness, or to the border of Hades. Their skin is so rough that before you have unhooked fifty the probability is that your thumb and finger will be getting raw, to say nothing of the dexterity with which the greeneyed wretch comes back after having his jaw hauled half out with the hook, and swims around as if to intimate that you have been exhausting your patience or your passion on him without disturbing his equilibrium in the least.

The trawl is coming up from a ledge now, as you may see by the pretty 
diminutive sprays of coral attached to some of the hooks. You will observe four or five varieties, but I have never yet been fortunate enough to haul up any of the kind valuable in commerce.

Here's a queer looking object coming-a fish skeleton. It is a codfish with nothing but the skin and bones left. He has been eaten since he got on that hook; as clean as a whistle, not a grain of flesh left if you'd give a guinea for it. Little insects that we call sand-fleas have accomplished this. There must be myriads of them, because in a couple of hours they will reduce a large codfish to the state in which we find this one, or, speaking mathematically, to his simplest terms. The fish, poor fellow, must feel very much like Gulliver when attacked by the Lilliputian army. They're too many for him.

Thus we go on to the end of the trawl, where we "break out" the anchor and haul it up, together with the buoy-line and buoy, rowing to the vessel and pitching our fish on deck. These we "dress down," and as the aggregate catch is not large, we heave up the anchor and shift a few miles away, where we "bring to" again, bait up the trawls, and then are done for the night, "till daylight doth appear." This time we get better fishing, and all the dories get a load.

Sometimes an uncommon incident takes place. Such an one happened to the writer a short time since. We were in our dory, hauling away in the most unsuspecting manner, when a whale, without the slightest previous notice, came right up under the dory, gave a snort which startled us as though it had been an earthquake, and in a moment we were sliding off the back of the monster, half capsized. Luckily we both managed to grab the upper gunwale, and saved her from going wholly over, coming off with no worse damage than being swamped with water and losing half our fish.

On foggy days a horn is blown at frequent intervals during the time the dories are hauling trawls, to enable them to judge of the whereabouts of the vessel. But withal, dories frequently lose themselves and row about for many hours without finding their vessels, and in such cases they are often picked up by passing vessels, after enduring great privations. Many a thrilling story might be told of narrow escapes from perils such as these, by our fishermen who follow up Bank fishing continuously.

When the bait gets exhausted, or becomes too stale for the fish to relish it, we proceed to Newfoundland to procure another supply. On such occasions we sometimes have many leisure days, and to beguile time we arrange a dance on shore, which is kept up from dark till daylight. 
MASSACHUSETTS MACKEREL CATCH FOR 74 YEARS.

\begin{tabular}{|c|c|c|c|c|c|c|c|}
\hline YEAR. & $\begin{array}{l}\text { Massachu- } \\
\text { setts. } \\
\text { BBLs. }\end{array}$ & $\begin{array}{c}\text { Gloucester. } \\
\text { BBLs. }\end{array}$ & & YEAR. & $\begin{array}{c}\text { Mass. } \\
\text { Inspection. } \\
\text { BBLS. }\end{array}$ & $\begin{array}{c}\text { Gloucester } \\
\text { Inspection. } \\
\text { BBLS. }\end{array}$ & $\begin{array}{l}\text { Rockport } \\
\text { Inspection. } \\
\text { BBLS. }\end{array}$ \\
\hline 1808 & 7,738 & 238 & & 1845 & 202,302 & 48,711 & \\
\hline 1809 & 8,865 & 46 & & 1846 & 188,261 & 41,513 & \\
\hline 1810 & 13,058 & none & & 1847 & 254,917 & 40,006 & \\
\hline 1811 & 17,890 & & & 1848 & 317,101 & 53,500 & \\
\hline 1812 & 6,750 & none & & 1849 & 231,856 & 45,579 & \\
\hline 1813 & 3,832 & 91 & & 1850 & 242,572 & 49,993 & 3,916 \\
\hline 1814 & 1,349 & none & & 1851 & 329,441 & 81,627 & 9,240 \\
\hline 1815 & 16,394 & 72 & & 1852 & 217,540 & 48,012 & 5,345 \\
\hline 1816 & 30.021 & 123 & & $185 \overline{3}$ & 130,423 & 36,196 & 4,523 \\
\hline 1817 & 37,482 & 115 & & 1854 & 134,848 & 43,201 & 3,278 \\
\hline 1818 & 47,210 & 154 & & 1855 & 130,850 & 73,102 & 5,740 \\
\hline 1819 & 105,433 & 109 & & 1856 & 214,017 & $66, \frac{\pi}{29}$ & 6,513 \\
\hline 1820 & 120,602 & 217 & & 1857 & 192,378 & 67,311 & 5,677 \\
\hline 1821 & 111,009 & 2,176 & & 18 8 8 & 131,601 & 56,489 & 4,152 \\
\hline 1822 & 150,294 & 2,804 & & 1859 & 99,845 & 59,664 & 3,004 \\
\hline 1823 & 145,006 & 3,570 & & 1860 & 244,703 & 97,992 & 5,561 \\
\hline 1824 & 180,636 & 6,303 & & 1861 & 194,281 & 90,516 & 4,989 \\
\hline 1825 & 254,381 & 9,359 & & 1862 & 260,863 & 116,238 & 6,100 \\
\hline 1826 & 158,740 & 11,668 & & 1863 & 306,941 & 153,892 & 5,671 \\
\hline 1827 & 190,310 & 16,288 & & 1864 & 273,355 & 154,938 & 4,970 \\
\hline 1828 & 237,324 & 34,203 & & 1865 & 202,775 & 141,576 & 5,746 \\
\hline 1829 & 225,877 & 37,683 & & 1866 & 231,390 & 114,053 & 7,562 \\
\hline 1830 & 308,485 & 51,613 & & 1867 & 210,712 & 113,917 & 6,479 \\
\hline 1831 & 383,658 & 69,759 & & 1868 & 179,492 & 75,517 & 5,260 \\
\hline 1832 & 222,452 & 40,674 & & 1869 & 234,199 & 93,126 & 5,962 \\
\hline 1833 & 222,926 & 45,529 & & 1870 & 318,520 & 129,595 & 9,800 \\
\hline 1834 & 252,884 & 61,319 & & 1871 & 259,414 & 107,008 & 6,940 \\
\hline 1835 & 197,411 & 48,539 & & 1872 & 181,956 & 67,395 & 3,679 \\
\hline 1836 & 177,056 & 43,937 & & 1873 & 185,736 & 83,459 & 3,084 \\
\hline 1837 & 144,891 & 33,274 & & 1874 & 258,359 & 118,314 & 4,124 \\
\hline 1839 & 110,740 & 24,262 & & 1875 & 130,017 & 51,040 . & 1,742 \\
\hline 1839 & 74,243 & 10,241 & & 1876 & 225,946 & 95,422 & 5,610 \\
\hline 1840 & 50,490 & 8,870 & & 1877 & 105,097 & 49,044 & 1,478 \\
\hline 1841 & 55,137 & 8,559 & & 1878 & 144,226 & ธอ์,741 & 975 \\
\hline $1842^{\circ}$ & 75,543 & 15,335 & & 1879 & 155,298 & 48,643 & 172 \\
\hline 1843 & 64,451 & 16,328 & & 1880 & 252,538 & 116,793 & 959 \\
\hline 1844 & 86,181 & 17,455 & & 1881 & 256,173 & 113,203 & 291 \\
\hline
\end{tabular}

Owing to the practice of selling mackerel "out of pickle," to be packed and branded elsewhere, the Gloucester "inspection" for the past few years shows only a portion of the catch of our fleet. The eatch of the Gloucester fleet in 1881 was 163,851 bbls., the amount inspected only $113,203 \mathrm{bbls}$. 1880 eatch, $129,680 \mathrm{bbls}$.

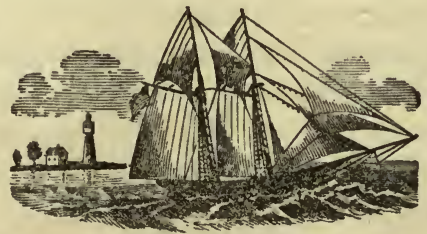




\section{The Fortune Bay Riot.}

The treaty of Washington opened the way to a satisfactory settlement of the Alabama Claims, so far as this country was concerned, Great Britain being called upon to pay over a handsome sum for the depredations of her cruisers upon American commerce during the War of the Rebellion. But the Treaty contained provisions concerning the Fisheries which have not resulted as satisfactorily, either to our own government or to the dependencies of Great Britain. Under these provisions the American market was thrown open to the products of provincial fishermen, iree of duty, thus bringing their catch into active competition with ours, while American fishermen were permitted to fish in provincial waters, on equal terms with British subjects, as they claim to their great detriment and loss. The Fishery provisons of the Treaty also contained a clause providing for a Commission, to sit at Halifax, and determine how much, if anything, the United States should pay for the valuable privileges vouchsafed her fishermen, over and above the value of the freedom of her markets to provincial-caught fish. The Commission met and heard evidence on both sides, and decided that the United States should pay the sum of $\$ 5,500,000$, an amount, as the Americans claim and believe, larger than the total value of all the fish taken or to be taken by American fishermen within provincial waters during the twelve years that the Treaty is likely to remain in force. The money was, however, paid without controversy.

The fishermen of Newfoundland were especially restive under what they regarded as the ceding away of their rights by the imperial government. They looked upon the shore herring fishery of their island as peculiarly their own property. It was their principal source of revenue, on which themselves and their families were dependent for bread, and if this fishery was taken away from them, or its value destroyed, starvation would stare them in the face. Accordingly, when a large American fleet appeared upon their coast, in the Winter of $1877-8$, with improved apparatus for the catching of herring, instead of purchasing a supply of the native fishermen, as had previously been the practice, they were greatly incensed, and resolved to defend what they felt to be their rights.

The Gloucester fleet arrived in Fortune Bay about the middle of December, and waited until the first week in January for the herring to strike in. They were provided with seines, and prepared to catch or buy fish, as circumstances might warrant. The fleet comprised twenty-two first-class vessels, as follows : 
Schooner.

Bonanza,

Bunker Hill,

Charles C. Warren,

Crest of the Wave,

Edward E. Webster,

F. A. Smith,

Fred. P. Frye,

Herbert M. Rogers,

Hereward,

Isaac Rich,

John W. Bray,

Lizzie \& Namari,

Mary M.,

Maud \& Effie,

Maud B. Wetherell,

Moro Castle,

Moses Adams,

Moses Knowlton,

New England,

Ontario,

Wildfire,

William E. McDonald,

\section{Tons.}

$\mathrm{r} 37.06$

100.77

ro8.87

$71.3^{8}$

98.80

77.10

85.37

77.65

90.1 I

92.18

$83.4 \mathrm{I}$

94.09

го1.62

85.23

107.90

88.85

90.87

III.00

86.29

91.29

ro8.90

98.37
Ow'zer or Charterer.

Humphrey C. Allen.

Walen \& Allen.

Peter Smith.

William B. Coombs.

Dennis \& Ayer.

Plumer and Friend.

Brown, Seavey \& Co.

Rowe \& Jordan.

James Mansfield \& Sons.

Walen \& Allen.

John F. Wonson \& Co.

John F. Wonson \& Co.

Brown, Seavey \& Co.

Gardner and Poole.

George Dennis \& Co.

Hardy \& Allen.

Samuel Lane \& Bro.

John Low.

John Pew \& Son.

John Pew \& Son.

Andrew Leighton.

Wm. Parsons, 2d, \& Co.

The herring struck into Fortune Bay on Sunday, Jan. 6, 1878, in such quantities that a few hours' seining would have sufficed to load the entire fleet. The schs. Nere England, Capt. Peter McAuley, and Ontario, Capt. John Dago, joined and set their seines, making a double seine about 2,400 feet long and $\mathrm{r}_{5} \mathrm{O}$ feet deep, which soon filled with herring, the catch being estimated at fully 2,000 barrels. This, with the operations of the other Gloucester schooners, maddened the Newfoundland fishermen, who had gathered in the vicinity to the number of two hundred or more, and they commenced to put off in boats, making warlike demonstrations and using threatening language, and commanding the American fishermen to desist from fishing. The seines of the Ontario and Nere England were seized by the mob, the fish let out, and the seines torn in pieces and carried away.

The rioters next turned their attention to the sch. Moses Adams, Capt. Solomon Jacobs, whose seine had been set and filled, and whose crew were busily engaged in scooping the herring into boats and transferring them to their vessel. Three separate attempts were made to seize this seine, but Capt. Jacobs and his crew were provided with loaded revolvers, and by threatening to shoot the first man who dared to interfere with them, succeeded in keeping the mob at bay until a partial cargo had been secured, when the Newfoundlanders tripped the seine and allowed the remainder of the herring to escape. Had they been allowed to continue fishing, they could have loaded their vessel and helped in supplying others. 
In the evening the rioters had a jubilee, blowing horns, firing guns and shouting, as if celebrating a victory. This was taken as an indication that the same course would be pursued if further attempts were made to fish, and the other vessels were deterred from making the attempt. Next day the herring struck off shore, and finding it difficult to purchase cargoes, the fleet soon set sail for home, mostly in ballast, although a portion of the fleet secured partial cargoes, mostly by purchase.

The following year (1879), in July, a similar occurrence on a smaller scale took place in Aspey Bay, Cape Breton. The schs. Bay State, Capt. Goodwin, and Cadet, Capt. Anderson, arrived at Aspey Bay June 20, to await the schooling of the squid, when they proposed to engage in seining operations. They were told by the inhabitants that they would not be allowed to set their seines, but continued to await the appearance of the fish, hoping that they would not be interfered with. The squid struck in July 8 th, but the threats of the local fishermen were so serious and determined that the Americans were obliged to refrain from fishing and come home without fares.

Aug. 16, r879, sch. Howard Holbrook, Capt. Daniel McFayden, of this port, while absent on a Bank trip, put into Trinity Bay, N. F., for the purpose of seining bait. Capt. McFayden was opposed by some thirty Newfoundlanders, who threatened to destroy his seine and dories if he attempted to fish, the spokesman of the party, one Cooper, declaring that no one should set a seine for squid within three miles of the shore and live to haul it.

On the $4^{\text {th }}$ of August, r88o, as the sch. Moro Castle, Capt. Loren B. Nass, of this port, was lying in Conception Bay for the purpose of purchasing squid to complete a Bank voyage, some of the crew threw over jigs and commenced to catch a few squid over the side of the vessel during the absence of the skipper. They were seen from the shore, and an angry crowd of native fishermen put off, seized the schooner, raised her anchor, hoisted the mainsail and jib, and came near getting her ashore upon the rocks. Seeing the danger she was in, the mob took their departure, leaving the vessel in the hands of the crew. The sch. Victor, Capt. Joseph Bowie, was also compelled by superior numbers to relinquish fishing for squid, at the same time, under threats of having the cable cut, allowing the schooner to drift on the rocks. Efforts were also made, on two occasions in August, to prevent sch. Martha $C$., Capt. Charles Martin, from taking squid, but Capt. Martin put a bold face on the matter, returning threat for threat, and took what squid he wanted without molestation.

Sch. Minnesota, of Pruvincetown, was also prevented from taking bait in the Summer of 1880 . At this time negotiations were in progress to secure indemnity for the outrages upon American fishermen, with a prospect of Newfoundland having to pay the bills, and the local authorities felt that it was time something was done to show that such lawlessness was not sanc- 
tioned by those in authority. Accordingly, five young lads were arrested for throwing stones at the crew of the Minnesota while they were engaged in taking bait, and four of them were convicted and fined.

Early in 1878 efforts were made to secure compensation for the losses of American fishermen in consequence of the unlawful acts of British subjects. One excuse after another was offered in justification of the course pursued by the riotous fishermen, but none of them could stand against the plain language of the Treaty, as interpreted by the evidence introduced before the Halifax Commission, which gave our fishermen an undoubted right to fish as they pleased in the provincial waters. The negotiations were prolonged until the Summer of $188 \mathrm{r}$, when the United States received from Great Britain the sum of $£ 55,000$, which was accepted in full for all claims to date on the part of American citizens against the government of Great Britain. On the roth of July a portion of this sum was disbursed among the Fortune Bay fleet of 1878 , leaving the losses at Aspey and Conception Bays for future consideration. The Fortune Bay fleet put in claims to cover the actual expenses of the voyages, including charter money, outfits, port charges, seamen's wages, etc., and the probable profits of the trips, had they been allowed to secure cargoes, based upon the profits of preceding years. The latter item was disallowed, and payment was made on the basis of the actual expenses, less value of cargo secured, with seventeen and onehalf per cent. interest, or at the rate of five per cent. per annum.

The following is a list of the claims presented, with the amounts actually disbursed in settlement thereof :

Schooner.

Bonanza,

Bunker Hill,

Charles C. Warren,

Crest of the Wave,

Edward E. Webster,

F. A. Smith,

Fred. P. Frye,

Herbert M. Rogers,

Hereward,

Isaac Rieh,

John W. Bray,

Lizzie \& Namari,

Mary M.,

Maud \& Effie,

Maud B. Wetherell,

Moro Castle,

Moses Adams,

Moses Knowlton,

New England,

Ontario,

Wildfire,

William E. McDonald,
Actual Expenses. Value of Cargo. Claim.

$\begin{array}{rr}\$ 2,855.94 & \$ 975.00 \\ 3,179.50 & 1,962.00 \\ 4,610.00 & 2,430.00 \\ 2,619.04 & \end{array}$

$1,754.50$

$2,495.50$

2,150.00

$3,066.18$

$4,300.00$

2,986.09

2,714.52

$3,133.65$

$2,180.53$

$3,333.13$

$3,797.84$

2,153.18

$2,607.30$

$2,661.60$

$1,530.97$

$2,153.95$
$\$ 3,022.17$

$2,677.00$

$4,680.00$

4,619.04

4,654.50

4,895.50

$3,700.00$

$5,876.30$

$5,748.00$

2,491.09

3.589 .07

$5,564.40$

$5,480.53$

$4,379.13$

$2,530.34$

4,134.19

$8,586.05$

$5,356.60$

$3,350.00$

$3,350.00$

6,309.82

$4,953.95$
Payment.

$\$ 2,210.10$

$1,430.56$

$2,561.50$

$3,077.37$

$2,061.44$

$2,932.21$

$1,997.50$

2,186.70

$4,392.15$

$1,351.36$

1,397.16

$3,013.17$

$3,327.12$

$2,795.48$

$2,033.15$

$2,529.99$

$1,863.60$

$2,769.00$

$2,722.18$

2,995.74

$1,798.89$

2,530.89 


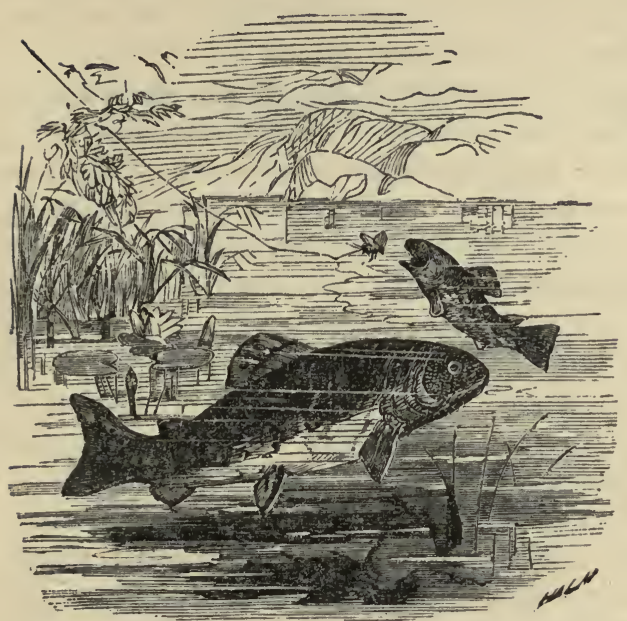

\section{Importance of Fish Culture.}

Day after day this wonderful enterprise is meeting with greater and greater encouragement. The fact of reproducing fish artificially is based upon the practical experiences of a Frenchman nearly a century ago, and although its success proved largely beyond his expectations, the world remained, as many people do to-day, skeptical as to the feasibility of the experiments. As in all other important events discovered by accident, science was essen. tial to the thorough illustration in the matter of fish culture. The advances made within the last half century are simply bewildering. The brook trout was first propagated by artificial means; now even salt-water fishes, including lobsters and oysters, are destined to yield to the manipulation of man, and have their number increased beyond the limits of calculation.

Necessity, the admitted mother of invention, should have prompted the European scientists to make the greatest efforts, yet the facts are, it is to those of our young republic to whom the honors have been awarded for the great work, though surrounded by an abundance. Under the skilful direction of Prof. S. F. Baird, the world renowned Seth Green, and others, the propagation of fish and inventions pertaining thereto, have won for these gentlemen notoriety unequalled by any pisciculturists of the world. Hatcheries, transporting implements, acclimatizing of fish, fishways, and the like, have been perfected in the United States to such a degree that the European Fish Congress held a year ago in Germany awarded their most valuable prizes to gentlemen of our country. The State Fish Commissioners have 
seconded their national official brethren by untiring energy and skill, which brings them under honorable notice by their colabarateurs abroad. The McDonald fishway is a monument which will perpetuate the name of its inventor. Eugene Blackford of New York has his name engraved upon the historical records of fish, with the Lutjanus blackfordii; so might be enumerated every one of these gentlemen who, without other consideration than the true manly sense of duty, have labored to protect and increase the fish supply of our country. Prof. Geck of 'Wurzburg, Germany, a noted scientist, is now compiling a book upon this interesting subject, and has wisely placed himself in correspondence with our National and State Fish Commissioners with a view of getting reliable data and information which has been derived from their relative experiences. This is one of many instances complimentary to American fish culturists, but when their present efforts will have been matured by material results, more of them will come pouring in.

Much has yet to be done to develop the plans of increased fish culture. The legislatures of the several States must make liberal appropriations, the people are to be educated to the importance of the enterprise, and then the whole world will marvel at what has and can be done. Oysters, which form so large a part of our food supply, must be artificially propagated. Scientists are already occupying themselves about it, and one or two have even devised apparatus for testing the subject. When this is made practicable, with what is being done towards the increase in the supply of fish, a fund of wealth will have been opened far greater than the gold fields of Australia or California. Only a few years ago German carp were introduced into the United States, yet at present their produce would represent edible fish to the extent of many tons. In less than ten years the whole country will be stocked with them. This will materially lessen the existing vandalism practiced in our lakes and streams, consequently assisting nature in the increase of fish in them.

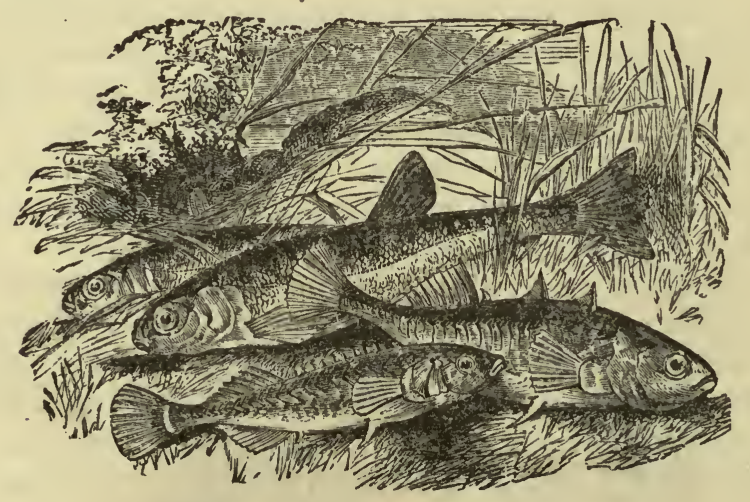




\title{
The Fisheries in the Olden Time.
}

\author{
BY W. E. S.
}

Upon visiting old Gloucester, my native place, recently, I was forcibly reminded, by way of contrast, of the ways and means by which the business was carried on in the years long, long ago, the days of our fathers and grandfathers, and even down to the time of my own boyhood's remembrance. The Grand Bank cod fishery was considered the "heavy business" in these old days. This was varied somewhat by occasional trips to Labrador, Bay Chaleur, etc. 'The pursuit of mackerel as a specialty had then hardly commenced, and the curing and smoking of halibut for the trade was unknown. The crews of the Bankers would sometimes bring home a few fletched for family use, that were cured in the smoke of the cabin.

Fitting away for the Banks was usually attended to along in March, and during April they were well on their way to their destination. Two trips, or fares, generally occupied the season; a Fall fare was sometimes undertaken, but for this the chances were not considered favorable, by reason of bad weather for fishing and the equinoctial gales. The "old salts" would sometimes tell of intending to partake of their Christmas dinner before getting up anchor for home; but I think that this feat was never accomplished, at any rate, "hardly ever."

It was the custom to keep count of the number of fish caught, and a fare of thirty to forty thousand, or enough to "eat all their salt," was considered fair luck. An expert could estimate very nearly the amount a given number of fish would weigh off when thoroughly cured.

The fish were all caught "over the rail." I remember of hearing it said that French vessels were sometimes met with on the Banks, that were fishing with trawls. On the arrival of a Banker the first move was to ascertain the number of fish caught, by hailing from the rocks back of the old Fort, and after coming to anchor in the inner harbor commenced the "washing out." The "pound," a frame, or raft of timber, loosely boarded over and around the sides, was made fast alongside; into this the fish were thrown, and the pickle and undissolved salt washed off, thence taken to the shore in boats, they were piled in "water house" upon a stratum of brush, shavings, etc. After remaining in this condition a week or more, to allow the superfluous moisture to drain off, they were transferred to the flakes, where, with careful tending, they were cured and thoroughly dried for market, foreign or domestic. 
For shipment to the West Indies, the Spanish main and other foreign ports, the fish were packed, under a powerful screw pressure, in large casks, made for the purpose, known as fish hogsheads. There were times after the close of our Revolution, and while Europe was involved in Napoleon's wars, that fish found a ready market and a high price on the continent. They were in great demand for army supplies.. I have heard of fish being sold there at such times, for a French crown (\$1.Io) apiece.

The fishing vessels were sometimes employed in Winter voyages to foreign ports, carrying the proceeds of their Summer's work, returning with cargoes of foreign produce and money. Many of the fishermen would ship for their Winter's voyage, and thus employ their time for the year round. I have heard Uncle Sam Day, a veteran hand-liner, tell of going to the Banks in the Spring and Summer, working awhile at shoemaking in the Fall, and going a "wige" to Bilboa in the Winter. It was thus, that in addition to their fishing experience, they became expert and able seamen, that could "hand, reef and steer" on board a man-of-war, with the same facility as they could haul a line over the rail. The sturdy fishermen of Gloucester, Beverly, Marblehead, and all along shore, have been well represented in our navy in the time of their country's need.

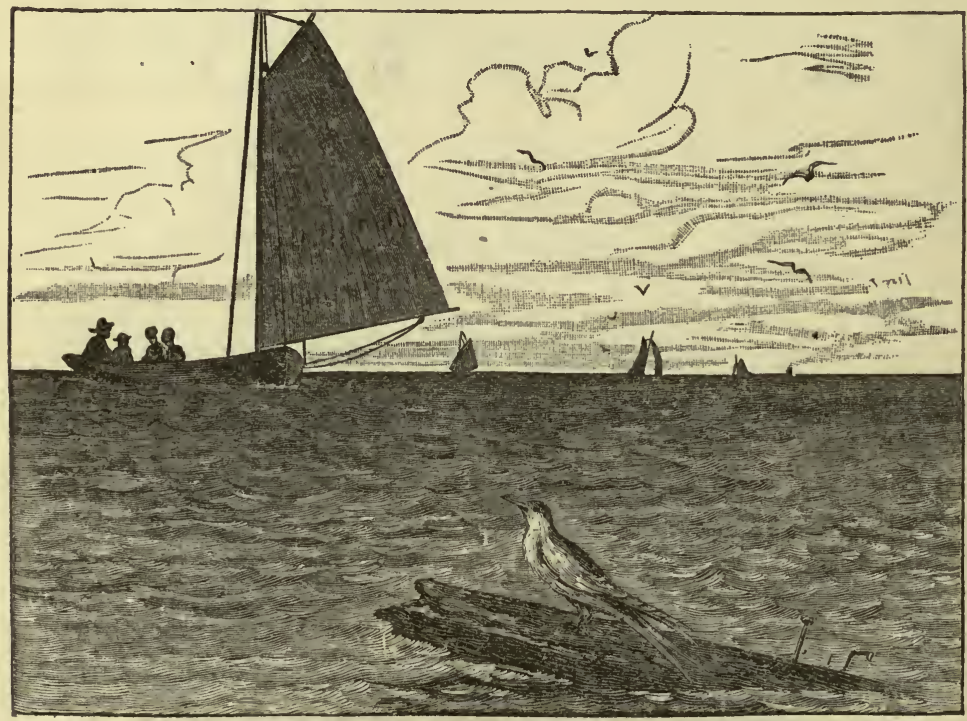




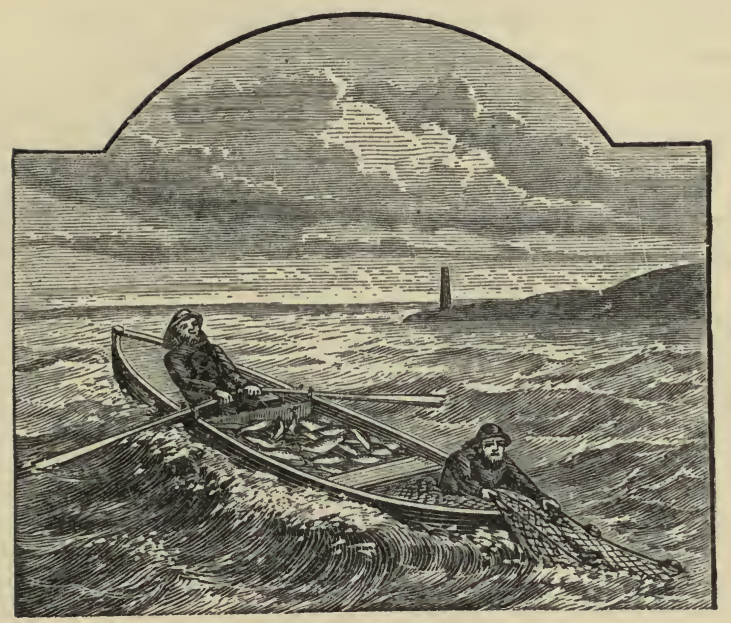

\section{Salmon Fishing at the Mouth of the Columbia River, Oregon.}

The season of the salmon fisheries of the Columbia river commences in April, and is over by the end of July. The fish are taken in tide-water by nets and traps, in immense quantities, as they ascend the river fresh from the ocean. They are cured fresh, in one and two pound cans, and cured by pickle in barrels and half-barrels. The Columbia salmon is very fat, and of peculiarly fine flavor. Salmon fishing is also carried on at the mouths of the Rogue, Umpqua, Coquille, and Nehalem rivers, where the catches, however, serve principally to supply the home consumption.

The salmon pack on the Pacific coast during the past season, I88r, has been the largest ever known. The following, from the San Francisco Journal of Commerce, are the particulars : Columbia River, 540,000 cases ; Sacramento River (Spring), 140,000 do.; Sacramento River (Fall), 40,000 do.; Fraser River, x 10,000 do.; miscellaneous-outside rivers, 30,000 do.; total, 860,000 cases. The total pack for the past four years has been as follows : r88 r, 860,000 cases; r880, 679,495 do.; r879, 539,600 do.; 1878,638,000 do. It is thus seen that $188 \mathrm{r}$ leaves all other years far in the shade, being nearly 27 per cent. higher than that of 1880 , the greatest previous year.

The first white men, as we learn from the "Astorian," who fished in the Columbia river to the extent of making a business of it, were Italians, who 
supplied the little market demand at Portland during the run, and salted down a few kegs for Winter use. In $1864 \mathrm{Mr}$. William Hume, a practical fisherman, started a cannery on the Sacramento river; California, and did a profitable business, but hearing that the Chinock or Columbia river salmon were of better quality than the fish of the Sacramento, came up in the Spring of 1866 to investigate. He at once secured a site at Eagle Cliff, on the Washington Territory side of the river, put up a small building, brought appliances and skilled men from his establishment on the Sacramento, and that season-1866-put up 4,000 cases of four dozen one-pound cans each. In this work he employed forty persons, ten of whom were fishermen. His success in catching and packing the fish, and his subsequent profitable sale of the pack, encouraged him and his partner (Mr. Hapgood, of California,) to double their facilities, and the next season they put up 8,000 cases. In I867 George W. Hume, who had been a sharer in the original venture, drew out and put up a cannery of his own, packing Io, 000 cases. The next year William Hume and Hapgood and George Hume continued in the business, and Capt. John West, of Westport, put up a cannery, the total pack of the three establishments being 28,000 cases. The next season R. D. Hume, brother of William and George, set up a cannery at Cathlamet, and from that year-r 869 -the business has grown rapidly until now, when salmon packing is the largest industry, save wheat growing, in the Northwest, when more salmon is put up on the Columbia river than in all other localities in the world.

The following table, showing the number of cases packed each year, the corresponding price of canned salmon, and the cost of fish on the river, will illustrate the progress and changes which sixteen years have made:

\begin{tabular}{|c|c|c|c|}
\hline Year. & Total Product. & Price. & Cost of \\
\hline 1866 & 4,000 & $\$ 16.00$ & $15 \mathrm{C}$ \\
\hline $1867^{\circ}$ & 18,000 & I 3.00 & I 5 \\
\hline 1868 & 28,000 & 12.00 & 20 \\
\hline 1869 & 100,000 & 10.00 & 20 \\
\hline $187^{\circ}$ & 150,000 & 9.00 & 20 \\
\hline $187 \mathrm{I}$ & 200,000 & $7 \cdot 50$ & $22 \frac{1}{2}$ \\
\hline 1872 & 250,000 & 8.00 & 25 \\
\hline 1873 & 250,000 & 7.00 & 25 \\
\hline 1874 & 350,000 & 6.50 & 25 \\
\hline 18.75 & 375,000 & 5.60 & 25 \\
\hline 1876 & $45^{\circ}, 000$ & $4 \cdot 5^{\circ}$ & 25 \\
\hline 1877 & 460,000 & 5.20 & 25 \\
\hline 1878 & 460,000 & 5.00 & 25 \\
\hline 1879 & 480,000 & 4.60 & 50 \\
\hline 188 & 530,000 & 4.80 & $5^{\circ}$ \\
\hline I 881 & 550,000 & 500 & 60 \\
\hline
\end{tabular}


Between Cape Disappointment and the Cascades there are thirty-five canning establishments and more than a dozen fishing stations. At each of these points there are houses of various kinds, canneries filled with expensive appliances, etc., etc. Ten steamboats and tugs, owned by the canners, run as tenders, and one large boat is run during the season by the O. R. \& $N$. Co., merely to carry fish. There are 1,400 fishing boats and nets on the river. The total value of all property engaged in the salmon business is above $\$ 2,000,000$, the largest individual interest being that of William Hume, $\$ 150,000$. Fishing boats cost $\$ 250$ each, and nets from $\$ 300$ to $\$ 400$ each. A boat will last ten years with ordinary usage. The boats are of Port Orford cedar and oak, with copper fastenings, and are made by builders at Astoria. Formerly all boats were made at San Francisco, but the Astoria merchants do better and cheaper work, and so have monopolized the business. More than fifty boats were built here this Summer. They are generally 24 feet long, 26 inches deep, and 6 feet 6 inches beam, sharp at both ends, narrowly decked on the ends and sides, furnished with centerboards, and can be rowed or sailed, as the winds serve. They are magnificent sea boats, run easily, and will carry about four tons.

The number of men directly employed in the fishing business during the busy season is about 7,500 , of whom 4,000 are Chinese. It is impossible to give exact figures, because the figures continually change, but these estimates are based upon careful inquiry, and are approximately correct. In the actual work of fishing about 2,500 white men were engaged from April I to August I-four months. Half of these are masters of boats and the other half assistants or pullers. Independent fishermen who own their boats and nets and sell their catch to the canneries, receive 60 or $62 \mathrm{r} / 2$ cents per fish. As a rule, however, the canneries own the outfits, for the use of which the fisherman gives one-third of his catch, receiving only 40 cents per fish from the cannery. Each fisherman employs and makes terms with his own boat puller, the usual rate for this service being a share in the catch, about the equivalent of $\$ 70$ per month. One hundred dollars per month, after charges for boat and net and pay of boat puller are deducted, is considered only a fair return to the fisherman, and the average is rather above than below this estimate. Only white men engage in fishing, the greater proportion, however, being Italians, Fins, and other foreigners, men without families, who come to the river from San Francisco only during the fishing season.

In the canneries all the responsible places are filled by white men, whose pay ranges from $\$ 50$ to $\$ 150$ per month, the average being about $\$ 65$. About one thousand men are so employed. The greater part of the inside work is done by Chinamen, whose average pay is \$I per day and board. Four thousand are employed on the river. 


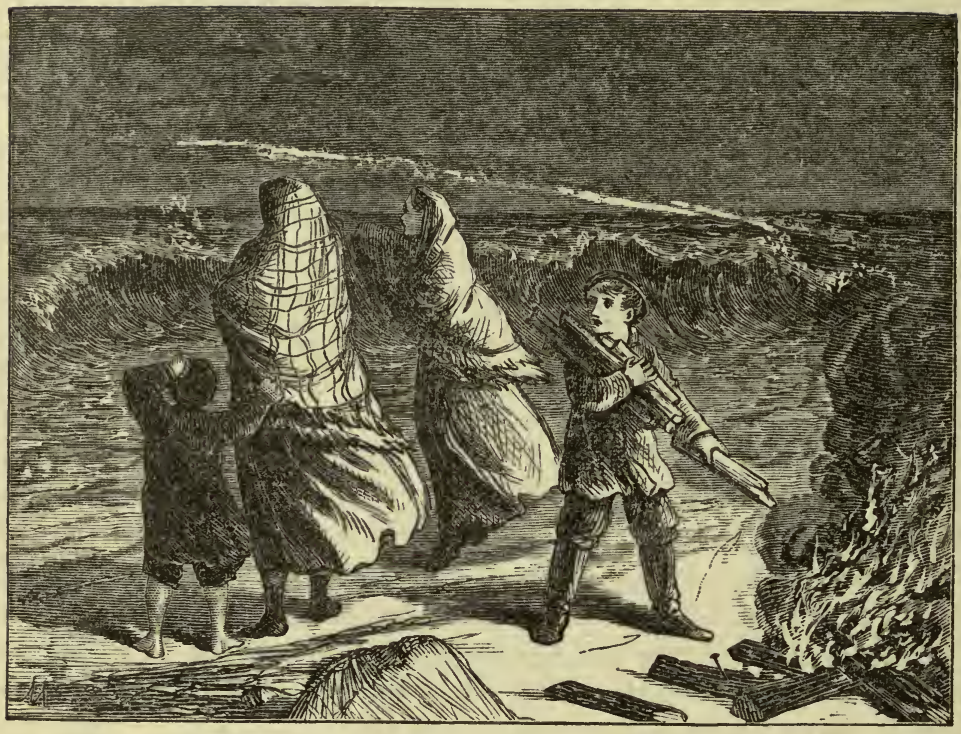

\section{On the Beach in a Storm,}

Is a suggestive picture, well calculated to awaken the sympathies. The women are the wives of fishermen, who are off on the waste of waters, seeking to make the harbor in the violence of the Summer gale. Night is fast settling down over the scene, and amid the gathering darkness the women, with hearts full of dread apprehensions, watch the little boats as they breast the waves, far out on the seething waters, ever and anon encouraging the active little fellow, who appears with his arms full of wood, to pile it on, and thus keep the fire burning brightly, as a beacon light, to guide their loved ones to safety when the night shuts down. They heed not the piercing winds, not the fury of the blasts - their hearts are out there with loved ones, and their prayer is that they may safely reach the harbor. Then, and then only, can they feel at rest. 


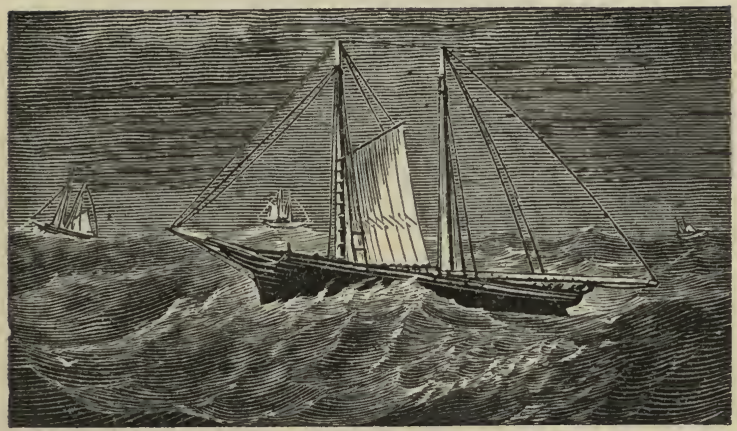

\section{Narrow Escape from Foundering.}

Sch. David A. Story, Capt. Joseph Ryan, left Gloucester, Nov. 12, I880, with a favoring breeze, and had a magnificent run, making the passage to Grand Menan, a distance of two hundred and twenty-five miles, in the remarkably short time of eighteen hours. After procuring a supply of bait she proceeded to Halifax, where she arrived on Sunday evening, and taking a supply of ice on board the next day, put to sea again on Tuesday evening, and arrived on St. Peter's Bank on Friday, the r 9 th. On Saturday one set of the trawls was made, the only set during the trip, and finding no fish, the vessel was got underway and moved farther to the eastward. No other opportunity was presented to fish, as it was blowing heavily all the while, and Monday, the $22 \mathrm{~d}$, at about four o'clock in the afternoon, the schooner then having about three hundred fathoms of nine-inch cable out in ninety-five fathoms of water, she struck adrift. She was given another hundred fathoms of cable, which failed to bring her up, the northwest wind blowing so furiously, and the tide running so strong, that she floated her cable and anchor and drifted before the wind and tide. The signal lights could not be kept burning a great while at a time in such a gale, but everything was made as snug as possible, and leaving the regular watch of two men on deck, the rest of the crew retired, six being quartered in the cabin and six in the forecastle.

About half-past two o'clock on the morning of Tuesday, the $23 \mathrm{~d}$, finding that the cable needed parceling, one of the watch went below to call the captain, leaving only one man, Lyman Murray, on deck. Just at this time the vessel was struck by a tremendous sea, knocking her down, with her masts level in the water. Murray saw the sea coming, and running to the 
leeward of the foremast, clung to the iron around the stovepipe, which was attached to the deck, where he was found insensible when the rest of the crew were able to get on deck, with his leg broken, and splinters of the shattered spars driven through his boot and into the leg. The house and forecastle companion-ways were stove, and a flood of water pouring into the cabin and forecastle prevented the egress of the men who were imprisoned there. One man succeeded in getting out of the cabin and walked along on the side of the house, holding on to the weather rail. Fortunately, in about a minute and a half the vessel wore round and righted, and the rest of the crew were released from their duress, when a scene of desolation met their gaze.

In capsizing, the cable had parted, involving the loss of four hundred and fifteen fathoms thereof, with an anchor; the fore-boom was broken into two pieces, and the fore-gaff into three, a piece of the latter being found forward of the foremast, and another portion across the bowsprit; the signal light was in pieces at the foremast head; the saddle and all the apparatus around the mast was destroyed; the foresail was badly split and the riding-sail blown away; the schooner's six dories were washed away or smashed to pieces on the deck; and the gurry-pens and everything movable on deck was destroyed. Below, the fires and lights were extinguished by the water, all the open stores and cooking gear were destroyecl, and the bedding and clothing of the crew completely soaked. As soon as possible steps were taken to clear away the wreck, two of the men setting their wounded companion's leg while the others were clearing the deck. An attempt was made to lay her to, which was ineffectual, as they could not balance-reef the mainsail, and she was run before the wind for about four hours. While thus running she was boarded by another, though smaller, sea, and Capt. Ryan had a narrow escape from being washed overboard, saving himself by clinging to a reef-point in the foresail. The weather was very severe, and with no opportunity to dry their clothes, the crew had a hard time of it for the ensuing week, while endeavoring to make a port. They arrived at Canso at noon on Wednesday, Dec. Ist, where they landed their injured shipmate, and after making a few necessary repairs proceeded to Halifax, and thence home.

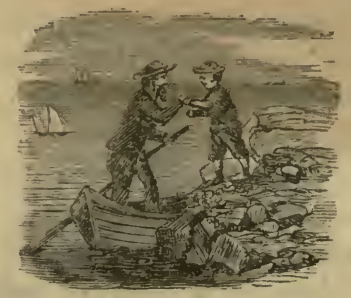




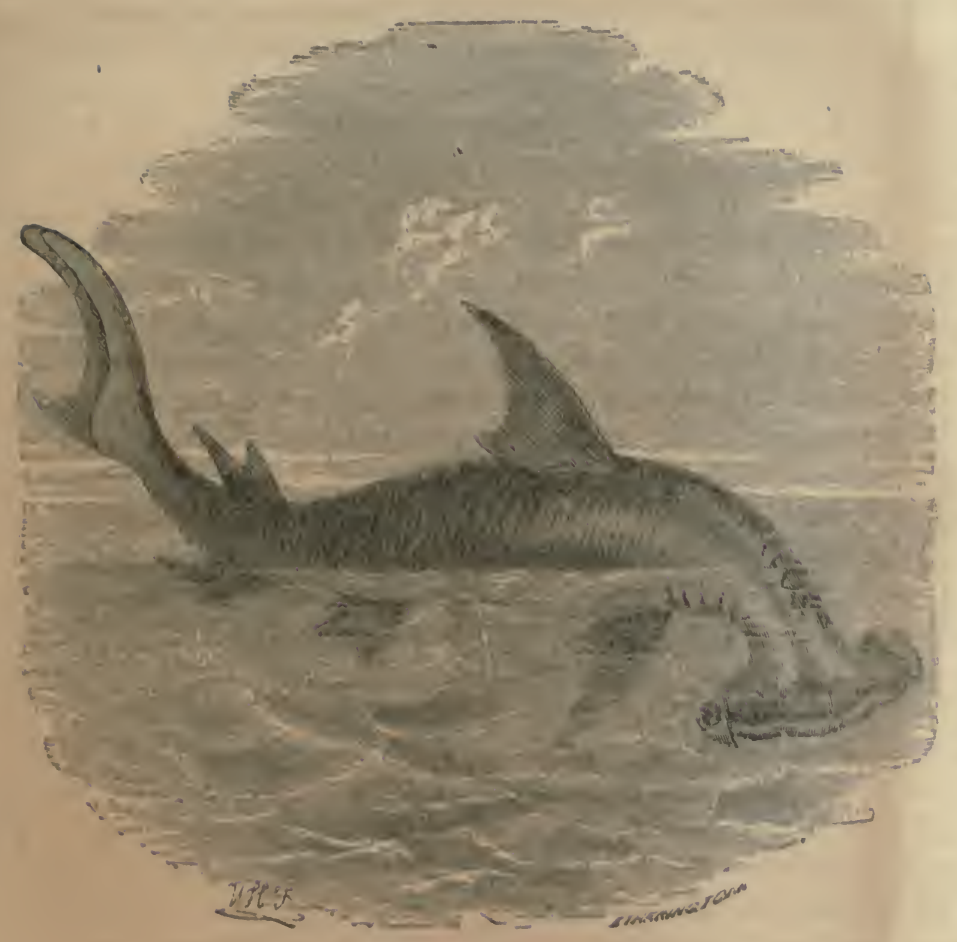

\section{Hammerhead Shark-The Shark's Mouth-Shark Fishing.}

The above engraving illustrates a species of shark of the genus Zygrona. The head is flat with the orbits extending laterally in a most extraordinary manner, flexible and doubled on themselves in the foetus, but standing out at right angles and to a greater distance as age advances. On the end of these lateral processes are the large eyes. Appleton's Encycloperlia states that "this strange form of head is found in no other vertebrate, and only in some dipterous insects (diopsis, $\mathcal{S}_{\mathrm{r}}$ ), and in many decapod crustaceans whose eyes are at the end of long pedicels. The snout is truncated so that the hearl resembles a clouble hammer; the nostrils are on the front border and have a small nasal flap; the teeth are alike above and below, compressed pyramids, sometimes with serrated external basal ridge and a mesial tooth in both jaws, tail pits distinct. It attains a length of twelve feet or more, and is grayish above, with head nearly black, and whitish below ; the iris is yellow; the first dorsal is high, triangular, falcate, and toward the upper part of the back, the second smaller and near the tail. It is found in 
the Mediterranean and in the warm seas of most parts of the globe, especially of the East Indies, and generally in deep water. The common species of America, between Massachusetts and Brazil, once considered the $Z$. malleus, has been described by Dr. Storer as the $Z$. arcuata; it attains a length of eleven or twelve feet, and is much dreaded by fishermen."

The shark's mouth is one of the most formidable means of destruction we know of among animals anywhere. It is on the under side of the head, some distance back of the end of the snout, and crescent-shaped. The teeth are in three to seven close, crescentric, parallel rows, the largest and oldest ones in front, the smaller ones behind-that is, further inside the mouth. Some sharks have more than two hundred of these teeth. They are three-cornered, exceedingly thin and sharp-pointed, and in some cases have saw-edges. When the mouth is wide open they stand erect, almost protrude from the lip, but when it is closed they lie down flat, out of the way. When those in the front row wear out or break off, the next row behind is gradually pushed forward to take their place. The shark thus has reserves of teeth which, operated by the tough and exceedingly muscular mechanism of the jaws, are able to bite through anything, especially since the bite is nearly always accompanied by a rolling or wrenching movement, which causes the teeth to act like a saw, and thus cut through the quicker. For some of the sharks in the South seas it would only be a moderate mouthful to take half a man's body in, and clip him off at the waist. Nevertheless, we believe fewer persons have lost their lives by sharks than we generally suppose, though many narrow escapes are constantly happening.

A veteran New York fisherman says : "Shark fishing pays, and it's great fun for a green hand. The business is carried on principally for the oil and fins. A big place for them is the White Sea, and again in Iceland. The sharks they get there are from thirty to fifty feet long. Sometimes they run in around the Grand Bank and are caught. About four barrels of oil is the average from a good-sized fellow. My shark fishing was all done near New Smyrna, Florida. Some sharks would give half a barrel of oil, but they were generally under fifteen feet. We usually hired from fifteen to twenty darkies to do the pulling and hauling, and camped out during the months of July, August and September, moving up and down whenever the biting was poor. We carried our pots and things along and tried out the livers, and shipped the oil by a smack up to Fernandina, where it was all bought by one man. I don't know what he did with it. Some said he sold it for cod liver oil. We used a regular hook and line, only it was a rope, and the hook was a foot long, and made fast to the line by a three-foot chain. Fish bait was the best. We kept about twenty of these lines over all the time at regular intervals along wherever the water deepened quick from the shore. All the lines were about fifty yards long. Sometimes they fool over 
the bait, but generally a big shark will nose it once or twice, and then suck it up and move off, swallowing the bait as he goes. You want to give him about fifteen feet of rope, and when he hauls the line taut all jerk together. Then the work commences-fun some people call it. As soon as he feels the hook he makes a big rush that will often start ten or fifteen men, and I've seen five jerked right into the water on the start. Up and down he goes, sometimes jumping into the air and trying to shake out the hook, and some old fellows will swim right for you and try to bite the line. In India they catch the sharks for their fins and send them to China, where they make them into soup."

In an interesting article on shark fishing, in Frank Leslie's Illustrated Newspaper, we learn that the "capacity of some of these sea-wonders is enormous. The writer caught one at Tortugas, Fla., that weighed about 900 pounds. It was a white shark, and for a long time had lived around the slaughter-house located on the edge of the channel. It took about twenty men to get him in ultimately. In the stomach was found the skull and horns of a steer that had been thrown over the day before, three hoofs, besides a heterogeneous mass of old rope, seaweed, and two or three old tin cans that perhaps retained some of the meats that had been packed in them. The jaw was saved. It had eight rows of serrated teeth, and fitted over a man's body easily. It is now in the Museum of Natural History, Central Park. The fossil sharks of the tertiary period grew to an enormous length, exceeding $\times 50$ feet. At Charleston, S. C., their teeth are found buried in vast quantities, some measuring seven inches in length. A horse and cart could easily have driven into the mouths of these monsters, that were fitting representatives of the age of expansion in which they lived.

\section{NO MORE SEA.}

BY S. G. D.

We wandered hand in hand that day, Beside the calm, blue sea,

The smiling, sunlit sea;

The waters murmured at our feet, The world was fair, and life was sweet, The hours sped by on pinions fleet,He told his love for me!

Alone I walk the shore to-night, Beside the stormy sea, The wildly tossing sea;

The watery waste is one vast grave;
O sweeping surf! O moaning wave! What far-off, dreary, sunless eave Keeps back my love from me?

The tides come in, the tides go out,But nevermore the sea, The restless, fickle sea, Brings back my love. Yet, hand in hand, I know my love and I shall stand, Some blissful day in that fair land, Where there is no more sea! 


\section{Fishermen's Superstitions.}

BY J. W. COLLINS.

That there is more or less superstitious feeling in all seamen, from the humblest fisher boy to the rear admiral, is apparent to every one who has had an opportunity to observe the peculiarities of seafaring men. The fact that seamen, and especially fishermen, seem to be more dependent on "luck" than almost any other class of men, and that they are constantly meeting with events calculated to excite superstitious feelings in the credulous, is, without doubt, the cause of their believing in omens, signs, etc., to a certain extent.

But, are fishermen much more superstitious than other people among whom they mingle when on shore, or even, to go farther than that, some who move in the "highest circles?"

Most writers on the fisheries have discussed the credulity of the fishermen, and, no doubt, many people have come to-think that in this respect they differ from the majority of mankind. Perley,* writing of the fisherman of the Bay of Fundy, says: "He will undertake nothing of consequence upon a Friday, and can prove by a hundred incidents how infallible are the signs and omens which he believes in. He thinks to die in his bed. True it is that he has been overset; that his boat, loaded with fish to the 'gunnel,' has sunk under him, and that a vessel has run over him; but he is still alive and was not born to be drowned." * * "He believes in witches and dreams."

Granting that fishermen are credulous, it by no means follows that they are peculiar in this respect; or that they are the only ones who believe that "coming events cast their shadows before." The thrifty New England housewife looks with unspeakable dread on a broken looking-glass, predicting "seven years' hard luck;" expects a stranger when she drops her dishcloth on the floor; tells her daughter, if the latter upsets a chair accidentally, "You won't get married this year ;" and so on, ad infinitum.

An excellent authority, Sabine, $\dagger$ writing of the American fisherman, says : "It is said that he is credulous and superstitious. Admit that 'Kidd's money' has been dug for in every dark nook of the coast, or talked about in every cuddy, for a century and a half, and that horseshoes are nailed upon the masts of fishing vessels to keep off witches; what then? Is he the

*M. H. Perley. " "Report on the Fisheries of New Brunswick," 1851.

†Lorenzo Sabine. "Report on Fisheries of the American Seas," 1853, p. 383. 
o:lly one who has been or still is, guilty of the same follies?" He adds, in a foot note: "In 1825 the Duchess de Berri visited a watering place in France, and indulged in sea bathing. Sea water and fish which were afterwards taken from the spot were articles of immense value, and sold at enormous prices. Indeed, those persons who could not purchase a whole fish gladly possessed themselves of a few scales or a fin! The water where the 'royal person' had been washed, when bottled, and offered for sale, was known as "Berri wine." Well may Sabine ask, "Have fishermen in any age been guilty of greater folly than these fashionable people of France?"

Among the New England fishermen the superstitious belief in the various signs and omens that will be spoken of farther on, is by no means universal. On the contrary, many of the most intelligent pay little attention to what they call "old women's yarns." Among the superstitions of the New England fishermen may be mentioned the following:

First-A belief in lucky and unlucky sailing days. Almost from time immemorial Friday has been considered an ill-omened day upon which to begin a voyage. Nor has this belief been confined to fishermen alone, but has been shared in common by all seamen. At present, little regard is paid what are called unlucky sailing days by the Gloucester fishermen. This is no doubt due, in a degree at least, to the sharp competition that has sprung up among the fishermen, and it is not an unusual sight, when a fine Friday comes after a period of bad weather, to see a large fleet spread their snowy canvas and sail away for the fishing grounds.

That the beginning of a voyage on Friday has been followed by both good and ill results in an equally great number of cases might easily be shown. I can relate two opposite instances out of my own experience, as, doubtless, could many others.

In the Spring of 1864 I started on a codfishing trip to Cashes, sailing on Friday. This trip, though not disastrous, was an eventful one, and did not prove so successful as circumstances had led us to expect. On one occasion during the trip, having to take the place in a dory of one of the crew who was sick, I went astray in the fog, and was out several hours-the only occurrence of that kind that ever happened to me. Another day the vessel caught fire in the forecastle, during the cook's absence, and while the rest of us were busy dressing fish. The first knowledge we had of it was the bursting of flames out of the forward companion-way. The fire had made such progress that we succeeded in subduing it only with the greatest difficulty and at considerable personal risk. One night, the man on watch, in trying to change the "net-swing," to which was attached a gang of herring nets, lost his hold of the rope, and away went the whole lot, drifting off with the tide. Prompt action on our part saved the nets, though it was not looked upon as a particularly lucky incident to have to turn out at midnight and 
start off, half naked, to search for the drifting property. But, to crown all, a big school of dogfish struck on the fishing ground and drove all other kinds of fish away, rendering useless all further attempts to complete our trip. As might have been expected, the more credulous ascribed these unfortunate incidents to having sailed on Friday.

On another occasion I began my year's work upon a Friday early in January, and it so happened that we left home on the same "unlucky" day every trip but one during the whole year. As we were successful in all instances, our crew came to think that Friday was a lucky sailing day.

Second-A belief in "Jonahs." A Jonah may be something animate or inanimate, or even the result of the actions or accidents of persons ; in fact, almost everything that is supposed to bring ill luck is called a Jonah. Thus, a vessel known to be unfortunate is said to be a Jonah; it is often difficult to obtain a crew of good men for her, if men are scarce, although she may be well adapted for the business in which she is engaged. Equal trouble is also sometimes experienced by expert fishermen in securing a berth on board of a fishing vessel, because they possess the unenviable reputation of being a Jonah. Of this I will speak further on.

As to the vessels, it occasionally happens, curiously enough, that some of them meet with ill fortune for several years in succession, and under such circumstances that, to believers, the evidence of their being Jonahs is as strong as "proofs of Holy Writ."

I recall a singular circumstance of this kind, with the particulars of which I was familiar at the time they occurred. Several years ago a new vessel was brought to Gloucester from the port where she was built. She was of the largest class employed in the fisheries-a beauty in model and rigand the skipper, who was a young man, and part owner, naturally felt a commendable pride in the fine schooner which he commanded. One day, however, while this vessel was being fitted for her first trip, an acquaintance of the captain said to him, "I'm sorry you have had that vessel built." When asked for his reasons, he continued, "I have known the man who built her to launch more than twenty schooners during the past few years, and none of them ever made a dollar for their owners, while few of them have lived more than two or three years, being either wrecked on the shore or foundered at sea." Strange to say, that, for the nineteen months the first skipper sailed in her, "there was nae luck aboot the house." This was exceedingly trying to one who had previously been fortunate and who felt a pride in his profession. Finally, becoming disgusted and somewhat disheartened by his ill success and unrequited labors, he sold out his share of the vessel and left her, almost convinced that what had been told him by his friend was not very far from the truth.

The sad sequel remains to be told. The schooner-not yet two years 
old-was lost at sea on her next voyage. The captain and two of the crew were drowned, and the survivors, after enduring much suffering while lashed to the wreck, were finally taken off and returned home to tell the particulars of this ill-fated episode.

From the day she first sailed out of Gloucester harbor-looking like a yacht, with a crowd of canvas spread to the breeze-to the time she lay a helpless and dismantled wreck on the bosom of the storm-swept Atlantic, she was continually meeting with ill fortune.

Quite as strange tales, nay, even more marvellous ones, could be related of the good or ill fortune of individuals, and the varying experiences of different persons often form the topic of conversation on board the fishing vessels.

Thank goodness, the superstitious belief in men being Jonahs often meets with a rebuff so severe as to hinder it from becoming anything like a general one! I was present once when one skipper enquired of another-nodding his head at the same time in the direction of a man who was at work on the vessel- "Are you going to carry that man?" Receiving an affirmative reply, he continued, "You won't get any fish then; he's a regular Jonah." The reply was, "Jonah, or no Jonah, he goes this trip anyway." As the trip in question was a successful one, nothing more was heard about the man being a Jonah, though, to tell the truth, he had been so considered by many of his associates.

Another similar instance may be mentioned. A young man who has sailed from Gloucester several years, had, for a while, rather hard fortune, and it was whispered that he was one of the much-to-be-shunned Jonahs. Nothing else could be said against him, since he was an excellent fisherman, daring, energetic, and, withal, a pleasant shipmate. "But, he is a Jonah!" the credulous exclaimed, whenever the vessel he sailed in failed to make a good trip. His luck changed, however, after a time, and thereafter those who previously had felt much opposed to being shipmates with him were glad to sail in the same vessel that he did. Meeting with him, not long ago, I was pleased to learn that he was enjoying better fortune than formerly. In reply to my enquiries as to his present success, he said: "Wherever I have been this year I have been lucky. It don't make any difference now what vessel I go in, I always get a good trip-the fish are sure to be there." One can readily imagine how gratifying such a change must be to a person who previously had met with undeserved ill-fortune.

But it often happens that some poor fellow has a "streak" of hard luck really astonishing, so much so, indeed, that it is not wonderful that, after a while, his acquaintances come to have superstitious feelings about him. It matters not how much he may change from vessel to vessel, his luck follows him, and, the strangest of all is that the vessels which are unfortunate while 
he is in them, meet with excellent success at other times. All old fishermen can tell such incidents. I knew a circumstance of this kind that occurred a few years ago:

A young man, engaged in the haddock fishery, secured a berth with one of the smartest skippers who sails from Gloucester. But, notwithstanding the fact that every possible effort was put forth, poor results followed, and the months of November and December wore away, the crew in the meantime not sharing more than $\$ 25$ to a man. Everybody felt discouraged. At this time, however, the young man of whom I am speaking, and who, it was said, was one of the unlucky ones, left the vessel and shipped in another. On the next trip the vessel he had left shared $\$ 20$ from only two days' fishing, and on succeeding trips did even better than that, making an excellent Winter's work. But the second vessel in which the man shipped (though commanded by one of the most expert skippers) failed to get a share of fish after he joined her, and the same result was met with by this unfortunate individual in a third vessel which he joined during the Winter. The mysterious part of it was that in each of the three cases the vessels which met with poor success while he was in them did much better than an average during the rest of the season. What wonder is there that, in the light of such experiences, fishermen are inclined to be somewhat superstitious?

Some fishermen believe that a valise, when carried on board a vessel, is a Jonah. Probably this belief is largely due to the prejudice felt against carrying such an-unseamanlike article on a fishing trip.

Opinions differ as to whether certain other things are Jonahs or not. Among those believed to be such by a few persons may be mentioned violins, checker-boards, toy-boats, a bucket sitting on deck partly full of water, soaking mackerel in a bucket, etc., etc.

The accidents and actions of members of the crew that are supposed to bring ill success, or to be forerunners of such, are, dropping a hatch in the hold, turning a hatch bottom up, breaking a looking-glass, driving nails on Sunday, ${ }^{*}$ and letting the splices of a cable stop in the hawse-pipe when the vessel is anchoring on the fishing ground.

As to other beliefs, it may be said that all fishermen whistle for a breeze when it is calm, and some occasionally stick a knife in the after side of the mainmast to bring a fair wind. A bee, or a small land bird coming on board, it is supposed, will bring good luck, while ill fortune will follow the lighting of a hawk, owl, or crow on the rigging of a vessel. It is believed that a smart blow on the head of a fish that has just been separated from the body, will kill the latter which still retains muscular motion. A hook, which has

* Some of the skippers make a practice of driving nails on Sunday if they have need to do so. This is, perhaps, done as much to antagonize the belief in its being unlucky as for any thing else. 
been stuck in the hand, is immediately thrust into a piece of pine so that the wound will not be sore. Just how and why the blow on the fish's head should have any effect on the body from which it has been previously torn, and why sticking the point of a hook into a piece of wood should make any difference in the healing of a wound, are subjects for the curiously inclined to investigate. It is, perhaps, hardly necessary to mention the belief in horseshoes warding off witches, etc., as among the superstitions peculiar to fishermen, since the belief in the efficacy of these objects to prevent ill fortune is now seemingly recognized in the highest society, if one is allowed to judge by the gilded horseshoes conspicuously displayed in the parlors of the fashionable.

"The earth has bubbles, as the water has; and these are of them."-Shakespeare.

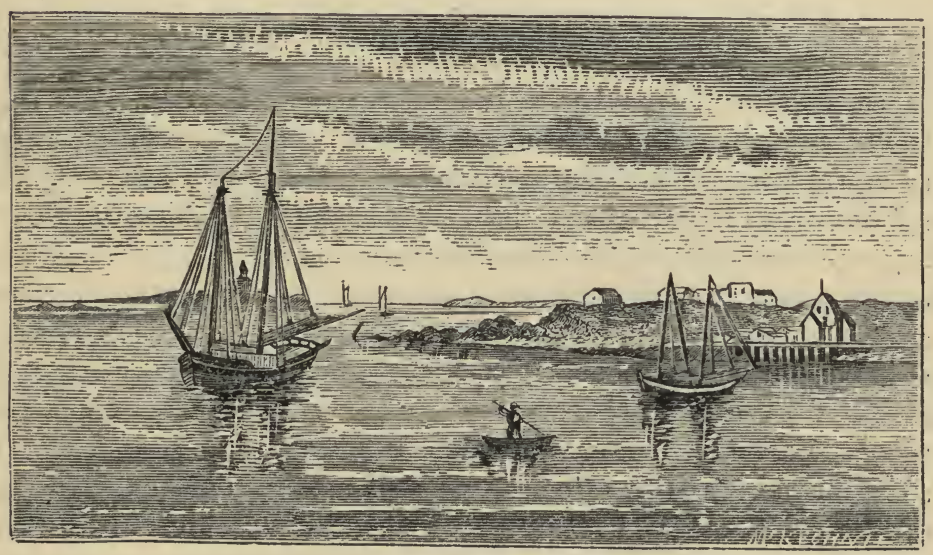

The above engraving gives a capital view of the old Fort and Gloucester Harbor in 1837. The Grand Banker and pinkey lying at anchor look as. natural as can be. There is a vast difference in the appearance of the old Fort property of to day from that of forty-five years agone. Then it had but one building besides the ruins of the Fort-now it is covered with dwellings and storehouses, and its entire water front converted into fine wharves, forming one of the most valuable pieces of property in the city. 


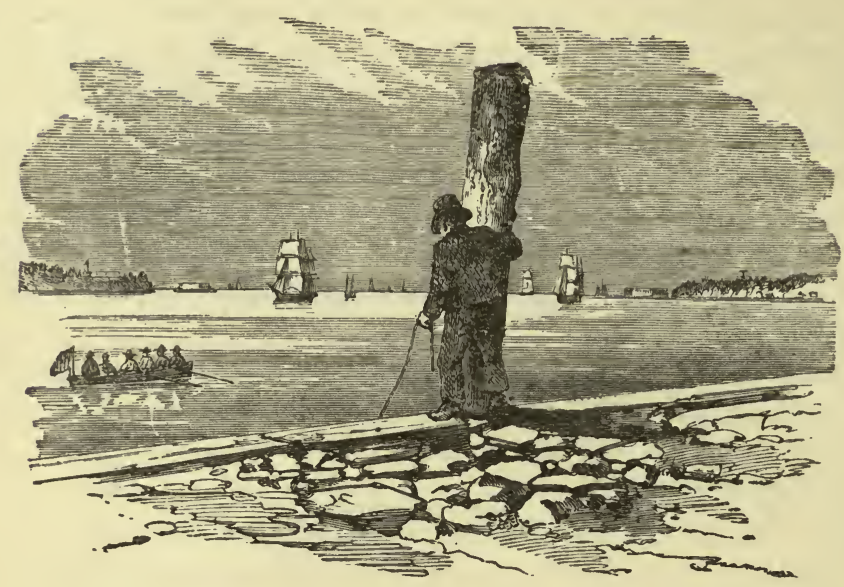

Foreign Commerce of Gloucester.

Gloucester, after Boston, has more foreign arrivals than any other seaport in Massachusetts! While Salem and Newburyport have hardly a squarerigged vessel arrive in their harbors for a year, Gloucester has sometimes a fleet of five or six in port at one time. Through the kindness of Collector Babson we are enabled to give the following statistics :

For the year ending Dec. 31, I881, there arrived at the port of Gloucester, I ship, 18 barks, 2 brigs, and 182 schooners from foreign ports. 27 ships, barks, brigs and schooners arrived from Cadiz, Trapani and other salt ports. Gloucester has become almost the headquarters for the salt trade of the fisheries. 126 cargoes of lumber, fish, wood and potatoes were received at this port last year from Newfoundland, Nova Scotia, New Brunswick and other countries. About $\$ 200,000$ worth of merchandise was imparted, at the foreign valuation, worth here at least $\$ 400,000$. By these figures it will be seen that besides its great fishing interests, and its being the great centre of fish distribution for the United States, Gloucester has quite a respectable foreign commerce. Gloucester owns 10,000 tons more shipping than Salem, Marblehead, Beverly and Newburyport combined. But while Gloucester has 473 vessels, not one square-rigged vessel is owned here, while in 1828 , fifty-four years ago, Gloucester had 29 foreign arrivals, and collected duties on goods to the amount of $\$ 127,000$, with one-quarter part of its present tonnage. 


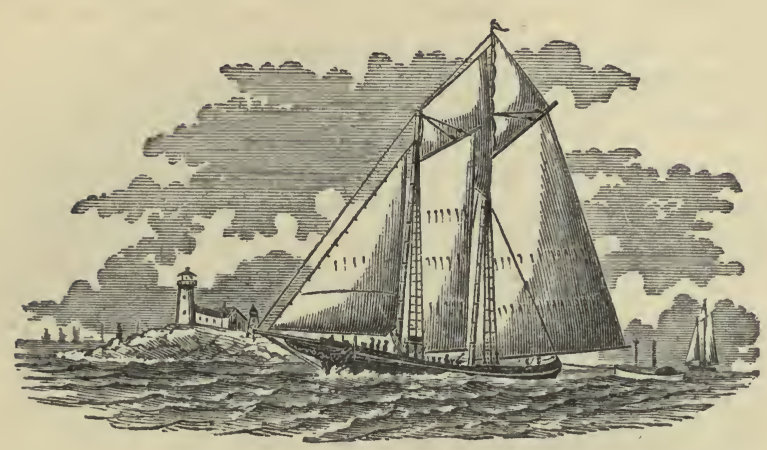

\section{Fishermen Coming into Port.}

From the Home of the Fish to the Table of the Consumer.

It is a lively scene, down at some of our wharves in the breezy days of midwinter, to witness one or more of the Bankers or Georgesmen round the Point and come gayly up the harbor. Sometimes they are minus a spar or sail and are all battered or iced up, the crew having had a hard time freeing the bows and rigging from the frozen spray, which in a bitter cold day hardens as soon as it strikes, and piles itself up on the overburdened craft with amazing quickness. Then the safety of the vessel and her management through the cold, seething waters, render it an imperative necessity that the ice be dislodged, and a cold, cheerless task it is which the fisherman has forced upon him. Short spells of this ice pounding, with the thermometer below zero, is all that men can endure, and they are frequently relieved, all hands taking their turn and making the best of an unwelcome duty. But snug in the harbor, anchor down, sails furled, pipes lighted, with the catch sold, the crew have a little resting spell. Then the vessel is hauled alongside the wharf of some of the fresh fish buyers, the hatches opened, and out from the depths below are hoisted the mammoth halibut, direct from the ice house, where they are kept as sweet and fresh as when first caught. Up they come in pairs, and sometimes in triplets, according to their size, and oftentimes a monster weighing two hundred pounds and upwards will show his nose above deck and be slowly landed on the wharf. . Visions of nice fried or baked halibut tickle the palate, as the fish are thus landed. After their heads are taken off and the fish thoroughly cleansed and packed in boxes, the last thing done, ere they are nailed up, is to fill their napes with crushed ice, which insures their preservation, and off they are shipped by rail 
or steamer to Boston, New York, Philadelphia, Lowell and other large cities, where they find ready sales. The codfish are discharged mostly at the wharves of the vessel owners, where they are decapitated and then salted in butts, and when sufficiently salt are transferred to the flakes for a given time and dried. Then they find their way, the most of them, in these days, to the skinning lofts, where nimble fingers divest them of skin and bones, and the solid pieces of fish, handsome as can be, are packed in boxes from ten to two hundred pounds each, which find their way from the warehouses of our enterprising fish producers to all sections of this country. The trade is simply immense, and constantly on the increase, for the praise of the Gloucester boneless cod is abroad in the land, and dealers and consumers demand it from headquarters, direct from first hands.

Who would have thought, from the small beginning in the putting up of boneless codfish, of only a few years since, that such large results would follow? And now that fish is packed in such clean, attractive packages, the attention of consumers is drawn toward it. The old objection to stripping and cleaning, and purchasing so much waste, is heard no more. The clean fish ready for a salt fish dinner or fish balls, is now for sale by all first-class grocers in the country, and the Gloucester brands, of which there are several hundred, each large purchaser having his private brands, are printed indelibly on the boxes. Some of these brands are very handsome and add much to the attractiveness of the packages.

The first man, Mr. George H. Smith, we think it was, who put up fish in this way, never dreamed that this act of his would revolutionize the entire fish trade, but so it has proved! The old fish dealers, conservative, as they had a right to be, saw not the cloud which was rising, but kept in the old channels of shipping whole fish, until their customers demanded of them the boneless fish in boxes. And then they gave way to the inevitable. There was no help for it. Either adopt the new mode or lose the business altogether. And they entered into the business with the same energy which characterized their other transactions, and we have to-day, here in old Gloucester, a business which is now only in its infancy, a business which will keep the fleet busy, which will take all the fish they can catch, at remunerative prices, a business which will keep Gloucester in the front as a fishing port and furnish occupation for her people.

It's lively all through, from the time the vessel leaves the harbor until she arrives on the ground, and from the catching of the fish to the dressing, then the salting and drying, boning and skinning, shipping, and finally the serving up of the toothsome dish on the table with drawn butter and egg sauce, or the good old fashioned pork scraps, with beets and potatoes. 


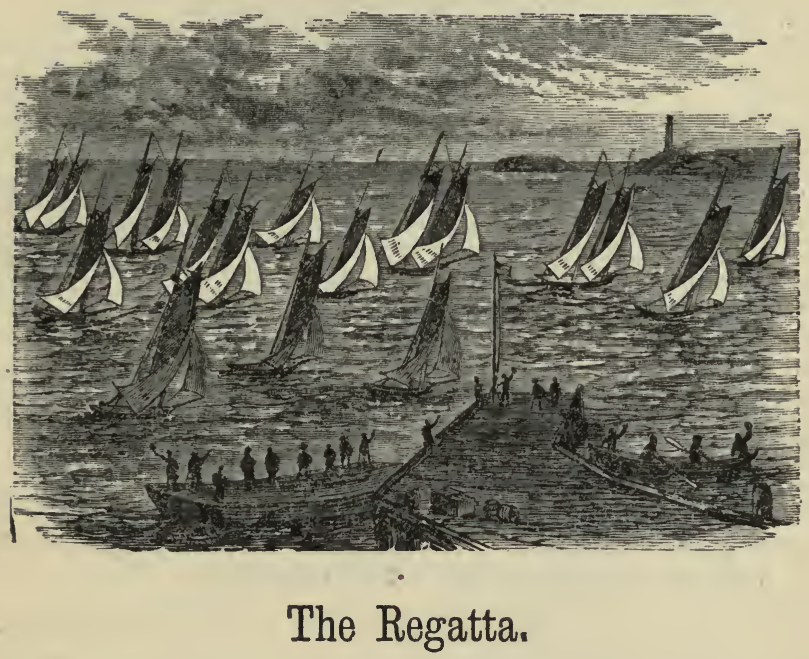

The above has the true salt water flavor, and causes the blood to course through the veins with quickened motion. The fleet of yachts are off for the race, sailing with a "start sheet," each one doing her best to lead. How they fly over the water, which is not very rough, although there seems to be a pretty decent breeze to waft them along.

It is, indeed, a pretty sight, and the yachtsman's life is replete with pleasure as he cruises along the coast during the Summer time, coming to anchor in the harbors and rivers, and participating in all the pleasures pertaining thereto. There is a deep love for it inherent in many hearts. To such the sea has attractions of which they never tire. Their enjoyment is to sail o'er the waters, free as the birds of the air; to inhale the sea breeze in all its freshness and health-giving powers; to join with others in the exciting regatta ; to crowd on sail and rush through the waters, doing their best to secure the prize and win a good name for their boat, which they love most intensely; and whose good points they strive so hard to bring out on such occasions.

"A wet sheet and a flowing sea, A wind that follows fast,

That fills the white and rustling sail, And bends the gallant mast." 


\section{A Night in Boston Bay.}

BY JACOB S. LORD.

"Yes! we had a rough night, you may believe, Uncle Moore;" Thus spoke a young fisherman, as he stepped on the shore;

"We ran off yesterday noon to set our trawl, Thinking to be home long ere nightfall; But the wind struck nor'west and did heavily blow, Accompanied with squalls of rain, sleet and snow. We three-reefed our mainsail, expecting a hard beat, From our jib took the bonnet, and trimmed down the sheet; We double-reefed the foresail and rolled it up snug, Well knowing jib and mainsail were all she could lug; The dories were lashed down, secure and compact, Then we gave her a good full, down helm and tacked. Though the sea was running heavy she did not misstay, And soon we were close hauled, standing up Boston Bay. It was fast growing eold, with the wind still increasing; But our twenty-ton boat was steadily forereaching; Quite fast made the ice from spray that she'd heave As through the turbulent waters her way she would cleave. The man at the wheel, and the lookout as well, Every half hour were given a spell;

For those who've beat up in a Winter's nor'west breeze Know full well how quickly the helmsman will freeze. So the night wore away till past four o'clock, When under the lee we made Half-Way Rock. The water now smooth, our position made clear, We gave her the foresail-off she went like a deer. For Norman's Woe Rock we now shaped our course, The wind being more westerly and lighter in force; In due season we heard the deep sullen roar Of the seas as they broke on the Magnolia shore; A few minutes later, as through the water we plough, The rock shows itself upon the port bow.

Our hearts were made light as out of danger we passed, At least for the present, and were near home at last. Passing Ten Pound Island, we shoot into the cove, And down goes the anchor of the W. H. Gove. Right proud are we of the staunch little boat, Which through so terrible a night kept us safely afloat. Let those who eat fish and growl at the price, Take a trip off shore, shovel snow and pound ice; One good shaking up in old Boston Bay, And they'll ne'er more find fault with fishermen's pay." 


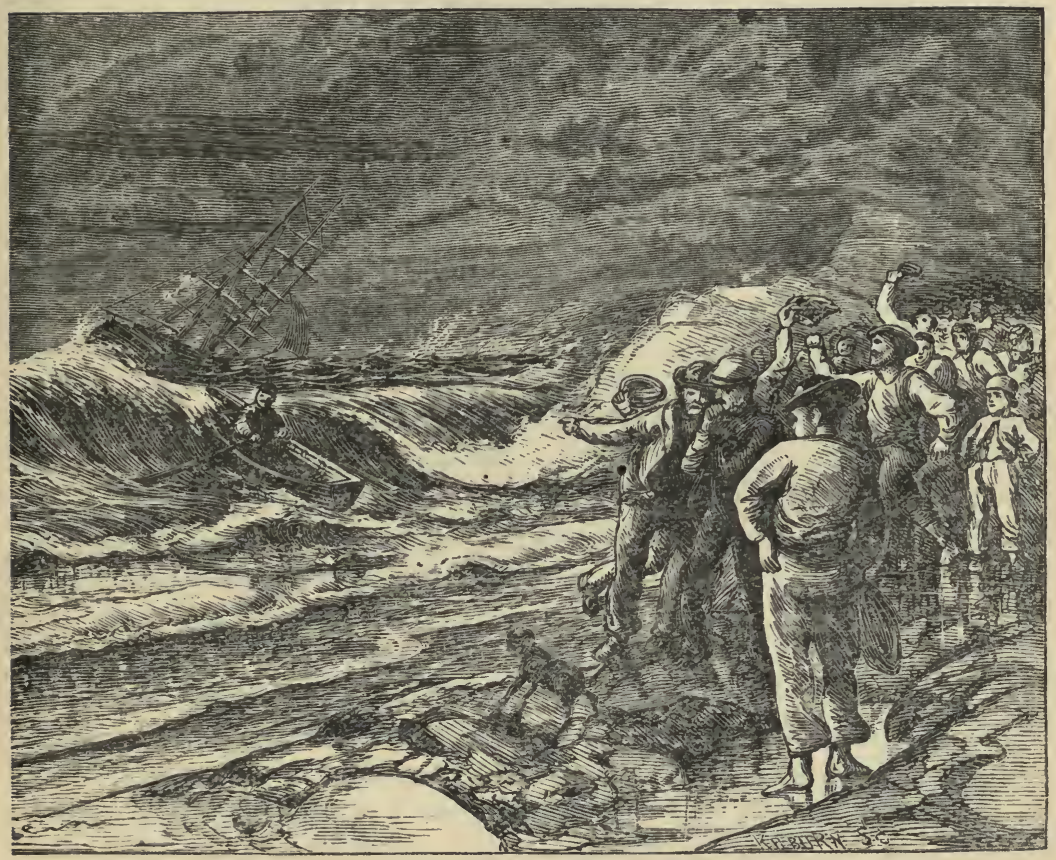

\section{Truthful and Startling Accounts}

Of Tough Times, Narrowe Escapes, Disasters, Plucky Doings, Thrilling Narratives, Perilous Positions, and Other Noteworthy Happenings to the Fishermen While in Pursuit of Their Calling.

Lost in the Fog.-Seven Days Adrift in a Dory on Grand Bank, without Food.-Two of the crew of sch. Marathon of this port, George M. Roberts of Yarmouth, N. S., and James Austin of Liverpool, N. S., left that vessel on Grand Bank, at half-past four on the afternoon of Oct. 7, 1874, to visit their trawls. Soon after, it commenced to breeze up and a thick fog shut in. A dory, in which were two of the crew, was paid out from the vessel to their assistance, but the warp proved too short, and the fog became so thick that they soon lost sight of each other. They could hear the shouts of their companions, but all efforts to reach them proved unavailing. It soon commenced raining, and the two men made up their minds to do the best they could through the night, in hopes to find their vessel in the morning. 
Fortunately there were three trawl tubs on board, and two of these were made fast to the painter of the dory, and did most excellent service as drogues, keeping her head to the sea. The night passed drearily, and they were glad enough when morning dawned; but the fog still continued to envelop them, and they concluded to row to the westward. It cleared up occasionally, but they saw no vessel, and night came on again. The next day was also foggy, and they laid to the drogue all day, drifting to the eastward. 'Took watch and watch this night, in hopes to catch a glimpse of some light from a passing vessel, but their hopes were disappointed. It rained during the night, and they were fortunate enough to catch a good supply of water in their remaining tub; of this they drank sparingly, and it served to appease the fearful pangs of thirst and hunger. On the third day they rowed to the northwest in hopes to get into the track of the steamers. The fog still continued, and no vessel was seen, and they passed another night in suspense. The men were by thị time getting discouraged, more especially Mr. Austin, who had contracted a severe cold the first night out, and was troubled with such severe shaking of his limbs that he could not sleep. The morning of the fourth day was clear, and it continued moderate through the day. This gave them courage, and although quite weak, they rowed to the westward, keeping an anxious lookout for some welcome sail, and doing their best to keep up each other's courage. A shark came alongside during the day, and they endeavored to catch him, as they would gladly have partaken of anything eatable, but were unsuccessful. When the sun went down that night, the poor fellows felt their hearts sink within them, and they thought their chances of being picked up were rather slim. Roberts was enabled to pass some of the weary hours in sleep, but this boon, for the most part, was denied his companion. The fifth day was foggy, and they rowed a couple of hours, but felt so used up that they gave up pulling, and another dreary night dragged its slow hours along. The sixth day they let the dory drift. Saw the sun once or twice, but no signs of any vessel; and the night shut down again, bringing sad forebodings. The seventh day was foggy, yet, strange to say, their courage again revived. They had drank sparingly of the water, and it seemed to satisfy the hungry feeling to a great extent, and rowing some three miles to the northward, they put the tubs out and let the dory drift.

Their longings to be rescued from that open boat can be imagined but not described. The sun went down for the eighth time, and still no signs of relief. They watched eagerly through the early evening hours, and knew full well they could not hold out a great while longer. They talked of their chances as men will talk when in the face of a common danger, and both were of opinion that they could not survive another twenty-four hours. They then lay down, and both men, in the silent depths of their hearts, 
prayed most fervently that they might be picked up before morning. Soon after, Roberts thought he heard the noise of a steamer, and raised his head above the side of the dory. Joy unspeakable! there were a steamer's lights not fifty yards distant. The dory had been seen from her deck, and the shouts of the men were soon answered. Roberts was enabled to get on board without help, but it required the assistance of two of the steamer's crew to get Austin on board. It proved to be the ocean steamer Greece, and the men were kindly cared for by her captain and officers, and by careful nursing were well nigh recovered upon her arrival in New York. Upon leaving the steamer the men were presented with twenty dollars each, a gift from her officers and passengers.

A very singular circumstance connected with this affair is, that at nine o'clock that evening the Captain of the steamer altered his course half a point to the northward. If he had not done so, he would have gone so far to the southward as not to have seen the dory, and in all probability the two men would have perished. A kind Providence had ordered it otherwise, their prayers were heard, and from the dangers which surrounded them they were returned to their friends.

Remarkable Circumstances.-In July, 1873, John Como, one of the crew of sch. Magic of this port, caught a small halibut on the Bank, on which he took a notion to cut his initials, and threw the fish overboard, not expecting to see him again. In 1874 he shipped in sch. Mary E. Daniels, and while hauling his trawl on Grand Bank, discovered, to his great surprise, the identical halibut he had marked some eight months before. The halibut was on exhibition at the wharf of the New England Fish Company. The initials were plainly discernible, although the fish had grown considerably since they were cut. This is no fish story, but a veritable fact, and the circumstance is certainly a most remarkable one.

Among the halibut landed by sch. Chester $R$. Lawerence, in May, 1875 , was one with the name "Lynch" cut thereon. The halibut had grown considerably since the carving operation, which from the appearance of the scars had been done about a year. The letters were some six inches in length and very clearly defined.

In February, 1876, while dressing fish at the Gloucester Fish Company's wharf, a plain gold ring was taken from the paunch of a codfish. It was brought to the "Cape Ann Advertiser" sanctum by Mr. William E. Ansell, and had the appearance of having been in the keeping of the fish for some time. The mark $18 \mathrm{~K}$, signifying the quality of the gold, was plainly discernible on the inside of the ring. The query is, how came the fish in possession of it, and who was the owner?

In March, 1877, George Harvey, one of the crew of sch. Rebecca Bartlett 
of this port, on her trip to Georges, hauled up a codfish, which upon being dressed, there was found in the paunch a wallet in a fair state of preservation. Unfortunately for the fisherman, there was no money in it; but there was an old letter and a horse-car ticket. The writing on the letter was so badly obliterated that it could not be read, therefore no clue as to the owner of the wallet could be obtained.

In January, r88o, sch. Bessie W. Somes, Capt. Hodgdon, from the Banks, brought in a twenty-pound halibut, in the skin of which were plainly visible the initials and date, "W. E. McD., 1877." It is supposed that when a young fellow he visited the sch. William E. McDonald, and was set at liberty bearing the above inscription.

Getting a Trip Under Difficulties.-Sch. Knight Templar, Capt. Michael McDonald, which arrived from Grand Bank Feb. 20, 1874, had a tough time of it ; but the plucky captain was determined to get a trip, and he did so, bringing in 40,000 pounds of halibut, which stocked $\$ 4,000$. $\mathrm{He}$ left port Jan. Io and arrived on Western Bank the $\mathbf{s}$ th, where they encountered a severe gale and broke the main-boom. Finding fish scarce, he determined to go to the Grand Bank. Most of the crew didn't relish sailing a thousand miles from home with a broken main-boom; but the captain was inflexible, and they started with a ten-knot breeze, under a foresail only. On the passage the foresail jibed over, breaking the gaff. Arriving on the Bank the 20 th, they set their trawls. A severe gale came on in the night, when the vessel shipped a sea and smashed all the dories. This was another stroke of ill luck, as what was the use of the trawls without any dories in which to get them? Capt. McDonald, however, was not the man to be disheartened. He had come for a trip of fish, and a trip he was going to have, if within the power of mortal man to get it. Taking the remains of one of the dories he used it to repair the others. Unfortunately he had no nails suitable for the work; but this difficulty was obviated by heating some board nails, thereby rendering them pliable. It blew a living gale of wind most of the time; but during the lulls of fifteen days there were opportunities to set the trawls several times, and this gave him his trip.

After hauling up the anchors to start for home, having no immediate use for the stocks, he sawed them in two, using them to "fish" the main-boom, and was thus enabled to carry the mainsail when needed. On the roth of February, while off the Gulf of St. Lawrence, just to the eastward of Sable Island, they were struck by a hurricane, shipping a sea, which again smashed the dories and threatened to swamp the vessel; but she came out of it handsomely and brought her plucky captain and crew safe to port. 
A Plucky little Captain Gets Fifteen Hundred Dollars SalVAGE! -On the afternoon of June $\mathbf{2} 2, \mathbf{1} 875$, sch. Addison Center was run down while at anchor on Cashes, during a thick fog, by brig Sarah M. Loring of Yarmouth, N. S. She struck her with great force, pressing her under water, and the crew naturally supposing that she was sinking, lost no time in getting on board the brig, and were carried into Portland. She was boarded by a number of vessels, the masters of which considered it impossible to get her into port. And they were not to blame for so thinking, as she had a big hole in her stern, through which the water was making rapidly, and it was apparent that she would soon go down.

On Monday, I $4^{\text {th }}$ inst., she was sighted by Capt. George Whitmore of sch. Ellen of Ellsworth, Me., bound for Boston. He had as crew two boys only. Letting his own vessel drift, they boarded the Center in their boat, and he conceived the idea of saving her. It was then two o'clock in the afternoon, and he immediately commenced operations. Cutting a large piece of duck out of the mainsail, he contrived, by dint of much ingenuity, to nail it over the hole. To do this required considerable exertion, especially the nailing under water; but he stuck to the job with a tenacity which knew no such word as fail, and after several hours of unremitting exertion, which will be understood by any one knowing the nature of such a task, he had the satisfaction of seeing it accomplished. Getting sail on her, he went on board his own vessel and gave instructions to the two lads how to run for Portland, and then returned alone to the Center. Giving the vessel a heel, so as to relieve the damaged part as much as possible, he cut the cable and shaped his course for Portland, followed by the Ellen. A fine little breeze sprang up, and the water in the vessel rushing forward brought the stern out of the water, which effectually prevented her taking in any more. This operated much in his favor, as she was then two-thirds full of water, and unless the leak had been stopped, she would have kept afloat but a short time longer. He ran all night, and reached port Wednesday noon.

Mr. Horatio Babson, one of the owners of the Center, upon hearing of her arrival, immediately went to Portland, and at once acceded to Capt. Whitmore's demand of $\$ 1,500$ salvage, in behalf of the Gloucester Fishing Insurance Company of this city, and the Naumkeag office of Salem, at which the vessel was insured. It was a plucky job throughout.

Mysterious Loss of Two of the Crew of Sch. Frederic Gerring, JR.-Two of the crew of sch. Frederic Gerring, Jr.-Capt. Edward MorrisWilliam Norton and Albert Sulkey, left the vessel in their dory on the afternoon of Monday, Feb. 28, 1876 , for the purpose of hauling their trawls. It was very moderate at the time, and others of the crew also left in dories for the same purpose. After they had been absent some twenty minutes, 
Capt. Morris, as is his custom, keeping watch of the dories, saw that the one in which Norton and Sulkey were seemed to be drifting, without any effort being made to reach the buoy, whither she was bound. Soon he saw one of the other dories pulling for her with all speed, and then he supposed that something was wrong. The other dory in due time reached the vessel, having in tow the drifting dory, and reported they had found her adrift and neither of the men were on board. The trawl gear was in the dory the same as when they started, she had shipped no water, and the cause of the drowning of the men was a mystery which could not be solved. One pair of oars was picked up in the water. This indeed is a very mysterious affair and without precedent, and no theory has ever yet been offered which throws any light thereon. They were both good friends, and were spoken of as first-class fishermen, Norton having been with Capt. Morris for four years. There was no squall to throw them out of the dory. The only supposition which has any feasibility is, that one of them accidentally fell overboard, and the other in attempting to save him lost his life, both going down together. They were both married men, about thirty years of age, and residents of this city.

Twenty-four Days in the Ice.-Schs. Hereward, Pennington, and Rattler, McPherson, which left this port for Newfoundland for a load of frozen herring in December, 1875 , got frozen in while on the homeward passage, Feb. 9, 1876 , in Fortune Bay, and there remained eleven days. Got clear the I 9 th and went into the ice again the same day and remained there until March 3. Schs. S. C. Noyes, Hatfield, of Newburyport, and Charles $A$. Ropes of Camden, Me., were also in the same predicament. Capt. Pennington made a drawing of the scene, in which the four vessels are visible locked in the ice, and the crews of the Hereward and Rattler busily engaged in getting some provisions from the $S$. C. Noyes, which lay at a distance of three miles. The ice was so rough that they were obliged to carry the flour in bags, and the men with these bags on their backs, and the captain with the empty barrel to put it in when it reached the vessel, made a lively scene. It was a tedious experience for all hands, and glad enough were they to get clear of their icy bonds. Fortunate it was that the Noyes could supply them with flour, otherwise the men would have suffered for this necessary of life.

Men Picked Up.-A Tough Time of It.-Sch. Cornelius Stokem, which arrived at this port May 23, 1876 , from Newfoundland, brought in two Frenchmen, John Bouche and Adolph Crochu, who were picked up in a dory in the Gulf of St. Lawrence on the 16 th inst. They were lost from their vessel on Banquereau while attending their trawls, and exposed to a violent gale, the sea breaking over them and the weather being very cold, 
enveloping them in ice. For seven days they were exposed to the severity of the weather, without food or drink, and when taken off were both in an exhausted condition and near the gates of death from hunger and exposure. One of the men was badly frozen, but both recovered from the effects of their exposure.

LosT IN THE Fog.-Eight Days without Food or Water.-During the years 1875 and 1876 there were numerous cases of fishermen getting separated from their vessels in consequence of thick fog setting in while at their trawls, most of whom were picked up within a day or two, before they had suffered greatly from hunger or thirst. In one instance two men were out six days before they were rescued, Patrick O'Neil and Frank Miller of sch. Tubal Cain of this port, in October, 1875 ; but never have we recorded an instance where men have been eight days without food or water, as was the case of Capt. William Hines and John Foster, of sch. Eben B. Phillips of this port, the particulars of which are as follows:

On the 18 th of May, 1876 , the two men left their vessel on Grand Bank early in the morning, to haul their trawl. It was not very thick at the time, but shortly after a dense fog shut in, and they were unable to find their way back. They drifted around all that day and night, occasionally rowing a little, but did not succeed in finding any traces of the schooner. On the following day the fog continued as thick as ever, and Capt. Hines thinking the vessel might be found by steering in a westerly course, headed their dory in that direction; but instead of going toward land they only got farther out to sea. For seven days and nights they continued to drift and row at intervals, the fog continuing very dense. Their sufferings for want of food and drink were most excruciating, and being thinly clothed they suffered considerably from the chilly wind which swept over them most of the time. On the morning of the eighth day the fog lifted, and much to the joy of the famishing men, who had now scarcely strength to move, they discovered a bark in the distance. Both were so weak that they could hardly do anything to attract attention except by rapping on the gunwale of the dory. Knowing that it was their last hope of safety, they roused themselves to renewed effort, took to their oars, and after rowing a couple of hours, were discovered by those on board the bark, which hove to, and about half-past eleven that night they came up with her. She proved to be the Norwegian bark Collector, Capt. Holstein, bound for the Provinces. Capt. Hines was able to get on board the vessel without assistance, but Foster was perfectly helpless and had to be lifted on board. They received the kindest treatment from the captain and crew, and by careful nursing soon began to recuperate. They had drifted one hundred and sixty miles from the Bank when rescued. The bark arrived at Dalhousie on the the $5^{\text {th }}$ of June, and 
on the following day the men were taken ashore and sent to St. John by the Norwegian consul at that place, he kindly paying their expenses. After stopping in St. John a few days with some of their friends, they were provided with free passes for Boston and arrived home in due season; and in time both men recovered from the terrible effects of their protracted exposure, which came so near causing them to die of starvation on the water-a fate which one fairly shudders to contemplate.

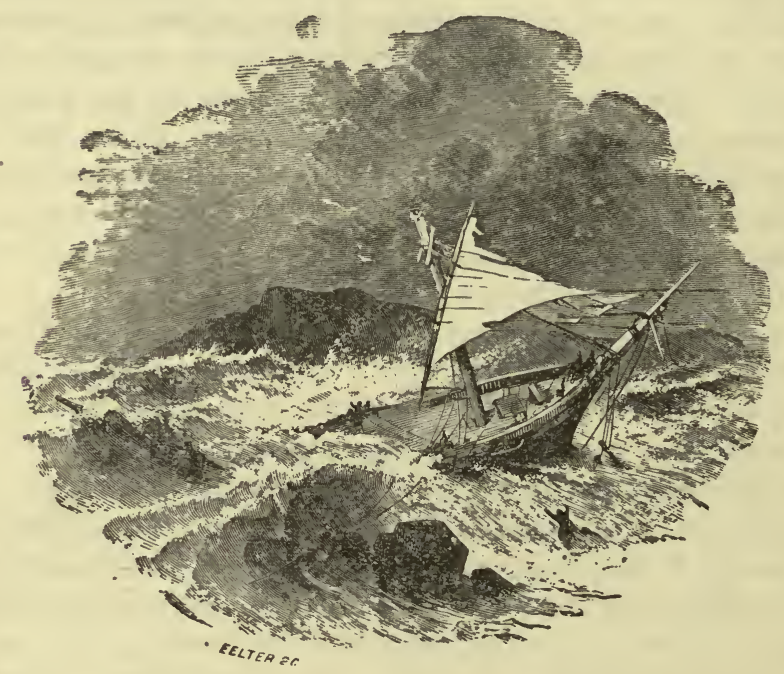

Terrible Disaster.-Loss of Sch. Kittie of Port Mulgrave, N. S., with Sixty-three Passengers Bound to This City to Engage in the Fisheries-Narrow Escape of Three Persons Who Were an Hour Late.-Sch. Kittie, commanded by Capt. James Forrestall, her owner, left Port Mulgrave Sunday, April .2, 1876 , bound for Boston, and there is no doubt but that she foundered in the severe gale of the $4^{\text {th }}$ inst., carrying with her sixty-three persons belonging in Port Mulgrave and vicinity, but who were identified with Gloucester, as they followed fishing from this port during six months of the year, and had many relatives and friends in this city who were anxiously expecting their arrival. The following is the list of the passengers, as nearly as could be obtained :

From Harbor Bouche-John Levangy, Hubert Levangy, Edward Decost, Frederick Levangy, Ben. Fougere, Michael Pebrine, Henry Benoit, John Paro, Jerry Fougere, Lucian Levangy, E. Fougere, (Jack's son) John King, (Pete's son) L. Fougere, Edward Decost, (Widow Tom's son) Jos. Decost, David Levangy, Ned Bouchy, Ben. Brean, Ben. Belfountain, Lewis Bouchy, 
Jeffrey Bouchy, Michael Oldfield, Wm. Oldfield, Fougere, (Ephraim's son), Daniel McDonald (Allan's son), Mrs. John O'Brien and three children, Sarah McDonald, (Allan's daughter) Augusta Fougere, John McDonald (Allan John's son), Rory McDonald (Donald's son, lighthouse), Wm. Forrestall (William's son).

From Steep Creek-Martin Doyle, N. Decost, Jos. Decost, Wm. Crittenden, (Hugh's son) John D. Whelan.

From Pirate Harbor-William Maguire.

From Port Mulgrave-Wm. Crittenden, Edward Ryan, Rory McDonald, George Longuill, James Perkins, Alex. Perkins, J. O'Handley, Peter Forestall, Arch. McDonald.

From Cape Breton-Roderick McDonald, McMillan's Point; John McEachren, Glendale; John McDonald, do.; Daniel McDonald, McMillan's Point ; James McDonald, Whycocomagh ; John O'Handley, Judique ; Alex. McDonald, do.; Rupert G. Ross, Port Hood ; Wm. Johnson, do.; Alex. McInnis, near Hawkesbury ; John Cass, do.; John McDonald, Keeper, Judique ; John D. McKinnon, do.; Daniel McEachren, Judique ; Henry Simpson, Manchester.

The crew consisted of Capt. James Forrestall, Capt. John Martin, James Martin, Daniel McDonald.

The sch. Kittie was built in Lunenberg, and was owned by Capt. James Forrestall of Auld's Cove, Strait of Canso, and was about ten years old. The above list is as correct as can possibly be got; there may be one or two that have not been obtained. The total, including passengers and crew, was sixty-eight.

There were three persons, viz., William McDonald and Neil McDonald, brothers, and Angus McDonald, who were coming on this vessel, but were an hour late, the vessel having sailed. All their clothing was on board, and they came by land. Their being behindhand on this occasion was the means of preserving their lives.

A Remarkable Experience and Narrow Escape.-The crew of the sch. Daniel A. Burnham of this port, had a singular and wonderful experience. While lying to off Sable Island on the evening of Jan. ro, 1877, the schooner was struck by a heavy sea, which turned her completely over, the masts giving way while she was under water. Of her crew of thirteen men all but one were below when the vessel capsized; and the rapidity of the entire transaction, which did not allow time for the vessel to fill, proved their salvation. They were thrown from the floor to the ceiling, when the schooner was bottom up, and immediately to the floor again, as she righted. On coming on deck, the man who had been on the lookout was found hanging over the side by a portion of the gear, and was speedily hauled on 
board. The crew remained on the wreck, on which they got some small canvas, and were heading for the land as best they could, when fortunately they encountered the mail steamer Austrian, who took them off and landed them at St. Johns, N. F.

NARrow EscaPe. - Two Fishermen Capsized in a Dory-Caught by a Trazel Hook-Fortunate Rescue.-Two of the crew of sch. Centennial, Peter Scanlan and George Stickling, were capsized in a dory on the fishing grounds, May 21, 1877, and had a narrow escape from a watery grave. They had completed the hauling of their trawls and were ready to return to the vessel, when a sea boarded and sunk the dory, but she soon capsized and came up again, and the men succeeded in getting hold of her, Scanlan at the bow and Stickling at the stern. In going over, the hook of one of the trawls caught in the leg of Stickling, and he was compelled to bear his own weight and that of the trawl, which he was enabled to do by fortunately securing a foothold in the stern becket of the dory. But the combined weight of man and line kept the unfortunate man nearly under water the greater part of the time, and his position was one of extreme discomfort and peril. Scanlan was more fortunately situated, having no encumbrance exept his clothing, and the forward part of the frail craft was kept well out of water by the weight at the stern; yet his position was far from enviable, clinging to an overturned dory upon a wide expanse of surging waters. After being thus exposed for about a quarter of an hour, they were discovered by the men in another dory, who were returning to the vessel, who at once went to their rescue. Stickling was nearly exhausted, and in pulling him in, the hook was broken off in his leg, and on reaching the vessel it was found necessary to cut it out, making an ugly wound. He must have been possessed of remarkable powers of endurance to maintain the position until assistance arrived, and his escape from death may well be considered as very narrow.

A Six Ton Boat Drags Her Anchor off Salt Island, and Her Crew to Keep Afloat Pound Ice All Night.-A Tough Time and Narrow Escape.-Jan. 23,1878 , will be remembered by a terrible squall, quickly followed by intense cold and a heavy northwest gale. Just previous to the squall, the little boat Hope of this port, a trifle short of six tons burthen, was to the southward of Brown's Bank, some eight miles off the Cape. She was commanded by Capt. Anthony T. Francis, and there was a crew of two men, John Conley and Joseph Adams, making three in all. The men had just been picking their trawls and had a dory load of fish and trawl lines, and seeing the squall coming, made all possible haste to get on board the boat. This they succeeded in doing just in time; but it was so rough that the dory collided with the boat, knocking off a piece of her rail, and came 
near staving a hole through her. Finding they could not tow the heavily laden dory, they were obliged to cut her adrift and she soon capsized, and dory and contents proved a total loss. The squall had by this time come upon them in all its fury; but the little craft behaved well, and they got her up under the lee of Salt Island and came to anchor; but the anchor would not hold and commenced dragging, carrying them off to sea. After dragging some four miles it finally held; but it was so rough, and the wind ahead, that they dared not attempt to get underway, so they hung to it, determined to take their chances. The cold was so intense that the water shipped on deck froze almost as soon as it struck, threatening to sink the little craft, and this danger was most to be dreaded. When men's lives are in the balance, however, they will accomplish almost incredible tasks, and so it proved in the case of these poor fellows. Notwithstanding the cold winds, which pierced them like a knife, notwithstanding the showers of freezing cold spray which constantly broke over them, there they stood at their posts, beating ice the livelong night-a night which none of them will ever forget-and by their almost superhuman efforts they kept their little craft afloat, and the next afternoon brought her safely into port.

A Perilous Time.-Friday afternoon, Jan. 4, 1878 , two young men of Riverdale named George Stanwood, Jr., and Fred A. Lewis, went out fishing in Ipswich Bay in a dory, and at noon time, just before the storm came on, started to pull in. The snowstorm came down upon them so thick that they could not see, and to their best judgment they pulled for Annisquam light. It was a tough pull, and to add to their perils their dory sprang aleak, requiring the utmost exertions of one of the men to keep her free with a bucket, while the other pulled. Thus passed the afternoon until five o'clock, when the dory drove ashore on Coffin's Beach, just this side of the Loaf, where she was dashed in pieces, the men, wet and well nigh exhausted, succeeding in making a landing through the surf. They then dragged themselves along as best they could to the house of Mr. Gardner W. Herrick, where they were kindly received, their wants attended to, and hospitably entertained for the night. In the meantime their friends at home were fearful that they were lost.- This anxiety was dispelled in the morning when a messenger was dispatched, assuring the anxious friends of their safety.

Loss of a Boston Fishing Schooner.-Sch. Little Kate of South Boston, 32.69 tons, formerly of this port, engaged in the haddock fishery, went ashore off Duxbury in the gale of Thursday, Jan. 10,1878 , and became a total loss. Of her crew of thirteen men not one escaped. All were residents of South Boston, all related by blood or marriage, four being brothers. Seven of them were married, leaving that number of widows and twenty-one 
fatherless children as the fruits of this sad disaster. The father of the four brothers mentioned, an aged man named Owen Hines, was indeed terribly afflicted. His wife died five weeks previous, and only one crippled son was left him of a family which a few days before was full of health and promise. The vessel, too, was his, and all the property he possessed was bound up in her. A short time previous he was offered $\$ \mathbf{1}, 500$ for the schooner, but as it furnished a means of livelihood to his family as well as to himself, he refused to part with it. There was no insurance on the vessel, consequently what represented the savings of a lifetime disappeared in a moment, and with it went every one whose strong hands should have supported the old man's trembling steps toward the grave.

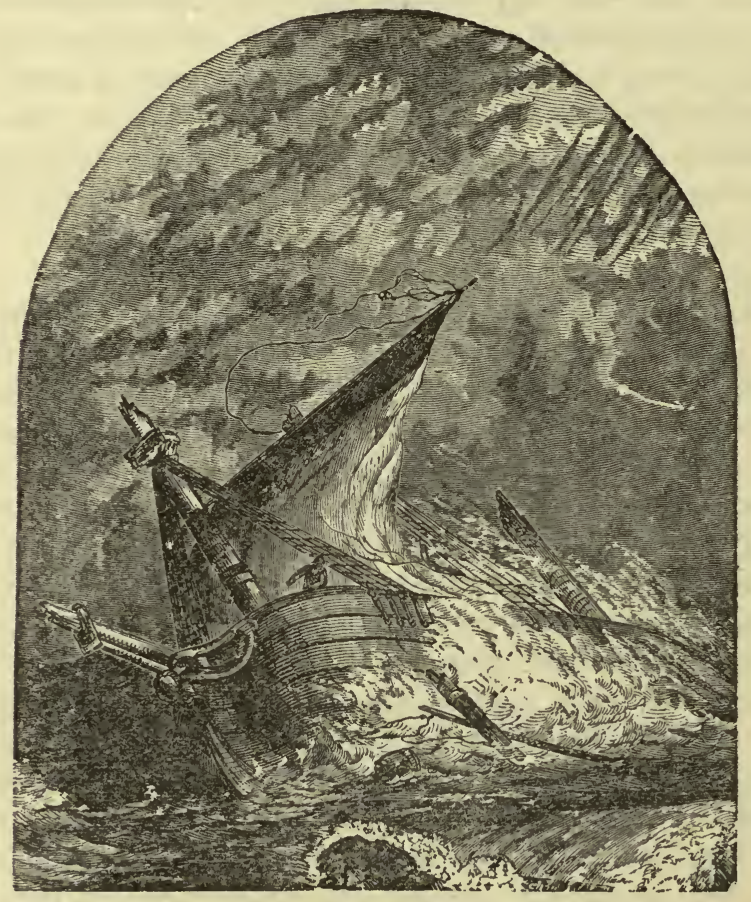

The Storm off Cape Cod.-Five Vessels Wrecked-Terrible Sufferings of the Men on the Powwow-Thrilling Scenes of Death-How the Survivors were Rescued.-The night of the $2 \mathrm{~d}$ and the morning of the $3 \mathrm{~d}$ of January, 1878 , were terrible for those unlucky mariners who found themselves in a snowstorm, being driven on the treacherous sands of Cape Cod. Five vessels were lost. From the largest two not a soul was saved; every man, from the captains down to the deck boys, was buried beneath the cold 
waters. A few bodies were recovered, but the majority sleep in watery graves.

The sufferings of the crew of the ill-fated Powzere of Provincetown were frightful. The hour of $4 \mathrm{~A}$. M. found them drifting helplessly to the lee shore of Wellfleet. With the hope of checking their drift they anchored, but the chain of their larger anchor parted and the vessel dragged the smaller one as if it had been a pound weight. Then, as the tempest lulled, "Hoist the jib," shouted the captain, "and we'll run her through the surf." With great difficulty the sail was partially hoisted and the vessel's head swung towards the land. But alas! she struck in the outer breakers. The great billows broke over her and in an instant she filled. A signal of distress was lighted, but was soon extinguished. "Set the kerosene afire," ordered Capt. Caton; "we must let the station men know we are here." This was done. Thank heaven, an answering signal was heard, and in the course of a half hour they discerned a horse and cart moving towards them along the beach, bearing a large box containing the patent rescue gun. A long hour crept by, but there came no other signs of succor. Their hopes fell. So cold were they that it was with difficulty they clung to the rigging. Drenched every moment with icy water, they were soon benumbed. One huge fellow, with the muscles of a Hercules, was three times washed away from the vessel. Twice he regained his hold, but the third time his strength failed, and he sank to rise no more. As the dreary morning passed two others gave up the struggle, and releasing their grasp, were swept away. One poor boy, named James Downling, whose home was in Boston, succumbed to the cold. "I can't stand it any longer, Captain," said he, "I am going to die." When last seen by the survivors he was lying in the lee scuppers, his head hanging listlessly to one side, his hair matted with ice, and his arms clutching in their death-grip a coil of frozen rope. And at. last the captain whispered hoarsely, "Good-bye, boys, I shall try for the shore. May God keep me for my poor wife's sake." A dory was got over the side, but was crushed in an instant. Capt. Caton then tore off the cabin. skylight, and heaving it overboard, sprang after it. His support was soon. wrenched from his grasp, but he struggled manfully. He reached the shore; twice he stood erect on the sand, but the undertow was too powerful, and he was drawn under the surf. The ten men who remained on the vessel were destined to be saved. After daylight the Life Saving Station men, who. had previously been devoting their energies to the vain attempt of rescuing. the crew of the other wreck, arrived. The first time they fired the mortar the ball with the line attached fell over the spring-stay, but the men were so. chilled with cold that it was impossible to get it. After several trials, however, the line fell where they could reach it. At ro A. M. they were all ashore and were tenderly cared for at the Humane House. 
Perilous Experiences.-Allen Maginnis, of sch. Centennial, was drowned by the capsizing of a dory on Grand Bank, Jan. 20, 1878 . His companion in the dory, John McLeod, succeeded in getting on the bottom of the frail craft, but this afforded a very insecure hold, and while all the other dories belonging to the vessel were provided with beckets fastened to the plugs for cases of such emergency, this particular one was not thus furnished. McLeod retained his hold as best he could, being sometimes washed off, until seeing a halibut-killer afloat a short distance away, he swam off and secured it, and pounding out the plug, was able to thrust one of his fingers through the hole in the bottom of the dory, and thus maintain his hold. In this manner, changing from one finger to another, he held his own with great difficulty for about two hours, when his cries were heard by some companions in another dory, who rowed to his assistance and took him off in an exhausted condition. Several of his fingers were badly chafed, and it is doubtful if he could have held on much longer.

Nov. 6, 1878, Thomas King and Charles Hubbley, of sch. Annie C. Norwood, on an off-shore codfishing trip, were out in their dories, when a squall came on and the dory capsized so suddenly as to throw them ten feet from her. They managed to swim to the overturned dory and to get upon her bottom, but King was greatly exhausted and soon succumbed. Hubbley succeeded in maintaining his position by getting a finger in the plug-hole, holding on for two hours, until his finger was nearly cut off, when he was taken off by sch. Rutherford $B$. Hayes, greatly exhausted.

Lost And Found.-A Happy Surprise.-Alexander McEachen and Augustus Armstrong, two of the crew of sch. Mary $F$. Chisholm of this port, left that vessel during a fog, May $9, \mathrm{~s} 878$, to attend to their trawls on Western Bank. They got out of hearing of the fog-horn and were unable to find their vessel. After rowing for twenty-four hours they fell in with a French fishing vessel and were taken on board, where they remained two days. They were subsequently transferred to sch. Viking, and arrived home the day before the Chisholm, and were the first to hail that vessel as she came up the harbor with her flag at half-mast in token of their loss. The flag was speedily flying from the mast-head in rejoicing at their deliverance, and their shipmates congratulated them heartily on their fortunate escape.

A Hard Pull in a Dory.-Two of the crew of sch. Ida A. Thurlow of Eastport, Me., named Alex. S. Morise and Thomas T. Goodwin, were lost from that vessel in May, 1878 , while attending to their trawls in a dory, and after an exposure of eighty-two hours, without compass, food or water, by making a perilous voyage of one hundred and twenty miles, succeeded in landing, through fearful breakers, forty-five miles east of Halifax. 
A Perilous Night.-Friday, Jan. 4, 1878, a severe storm came on during the afternoon, and most of the Lanesville dory fleet arrived in ere it became very severe. At sundown there was great anxiety felt for the safety of Sylvanus C. Lane and Lorenzo Griffin, who had not arrived. Sad were the hearts on the shore as the cold wind blew its fitful blasts and the blinding snowstorm raged in all its fury. It was a tough night to be exposed in an open dory on the rough waters of Ipswich Bay, and so these fishermen found it. They could not make any headway to the port which they wished to gain, so they drifted to leeward, having hard work to keep their craft afloat. Soon they heard the breakers on the beach toward Ipswich, and their only chance was to throw their anchor, and it held them in eight fathoms of water. There they waited for the wind to change, knowing full well their fate if the anchor parted. It did not part, although several times they shipped heavy seas, nearly filling their dory with water, which they bailed out with a bucket. Fortunately the wind changed, and the worn out fishermen rowed home, arriving at midnight, where they were received by their loved ones with thankful hearts.

A Rough Experience.-Feb. 28, 1879, sch. Alfred Walen, Capt. Patrick O'Neal, was coming home from Brown's Bank, and while reefing the mainsail, the vessel took a roll to windward, and one of the crew, Richard Costillo, who was on the end of the boom, lost his balance and went overboard. After making four attempts to catch the log line he succeeded in grasping it. The vessel was going nine miles an hour, with a heavy sea running, and he was dragged under water. The vessel was put up in the wind, and the unfortunate man was some three hundred feet off, still clinging for dear life to the $\log$ line, and swashed up and down by the heavy seas, rendering his position extremely dangerous. He felt the pulling of the men on the line, the force of which pulled him under water, and he could not remain on the surface. He was hauled, as near as he could judge, some sixty feet, when he gave up all hopes of being saved, as he did not come to the surface until he was hauled under the quarter of the vessel, when the men got into a dory, and getting a rope about him, got him on board the vessel, where, after long and repeated efforts, they succeeded in resuscitating him. $\mathrm{He}$ never has recovered from his fearful experience, having raised a great deal of blood, and has not been able to do much work since.

An Unfortunate SkipPer.-The captain and owner of a small schooner at Portland had hard luck of it. He had fished on Georges seventeen years, and in the Spring of 1880 concluded he would sell his little home in Gloucester, pay off the mortgage and with the proceeds go to Boothbay and live quietly. Afterwards, in Gloucester, he accidentally lost his right index fin- 
ger. He lifted the mortgage by selling his house, and had $\$ 233.50$ left. This money he put in an envelope, and the envelope in an inside pocket. He set sail for Boothbay with his family in his vessel, and on Saturday, Sept. 3, when off Cape Elizabeth, as he leaned over the rail to pull in a rope, the envelope fell from his pocket into the water, and as $\$ \mathrm{r} .5^{\circ}$ of the money was in silver it sank before his eyes.

At the Mercy of the Seas.-Five Days without Food or Drink.-John Whitlaw and Samuel Orgrove, two of the crew of fishing sch. Edward $A$. Horton of this port, left that vessel on Grand Bank, Thursday, July I, I880, for the purpose of hauling their trawls. After loading their dory they found themselves unable to return to their vessel, on account of a heavy fog having shut in, and rowed aimlessly away in the hope of finding succor. After undergoing great exposure and hardships, on the following Tuesday they effected a landing upon the coast of Newfoundland, greatly reduced and almost in a dying condition from their enforced abstinence from food and drink. They were kindly treated, and were forwarded to St Johns, N. F., where they arrived on the evening of July 9.

Death from Exposure on the Fishing Grounds.-Sch. Polar Wave, Capt. Jerome McDonald, was on Banquereau, March 24th, I88o, when the wind suddenly shifted and it set in extremely cold while six of her dories were out. The vessel got underway and found five of the dories without difficulty, but the other, containing George Nelson and Charles Ray, remained undiscovered until morning. These men had hauled up and rowed away from the vessel instead of towards her. They soon discovered their mistake, as a strong light was set in the rigging of the vessel, and they remained within sight of it all night. They threw overboard their fish and gear, but were unable to make headway against the wind and sea to the vessel. The next day they were seen by the crew, who went to their succor. When found at three o'clock, P. M., Nelson was dead, having died from the exposure at about nine, A. M. He was an Austrian, a native of Tricate, about twenty-three years of age, and had followed fishing from this port for some time. He was buried at sea March 30 . He was spoken of as of a very delicate constitution, weighing about one hundred and ten pounds, and notwithstanding the continued cheering up and entreaties by his companion, to continue rowing, and they would surely be saved, the poor fellow was so utterly exhausted that he could not make further efforts and succumbed to the terrible cold and exposure.

A Caution Which Should Be Heeded.-If the fishermen would only take the precaution to place a jug of water and some hard bread in their 
dories, it would oftentimes save much suffering and perhaps life. It is full time that masters and owners of fishing vessels interested themselves in this matter and insisted that it should be done. The expense and trouble is but trifling compared with the benefits which might follow, and it should be among the duties required of fishermen each trip to see that every dory was provided with the wherewithal to sustain life when lost in the fog or driven out of sight of their vessel, as is frequently the case. There is no excuse for the fishermen if they fail to comply with this simple duty, and we trust that they will heed this advice and provide a remedy for one cause of danger and suffering attending the business.

Five Days Adrift in a Dory Without Food.-James McGrath and Michael Coleman left sch. Procter Brothers on Western Bank, March 18, $\mathbf{r} 880$, to attend to their trawls, and a gale springing up, were unable to return to the vessel. After drifting about at the mercy of the wind and waves for five days, without food or water, drove ashore at Sable Island on the evening of the $22 \mathrm{~d}$. The weather was intensely cold and their sufferings extreme while they were in the dory, and McGrath had both feet badly frozen. When taken out of the dory they were unable to walk, and had to be carried on the shoulders of the men stationed on the island to aid wrecked people. They were taken to the hospital, and being sufficiently recovered, were taken to Halifax by the Dominion Government steamer Nerefield.

The Colemans, as it would appear, were not born to be drowned. On Feb. 15, 1879, Charles Coleman was capsized on the Banks in a dory from sch. Commonwealth, and with his companion, Sweeny McKenzie, clung to the dory's bottom for an hour and a half with such desperation as to leave the imprints of their fingers in the wood. Coleman slipped from his hold three times, and three times his comrade battled the waves to rescue him, and he was so exhausted when taken on board the vessel that it took three hours to bring him to consciousness. Michael Coleman, whose second narrow escape is narrated above, was lost in a dory with $\mathrm{H}$. Choate Allen from sch. Addison G. Procter, June 29, I879, on St. Peter's Bank, and after subsisting on small pieces of raw halibut for four days, and rowing one hundred and sixty miles, they were picked up by a Lockeport, N. S., schooner.

\section{Shipwreck And Loss of Life.-Gallant Rescue by a Gloucester Fishing} Crew.-Sch. Laura Sayward, Capt. James Moore, arrived from a Georges trip Sept. I4, I880, bringing the captain, John C. Winchester, and mate, Thomas Lewis, of sch. Maggie Blanche, of Digby, N. S., for Barbadoes with a load of lumber and potatoes, being accompanied by the owner of the vessel, Mr. Wesley K. Rice, who designed selling the vessel on her arrival at the West Indies. The Maggie Blanche set sail Sunday, Sept. 5, and every- 
thing went well until Wednesday, the 8th, at about ten o'clock, A. M., when she encountered a strong gale from the east-southeast with a heavy sea, accompanied by rain and squalls. During the gale the schooner was hove on her beam ends, shifting the cargo in her hold, and laid dead in the water under a three-reefed foresail. The wind veering to the northeast, causing a heavy cross sea, an effort was made to take in the reefed foresail with the design of jettisoning the deck load, and while furling the sail a sea ran in to leeward and capsized the vessel. About eight o'clock, Thursday morning, the cargo having washed out, the mainmast broke off at the deck and the vessel righted full of water. The owner, Mr. Rice, was drowned in his cabin, his body washing out, and the officers and crew, four in number, were confined to the deck, all below being full of water. Two of them, William Vroon, one of the crew, and Augustus Theodore (colored), the cook, were washed overboard and drowned, and the captain and mate lashed themselves to the deck. A brig passed quite near them, and they signalled her by every means within their power, but without avail, and she kept on her course. On Saturday morning, the I Ith, about seven o'clock, the wreck was descried by sch. Laura Sayward lying at anchor on the northeastern part of Georges, and Capt. Moore at once commenced making arrangements to go to her assistance. The windlass was manned and an attempt made to raise the anchor, but there was a heavy cross sea running, and but little progress could be made in that direction. Finding that the wreck was fast sinking and that prompt measures must be taken, Capt. Moore ordered his cable cut, having a whole string out, and a dory was launched and manned by two of the crew, Dean Crockett and James Lord, who went to the wreck and took off the suffering men.

These men, Crockett and Lord, were subsequently the recipients of two magnificent stem-winding watches from the Canadian Government, through Hon. Edward Thornton, British Minister at Washington, in recognition of their humane and gallant exertions in saving life.

\section{A Tough Experience.-Charles Lunt and Paul Nelson of sch. Waldo} Irving, haddock catching, off shore, left the vessel Wednesday, Dec. 29, 1880 , to visit their trawls, and were unable afterwards to find trace of the vessel, and those on board could not find the men. They started to row for the land, but were blown off. Thursday afternoon, about two o'clock, after having been exposed in their frail craft to the severe snow squall and terrible cold which followed, and when, as near as they could judge, they were about thirty-five miles from Boston light, they saw a steamer and rowed in her track. It proved to be the ocean steamer Sardinian, on the passage from Boston to England, via Halifax. It came alongside the dory, a sailor got down and bent a line to each of the men, as they were so exhausted 
they could not help themselves, and they were hoisted on deck. They were so much exhausted from exposure, hard work and want of food, that they could have survived but a short time longer. Their hands and feet were badly frostbitten and their sufferings indescribable. During the heavy gale of Wednesday night they kept their dory's head to the sea by means of a drogue made from their fishing tackle and trawl tub. They were taken in charge by the American consul at Halifax and sent home.

Particulars of the Loss of Sch. Lizzie K. Clark.-Sch. Lizzie $K$. Clark, Capt. Ambrose Melanson, left port March 22, r881, bound South on a mackerel trip, and capsized and sunk about twenty miles southeast of Barnegat on the $25^{\text {th. The }}$ weather was rough from the start, but on the

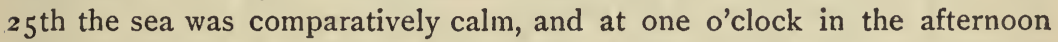
all hands except the helmsman were below putting the seines and gear in order. The vessel was under full sail and heading west, one-half north, when she was suddenly struck by a squall and capsized. Capt. Melanson rushed upon deck and hove the wheel down, but she was too far over to obey the helm, and he seized an axe and ran forward to cut the fore sheets, but being unable to reach them, got into the main rigging and severed the halyards. At this time the ice-pens gave way and their contents shifting prevented the schooner from righting. Both companion-ways were open, and the water rushed down, filling the hold. The crew reached the deck with considerable difficulty, and one of their number, Edward Ryan, the first to follow Capt. Melanson on deck, was washed overboard. The others climbed upon the weather side, and cutting adrift the seine boat, lashed between the masts and rigging, got her afloat half filled with water. They picked up Ryan, and were scarcely a hundred feet away from the schooner when she sank. After floating about for half an hour they were picked up by Pilot Boat No. 3. Seven were put on board the tug Knickerbocker and taken to New York, and seven were taken to the same port in the brig Mary Fink, from Matanzas.

Picked Up Adrift- - A Humane Shipmaster.-George Strowhan and John Kerry, two of the crew of sch. George S. Boutzell, Capt. Gorman, of this port, left that vessel on Western Bank to set their trawls, Aug. I, r88I, and were lost in the fog. After being adrift for eighteen hours without food or drink, they were picked up by the coal laden steamship Wilton of and for Hartlepool, Eng., from Philadelphia. Sighting a vessel in the distance, which proved to be the schooner to which they belonged, the captain of the steamer went some ten miles out of his course to put them on board, instead of taking them across the Atlantic. After the men were picked up there was a thick fog for three or four days, and they probably would have perished but for the timely succor. 
Capsized on the Banks.-Seized by a Shark When Succor Was at Hand. -Sch. Victor, Capt. John E. Sigsworth, arrived from a Western Bank trip, Aug. 16, 1881, and reported a sad accident on the Banks on the I2th, resulting in the horrible death of one of her crew, George M. Sigsworth, a brother of the skipper. Young Sigsworth and a companion named David A. Raymond had been out to set their trawls, and while returning to the vessel, a tub in the after part of the dory interfering with their rowing, they hauled in their oars to change its position. Just then a heavy sea struck and capsized the dory, throwing its occupants into the water. Sigsworth kept afloat by means of an oar held under his breast, and the air filling his oil jacket, and his companion succeeded in getting upon the bottom of the dory and holding on by the stern becket. Sigsworth made his way towards the dory, and had just reached out his hand to take that of Raymond, which was extended to aid him, when a huge shark made its appearance, and seizing the unfortunate man disappeared with its prey, who was not seen again. He was a young man of good character, about twenty-seven and a half years of age, unmarried, a native of Prince Edward Island, and had followed fishing from Gloucester for several years.

Narrow Escape.-Sch. Davy Crockett, while on Cashes, in September, $188 \mathrm{I}$, ran over her seine boat containing eleven men, and they had a lively time to save themselves. They were overhauling the seine, taking it on board the boat, when the cook, who with another man was left on the vessel, endeavored to bring her alongside the boat, but made a miscalculation in "luffing," and she struck the boat amidships. Seven of the men managed to cling to the boat; one, Christie Johnson, swam for the dory; and A. G. Eisener, Dighton Simons and Wiley Havener, happened to be good swimmers and succeeded in getting hold of the vessel's fenders.

\section{A Daring Deed.-Two Gloucester Mariners Risk Their Lives to Rescue} a Comrade.-April 2, 1881, Albert F. Fitch, one of the crew of sch. Star of the East, was washed overboard while dressing fish on Brown's Bank. He was fortunate in catching hold of a shifting plank which had washed overboard, on which he succeeded in keeping afloat for an hour and ten minutes before being picked up. It was blowing a heavy gale from the northwest, with a strong tide running to leeward, and any attempt to go to his rescue was fraught with great peril. But unmindful of the serious risk, Michael Doyle and Joseph Hackett jumped into an old dory. and started away before the wind and sea to rescue their imperilled comrade. After they got him on board of their frail boat they found it absolutely impossible to return to their vessel, but succeeded in boarding sch. Joseph 0 ., which was also lying at anchor on the Bank. It took some three hours of constant labor, 
after arriving on board the Joseph $O$., to resuscitate Fitch, and the three men remained on board the latter vessel from Sunday night until Tuesday afternoon, when the Star of the East was signalled, and ran down and took the men on board. It was a noble deed, and as such we herewith record it in the "Fishermen's Own Book."

Rescue of a Crew in an Open Boat.-Sch. Thresher, Capt. Andrew McKenzie, at this port from the Banks, May $17, \mathrm{r} 88 \mathrm{r}$, reported on the outward passage, April 22 d, lat. 46.39, lon. 58.5, falling in with Capt. E. Jeary and crew of five men belonging to sch. Flora, of and from St. Pierre. They were in an open boat and had been exposed to the elements eight days and were on allowance of one biscuit daily each. The Flora was bound to Sydney for coal, had got caught in the ice, sprung aleak and sunk. Everything was done for the comfort of the sufferers, and they were landed at St. Pierre. Capt. Jeary testified his appreciation of the kind treatment received by giving Capt. McKenzie a written acknowledgment of the same, expressing heartfelt gratitude.

Four Days and Three Nights Adrift in a Dory Without Food.Angus Chisholm and William Kénnedy left sch. Bellerophon on Grand Bank, April $\mathrm{r}_{5}, \mathrm{r} 88 \mathrm{r}$, to visit their trawls. The fog shutting down they succeeded in getting on board of sch. Solomon Poole. When the fog lifted they made another start, but were soon enveloped in the misty haze, from whose perils they escaped a second time by boarding sch. Ocean King. Nothing daunted, as soon as it lighted up a little, they made a third attempt to find their trawls. From that time their experience was the "oft-told tale." Astray upon the high seas, encompassed by a dense fog, with nothing to guide their course, and destitute of food, they rowed and rowed and rowed in their wellnigh hopeless quest for a friendly sail. To their discomforts from exposure in their frail boat, their labor at the oars, and their wearing anxiety as to their possible fate, were soon added the pangs of hunger. These they endeavored to palliate by eating pieces of raw fish, but their stomachs rejected the unwonted and unsuitable food. Fortunately they were supplied with a quart bottle of fresh water, which was carefully husbanded, and which did much to sustain and cheer them on their weary round. Only a quart of water! yet for the time to them their most valuable possession, compared with which all the glittering, wealth of the world would have been valueless. For four dreary days and three long nights their lives were one constant monotony of desolation, of fruitless longing and unfulfilled hopes. Finally, April 19, they were picked up by the bark Von Moltke, Capt. McCully, from Londonderry for Baltimore, and kindly treated. The bark landed them at Delaware Breakwater, whence they were furnished a free passage home, arriving May 3. 
Home from a Fishing Voyage via England.-Charles Beranson and William Dousey, two of the crew of fishing sch. Notice of this port, left their vessel on Grand Bank, Aug. 23, 1881, for the purpose of visiting their trawls, and becoming involved in the fog failed to find their way back. They were without provisions, but the second day adrift came across a trawl from which they took two halibut to appease their hunger. After drifting about for three days and four nights they were picked up by the Norwegian bark Tancred, bound from the West Indies for Liverpool, Eng., and in due time were landed at the latter port, where they were taken in charge by the American consul, who supplied them with clothing and other necessaries and secured them passage to Boston on a schooner, and they arrived home about the middle of October.

A Hard Time of It.-All Night in a Dory with the Oars Gone.-Friday morning, Jan. 27, 1882, sch. Emma S. Osier of this port was about four miles southwest of the Isles of Shoals. Soon after it came up squally, and she picked up her dories, all but one, which was manned by John W. Gaskell, about a mile and a half to the leeward. It was easy for him to see the vessel, but not so for those on board to see him, as he pitched up and down on the heavy seas. Capt. Osier did everything in his power to find the missing man, but all efforts to get the buoy marks in the heavy squall were unavailing. Gaskell concluding that his best chance for getting on board was to row, let go the lee buoy, on to which he was holding, and started. When he had got about half way to the schooner she kept off, and he made up his mind that there was a hard pull for him ere he could reach the land or be picked up by some vessel. About eleven o'clock a heavy sea struck the dory, breaking the forward thwart, nearly filling her. The oars were washed overboard, and there he was in a heavy sea with no oars with which to help himself. $\mathrm{He}$ at once made a drogue of his nets, adding a dozen bricks, and lay quite comfortable to it until three P. M., when it moderated, and he commenced paddling with the damaged thwart, making very good progress and keeping himself comfortably warm with the exercise, although it was hard work. At 7 P. M., being entirely exhausted, he came to anchor abreast Halibut Point. Here he passed the night, which was cold and uncomfortable, and the hours seemed long and dreary. At sunrise, Saturday morning, he was glad to see the fishing boat Pinafore come out of Rockport harbor, and paddling toward her was cordially received, and after partaking of a good breakfast he proceeded with them to the fishing grounds, arriving back in season to take the afternoon train home. Gaskell's hands were badly blistered and his fingers frozen, but he soon recovered from the effects of the exposure. His arrival home caused great rejoicing, as it was feared that he was drowned. 


\section{The Frenchman's Stew, and the Disgusted Irishmen.}

\section{BY DICK SKYLIGHT.}

On a pleasant evening in the Summer of $186-$, the sch. Clara F. Friend came sailing into Gloucester harbor, having on board in addition to her regular crew a young Frenchman, whom we will call Louis D. One night, while laying at anchor on the Bank, he had left his own vessel and swam on board the Friend, which also lay anchored about a mile distant from the French bark he had left. He could not speak a word of English at that time, but by language of signs, which is understood by all men, he succeeded in making the American fishermen aware of his desire to visit the United States, and they cheerfully acceded to his wishes, assuring him that they would take him home with them.

On arriving in port the Friend was hauled into the wharf and well secured, and, it being Saturday night, all her crew went home to stay over Sunday, leaving the Frenchman alone on board.

The following morning Louis was out bright and early, and having eaten a hasty breakfast, took a stroll around the wharves to look at the vessels and also to to get an idea of the place which he now saw for the first time. During his wanderings about he saw a pet cat on the wharf at which the vessel lay, and pussy, with trusting confidence, came running up to him, and began purring and rubbing herself against his leg. Now this was a most unfortunate thing for the cat; she took the same risk of destruction that is taken by the unwary whale which ventures inside of Race Point, or the school of mackerel that comes flipping along near Cape Ann. As the eager Frenchman took the unsuspecting feline up in his arms bright visions of a delicious soup danced before his imagination. "Now for a fresh mess!" he mentally exclaimed.

"Oh, my! ugh! the cruel, nasty thing!" exclains some fair reader, as she pictures to herself her favorite Tabby in the grasp of such a remorseless cat destroyer.

But Louis knew nothing and cared less about the prejudices of the AngloSaxon race in regard to the place which the cat should occupy in domestic economy. He had tramped the sun-burnt plains of Mexico as a soldier, served a term on a man-of-war, and lastly, dined off salt grub and skate chowders in the forecastle of a French fishing vessel, and had long before this got over being fastidious, therefore he was no way loath to indulge in the luxury of a cat stew, the principal ingredient for which he had so easily 
secured. It is not necessary to speak here of the modus operandi of preparing the stew ; suffice it to say that in due course of time it was ready.

While this was transpiring a market boat, manned by a crew of hardy Irishmen, came in the harbor and hauled alongside of the wharf at which the Friend lay. It was now near noon, and the olfactories of the new comers were greatly refreshed by the smell of the savory stew which was then in process of cooking.

Louis, being socially inclined, soon made the acquaintance of the boat's crew, and with true French politeness invited them, in broken English, to partake of his dinner. This was an opportunity for a good "feed" not to be neglected, and soon the party of six or eight were seated at the table and busily employed in gratifying their appetite, the stew being highly appreciated and praised by all the invited guests, who innocently supposed it was made of chickens or some sort of game.

"Be dad, that's a foine stew, Larry, me b'y," said one of the fishermen to his shipmate, after dinner, and while they were filling and lighting their dudeens for a "schmoke."

"Yer right there, Mike, but phat was it made of I'd like ter know ? Divil the bit can'I tell phat kind of a bird it was."

"Sure, it's aisy enough ter find out. Say, me b'y," addressing the Frenchman, "phat kind of a bird did yer make that soup of ?"

Now Louis, though he comprehended the meaning of the question, could not answer it in. English; therefore he did the next best thing, that is, quickly stepped into the forehold and brought out the "bird's" skin, which he displayed to the amazement and disgust of his visitors.

"Howly mither!" one exclaimed as he caught sight of the skin and the species of animal which had figured as the basis of the soup was made apparent to him.

"Dear Jasus!" shouted another, grabbing his dudeen in his hand, and turning pale ; "the dirty haythen has been feeding us with a cat."

A rush was now made for the deck, and never, perhaps, was seen a group of men more thoroughly demoralized and sickened than these now unhappy Irishmen. Each one seemed as intent on getting rid of his dinner as he had been to eat it, while poor Louis, the innocent cause of all this trouble, looked on in wonder, not clearly comprehending the situation, and hardly knowing what to expect.

It is not necessary to describe the closing scene more in detail, since the imagination can best fill up the picture. It is safe to say, however, that the Frenchman's cat stew has never been forgotten by any of those who partook of it, the particulars of which, as related above, were told the writer some years later by the principal actor, Louis, himself. 


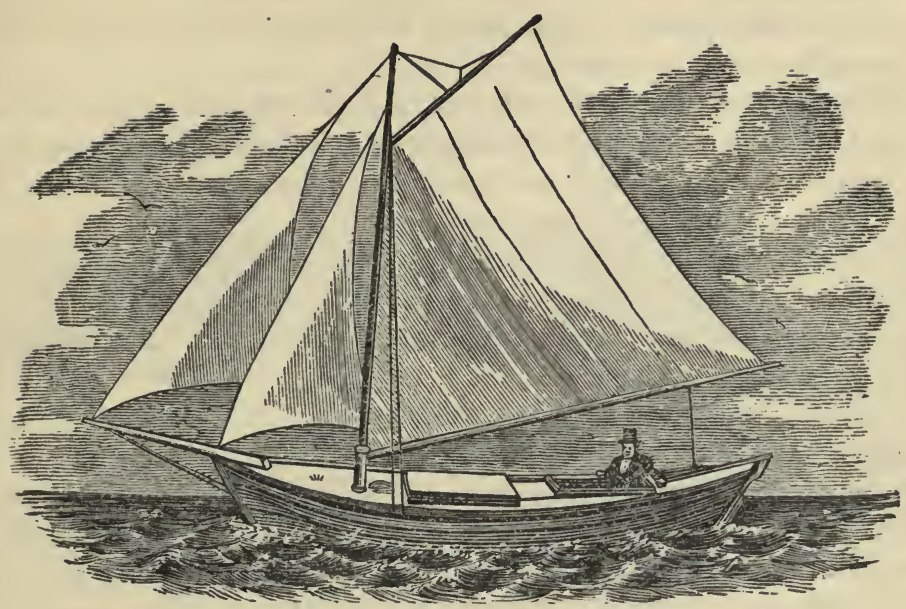

[THE DORY "CENTENNIAL."]

\section{Dory Voyagers Across the Atlantic.}

The fact that three Gloucester-built dories have successfully crossed the ocean in recent years makes it fitting that some reference should be made to such voyaging in "The Fishermen's Own Book."

A little boat of ten tons burthen is said to have come to America from the mother country in the colonial days, while of the fleet of Columbus in r 492 two were only half-decked over, and were of less than forty tons burthen.

The first man to cross the Atlantic alone was Capt. Josiah Shackford, a Portsmouth, N. H., seaman, who sailed from Bordeaux, France, in $\mathbf{1} 786$, in a "cutter-built" sloop of fifteen-tons, accompanied only by a dog, and after a passage of thirty-five days arrived safely at Surinam, South America.

June 15 $_{5}$ 1864, Capt. John Donovan sailed from New York for London in a brig-rigged yawl-boat called the Vision, put into Boston July 5 , leaking, repaired and set sail again, was spoken July 20 and supplied with provisions by an ocean steamer, and was never afterwards heard from. The Vision was 16 feet keel, $4 \mathrm{ft}$. 10 in. beam, $2 \mathrm{ft} .9$ in. deep, and had masts $19 \mathrm{ft}$. high, spreading 50 yards of canvas.

The famous little Red, White and Blue sailed from New York July 9, 1866, and made the trip to London in thirty-eight days, the shortest time known to dory voyagers. She was $24 \mathrm{ft}$. long, $5 \frac{\mathrm{T}}{2} \mathrm{ft}$. beam, drawing 18 inches of water forward and 20 inches aft, and was ship-rigged, spreading 65 yards 
of canvas. Her crew consisted of Capt. John N. Hudson, Francis E. Fitch and a small poodle.

About the same time a ten-ton fishing boat is said to have made the passage from Penzance to Australia.

In 1867 the Nonpareil, a life-raft constructed of three rubber cylinders 25 ft. long and schooner-rigged, sailed from Boston June 4 , and made the passage to Southampton in fifty-one days. She had three men on board, Capt. Mikes, George Miller and Henry Lawson.

The same month the John T. Ford, a schooner-rigged boat $25 \mathrm{ft}$. long, sailed from Baltimore with two men on board, but capsized off Waterford, on the coast of Ireland. The captain was drowned, but the other man was rescued by a passing vessel.

The City of Ragusa, sloop-rigged, $19 \mathrm{ft}$. long, $6 \mathrm{I} / 2 \mathrm{ft}$. wide and $5^{\mathrm{T} / 2} \mathrm{ft}$. deep, manned by an Austrian named Primnaiz and an Englishman named Hayter, made the passage from Liverpool to Boston in ninety-eight days, in the Summer of 1870 . The following year she made the passage from New York to Queenstown in forty days.

Alfred Johnsen, a Gloucester fisherman of Danish birth, was the first man to cross the ocean unaccompanied even by a dog. His dory, the Centennial, was built in this city by Messrs. Higgins \& Gifford, and was $16 \mathrm{ft}$.

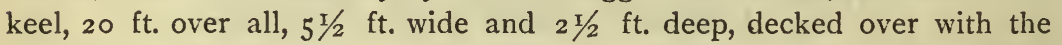
exception of a standing room and hatchway, sloop-rigged, with two jibs, mainsail and square-sail. The Centennial sailed from Gloucester June $\mathbf{1}_{5}$, 1876 , touched at Barrington, N. S., sailed again June 25 , and arrived safely at Liverpool, England, Aug. 2 I, sixty-seven days from Gloucester. Johnsen was a close calculator, and his log gave evidence that he followed the general route of steamship travel. Aug. 2 his boat was capsized by a heavy sea, but he managed to right her. Soon after, a huge shark appeared alongside, which he frightened away with a knife fastened to a pole.

Another dory, the Brittle, Capt. Madison, attempted to make the voyage from New York to Liverpool in the Summer of 1876 , and was last heard from in lat. 42, long. 46 , where she was spoken by the ship Beethoven. The Brittle was $16 \mathrm{ft}$. keel, clinker-built, sloop-rigged and decked over, with a small hatchway amidships.

The first woman to cross the Atlantic in a dory made the perilous passage in 1877 . On May 28 of that year Capt. and Mrs. Thomas Crapo set sail from New Bedford in a boat $19.55 \mathrm{ft}$. long, $6.4 \mathrm{ft}$. wide and $3.16 \mathrm{ft}$. deep, named New Bedford. She had two masts, 18 and $17 \mathrm{ft}$. high respectively, with leg-of-mutton sails. She made the passage without accident, reaching Mount's Bay, near Penzance, in forty-nine days. Capt. Crapo is now (1882) master of sch. Adelia Felicia of New Bedford. 
The Nautilus came next. She was also built by Messrs. Higgins \& Gifford, and was a lap-streaked dory ${ }_{5} \mathrm{ft}$. keel, $19 \mathrm{ft}$. over all, $6 \mathrm{ft} .7$ in. wide and $2 \mathrm{ft} .3$ in. deep. She was manned by William A. and Asa W. Andrews, brothers, of Beverly, grandsons of the late Zebulon Andrews of Essex, and sailed from South Boston June 7, 1878 . Put into Beverly and sailed again June I2, made Bishop's Rock Lighthouse in the English Channel July 28, put into Mullion Cove July $3 \mathrm{r}$, and arrived at Havre, France, Aug. 8.

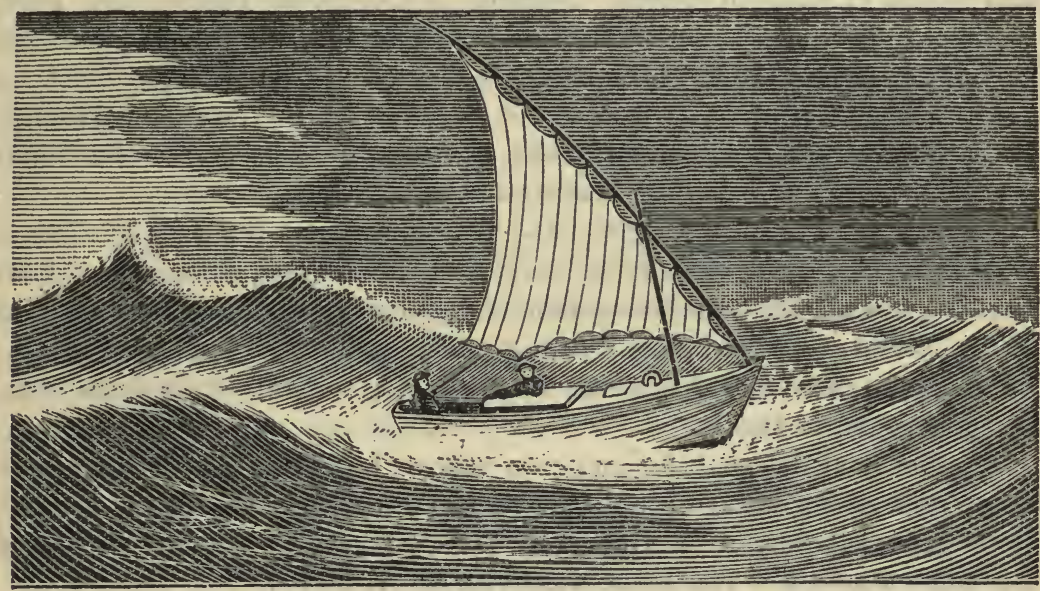

[THE DORY "NAUTILUS" IN MID-OCEAN.]

June I, 1879, Capt. and Mrs. Lewis G. Goldsmith sailed from Boston for England in the Uncle Sam, a boat $18 \mathrm{ft}$. over all, $6 \mathrm{ft} .4 \mathrm{in}$. beam and $3 \mathrm{ft}$. 2 in. deep. They were obliged to put back, sailed again June 5, put into Cape Island, N. S., June I6, arrived at Halifax, N. S., June 20, touched at Canso, N. S., July 4 and Sydney, C. B., July 7 , arrived at St. Johns, N. F., Aug. 7 , set sail again Aug. I 1 , were disabled in a gale Aug. 16, and were taken off by a passing ship Aug. I 9 and landed at New York.

Capt. Henry Otto of Baltimore had a boat built the same year for the purpose of making a voyage to Liverpool and Hamburg and back. She was $18 \mathrm{ft}$. long, $6 \mathrm{ft}$. beam, 25 in. deep and cat-rigged, but the voyage was probably abandoned, as we have seen no account of Capt. Otto embarking from port.

Capt. Herbert F. Burrill of Falmouth and Andrew R. Coan of Nantucket set sail from Boston July 9, r879, for a voyage to Australia and thence to San Francisco in the Golden Gate, a boat $19 \mathrm{ft}$. long, $5 \mathrm{ft} .4$ in. wide and 2 ft. 6 in. deep, schooner-rigged and spreading 75 yards of canvas. After meeting with many misadventures they landed at a little fishing village on the coast of Brazil, and were sent home by the American Consul at Bahia. 
The same year a "sea-tramp" sailed from New York to Boston "in a cockle shell about the size of a coffin, being forty-nine days on the passage." Two Boston architects cruised from London to Constantinople in a ten-ton yacht named Dorian.

The last Gloucester-built dory to cross the Atlantic was the Little Western, also built by Messrs. Higgins \& Gifford. She was $\mathrm{r} 6 \mathrm{ft} .7$ in. over all, $\mathrm{r} 3$ ft. 6 in. keel, 6 ft. 8 in. beam and 2 ft. 6 in. deep, clinker-built, cutter-rigged, and spread $5 \mathrm{I}$ yards of canvas. Manned by George S. Thomas and Fred. Norman. She sailed from Gloucester June 12, 1880, and arrived at Cowes July 28, forty-six days from Gloucester. She sailed from London June 14, I88I, on the return trip, arrived at Port Mechan, C. B., Aug. 28, at Halifax, N. S., Sept. 2, and at Gloucester Sept. 15 $_{5}$ being the only one of the Gloucester-built dories to make the ocean passage both ways.

The last successful venture in this line was made by the City of Bath, a dory $\mathrm{I} 4 \mathrm{ft}$. long, $5 \mathrm{ft}$. wide, $2 \mathrm{I}$ in, deep, decked over and sloop-rigged, built at Georgetown, Me. She was manned by John Traynor, Ivar Olsen and a kitten, sailed from Bath, Me., July 5, 188I, put into Trespassey, N. F., sailed again, arrived at Falmouth, England, Aug. 24, fifty days from Bath, and proceeded to Havre.

Another boat was built for an ocean venture last year, but we have seen no account of her voyage. She was $19 \mathrm{ft}$. keel, $5 \mathrm{ft}$. beam, I3 in. draught, brig-rigged, and was to sail from New York, manned by Charles Moore and Benjamin Radford. Her name was William H. Grace.

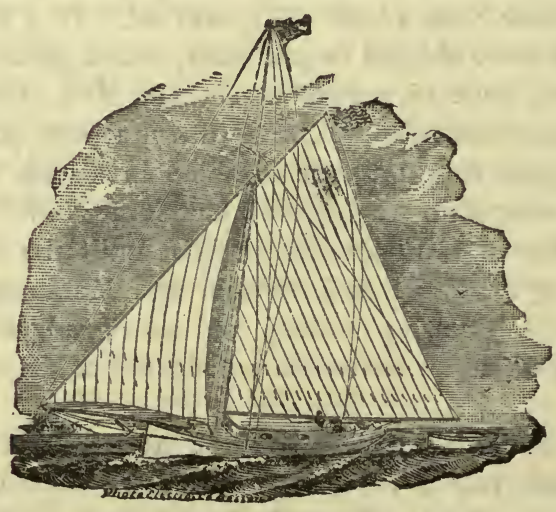




\section{[From Report of Commissioner of Fish and Fisheries.]}

\section{Life on Board a Mackerel Catcher-Mackerel Catching with the Purse-Seine.}

BY FREDERICK M. WALLEN,

\section{Norwegian Commissioner to the Centennial Exhibition at Philadelphia.}

After having waited some time for an opportunity to go to sea, to witness the business out there, I succeeded in getting a promise of a place on board the sch. William S. Baker, Captain A. K. Pearce. It was an old vessel, but a good sailer, and the captain was recommended to me as an experienced, enlightened, and generous man, who would take much interest in communicating to me all the information he could give. He had carried on the herring fishing at Labrador, halibut fishing off the west coast of Greenland, and was now determined to prosecute mackerel fishing in the sea north of Boston.

Late on a rainy evening I was informed that the vessel was now ready to sail, in Gloucester Harbor, and that I could come on board. Neither the weather nor the vessel particularly invited one out in the dark, foggy night. But after being shown a tolerably good bunk astern, where besides myself four of the crew had quarters, I soon found myself adjusted and anxious to get under sail. Early in the morning we cast loose and the vessel hauled out into the channel. But the wind was still; we could make no headway. While we waited for the wind a portion of the crew passed away the time by taking a bath and swimming out into the deep. Their invitation to me to swim a race with them I was in the notion of accepting, when the signal was given to make sail and get under way. All came on board, took off their swimming clothes, put on dry clothes, and caught hold at the anchorbreaking and later at the hauling out, so that it was a pleasure to see them. The brutal execution of discipline, so often censured on American merchantships, did not exist on board here. The whole crew were native Americans, active and experienced fishermen. They associated with one another with good-will, eating at a common table to us all, and carried on their work with mutual satisfaction. Neither beer nor whisky is found on board ; but warm coffee and tea can be had from five in the morning to six o'clock in the evening. In other respects the victuals were good and nourishing, consisting mostly of beef, pork, all kinds of fresh fish, different kinds of pie and pudding, sometimes vegetables, with eggs occasionally; in short, about as 
in a frugal municipal family in Norway. The men were not hired, but had half the weight or a half share of the profits, which were calculated after the expenses of salting, packing, barrels, \&c., were deducted. The cook, who besides the usual work in catching had to prepare the meals, got besides for his part $\$ 27.3 \circ$ per month. The trip just ended had been made in three weeks, and had yielded a profit of a little over $\$ 8 \mathrm{r} .90$ net per man, which is considered a very good trip. The crew in herring fishing, on the contrary, is generally hired. They ship at $\$ 10.92$ to $\$ 13.65$ per month for boys; $\$ 32.76$ to $\$ 40.95$ for able-bodied fishermen.

After being under sail a couple of days we saw a whole fleet of mackerel schooners. There were between eighty and ninety sail, some of which had made a light catch. We passed some steamers which carried on menhaden fishing, and which went into port every evening to unload. These vessels were quite recognizable by this, that they had two men on the lookout in the cross-trees, on the foremast, and the rest in boats prepared for fishing. Among other sail we passed also an old-fashioned French-rigged vessel, which carried on mackerel fishing with trolling lines; the vessel was belayed and went before the wind. A crew of ten men stood to leeward, and each man with at least two hand-lines, which he incessantly cast out and hauled in, while two men ground bait (in a hand-mill) and threw out "chum." The catch was poor, and the mode of catching, itself, most fishermen had given up for capture with purse-seines, which have superseded all other implements.

While crossing back and forth we often saw máckerel schools playing in the water, but they vanished suddenly. The folks told me that one could smell mackerel as well as menhaden when the large schools of fish were in the water. I entertained doubt of the truth of the information, but in the following week I became perfectly convinced of its authenticity. Early one morning one of the crew said that he smelt menhaden, and went immediately aloft on the foremast to discover the school. A half hour later we saw a school playing on the surface of the water; it was large mackerel. In haste everything was made ready; the purse-seine, which lay on the after hatch coiled up in a bundle and wet with brine (to prevent rotting), was quickly flung down in the seine-boat, which was kept constantly in tow ; next, two small boats set out, so-called "dories," flat-bottomed, light-rowing boats, half "sjagte" and half lighter. These are said to be the best fishing-boats known. When all was ready I leaped down into the boat, and away it went. After a half-hour's rowing the seine-boss found that the time had come to row in on a large school, which played quite delightfully. In three minutes the seine, of about $25^{\circ}$ fathoms, was rowed out and cast in a circle around the school. After ten minutes more the seine was pursed, and in it they estimated that they had caught 300 barrels of mackerel. A dory was sent with a message on board the schooner, which was managed by the cap- 
tain and a small boy; after a little manœuvering the schooner sailed close to the seine, got a portion of the cork-line on board, so that the catch was brought between the vessel's side and the seine boat. A large dip-net, with tackle and a long handle, was made ready, and in a few minutes the living mackerel were thrown upon the deck by the half-barrel. The captured fish in the seine became, in the mean time, very uneasy, and rushed from one side of the seine to the other; suddenly the seine burst in many places; they sought to haul in the seine, both in the boats and on board, and after much trouble they succeeded in retaining and heaving on board a total of about $5 \circ$ barrels. The rest of the mackerel escaped through the large holes in the seine.

As soon as the catch was secured on board they took in all sail and began on the preservation of the mackerel. With small dip-nets the fish were thrown in a square trough, and from this, as they were cut and washed, they were assorted according to size. The fish was split or cut in the belly (?) about as cod which are manufactured into split fish. While sprinkling them with salt they give them some slight cuts in the back to make the flesh swell and give the fish a fatter and fuller appearance. This is a trick which both the sellers and buyers understand. Twelve men are engaged at a time with the salting, while the remaining two men examine and repair the seine. In the space of two and a half hours 47 barrels stood ready salted. For every four barrels of fish was required one barrel of Liverpool salt, the packing being done later on shore.

The next morning at 6 o'clock we were again in the boats, made a new cast, but caught nothing. At 8 o'clock we were again out, went half way round with the seine, when the whole school sank to the bottom. We caught nothing. The mackerel were wild and shy, played a little at the surface of the water, but vanished quickly, to emerge again farther away. The mackerel schools were very large this day; for as far as we could see on all sides they were playing on the surface of the water. We made no catch notwithstanding. The captain's attempt to entice the school with "chum" also failed. At I I o'clock we again made a cast, but took only eight mackerel. At 2 o'clock, P. M., we made the fourth cast and got a couple of barrels ; at 4 o'clock, another cast, and took Io barrels, but small mackerel; and at 6 o'clock we made another, but got almost nothing save small fish. This was a laborious day ; but, notwithstanding, we were the next day, at 5.30 in the morning, again in the boat, made a cast, but simultaneously the school turned around and made their escape. We saw many schools also this day, and at 6.30 we were again on the way after one. This time we were successful. They estimated the catch in the seine at 400 to 500 barrels. They were very large and fat mackerel. After some trouble, the vessel sailed to us, got a portion of the seine on board, and the taking in the fish was about 
to begin. But the fish were very uneasy in the seine; sunk to the bottom with such force that the boat was on the point of capsizing, although we placed eight men on the other gunwale to counterbalance the mackerel. At one time all went smoothly enough to haul in on the seine and make the purse smaller and smaller to prevent the frantic rushing of the mackerel. But suddenly they sank again to the bottom, careened the boat over so that we took in a quantity of water. We were scarcely ready to place ourselves on the other gunwale when we felt that the boat suddenly righted itself and lay still. The most knew what had happened; it was that the mackerel succeeded in breaking the old seine. Through a large hole, which became larger and larger, about the whole school escaped; and although we in all haste hauled in on the fragments and tried to form a new purse, we succeeded in saving not more than 5 in the whole 500 barrels.

At 9.1 5 we set sail for the nearest port; it was considered useless to attempt to mend the more than half worn-out seine. After a day's quick sailing, we reached Boothbay in the evening. In the harbor lay a schooner just arrived, which was filled to the rail with fresh-caught mackerel. The crew worked the whole night in preserving them. With resignation our crew saw this work. Had we had a better seine, we would also have had remunerative night-work in salting some hundreds of barrels of mackerel. The next morning I left the vessel, to return to Gloucester by steamer and railroad.

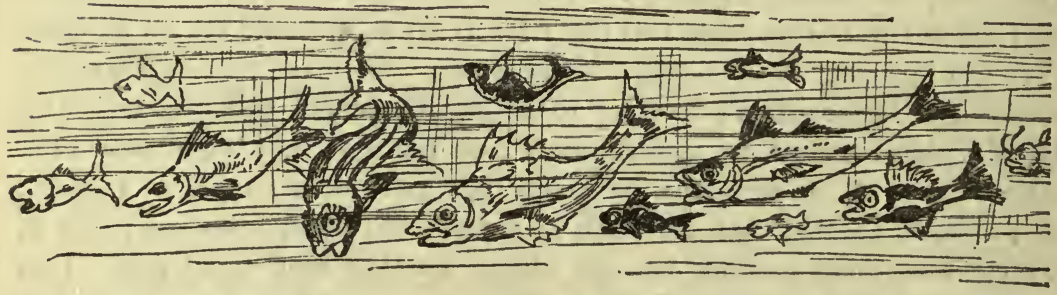




\title{
The Merry, Merry Mackerel Catchers.
}

\author{
BY JACOB S. LORD.
}

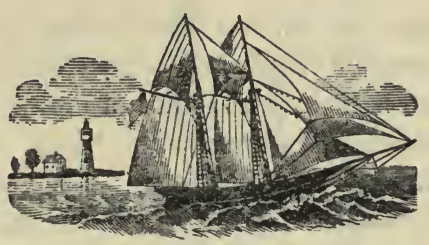

Then it's laugb, "Ha! ha!" and shout, "Hurrah!"

We are bound for the coast of Maine;

Our hold is well stored with salt and food,

In the boat we've a fine new seine.

The sun goes down as we round Eastern Point-

For Monhegan our course is laid;

The watch is set--the pipes are lit,

And a game of cards is played;

A lively lad has a song to sing;

Uncle Ben has a yarn to spin;

So pleasantly passes the time away

Till eight bells, when all turn in,

Except the lonely watch on deck,

Whose measured tramp is heard

As smoothly o'er the water skims

Our vessel like a wild sea-bird.

It is break of day-the sun peeps up,

The morning's clear and cool,

Aloft the lookout makes his way,

To sight the early school.

He espies the fleet-they are dead aheadAnd right lustily does he shout

To the skipper, who nervously walks the deck,

"Yes, yes, the boats are out."

Now all is life on the schooner's deck, As she ploughs thro' the sparkling brine;
Her erew in oiled clothes anxiously wait For a chance to wet the twine.

"A school! a school!" from the foremasthead

Is the lookout's exciting call;

"On the weather bow! it's showing red, Can't say if it's large or small."

"Come down from aloft! haul up the boat! Out with the dory, tumble up here, cook!

Work lively, lads-yes, cast her off, Pull out, and we'll have a look.

Hold! way enough; ah, there they riseGood fish! I should say they were fine; Now gently start her ahead, my boys, Quick, seine-master, give them twine!

Pull hard, my men! now bend your backs! Lively! over with the corks, my friend;

That's way enough-take on your oars, Pass along the dory's end;

Jump to the purse-line, one and all, Give a long, strong and a steady pull; The rings are up-yes, take them on; By Jove! I believe she's full."

And so it proved-of number twos, Right cheerily did we bail

Till the skipper cries, "We've got enough, She's full from rail to rail."

All night we worked at split and gib, Next day they were salted down.

As the sun sank low in the ruddy west, We made sail for Gloucester town. 


\section{Saving the Cable.}

\section{BY DICK SKYLIGHT.}

One of the chief dangers to which a véssel at anchor on the Banks is liable, is that of having another vessel drift across her bow during a gale. If this should happen there is little probability of either of them escaping destruction. We had such an experience in the "gully" between Banquereau and Sable Island, on the 23d of June, 1877. The wind, which had blown fresh all day, increased towards sunset, and there was a sharp combing sea running. We paid out all our cable and cleared up things on deck. Just as it was growing dark I saw the Lizzie-which was lying directly ahead of us-break adrift and fall off broadside to the wind and sea.

At first I thought her crew would heave in her cable and set sail to clear us, but as she kept drifting and had no riding-light up, I was reluctantly forced to the conclusion that the watch on board of her was asleep. If that was the case, the only thing to do in order to avoid a collision was to cut our cable and go adrift too, unless we could sheer our vessel away from her path. The tide was running to leeward, so that we had some command over our vessel with the helm; one man was, therefore, stationed at the wheel ready for action; the jib was cut loose, and a rope taken from the clew to each bow, so that we could sheer the vessel either way, as the case should demand. When the drifting vessel was about two hundred feet distant, she was driving right athwart our hawse, so that our jib-boom pointed straight between her masts. We had previously fired our gun several times; but as there was no sign of life on board of her, the moment to try our plan had arrived. While I stood ready with the axe to cut the cable in case of a failure, the wheel was quickly put hard-a-starboard, the jib run up and hauled well over on the starboard bow, so that it caught aback, and our vessel slowly sheered to port, while we held our breath in suspense. The manœuvre succeeded very well indeed, for we passed around her stern without striking. It was a close shave though, for her main-boom cleared our rigging by only a few feet. The quietness and good order that our crew had observed, while danger threatened and discipline was necessary, were now broken by a general yell, which brought the other crew on deck, bareheaded and stocking-footed, to receive, from my justly indignant men, some remarks and advice that were certainly forcible if not polite. But we saved our cable, and, as a consequence, could continue fishing, and therefore felt thankful that nothing worse had happened. 


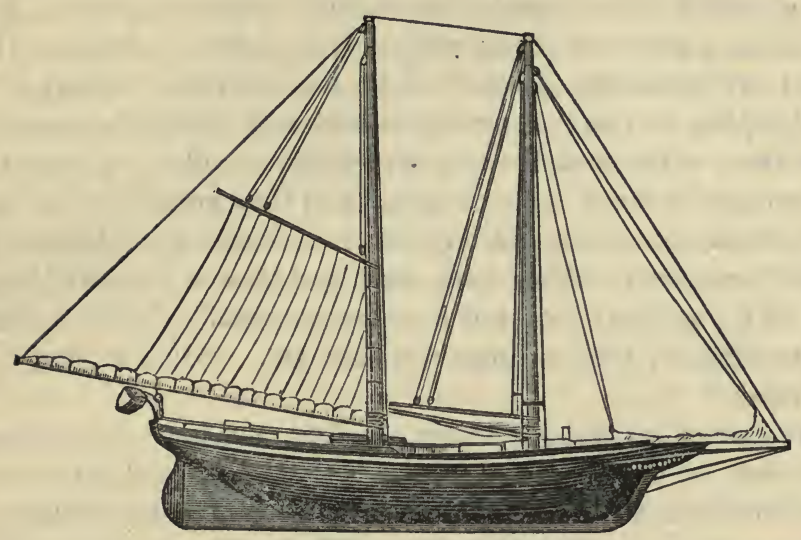

[MODEL OF A GEORGESMAN, 1882.]

\section{A Summer Trip to Georges.}

BY WALTER HILL.

Outward Bound-Soundings-Lively Work-Pulling in the Cod and Halibut -A Good Fare-Homeward Bound.

As our bait is iced, and we are all ready for a start, you had better jump on board and take a trip with us. We hoist mainsail and foresail, trip the anchor, fill away the jib, and stand out of Gloucester Harbor. That little island with the lighthouse on it, which we are leaving on the port or left hand side, is Ten Pound Island, outside of which is the outer anchorage, and still beyond is Eastern Point, also on the port hand, on which you observe is another lighthouse. To the westward of us the land stretches away to Salem and Marblehead. Now turn and look at the scene we are leaving. Beautiful, is it not? The city of Gloucester is stretched out like a panorama. The City Hall, a noble building, and the church steeples, are the most prominent features; not forgetting the Pavilion Hotel on the beach. The innumerable fishing schooners, standing in all directions with their snowwhite cotton sails, give an animation to the scene not often equalled. Away on the starboard quarter you may catch glimpses of the high-road to Magnolia and Salem.

And now, with a freshening breeze, the sun dipping to the westward, and the land gradually fading behind us, we are bowling off with our head eastsoutheast for Georges. There'll be fish on deck before to-morrow night if 
the wind holds good and fortune favors us-that is, if you don't turn out to be a Jonah! Fishermen are pretty superstitious, and have a great belief in Jonahs. Should it unfortunately happen that we do not make a good trip this time, being a green hand, you will surely be dubbed a Jonah. However, greenhorns are generally assumed to be lucky till the contrary is proved; which will explain to you the suaviter in modo with which they seem to treat you. But there is the cook blowing his whistle to call us to supper; so we will go down and make a "square meal," and then prepare for a nap.

"Hallo, there! rouse out, old boy; do you calculate on sleeping all day? The whistle went for breakfast long since, and the old cook will be clearing the table off if you don't soon put in an appearance." Make a good breakfast, and no signs of the landsman's malady yet. "Glad to hear it; you're quite a Trojan."

We have carried a spanking breeze all night, and have come about sixtyfive miles since we started. Suppose we round her to and get a cast of thelead; one hundred and twenty fathoms of line out, and no bottom. We'll stand along a while longer. Meanwhile, I'll rig a line for you to fish with. We use two hooks to each line with a snood of about one and a half fathoms to each hook, depending from the bottom of the lead. Having got a basket of bait up from the hold, we'll take another sound; seventy-five fathoms, hard bottom; we'll have a try here, lads. Down go the lines, and, bye-and-bye, Tom commences hauling. "What have you got on, Tom? A snapper (a small codfish), I guess, I've got something small on, too." They're too small here to pay us, so we'll go further for a field. My olfactories inform me that the cook is progressing favorably; so we will have dinner before sounding again. I don't want to make any invidious remarks, but the sea air seems to act magically on our appetites. Now for another sound; sixty fathoms-that's better. "By Jove! that jerk was from no small fish. There, he smells around again. Aha! I've captured you this time, old boy." Hallo! Tom, Harry, Dick, all hauling as if for a wager. Bear a hand, boys, and heave that anchor off the bow before she drifts away from the "school." We're on fish this time, and no mistake. Let her have a good scope of cable, and furl the sails. There! we are all snug.

And now, gentle reader, whoever you may be, for whom I rigged that line, you may take the next berth alongside of me and try your luck. Heave over your snoods with the baited hook first, and then the lead, taking care that the snoods go down clear, as on that depends whether you haul up one fish or a pair. Hold the line in check a little, as it runs down, or the tide will run it out in a bite, and it will foul the other lines coming up with fish on them; and then you'll get-anything but blessings. Directly you feel your lead strike bottom, haul back a little, so as to leave the hooks dangling at or near the bottom. That's very well; watch the rest and you'll 
soon get initiated. There! you have got a bite, and a good one, too; haul steadily away, you'll find sixty fathoms a long haul, but that won't trouble you after a day or so. He's alongside, take him aboard with the gaff. I've got a pair coming, too. That won't do, however; your hands will soon get torn and scratched if you try to unhook the fish before killing him. Hit him on the head with a short stick the first thing after you get him on deck. There's a knack, too, in unhooking; see how easy it comes to me-a twist and a jerk, and it's all done. Faster and faster the fish begin to come ; everybody working like beavers; the fish hooking themselves as fast as the lines reach the bottom. What a scene of animation! Some gaffing in fish, others killing, some unhooking, and others, again, clearing a foul. H-s-s, h-s-s, see your lines! By Jove! my boy, you've got a halibut on. Easy now. That fish is worth a five-dollar bill to you if you get him up. There he snubs-give him line-don't hold him too hard, or he will break the gear. He is beginning to stay his downward course-hold him. Now he runs up; take in the line smartly, or he may unhook himself. H-s-s, h-s-s, he's taking another downward dive and making the line smoke again. Stand by to haul him away. as he tires. Up he runs again. Keep him well in

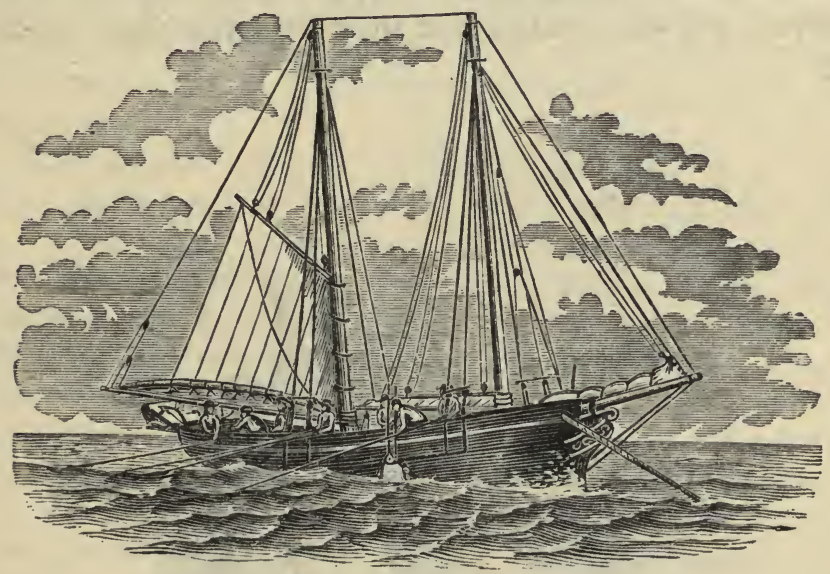

[GOT A HALIBUT ON.]

hand now ; stand by with gaffs, here, two or three hands. There he heaves in sight. A one hundred and fifty pounder, at least. Stick the gaffs in his head, and be sure to get a good hold. Now, then, yeo! heave-ho! all together! up with his flat lordship. Slap, oh! he falls on deck, and such a floundering, thrashing time of it you never saw. Hit him a tap or two with the killer just over the nose. That quiets him. Now get him away clear of the gear, and heave your lucky line over again. 
Thus we go till near nightfall, when we haul in lines and dress the fish secured. Two gangs form to dress down, one on each side of the vessel. One man pitches the fish along into the tub for dressing; the next cuts off the head and slits the fish down the belly; a third takes out the gut and deposits the liver in a basket by his side; while a fourth "splits" the fish and takes out the backbone; and from his hand it goes into a tub of water, and thence into the hold of the salter. The halibut are then gutted and put into the ice-house, as they have to be kept fresh. We've got, to-day, about I, 000 pounds weight of halibut and 3,000 pounds weight of codfish-a very good day's work, considering it was dinner-time when we struck fish. A week of this fishing, and we shall use up all our bait; but then, it is seldom fish stay in one place so long in Summer time.

It is now ten days since we got on the Bank, and, although we did not keep the first "school" round us more than three or four days, we have been fortunate enough to strike them again since, and have made a rousing trip, after all-about 35,000 pounds weight of salt codfish and 4,000 pound weights of halibut. The crew will make about fifty dollars apiece on an averagenot a bad fortnight's work. As the wind is fair, I think we may put her head for Gloucester. Things don't always go so smoothly as they have this trip, however; and sometimes we beat about for days without meeting with anything.

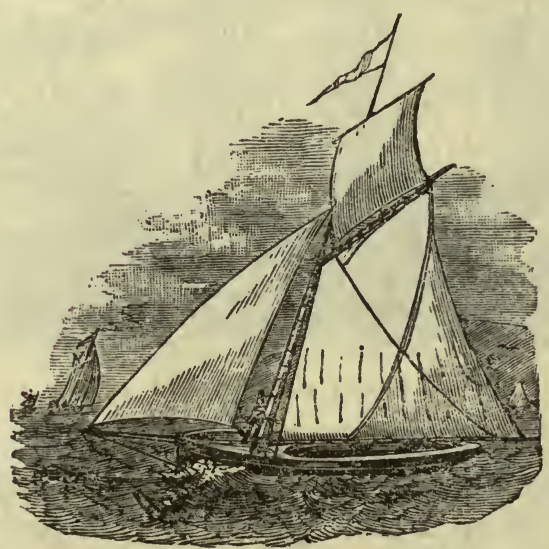




\title{
Rob's First Cruise.
}

\author{
BY S. G. D.
}

It was an event of importance when John Wayne bought the Phillis with the accumulated savings of many years, and began to go master of his own vessel. $\mathrm{He}$ and his wife Margery had discussed the matter many times and weighed the pros and cons carefully before the purchase was completed. And when the bargain was fully concluded, and the Phillis was brought round to the little cove before the cottage door, the repairing and painting and outfitting of the Phillis was a topic of ever fresh and all-absorbing interest to John and Margery, and Rob and little Ran; and the fishermen at the cove, and all the boys in the region roundabout came by twos and threes to critically inspect and comment on John Wayne's craft.

Proudest of all was Rob. "Father 'll go skipper now," he remarked gleefully. "I'll tell you what, I shall be skipper a good part of the time when I play with the cove boys, that is, if I play with them any more now. I think I am big enough to leave school and go cook. Can't I go, father? I shall be thirteen next Spring, you know, and I have got to the Rule of Three in arithmetic."

John Wayne thought, however, it would be wiser for Rob to keep on at his ciphering awhile longer, and when the long Summer vacation came, he should go two or three trips and see how he liked fishing. But he must learn a little about cooking first. And with that Rob had to be content.

Did ever the weeks of a term of school before stretch out so endlessly? Long before vacation came Rob had become quite an adept in the making of bread and molasses short-cake, and in the preparation of various dishes adapted to the menu of a Galilee fisherman. But, as an end comes to all terrestrial things, tedious howsoever they may be, so there came a blissful day when Rob danced home with his books, too happy to walk soberly, now that the vacation had really come. And for once he was in great luck; for the Phillis was in and would be ready to sail for the fishing ground the first of the following week.

What a perfect Summer morning it was when Rob proudly sailed away on his first cruise just as the rays of the rising sun illumined the sparkling sea. Margery fondly looked after her boy so gaily swinging his hat, and her husband standing at the tiller, till she could distinguish them no longer, and then she watched the Phillis till it was a mere speck on the blue waters of the bay. And when she turned to her morning tasks how still and lonely 


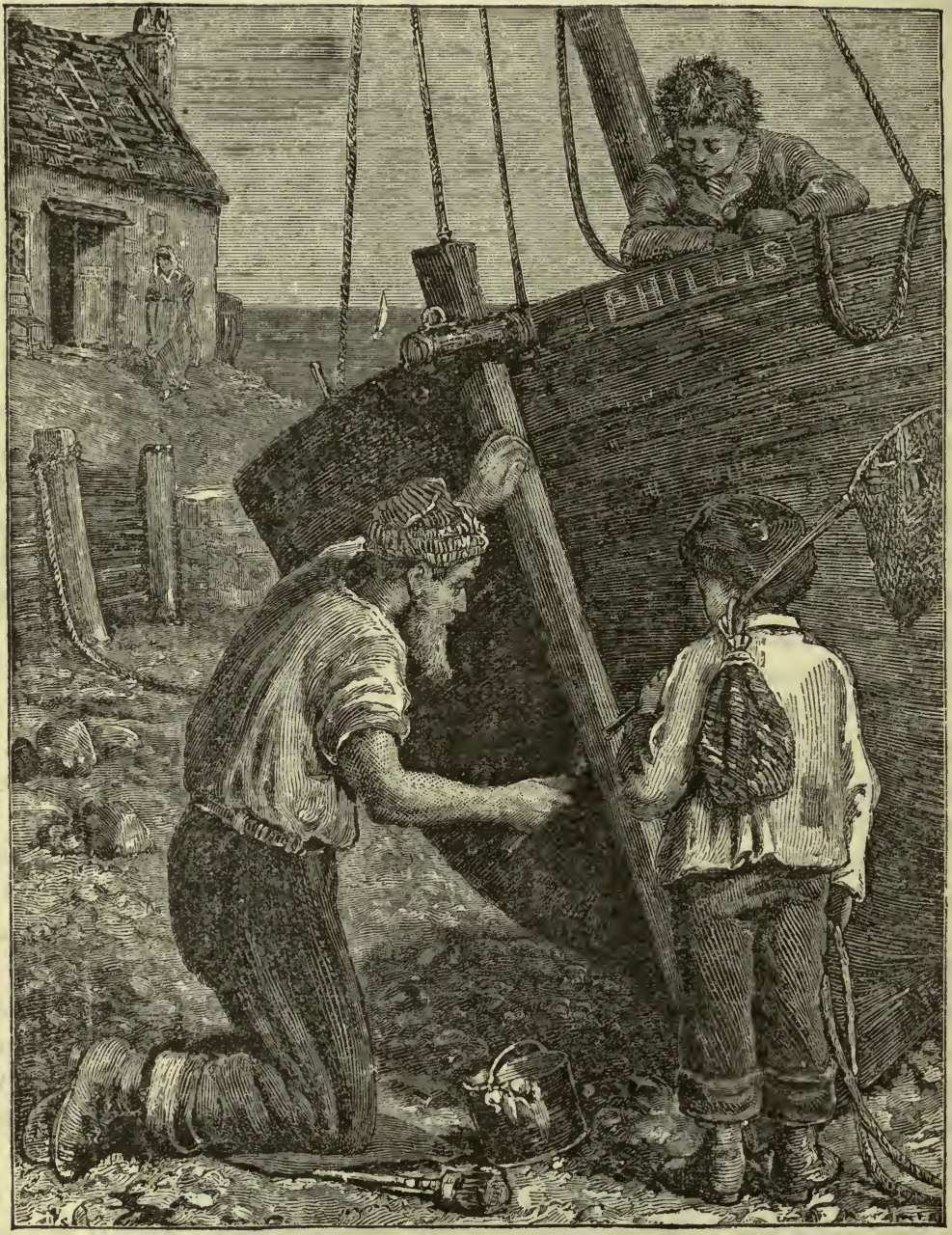

GETTING THE "PHILLIS" READY FOR THE SEASON'S WORK. 
the house seemed now that her noisy boy was no longer in it. Little Ran was still quietly sleeping, and it would be perhaps two or three hours before he would wake and want his breakfast. Margery sat down to do a few rows on her net, but the stillness was so oppressive that it presently became unbearable, and she arose and went out to work awhile in her garden, in the dewy freshness and coolness of the morning.

Bye-and-bye she heard Ran's voice at the open window. "Where is Wob ?" he asked.

"Rob has gone with papa in the Phillis. Don't you remember he carried his clothes aboard last night? He got up very early and went away while you were fast asleep."

"I want Wob!" was the response, with a gush of tears.

Margery's heart echoed the cry as she went in to console her little one and to get him his breakfast of bread and milk. The day was long for Margery, and long for little Ran, who missed his playmate. And when he went to bed he asked, "Will Wob tum in the night?" And in the morning the first question was, "Will Wob tum to-day?" And the questions were daily asked, morning and night, during Rob's absence.

The days went by one after another, till a fortnight had passed, and it was time to look for the Phillis. And Margery, sitting at her net, or chatting with some neighbor who had come in, often looked out on the bay, hoping to catch a glimpse of a white sail that was dearer to her than all the other white sails flitting to and fro on the broad blue sea.

There came a day when the Summer sun shone fiercely down on a parched earth. All the morning there was an ominous stillness in the air. There was no note of bird or sound of insect, and even the waters for once seemed hushed into absolute silence. When Margery had finished her midday meal, she went to the door and sent a sweeping glance over the darkening waters. She saw a sail-yes, it was the sail she longed to see. But what a lurid light filled the air, and what threatening clouds were piling up in great masses towards the zenith. "O if they were but here," she sighed.

The storm broke long before the craft Margery's eyes so eagerly watched could reach a haven. How the lightning flashed, and the thunder roared, and the wind swept round the little house on the headland! How the rain poured in a blinding sheet, that shut out from Margery's sight the vessel on the tossing billows of the bay! She drew back from the window, and clasping closely Ran in her arms, she waited for the power of the tempest to be spent. Hours passed by, but still the wind blew a gale, and the rain fell in torrents, when the shades of night gathered, and darkness covered the face of the mighty deep.

A sleepless night it was for Margery Wayne, and when day dawned, though the rain had ceased to fall, a turbulent, stormy sea was still lashed 
and vexed by the wind. And as it grew lighter not a sail was to be seen on the bay. Where was the Phillis and her crew?

It was nearly noon, when one of the cove boys burst open the cottage door, and cried out abruptly, "They've found the name of the Phillis over there on the rocks, and they're bringing it up here."

Pale and speechless, Margery sank into the nearest seat. Ran felt that something had happened. "What is it ?" he asked; "Is Wob tummin and my faver?"

"O Ranold, Ranold," cried his mother, "your father will never come home any more, and Rob will never come back to us!"

The sign was brought up and laid on the grass-plot before the door. Yes, it was the very sign that John Wayne had painted with such patient and loving care. In what fearful moment was it wrenched from its hold, and where now were the timbers of the Phillis scattered, and where alas! was the brave crew?"

One, two, three days went by. It was a golden Summer afternoon, and the sea was as gentle and placid as if it had never been storm-tossed. Margery, pale and listless sat, slowly drawing her netting-needle in and out through the meshes of her net. She was stunned. It was not possible yet to think of the future, and so she went on doing mechanically as she had done. Ran, rosy, dimpled and dewy-eyed, scarcely awake from his afternoon nap, stood looking out of the cottage door. His long silence attracted Margery's attention. She turned her head wearily to see what he was doing.

"What is Rannie looking at?" she asked indifferenly.

"My faver's boat," said the little one sturdily. "My faver is tummin some more, and Wob, too! I sees 'em my own self."

Margery's heart gave a great throb. Another instant and she stood beside Ran. Did her eyes deceive her, or was it a phantom craft that was rounding the headland and sailing so noiselessly into the little cove? Was it really her husband giving directions to his crew, and Rob himself waving his hat as joyously as when he sailed away, or were her senses leaving her?

Ah, yes, she notes now, with a sob of relief, that the name is gone from the bow, but the vessel otherwise seems as staunch as ever.

The Phillis had been blown off shore and somewhat strained, but had received no other injury save the loss of her name, which had been insecurely fastened and which the capricious waves must wash up on the cove rocks, and so cause Margery Wayne such days and nights of anguish. The vessel itself had been in a safe harbor before dark on the night of the storm.

Rob had come home in high feather. He had been all about the city with his father while the Phillis was lying wind-bound. His father had found a good market for his fish, and Rob had taken part of his earnings to buy for himself a four-bladed knife, and for Ran a most wonderful gun, 
that could be half cocked and wholly cocked, and that would make a great noise.

Rob went three trips that Summer, and he was quite a hero among the cove boys when he went back to school in the Fall. His knife was the envy and admiration of all the other boys, and often while he was busy carving elder into fanciful shapes, he was wont to hold forth to an eager audience his narrative, invariably commencing, "When I went my first trip in the Phillis-"

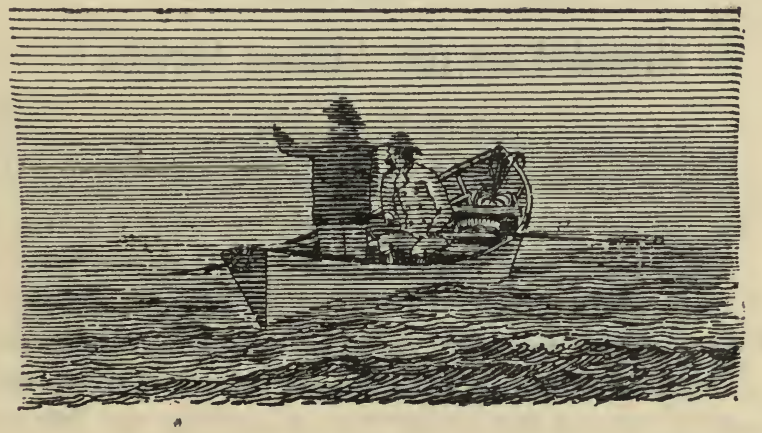

\section{Lost in the Fog.}

In the preceding pages are given many instances of fishermen lost in the fog on the Banks, and of great sufferings caused thereby from hunger and exposure. The above engraving did not reach us in season to be placed in that chapter, so we insert it here. It illustrates an instance where two pour fellows are thus adrift on the wide expanse of waters. One is standing up, pointing, seemingly, at some slight object which may be dimly discerned, to which the attention of his companion, who has stopped rowing and is anxiously looking, is directed. Or it may be that they are holding a consultation as to which dierction it would be best to pull, in order to meet. with some vessel or fall in with the land, and thus escape the perils which surround them. It is a perilous position to be placed in, especially without food or drink, and we do earnestly hope that each dory while on the grounds. will in future be well provided with these important articles. 


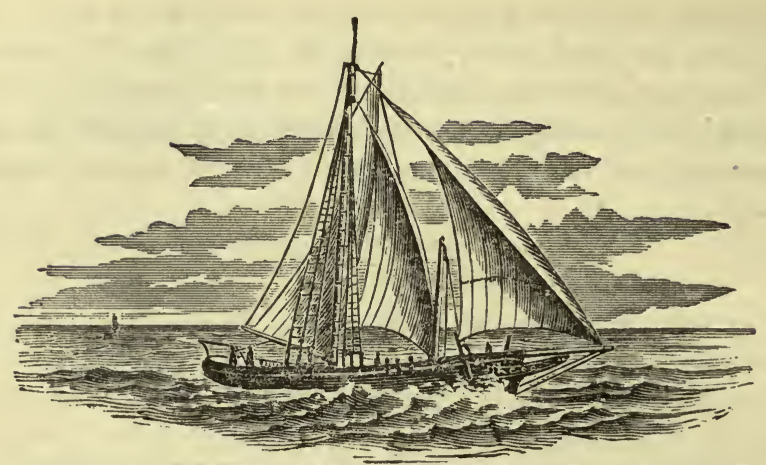

\section{Crippled on the "Home Stretch."}

BY DICK SKYLIGHT.

No branch of the fishery is so uncertain, as to the returns, as that for halibut. One vessel may get a high price for her fish, while a second, a few days or hours later, by striking an overstocked market, may receive not more than half as much. As the success of the trip therefore depends very much on the rapidity of the homeward passage, sail is crowded on, even to the point of extreme danger, and the "home stretch" frequently becomes the most exciting part of the whole trip, demanding the best seamanship and skill on the part of the skipper and crew.

Fishermen as a class take especial pride in the sea-going qualities of the vessel they sail in, and esteem most highly her ability to carry a crowd of sail in a fresh breeze. This particular pride is often more forcibly exhibited-perhaps recklessly so-by the men composing the crews than by the skippers, since upon the latter rests the responsibility. It is sometimes quite amusing to overhear some of the remarks of the men on deck in relation to carrying sail. "I tell yer what 'tis," says one to his watch-mate, "the old critter's stiff 's a church." "Yes," replies the other, " the old gal can wear her muslin 'bout 's long 's any of 'em. I don't believe them they blow so much about can stand it much longer; not if the old man's a mind to lug it on her." This desire to "lug it on her" is expressed, too, when the little schooner is probably buried all under water on the lee side, and the spars and sails are strained to the utmost. On more than one occasion I have, myself, barely escaped evil consequences from carrying a "taut rag" when homeward bound.

One night in March, 1878 , we left the Grand Bank just at the commence- 
ment of a southeast storm, which rapidly augmented in fury. About 3 o'clock in the morning all hands were called to take in the staysail, after which the dories were turned bottom up and lashed securely. This work occupied about an hour, when all but myself and the watch went below. The night was intensely dark, and all that it was possible to see was the sparkle of the spray as it flew from the bow, and the luminous phosphorescent track behind our vessel, as, with her sheets well off, she rushed through the waters and the darkness like a great black-winged spectre. A half hour later I again called all hands: "Get on your oil clothes and stand by the halyards," is the order. Hardly had this been done, when a squall struck us almost with the force of a thunderbolt. Feeling the vessel settling, I shouted to the man at the wheel, "Let her come to," and to his watchmate, "Let go the main-peak halyards." At the same time I sprang to the main-throat halyards and tried to get them clear, but could not, owing to the darkness, and the fact that they were not belayed as usual. In the meantime our little vessel came near going to the bottom, for she was under water from her cat-head to the taffrail, on the lee side. When the man at the wheel first heard my order, he put the helm down, but, finding the vessel was going so low, kept her off again (thinking that the safer thing to do), at the same time climbing on top of the wheel-box to get out of the water. His watch-mate, though floated off his feet on the lee side, let the peak halyards go by the run. This reduced the sail considerably, and, the first fury of the squall being past, the "old boat" shook off part of the water, and, still running at an appalling rate, kept afloat until we could shorten sail still more.

On another occasion, in the Spring of 1876 , while running for home in a northeast gale, our vessel was "sprawled out" by heavy seas twice in one day, being knocked down so that her sails were in the water, and the lee side completely buried. The night preceding the day on which we were knocked down we had a tussle with the ice, immense floes of. which, in the Spring of 1876 , were driven by a succession of northerly winds nearly to the edge of the Gulf Stream. We were running under a double-reefed mainsail, whole foresail and jib (with the bonnet out) -all the sail we could stagger under-when, a little after midnight, the watch shouted down the companion-way: "Hear the news there below! rouse out, here's ice close aboard!" It needed no second call to bring us out, for all realized the danger of meeting with ice while running at such a rate; if the vessel struck a heavy piece her bows would be crushed in like an egg shell. As for myself I hurried on deck in my shirt sleeves, and, jumping into the rigging, climbed far enough above deck to get a good view, and clung there for nearly two hours directing the wheelsman how to steer to avoid coming in contact with either the floe or straggling pieces of ice. The latter, which 
were of various sizes, were really the most dangerous, since they could not be seen so quickly. It was bright moonlight, however, which was much in our favor, and by taking in the foresail we reduced the speed of the vessel, so that we passed safely by hundreds of isolated ice cakes, any one of which would have knocked in our vessel's bow had she struck it. With the wind blowing a northeast gale and sweeping down from such a vast body of pack ice as lay to windward, the air was keen and biting, as may easily be surmised, and when at last we had cleared the last of the lolly-ice* which strung out to the leeward of the main floe, and the increasing motion of the vessel gave evidence of open water to windward, I crawled down out of the rigging, but was so thoroughly chilled through that I could scarcely stand.

As there was possible danger of meeting more ice, and the wind had increased somewhat, I concluded not to set the foresail before daylight. When we cleared the ice we were nearly a hundred miles south of the latitude of Sable Island, and were therefore obliged to steer W. N. W., which brought us almost in the trough of the sea. Having warmed myself, and ordered the watch to "call me if there were any indications of ice, or increase in wind," I turned in. The sea increased very much towards morning, and a little after daybreak we were tripped and knocked down; the mainboom went under nearly to the mast, parting the boom-tackle; one man in the forecastle was thrown from a weather into a lee bunk, and another who was lying in a berth on the lee side was scalded by the contents of the coffee pot which came tumbling on top of him from the stove on the opposite side. Altogether there was quite a mixing up of things, but almost before we had a chance to realize the situation, the vessel was back on her bottom and tearing along on her course again. Not caring, however, to repeat the performance, if we could avoid it, we set a doublereefed foresail, took in the mainsail, and bent the riding sail in its stead. Under this canvas we kept along on our course, though, such was the danger of being sprawled out again, that I staid on deck all day directing the man at the wheel how to steer to escape the ugly cross seas that quite frequently came along. It was anything but pleasant, to be sure, to run a vessel under such circumstances, but nevertheless we kept her going, swinging off almost before it sometimes, and hauling to on our course again when a chance offered. In this way we went along safely until about sundown, when, being very hungry, I went below for a lunch, first giving the man at the wheel the order to "Watch her sharp; swing her off quick if

*Lolly-ice is the name given to the fine ice which generally extends to a greater or less distance to leeward of field ice. It is formed by the grinding together of the larger pieces, and being of small size, and, of course, comparatively little under water, usually drifts to leeward faster than heavy ice. 
you see a bad one* coming, and let her take it stern to." I had scarcely seated myself on the weather side of the forecastle table, with a piece of bread in one hand and a mug of tea in the other, when the vessel was thrown completely on her beam ends. Dropping whatever I held, I sprang for the companion-way the instant I felt her going over. But the water, rushing over the top of the companion doors, met me as I gained the top of the steps, and as the vessel was at that time lying flat on her side, the prospect of her righting again before she filled looked rather dubious. There was a strong probability, too, that the man at the wheel had been washed overboard, or injured, and if such was the case the vessel (should she right) would be in dainger of broaching to and having another sea sweep over her. Fortunately, as in the morning, she soon straightened up again, and I jumped out on deck and ran for the wheel. By the time I reached the main hatch, though it took scarcely an instant, the wind struck into the sails, and the vessel, starting ahead with a rush, drew herself out from beneath the water under which she was buried from the mainmast aft, and which went dashing and splashing out over the stern and both rails as our "old boat" once more rose buoyant on top of the waves. So far under water had the stern been that the wheelsman-a six footer-was entirely submerged when the vessel righted, though he stood on his feet, still retaining his grip of the wheel; the men in the cabin were nearly smothered by steam and gas which was driven from the cabin stove by a stream of water which ran down the stove pipe on to the burning coal. Barefooted, bareheaded, and panting for breath, they were glad enough to get out on top of the house where they might get the fresh air.

Although we had met with little or no damage, from being sprawled out twice, it was, nevertheless, a little more than we had advertised for, so we hove to for a few hours. until the moon rose, when, the sea having gone down somewhat, we started again on the home stretch.

"Eternal vigilance is the price of liberty," it has been well said, and the foregoing will show that the success and safety of the winter fisherman demands almost as great watchfulness and circumspection, since the incidents mentioned above are only two of hundreds that might be related.

*A sharp and heavy cross sea, which would be likely to break aboard and sweep the deck, if nothing worse happened. 


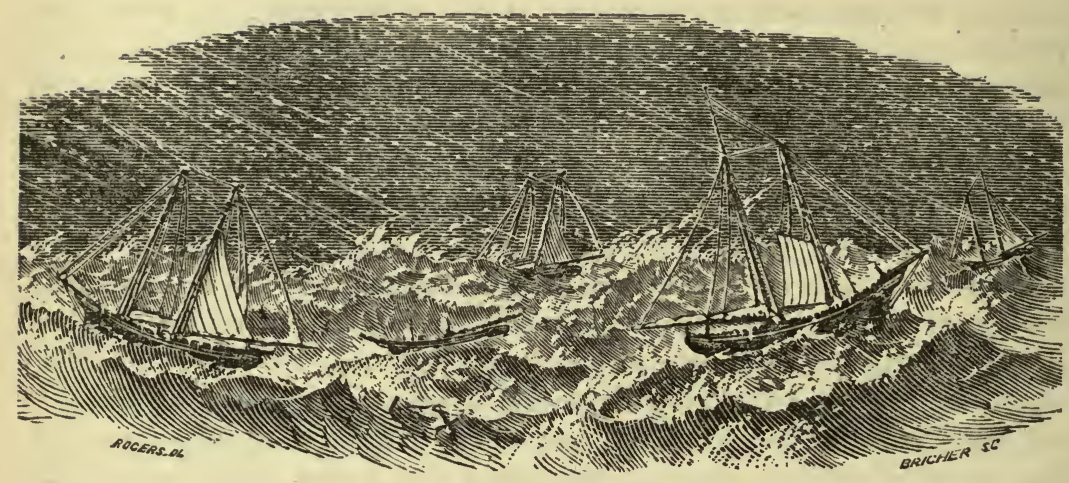

\section{The December Gales of 1876.}

The gales which swept over the fishing banks on the 9 th and 16 th of December, 1876 , were terrific. All who were exposed to them and returned to port affirmed that in all their experience nothing was ever encountered which would compare with the fierceness of the winds and the waves and the narrow chances which beset the fleet exposed to their fury. Herewith we publish the accounts of our interviews with the skippers. These gales swallowed up ten vessels, and ninety-eight men were buried beneath the treacherous billows, the full particulars of which will be found under the appropriate heading.

Experience of Sch. "Augusta H. Johnson"-Her Captain Obeys a Premonition and Saves a Man's Life.-Capt. George A. Johnson of sch. Augusta H. Johnson, left Banquereau on the 7 th of December for home. Encountered the gale on the night of the 9th. A 7 o'clock came to anchor thirty miles to the westward of Sable Island. The wind blew a perfect hurricane with an ugly sea running. Parted at 11 o'clock; hove in the cable, and at 4 o'clock on the morning of the roth anchored again; parted again at 7 o'clock; a tremendous sea boarded her at 9 o'clock, which stove five dories, broke fore-boom and fore-gaff in two places; took three hundred fathoms of cable from the weather side to leeward, when John McDonald, one of the crew, got caught in the coil and received severe injuries. Run her from ro o'clock A. M., to 2 o'clock P. M., when the storm abated, and put on sail for home. Was in Shelburne, N. S., r 7 th, and on the morning of the 18th saw a disabled brig about thirty miles off Seal Island. A barque was near by, and Capt. Johnson concluded that she would give all needed 
assistance. Then a strong impression came over the captain to board the brig, and he could not shake it off. He was extremely desirous to keep on his passage home, but the impression weighed on his mind. He felt uneasy. Go on board the brig! was the mandate plainly given, and he could not dispel it. Finally he obeyed the premonition, and with four of his men he boarded the brig in the dory. It proved to be the Wildhorse, coal laden and abandoned. (She afterwards went ashore at St. John's Island.) Capt. Johnson got sail on her, and after she got well on her course he descried an object as far ahead as he could see, which resembled a man on a cake of ice. He at once called attention to it and signalled to the schooner. With all speed they hastened to it in the dory, and on drawing near, what was their surprise in finding a man clinging to the bottom of a boat which was painted white, thus giving the appearance of an ice cake in the distance. It proved to be Mr. Gottfried Frankfurt, mate of barque Seazeod, who with three men had boarded the brig, and upon their return the boat was capsized alongside. Two of the men succeeded in getting on board, leaving Frankfurt and a seaman named Peter Anderson, in the water. They both succeeded in clinging to the boat's bottom; the barque drifted away, and ere the men on the vessel got their boat ready the two were out of sight. They had cruised around, and not succeeding in finding them, had given them up. The cold was most intense, with a heavy sea, and for two hours Frankfurt had managed to hold on to the submerged boat, with the water up to his breast, the sea beating over him and the cold piercing his vitals. It was a terrible struggle for life, and his companion succumbed to the fearful ordeal, and slipping off the boat disappeared beneath the waters! The suffering man was taken on board the Johnson, where kind hearts and willing hands administered restoratives, and he escaped without any serious illness. The probabilities are that if Capt. Johnson had kept on his course and not heeded the premonition, the man would have been drowned, as he could not possibly have held on but a few moments longer. Who can account for such a premonition? Surely it was not of the captain's seeking, as he was opposed to heeding it, supposing that the barque had rendered all the necessary assistance, and he wanted to get home. The Seawood arrived at Portland, where the mate joined her.

Loss of Sch. "Daniel A. Burnham."-Sch. Daniel A. Burnham, Capt. James Nickerson, was capsized on Grand Bank in the gale of the roth, carrying away both masts level with the deck. The crew remained on the wreck five days, suffering great hardships, when they were taken off by a steamer and carried into St. Johns. The wreck was in a sinking condition when the men were rescued. They lost everything, and were more or less injured from exposure. 
Experience of the "John Dove"-A Tough Time of It.-Sch. John Dove was exposed to the full severity of the gale of Dec. I6th and $\mathrm{I} 7$ th, on La Have Bank. On the 16 th one of the crew named Augustus Brown fell overboard, but being an expert swimmer, kicked off his heavy rubber boots and struck out bravely for the vessel. Ropes and tubs were thrown over from the vessel, but the tide was running strong and the current bore him away from them. The cable was paid out until the vessel backed down to where Brown was swimming, and he was taken on board, after having been in the water about eight minutes. Early on the morning of the 17 th a tremendous sea broke over the vessel, sweeping the decks, carrying away two companion-ways, smashing dory, staving rail, breaking the wheel-box, demolishing the cooking stove, and doing other damage. But for the parting of the cable the vessel must have foundered. One of the crew, Maurice Wiley, was washed against the companion-way and had his face severely cut. The Dove put into Halifax on the $23 \mathrm{~d}$ for repairs. She had rough weather all the time after leaving port, being three times blown off her fishing grounds, once a distance of some seventy-five miles.

Experience of the "Ruth Groves."-Sch. Ruth Groves was knocked nearly bottom upward by a heavy sea, her foremast carried away to the deck, and lost mainsail, main-boom, and main-gaff. Two of her-crew, Chas. Cook of Lockeport, N. S., and Joseph Teddy of Sydney, C. B., were swept overboard and lost. The crew were obliged to pump and bail all night to keep her free. Some sails were rigged and a drogue put out. They steered for Liverpool, N. S., which they reached after a dangerous passage. Charles McKinney, one of the crew, was thrown out of his berth upon the stove, and was so severely burned that he was sent home in sch. Howard.

Sch. "Edwin C. Dolliver," Capt. John Thompson, from Western Bank, reported the gales as very severe. Lost three anchors. On the Irth of December saw brig Lucy in a disabled condition on the southern part of the Bank; took off her crew of eight men and brought them to this port. The vessel soon after sunk. She was commanded by Capt. James Irving, loaded with coal and potatoes, and bound for Cuba.

Sch. "Riverdale," Capt. Forristall, while lying at anchor on LaHave Bank, in the gale of the gth of December, was struck by a heavy sea, which swept the decks, smashed three dories and sent them adrift, and carried away everything moveable. The vessel was hove on her beam ends, and the cabin and forecastle filled with water. The cable parted, and the crew shifted the salt and fish in the hold, and the vessel righted. The Riverdale lost her other anchor and cable in the gale of the 16 th, and was obliged to put into Halifax for repairs. 


\title{
Fearful Experience on Board Schooner "Howard."
}

\author{
BY J. W. COLLINS.
}

There are few, indeed, who have never experienced it, that can form any adequate idea of what it is to ride out a gale-a regular "sneezer"-at anchor in mid-ocean, where even the staunchest ocean steamers are like playthings of the mighty elements. As a rule, a fishing vessel rides like a seagull, gallantly breasting the waves that go seething and swishing by, although the violence of the wind often makes the little schooner tremble like an Autumn leaf, as it rises on the top of a huge wave to plunge the next moment down its opposite side. Nevertheless, an "unlucky sea" will occasionally break on board, and, if the man on watch is not on the lookout for it, he is likely to be injured if not washed overboard. But, whatever the danger to individuals, a lookout must be kept, for in a gale many most serious perils threaten, which can only be successfully met by utmost care and vigilance.

It frequently happens that after a long day (often eighteen or nineteen hours) of fatiguing work at fishing, the weary crew, with the exception of the watch, turn in for the much needed sleep. It may be scarcely an hour later, when the watch goes below and, giving the skipper a shake to waken him, says: "Cap'n, it's blowing again like great guns, and I think she needs the rest of her cable ; you'd better turn out and look at it." Of course there is no shirking this duty, and the skipper, knowing he is not called without good reason, tumbles out of his bunk, puts on boots and sou'-wester, and goes up in the companion-way, greeted, the moment he thrusts his face outside, by the full force of a nor'west snow-squall. The roaring of the waves as they go rushing by, the dismal howling of the wind through the rigging, added to the darkness of the night, intensified by the blinding effect of snow and hurling spray, leave no choice but to order the watch to "call 'em out, for'ard," while at the same time the shout, "Come! rouse out here! we've got to give her the whole string," wakes the heavy slumberers in the cabin, and the half-asleep and thoroughly disgusted men crawl on deck with many cbjurgations and odd, but innocent remarks.

". What kind 'er weather d'ye call this!" one growls out; while another exclaims, "If I had the job, and couldn't make any better, I'd give up the contract and hire out to a farmer." The air with which the closing sentence is uttered plainly tells that, in the mariner's estimation, the lowest degradation one could possibly reach would be to "hire out to a farmer."

But this is only cheap talk, and, notwithstanding the danger from shipping seas, the crew soon muster around the windlass, and sufficient cable is 
veered out for the occasion, often amounting to three hundred and fifty or four hundred fathoms, if there is a heavy gale, and the vessel is in deep water, though on the shoal part of the Bank, in thirty to fifty fathoms, much less cable is required.

In ordinary gales fishermen are rarely anxious for their safety, for, like veteran soldiers, they come to think little of their perils, and while the storm howls, the vessel rolls, staggers, rises and plunges again, the crew off duty will frequently gather in the cabin and "pitch in for a sing," and at such times groups of four often improvise a low table on the cabin floor, and have a game of "Seven Up," or "Euchre." Exclamations of "Swing for his Jack," "That makes us game," and the like, are sometimes interrupted by a dash of water down the companion-way, which obliges everybody to scramble to their feet to save themselves and the precious cards from a wetting.

But furious hurricanes often sweep across the Banks with almost resistless fury, carrying destruction and death with them, and appalling even the stoutest hearts. Such was the terrific gale of Sept. 9th and roth, 1876 , in which many staunch vessels succumbed to the power of the wind and waves, carrying down with them the hardy and daring men who formed their crews.

The writer was then in command of the sch. Howard-one of the very few, if not the only vessel, to hold on and ride out the gale at anchor. The vessel was on Banquereau, and the following extract from a letter gives the principal incidents of the occasion :

On the morning of the $9^{\text {th }}$ of December we made sail* before daylight and got all ready to set our trawls, but by the time it was fairly light it blew up smart from the southeast and began to snow. We lay by for awhile around the Andrew Leighton and her dories, some of which were out. After an hour or two, finding the wind increasing fast, we ran in on the Bank until we reached a depth of sixty fathoms, where we anchored and got all ready for a gale. The southeaster blew heavy, but was of short duration, being about what Winter southeasters generally are.

The night of the $9^{\text {th }}$ the wind jumped in to west-northwest, and towards morning of the roth blew very heavy; so hard indeed that, fearing the riding-sail would go to pieces, we hauled it down. The riding-sail, which belonged to another vessel, and which we had taken temporarily, was a new one which had no reef in it, as did our own. The latter had been left ashore, as it was too old for a Winter trip.

The gale increased in fury, and after daylight blew extremely hard, while, to make matters worse, the tide set out to run to the southward, hawsing the vessel up in such a manner that she lay almost in the trough of the sea.

*Set mainsail and jib. We had been lying to during the previous night under a foresail. 
There was a fearful sea going, too, I think the worst I ever saw; but we did not ship any heavy water before eight o'clock, A. M. Just before that hour I went up in the companion-way and spoke to the man who had the watch, and who was busy aft by the wheel-box clearing the log-line, or some other small gear which had been fouled up by the water washing it about deck. He was standing with his back to the sea, totally unmindful of his danger. As I went below I said to him, "Keep a good lookout for yourself, George ; keep your eye to wind'ard, for there are some nasty seas coming along." "All right, skipper, I'll look out for myself," he replied in a cheerful tone. His watch was just out, and the man who succeeded him was nearly ready to go on deck as I went below.

I had not been in the cabin more than a minute, when a tremendous sea broke on board abaft, or about the main rigging, swept aft with resistless force, knocking the companion-way slide to as though it was struck with a trip-hammer, ripping two boards off of it; also the bait planks off the house ; and last, and most appalling of all, sweeping the unsuspecting man (George Miller) into the foaming and seething waters astern, so far away as to be beyond the reach of all human aid. A feeling of horror, like an electric shock, passed through me as I heard the roar of the breaking waves and the peculiar swishing sound of the waters rushing across the deck, and I exclaimed to the man who was standing by the steps ready to go on deck, "My God! Silas, I'm afraid that sea has washed George overrboard." Reaching up, Silas shoved the slide back, and we both sprang on deck. But what a sight met our eyes! More than a hundred feet astern and drifting with the current, every moment still farther away, we saw the poor fellow rise to the surface, struggle for a few seconds, and then, buried beneath a huge wave, disappear forever from mortal sight, while the shrieking and howling winds sounded a requiem over his untimely grave. Sad, indeed, were the faces of our crew when it became known that we had lost a man.

However, we had but little time to indulge in regrets or sorrow, for the gale, which had then increased to a furious hurricane, compelled us to make extra endeavors for the safety of the vessel and our own lives. She hawsed up so badly soon after the event just described, that we were compelled to set the riding-sail to keep her more nearly head to the sea. We reduced the size of the sail as much as was practicable, by making a "bag reef" in it. This was done by tying up the clew and lashing the bottom hoops together, which being done, we hoisted it up a little before nine o'clock, A. M.

Shortly after the riding-sail was set, we had a succession of tremendously heavy snow squalls, which blew with a fury I never saw equalled or even approached during an experience of thirty years battling with the Atlantic storms; while the snow was so dense that, when we were in the hollow of a sea, the top of it could hardly be seen. The Howard quivered and trem- 
bled like a stricken dolphin, as she struggled with great apparent effort up the steep sides of the mountainous waves, which threatened to bury her beneath their curling crests. Even with the small sail which we had set-a mere rag in size-and lying nearly head to the wind, she buried her lee side nearly to the hatches. To walk against the blast was out of the question, and all one could do was to haul themselves along by the life-lines,* or cling to the rigging for safety. She plunged so heavily into the waves that the jib was soon washed loose from the bowsprit. While I was in the cabin after a rope to secure it, a second heavy sea boarded us, breaking over the port bow, covering our little vessel nearly out of sight beneath a deluge of rushing water and flying spray. When the men on deck saw it coming they sprang for the rigging. Two of them, who got on to the fore-gaff, held on to the peak halyards, clinging to the ropes with their hands and legs. The sea broke so high that both of these men were nearly washed clear of their hold, although they were eight to ten feet above the deck. The latter was filled with water nearly to the tops of the rails, compelling us to knock off some waist boards so that the vessel would clear herself.

Between the squalls we managed to secure the jib, though it was extremely hazardous going out on a bowsprit in such a gale. The squalls had the most terrifying appearance that I ever witnessed, as they came tearing down from to windward. Black as night and driving the white foam before them, they were an awful sight, and enough to strike terror to the hearts of those who never felt a sense of fear, and who, even then, when death was imminent, bravely faced the storm, disdaining to flinch from the peril which duty and self-preservation called them to meet.

Fearing the cable would part, and feeling sure that the vessel would be knocked down on her beam ends if she fell off with any sail set, I stationed myself at the mainmast, whenever the squalls came along, ready to let the riding-sail run down if necessary. When the fourth squall was coming I took my usual position, standing on the bit-head of the fife-rail with my right foot, and grasping the riding-sail halyards with my right hand. While I was standing in this position, and in the midst of a flurry of flying snow, a ball of lightning $\dagger$ burst between the masts, and I was knocked insensible to the deck. Others of the crew were slightly shocked. As soon they could, the men who were on deck ran and picked me up, thinking I was dead, and carried me below.

I would not speak of the intense suffering which I endured for four hours

*During heavy gales life-lines are generally rigged by stretching, on each side of the vessel, a rope from the fore-rigging to the main, and from that aft to the davit.

+ The men who saw it said it was like a ball of fire, and burst between the masts like a rocket. It is probable that a fragment ran down the wet rope to which I was clinging, and struck my arm. 
-hours of dreadful agony-while I was being resuscitated, were it not to mention the conduct of my men, all of whom showed a devotion and nobleness of spirit rarely equalled and never excelled. Though in almost momentary expectation of death themselves, they continued their efforts for my relief with extraordinary zeal and coolness. Fortunately I could speak soon after being taken into the cabin, and was thus able to direct what should be done both for myself and for the safety of the vessel.

We had only three more squalls after I was struck by lightning; those were not so heavy as the previous ones, and after they were past, the wind soon subsided to an ordinary gale.

After recovering sufficiently to examine my injuries, I found that the lightning had ploughed along my right arm from the wrist to above the elbow, scorching it severely; while five smaller burns were on my right leg below the knee, mostly about the ankle. My right side was paralyzed, and I could not stand on my feet for several days.

We started for home as soon as the gale was over, but had a long, hard passage. My burns were so painful that when we got as far as Liverpool, $\mathrm{N}$. S., we went in there for medical assistance, and arrived home the $23 \mathrm{~d}$ of December.

\section{THACHER'S ISLAND.}

BY THOMAS J. PARTRIDGE.

Hail, ye stately columns on that rock-bound isle, That cast your lurid warnings far out for many a mile, To warn the hardy mariner of the jagged rocks so dread,Who safely into harbor by your brilliant lights is led.

How sad to part from one who has proved a friend in need, Or wave adieu to loving ones who come to say, "God-speed;" Thus must the sturdy fisher feel as he leaves thee far astern, Bound off for Georges stormy Bank, perhaps ne'er to return.

Majestic forms! you rear your lordly heads as if to emphasize The great and glorious good that's done by thy two fiery eyes, And when the golden sun is hid behind Bond's rocky sod, You throw them far out o'er the sea, from Boon Island to Cape Cod.

With what an anxious, beating heart have fishers watched for thee, When almost home from the Grand Bank or Fundy's stormy sea; By sigus, log, compass, and by chart and reckoning, they knew That Thacher's welcome twin lights must soon come into view.

Watching as only mortals watch wheu they know the port is near That holds within its sacred walls all they consider dear; And when at last their eye doth rest upon thy garnished domes, Then bubble up four English words-wife, children, rest and home. 


\section{Foundering of Schooner Almon Bird.}

Terrible Sufferings of Her Crew-Four of Them Die-Praiseworthy SelfSacrifice of Cape Ann Fishermen.

Sch. Almon Bird of Rockland, Me., for Alexandria, Va., loaded with plaster, encountered a severe northeast gale off Monhegan, Sunday evening, Jan. I, 1882. At two o'clock, Monday morning, the sea made a clean breach over her. The vessel continued to ship heavy seas, all doing more or less damage, and at seven o'clock, A. M., when about half way between Boon Island and Thacher's Island, some thirty miles off shore, the after hatch was stove in by a sea, and the vessel commenced to fill, and there was nothing to do but to take to the boat and trust to the chances of being picked up. One of the boats, containing the only pair of oars, had been washed overboard.

Her crew list was as follows : C. A. Packard, master, of Rockland, Me.; William H. Harriman, first mate, of Prospect, Me.; Charles Chaples, second mate, of Rockland, Me.; A. B. Henderson, steward, of Friendship, Me. Seamen-Allen Small and Horace Small, brothers, of Deer Isle, Me.; Fred. Hamilton and Patrick Hogan, of Rockland, Me.

All were strong, able-bodied seamen, except Horace Small, who was a frail lad of sixteen years, who had never been to sea in Winter time, and who ran away from home to join his brother on this voyage. He had been struck by a heavy sea, knocking him against a cask, breaking his wrist. Mr. Harriman, the mate, was also injured in the groin while attempting to save the oars. The hatchet was lost overboard in attempting to cut away the jib-boom, and the axe shared the same fate while being used to cut away the main rail to launch the boat, which was finally got afloat and hastily manned, as the vessel was fast sinking. The injured lad was taken from the forecastle and put into the boat, but he had no oil clothing, and there was no time to get him properly dressed. A few bed clothes and an old coat was thrown into the boat, and about a peck of hard bread in a small barrel was put on board, with about a quart of rum and three or four quarts of oatmeal. Water they had not, and they were without oars or tools except a hand saw. In about ten minutes after taking to the boat the schooner went to the bottom.

Before leaving the sinking craft, the mate constructed a drogue, and after taking to the boat the barrel containing the ship bread was stove up, and with the staves and a new thwart which happened to be in the boat, some rude paddles were improvised. The boat lay to the drogue Monday and 
Monday night. Tuesday morning a fishing schooner was descried in the distance, but she passed out of sight. Tuesday afternoon a blanket was fastened to the jib and the boat was under sail for a time, but at night it breezed up, and fearing in their benumbed and exhausted state to attempt to unship the mast and take in sail, the mast was sawn through just above the thwarts. The icy spray dashed constantly over the boat, freezing as it fell, and everything was covered with a coat of icy mail. The drogue kept the boat's head to the sea, but the waves constantly deluged her, and the exhausted men were employed all night in bailing. The uncooked oatmeal was uneatable, the hard bread was at first so dry as to be swallowed with difficulty without water, and afterwards so wet with the spray as to be unfit to eat, and the sufferings of the men from cold, hunger and thirst were excruciating. Two of the number, Chaples and Hogan, though warned of the consequences, endeavored to slake their thirst by eating salt-water ice, and the presence of two maniacs was soon added to the other horrors of the situation. The quart of rum was carefully husbanded, by administering a teaspoonful at a time, and was made to last until the early part of Wednesday evening.

On Wednesday morning a new step was made to the mast, and the boat sailed westward all day and all night. In the afternoon another schooner was sighted, but she did not see the boat. During the night a hermaphrodite brig passed close by and was hailed with weakened voices. The cries were doubtless heard, as the brig showed a flash light two or three times in the darkness, but kept on her course and was soon out of sight. About ten o'clock in the evening, the sixteen-year old boy, who had suffered greatly from his broken wrist and insufficient clothing, died in his brother's arms. He was conscious within an hour of his death, when he said he was not afraid to die, and left a loving message for his mother. He had left home unbeknown to his parents, who did not know his whereabouts until they received the telegraphic dispatch announcing his death. The young Irishman, Patrick Hogan, died about an hour after the boy. He had been delirious about six hours, talking constantly about something to eat. The second mate, Chaples, was delirious about twelve hours, babbling incoherently all the time. In his delirium he seized the saw, and before he could be preverted, sawed his hands terribly with it, the blood spurting over the boat. He died about three o'clock, Thursday morning, and his body was committed to the deep.

At daylight on Thursday morning, three fishing vessels were descried at no great distance. One of these proved to be the sch. Cora Lee, Capt. George A. Saunders, of Pigeon Cove. Her crew consisted of John Hickey, Scott Geyer, John Newman, Joseph Sears, Joseph Silva, William Grant, Edward Saunders, Joseph Bushy, Joseph White, Joseph Muise, Charles R. 
Goodwin, James E. Tinker, Edward Griffin, and were engaged in setting their trawls. When they discovered the unfortunate mariners they immediately went to their rescue, and towed the boat to the vessel. The sight was one never to be forgotten. The mate, who alone was able to do anything, was steering. In the bow lay two dead bodies, frozen stiff and covered with ice, so that when the shore was reached they had to be cut out of the boat with a hatchet. The captain was lying in the forward part of the boat, with both feet frozen above the ankles (he had been thoroughly drenched before abandoning the vessel and had no oil clothing excepting an oil-skin coat), and the other survivors were half sitting, half reclining about the stern. Hamilton's legs were frozen half way to his. knees, and he died on Friday evening. The steward and Allen Small suffered less from the frost, and the mate had the tips of his fingers only, frozen. The boat was half full of ice and covered with blood, and presented a ghastly spectacle.

The sufferers were speedily taken on board the Cora Lee, put in berths, their clothing changed, and their frozen limbs wrapped in salt. The friendly fishermen stripped off their own clothing to cover the frozen sailors, and some of them came on shore with nothing on but a suit of oil clothes. Tea, water and rice broth were administered to the rescued men in small quantities, and the vessel abandoned her trawls and started for home. The wind was light and she was nearly all day coming in. When about eight miles off, Capt. Saunders and two of his crew rowed ashore and made preparations for the comfort of the shipwrecked men. Several dories went out to meet the Cora Lee and tow her in, taking on board Drs. Sanborn and Tupper, who ministered to the wants of the sufferers in the cabin, and when the vessel arrived at 7 P. M., a team was waiting to take the men to Mrs. Ann Pierce's house, where they received the kindest attention.

The captain and crew of the Cora Lee are entitled to much credit for their prompt action. Despite the remonstrances of Capt. Packard they abandoned their trawls, of a value of $\$ 180$, and lost their trip with a probable profit of $\$ 200$ or $\$ 300$ more. An attempt was made to recover the trawls, but in order to do so it was necessary to locate an unmarked spot two-thirds of a mile in length, situated forty miles from shore, and the search proved unavailing. A sum of money was subscribed, which partially compensated for this loss.

The Almon Bird was valued at $\$ 16,000$, and there was very little insurance on her. Capt. Packard was also a heavy loser, losing his instruments, charts, clothing, gold watch and chain, etc., of a value of $\$ 600$ or $\$ 700$; and after arriving home he suffered amputation of portions of his feet.

In this sad recital of suffering, one thing is prominent-the generous outpouring of volunteered kindness, offered from all sides, by scores of persons, eager to help the distressed mariners. To mention all the helpers would 
be to call the roll of almost the entire community of Pigeon Cove. First of all, special credit is due to the brave captain and men of the Cora Lee, who, at risk and great personal loss, rescued the men from their perilous condition; then to Mrs. Pierce, who freely opened her entire house to the wrecked men and their numerous attendants. Mrs. Corrinna H. Bishop made welcome donations of clothing to every man, and added other contributions; Mrs. Levi Robinson assisted freely, and numerous noble women acted as nurses many weary hours during the first night and day. All along most efficient aid was rendered by Messrs. Leroy Goldsmith, Joseph M. Reed, George Cross, Elbridge Witham, William Pike, and very many others. No braver sailors, no kindlier men and women than those of Pigeon Cove. Beside all the rest, subscription papers were early passed for money to defray the numerous immediate expenses, and the amount on both papers reached some $\$ 170$.

THE HARBOR BAR.

BY CHARLES BURR TODD.

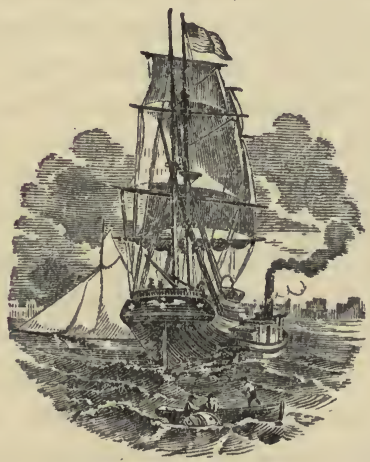

A ship has crossed the harbor bar, The sunlight glinting on sail and spar: Whither she goes, who knows? who knows? She carries pearls of lustrous hue, Costly fabries from far Hindoo, A tender maid to her lover true.

The wind has crossed the harbor bar, All armed and panoplied for war: Whither it goes, who knows? who knows?
It darts on the ship far out at sea, It tears and rends her with savage glee, And, lo! a wreck drifts wild and free.

The sea has crossed the harbor bar, It hears a potent voice from afar: Whither it goes, who knows? who knows? Rising upon a land of palms, It throws a wreck to sea-walled farms, And a lifeless maid to her lover's arms. 


\section{Ninety-Three Voyages to Surinam.}

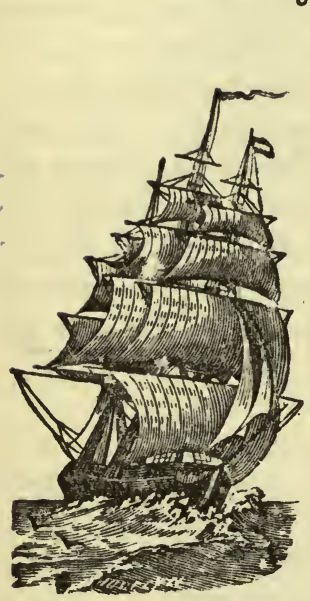

\section{A Remarkable Record.}

Capt. William Tucker of this city has made ninety-three voyages to Surinam, and has well earned the title of the "Veteran Master" in this branch of maritime business. He commenced going in 1843 , and made his last voyage in $188 \mathrm{I}$. He never had occasion to call upon the underwriters for a cent of damage to his vessel, or cargo. The only disasters he ever met with was the carrying away a jib-boom, the loss of a man and a main-topmast. Allowing fifty days for an average passage to and from that port, Capt. Tucker has passed four thousand six hundred and fifty days of his life on the water, or nearly thirteen years.

What an experience has been his, sailing smoothly over tropical seas, 'neath Summer skies, now and then interspersed with the sudden squalls so prevalent in those latitudes, running along the low coast of South America, looking out for the lightship off the Surinam river, running in and anchoring off the city, receiving the congratulations of friends, visiting plantations and enjoying the many pleasures of that country. Then, on the other hand, coming home on a Winter's coast, experiencing all the hardships connected therewith; oftentimes being blown off for a week after sighting the land, beating about in the bay, 'mid storm and cold, with anxious hours by day and night, longing to get into port and come safely to anchor.

The Surinam trade, once the pride of old Gloucester, has long since departed, and there are but few American vessels now engaged therein. The old captains who were wont to walk these streets and whose presence was so warmly welcomed, have also, for the most part, gone their last voyage and found a haven beyond. We call to mind among these, the brothers Foster, Thomas, Jere., Benjamin and Joseph ; the Sayward brothers, John and Samuel; the brothers Center, Solomon and Loami; Capts. William Grover, James Rowe, Solomon H. Davis, Francis Procter, David S. Day, John Corliss, William H. Herrick and his son William E. Herrick, Averil Rowe, Joseph Procter, Edward Babson, Charles Fitz and Eben Higgins. Among those living are, Capts. John Hawson, Nehemiah D. Cunningham, John A. Pulcifer, Charles A. Homans and others. 


\section{Recollections of a Veteran Fisherman.}

BY S. B. BROWN.

When I first went to Gloucester, in 1832 , John Wonson, of the Point, owned five small vessels, viz.- - the Confidence, Lucy, Jane, Lucinda, and Benevolence. Edward Wonson, his son, was master of the Benevolence, and another son, John, was master of the Lucinda. I made one trip with Edward Wonson in August, 1832. Our crew consisted of old Charlie Wonson of Rocky Neck, Reuben Rich of Cape Cod, Joseph Wonson and James Green of the Point, and myself. We had bad luck, so we made but one trip. The next year I went to Gloucester, hunted up my old skipper, who was still master of the same boat, and went with him that season.

I recollect well the great school of mackerel that struck Middle Bank that year. Sept. $22 \mathrm{~d}$, at ten o'clock at night, there were some two hundred sail at anchor, twenty-five miles southeast of Eastern Point light, in a dead calm, when our skipper sang out, "Here they are, boys!" At the same moment every vessel in the fleet commenced the catch. We fished for three days and filled everything, even our boat, and struck on deck until we were in fish knee-deep. Then, a breeze springing up, we ran in and packed out two hundred and eighty barrels, and returned to the Bank just as the wind left us. We fished three days more, when they struck off as suddenly as they had come.

Now, just as I have got a range of memory overhauled and am picking up a few incidents, the "Advertiser" comes in. I stop writing and open the dear old sheet, when the first article that meets my eyes is, "Around the Wharves of old Old Gloucester Half a Century Ago," in which I find much that I was familiar with, as vessels belonging to S. W. Brown, the Lapwing, John Edgar, master, Henrietta, Reform, etc., etc., and others belonging to Epes Merchant \& Son. I knew John and Harry. Pew, when in the Volant and Romeo, and John Hammond of the Brilliant, afterwards of the Warrior, of same owners.

In April, 1837, I came on the coast in the brig $O a k$ of Baltimore, from Smyrna, for Boston. When on Georges we ran into the fleet of fishermen at anchor, just at daybreak. Spoke sch. Fair America, John Wonson, master, wind blowing heavy from south-southwest, with snow. Capt. Wonson informed us, in language peculiar to himself, that he would not heave up his anchor, but would sink her first. It was generally supposed that he did go down, as he was never known to be spoken afterwards. We ran in company with the smack Ben. Franklin, Ben. Norwood, master, which went 
down in the same gale. She was owned by S. W. Brown. She and the sch. Canton came out new that Spring, and were rivals; they both left the Bank at the same time, and both carried sail heavily; but, as both captains were much censured at the time for carrying sail so heavily, I will only say we saw the Franklin come up in the wind, evidently to shake the snow from her sails in a heavy snow squall, after which we saw no more of her. After it cleared somewhat, we saw the Canton under snug sail. I went to Gloucester that Summer and sailed in sch. Clarion, Capt. James Elwell.

Since I left Gloucester I have visited a great many ports of the world, and in whatever place I found a Cape Ann man', if in 'want, he had half of my pile, if necessary, and so it would be to-day.

The place then called the "Farms," between the old Farm Ledge and the stone barn once belonging to Mr. Manning, always had a great attraction for me. If I could talk with you I could tell you much of old Gloucester. I used to know every point of interest between Kettle Cove (now Magnolia) down to Sandy Bay (now Rockpott).

But I will not put any more thoughts on paper, but will say in conclusion, whatever fate may be mine, there are friends in old Gloucester that I shall cherish while I am conscious, although they have lost all knowledge of me for over forty years. They are still held in the same esteem as if they were friends of yesterday. Those days are remembered as the happiest of my life, and my last dying wish will be-God bless and prosper old Gloucester and all her children and interests. I am no writer, only an old wornout sailor, waiting the word to cross over to a higher life.

I was well acquainted with Edward Wonson, Chester Marr, Sr., Nathaniel Webster, Sr., James Hibbard, James Elwell, Ben. Elwell, Albert Marchant, Simeon Burnham, James Marchant, each of the elder Peabodys, Addison Merchant, James Pattillo, and hundreds of others. Most of the old stock are probably dead, say-Phil. Priestly, Capt. Charles Wood, and Capt. George Brown of the sloop Henry, which ran forty-five years ago as a freighter to Boston.

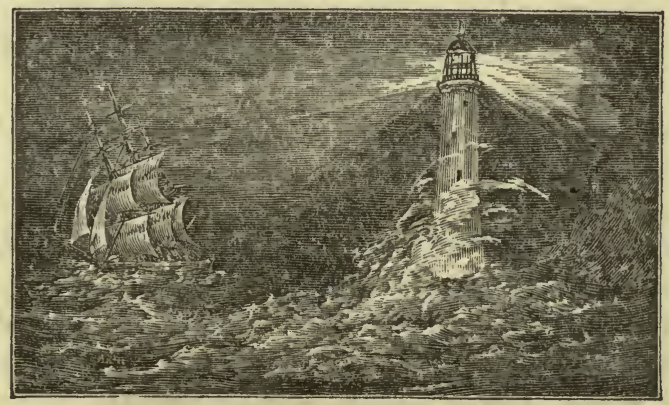




\section{Making a Harbor in a Snow Storm.}

BY J. W. COLLINS.

No incident in the passage home, in Winter, causes greater anxiety than that of approaching the land during an easterly wind, which is almost always a stormy one on our coast. The fisherman, anxious to reach home, piles on the canvas, and if there is sufficient wind the little schooner is driven to her utmost. As long as the weather remains clear all is well; but it frequently happens that snow storms come on suddenly just at that critical period when the vessel is nearing the land: The result of this is that she is often caught on a lee shore, with a fast increasing gale, while the snow is so dense that even the most daring will scarcely venture the attempt to make the land, knowing full well that it would be almost madness to do so. The only alternative is to come to anchor or "haul off" and try to keep off the rocks.

The following extract may serve to give an idea of the difficulties of approaching the coast in a storm, even in comparatively moderate weather. These difficulties are much increased when the wind blows a gale, and many thrilling adventures have been encountered in Massachusetts Bay by the Gloucester fishermen while endeavoring to make a harbor:

On Thursday, Jan. 16, r879, at four o'clock in the morning, Thacher's Island lights were in sight from deck. At this time there was a slight breeze from the southeast, but it soon died out, and we lay becalmed with the exception of occasional cat's paws, which came from all points of the compass. There were indications of a storm, which gave me much uneasiness. My anticipations were soon realized, for it began to snow before daylight, and in a few minutes the air was full of the soft feathery flakes, which effectually shut out from view every object at a greater distance than one or two hundred fathoms. All hands were called out to pound the ice off of our cable and running rigging, since it is of the highest importance to have everything ready for anchoring or taking in sail when approaching the land, especially in thick weather. Although it continued calm during the early part of the forenoon, the barometer fell very rapidly, giving indications of an approaching gale, which might be expected in a few hours; consequently I determined to make the land if possible. One of the most unpleasant and dangerous positions that one can be in is to be caught on a lee shore in Winter when an easterly gale is accompanied-as it generally is-by a blinding snow storm.

About ten o'clock in the forenoon the wind breezed up from the southeast and increased quite fast. We ran for Eastern Point as nearly as I could 
judge, the various courses and distances which we had steered during the morning, in consequence of the baffling winds, rendering it somewhat uncertain in what direction the Point lay from us. Soon after the wind came, the snow cleared up so that objects could be seen about a mile distant. We saw a shore fishing vessel-a haddock catcher-coming astern, and wishing to speak with her we hauled our sheets aft and let her run up on us. She proved to be the David F. Low, bound to Gloucester, having run across from Cape Cod. She ran ahead of us a little way, and just before we saw the land the snow came down so thick that we lost sight of her.

Knowing that we were close in and fast approaching the shore, all hands were on deck and on the alert to do any duty which circumstances might demand. A dozen pairs of eyes peered out ahead, anxiously watching to catch a glimpse of the land or breakers. A few minutes later the thrilling cry of, "Land ho! breakers ahead!" came from a half dozen at once, and a line of white foam and the snow-covered shore above it were indistinctly seen to leeward. "Hard down! hard down the helm!" was the order shouted to the wheelsman, for so close in were we that any delay in changing the course of the vessel must have resulted in piling her up on the rocks. As the wheel was put down and the vessel came to the wind, most of the men, in obedience to orders, quickly pulled in the sheets, while the rest of us strained our eyes to make out some familiar object on the shore whereby we might be certain of our position.

We made the land a little to the westward of Bass Rocks. When we first saw it we were running in with the sails on the port side, the wind at that time blowing a smart breeze from south-southeast, and as we hauled to, just clearing the surf on the shore, we fortunately saw and recognized the Summer houses which are only a short distance from the water. As soon as I was sure of our "land fall," we tacked and ran for Eastern Point, following the line of breakers along the shore as near as safety permitted. Every eye was now on the watch for well-known land-marks, and soon the spray dashing over Brace's Cove Rock was seen, and a few minutes later we went sweeping in by the Point, near enough to it to catch a momentary glimpse of the white tower of the lighthouse, and to hear the hoarse-toned fog-bell which rang out its notes of warning.

We could now laugh at the storm, and the broad grin which appeared on the bronzed faces of many of our crew and the shrugging and chuckling of others gave ample evidence of the general feeling of satisfaction among all hands.

After anchoring, I went ashore and sold the trip of fish, but, as there were strong indications of a coming gale, and the wind already blew strong, we decided to let the vessel remain in the stream until the next day. Before the men went home we let go the second anchor and made all necessary 
preparations for the safety of the vessel. As soon as the work was completed we went ashore, some going to their boarding houses and others to their homes. The increasing wind whirled and blustered the fast falling snow in a manner that was anything but pleasant to the wayfarers who were obliged, as we were, to meet and face the storm.

My family, the members of which had been picturing me as struggling with the tempest at sea, received an unexpected and pleasant surprise when, with my rubber suit on and covered with snow, I opened the kitchen door and suddenly entered the room. One general exclamation of, "O $\mathrm{O}$ father," came from my children, as they sprang with open arms to greet me. The joy of such meetings can, however, be better imagined than described ; suffice it to say that such are the brightest spots, the oases, so to speak, in a fisherman's life, and none but those who have been separated under similar circumstances from those they love can realize the pleasure of such home comings :

"It scatters sunshine o'er our way,

And turns our thorns to roses;

It changes weary night to day,

And hope and love discloses."

AN OLD BOAT.

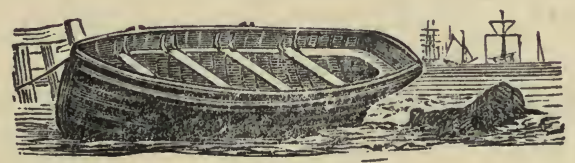

I passed a boat, to-day, on the shore, That will be launched on the sea no more.

Worn and battered-the straight keel bent, The side, like a ruined rampart, rent.

Left alone, with no covering,

For who would steal such a useless thing?

It was shapely once, when the shipwright's hand

Had laid each plank as the master planned;

And it danced for joy on the curling wave, When first the sea's broad breast it clave.

And it fclt the pulse of the well-timed stroke
That rang on the thole-pin of tuneful oak.

Oft it has carried home the spoil

Of fishers, tired with night-long toil;

And often, in Summer days, it knew The laugh of a pleasure-seeking crew;

Or, launched by night on the blinding waves, It has rescued a life from the sea's dark graves.

It is useless now as it lies on the beach, Drawn high beyond the billow's reach;

And none of all it has served in stress Remember it now in its loneliness. 


\section{Hand-Line Mackerel Fishing.}

BY AARON LIGHTFOOT.

The amount of moral courage and Christian fortitude required for a landsman to get up out of a comfortable bed and struggle up on a cold, wet, cheerless deck to handle cold, wet lines and colder, wetter fish, all for the "experience," will never be known except by those who have allowed themselves to be deluded into the thing. It is diabolical. Now the mainsail is up, the jib down, and the captain is throwing bait. It is not yet quite light, but we hear other mainsails going up all around us. A cold, drizzling rain does not add to the comfort of the situation, and we stand around shivering, half asleep, with our sore hands in our wet pockets, about as "demmed, moist, uncomfortable bodies," as ever dear old Mantilini saw, and all wishing we were home, and had never heard of a mackerel. The skipper, however, is holding his lines over the rail with an air which clearly intimates that the slightest kind of a nibble will be quite sufficient this morning to seal the doom of the unfortunate mack.

"There, by Jove! the captain's hauling back-I told you so! Skipper's got him-no-ah, captain, you haul back too savagely!"

With the first movement of the captain's arm indicating the presence of fish, everybody rushes madly to the rail, and jigs are heard on all sides plashing into the water, and eager hands and arms are stretched at their full length over the side, feeling anxiously for a nibble.

"Sh-hish!" there's something just passed my fly-I felt him," says an old man standing alongside of me. "Yes, and I've got him," triumphantly shouts out the next man on the other side of him, hauling in, as he speaks, a fine mackerel and striking him off into the barrel in the most approved style.

Z-z-z-zip goes my line through and deep into my poor fingers, as a huge fellow rushes savagely away with what he finds is not so great a prize as he fondly supposed. I get greatly flurried, miss stroke half a dozen times in as many fathoms of line, and at length succeed in landing my first fish safely in ny barrel, where he lies floundering, "melancholy and melodious," as my next neighbor styles it.

Daylight soon dawns, and the rain, which has been threatening very moistly all night, begins to pour down in dead earnest; and as the big drops patter in the sea the fish begin to bite furiously.

"Shorten up!" says the skipper, and we shorten in our lines to about 
eight feet from the rail to the hooks, when we can fork them in just as fast as we can move our hands and arms. "Keep your lines clear!" is now the word, as the doomed fish flip faster and faster into the barrels. Every face wears an expression of anxious determination. Everybody moves as though he had a full set of very elastic springs within him; every heart beats loud with excitement, and every hand hauls in fish and throws out hooks with a method; cool precision, a kind of slow haste, which unites the greatest speed with the utmost security against foul lines.

The rain momentarily increases. We hear jibs rattling down ; and glancing up hastily I am surprised to find our vessel surrounded on all sides by the fleet, which has already become aware that we have fish alongside.

Meantime the wind rises, the sea struggles against the rain, which is endeavoring with its steady patter to quiet the turmoil of old ocean. We are already on our third barrel of fish, each, and still they come as fast as ever, and the business (sport it ceased to be some time ago) continues with undiminished vigor. Streams of perspiration course down our faces. Jackets, caps, and even our shirts are thrown off to give greater freedom to limbs that are worked to their utmost.

"Hello! where are the fish?" calls out somebody; and sure enough, all at once the whole business comes to a standstill-the fish have apparently "shut up shop" and gone home, for not the faintest nibble does one fisherman get. The mackerel, which a moment ago were fairly rushing on board, have in that moment disappeared so completely that not a sign of one is left. The vessel next under our lee holds them a little longer than we, but they finally also disappear from her side. And so on all around us.

And now we have time to look around us; to compare notes on each other's success ; to straighten our backbones, nearly broken and aching horribly with constantly reaching over; to examine our fingers, cut to pieces and grown as sensatiorless as a piece of salt junk, with the perpetual dragging of small lines across them.

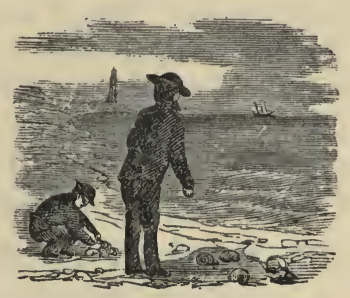




\section{"Setting Under Sail."}

BY DICK SKYLIGHT.

The term, "set under sail," or "flying set," implies that the vessel, instead of being anchored, as is the most common way on the Banks when trawls are to be set, is kept under way, the performance taking place as follows :

If a "set under sail" is decided upon, the depth of the water is first ascertained by sounding where the skipper intends to set his apparatus and begin his fishing. He then directs the dories to be made ready. This sets all hands on the alert, especially the crews of the top dories, who quickly arrange in them the buoys, buoy-lines, etc., that are required. Having rigged their "black-balls" and prepared the lines for running, the dories are hoisted over the rail, where they are left to hang until the next are ready, when they are lowered into the water. Dropping aft on the quarter, they are held there while one of the two men who form the crew leaps in and receives the complement of trawls-an operation requiring no little skill and confidence in one's sea-legs when the water is at all rough. This done, his mate also gets in, and the boat is paid astern, the painter being fastened to the davit. Meanwhile, the two middle and the bottom dories are being prepared and hoisted out in a similar way.

When the six dories are ready, and the proper time has arrived, the skipper shouts to one of the men in the first boat, "Heave out your buoy!" This buoy, remember, marks the position of one end of the trawl, for to it is attached the anchor which holds the ground line in its place. As the buoyline is running out and the boat is about to be cast off, the skipper instructs the men in which direction to row while setting the trawl. This is generally to leeward and in a straight line at right angles to the course of the vessel. A moment later the same orders are given to the next dory's crew for setting the second trawl at a suitable distance from the first, and so on until the whole six have been set out. Spread along in this way, a "gang" of trawls will generally cover two or three square miles.

The act of setting the trawl is performed in the following manner:* Before the buoy-line is all out, one of the men lifts a skate of trawl on to the after thwart and attaches the end of the trawl to the anchor, which he throws overboard. Then, while his mate rows away, he lets the trawls go out, throwing hook after hook, so that they shall not become fouled. When

*This description of setting a halibut trawl will answer equally well for a cod or haddock trawl, the only difference being that the latter are stowed in tubs instead of skates, and the hooks are closer together. 
one skate is out another is knotted to it, and the performance goes on until all of the trawl is disposed of. When the end of it is reached it is bent to the last anchor and buoy, these also being thrown, the process is completed.

The first crew are usually nearly done with their work by the time the vessel has let go her sixth dory, so she immediately turns back and picks up this and the other boats in succession. This done, she lies by until it is time to haul, when the vessel is run along from buoy to buoy, dropping each dory near its own trawl. The holding up of an oar is a signal that the men have finished hauling their trawl or want help, seeing which the vessel runs down and receives the cargo or takes the boat in tow.

The act of "picking up" a dory while under sail is a manœuvre requiring considerable skill, and it occasionally happens that the boat is struck by the vessel and the occupants are thrown into the water. An accident of this kind happened in my own experience in the Summer of 1879 . Running the vessel to leeward of one of our dories, I put the wheel down, intending to tack short of her and lay to with the jib to windward while she came alongside. The vessel ranged further ahead than usual, and struck the dory a glancing blow with her bow. I should have righted the wheel and cleared her, but a man sang out that she was all right, and, as I could not see her myself, I supposed she was, until another exclaimed, "My God! she's hit the dory, and there's three men overboard."

The jib had caught aback at this time, and as the wheel was rolled hard down, I shouted, "Heave out that lee dory as quick as you can and pick them up." Running to assist in getting the dory out, I saw two of the men climbing over the vessel's bow. They came to help us, exclaiming, "Sank's* in the water; let's hurry up." Although we made all possible haste, by the time the dory was well clear of the vessel's side with two men pulling their utmost, I saw the sther dory uninjured on our weather quarter and "Sank" standing in her dripping wet, his face streaming with blood. Like the others, he had attempted to jump and catch the bowsprit rigging, but the vessel's bow was falling, and something struck his head, cutting a gash more than an inch long, and knocking him backward into the water. Fortunately he was not stunned, and when he rose to the surface he grasped the gunwale of the dory and hauled himself into her. Nothing daunted by his mishap, his first words to his shipmates were: "I'm the proper lad to go haddocking ; $\dagger$ it don't bother me much to be run down." The words were uttered with a carelessness of tone, and a quiet laugh that showed an utter disregard of such dangers.

\footnotetext{
*A young man whom, on account of his proficiency in singing hymns, we nicknamed "Sankey," and this had become abbreviated into "Sank."

+Vessels employed in the Winter haddock fisheries almost always set under sail, and their men are therefore more liable than any others to this particular accident.
} 


\section{In a Fog on the Banks.}

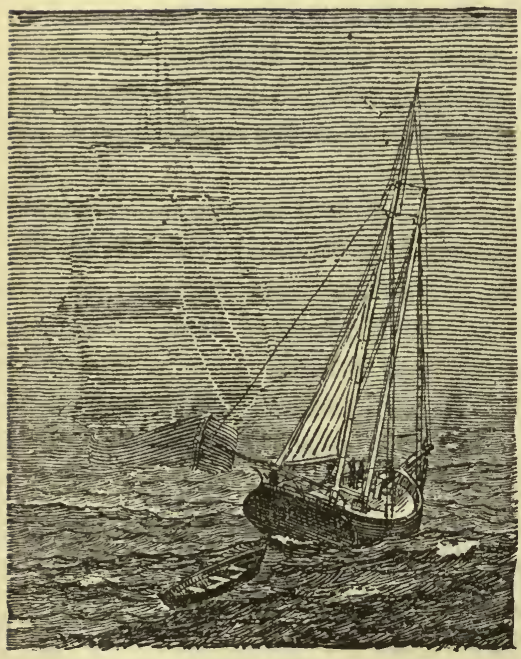

The accompanying engraving gives a vivid illustration of one of the dangers incident to the fisheries-that of being run down in the fog while at anchor. We have heard of numerous narrow escapes from this danger, where a slight deviation from the course of the vessel under sail, or a moment's delay in changing the position of the vessel at anchor, by paying out the cable, would have added another to the list of lost fishermen. It is supposed that the Guy Cunningham was run down by a steamer; and no doubt many others of whom no tidings have been heard, have shared the same fate. During the night a light is kept in the rigging, and fog-horns are frequently blown during the day. The utmost precaution is necessary to avoid the dangers which a thick fog engenders, and the lookout's position on board all vessels crossing the Banks, as well as on board the fishermen, is one of great responsibility.

Lines on the Loss of Schooner "Guy Cunningham," and in Memory of Her Master, Captain Daniel O’Brien.

BY S.

'Twas July thirty, eighty-one, a beauteous Summer day;

The sehooner staunch, Guy Cunningham, for Grand Bank sailed away,

Manned by a crew of hardy men-none braver ere set sail

To haul the trawl in Summer's ealm, or meet the Wintry gale.

Eight fearless men of the thirteen were free from marriage ties;

One's darling bairns were far away, beneath the Swedish skies;

And four in Gloucester had their homes, with wives and ehildren dear, When for the Banks they sailed away, nor thought that death was near.

No storms arose the sea to vex; no angry billows' roar

Disturbed the seamen's hour of rest, when the day's toil was o'er;

Each morn the laden trawls were hauled, the finny treasures stored;

The time drew nigh when safe at home their vessel should be moored. 
Alas! that such a peaceful scene should hide so dread a foe!

Alas! that no precaution can guard against the blow!

Alas! that sailors brave must drown, and wives and children weep,

Though winds are soft, and seas are smooth, and crews their vigils keep!

No fear of ill their dreams disturb-no dread of danger near-

By gentle billows rocked, their thoughts are with their loved ones dear.

Out from the mist a sail gleams forth-a mammoth hull draws nigh-

A shock! a crash! the erew go down with one despairing cry!

At home their dear ones wateh and wait, and wait and watch in vain;

The sailor-husbands, dearly loved, will never come again.

No sturdier crew than sailed the "Guy" e'er manned a fishing boat,

None braver than her skipper bold e'er trod the deck afloat.

An aged mother mourns the son she soon will meet above;

A sister mourns a brother dear whose every look was love;

A widow mourns a husband true, the wreek of prospects fair,

And children three are left behind without a father's care.

The five days' babe he left behind when bidding home good-bye,

Will never know how great a loss that deadly hour brought nigh.

But God is good, and he has power the balm of peace to pour

On bleeding hearts, and comfort bring from out his bounteous store.

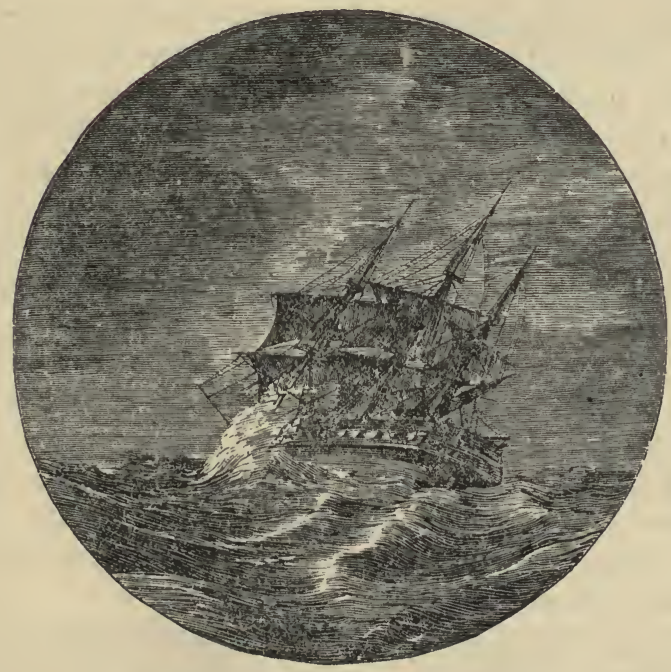




\section{Around the Wharves of Old Gloucester Half a Century Ago.}

Names of Those Then Engaged in the Fisheries, with the Names of Most of the Fleet and Their Skippers.

As we thought of the large and important fishing interests of Gloucester the current year of $\mathbf{1 8 8 2}$, with the fleet of first-class schooners, employing at sea and on land nearly six thousand men, with their annual product exceeding four millions of dollars, we had a strong desire to give a pen picture of the appearance of the wharves, and recall to mind the fishing owners and some of the skippers and vessels which constituted the fishing interest of the town of Gloucester half a century ago.

To this end we held pleasant interviews with Messrs. William Babson, George Merchant, Gorham Parsons, Epes W. Merchant, Stephen J. Martin, B. H. Corliss and George W. Plumer, and from them have gained the following facts. There may possibly be a few trifling discrepancies, but the account in the main will be found correct.

In imagination, reader, let us take a walk about the wharves, see who was carrying on the business, look at the vessels and have a chat with some of the skippers of $1830-31-32$. Commencing near the Fort, we find the remains of a cob and ballast wharf, on the site of Messrs. Cunningham \& Thompson's premises, then owned by Gorham Parsons and occupied by John W. Lowe and Joseph Johnson Procter, which was in rather a dilapidated condition and but little used. Then came a graving dock occupied by the Gaffney Brothers, where vessels were hauled up for repairs, and for caulking and graving.

The wharf of Messrs. Maddocks \& Co., which, of course, has been greatly improved since those days, was then occupied by Matthew Gaffney and William Ellery, who carried on the fishing business under the firm name of Ellery \& Gaffney. Their vessels were as follows: Schs. Harvey Birch, Capt. J. M. Parsons; Sevo, Rising Empire, and Ida, the latter commanded by Capt. Job Rowe, and the Charles. The Amazon also fitted with them and was owned by Daniel Gaffney.

Joseph Johnson Procter and John W. Lowe also occupied the wharf then known as Mechanics' wharf, now owned by Messrs. Swett \& Co. Their vessels were: Sarah, Tam O'Shanter, Metamora, Euphrates, Triumph, Superior, and perhaps others.

Samuel Gilbert then carried on the fisheries at the wharf next to the 
Town Landing, then and now known as Gilbert's wharf, occupied at present by Francis W. Homans. His fleet comprised the Phoenix; Economy, Capt. Jonathan Gilbert; Sea Serpent, Capt. Nathaniel Thurston; Addison, Arab; and Shamrock, William Marshall, skipper.

James Mansfield \& Sons' came next. Wharf now occupied and the business continued by successors under the same style. The wharf extended far out into the harbor on account of the flats. They owned and fitted schs. Susan and Eliza, Capt. Elias H. Day; Abigail, Capt. William Shackelford; Ann and Mary, Capt. John M. Parsons. The last-named schooner was scuttled inside of Rocky Neck during the war of 1812 , to preserve her from the English cruisers. The rigging and materials were stored in the barn of the old Low mansion house in Town Parish. After the war, Mr. William Pew went master of her, and in three Grand Bank trips in one year stocked \$10,000, without bounty and oil. Their other vessels were: Diligent, Mary Elizabeth; Industry, Capt. George Gerring; Active; Leader, Capt. Samuel Curtis ; Friendship, Capt. Gorham Riggs; and Hornet.

Next to the Mansfields' came the wharf then owned by Zachariah Stevens, where the Riggs Brothers subsequently carried on the fishing business.

The wharf now owned by Charles H. Boynton was then owned by Charles L. Roberts, who had the schs. Frances and Elizabeth, Mary, and perhaps others.

Dr. Coffin's adjoined this. It was a small wharf and a noted resort, where Town Meeting orators, waxing warm with each other in the discussion of local affairs, would adjourn to and fight it out. It was the scene of many a hotly contested rough-and-tumble fight over questions which agitated the minds of those who were interested in town affairs-and perhaps had imbibed too much of the famous New England rum of that period. There was not much business done at this wharf, as it served more for a landing place for small boats. Mr. Gorham Burnham commenced his blacksmithing business at this wharf.

Next to Dr. Coffin's was the Central Wharf, now owned by Charles H. Boynton. For many years it was occupied by Darid Pearce, who was largely engaged in the West India trade. William Pearce \& Sons had a distillery on this wharf, which was destroyed in the great fire of 1830 . Cargoes of Surinam molasses were here landed and made into rum. There were also two small wharves adjoining, owned respectively by Abraham Sawyer and Daniel Gaffney.

William Parsons, Jr., had the wharf now owned by George Steele. He owned and fitted schs. Peacock, Capt. Benjamin Rowe; Hussah, Capt. John Blatchford; Herald; Amaranth, Capt. George Blatchford; Mariner, Capt. Charles Wood; Henrietta, Capt. William Dolliver; William, Capt. William Blatchford; Six Brothers, and the Illinois. 
Then came the wharf of Joseph Smith,"now part of the property of Messrs. Clark \& Somes.

Frederick G. Low had a large wharf on the site known as the Sargent wharf, now occupied. by Mr. John G. Bennett. He was largely engaged in the wood and coal business.

John Honnors' wharf was a portion of the wharf property now owned by Mr. Robert Fears on Duncan street. He owned and fitted schs. Nymph, Glide, Favorite, Yarico, Ariel, Myrrh, and Ospray.

Where the gas wharf, now is was a stone wharf occupied by Mr. Calvin Swift, engaged in the fish oil business.

Sargent's wharf then occupied the premises now known as Andrew Leighton's wharf. There was also a small wharf adjoining, known as Caswell's wharf, used for the graving business.

The Col. Pearce wharf occupied the site of the wharf property of Michael Walen \& Son. This property has been greatly changed and improved. It was a great wharf in those times, where foreign commerce was carried on, and was the scene of great business activity.

In Vincent's Cove there was a small wharf, the premises now owned by B. F. Cook. It was then owned by Samuel Caswell. Then came a little wharf, now owned by John Nelson, and Capt. Israel Trask's wharf, where Chresten Nelson is now engaged in business.

At Vincent's Point, Messrs. Caswell \& Leighton carried on the fisheries, now known as William H. Friend's wharf. They owned schs. Ontario, Isaac Day, master ; Volant, Benjamin Rowe, master; Lady of the Lake, Cyrus Story, master ; Decatur, Monroe, Robert Rantoul, and a freighter commanded by Capt. Benjamin Brooks, of Rockport.

Brown \& Woodbury's wharf, since purchased by John Pew \& Son, forming one of their four wharves at Rowe's Bank, came next. Among the vessels which they owned and fitted, were schs. Lapwing, Reform, Antelope; Enterprise, Capt. Jonathan Burnham; Henrietta, Capt. Gorham Riggs; Olive Branch, Capt. Samuel Dowle ; Falcon, and Independence.

Where George Todd's coal wharf now is was at that time occupied by Richard Friend \& Sons, who owned and fitted schs. Monticello, Capt. Joseph Herrick; Martha Washington, Capt. George Watson; Cion, Capt. John Blatchford; Laurel, Capt. George Blatchford; Columbus, Capt. Lemuel Friend; Three Sisters, Capt. Josiah Norwood; President, Capt. William S. Friend ; Branch, Capt. Simeon Burnham ; Splendid, a freighter, Capt. Frederic Norwood; Four Sisters, a freighter commanded by Capt. Simeon Burnham; Emerald, Capt. James Norwood; and Olinda.

Epes Merchant \& Son carried on business at the wharf now owned by Sylvanus Smith. The vessels they owned and fitted were the Wasp, Capt. Charles Merchant; Emblem, Capt. Elisha Smith; Orontes, Capt. Henry 
Merchant ; Rrilliant, Capt. John Hammond ; Volant, Capt. John Pew ; Romeo, Capt. Henry Pew ; Paragon, Capt. William Tarr.

William Parkhurst had a small wharf near the premises now owned by Messrs. Shute \& Merchant. He owned and fitted schs. Fair American, Capt. John Wonson; Ida, of which he was master; and the Science, owned and commanded by Capt. David Parkhurst.

At Deacon Andrew Parker's wharf, now owned by Charles Harriman, was the sch. Brainard, of which he was master and owner; also the Good Intent, Capt. Charles Brown.

On the premises now occupied by Sayward Brothers was a small wharf: or landing where two vessels were owned and fitted by Daniel Sayward \& Sons-schs. Helen Marr and Delegate.

There was not a building or wharf on the Plain, or at Clay Cove, with the exception of a small landing belonging to Daniel Norwood, at the foot of what is now Hammond street.

At East Gloucester, Benjamin Parsons had a small wharf at what is now the premises of William Parsons, 2d, \& Co. He owned and fitted schs. Susan Eliza, B. Parsons, Jr., master; Protector, Martha Eliza, and others.

John Wonson's wharf was on the site of that now occupied by William C. Wonson \& Co. He owned and fitted schs. Benevolence, Licandas, Essex, Confidence, boat Lucy, and others.

Giles \& Wonson, on the premises now occupied by Wonson Brothers, and previously by George F. Wonson \& Co., owned and fitted schs.. Nautilus, J. F. Wonson, master; Forest, Capt. Stephen Rich; Good Hape, Augusta, Mt. Vernon, Eagle, Tiger, and others.

There was also a small landing near the premises now: occupied by the Ferry Landing, owned by Benjamin Smith. There was no: wharf at Rocky Neck.

This, so far as we have learned, comprises the names of those engaged in the fisheries half a century ago, and the vessels of the fleet. But few squaresterners were among them; but nearly all were pinkeys of about forty tons burthen, with three sails, and valued at about $\$ 1,500$ each. In 1840 the catch of mackerel for the season was only about 8,000 barrels, and the total product of the fisheries for the year was only $\$ 500,000$. The fishing business at this port was at its lowest ebb of depression; but in 1843 and ' 44 there began to be a great improvement. The old class of vessels were sold to go "Down East," where some of them are still running, and the shipyards of Essex were busily employed for years in furnishing a superior class of vessels which the vigorous prosecution of the new branches of the fisheries -Georges and Grand Bank for halibut, and Bay of St. Lawrence for mackerel-required.

Let the reader commence his walk at the Fort and proceed to Rocky 
Neck with this list of wharves, and notice the great improvements which the last half-century has made, and the surprise will be great. The entire water front to the Neck is mostly occupied by substantial wharves and fine buildings thereon, representing business energy and a determination to improve the natural facilities which have been so lavishly bestowed. The march of improvement must continue. Rocky Neck has many valuable wharf lots, and in the course of time we predict that the coves and shores on the southeasterly side of the harbor will be converted into wharf property; for Gloucester's advance the next fifty years will, undoubtedly, be fully as rapid as that which has characterized her past half-century.

\section{THE JOLLY YACHTSMAN.}

BY ZIP.

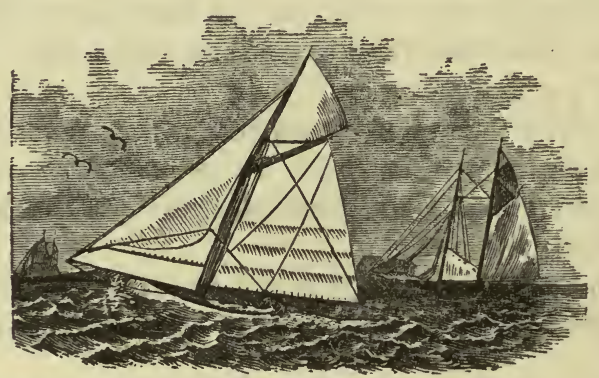

Who would not a jolly yachtsman be, Upon a Summer's day,

Dressed in a nobby suit of blue,

Go dancing o'er the bay?

In his natty yacht so neat and trim,

His comfort and his pride,

Freed from city's noise and dust,

He enjoys the ocean ride.

He cares not for strolls upon the beach, Or drives o'er hill and dale-

His pleasures lie in the speedy craft

With flowing sheet and bellying sail
Filled by balmy winds of June From off our western shore, Laden with odors from blossoming treesGive him this, and he asks no more.

To while away his leisure hours And rest his weary limbs, The yacht to him is an easy chair, As o'er the wave she skims.

With hull as smooth as polished steel, Sails white as drifting snow, With lockers stocked with goodiesWho would not a yachting go? 


\section{The Haddock Fisheries-Then and Now.}

\section{Marked Changes within a Half-Century.}

BY CAPT. STEPHEN J. MARTIN.

My recollection of the haddock fishery extends back to the days of my boyhood at East Gloucester, in $18_{32}$. From $183_{2}$ to about $188_{3}$ Amos Story and Jefferson Rowe would go out at daylight and be back at $8 \mathrm{~A}$. M. with a dory full of haddock, dress them, and go out in the afternoon, catch another dory load, and be back at 4 P. M. in season to dress their fare before nightfall. They would go no farther than the Old Pine Tree. I have known them to load their dories on a ledge between Ten Pound Island and Niles' Wharf.

In the years 1838 and 1839 I went fishing from Eastern Point in a boat called the Eastern Star. When the haddock came on the coast in April we tended Boston market with haddock, and would be on the fishing ground at daylight, catch what we could ourselves and buy all we wanted from the dories at one cent per fish, and start for market. The Eastern Star was fourteen tons, with no bowsprit. If we got two cents apiece for our fish we thought we were doing well.

The haddock remained inshore and were caught in the harbor until $18{ }_{5} \mathrm{r}$. In 185 . James Coas and myself loaded a fifteen-foot dory twice in one day, within two miles of the mouth of the harbor. From that time until 1864 the boats caught their haddock from three to four miles from the shore. From 1832 to 1845 the haddock were taken with hand-lines.

In the year 1864 Capt. Daniel Douglass fitted out the schooner Romp for haddocking. There was a good deal of talk at the time because he went haddocking in so large a vessel, her measurement being 66 tons. He carried four dories, five hundred hooks to a dory, and fished on the Inner Bank. Some days he would catch 40,000 lbs., and sell them for 75 cents a hundred, by count. Now the haddock vessels carry six dories, 1,200 hooks to a dory.

Since 1866 the haddock have been working off shore. For the past fifteen years the small vessels, 45,50 and 60 tons, have fished on the off-shore grounds, on Jeffries, Tilley's, and sometimes on Middle Bank, some twenty or twenty-five miles off, and but few haddock have been taken in-shore in the Winter months during the last ten years.

Now the haddock fleet go to Georges and LaHave Banks, and some of them go as far as the Western Bank. They go in the largest fishing vessels, 
some of them of 120 tons burthen, and carry six dories, from 1,000 to 1,500 hooks to a dory. There are two vessels that carry eight dories each.

The haddock fishery commences, as a general thing, about the first of November. Some vessels go earlier. It is nothing unusual for a vessel to be gone ten days and return with $75,000,80,000$ and sometimes $90,000 \mathrm{lbs}$. The price of haddock has been high all this Winter $(188 \mathrm{I}-2)$. In years gone by, when there were twenty-five sail of vessels tending the market, the market would sometimes be overstocked. Now there is a haddock fleet of one hundred and fifty sail, carrying their catch to market-not to Gloucester alone, but to Portland, Portsmouth and Boston-and all the haddock find a ready sale. There has been but once this Winter when the market was overstocked and the haddock were sold to be split and dried at $\$$ r.35 per cwt. Twenty years ago that was considered a good price.

Thirty years ago haddock were very scarce on Georges, and the vessels used to carry them there for halibut-bait. Now a vessel. will catch $, 50,000$ lbs. there in one day. The haddock generally come on Georges the first of February; before that time the fleet go to Cape Negro and LaHave Bank. The Georges haddock vessels, the large ones, discontinue that fishery about the first of April.

Sch. Martha C., Capt. Charles Martin, of this port, arrived in Boston Feb. 17,1882 , with the largest trip of haddock and best stock ever reported in the haddock fishery. She weighed off 93,000 lbs., stocking $\$ 1,943$, the crew sharing $\$ 9$ I each. This was' the result of two and a half days' fishing; time absent, ten days. On her next trip she landed $55,000 \mathrm{lbs}$. on a good market, and stocked $\$ 1,5^{1} 3$, giving her a stock of $\$ 3,45^{6}$ on the two trips.

Mr. George Steele's new schooner Dido, Capt. William N. Wells, made eight haddock trips in nine and a half weeks, the present year (1882), stocking $\$ 7,060$. On one trip she was absent ninety-four hours, and stocked $\$ 1,404$.

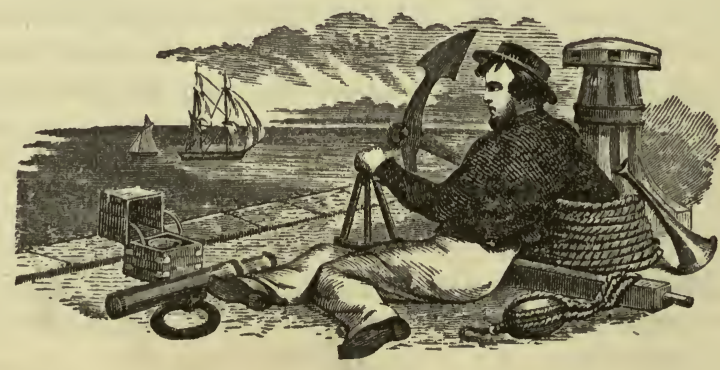




\section{A Mackerel Catcher Dressing Her Fare by Moonlight.}

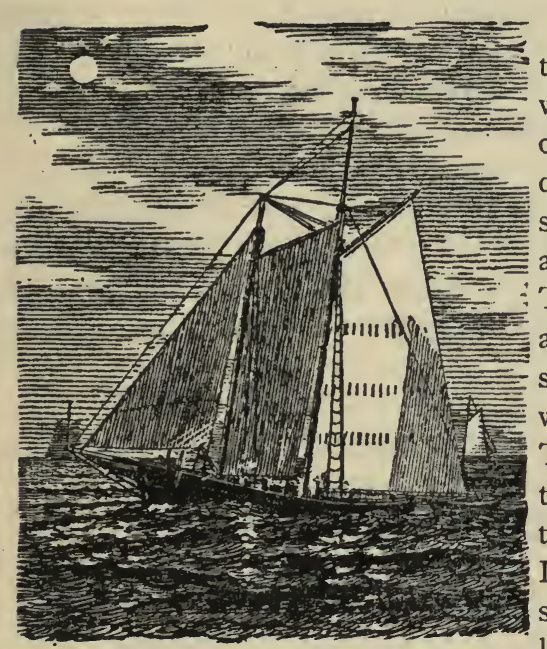

The accompanying engraving illustrates a mackerel catcher whose crew were so fortunate as to strike a school of fine, fat mackerel, just before sundown. The boys were all alive for such sport, and handled the seine-boat and net lively, securing "heavy decks." The steward had plenty of hot coffee and "Joe floggers" on hand for just such a lucky strike, and kept the crew well supplied with these refreshments. The moon had risen just as they got their catch on deck, and with a will they turned to and dressed all night. It was a lively time, splitting, gibbing, soaking them out, salting and barrelling, and the vessel, with a light wind, pursued her course for old Gloucester, where they got a quick pack out, and replenishing with salt and stores, were soon off again, as every day in the mackereling season counts, and the fishermen like to make the most of it.

\section{Frightened by the Moon.}

\section{BY DICK SKYLIGHT.}

Friday, May 16, r879, we were running across the Bay of Fundy, bound to Nova Scotia for bait. It was foggy, but not very thick, the first of the morning, and at three o'clock the man on the lookout sang out, "Light ahead!" The man at the wheel shouted back the inquiry, "What shall I do-luff or keep off ?" "Luff! luff hard!!" came the answer from the lookout.

By this time I was out of my bunk, and had jumped into the companionway just as the lookout ran aft, exclaiming, "Give me the horn!" I stepped back into the cabin to get it, and giving him one horn, took another with me on deck, blowing a blast myself before I stopped to look. The lookout said, "I think it's a steamer's masthead light." 
I now could see what looked like a bright light glimmering through the fog, about the height a steamer's light would be, half a mile distant, the fog being quite thin). After taking a good look, I said I thought it was a star, and told the man at the wheel to keep the vessel on her course, but a moment later it showed plainer, and the lookout exclaimed, "I'm $\mathrm{d}-\mathrm{d}$ if 'taint the moon!" I could not help laughing at the fright it had given him, and told him to blow the horn loud, and if the "man in the moon" heard it he would probably keep off and let us go along.

Such mistakes occur quite often. I have been called out many a time, when running for the land on a clear night, to see a star rising, that the watch had mistaken for a light on the land. This is not so much to be wondered at, since the appearance of a bright star near the horizon so closely resembles a fixed light on shore, that almost any one is liable to be misled.

\section{GLOUCESTER HARBOR.}

BY WILLIS G. BURNHAM.

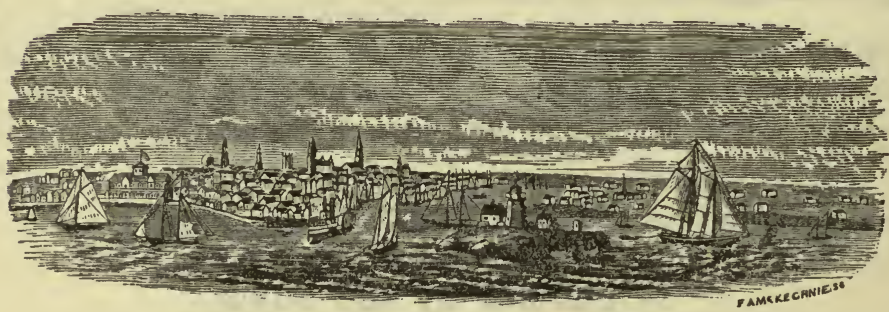

How oft, like some fond mother-bird,

Who, when the clouds foretell the storm,

Gathers her little trembling ones

Beneath the shelter of her form,

Do thy bright waters, when the wind

Sweeps mournfully across the sea,

Gather the white-winged, wave-tossed craft

From storm and wreck protectingly.

How beautiful beneath the rays

Of a bright sun, or fair full moon,

Thy surface shines with pleasant light,

At midnight, or at day's full noon;
Like some dear friend whose kindly smile Has cheered us both in storm and calm, And for our hearts' deep, secret wounds Has been a healing, welcome balm.

Alas! that as we look far out Beyond thy peace, we watch in vain The schooners coming from the sea, Which will not meet our gaze again; When, long ago, each sunlit sail

Went down below the horizon's blue, How little, ah! how little then

We of time's hastening changes knew. 


\title{
Adventures of Captain Richard Murphy.
}

\author{
BY J. W. COLLINS.
}

"Cease, rude Boreas, blustering railer; list, ye landsmen all, to me; Messmates, hear a brother sailor tell the dangers of the sea."-Old Song.

There are few, even among the hardy fishermen sailing from Gloucester, who have had so many wonderful escapes from imminent death as "Dick" Murphy, as he is familiarly called by those who know him. Born in Guysboro, N. S., he shipped at an early age on a Gloucester mackerel schooner, and since that time (a period of twenty-nine years) he has followed the fisheries from this port.

From an interview with Captain Murphy the following facts have been obtained relative to his experience :

The first incident of any note was his falling overboard in the Bay of St. Lawrence, while "skylarking" with a youthful companion on the deck of a mackerel schooner. Fortunately it was moderate, and Murphy, then a young lad, succeeded in grasping the rope which was thrown him, and was soon hauled in, dripping wet, to be sure, but otherwise none the worse for his involuntary bath.

His second experience in falling overboard occurred during a March gale on Georges, in 1855 . At that time he was one of the crew of the sch. Typhoon, and, the vessel having struck adrift in the midst of a furious snow squall, Murphy jumped on to the fore-gaff to take down the signal lantern. Just as the lashings of the lantern had been cast off, the vessel took a heavy lurch ; the fore-boom came out of the crotch and swung suddenly out to leeward, throwing Murphy into the water. But he clung to the lantern-one of the old-fashioned box-like affairs-which, he says, "made a good life buoy," and adds: "As the vessel rolled to leeward the next time, I put one hand on the lantern to partially raise myself from the water, and grasping the rail with the other hand, was. half way over it before any of my shipmates knew of my mishap. Some three or four of them then ran to my assistance and hauled me in."

In August, 1857 , he was in the sch. Queen of Clippers, bound home from the Bay of St. Lawrence. When the vessel was nearing Cape Ann, Murphy climbed up nearly to the jaws of the main-gaff-about forty or fifty feet from the deck-on the mast hoops. When he got high enough so that his feet rested on the second hoop below the gaff, and his hand grasped the next one above, he stopped to have a look for the land. While standing in this position, the seizing of the upper hoop parted and being thus instantly 
deprived of support he fell to the deck, striking his back and shoulders on the head of an upright water barrel. The blow broke in the head of the barrel, and the back of the unfortunate man was completely flayed and the skin turned up in strips and rolls on his shoulders. In addition to this, his ankle, which had struck on the house when he fell, was out of joint, and altogether his condition was most deplorable. It is easier to imagine than to tell of the dreadful agony endured for twenty-four long hours before the light winds carried the vessel to port, where medical treatment could be obtained.

While engaged in bending the mainsail on a new schooner, the $J$. $G$. Dennis, he fell from the taffrail and struck on the wheel, receiving a severe injury. So great was the force with which he fell, that the spoke of the wheel, striking between the hip and lower rib, fractured the skin, and his right side was paralyzed for more than a week.

While in the Dennis, in February, 1862, Murphy assisted in the rescue of the crew of the water-logged sch. Life Buoy, of Shelburne, N. S., an event which illustrated in a striking manner the readiness with which our fishermen frequently apply means to ends in times of emergency and danger. The former vessel had lost her boat and most of her sails in a severe gale on Georges, and the boat of the Life Buoy had also been swept away. How could the fishermen, without a boat, and with their vessel in a disabled condition-having for sails only the foresail below the third reef and a jib bent for a mainsail-render any aid? The question was how to improvise some sort of a boat. Having decided to construct a boat of one of the gurrypens, which fortunately still remained intact, the skipper of the Dennis ran close by the Life Buay, and hailing her crew desired them to throw overboard some of the planks which formed the latter vessel's deck load. By skilful manœuvring these planks were picked up by the crew of the former vessel, and a bottom. was soon made for the gurry-pen and tightly caulked. The fishermen then ran near enough to the wreck to throw a rope on board, and the gurry-pen boat was got afloat and was hauled back and forth between the two vessels, making two trips. Before leaving the wreck her crew sent on board of the Dennis a jib and gaff-topsail, so that the latter might have sufficient canvas to reach the land. Four men were rescued; the mate had been washed overboard and drowned during the gale.

In March of the following year, and while still in the same schooner, Murphy had another fall from aloft. While lying to in a gale on Georges, the vessel plunged so heavily into the sea that the spring-stay became detached from the foremast-head, leaving the mainmast without support on the forward side, and liable to fall unless something could be done to stay it up. This could only be effected by some one taking the risk of going aloft on the mainmast, which, as stated, might break at any minute. But we will 
let Murphy tell the story in his own words: "The skipper told me to take the end of the "net-warp" "-a three inch manila rope, usually about fifty fathoms long-" "aloft with me and bend it around the mainmast with a running bowline as high above the gaff of the three-reefed sail as I could reach. Making a loop in the end of the rope, I threw it over my head and climbed up on the mast hoops till I reached the gaff, which I got astride of, and proceeded to execute my task. This I accomplished in a few moments, and having shoved the rope up as high as I could, again sat down on the gaff, unconsciously throwing both legs on the weather side instead of sitting astride of it, as one almost always will. This seemingly trifling circumstance probably saved my life. It was the intention of the skipper, as soon as I got the end of the warp fast, to take the other end to the windlass and heave taut on it. But before this could be done, and while I was intently watching the movements on deck, the vessel took a heavy plunge, and as her bow rose again and her stern dropped suddenly into the hollow of the sea, the mainmast broke under me and fell with a crash over the stern, breaking again where it struck on the taffrail. Just how I escaped I can hardly tell, the whole thing was done so quickly. I only know that, feeling the mast going, I threw myself from the gaff and fell all in a heap in the corner formed by the taffrail and lee-quarter rail. At the same instant the mast struck on the taffrail, above my head, as I lay on deck. Had I fallen a few inches farther aft I should have struck in the water, and rescue would have been impossible. As it was, I received no injury beyond a little shaking up, a few bruises, etc., and was soon able to resume duty."

The next remarkable adventure that he had occurred in the Fall of 1869, while he was with me in the sch. Glenwood. Toward the close of a disagreeable drizzly day in October, we ran into Port Hood, C. B., where a large fleet had collected in anticipation of a storm. All of the best anchoring grounds were occupied, and we were obliged to take a berth not far from the long sand bar which extends nearly two-thirds of the distance across the southern side of the harbor, leaving a comparatively narrow channel between that and the sand spits off the eastern shore. That night and the next day the weather was only what might be expected-raw, breezy and unpleasant. About nine o'clock on the second night the wind backed to north-northeast and began to pipe in good earnest with occasional "spits" of snow. We let go the second anchor, paid out a good scope on both cables, and having set an anchor watch, turned in. All hands were called again at midnight to pay out more cable, though, on account of the Lizzie $A$. Tarr lying directly astern of us, and very close, there was not room enough for so long a scope as we wished to have out. At this time it was intensely dark, the air was filled with snow and sleet, and the gale had increased to almost a hurricane. The tide, too, had risen to an almost unpre- 
cedented height, and there was a sharp choppy sea in the harbor. After we had veered out the cable, but while the men were still on deck, we saw a vessel* driving down directly for us, broadside to the wind. We made an attempt to sheer our vessel out of her path, but were only partially successful. She struck us on the port bow, and her starboard anchor, which hung at the cat-head, caught over our port cable. This brought the strain of both vessels on our anchors, which gave way, and down we went under the bow of the Lizzie Tarr, broadside on, the bowsprit of the latter vessel coming in over our quarter-rail, and passing between the starboard main rigging and the mainmast, while the Lizzie Cook lay on our port side, pounding away at us as she rose and fell with the sea. For a time it seemed that our vessel would be ground up between the other two, or that the whole three of us would be driven together in a pile on the bar, not more than three hundred fathoms to leeward, over which the sea was breaking masthead high. Fortunately the Tarr's anchors held on, and gave us time to extricate our vessel from her dangerous position. In less time than it takes to write it, I had jumped on board of the Cook and requested her skipper to pay out more cable so that his vessel would drop aft on our quarter. This he did, and, watching for the right moment, the lanyards of our starboard main rigging were cut away, freeing the bowsprit of the Tarr; our vessel swung head to the wind, and we paid out on our cables, dropping down between the other two vessels, and astern of them, where we held on, thinking we would be safe. But in this we were disappointed, for before we had a chance to reeve off new lanyards for our rigging, we were startled by the cry that our starboard cable had been cut by the crew of one of the vessels we had been in collision with. The first thing to be done was to rig the stock in the "spare anchor" which we had on deck. We had just completed this job and were about to bend the cable to the anchor, when some one shouted out in a dismayed tone, "We're all adrift! they've cut our other cable." Not a moment could be wasted, for the foaming and roaring breakers on the bar were right to leeward. Luckily our vessel fell off head to the eastward, and I instantly determined to run out of the harbor, though the darkness of the night, intensified by the blinding snow, rendered the attempt to pass between the southern bars an extremely hazardous undertaking. As I ran aft to clear the wheel, I shouted, "Bear a hand on the foresail; be lively, now, and get it on her!" It was soon up about as high as if it was singlereefed, when I righted the wheel, the sail filled, and our little vessel started off with the speed of a race-horse, dragging behind her the port cable, which, stretching out in the wake, and glistening with phosphorescence, looked like an immense fiery sea serpent. "Hard up! keep her off!" shouted the look-

\footnotetext{
* The Lizzie Cook of Newburyport.
} 
out. Up went the wheel, the vessel swinging quickly off until a light was dimly seen on the weather bow, and the cry of, "Steady! so," assured me that we were heading all right. The next instant we went rushing by the stern of one of the fleet, just clearing her main-boom. Hardly had we passed that one, when a voice cried out again, "Luff! luff hard!" and we swept by another schooner, almost scraping the end of her bowsprit with our lee rigging. These were the outside vessels of the fleet, and having kept a mental calculation of the distance run, I judged soon after passing them that we were far enough to keep off and run out of the channel. When out by the bar we jibed the foresail and hauled to on the starboard tack. In jibing, the gaff was broken, and the peak-halyards caught over the horns of the cross-trees. Notwithstanding this, we were able to range ahead slowly up under the lee of the bar, close enough to it to make comparatively smooth water. Probably not more than fifteen minutes had passed from the time our second cable was cut until we hove to outside of the bar. At this time the anchor was bent, with the exception of the last seizing, which was soon put on. We then took hold of the anchor and threw it over the bow, but, in our hurry, did not lift the bight of the cable clear of the cat-head. The result was that the anchor fetched up with the stock just under water, and, as we were drifting off shore, it was important that it should be cleared from this awkward predicament with as little delay as possible. The quickest way, of course, was to reeve the cat-stopper and cut the anchor; but this could only be done at considerable risk. But, without waiting for orders, and only saying to the men about the windlass, "Look out that the cable don't slip," Murphy slid down on the hawser, rove off the cat-stopper, and was soon on deck again; not, however, before he had been soused under water several times. Having cleared the cable, we paid out sixty or seventy fathoms, and rode out the gale. The following day we were almost compelled to part with our last anchor. The high tide had floated off the beach at the head of the harbor an old vessel which had been hauled up there. Once afloat she went driving on down through the fleet and brought up on the bar. When the tide rose about noon she floated off and came drifting down straight for us. We made all possible preparations to clear her, but when she neared us the current or untertow changed her course somewhat, so that she passed by a little distance off, and driving ashore on the cliff astern of us soon went to pieces. That afternoon we ran to Canso, where we refitted.

In 1870 Murphy shipped with Capt. James Lunderkin, in the sch. William F. Poole, but backed out. The vessel was lost on Georges with all hands.

The same Winter, Murphy had another tumble overboard. He was then in the Hiawatha, which lay at anchor on Georges. He says: "I went on the house to cast off the fall of the main-boom topinglift, when, just as I 
had grasped the rope, our vessel gave a tremendous lurch, throwing me over the rail into the water. I clung to the rope, however, which was of considerable length, and hauled myself alongside by it, when my shipmates reached down, grabbed me by the arms and assisted me to climb over the rail." Had he lost his grip of the rope his rescue would have been impossible.

In the Summer of 1873 , when returning home from the Grand Bank in the sch. $B . D$. Haskins, Murphy encountered the terrific hurricane of Aug. 24 and 25 , which wrought such awful havoc among our fishing fleets. The little vessel, deeply laden with salt codfish, slowly pursued her way towards home until she neared Sable Island, where she was overtaken by the storm. An attempt was made to carry reefed sails and gain an offing from the Island, but so rapidly did the gale increase that the vessel was soon hove to under close-reefed foresail, and even with this small sail her lee side was buried; while to make matters worse, it was ascertained by sounding that she was drifting into shoal water. It was night, intensely dark, and every wave looked like a breaker. The little schooner was continually swept by the seas which ran sharp and high; everything moveable on deck was carried away; the waist-boards stripped off ; and it seemed impossible for her to outlive the hurricane. Finding the water constantly shoaling, and despairing of escape under sail, the anchor was let go, but the storm was so violent that it would not hold. About midnight the wind, which had been blowing from southeast changed suddenly to north-northeast, and for a while kept jumping from one point to another, howling fiercely from whichever direction it came, and knocking the sea all up in heaps. About this time the men on the Haskins, who scarcely expected to see the light of another day, were startled and terrified by a most remarkable phenomenon. "Driven swiftly along by the hurricane," says Murphy, "came a dense black cloud, bearing on its eastern end a huge fiery pillar." The cloud, resembling an unearthly spectre, carrying with it phosphorescent fires, passed close by the vessel and swept out of sight to leeward. "So appalling was its appearance that four of the men, overcome by their superstitious fears, as well as the terror inspired by their fearful situation, went into convulsions." In the meantime the vessel was drifting, and a depth of only sixteen fathoms having been reached, it was determined to cut away the masts, in hopes that the schooner might fetch up. The only tools available for this purpose were two dull hatchets. It was slow work to cut in sufficiently on one side of the masts, especially as the workers had to be constantly on the alert to save themselves from being washed overboard. After a while, however, the job was accomplished, the lanyards cut away, and, after stand-

*Murphy. 
ing for a roll or two, the masts went crashing over the side into the water. The next thing was to clear away the lee rigging and head-stays which still held the spars alongside, bumping and pounding, and threatening to knock a hole in the vessel. This was the most dangerous task of all, but was successfully accomplished without any one meeting with serious injury.* But even after the masts were gone, and the little vessel lay a dismantled wreck on the water, the anchor would not hold steadily. In the meantime, somewhere about an hour after the spars were cut away, a huge wave swept over and across the bow, tearing off the cutwater and head, and also carrying away the bowsprit. At last, when even the bravest were almost ready to despair, the anchor took a firm hold of the bottom, and the hull of the little schooner, stripped bare for the fight, rose more buoyantly on top of the waves. The sounding line showed a depth of ten fathoms when she brought up. But notwithstanding the dangerous character of the sea caused by the shallowness of the water and the fury of the gale, the gallant little craft rode it out in safety. Toward the close of the $25^{\text {th }}$ the storm abated. As soon as practicable, jury-masts were rigged, and sufficient sail (the sails had been saved when the spars were cut away) was set upon these to work the vessel in near Cape Canso, where she was fallen in with by the sch. Frank of Charlottetown, P. E. I., and towed to Port Hawkesbury. Lying at the wharf, with jury-spars lashed to the stumps of the masts, the naked stanchions sticking up along her sides, and with deck polished to immaculate whiteness by the sand that had swept over it in the gale, $\uparrow$ the Haskins pre. sented a scene sufficiently desolate looking to convince any one of the terrible ordeal through which she had passed.

A short time afterwards Murphy met with another adventure, from which his escape with life was as remarkable as in the previous instance. This was on the $14^{\text {th }}$ of January, 1874 , at which time he and I were shipmates on the sch. Eastern Queen, engaged in the haddock fishery, under command of Capt. William Corliss. On the evening of the $3^{\text {th }}$ we hauled out of Commercial dock and started down Boston harbor, beating out against a moderate southeast wind. The night was dark, with an overcast sky and some indications of snow, but, nevertheless, we worked slowly along. The skipper staid on deck directing the movements of the vessel until one o'clock on the morning of the 14 th, by which time we were down off Nahant. Myself and watchmate were then called to relieve the watch on deck. I had

*The skipper of the B.D. Haskins told me, soon after the gale, and while the vessel lay in Canso waiting for repairs, that the preservation of the schooner and the lives on board of her, was largely due to the coolness and pluck of Murphy during the storm. He particularly distinguished himself in cutting away the spars and clearing the wreck.

- The water is often thick with sand during heavy gales, even in a depth of twenty to twenty-five fathoms. 
scarcely taken the wheel when I noticed that Long Island light, which was almost directly astern, was "shutting in," and could barely be seen. I immediately notified the skipper, but when I looked the second time, to ascertain the correct bearings of the light, it could not be seen. Almost at the same instant we had a snow-puff, and the wind veered to the eastward a couple of points. We tacked and ran back for Broad Sound. After tacking, a bright lookout was kept, the skipper himself being forward, anxiously watching to catch a glimpse of Long Island light. After a while, the skipper shouted, "How do you head ?" "Southwest by west," I replied. "Let her luff, then," he sang out again. I began to roll the wheel down as quickly as possible, but before the vessel had swung to more than two points she struck on bottom, jumping, bumping and pounding, until at last she stopped still; heeling down considerably, the speed with which she was running having carried her into somewhat less water than she drew. A dark object could now be indistinctly seen on our weather bow, which we knew to be Faun Bar Beacon. Four of us started for the city in a dory to secure the services of a steam tug, the skipper being one of the party. Almost as soon as we left the side of the vessel we found ourselves among breakers; the dory was half filled with water, and we began to realize the difficulties and dangers that lay before us in threading the tortuous channels of Boston harbor at night in a frail boat during a wild wintry snow storm. But there was no thought of backing out, and having got clear of the breakers and freed our boat from her waterlogged condition, we started again. At last, and much to our joy, we made Long Island light, its rays looming dimly through the snow almost over our heads. Rowing past the fleet anchored in the Roads, we soon after came to Spectacle Island, and in due time reached the Castle. Bye-and-bye we came to a long pier, at the head of which lay a large schooner, while a short distance off could be seen the ruddy reflection of light from some sort of blasting furnace.* We started again, and after a hard pull against the wind, which was then about eastnortheast and blowing strong, we reached " $T$ " dock, where we found, and went on board of, the steam tug $C$. $M$. Winch, which lay there with banked fires. Notwithstanding the oil clothes we all had on, we were drenched to the skin, and the skipper, who had sat in the stern of the boat looking out, not having had any exercise like the rest of us, was so thoroughly chilled when we reached the steamer that he could not speak coherently, and could scarcely stand. We soon made known our wants to the captain of the tug, but the weather was so thick that he did not dare to start before daybreak. At last the anxiously watched-for daylight began to appear; the steamboat men bustled around, casting off lines, and shortly the puff, puff of the engines

*The South Boston Iron Works. 
assured us that the much wished-for start was being made. But so intensely thick was the misty fog, that in the gray light of the early morning that it was impossible to discern anything a hundred yards distant. Reaching Deer Island Beacon, we headed out into Broad Sound. A little later we saw a vessel on our port beam that had evidently just anchored. We slowed up, thinking it might be ours, but deciding it was not, we started on again. But now we began to meet with the ocean swell, and the little steamer plunged and rolled terribly, sending showers of spray over the top of the pilot-house. Down off the Faun Bar buoy the sea almost broke from the bottom, and considering it too risky to venture on the back side of the bar, the captain of the tug turned her around, and ran back again for the schooner we had seen on our way out, and which, much to our surprise and pleasure, proved to be the Eastern Queen. We now gave her a towing warp, and, the anchor having been weighed, towed her to Commercial dock, where, at last, we could hear the story of the escape, which before we could only conjecture. After we left the vessel in the dory the tide rose slowly, the wind and sea increasing at the same time, causing her to pound very heavily. The men on board, one of whom was Murphy, deeming it unsafe to stick by any longer, if they could leave in the boats, hoisted out a dory, by way of experiment, and paid her down to leeward of the vessel. But it was soon evident that the attempt to row a boat through the breakers would be absolute madness, for the dory had been but a few moments out when she was struck by a wave, rolled over and over, and knocked about like an egg shell in the yeasty waters that were then foaming all about the apparently doomed Queen. Failing in this scheme, and knowing that the vessel would soon pound her bottom out unless something more was done, since, every time she fell, the grinding of planks and cracking of timbers could be distinctly heard, the men determined to put her head on. They therefore hoisted the foresail and jib, and slipping the cable, drove her on as fast as the tide came; whenever she rose on a sea she gained a little ahead. The case with them was now absolutely desperate. There would not be, even at full flood, as much water on the bar as the Queen drew by nearly two feet.* The wind blew almost a gale, and the sea broke over her in all directions. There was every reason to suppose that she might bilge and break up. If this happened every soul on board must perish. But Murphy resolutely clung to the wheel and headed her on the bar. At last she rose on a wave, started ahead, kept going/ while the joyful shout of, "We're off! we're afloat!" was raised by every one. Owing to the density

\footnotetext{
*When we returned to the place at low tide on the next day, to secure the cable and anchor that had been slipped, the bar was dry; and a deep track, like a furrow, marked the point where the Eastern Queen had ploughed her way through a mass of rocks varying in size from a water pail to a large eask.
} 
of the fog they ran only a short distance, and having made the buoy on the Inner Faun, came to anchor, where, shortly after, we saw them. The fact that the forefoot and after part of the keel of the vessel was ground off into the wood ends, and six or seven bilge planks were cut through, or nearly through, causing a leak of 2,500 strokes an hour, tells how narrow an escape from death those had who remained on board.

Such are some, though by no means all, of the adventures through which Capt. Murphy has passed ; and the fact that he still lives to brave the perils of the deep, and is as vigorous, "hale and hearty as any on 'em," might be cited as proof that

"There's a sweet little cherub sits up aloft

To watch over the life of poor Jack."

\section{THE OPEN SEA.}

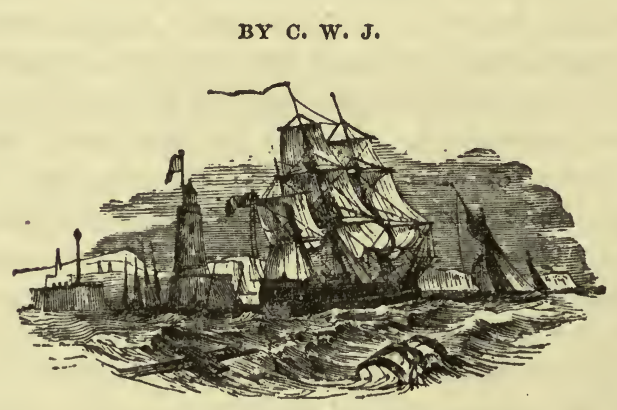

Far out at sea,

Where tossing billows mock the sky And shrill winds whistle free

And fleecy clouds go hurrying by.

What care we for the land

Except to keep it far away?

For here no rocks or whelming sand Along our free course lay.

Along the land lie shoals,

Treacherous bar and cruel reef,

Where the curling breaker rolls

With mournful moan of woe and grief.

On the land is guile

Fraud and treachery, vile and base,

Where the coward lurks with stealthy wile And smooth, deceitful face.

Here is no deceit!

The Storm King warns ere he makes attack; Swift heralds, with white hurrying feet, Tell the approach of the tempest black. Man struggles 'gainst wind and wave 'In an honest fight that is fair and free, And God alone can save.

Hurrah for the open sea! 


\section{Gloucester's Exhibition at the Centennial.}

The Fishery Exhibit made by this city at the Centennial, at Philadelphia, in 1876 , gave much satisfaction to the thousands who witnessed it, and this, together with the distribution of the five thousand copies of the Centennial Pamphlet giving a full description of the fishing industry and the relation which Gloucester sustained as the largest fishing port in the United States, undoubtedly resulted beneficially in a business point of view. Mr. Edward King, the able and interesting Centennial correspondent of the Boston "Journal," wrote the following account of the Gloucester exhibit, which was published in the columns of that paper, and we are pleased to reproduce it in the pages of "The Fishermen's Own Book":

"In the vicinity of the Aquarial Department in the Agricultural Hall the city of Gloucester has erected a tank 23 by 12 feet, filled with water, in which correct models of the fishing fleet of the old and new times are afloat, illustrating the different branches of the fisheries. In one corner is the old 'cob wharf' of Revolutionary years, with its primitive appliances, and the odd, quaint 'pinkies' lying beside it. Opposite it is a model of the massive and durable pile wharves, such as are built in Gloucester in 1876 , ten times as large as the old ones. On this the fishermen are shown at work packing mackerel. All the appliances of fishing wharves are exhibited. Ranged about in the little harbor are models of all the various improvements in fishing craft, from 1800 down to the present time. The old Manchester, a famous fisher in her day, built about the beginning of this century, is exhibited in model. The Manchester is still in existence, and is now in the carrying trade somewhere 'down East.' The 'bankers' that go to Georges Bank, the 'seiners' and the 'market boats' are all shown, and a practical model gives a very correct idea of the setting of a mackerel seine.

"In addition to the exhibit in this tank there is a fine collection of objects belonging to the fisheries, or of curiosities collected during the voyages. The quadrant, made in $176 \mathrm{r}$, and used by Capt. Isaac Day over a century ago, is shown; near it stands an hour-glass still older. There is also a curious substance resembling branch coral, which is said to have been fished up in one hundred and fifty fathoms of water by a 'banker.' Here, too, are seen all the appliances which make the fishing vessel of to-day a palace compared with its rude prototype of a century ago.

"Gloucester maintains her position as first among fishing ports proudly. Every year more and more direct trade comes to her; and she still controls her market even on the Pacific coast, sending great quantities of fish to 
Sacramento. It is not a little curious, also, that this very year she has begun exporting fish to Sweden. One would have thought that like carrying coals to Newcastle. But even stranger things may happen.

"The exhibit of the Gloucester fisheries is, however, the most interesting one of its kind in the Exhibition. It is by far the most complete, as it gives an accurate idea of the growth from very small proportions to their present gigantic status of the fisheries of the largest fishing port in the world. Brave old Gloucester! There is almost poetry in these toy sails and mimic wharves, and imitation seas spread out before the eyes of visitors to the Exhibition, for they recall the many pathetic stories which we have heard of the losses of good fishermen and their ships on the gloomy and treacherous "banks." "

\section{THE WIDOW'S APPEAL TO THE WINDS AND SEA.}

BY GEORGE H. PROCTER.

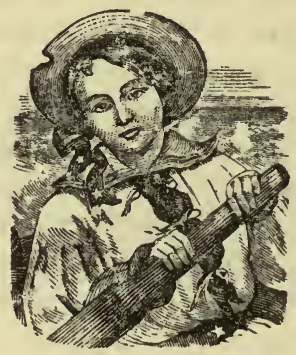

Winds, to your charge I give My bonnie fisher lad;

A treasure very dear to me, Whose absence makes me sad.

He toils that we may live, His mother, sisters three, Widowed and fatherless, Made so by thee.

Blow steady-let no gales

Their fury burst upon

The craft which holds my boy,

This darling, only son.

Gently the snowy sails

Fill with thy wondrous breath, And waft him back to me, And not to death.
O sea, a boon I crave, Thou, too, must guard my boy;

Do not his graceful form

To thy embrace decoy;

But bear him safely o'er Thy pathless, billowy space,

That we may gladsome be At sight of that dear face.

Buoy up his vessel well, Ye waves, your force subdue;

No sullen humors take, But to jour charge be true. Around the schooner's prow In tiny wavelets break, 0 treacherous, heaving sea, For his dear sake. 


\section{Picking the Nets and Trawls,}

Wherein We Find Good Hauls of Facts, Incidents, Off-Hand Sketches, and Items of Interest Concerning the Fishermen and Their Calling.

Important to Fishermen.-The Direct United States Cable Company have charts for the guidance and information of fishermen, showing the location of the company's cables, with the depths of water, and request captains to give them a wide berth. Should any vessel, however, lose her anchor or cable by reason of coming in contact with the telegraph cable, and will use every endeavor to save the same from damage, the company will reimburse the loss, subject to adjustment, upon being satisfied that the claim is a just one. On the fourth page of the advertising department may be found full particulars, and it being of great public interest, we thus call attention to it.

The sum of $\$ 100$ was received by Collector Babson in March, $188 \mathrm{r}$, from the Direct United States Cable Co., as compensation for the loss of anchor by sch. Oliver Eldridge, Capt. John Scott. The schooner was at anchor on Brown's Bank, and had drifted during a high wind and fouled the telegraph cable. Upon ascertaining the fact, Capt. Scott cut his cable and reported the case to Collector Babson, who sent on the evidence, and the company promptly paid the damages. The honorable manner in which the company proposes to deal with our fishermen should entitle it to the most careful consideration when they are fishing in the vicinity of the cable, by using every precaution to avoid fouling it, and when fouling, to cut at once rather than run the risk of injuring the cable.

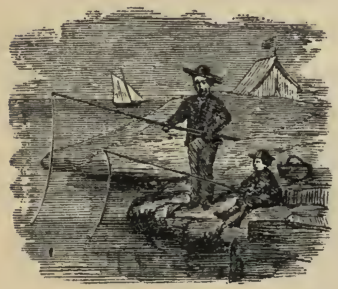

Interesting Statistics Gleaned from Experiments of the U. S. Fish Commission in GloucESTER.-The loss of weight of codfish from the round to the market-dried fish is from $54^{1 / 2}$ to $65^{1 / 2}$ per cent., the average loss being about .6023 , distributed as follows: Loss in splitting, .4044; loss in pickle, .1496 ; loss on flakes, .0483. The shrinkage in length from the round to the split fish is from $61 / 2$ to $111 / 2$ inches. By extra drying, in the warmest weather, the average loss in weight is about a half per cent. more. The loss of weight of Georges cod in curing, after being split and salted on board the vessel, averages about I I $1 / 2$ per cent. The average loss in weight of market-dried fish in boning is nearly 22 per 
cent (.219). Pollock, from the round to the market-dried fish lose on an average 59 8-10 per cent., and shrink in length from 8 to 12 inches. Haddock shrink in length from the round to the marked-dried fish from 4 to $5 \frac{1}{2}$ inches, and lose in weight 62 -ro per cent. The loss of weight in hake from the round to the market-dried fish averages $55^{1} / 2$ per cent., the loss in length from $4 \frac{1}{2}$ to ro inches. Cusk lose from the round to the marketdried fish $50 \frac{1}{2}$ per cent. in weight and from $4 \frac{1}{2}$ to $7 \frac{1}{4}$ inches in length.

Protecting Trawl and Net Fishermen.-The following is the full text of the bill approved March I I, I882, to take effect forty days thereafter, for the protection of the rights of lobster, net and trawl fishermen :

"Any person who shall take any fish or lobster from any trap, trawl or seine set for catching fish or lobsters, except by consent of the owner thereof, and any person who shall wilfully molest or interfere with such trap, trawl or seine, shall for the first offence be punished by a fine of not less than five nor more than twenty-five dollars, or by both fine and imprisonment ; and for any subsequent offence by a fine of not less than twenty nor more than fifty dollars, or by imprisonment for sixty days, or both fine and imprisonment."

Some Mackerel Trips Forty-five Years Ago.-A blue-covered pass book preserved among the papers of Messrs. James Mansfield \& Sons, gives an account of the outfits of a schooner commanded by Capt. Ignatius Sylvester of Riverdale, on half a dozen or more mackerel trips in the Summer and Fall of $18370^{\circ}$ The book is in the handwriting of Capt. George W. Plumer, with occasional entries in the writing of Mr. James Mansfield, then the head of the firm, both of whom are still living, and indicates that besides Capt. Sylvester the crew consisted of George Stanwood, Addison Griffin, Tristram Griffin, Henry Stanwood, John Parsons and Issac Babson, all of whom with the exception of the two last named are still among the living. Three of the number, Messrs. Sylvester, Henry Stanwood and George Stanwood commanded vessels in the employ of the Messrs. Mansfield for an aggregate of one hundred years. The accounts are made out in the form of "Great General" and "Small General," the former covering salt, fuel and lights, bait and use of bait mill (\$2), and the latter including provisions, hooks, lines, leads, sawing wood, etc. The time covered by the pass book was from June 30 to Nov. 16 . The fuel consisted of wood, a cord and five feet being required for the season, at $\$ 7$ per cord. For light four gallons and a quart of oil at $\$ \mathrm{r}$.ro per gallon, and six pounds of candles at 15 cents per pound, were required. We find only 3 bbls. of bait charged, 2 at $\$ \mathbf{2 . 2} 5$ and I at $\$ 2.75$. Salt was billed at $\$ 3.30$ and $\$ 3.371 / 2$ per hhd., all but 9 hhds. at the higher rate, and 37 hhds. were taken on board, of which a portion was returned. 
The meat provided, excepting 53 cents worth of veal, consisted of 142 lbs. beef at 8 cents per lb., and $1703 / 4$ lbs. pork, from 12 to 14 cts. per lb.; $203 \mathrm{lbs}$. flour were supplied at $61 / 4 \mathrm{cts}$. per lb., 4 pecks meal at $34 \mathrm{cts}$. per peck, $445 \mathrm{lbs}$. bread from $7^{1} / 2$ to $81 / 2$ cts. per lb., $5 \frac{1}{2}$ bush. potatoes from 40 to 67 cts. per bush., 59 gals. molasses at 34 and $36 \mathrm{cts}$. per gal., $33 \mathrm{lbs}$. rice at 5 and 6 cts. per lb., 3 bush. beans at 8 cts. per qt., 2 gals. vinegar at 20 cts. per gal., a can of mustard, a pound of saleratus and a bottle of pepper sauce. For drink there were $35 \mathrm{lbs}$. coffee at ten cents per pound, and r lb. chocolate at 22 cents. $343 / 4$ lbs. of lard were used at ro cts. per lb., and the butter and cheese bill was very moderate,

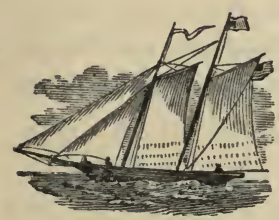

A Singular Circumstance.-Dec. 15, I865, sch. Live Yankee, then owned at this port by Daniel Sayward, while anchored on Georges during a heavy sea, unshipped her bowsprit shroud, which was lost overboard, and when she returned to port a new one was furnished by Mr. Addison Witham, rigger. The next Spring, while the crew were engaged in fishing on Georges, one of them caught something on his hook, and pulling up, was surprised to find a bowsprit shroud attached. Supposing themselves to be anchored over the wreck of some Georgesman, they brought the shroud in, and called some of the riggers to examine it for the purpose of identification, and thus to gain information of a lost vessel. Among them was Mr. Witham, who at once pronounced it the one lost by the Live Yankee the December previous. He was positive of this, as it had a very peculiar long-shanked hook, different from any other in our fleet, and it corresponded exactly with the other one which is still in use on the vessel. It was in good condition, with the exception of some parts of it being covered with small barnacles. It was indeed singular that it should be hooked up in the manner it was, by one of the crew of the vessel from which it was lost.

The Isinglass Industry.-The first establishment in this country for the manufacture of isinglass from fish sounds was set up in Rockport, Mass., in $\mathrm{r}_{22}$, by a Mr. Hall, an Englishman, who came to the town for that purpose, because he could best buy here the hake sounds he wished to use. His shop was out near the end of the neck, the same building Mr. Addison Gott now uses as a fish house. He first used wooden rollers, which had the disadvantage of warmth and adhesiveness. Besides, his rollers were turned by hand power, two men to a roller, making very unsteady work; it is said the wages of this human power was from thirty to forty cents a day. After some years, iron rollers were introduced, and the next improvement was horse power, using a treadmill. Mr. Hall, within a few years after he start- 
ed here, took in Jabez Rowe as partner, and they continued together some years. After some twelve years here Mr. Hall died, and tradition says was quite poor. In the course of time Deacon Gott, Messrs. William Burns and William Norwood became interested in the dawning enterprise, and they built the now old Rockport Sound Factory on Dock Square. They had introduced steam power and many other later improvements. The price at first paid for sounds was usually five or six cents a pound. One year, when the price was held as high as eight cents, they thought of abandoning the business on account of the enormous cost of sounds. This seems singular to us, who in our time have known sounds to bring over $\$ 1.50$ a pound.

Two OlD Jokers.-Among the fishermen of Maine who formerly sailed from Gloucester was Captain Ezra T-, a great wit in his way, and always ready with a joke or repartee. On one occasion, while engaged in the mackerel fishery, he had as one of his crew Hiram S-, who was noted among his compeers for having a remarkably large head. The last-named individual being employed one day in stowing mackerel barrels in the hold of the vessel, a discussion arose as to whether a barrel would go in a certain place or not. Captain $\mathrm{T}$-, who was on deck, happening to overhear the remarks, pro and con, of the men in the hold, leaned over the hatchway and, speaking to S-, said, "Shove your head in there," Hi. (an abbreviation for Hiram)-_"if your head will go, a barrel will!"

But Captain $\mathrm{T}$ - met his match on one occasion in his friend and neighbor, Captain R-: As the story was told, the former, who was sometimes addicted to convivial habits, crooked his elbow rather too frequently one evening, and having to pass through a growth of woods on his way home, got astray. After struggling through underbrush and other obstructions, and losing his hat, he finally reached the house of his friend $\mathrm{R}$-, who, of course, supplied him with a hat, and started him on the right track for home. A few months later Captain $\mathrm{T}$ - was engaged in trading along the coast of Maine in his vessel, and, among other things, had some furniture to sell. One day he called at the house of Captain $\mathrm{R}$-, and tried to induce the latter to buy something. After enumerating the various kinds of goods he had for sale, a thought struck him, and he asked, "Don't you want to buy a table, R-?" R-, who had a large family, replied, "Dod blast it, no! I've more tables now than I can fill with grub." "I believe that," said T-, "but, at least, you ought to have one respectable table on which to put gentlemen's hats, when any, like me, for instance, comes to see you." "Oh, yes, that's so," exclaimed R-, "but when gentlemen like you come to see me, they generally come drunk and bareheaded." 


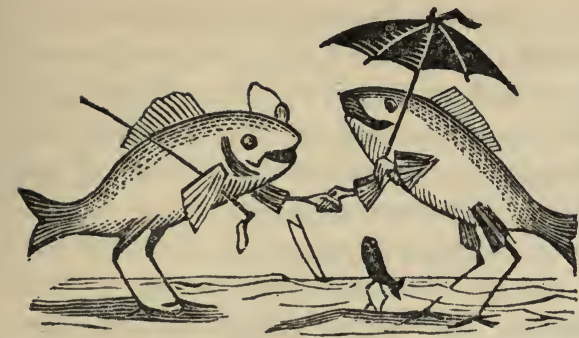

Every Part of the fish is now utilized, the skin being the last to. find its place among merchantable articles. This is used for the manufacture of fish glue and cement, and the product is ranked among the best in the world. There are two companies in Gloucester engaged in its manufacture, and their business is constantly increasing. The raw material is held at $\$ 12$ per ton, at which price it finds a ready sale. The skins are also used in the manufacture of guano, and now that the boneless fish industry has assumed such large proportions these skins form a large source of profit to the fish dealers.

The First Trawl Fisherman of whom we have any record was $\mathrm{Mr}$. Coleman Manning of Rockport, whose unexampled success in fishing was long a mystery to his fellow fishermen, until the secret was discovered, causing considerable-indignation at the method pursued, as it was thought it would damage the fisheries. This was about $185^{2}$, and the trawl roll used by Mr. Manning, an uncouth-looking affair, has been presented to the National Museum of the United States. Mr. John Rowe, of East Gloucester, claims to have set a trawl across Brace's Cove, in May, 1820 , but the practice was not then followed up.

MENhaden Factories.-The number of menhaden factories in operation last year, $188 \mathrm{r}$, was 97 , employing 73 steamers and 286 sailing vessels, with $2,805 \mathrm{men}$, who caught $457,192,000$ fish, from which were made $1,266,549$ gallons of oil and 27,592 tons of crude or $\mathrm{r}_{5}, 027$ tons of dried guano.

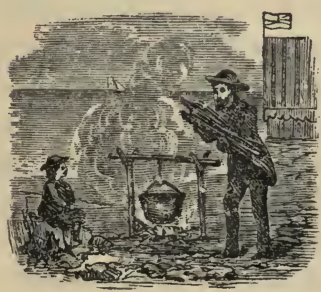

The Materials of Which Fish Are Composed. -Considered from the standpoint of the food, fish, as we buy them in the market, consist of flesh, or edible portion, and refuse-bones, skin, entrails, etc. The proportions of refuse in different samples of the same kind, in different conditions, vary widely. Thus a sample of flounder contained 68 per cent. of refuse and only 32 per cent. of flesh, while one of halibut steak had only 18 per cent. of refuse and 82 per cent. of edible materials. Among those with the most refuse and least edible flesh are the flounder, porgy, bass and perch. Among those with the least refuse are fat shad, fat mackerel, salmon, and dried and salt fish. The edible portions consist of water and solids, actual nutrients. The proportion of water and 
solids in the flesh of various kinds of fish is much more variable than most people would suppose. Thus the flesh of flounders had 85 per cent. of water and only 15 per cent. of solids, while that of salmon contained $36 \mathrm{~T} / 2$ per cent. solids and $63 \mathrm{x} / 2$ per cent. water, and the flesh of dried, smoked and salt fish have still less water. Lean beef contains, on the average, 25 per cent. or one-quarter its weight of solids, the other three-quarters being water, while fat pork has one-half solids. Ordinary fresh meats are from onehalf to three-fourths water, while the water in the fresh fish varies from three-fifths to six-sevenths of the whole. To find the actual nutritive materials of a sample of fish, we must first subtract the refuse-the entrails, bones, etc.-which leaves the flesh. Then we must allow for the water in the flesh. What remains will be the total edible solids, the actual nutritive material. The per centages of edible solids in the different samples of fish were more varied than those of refuse and water. Thus roo pounds of flounders contained only 5 pounds of actual nutrients ; 100 pounds of haddock, 9 pounds ; of bluefish, II pounds ; of cod, I 2 pounds; salt mackerel, I 6 pounds ; shad, $\mathbf{x}$ pounds ; salt cod, 20 pounds ; salmon, 27 pounds ; and smoked herring 28 pounds. - Sea World.

GEORGES BANK.-For the benefit of many who will peruse this volume we will state that Georges Bank is rgo miles east-southeast from Cape Ann, and about a twenty hours' run in a good breeze for one of our fishermen. There is shoal water fishing and deep water fishing-the latter requiring from roo to 150 fathoms of line, and is comparatively new, the first season of its success being in 1876 . LaHave Bank is 100 miles east of Georges, and fishing thereon has been commenced by our fleet within the past five years.

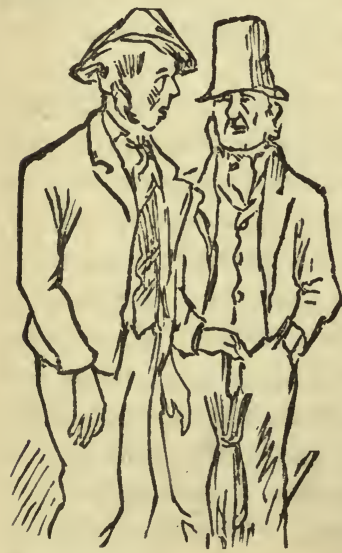

The Old Man's Yarn.-An Of-fish-al Narrative.-'Twas in the Summer of 'seventeen, as fine an August day as you have ever seen. Our Sary Ann, upon the beach, set up a most unearthly screech, and in a fit she fell. From cot and windmill near at hand, alarmed to hear her yell, quick out upon the glistening sand the neighbors rushed pell-mell. No need of words from Sary Ann, what startled her to tell, for every maid and every man, who to the beach so quickly ran, soon saw a sight that caused a fright, and made them feel. from head to heel as limp as this umb'rel. For there, two hundred yards from shore, a monster none had seen before, upreared its hideous head; with fork-ed tongue and eyes of flame, and looks of menace, on it came, as 
if to strike them dead; the waters half a mile away were lashed with fury into spray each time it moved its tail, and all the way between rose hump on hump of olive green, like huge waves in a gale. Glad hearts were theirs who watched that day-to apprehension dire a prey-to see the monster turn aside and from the harbor quickly glide. Horse mackerel and porpoise schools will do to talk about to fools; but we who lived in 'seventeen know that the sea serpent was seen.

Veteran CRAFt.-Pinkey Senator, 32.67 tons, built at Essex in 1831 , is still owned at this port. Sch. Ann Parker, built at Wells, Me., in 1850, is owned at Pigeon Cove. Pinkey Albatross, of Castine, Me., built in 1829, was at this port with a load of barrels in the Summer of $188 \mathrm{r}$. The whaler Mt. Wallaston, whose wreck was discovered in the ice of the Arctic ocean in r88 $\mathrm{r}$, formerly hailed from Gloucester at a time when it was proposed to establish the whaling business from this port. She sailed on her first voyage Jan. 9, 1834. Four months out she was spoken with 250 bbls. of oil ; Oct. 20,1834 , with 750 bbls.; Dec. 14, with 1,200 bbls. She arrived home May I7, r835, with I,600 bbls., r50 sperm, and r3,000 lbs. bone. The voyage did not prove so successful as had been anticipated, but she was again fitted out, and sailed on her second voyage in July, 1835 . In August she was spoken, having taken four whales. Jan. 13,1836 , she was again spoken, and reported 2,200 bbls. March 29 she arrived home with 1,600 bbls. whale, $55^{\circ}$ sperm, and $r 6,000$ lbs. bone. This would now be considered a successful voyage, but on account of the low price of oil it was not then regarded as satisfactory, and the ship was sold at auction for $\$ 4,5$ ro to J. B. Osgood of Salem, from which port she made several voyages.

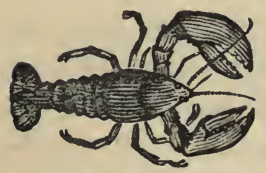

Something ABout LoBSTERS.-It has often been stated that "in general lobsters change their shell once a year, and it is a painful operation." A friend of ours in this city, who has an aquarium, states that he has a lobster which changed his shell three times within a year. He is also of opinion that when in the sea where they get a full supply of such food as they require, that they change their shells even oftener than this, as it is necessary for them to do so, in order to grow. Can any one give us any more light on this subject?

There is no doubt that the blasting of Hell Gate destroyed immense quantities of lobsters; so great a dread have lobsters of thunder that they will cast off their big claws when a loud clap occurs or when a gun is fired. In olden times captains of vessels often extorted blackmail from lobster fishermen by threatening to fire cannon over the fishing grounds, knowing 
full well that the concussion would cause the lobsters to cast their claws, thereby destroying their value.

Lobster spearing is pursued in the Indian fashion, by torchlights. A dark, calm night and a falling tide are the first requisites, and the crew of the canoe must consist of three-one to row, one to hold the torch so that its light will fall through the shallow water and light up the bottom to show the lobsters crouched among the seaweed ; and last, but not least, the spearer, armed with a long wooden spear, which it requires considerable skill and practice to drive down, so that the two prongs will close over the lobster's back, capturing him firmly, leaving the body uninjured. It is a sport both exciting and picturesque, as the boat creeps along under the shadow of the bank and the torch casts a Rembrandtish light on the occupants and on the overhanging trees. The captive lobsters sometimes make very unpleasant occupiers of a boat, and it requires great equanimity to feel them crawling about one's feet.

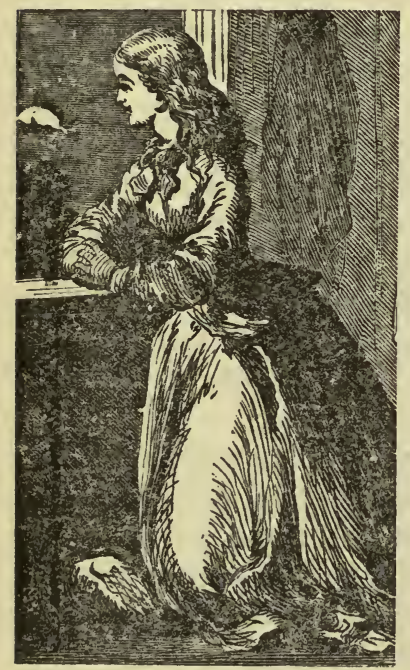

A Faithful Beacon Light.-It is a very tender story of faithfulness in humble places, which Jean Ingelow relates. It was in one of the Orkney Islands, far beyond the north of Scotland. On the coast of this island there stood a rock called Lonely Rock, very dangerous to mariners. On a night, long ago, a young girl was kneeling at the window in her chamber in a fisherman's cottage, looking out upon the dark and driving clouds, and listening anxiously to the wind and sea. At last the morning came, and one boat that should have been riding on the waves was missing. It was her father's boat, and half a mile from the cottage her father's body was found washed upon the sand. He had been wrecked against the Lonely Rock. The girl watched her father's body, according to the customs of her people, till it was laid in the grave, then she lay down on her bed and slept. When the night came she arose and set a candle in her casement. All night she sat by the candle, trimmed it when it flickered down, and spun. So many hanks of yarn as she had spun before for her daily bread, she spun still, and one hank over for her nightly candle. And from that time to the time of telling this story-for fifty years, through youth, maturity, into old age-she has turned night into day. And in the snowstorms of winter, in the serene calms of Summer, through driving mists, deceptive moonlight and solemn darkness, that northern harbor 
has never once been without the light of that small candle. However far the fisherman might be standing out to sea, he had only to bear down straight for that lighted window, and he was sure of a safe entrance. And so for all these fifty years that tiny light, flaming thus out of devotion and self-sacrifice, has helped, and cheered, and saved.

RARE Fish.-Sch. Laura Nelson, Capt. Roderic Morrison, arrived from Grand Bank in July, $188 \mathrm{r}$, bringing in a very curious fish taken from the stomach of a halibut caught on the western end of the Bank. It measured three feet, one inch, in length, and about two inches through, and was of a silvery color, having a sharp-pointed head, with a projecting flexible under jaw, and a small fan-shaped tail. It was presented to Capt. Martin, local representative of the U. S. Fish Commission, by whom it was forwarded to Prof. Baird at Woods Holl. The professor is of the opinion that it is of a new genus and new species, closely allied to the scabbard fish, of which two or three specimens have been received from the Banks.

LOOK OUT FOR THE RAw MATERIAL. - It is a mistake for any community to allow its raw material to be carried away, to have its value increased by labor somewhere else. Gloucester is learning this to some extent, and the preparation of boneless fish, the canning of mackerel, and the manufacture of fish glue and fertilizers are all steps in the right direction, making labor for many hands, and enhancing the value of our fish products. The practice of selling mackerel out of pickle, on the other hand, which has grown up of late years, is a step in the wrong direction, as the profits of packing and inspection might just as well be kept at home. Selling from pickle all the early part of the season, and thus giving to other markets the profits of handling the catch, and compelling purchasers to seek their supplies elsewhere than at the producing headquarters, will, ere long, cause Gloucester to lose its prestige as a mackerel market, and the later catch of home inspection will have to seek a market through second hands. Gloucester is a loser by many thousands of dollars, from the practice of selling out of pickle, which we hope to see done away with another season.

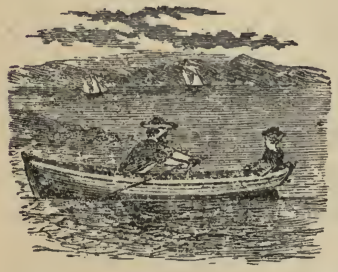

The Talking Codfish.-Recently two chaps, whom we shall call Bill and Joe, went out back of the Point in a dory to try their luck fishing. Bill possessed good powers of ventriloquism, which Joe was not aware of. They spent a couple of hours in fishing, and had good luck, when Joe hauled in a large-sized cod, and when he came up alongside, imagine his surprise when there issued from the cod's mouth, in words as 
plain as human lips could speak, "Halloo, Joe, so you've got me, after all!" To say that Joe was frightened does not express it. He was fairly stunned -so much so that he couldn't get the fish on board the dory, and he went down again the length of the line. Bill, also, showed signs of agitation, but endeavored to make Joe think that he was mistaken, and commenced pulling the fish in. When he again reached the surface, Joe was amazed to hear from the fish's throat, as distinct as could be, "Bill, you hurt! Pull out the hook and let me go." That was too much for Joe. He cut the line, hauled up the anchor and commenced rowing home, vowing that it was the d-l's own work, and he was afraid that it was a forerunner of ill-luck. Bill was scared, of course, and the affair formed the theme of conversation among their circle of acquaintances for several days. Soon after, the cat was let out of the bag, and Bill gave some good tests of his powers, which carried conviction with them. Joe treated all hands to birch beer, and the talking codfish was no longer a mystery.

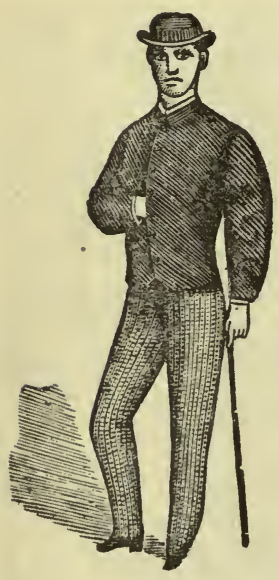

What the Old Blubber Man Said.- "It may smell a little fishy, but you soon get used to it," said an old man who was trying out blubber on one of our wharves to a young dandy-looking chap, who thought the effluvia was "perfwectly horwid." "And then," continued the old man, "it brings in the crispy greenbacks, you know, and your father was one of the best blubber b'ilers I ever knew." The young man fidgetted a little with his kid gloves and cane, and then quickly passed up off the wharf. He didn't care about hearing the old "blubber and ile" man give him any further reminiscences of his family. It's the case with a good many now-a-days. They like to spend the old man's money, but don't care to remember that the old gent ever went fishing or followed any of the honest occupations connected therewith. A great pity it is that many of the young men of to-day are not obliged to commence life as their fathers did. The experience would be the means of making good business men of them, as they would then know the value of money by being obliged to work hard in order to obtain it.

The First Shipment of Herring from Gloucester to Germany.As Mr. Addison G. Procter, of this city, senior member of the firm of Procter, Trask \& Co., was cashing a Swedish draft in Boston, Feb. ${ }_{5} 5,1877$, the banker remarked, "Why don't you ship herring to Germany as well as to Sweden, as the people of that country are large consumers of that fish?" 
One remark led to another, and the conversation concluded by the banker's giving him the address of a party in Hamburg, and becoming responsible for a shipment of fifty barrels, which were sent per steamer. They were put up with extra care and handsomely stenciled, "Procter, Trask \& Co., Cape Ann Herring," on the barrel head. While the herring were lying in New York, a German merchant saw them and obtained permission to open one of the barrels. He was so well pleased with the fish that he immediately telegraphed on for the price of 200 barrels of the same kind. The price was given and the order at once received. They were immediately packed and went on the steamer. Procter, Trask \& Co. therefore have the honor of shipping the first lot of herring from Gloucester to Germany.

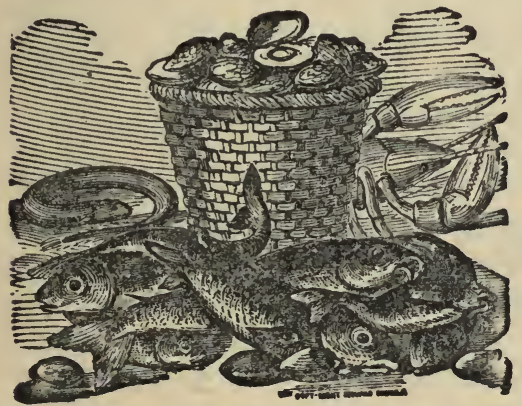

The Worth of Oysters and Fish FOR FOoD.-The researches of Prof. W. O. Atwater of Wesleyan University of Middletown, Conn., in getting at the facts of the worth of fish and oysters as food are worthy of the attention bestowed upon it. Exceedingly interesting have been the determinations of the nutritive values of some of the invertebrates, as oysters, scallops, lobsters and crayfish, which are to be found in these investigations. It is well known that in the mollusks water forms the largest proportion. So in Stony Creek oysters we find 90.47 of water ; in Blue Points, 80.76 ; in Norfolks, 91.45 ; in scallops, 80.32 ; in clams, 86.20 ; in lobsters, 82.73 , and in crayfish, 8 r.22. The fat in oysters finds its maximum in 2 per cent., though about 1.25 is a fair average. In the albuminoids they are fairly rich, the Blue Points having 8.20 , but the scallop, the muscular part, of course, only being considered, has as much as 14.75 per cent. In lobsters the fat is I.97, the albuminoids 13.57 , and the nutritive value is 62 , about the same as flounder. These considerations about the nutritive values of oysters only regard the edible portions, but Prof. Atwater has studied the relations of shell to meat, and we find that in roo pounds of Norfolk oysters, shell and all, there is really only one pound of nutritive material. The highest in the list is the Blue Point, which for every roo pounds of weight of shell holds $3 \frac{x}{3}$ per cent. of meat. But when Long Island clams are examined, there is an increase in nutrients, for in the roo pounds of shell and all there is 7.77, and in lobsters 6.80. In general, Prof. Atwater's tables seem to show that the Northern oysters are the richer and the Southern the poorer in nutritive elements. When relative nutritive values are studied, the worth of fish food will be thoroughly appreciated. 
Capture of a Trunk Turtle.-Sch. Herman Babson, Capt. Williams, captured a rare reptile for these parts in the shape of a trunk turtle, Oct. 3, 1877 , ten miles off Cape Elizabeth. In getting it on board the vessel it was injured so badly that it survived but two days, having bled to death from one of its flippers. It measured seven feet across the back and was six feet in length, and its estimated weight was six hundred pounds. It differs from other species of turtle in having the carapace overlaid by a leathery skin instead or horny plates, and this skin is easily punctured by a sharp instrument. The head is large, narrowed in front of the eyes, with small circular nostrils and large eyes, with lids opening nearly vertically; jaws apparently very strong and sharp edged; neck short and thick, and the anterior limbs are twice as large as the hind ones. It was a great curiosity in this section, and hundreds availed themselves of the opportunity of seeing it. Its flesh is said to be of no value. It is found on both sides of the Atlantic, especially in the tropics, coming north as far as Massachusetts Bay.

"Right ARTER ROBERT."-Years ago there were two brothers following fishing from this port, both of whom were skippers, owning crafts of their own. Robert was the elder, and William used to follow in his wake as near as he could, when on his fishing trips. One day they both started out together, William following and Robert taking the lead, as usual. When William went down to supper, the man at the helm asked him how he should steer. "Right arter Rober," was the reply. It so happened that William's vessel was a little faster than Robert's, in a light breeze, and the wind moderating suddenly and the helmsman not being first-class at the business, let her get too near, and ere he could avoid it the vessels collided. The shock brought skipper William on deck, who sang out, as he came up the companion-way, "How are you steering?" "Right arter Robert, sir, just as you told me to," was the reply. Fortunately there was but little damage done, but "Right arter Robert" served as a by-word on board the crafts during the entire season.

The Norwegian Flounder has been added to the list of edible fishes taken off our coast. Quite large quantities were secured on the dredging expeditions of the steamer Speedreell, about one hundred pounds being taken at one dredging in 1878. Through the courtesy of Prof. Baird a liberal supply was sent to Taft's at Point Shirley, and Parker's, Boston, where they were served up and pronounced excellent eating. These deep-sea flounders are some fifteen or eighteen inches long, resembling a small chicken halibut in form, and of a dull white color underneath and a light slate-colored back, with some peculiar markings about the head. Their presence in our waters 
was unsuspected until brought to light by the investigations of the Fish Commission.

How the News of His Wife's Death Was Told Him.-One of our fishermen sailed on a mackereling trip, leaving his wife in her usual health, with no thought that the messenger of death was hovering so near. After a few days the wife died, and telegrams were sent to the husband along the coast, to such ports as it was likely the vessel might put in. But he never received them, and the vessel came home in about four weeks' time, arriving at two o'clock in the morning. The skipper and crew came ashore, and on reaching the wharf the watchman asked the name of their vessel, and upon being informed took the skipper one side and told him the sad news and asked him to break it to the husband, as he had not the heart to. The skipper's heart failed him also, as he walked alongside the man up the wharf, into the familiar streets. Their houses lay in the same direction, the skipper's being the farthest off. Finally they reached the man's home, and as he stooped down to pick up a little stone to throw against the window of the chamber, to awaken his wife, as was his custom when arriving in the night, the skipper. could no longer hesitate, but calling him by name, said : "Your wife will never awaken on earth again, as she died three days after you left home, and this was what $\mathrm{Mr}$._- told me when he took me one side on the wharf; but I couldn't find heart to tell you before." The terrible news almost paralyzed the poor fellow, and he could not realize that the wife whom he had left and whom he had hoped so soon to meet again, was gone from his sight forever. The family were soon awakened, and he was made acquainted with the full details of the event which cast a shadow over his life which time will never fully efface.

OFF FOR GEORGES.-The regular February appearance of large schools of codfish on Georges Bank, which are used by the fish for their spawning grounds, insures a large catch for the early fleet, and the temptation of big trips, and the consequent realization of good returns, cannot be resisted by men who have been lying idle and whose funds have run low, or to express it as they do, more emphatically, "We haven't a shot in the locker; the fish are there and we're just going for 'em!" And who can blame them? It is their business. They know its excitements and its dangers. Old ocean has been their cradle for many a year. They have been rocked to sleep by it in its calmer moods, as well as when in anger it has tossed their little crafts up and down on the billows, and the stormy blast has shrieked through the rigging, 'mid the gale. Georges may be their grave; but this thought does not deter them from going. And no wonder they are anxious to start when they remember the big trips they have shared in; quickly earned, too. 
An India Rubber Stomach.-The Chiasmodes Niger, brought in by sch. Bessie W. Somes, July 30 , r88o, proved a rare specimen indeed, since it is a fish that can swallow fishes twice as large and four times as heavy as itself. This it can do because its mouth is very deeply cleft, its teeth bent, and its stomach elastic like india rubber. This is the third specimen known to science, the first having been found off the island of Madeira, and the second in the Dominican Sea. The specimen brought in by the Somes was ten inches long, and had in its stomach a codfish eighteen inches in length.

Eccentricities of THE Swordfish.-The swordfish is found here and there from Spring to Fall in the ocean on our coast, lying "asleep," the fishermen call it, on the very surface of the water. Nobody on the Ameriican coast, so far as reported, ever saw a little swordfish. The smallest recorded by a correspondent of the "Forest and Stream" weighed forty-six pounds. Their only known breeding ground is in the Mediterranean Sea. There the same fish is found weighing half a pound; from that they go up to very heavy measurement. It is naturally inferred from this that all our swordfish are Mediterranean products. What mysterious ocean current guides them over here? Or is it instinct that teaches them that here they will find the mackerel and the menhaden that they feed on? One can almost imagine that the game of flight and pursuit kept up by these two species starts at Gibralter and is run to Block Island every year. The swordfish darts upon a school of its prey and by skilful use of its sword wounds those that it afterwards captures and eats. Until within a few years nobody ever thought of catching it except by harpoons. Recently, however, it has taken the bait of the trawls of our cod fishermen, and many swordfish have been caught in that novel way. What they come up and "sleep" for is one of the puzzles of their nature. They come and go as the mackerel and menhaden do, and from that it is naturally concluded that they spend their time chasing these small fish. What with sharks, swordfish, porpoises, bluefish, sea-gulls, eagles and seines, and all the rest after them, the fish of the herring tribe have led such lives of fright and terror that it is no longer a wonder that the movements of any school of them seem guided by an inherent idiocy. It is even less strange that they are all the while victims than that, being caught by millions yearly, they should steadily increase.

Why the Red Sea Is Red.-Geographers were not able to determine why the Red Sea was so named until Ehrenberg, sailing over a part of it, observed that the water of the whole Gulf of Tor was colored a blood red. Drawing up some of the water, and examining it with a microscope, he found that the color was due to a minute, thread-like oscillatoria or alga. The same alga was observed by Dupont twenty years afterwards, giving rise 
to the same appearance even on extent of $55^{6}$ nautical miles. A similar plant was noticed by Darwin, in his voyage around the world, covering the water near Abrolhos Island, off the coast of Brazil. Oersted, in I845, noticed that the water near Maderia had a peculiar obscurity, which was occasioned by numerous minute tufts of oscillatoria waving in the mass. These plants are found all the way to the West Indies, sometimes thick enough to give a color to the water, but never wholly wanting. In other cases the sea is colored red by animals, of different kinds, by minute crustaceans or infusoriæ, or eggs. The name red or vermilion sea has been given to two different microscopic infusoriæ. One of the coloring animals is irritating to the skin, and produces blisters and sores on the bodies of those who come in contact with it.

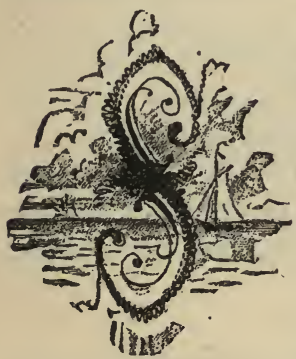

UBSTITUTE FOR COD LIVER OIL.-It is claimed by a writer in "Nature" that the oil of the "oolachen" or "ulikou," the candlefish of Alaska, possesses all the medicinal qualities of cod liver oil. This fish has long been an ichthyological curiosity, and has been noticed by almost every traveler who has visited the coasts of British Columbia and Southern Alaska. It is a small silvery fish, averaging about fourteen inches long, in general appearance much resembling a smelt. It is the fattest of all known fish, affording a very superior oil when tried out. Dried, the fish serve as torches. When a light is needed the tail is touched to the fire, and they will burn with a bright light for some time. No description can give an adequate idea of their numbers when ascending the rivers from the sea. The water is literally alive with them and appears to be boiling. These fisheries appear not to have been hitherto utilized except by the natives, who esteem the ulikon as a great delicacy. The oil at present is said to be gaining a high reputation in this country and has recently been introduced into England, where it will probably take a prominent place as an important medicine.

Habits of Eels.-The habits of the eel are very different from those of any other fish, and are as yet but little understood. "This, so far as we know," writes Prof. Baird, "is the only fish the young of which ascend from the sea to attain maturity, instead of descending from the fresh to the salt water. Its natural history has been a matter of considerable inquiry within a few years, although even now we are far from having that information concerning it that would be desirable, in view of its enormous abundance and its great value as a food fish. The eggs of the eel are for the most part laid in the sea, and in early Spring, the period varying with the latitude, the young fish may be seen ascending the river in vast numbers, and when 
arrested by an apparently impassable barrier, natural or artificial, they will leave the water and make their way above the obstruction, in endeavoring to reach the point at which they aim. Here they bury themselves in the mud and feed on any kind of animal substance, the spawn of fish, the roes of shad, small fish, etc. At the end of their sojourn in the ponds or streams they return to the sea, and are then captured in immense numbers in many rivers in what are called fish-baskets. A V-shaped fence is made, with the opening down stream into the basket, into which the eels fall, and from which they cannot easily escape. This same device, it may be incidentally stated, captures also great numbers of other fish, such as shad, salmon, and other anadromous fish, to their grievous destruction. As might be expected, however, the Falls of Niagara constitute an impassable barrier to their ascent. The fish is very abundant in Lake Ontario, and until artificially introduced was unknown in Lake Erie. At the present time, in the Spring and Summer, the visitor who enters under the sheet of water at the foot of the falls will be astonished at the enormous number of young eels crawling over the slippery rocks and squirming in the seething whirlpools. An estimate of hundreds of wagon-loads, as seen in the course of the perilous journey referred to, would hardly be considered excessive by those who have visited the spot at a suitable season of the year."

The Men Who Man the Fishing Fleets.-From carefully prepared statistics we learn that the number of men engaged on board the Gloucester fishing fleets the past year (188I) was 4,I 42, divided as follows: Georges fleet, 1,460; Western Bank, 284 ; Grand Bank, 360 ; fresh halibut, 330 ; mackereling, I, 120; shore fishing, 430; dory fishing, 125 ; trap fishing, 24. This does not include the crews of vessels from other ports who fit from here.

The Alaska Codfish.-Dr. Tarleton H. Bean, who was on the U. S. Fish Commission Corps in this city in 1878 , and who was sent to Alaska by Prof. Baird in the Summer of 1880 , to investigate the codfishery of that country, reports that the Alaska cod is the same as that of New England and Europe, the Gadus morrhua, with the same occasional variations. $\mathrm{He}$ says that Golden cod, red cod and other algæ forms are as well known at the Shumagin Islands as they are around Cape Cod and Cape Ann; the beautiful lemon-yellow fish, which occasionally are found in Ipswich Bay schools, are duplicated in Alaskan waters. The habits and food of the cod are similar to those on our coast. The shore fish about Kodiak make their appearance in schools similar to ours-first the "herring school," next the "lant school," then the "capelin school," followed by the "squid school," and the "winter school." Besides these there is an abundance of bank fish, which are always larger than those previously named. The cod come on 
the rocks in twenty-five to thirty fathoms about Kodiak to spawn in November and December, just as they do in the East, and these spawning fish will at times be perfectly still on the bottom and refuse to take the hook. Young cod swarm near the shores, just as they were observed to do in Gloucester Harbor after the experiments of the U. S. Fish Commission with artificial propagation. The Pacific waters have also a genuine pollock, weaker than its Eastern relative, and halibut also abound, but the cusk and haddock have not yet been found in Alaskan waters.

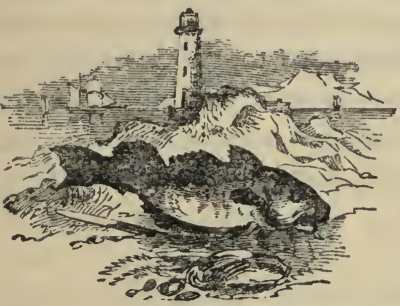

What One Fishing District Does for the Farmer and Planter.-To one who has given the subject no thought, the extent to which the fishing industry is a patron of agriculture is a matter of surprise. The jealousy with which the people of the West and South have regarded the protection extended by the government in times past to the fisheries, and which it now inadequately provides in certain concessions in regard to the duty on salt, has been ill-judged and unreasonable, since equal protection has been afforded to other producing interests, and the fishing business is an important customer for the products of the plantation and field. A careful investigation shows that the fishing fleet of Gloucester consumes annually the following products of the farmer and planter:

Cotton, in fishing lines, seines and nets, $530,000 \mathrm{lbs}$.; in sails (yearly wear), 225,000 lbs.; rice, 24,300 lbs.; butter, 198,450 lbs.; lard, 182,250 lbs.; dried apples, 6r,560 lbs.; mustard, r,2 5 lbs.; sage, Iro lbs.; squashes, 26,550 lbs.; fresh meat, 126,765 lbs.; flour, 7,985 bbls.; beef, 4,455 bbls.; pork shoulders, I,72 I bbls.; pork, I, 2 I 5 bbls.; beans, I, 822 bush.; peas, 8 I 0 bush.; potatoes, 33,6 5 bush.; onions, 2,430 bush.; beets, I, 2 I 5 bush.; turnips, I,620 bush.; meal, I,280 bush.; cabbages, 4,560 doz.; vinegar, I,620 gals.; pepper sauce, I,3 5 bottles; milk, 38,400 cans.

To the above add the amount consumed by those employed in the fishing business ashore, together with the necessary provisions for their families and the families of those at sea, and it makes the fishing business one of great pecuniary interest to the planter, farmer and stock-raiser.

The Highest Price ever received for mackerel was in 1879 , when sch. Crest of the Wave, Capt. David Melanson, took 80 bbls. off Thacher's Island, of which 25 bbls. were the largest and fattest ever brought to this port, eighty mackerel filling a barrel, and selling for $\$ 40$. Sch. Mary Odell, Capt. McClain, took 20 bbls. of the same quality, which were sold in Boston, also for $\$ 40$ per bbl. 
Veteran Fishermen.-Mr. George Merchant, 74 years of age, was engaged in the mackerel fishery from May 4 to Sept. I, r88 r, and helped to take care of a catch of 1,200 barrels of mackerel; he has been engaged in fishing some part of the season ever since he was ten years of age.

Mr. George Gerring of East Gloucester, 72 years of age, was engaged in the Georges fishery in the Spring of $188 \mathrm{r}$ on board sch. Light Wing, and caught an average share; he commenced fishing when thirteen years of age.

Mr. Charles A. Furgerson of Robinstown, Me., 50 years of age, has followed fishing from this port for thirty-four years, and for twenty-one years was on Georges every season regularly. His first trip was in sch. Cherokee. Mr. Furgerson was one of the original subscribers to "Procters' Able Sheet." When he was in the Pioneer he hauled one pair of halibut weighing 300 pounds, which sold for $\$ 42.62$. He is now on board the Charles $H$. Hildreth. He states that he never saw good luck on board a vessel when a land bird flies on board.

The New England Codfish Catch for i 88r.-The New England catch of cod and other ground fish is reported at 775,627 qtls., against 647,426 qtls. the previous year. The Massachusetts catch alone was 548,640 qtls., Gloucester taking the lead with $43 \mathrm{I}, 800$ qtls. (nearly $553 / 4$ per cent. of the New England catch, and nearly 77 per cent. of the Massachusetts catch), and Provincetown coming next with 86,317 qtls. The Portland catch was 78,000 qtls., Eastport, 28,000, Boothbay, 19,071, Vinalhaven, 14, 175, Beverly, 10,400, and no other New England port exceeded ז, 000 qtls.

Catching Cod around Newfoundland.-There are two ways in which the people around the Newfoundland coast and on that of Labrador engage in catching cod. Fish are caught in boats about the size of small schooners, decked in and provided with comfortable "cuddies," which is where the fishermen cook, eat and sleep, or rest after the immediate toil is ended; and they are caught in little open boats or skiffs, having two masts and sometimes a saucy little jib-boom, and these little boats they sail when there is wind, and row when it is calm. The large boats sometimes go a hundred miles from home around the coast to fish, and the fishermen live in them through the Summer, but the small boats go only a few miles from home, seldom stay out all night, but getting their loads, return to land. The former belong to the towns and harbors, or large villages; the latter to the coves, we might say the crevices, around the coast. About the first of June the fishery commences, and in the first gray of the morning flocks of little boats with barked sails may be seen putting out from the rocks. At this time of the year the cod is usually hungry, for it has just come in from the banks of Newfoundland, meeting perhaps but few fish to prey on on its way. 
When it reaches the coast it finds the herring there before it, and has a feast for its late fast. It is with the herring that the fisherman now catches the cod, for the caplin has not come, and it is too early for seines or nets, and fish being hungry, the hook and line and "bull-tow" train are in demand. The boat is a quarter of a mile out from the rocks, and on the Atlantic waters. There are two men in the boat, and having reached the spot where they intend to "try," they take down their sails and both stand up, one in the fore part of the boat, the other aft. Each has a pair of lines, and to each line a hook is set in a piece of lead, made in the shape of a fish, to make it sink. Each line is fastened to the boat. A sheath-knife is in the fisherman's belt, and with this he cuts his herring into bait sizes, puts a piece on the hook, which he throws to his right a distance of about twenty feet. He does the same with the line on his left, and his companion in the other end of the boat does the same thing. Thus each man has two lines out; he stands erect and "saws" his lines till he gets a bite-the sawing being a sudden long jerk, now to the right line, and now to the left, in regular time. He starts. There is a sudden tug, and a thrill of life comes up the line to his hand. He lets go the other and hauls away, and the greater

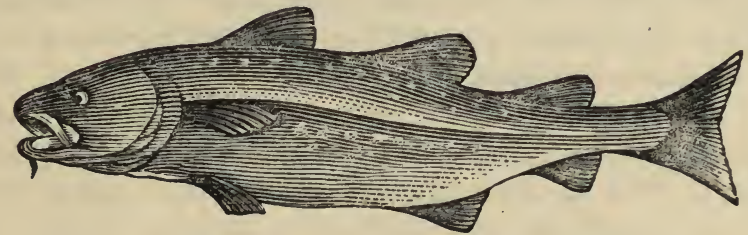

the weight the more gleefully does he haul, till the cod "breaks water," when, seizing a gaff-a contrivance with a wooden handle two feet long, to which is affixed a large iron hook-he sticks it into the body of the fish and jerks it in over the gunwale. While the hook seized by the fish serves to draw the fish to the surface, it would not be sufficient to lift it from the surface to the boat. The process of unhooking the fish to the novice is not an easy one, but to the expert it is not a matter of two seconds. Sometimes a "spurt" comes on, which means that a school of hungry fish is passing under the boat, and then the rapidity with which two practiced fishermen can haul in, unhook, bait, throw out and haul in again is certainly marvelous.

An Important Discovery.-Mr. Robert E. Earle, who for some months was connected with the artificial propagation of deep sea fish experiments in this city, is credited with the discovery of the important fact that Spanish mackerel are vastly more productive than cod or shad, and that they can be artificially hatched in much less time. Mr. Earle learned from the Chesapeake fishermen that large numbers of these fish annually frequented the 
waters of that bay, and on reporting that fact to Prof. Baird, was detailed to make experiments for their reproduction. On getting to work, he was surprised to find that the fish were hatched within eighteen hours from the time the milk and spawn were brought together, whereas it requires five days to hatch shad and eight to twelve days to hatch codfish. The number of eggs operated upon at a single time is between 200,000 and 300,000 , while only 20,000 to 30,000 shad eggs are treated at once. The season for operations with the spawn of this fish is toward the last of June and first of July, after the shad hatching is over and before that of codfish commences.

The First Wholesale Fish Store in Boston was established on Long Wharf by Mr. Ebenezer Nickerson in 1807 . The first wholesale fresh fish store in Boston was opened on Long Wharf in 1835 by Messrs. Holbrook, Smith \& Co. The mackerel purse seine dates from 1855 . The canning of fish dates from 1845 , in Maine. Vessels first began to carry ice to sea in 1845 , and dealers began to use it in shipping fish the same year; $20,000,000$ lbs. are now annually consumed by vessels and fish dealers. Nets were home-made until 1842 , when the first net factory was established in Boston; they were hand-made until 1865 , when machinery was introduced in their manufacture. The earliest importations of mackerel were seven barrels in 1821.-From Records of Boston Fish Bureau.

The Best Halibut Fare received at this port for several years was landed March 22, 1882, by sch. Grace L. Fears, Capt. Nathaniel Greenleaf. Her fare was taken by the New England and Atlantic Halibut Companies, and she weighed off $98,825 \mathrm{lbs}$. halibut and 3,000 lbs. codfish, ror,825 lbs. in all, stocking $\$ 6086.5 \circ$. Her crew shared $\$ 206.30$. The cook's share was $\$ 253.05$. She was gone five weeks and one day, during which time she was frozen up for eight days at Canso. This is the largest stock ever made on a halibut trip, although larger fares have been received several years ago.

\section{The Codfish-Its Value as Food-How the Grand Bank Was Formed.-} What a marvelous influence upon civilization and human progress the humble but nutritious codfish has had. He has been a mine of wealth to a vast population. It seems as though good Mother Nature, foreseeing the needs of humanity, had made special preparations for a good supply of this very necessary article of food for body and brain. She floated her icebergs, which were filled with the sandy bottom of northern seas, down to the Gulf Stream, where they melted and, depositing their debris, formed the Grand Bank of Newfoundland. It was the work, the slow and toilsome work, of ages. Every Spring thousands of these bergs, one-third above water and two-thirds below, the upper part clear, sparkling and translucent, reflecting 
the sunshine and giving it back to the enraptured eye with that prodigality and brilliancy of coloring which only nature can afford, the lower part mixed with the coast bottom of Greenland or Labrador to the extent of thousands of cart-loads, came floating down majestically through Davis' Strait, and meeting the warm air and warm water of the Gulf Stream, melted and deposited their contribution, until at last those immense shoals were formed where the cod and haddock swarm. And it is said that these sand banks have huge depressions, like vast valleys, which serve as aquaria, and that when a fishing vessel is lucky enough to anchor over one of them, it can fill its hold and deck with as many as it can carry. For generations the inhabitants of Newfoundland, and the venturesome folk who live all along the New England coast, get their daily bread, or lay up a competency from this never-failing source of wealth. What a vast number of people on the globe get their living out of and subsist principally on the invaluable cod, and what vast quantities have been landed by the fishing fleet of Gloucester, since her fishermen first engaged in the business.

The Iceland Cod Fishery.-It is not generally known that next to Newfoundland, Iceland is the rendezvous for the vessels engaged in cod fishing. Large numbers of French smacks choose the latter ground. During the season of $188 \mathrm{I}$, owing to the large quantity of dried fish remaining unsold from the take of the previous season, there was a marked reduction in the number of fishing craft, but 193 having started for Iceland. The Norwegians engaged in the trade are improving their fishing apparatus every year, and they are extending their markets also. They have established herring fisheries all along the Icelandic coast, and not long since a large company was formed for the prosecution of this industry on a large scale; but the results this season, we are told, have been discouraging for almost everybody engaged in it. Time and money have been lost for want of accurate information as to the weather, and, with a view to remedying defeat, telegraphic communication between the coast of Scotland and Reikiawick, the capital of Iceland, is now spoken of.

A Mermaid Captured.-A fisherman, a resident of Aspinwall, is reported to have recently captured a mermaid. There is silky blonde hair on the head; the features of the face are perfectly even to the teeth, the arms are the same as human beings', with claws resembling an eagle's talons in place of finger nails. From the waist up the resemblance to a human being is unmistakable, and from the waist down the body is exactly the same as an ordinary mullet, with scales, fins and tails perfect. 
Net Codfishing has been practically a failure the past season. In the Winter of $1880-8 \mathrm{I}$ the netting fleet in Ipswich Bay took large fares, while the trawlers met with much poorer success. On a recent trip in the same waters the sch. Magellan Cloud, with twenty-four nets set, took only about $\mathbf{I}, 000$ pounds codfish, while in four days fishing there a trawler took 20,000 pounds.

Helping Themselves.-One of the peculiarities of the white fish trade of the lakes is the traffic between the fishermen and the lake craft engaged in the carrying and passenger trade. These boats as they pass up and down the lakes frequently stop and take up the fishermen's nets and help themselves to what they want. The fish taken are weighed and the money to pay for them is attached to the nets, which are again let down to the bottom of the lake. So it often happens that the fishermen in lifting their nets take in considerable money as well as fish. The lake captains are very honorable in this matter, and it has come to be an understood arrangement, satisfactory all around.

The French Sardine Fishery.-Not less than 30,000 persons are engaged in the sardine fishery in France, and fully as many find occupation in "preserving" this fish. A writer in the Journal of the Society of Arts says that in taking the sardine the bait, which is called roe, plays an important part. This lure is a kind of caviare made from the eggs of the cod preserved in brine, 35,000 barrels of which are imported from Norway every year. When the position of a shoal is ascertained the nets are let down and the master of the boat throws the bait, mixed with sand to cause it to sink, into the water. Emerald green flashes on the surface of the water denote the rise of some of the fish. Then the bait is liberally cast out, and soon the whole shoal rises into the nets. At one time a boat could take 20,000 sardines, but now it is a rare thing to bring in more than from 5,000 to 6,000 at a trip. When the boats land, the sardines are taken to the factories in hampers containing about 500 apiece. There women cut off the heads of the fish, open and clean the bodies, and place each fish one by one on stone or marble slabs previously strewed with salt. While this preliminary drying is going on, the fires are lighted and the purest olive oil is put into immense caldrons. When the oil is boiling, the sardines are laid in layers in iron wire baskets provided with handles. These baskets are plunged into the oil and then placed on shelves covered with zinc to drain. When they are moderately dry they are taken to the large drying house, exposed to the sea breeze, and there they remain until fit to be stored and put into boxes. The largest are considered the finest, and the small ones are frequently passed off as anchovies. 
Steam Whalers. - Steam vessels for whaling have proved highly profitable. The first one ever sent out from the Pacific coast was the Mary \&o Helen, which cleared in $188 \mathrm{I}$ enough to pay her entire cost and $\$ 40,000$ besides. The second venture, that of the Belvidere, came back from a voyage of only six months with $\$ 100,000$ worth of oil above the investment. The great success of these-steamers is likely to revive the business of whaling.

P. E. I. Fisheries.-The Prince Edward Island mackerel catch for $\mathrm{I} 88 \mathrm{I}$ was 36,083 bbls., about one-half the catch of 1880 . 228,593 pound cans of lobsters were put up, double the quantity of the previous year. The codfish catch was 16,934 qtls., against 28,045 in 1880 ; hake, 10,023 qtls.; halibut, 4,575 lbs.; haddock, 72,600 lbs.; herring, 28,545 bbls.; alewives, I,9 7 bbls.; oysters, 20,815 bbls.

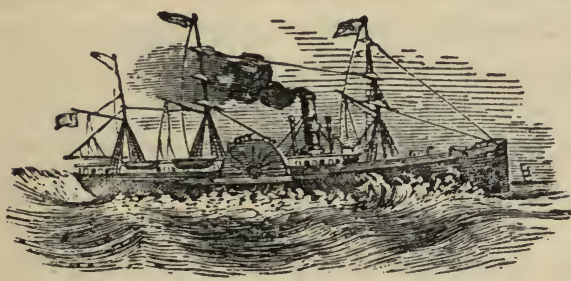

Dangers of THE Sea.-The difference between handling a ship so that she escapes a danger, and in a way to plunge her headlong upon it, was doubly illustrated on a passage by the Algeria, which runs between New York and Liverpool, England. On her sixth day out, in February, 1881, the Algeria found herself in a heavy fog on the Banks of Newfoundland. The ship was feeling her way cautiously along, all eyes and ears, so to say, when from over the port bow there sounded a fog bell. It seemed some distance off ; but Capt. Gill, swift as light, ordered a reversal of the engines. The screw flew round, the great ship paused, slowly backed, and none too soon. In a trice there loomed up through the fog a huge three-masted schooner rushing forward under full sail. Had the course of the Algeria been kept, had she failed to retreat at the moment she did, a collision would have been inevitable. The schooner flew on her way straight across the foaming wake of the steamship, and a terrible calamity that might have cost hundreds of lives was happily averted. Very nearly the same thing happened again on the same evening, the dangerous craft that approached the Algeria in this instance being another large steamer. This time the stranger was not seen through the dense mist, but the voices of persons on the decks were heard with startling distinctness, and the case was apparently as narrow as in the case of the schooner. Eternal vigilance is as clearly the price of safety at sea as it is of liberty everywhere. Undoubtedly many of the fishing vessels which disappear so mysteriously, with no heavy gale to account for their loss, are run down by steamers or other large vessels, while at anchor on the Banks. 
Fishing In LAPLAND.- The water is very clear at Hamerfest, in Lapland, and one may see everything that goes on among the fish. A few feet down you can see the young cod snapping at your hook; a little lower down the coalfish, and the huge plaice and the halibut on the white sand at the bottom; in other places the starfish, as large as a plate, and purple and green shellfish of all sizes. The plaice is taken in the following manner: In calm weather the fisherman takes a strong, fine cord, to which he has fastened a heavy spear-head, like a whale harpoon. This he holds ready over the bow of the boat, while another person paddles it forward slowly. When the fish is seen at the bottom, the boat is stopped and the harpoon is suddenly dropped upon him, and thus the fish is caught. In two hours the fishermen will get a boat load. The halibut are caught with hooks. They sometimes weigh 500 pounds, and if drawn up carelessly will overturn the boat. In many of the mountainous districts the rivers swarm with trout, the habit of which is to conceal themselves beneath the bowlder rocks in the bed of the stream, venturing out to feed only at night. Men, each with a heavy hammer, will enter these waters and strike one or two blows on the stones, when the fish run from their lurking place, partly stunned, and are easily caught.

The Sea Cucumber, one of the curious jelly bodies that inhabit the ocean, can practically efface himself when in danger, by squeezing the water out of his body and forcing himself into a narrow crack-so narrow as not to be visible to the naked eye. He can throw out nearly the whole of his inside and yet live and grow it again.

Swedish Popular Beliefs.-The teeth of large fish should be burnt, in order to be lucky in fishing.

One ought to tell no one when one goes out to fish, and not mention whether one has caught many or few.

Nor should any stranger see how many fish one has taken.

When one rows out from land to fish, one must not run the boat against the sun.

Pins found in a church and made into fish hooks catch the best.

If a woman passes over the rod, no fish will bite.

Stolen fishing tackle is lucky, but the person robbed loses his luck.Thorpe's Northern Mythology.

SAlted Herring.- - The art of salting and packing herring was discovered in the fourteenth century by Beukels, of Biervliet, in Flanders, who, after introducing it into his own country, went to Finland and established it there, whence it spread to all the Baltic provinces. In 1856 , Alexander 
II, Emperor of Russia, in his visit to Finland, after leaving Helsingfors, went to the little town of Borgo, and laid with great ceremony the first stone of a monument to the memory of the fisherman Beukels, who died in 1397, in his native village, where his tomb was once visited by the Emperor Charles V; and Peter the Great, in recognition of the importance of his discovery, gave a pension to one of his descendants.

A Valuable Nautical Contrivance.-An extremely simple but invaluable aid to navigation has recently been proposed by an experienced British master mariner, by which he is confident the largest steamship in an ocean gale can be hove to with safety. His contrivance, as described in the London "Shipping Gazette," is on the drogue system, and the advantages he has experienced from it in emergency are "too great to express." His sea anchor or drogue is made of stout canvas in the shape of a bag, with a strong wire hoop at the top, to which the lanyard is fastened-the latter being shackled to a spar thirty feet long. The spar, fitted with three iron bands, is kept square by two wire guys, and fastened to a riding hawser made of wire or manila. The drogue, when in use, is about four fathoms beneath the surface of the agitated sea, thus escaping its force, and when full of water proves a great resistance, keeping the ship's head to the sea when driving to leeward in a heavy gale. This simple, cheap and quickly improvised contrivance would undoubtedly be useful to vessels thrown on their beam ends, or experiencing that ofttimes fatal accident-shifting of the cargo in the presence of a severe storm. It would also, in many cases, by enabling a disabled steamer to avoid drifting out of her course, or helping her to keep out of the central path of an advancing cyclone, prove a timely safeguard to life and property at sea.

A Novel Experiment has been tried at the port of Peterhead in Scotland, where the waves of the North Sea have an unchecked sweep from the wild coast of Norway, and break so furiously at the harbor mouth that warning signals are given against attempting to enter the harbor. A wooden shed was erected and iron and lead piping carried down the beach a distance of nearly one hundred yards. Then a strong gutta-percha pipe with three openings seventy-five yards apart was laid across the entrance to the harbor. A force pump in the shed supplies this tubing with oil to allay the waves. Recently the waves were running twenty feet high at the mouth of Peterhead harbor, and the pump was put at work. The oil was forced through the pipes and out of the valves. It spread over the bottom, rose to the top of the water, and in a short time the seething foam was gone. Not a white cap remained within reach of the calming fluid. Although the swell continued, the surface of the sea was quite smooth, so that "a small boat 
could have entered the dock without the slightest danger." The ship masters who witnessed the experiment were satisfied with the result.

Why would it not be well for our fishermen on the Banks, or elsewhere, in some of the terrible gales, to try this experiment? It has the same effect when poured upon the troubled waters as if pumped or otherwise placed thereon.

A Remarkable Spectacle.-The steamer Victoria, at New York from Glasgow, reported witnessing a remarkable spectacle on the eastern edge of Grand Bank, December 18, 1876. During the height of a gale of unusual severity there appeared on the trucks, yards and stays, large balls of fire or phosphorus, strung on the stays or yards at intervals of a foot or two, giving the ship the appearance of being decorated with Chinese lanterns, only more brilliant; they settled on the vessel like a shower of meteors, and disappeared almost as suddenly as they appeared, an occasional one dropping from the yards, bursting with a loud report; one of them fell and burst almost in the face of the chief officer, making a noise like a small piece of artillery, but causing no more inconvenience than dazzling him for the moment.

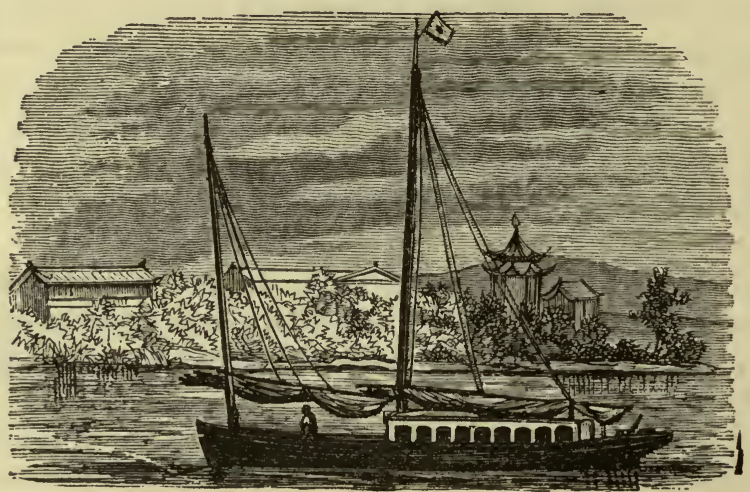

[CHINESE HOUSE-BOAT.] 


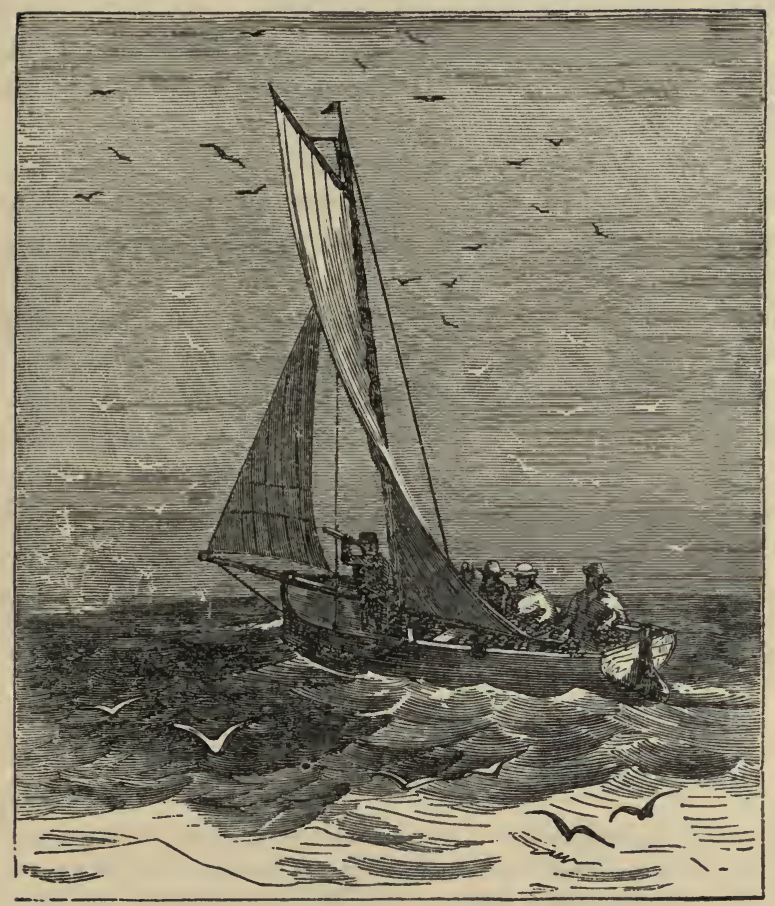

\section{A Fishing Party.}

A bright Summer day, with a good breeze stirring, can be used most enjoyably on a fishing party, similar to that depicted above. They are bound out on the grounds, and are having a good run off. Let us in imagination follow them. In about an hour they will reach one of the many spots where fish do congregate off Cape Ann's rugged shore, when down will go the anchor and sails; the lines will be in readiness, and all will "chip in" a silver coin, the whole of which will be given to the lucky individual who shall pull in the first fish. Now all is excitement. The hooks are baited and the lines with their heavy leaden sinkers lowered until the bottom is felt, then pulled up a couple of feet, all ready for some hungry cod to snap at the bait and get hooked on by the dexterous jerk which will follow the first nibble. There's one around your line! Careful, now! Ah, you've got him! And up he comes, a six-pounder, and the fish for the chowder is secured, and you also have earned the prize money. 
The fun now commences, and there is rare sport bringing in the thrifty fish. It is most exciting, and a generous rivalry prevails as to who will catch the most fish. Bye-and-bye they slack up biting, and the "inner man" calls loudly for something to appease that terrible appetite which the exercise and cool sea breezes have provoked. A savory odor pervades the atmosphere, which indicates that the chowder is underway, and soon it is served up smoking hot, and receives that attention which it so well deserves. The day passes merrily by, with song and story and good cheer, when, late in the afternoon the return is made, and all agree that the day has proved a "red one" in the calendar.

This party; as will be observed, is composed of the male gender entirely, and is an impromptu affair; but oftentimes large yachts are used, with finely fitted up cabins, having accommodations suitable for the fair sex, and in company with the ladies the enjoyments of a fishing party are greatly enhanced. This is one of the many pleasures of the sea coast in the pleasant Summer months, and once participated in there is a desire to repeat it.

\section{"NOT A BENE."}

\section{BY JUNIPER.}

A ship, once crossing over the sea-

I tell the story as 'twas told to me-

Made a hundred miles or so from shore,

When a craft was one day seen that bore

Her flag reversed, while 'gainst the mast

The torn sails fluttered as the wind rushed past.

"Out with the boat!" the captain cried, And the seamen darted over the side; Their oars fell in with a regular dip, As they rapidly neared the silent ship.

When they reached the deck a sight met their eyes

Which made them start with fearful surprisc.

All around on the deck the crew were lying,
And groaning aloud as tho' they were dying; The captain alone on a hen-coop sat, With his face in hands and a weed on his hat; He gazed on them all with a bloodshot eye, And the crew looked up with a heart-rending sigh.

"Say, why do you raise the flag of distress, And sit around deck in idleness?

Are you out of food? Have you used up your water?

Have you got the plague? Or what is the matter?"

"We came from Beverly, and the flag you have seen

Is because for three days we have been out of beans!" 


\section{The Mackerel Pocket, or "Spiller."}

Among the improvements in fishing apparatus there are none, perhaps, that appear to be more important than one patented by H. E. Willard, of Portland, Me.-an article long needed in the mackerel seine fishery, and which has received from the fishermen the name of "Mackerel Pocket," or "Spiller." It was first used by the patentee in 1878 , and Capt. George Merchant, Jr., of this city, subsequently invented and put into practical operation an improved "spiller."

The apparatus is a large net bag, 36 feet long, ${ }_{5} 5$ feet wide and 30 feet deep. It is made of stout, coarse twine, and is attached to the side of the vessel, where it is kept in position, when in use, by wooden poles or "outriggers," which extend out a distance of fifteen feet from the schooner's rail. When distended in this manner a spiller will hold over 200 barrels of mackerel, which can thus be kept alive, as in the well of a smack, until the crew have time to cure their catch. As is well known, it frequently happens that several hundred barrels of mackerel are taken at a single haul. Heretofore, when such a large quantity of fish were caught, but a comparatively small portion of them could be cured by the crew of the vessel to which the seine belonged. The result was that when a large catch was made, a considerable percentage of the fish were generally "given away" to some other vessel, since if only a part of them were removed from the seine to the vessel's deck, the remainder being left in the net until the first lot were cured, the chances were nine to one that the fine twine of which the purse-seines are made would be bitten in many places by the swarming dogfish. In addition to the injury of the net, the inclosed body of fish were thus allowed to escape, robbing the fisherman of a large portion of the fruit of his labors.

The spiller being made of coarse twine, though not entirely exempt from the ravages of the dogfish and sharks, is rarely injured by them. And now when a large school of mackerel are caught in a seine, the fish are turned into the bag, from which they are bailed out on the schooner's deck only as fast as they can be dressed, and in this way it frequently happens that a full fare may now be secured from a single set of the seine. 


\title{
On the Loss of the "Royal George."
}

\author{
Written when the news arrived, 1782.
}

BY WILLIAM COWPER.

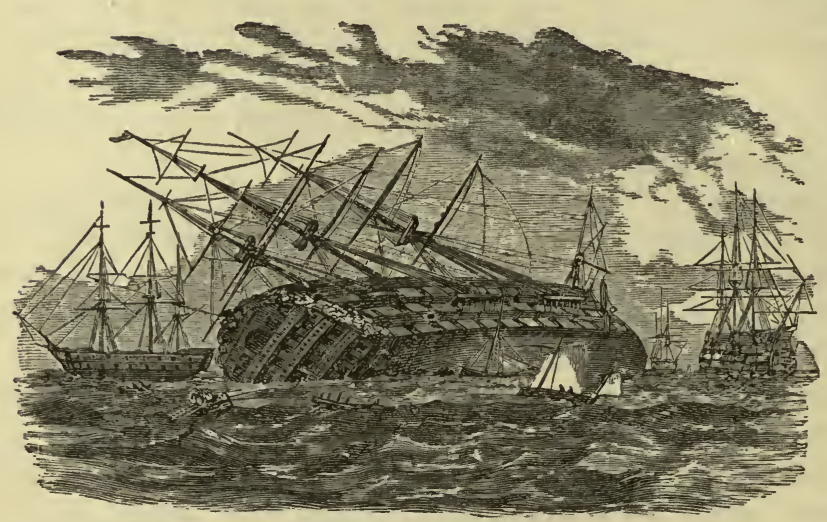

Toll for the brave-

The brave that are no more!

All sunk beneath the wave,

Fast by their native shore.

Eight hundred of the brave,

Whose courage well was tried,

Had made the vessel heel, And laid her on her side.

A land-breeze shook the shrouds, And she was overset;

Down went the Royal George, With all her crew complete.

Toll for the brave!

Brave Kempenfelt is gone;

His last sea-fight is fought,

His work of glory done.

It was not in the battle;

No tempest gave the shock;
She sprang no fatal leak; She ran upon no rock.

His sword was in its sheath;

His fingers held the pen,

When Kempenfelt went down

With twice four hundred men.

Weigh the vessel up,

Once dreaded by our foes!

And mingle with the cup

The tear that England owes.

Her timbers yet are sound, And she may float again,

Full charged with England's thunder, And plough the distant main.

But Kempenfelt is gone, His victories are o'er;

And he and his eight hundred Shall plough the wave no more. 


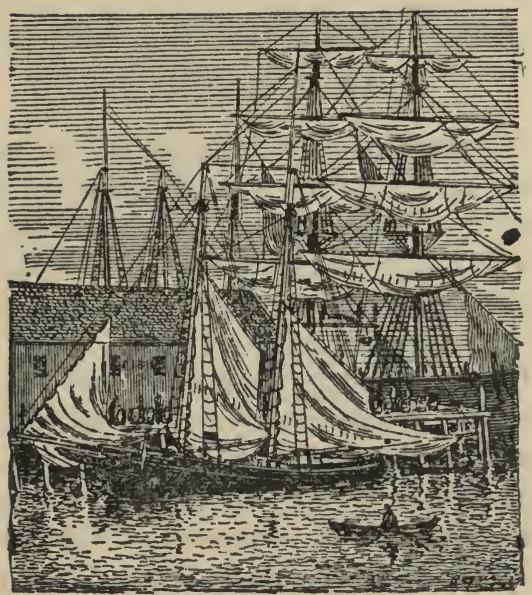

\section{A Banker Discharging Her Fare.}

Here we give a familiar scene to the Winter fisherman and the many who congregate at this busy spot-a Banker getting ready to discharge her fare of halibut at the Atlantic Halibut Company's wharf. She has had a hard time of it on the passage home, as it was cold and stormy, and got badly iced up. But she is all safe now, with her halibut in prime order, a quick market and good prices. This compensates for the hardships endured, and the fishermen are feeling jubilant at the prospect of a pile of crisp bank notes when they take their check up to the bank to be cashed. The square-rigger is a salt vessel at the head of Parkhurst's wharf, which gives a commercial aspect pleasing to look upon.

A Good Answer.-At the hearing before the Fishery Committee at the State House, not long since, a veteran fisherman from this city was asked by one of the lawyers what he knew about fishing. "What don't I know, would be a better question to ask, 'Squire," was the reply. "Why, I've followed it forty years and caught everything that swims, from a whale to a shrimp." There was a hum of subdued merriment, and he was not further interrogated. 


\section{Loss of Life and Vessel Property from January 1 to April 1, 1882.}

Since our report was made up at the beginning of the year and put in type for this volume, there have been lost from this port 102 lives, and 9 vessels valued with their outfits and one cargo of herring at $\$ 5^{2}, 000$, as follows:

Sch. WATER SPIRIT, 60.28 tons, owned by George Garland, engaged in the Winter shore fishery, went ashore on Rye Beach during a thick snow storm, on the night of Jan. $3 \mathrm{I}$, and proved a total loss. Crew saved. Value, $\$ 3,000$; insured for $\$ 2,200$, with $\$ 400$ additional on outfits.

Sch. BUNKER HILL, Ioo.77 tons, owned by Michael Walen \& Son and Capt. John McDonald, on the passage home from Fortune Bay, N. F., Jan. 25, with frozen herring, went ashore during a heavy snow storm, on Bemo Ledge, Eastern Point, and became a total wreck. Value, with outfits, $\$ 7,500$; insurance, $\$ 5,017$, and $\$ 1,000$ on outfits. The cargo was valued at $\$ 4,000$, and uninsured.

Sch. EDITH M. PEW, 62.75 tons, owned by John Pew \& Son, engaged in the Georges haddocking fishery, left port Jan. 18. Was reported in a Nova Scotian port, and last seen on Georges by sch. Noonday, Capt. Edward Trevoy, Feb. 3, two days before the gale in which it is supposed she was lost. Crew list-William Corliss, master; Martin Moran, Samuel Byers, Murdock White, Andrew Conley, Michael Norton, Charles Lawson, Keaton Roderick, John Taylor, John LeeVanance, Martin Lewis, Bartholomew Ryan, William Davis, Hugh Phalen. Value, $\$ 5,500$; insurance, $\$ 3,000$, in the Gloucester Fire Insurance office.

Sch. PAUL REVERE, $64.9 \circ$ tons, owned by Capt. Andrew Leighton, another of the Georges haddocking fleet, sailed Jan. 24, and was last seen by Capt. John Ryan of sch. David A. Story on Georges, Feb. 4, the day before the heavy gale, in which it is supposed she was lost. By many it is thought that this vessel and the Edith $M$. Pew collided during the storm and went down together. Crew list-John Bentley, master; Martin Thomas, Henry Luf kin, Fred Scott, Patrick Durant, Patrick Kennedy, Martin Costello (father-in-law to Capt. Bentley), James Fitzgerald, Martin Conley, John Francis, Joseph Simmons, Patrick Nye, Michael Naughton, Michael King. Value, $\$ 5,000$; insurance, $\$ 4,034$, and $\$ 1,100$ on outfits, in the Gloucester Mutual Fishing Insurance office.

Sch. BESSIE W. SOMES, 92.56 tons, owned by George Clark \& Co., sailed for Grand Bank Jan. 2, and was last seen Feb. 2 by a returned Banker, when she was ready to come home with her trip. She was probably lost 
in the gale of Feb. 5. Crew list-Merrill Wright, master; Felix Gallant, Peter Scanling, Albert Gardner, Augustus Morine, James Burbank, Daniel Hiltz, William Davidson, Henry McLaughlin, Edward Butt, James Johnson, William Parsons, John McPherson, William Wyman. Value, $\$ 6,000$; insurance, $\$ 5,598$ and $\$ 1,200$ on outfits, in the Gloucester Mutual Fishing Insurance office.

Sch. CHARLES CARROLL. 58.64 tons, owned by Benjamin Montgomery \& Son, left on a Georges trip Jan. 12, and was last seen the day of the gale. Crew list-John Publicover, master; Albion Robinson, Herbert Norton (brother-in-law to master), Charles Deimon, W. J. Louder, Robert Wilkinson, John Hayden, John O'Hara, Fred. Watts, Paul McDonald, John Noland. Value, $\$ 2,700$; insurance, $\$ 2,200$, in the Gloucester Fishing Insurance office.

Sch. BELLEROPHON, 85.65 tons, owned by Michael Walen \& Son, left port, Jan. 23, on a Bank halibut trip. She was out in the severe gale of Feb. 5, and it was reported that she was seen previous to this gale with her windlass broken. Crew list-Alfred Wyman, master; James E. Mullen, Lee F. Gilpatrick, Andrew J. Olson, George Rudolf Liledahl, William W. Marshall, Frank Long, Alexander McCloud, Joseph A. Campbell, James McNair, Francis A. Harding, William H. Cook, Samuel Hayes, H. P. Peterson. Value, $\$ 6,000$, and outfits, $\$ 1,200$; insurance, $\$ 4,300$, and $\$ 1,200$ on outfits, in Gloucester Mutual Fishing Insurance office.

Sch. NORTHERNER, 65 tons, owned by Sylvanus Smith \& Co., left port Feb. 28 for a Georges trip, and is supposed to have been lost in the terrible gale of March 17 th. Crew list-Isaac H. Goodwin, master; Israel Goodwin, Amos Goodwin, Robert Lennox, Foster Grayton, George Larken, Daniel McConneskey, Thomas J. Morris, Robert Lennox, James Malone, Thomas Wilson; Edward A. Gilson, steward. , Value, $\$ 3,000$; insurance, $\$ 2,200$ and $\$ 400$ on outfits, in the Gloucester Mutual Fishing Insurance office.

Sch. VICTOR, 70.9r tons, owned by J. O. Procter, Jr., also of the Georges fleet, left port March 3 , and no tidings were heard from her after the terrible gale of the 17 th. Crew list-Patrick J. Fanning, also known as Charles Whalen, master; George Powers, John Callanan, John Welch, Frank Dixon, Dennis Hessian, Thomas Eylward, John Ryan, Martin Simmons, William H. Perrill, James Murphy, Michael Tohey. Value, $\$ 4,500$; insurance, $\$ 3,87 \mathrm{r}$, and $\$ 500$ on outfits, in the Gloucester Mutual Fishing Insurance office.

Lost Overboard.-George Devine fell from the main-boom of sch. Etta Gott on the passage from Georges Jan. $3 \mathrm{r}$; John B. Nelson, from sch. Herman Babson, on the passage to Fortune Bay, N. F., Jan. 2 ; Manuel Repose, from sch. Anna D., on Georges, March 17 : Michael Savage from sch. 
Smuggler, on Georges, March 20 ; Capt. George Bearse from sch. Jonas $H$. French, in the mackereling fishery, March 26.

Lost in Dories.-Jeremiah Haley and James Dunphy from sch. $M$. $A$. Baston, Feb. 3. James McGrath, Peter Christian, Charles Rosmuson and Fred, Keamp, from sch. Corrinna H. Bishop, Feb. 5 .

With these additions the aggregate losses in the fishing business from Gloucester since 1830 , the year the Georges fishery commenced, are $2,35 \mathrm{I}$ lives, and 428 vessels valued at $\$ 1,862,710$.

The following are the details of the losses from Oct. I, 1873 to Jan. I, 1874. The aggregate is given in the table, but the details were overlooked in making up the account on page 66; we therefore insert here.

Sch. CONNAUGHT RANGER, 2 I.I I tons, owned by Capt. Nicholas Murphy, was wrecked at Fresh Water Cove Oct. 20. Crew saved. Value, $\$ 1,000$; insurance, $\$ 500$, in the Gloucester Fire Insurance office.

Sch. JOHN P. HALE, 38.59 tons, owned by J. F. Wonson \& Co., drove out of the harbor on the night of Nov. I7, and was totally wrecked near Old House Cove. Crew saved. Value, $\$ 2,000$; insurance, $\$ 1,800$, in the Gloucester Fire Insurance office.

Sch. EXCELSIOR, 38.30 tons, owned by Capt. George Merchant, Jr., and others, sunk at her anchors in Marblehead harbor, on the night of Nov. 17 . Crew saved. Value, $\$ 1,000$; insurance, $\$ 875$. Abandoned to the underwriters.

Lost Overboard.-George Farrance from sch. Fanny Fern, Oct. 5 ; William Colwell from sch. Noonday, Oct. 7 .

LOST in DORIES.-George Cook and Jesse Oliver from sch. Tubal Cain, Oct. 14 ; Charles Reynolds and Patrick Phalen from sch. Mary E., Oct. ז8; Moses Cahoon and William Reeves from sch. Sultana, Nov 4; Daniel Manning and John Donnelly from sch. William T. Smith, Nov. I9. 


\section{LIST OF VESSELS.}

The following list comprises the vessels owned in the District of Gloucester, April 15, 1882, together with the tonnage, the year built, and the fitters' or principal owners' names. All are schooner's with the exception of those otherwise designated.

\section{GLOUCESTER HARBOR.}

Name of Vessel.

Abbie Dodge,

Abbott Coffin (stm lighter),

Aberdeen,

A. C. Newhall, Active, (sloop,)

Ada R. 'Terry,

Addie Emma,

Addie M. Story,

Addison Center,

Addison G. Procter,

Adelia Hartwell,

Admiral,

Alaska,

Albert H. Harding,

Alfaretta,

Alfred Walen,

Alice,

Alice, (boat,)

Alice G. Wonson,

Alice M. Williams,

A. Lincoln,

Amos Cutter,

Anable, (boat,)

A. N. Clark,

Anne D.,

Anne \& Mary,

Anna H. Frye,

Anna H. Mason,

Annie W. Hodgdon,

Annie E. Lane,

Ann Eliza,

Apollo, (boat,)

Aqua Pura, (boat,)

Arequipa,

Arethusa, (boat,)

Argonaut,
Tons. When Built.

$59.61 \quad 1868$

68.80

70.12

37.31

73.62

69.29

37.10

61.36

74.94

89.15

60.29

77.42

63.87

64.33

55.32

66.77

72.18

8.11

64.18

82.06

46.76

60.35

16.27

51.46

67.67

72.29

67.40

30.64

25.24

50.85

58.43

12.24

11.23

71.95

17.32

74.
Owners' or Fitters' Names.

Sylvanus Smith \& Co.

Francis Locke.

James G. Tarr \& Bro.

Atlantic Halibut Co.

Lanesville Granite Co.

D. C. \& H. Babson.

George Garland.

Oakes \& Foster.

D. C. \& H. Babson.

Joseph O. Procter, Jr.

D. C. \& H. Bahson.

Joseph O. Procter, Jr.

George Norwood \& Son.

George Norwood \& Son.

Eli Jackman \& Co.

Cunningham \& Thompson.

John Pew \& Son.

George H. Oakes.

William H. Perkins, Jr.

D: C. \& H. Babson.

John Pew \& Son.

James G. Tarr \& Bro.

Master.

Atlantic Halibut Co.

John Pew \& Son.

Michael Murray.

John F. Wonson \& Co.

James Lyle.

William Wiley.

George Dennis.

John Pew \& Son.

Daniel Smith.

Peter Hamlin.

Rowe \& Jordan.

Master.

James G. Tarr \& Bro. 


\begin{tabular}{|c|c|c|c|}
\hline Name of Vessel. & Tons. & When Built. & Owners' or Fitters' Names. \\
\hline Arizona, & 48.95 & 1857 & Andrew Leighton. \\
\hline Augusta H. Johnson, & 65.71 & 1874 & George A. Johnson. \\
\hline Avon, (boat,) & 6.91 & & Master. \\
\hline Azalia, & 13.22 & & Master. \\
\hline A. Kimball, (boat,) & 11.62 & & Michael Kelly. \\
\hline Barracouta, & 68.57 & 1870 & Rowe \& Jordan. \\
\hline Belleview, & 15.61 & & Master. \\
\hline B. Gangloff, (steamer,) & 13.65 & 1869 & Master. \\
\hline B. D. Haskins, & 56.69 & 1860 & James G. Tarr \& Bro. \\
\hline B. F. Sumes, & 59.22 & 1868 & $\mathrm{Sa}$ \\
\hline lanche Creamer, (boat,) & 15.90 & & \& Co. \\
\hline Bloomer, & 50.64 & 1851 & F. Wonson \& Co. \\
\hline Blue & 29.10 & & \& Co. \\
\hline g Billow, & 57.18 & 1860 & $\& 1$ \\
\hline Capitola, (boat,) & 6.61 & & Jar \\
\hline arl & 63.08 & 186 & on \& Co. \\
\hline urz, & 72.60 & & \\
\hline irl W. Baxter, & 69.38 & 18 & unninghan \\
\hline arrie $\mathrm{C}$ & 75.47 & 32 & \& Ayer. \\
\hline Sayward, & 62.18 & 1870 & $\mathrm{Sa}$ \\
\hline it & 65.94 & 18 & $G$ \\
\hline g, & 72.25 & 18 & De \\
\hline I, & 115.96 & 18 & $\mathrm{D}$. \\
\hline 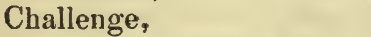 & 56.27 & 18 & Co. \\
\hline & 68.41 & 1876 & \\
\hline (boat,) & 19.32 & & W \\
\hline har & 53.91 & 1859 & Chisholm. \\
\hline 1 & 108.87 & & $\mathbf{A}$ \\
\hline & 71.79 & & \\
\hline C & 65. & & Sal \\
\hline Hildreth, & 58.20 & 18 & Wo \\
\hline & 47.89 & 1867 & ardy \& Co. \\
\hline Che & 73.53 & 1866 & \\
\hline Chester R. Lawrence, & 90.97 & 1874 & \& Co. \\
\hline & 62 & 1869 & $\mathrm{~J}$ \\
\hline & 44. & & $\mathrm{Fr}$ \\
\hline Swett, (boat,) & 14.47 & & \\
\hline $\mathrm{Cl}_{\mathrm{b}}$ & 64. & 1867 & $\mathrm{Be}$ \\
\hline & & & \\
\hline Clytis & 72.17 & 18 & Ro \\
\hline 13 & & & An \\
\hline H. Fr & 83 & & \\
\hline & 58.26 & & ntgomery. \\
\hline Con & 63.80 & & $\mathrm{Cur}$ \\
\hline Ith, & 85.51 & 18 & $\operatorname{Bro}$ \\
\hline Concord, & 98.56 & 1875 & Pew \& Son. \\
\hline & 73.66 & & el Haskell. \\
\hline & 28.21 & 18 & Wo \\
\hline Cor & 13.99 & & Brown. \\
\hline Corrinna H. Bishop & 81.61 & 1875 & George Dennis. \\
\hline
\end{tabular}


Name of Vessel.

Cottage,

Crest of the Wave,

C. Taylor, 3d,

Dacotah,

David A. Story,

David F. Low,

David J. Adams,

David M. Hilton,

David Sherman,

Davy Crockett,

Defiance, (boat,)

Delia, (boat,)

Delia Maria,

Dictator,

Dido,

Dixie, (boat,)

Dragon, (boat,)

Eastern Light,

Eastern Queen,

Eben B. Phillips,

Eben Parsons,

Edward, (boat, )

Edward A. Horton,

Edward Everett,

Edward E. Webster,

Edward Grover,

E. K. Kane,

Electric Flash,

Elisha Crowell,

Eliza Abby,

Eliza K. Parker,

Ella F. Bartlett,

Ellen H. Powers, (boat,)

Ellen M., (boat,)

Ellen M. Adams,

E. L. Rowe,

Emma, (boat,)

Emma S. Osier,

Enola C.,

Epes 'Tarr,

Equal, (boat,)

Ernest F. Norwood,

Esther Ward,

Etta E. Tanner,

Etta Gott,

Ethel,

Eureka,

Eva May,

Everett Pierce,

Everett Steele,
Tons. When Built.

$30.39 \quad 1846$

$71.38 \quad 1877$

$33.71 \quad 1853$

$60.44 \quad 1858$

$91.47 \quad 1876$

$60.77 \quad 187.2$

$69.86 \quad 1867$

$66.50 \quad 1868$

$71.36 \quad 1873$

$84.97 \cdot 1876$

$18.97 \quad 1876$

10.34

55.75

63.18

81.88

14.98

9.49

70.29

60.11

66.91

91.48

9.83

66.46

57.84

98.80

77.26

52.29

82.19

67.78

49.29

57.05

56.86

18.03

6.43

90.33

68.78

13.23

23.91

65.28

70.06

10.89

74.50

62.23

66.32

59.10

71.73

51.96

27.50

67.94

70.54

1872

1882

1881

1866

1860

1866

1875

1876

1870

1860

1874

1857

1859

1869

1854

1857

1860

1860

1876

1871

1878

1869

1873

1871

1868

1867

1868

1881

1866

1871

1881

1863
Owners' or Fitters' Names.

James Parker.

William B. Coombs.

Eli O. Cleaves.

Shute \& Merchant.

Benjamin Low.

Benjamin Low.

Jesse Lewis.

Pettingell \& Cunningham.

Janes G. Tarr \& Bro.

James G. Tarr \& Bro.

Elisha C. Wheeler.

William M. Lane.

1864 Chresten Nelson.

1875
George Steele.

John Foster.

Master.

Maddocks \& Co.

John Pew \& Son.

Michael Walen \& Son.

Wm. Parsons, 2d, \& Co.

Master.

Daniel Allen \& Son.

Cunningham \& Thompson.

Solomon Jacobs.

Dennis \& Ayer.

Michael Walen \& Son.

T. A. Langsford \& Son.

Daniel Allen \& Son.

James Parker.

Leonard Walen.

John Pew \& Son.

Patrick Powers.

Master.

George Norwood \& Son.

Samuel Lane \& Bro.

Atlantic Halibut Co.

David A. Osier.

Andrew Leighton.

James G. Tarr \& Bro.

Eben Brazier.

George Norwood \& Son.

Oakes \& Foster.

Samuel Haskell.

Sylvanus Smith \& Co.

Sylvanus Smith \& Co.

Benjamin Low.

Howard A. Wonson.

J. F. Wonson \& Co.

B. H. Spinney.
John Pew \& Son. 
Name of Vessel.

E. W. Merchant,

Excelsior,

Falcon,

Fanny Fern,

Farragut,

F. A. Smith,

Finance,

Fitz J. Babson,

Flash,

Fleetwing,

Fleur de Lis, (boat,)

Flora Temple,

Flying Scud,

Frank A. Williams,

Frederic Gerring, Jr.,

Fred P. Frye,

Fred L. Webb,

F. W. Homans,

Gardner W. Tarr,

Garnet, (sloop,)

- Garibaldi,

Gatherer,

Gazel,

George A. Upton,

George Clark, Jr.,

George H. Pierson,

George J. Tarr,

George O. Hovey,

George P. Rust,

George P. Trigg,

George S. Boutwell,

George W. Stetson,

Georgianna,

Gertie E. Foster,

Gleaner,

Golden Hind,

Goldsmith Maid,

Good Templar,

G. P. Whitman,

Grace C. Hadley,

Grace L. Fears,

Gracie Smith, (boat,)

Gussie Blaisdell,

H. A. Duncan,

H. A. Johnson,

Hannah, (boat,)

Harvest Home,

Hattie B. West,

Hattie Chester,

Hattie L. Newman,
Tons. When Bullt.

$47.84 \quad 1850$

$38.30 \quad 1847$

$71.67 \quad 1873$

$48.39 \quad 1858$

$50.85 \quad 1867$

$77.10 \quad 1869$

$67.58 \quad 1869$.

$69.25 \quad 1871$

$73.37 \quad 1875$

$59.29 \cdot 1859$

$15.40 \quad 1879$

$52.59 \quad 1858$

$65.88 \quad 1870$

$66.49 \quad 1869$

$70.88 \quad 1870$

$85.37 \quad 1870$

$54.92 \quad 1867$

$66.21 \quad 1870$

$66.07 \quad 1875$

$27.03 \quad 1866$

$51.99 \quad 1859$

$95.70 \quad 1876$

$37.62 \quad 1846$

$56.29 \quad 187$ Ј

$65.25 \quad 1866$

$68.11 \quad 1867$

$59.85 \quad 1869$

$63.85 \quad 1864$

65.05

$123.56 \quad 1868$

$66.87 \quad 1869$

$74.32 \quad 1869$

$52.01 \quad 1851$

$88.28 \quad 1874$

$63.52 \quad 1871$

$74.60 \quad 1877$

$51.24 \quad 1872$

$57.07 \quad 1867$

$94.39 \quad 1874$

$67.03 \quad 1873$

$88.94 \quad 1874$

$12.63 \quad 1880$

$89.05 \quad 1876$

$87.70 \quad 1876$

60.65

8.59

56.88

56.36

73.82

98.34

1856

1866

1878

1875
Owners' or Fitters' Names.

George. J. Tarr \& Co.

J. J. Burns \& Co.

Andrew Leighton.

George Garland.

John F. Wonson \& Co.

Joseph Friend.

Shute \& Merchant.

James Mansfield \& Sons.

James G. Tarr \& Bro.

Wonson Bros.

Master.

Harry Hardy.

Joseph O. Procter, Jr.

William C. Wonson \& Co.

Edward Morris.

John S. McQuin \& Co.

Michael Walen \& Son.

George Clark \& Co.

James G. Tarr \& Bro.

Francis Locke.

George J. Tarr \& Co.

Rowe \& Jordan.

'T. A. Langsford \& Son.

Andrew Léighton.

George Clark \& Co.

Cunningham \& Thompson.

John F. Wonson \& Co.

Benjamin Low.

George Clark.

Benjamin Haskell \& Sons.

McKenzie, Hardy \& Co.

Joseplı O. Procter, Jr.

Stockbridge \& Co.

George Clark \& Co.

William C. Wonson \& Co.

Rowe \& Jordan.

Rowe \& Jordan.

Samuel Lane \& Bro.

Andrew Leighton.

Pettingell \& Cunningham.

Atlantic Halibut Co.

Sylvanus Smith \& Co.

Sylvanus Smith \& Co.

George Steele.

Wm. Parsons, 2d, \& Co.

James MeGrath.

John Knowles.
Shute \& Merchant.

George Steele.

Michael Walen \& Son. 
Name of Vessel.

Hattie N. Gove, (3 m'st,) 347.62

Hattie N. Reed,

Hattie S. Clark,

Haze, (boat,)

Hector,

H. B. Griffin,

Helen M. Crosby,

Helen M. Dennis,

Helen R. Low,

Henrietta, (sloop, )

Henry Ellsworth,

Henry Friend,

Henry L. Phillips,

Henry Stanberry,

Henry Wilson,

Herald of the Morning,

Herbert M. Rogers,

Hereward,

Herman Babson,

Hildegarde,

Hope, (boat,) .

Hope, (boat,)

Horace Albert,

Howard,

Howard Holbrook,

Hyperion,

Ida A. Mayhue, (boat,)

Ida Chase, (boat,)

Ida May,

Ida May, (boat,)

Ida May, (boat,)

Isaac A. Chapman,

Isaac Patch,

Island Belle, (boat,)

Island Home,

Ivanhoe,

James Bliss,

James A. Garfield,

Jamestown,

Jennie B. Thomas,

J. H. G. Perkins,

J. J. Clark,

Joe Hooker,

John D. Griffen,

John D. Long,

John F. Wonson,

John S. McQuin,

John Smith,

John S. Presson,

John W. Bray,
Tons. When Built.

48.04

70.63

8.04

31.78

123.93

66.62 .

68.10

59.25

44.45

59.33

67.39

80.04

59.42

93.31

71.63

77.65

90.11

100.52

71.39

8.85

5.90

68.70

74.80

97.47

68.59

12.05

6.04

45.17

7.79

8.96

85.06

72.80

5.51

43.32

75.85

62.63

73.58

69.

50.95

59.23

69.68

62.

104.02

66.35

58.03

81.76

65.51

92.82

83.41
1873

1867

1866

1854

1875

1865

1868

1881

1869

1865

1875

1868

1868

1876

1874

1875

1874

1876

1876

1878

1880

1874

1877

1875

1867

1855

1879

1867

1860

1879

1868

1881

1876

1867

1867

1870

1864

1863

1880

1868

1877

1868

1874

1875

Owners' or Fitters' Names.

Shute \& Merchant.

Michael Walen \& Son.

Joseph O. Procter, Jr.

William Remby.

Thomas Douglass.

Daniel Allen \& Son.

Rowe \& Jordan.

George Dennis.

Benjamin Low.

Master.

Sayward Bros.

Joseph Friend.

George Dennis.

William C. Wonson \& Co.

Pettingell \& Cunningham.

John Pew \& Son.

Rowe \& Jordan.

James Mansfield \& Sons.

D. C. \& H. Babson.

Rowe \& Jordan.

Henry Dennis.

Master.

Sylvanus Smith \& Co.

Sylvanus Smith \& Co.

Oakes \& Foster.

Cunningham \& Thompson.

John Shean.

Master.

James Mansfield \& Sons.

Master.

Albert O. Wonson.

D. C. \& H. Babson.

Atlantic Halibut Co.

Master.

Albert R. Duley.

Cunningham \& Thompson.

Wm. Parsons, 2d, \& Co.

Rowe \& Jordan.

George Steele.

Joseph Friend.

Burnham \& Winter.

Rowe \& Jordan.

Shute \& Merchant.

Master.

Andrew Leighton.

John F. Wonson \& Co.

John S. McQuin \& Co.

Oakes \& Foster.

George Clark \& Co.

John F. Wonson \& Co. 
Name of Vessel.

Joseph Garland,

Joseph O.,

Joseph Story,

Josie M. Calderwood,

J. S. Lamprey, (3 m'sts,) 306.10

J. W. Campbell,

Knight Templar,

Knutsford,

Landseer,

Laughing Water,

Laughing Waters,

Laura Nelson,

Laura Sayward,

Legal Tender,

Leone,

Levanter,

Light Wing,

Little Antie, (boat,)

Little Giant, (steamer,

Lizzie,

Lizzie J. Jones,

Lizzie Myrtle, (boat,)

Lizzie W. Hannum,

Lottie K. Friend (3 m'st), 367.09

Lottie S. Morton,

Lucy, (boat,)

Lucy Ann,

M. A. Baston,

Mabel Dillaway,

Madame Roland,

Madawaska Maid,

Magellan Cloud, (boat,)

Magic,

Marathon,

Margaret,

Margie Smith,

Marion,

Marion Grimes,

Martha and Susan,

Martha C.,

Martha Jane, (boat,)

Mary A. Brown, (boat,)

Mary E.,

Mary F. Chisholm,

Mary E. Daniels,

Mary Elizabeth,

Mary Fernald,

Mary Story,

Massasoit,

Massena,

$\begin{array}{cc}\text { Tons. } & \text { When Built. } \\ 51.44 & 1866 \\ 65.12 & 1867 \\ 55.32 & 1860 \\ 90.69 & 1875 \\ 306.10 & 1872 \\ 83.21 & 1881 \\ 73.26 & 1870 \\ 83.64 & 1882 \\ 98.99 & 1875 \\ 49.01 & 1858 \\ 31 . & 1866 \\ 89.35 & 1874 \\ 68.05 & 1866 \\ 51.03 & 1868 \\ 100.56 & 1871 \\ 50.08 & 1869 \\ 33.84 & \\ 5.42 & 1877\end{array}$

1877

$\begin{array}{rr}5.42 & 1878\end{array}$

$72.47 \quad 1875$

$63.95 \quad 1875$

$5.27 \quad 1875$

$75.12 \quad 1868$

1873

1882

11.56

46.54

47.46

81.88

62.39

63.06

19.97

67.83

68.43

46.55

61.13

82.25

61.36

70.73

79.16

16.89

15.65

67.22

73.93

67.68

22.51

80.27

64.09

73.63

59.54

1849

1878

1882

1860

1868

1871

1874

1866

1875

1877

1868

1878

1875

1871

1875

1868

1852

1875

1875

1868

1860
Owners' or Fitters' Names.

Master.

Joseph O. Procter, Jr.

Charles Dagle.

Dennis \& Ayer.

Master.

Benjamin Low.

George Steele.

John Pew \& Son.

Michael Walen \& Son.

Master.

Master.

Atlantic Halibut Co.

Sayward Bros.

Shute \& Merchant.

W. G. Pool.

George Norwood \& Son.

B. H. Spinney.

Master.

Douglass Bros.

Daniel Allen \& Son.

Wm. Parsons, 2d, \& Co.

Master.

John Collins.

Master.

J. F. Wonson \& Co.

Master.

Samuel Haskell.

Master.

Michael Walen \& Son.

Burnham \& Winter.

John S. McQuin \& Co.

Alex. McCloud.

John F. Wonson \& Co.

George Steele.

Benjamin H. Spinney.

Sylvanus Smith \& Co.

Sylvanus Smith \& Co.

D. C. \& H. Babson.

Dennis \& Ayer.

Leonard Walen.

Simeon McCloud.

John Guthrie.

Shute \& Merchant.

Benjamin Low.

Leonard Walen.

George Norwood \& Soll.

Dennis \& Ayer.

Sayward Bros.

McKenzie, Hardy \& Co.

Wm. Parsons, 2d, \& Co 
Name of Vessel.

Matthew Keany,

Mand F. Leighton,

Mand Gertrude, (boat,)

Metacom, (boat,)

M. H. Perkins,

Midnight,

Minnehaha, (boat,)

Minnie Dell, (boat,)

Mist,

M. L. Wetherell,

Monmouth,

Moro Castle,

Morrill Boy, (boat,)

Mountain King,

Mystic,

M. G. O. B., (boat,)

Napoleon, (boat,)

Nelson Wells,

Nevada,

New England,

Newsboy, (boat,).

Noonday,

Northern Eagle,

Northern Star,

Notice,

Nellie Burkett, (boat,)

Neison Y. McFarland,

Nellie N. Rowe,

Ocean King,

Ocean Ranger,

Oceanus,

Oliver Eldridge,

Ontario,

Onward,

Optimates, (boat,)

Orient,

Ossipee,

Otis P. Lord,

Pathfinder,

Percy,

Peter D. Smith,

Phantom, (yacht,)

Phantom,

Phaselus, (boat,)

Phœnix,

Pioneer,

Piscataqua,

Planet,

Pluribustah,

Polar Wave,
Tons. When Built.

$69.80 \quad 1882$

$72.55 \quad 1882$

15.01

11.31

76.14

69.48

10.18

8.27

72.39

69.42

71.68

88.85

17.08

54.58

83.09

6.38

7.01

63.20

62.06

86.29

12.67

75.25

36.97

56.16

66.50

6.97

69.15

83.22

79.79

57.20

47.44

65.86

91.29

45.47

6.65

93.76

72.58

75.63

67.26

72.27

69.49

72.56

30.05

14.30

60.33

66.19

64.51

32.24

20.39

90.93

1876

1865

1875

1865

1876

1874

1878

1879

1853

1868

1877

1877

1873

1857

1860

1868

1881

1882

1877

1858

1870

1870

1873

1852

1866

1875

1872

1876

1871

1878

1868

1865

1875

1869

187.2

1866

1845

1865

1875
Owners' or Fitters' Names.

Maddocks \& Co.

Andrew Leighton.

Daniel Gill.

Master.

George Dennis.

Maddocks \& Co.

Master.

Master.
James G. Tarr \& Bro.

Shute \& Merchant.

George Steele.

McKenzie, Hardy \& Co.

B. D. Haskins.

Benjamin Gerring.

John McKinnon.

Master.

Master.

Michael Walen \& Son.

Michael Walen \& Son.

John Pew \& Son.

Master.

Maddocks \& Co.

George H. Martin.

Joseph O. Procter, Jr.

Master.

Master.

Samuel Lane \& Bro.

Rowe \& Jordan.

Maddocks \& Co.

Wm. Parsons, 2d, \& Co.

William Gibbs.

George Steele.

John Pew \& Son.

James G. Tarr \& Bro.

George Wonson.

Charles Lee.

Cunningham \& Thompson.

Dennis \& Ayer.

Wm. Parsons, 2d, \& Co.

Dennis \& Ayer.

Oakes \& Foster. .

Henry S. Hovey.

David Lyle.

Master.

George Clark \& Co.

James G. Tarr \& Bro.

John F. Wonson \& Co.

Master.

Master.

Andrew Leighton. 
Name of Vessel.

Procter Brothers,

Plymouth Rock,

Racer,

Ralph E. Eaton,

Rambler,

Rattler,

R. D. Litchfield, Jr., (st.,)

Rebecca Bartlett,

Reporter,

Restless,

Rising Star,

Richard Lester,

Rough \& Ready,

Royal Oak,

Rushlight,

Rutherford B. Hayes,

Ruth Groves,

S. A. Parkhurst,

Sarah C. Pyle,

Sarah C. Wharff;

Sarah E. Wetherell, (st.,)

Sarah M. Jacobs,

Sarah P. Ayer,

Schuyler Colfax,

Sea Foam,

Sea Witch, (boat,)

Seth Stockbridge,

Shiloh,

Shooting Star, (boat,)

Sigfrid,

Smuggler,

Solomon Poole,

Sophronia,

S. P. Greenleaf, (boat,)

S. R. Lane,

Star of the East,

Starry Flag,

Sterling,

St. Michael,

St. Patrick, (boat,)

Sultana,

Sunshine,

Samuel B. Jones, (st.,)

Senator, (pinkey,)

Susie Hooper,

Thomas W. Knight,

- Teddie, (boat,)

Telephone,

Tidal Wave,

T. L. Mayo,
Tons. When Built.

$77.05 \quad 1876$

$96.94 \quad 1876$

$53.95 \quad 1852$

$68.96 \quad 1877$

$66.91 \quad 1865$

$82.72 \quad 1859$

1871

1869

1874

1870

1871

1881

1847

1846

1863

\subsection{8}

66.98

71.84 .

68.82

53.35

52.62

51.43

22.48

80.04

71.38

62.82

57.88

7.77

89.94

85.98

14.96

76.54

67.92

86.20

57.03

11.07

72.

56.13

59.50

63.62

28.24

17.79

69.84

66.29

33.54

32.67

76.91

66.26

10.57

20.25

70.28

62.46
1877

1867

1861

1869

1871

1872

1878

1869

1868

1853

1875

1874

1882

1877

1876

1860

1873

1867

1871

1868

1865

1859

1869

1866

1872

1831

1882

1881

1878

1878

1871

1866
Owners' or Fitters' Names.

Daniel Allen \& Son.

George Steele.

Walter M. Falt.

James G. Tarr \& Bro.

D. C. \& H. Babson.

Andrew Leighton.

Master.

Oakes \& Foster.

John F. Wonson \& Co.

George Clark \& Co.

Jesse McCloud.

James G. Tarr \& Bro.

John Carter.

D. C. \& H. Babson.

John F. Wonson \& Co.

Dennis \& Ayer.

James Mansfield \& Sons.

Eli Jackman \& Co.

Joseph Friend.

George Clark \& Co.

Dennis \& Ayer.

Samuel Lane \& Bro.

Dennis \& Ayer.

Joseph O. Procter, Jr.

Walter M. Falt.

Master.

George Norwood \& Son.

John Pew \& Son.

Master.

Cunningham \& Thompson.

Andrew Leighton.

Cunningham \& Thompson.

Benjamin Low.

Master.

Saniuel Lane \& Bro.

Master.

Wm. Parsons, 2d, \& Co.

John Pew \& Son.

Michael Curon.

Peter Conley.

Andrew Leighton.

John Pew \& Son.

Master.

John Parker.

Daniel Allen \& Son.

Andrew Leighton.

Master.

Joseph Lyle.

John Pew \& Son.

James G. Tarr \& Bro. 
Name of Vessel.

Tragabigzanda,

Triton,

Tubal Cain,

U. S. Grant, (boat,)

Undine,

Veteran,

Vidette,

Viking,

Vision,

Volunteer,

Wachusett,

Waldo Irving,

Wanderer, (sloop,)

Webster Sauborn,

Welcome,

W. E. Terry,

Wildfire,

Wild Pigeon,

William A. Pew,

William H. Raymond,

William H. Oakes,

William M. Gaffney,

William S. Baker,

William V. Hutchings,

Willie M. Stevens,

William E. McDonald,

William H. Foye,

William Parsons; 2d,

Willie,

Winged Arrow,

Witcheraft,

Z. S. Wallingford, (boat,)

Zenobia,
78.73

Tons. When Built.

$68.03 \quad 1870$

$71.51 \quad 1875$

$63.39 \quad 1871$

7.19

10.34

63.64

58.07

73.63

50.37

69.58

79.14

64.35

13.66

99.89

61.26

63.

108.90

46.87

70.19

70 .

70.89

74.65

103.95

62.68

80.56

98.37

70.45

64.41

91.58

58.85

57.73

9.86

Owners' or Fitters' Names.

Wonson Bros.

Sayward Bros.

Wm. C. Wonson \& Co.

Nehemiah Adams.

Henry Smith.

1865 Benjamin Montgomery.

McKenzie, Hardy \& Co.

James Mansfield \& Sons.

Master.

Joseph Smith.

Cunningham \& Thompson.

John F. Wonson \& Co.

Master.

Maddocks \& Co.

John Pew \& Son.

J. O. Procter, Jr.

Andrew Leighton.

Daniel Allen \& Son.

James Mansfield \& Sons.

Dennis \& A jer.

Atlantic Halibut Co.

Joseph Smith.

Joseph Friend.

George Friend \& Son.

George Dennis.

Wm. Parsons, 2d, \& Co.

Sylvanus Smith \& Co.

Wm. Parsons, 2d, \& Co.

Master.

Sylvanus Smith \& Co.

William B. Coombs.

John Cadwallader.

1881 George Steele.

\section{ROCKP゚ORT.}

\begin{tabular}{|c|c|c|c|}
\hline & Tons. & hen B & $T$ \\
\hline tive, (sloop,) & & & e Co. \\
\hline A., (sloop, ) & & & C \\
\hline (sloop, ) & & 1869 & ngell. \\
\hline ., (boat,) & 11 & & $\mathrm{H}$ \\
\hline Parker, & & 185( & F \\
\hline (sloop, & & & $\mathrm{F}$ \\
\hline 9 & 99 & 1 & \\
\hline oat,) & & 18 & \\
\hline & & & aite Co. \\
\hline (alo & & & Co \\
\hline & 47. & 186 & J0 \\
\hline & 39.61 & 1857 & Master. \\
\hline
\end{tabular}


Name of Vessel.

Daniel Webster, (sloop,)

Edith Bean,

Edith L. Conley,

Fanny R.,

Franklin S. Schenck,

Glide, (boat,)

Golden Rule,

Hard Chance, (sloop,)

Ida May, (sloop,)

Isabella,

Jenny Lind, (boat,)

John P. Ober,

Josephine,

Joseph M. Lane,

J. Y. Baker,

Lady Lincoln,

Lizzie D. Saunders,

L. Snow, Jr.,

Lodowick Bill,

Mary Ellen,

Minnie, (boat,)

Nellie Florence, (boat,)

Nellie T. Gaskell, (boat,)

New Era, (sloop,)

Parnet,

Pinafore, (boat,)

Quickstep,

School Girl, (boat,)

Screamer, (sloop,)

Shooting Star, (boat,)

Sina Sbore,

Theresa, (3 mast,)

Waverly,
Tons. When Built.

$46.11 \quad 1853$

17.22

58.90

55.37

46.03

7.81

41.67

64.60

63.05

50.61

15.96

55.72

38.68

53.73

55.69

26.42

43.54

41.90

59.93

54.11

6.60

7.13

15.12

62.54

21.19

10.65

11.73

29.08

9.08

63.93

10.70

12.64

226.68

52.09

1869

1862

1855

1855

1851

1873

1868

1852

1849

1861

1867

1851

1866

1855

1853

1838

1856

1873
Owners' or Fitters' Names

Pigeon Hill Granite Co.

Francis Tarr, Jr.

1876 Master.

1859 Master.

Bradley \& Co.

Henry W. Colburn.

Zenas Brown.

Lanesville Granite Co.

Rockport Granite Co.

C. C. Pool.

Master.

John Story, Jr.

Eben Blatchford.

Master.

Joshua Turr.

John Story, Jr.

Master.

A. C. Pierce.

John Story, Jr.

Master.

Master.

Joshua Tarr.

Rockport Granite Co.

Master.

Loring Grimes.

A. B. Seaborn.

Master.

Master.

Pigeon Hill Granite Co.

Master.

Master.

1874 George J. Tarr \& Co.

1853 J. Story, Jr.

$M A N C H E S T E R$.

Name of Vessel.

Tons. When Built.

Owners' or Fitters' Names.

Mary A. Downes, (boat,) 12.241878

Ranter, (boat,)

5.07

George A. Jones.

Gorham Morse.

$A N N I S Q U A M$.

Name of Vessel.

America, (yacht,)

Belle Gilmore,

Bonita, (boat,)

Eva May,

I Am Here, (boat,)
Tons. When Built.

$89.59 \quad 1849$

$46.08 \quad 1853$

18.67

27.50

11.06
Owners' or Fitters' Names. Jonas H. French.

Master.

Master.

1871 Master.

Master. 
Name of Vessel.

Island Home, (boat,)

John Mettler,

May S. Roundy, (boat,

Sardina, (boat,)

Venus, (boat.)

Vesper, (boat,)

Wide Awake,
Tons. When Built.

12.02

62.83

11.16

9.11

12.44

17.10

63.41
Owners' or Fitters' Names.

Master.

1848 Master.

Geo. W. Langsford.

Bartlett Morgan.

1878 Master.

Master.

1859 Master.

The aggregate number of vessels and tonnage enrolled in this district when this list was made up, April 15, 1882, comprised 483 vessels, with a tonnage of $27,809.75$. Of this number, 423 belong to Gloucester Harbor, of a tonnage of $25,254.90$ : 353 schooners, 4 sloops, 1 yacht, 6 steamers, 59 boats. Rockport has $2,156.57$ tonnage, 46 vessels : 25 schooners, 10 sloops, 11 boats. Annisquam, 380.97 tonnage, 12 vessels : 4 schooners, 1 yacht, 7 boats. Manchester, 17.31 tonnage, comprising 2 boats.

\section{FISHING FIRMS AND FITTING-OUT ESTABLISHMENTS.}

The number of fishing firms and fitting-out establishments in Gloucester Harhor at this date, April 15, 1882, is 46 , which fit out 302 schooners and boats. The balance of the fleet is composed of vessels whose masters are owners, and they fit where they please. Messrs. John Pew \& Son are the largest fitters, having 19 vessels; James G. Tarr \& Bro. come next, with 16, and J. F. Wonson \& Co. are third on the list, with 15; Andrew Leighton fits 14; Rowe \& Jordan, 13; two, 12 each, two, 11 ; two 10, four, 9 ; one, 8 ; three, 7 ; five, 6 ; five, 5 ; two, 4 ; four, 3 ; eight, 2 ; three, 1 . The following is the list of the Gloucester Harbor fishing firms and fittingout establishments, with their number of vessels :

Atlantic Halibut Co.,

Burnham \& Winter,

Daniel Allen \& Son,

D. C. \& H. Babson,

J. J. Burns \& Co.,

Cunningham \& Thompson,

George Clark \& Co.,

Williain B. Coombs,

Dennis \& Ayer,

George Dennis,

Joseph Friend,

Walter M. Falt,

George Garland,

Samuel Haskell,

\begin{tabular}{r|lr}
7 & B. Haskell \& Sons, & 1 \\
2 & Eli Jackman \& Co., . & 2 \\
7 & Samuel Lane \& Bro., & 5 \\
11 & Andrew Leighton, & 14 \\
1 & T. A. Langsford \& Son, & 2 \\
10 & Benjamin Low, \\
9 & Benjamin Montgomery, \\
2 & James Mansfield \& Sons, \\
12 & John S. McQnin \& Co., \\
6 & McKenzie, Hardy \& Co., \\
5 & Maddocks \& Co., \\
2 & George Norwood \& Son, \\
2 & Oakes \& Foster, \\
6 & John Pew \& Son,
\end{tabular}


J. O. Procter, Jr., William Parsons, 2d, \& Co., Pettingell \& Cunningham, Rowe \& Jordan, Sylvanus Smith \& Co., George Steele, Sayward Bros., Shute \& Merchant, B. H. Spinney,

9 | Joseph Smith,

10 Seth Stockbridge \& Co., 1

4 James G. Tarr \& Bro., 16

13 George J. Tarr, 3

12 J. F. Wonson \& Co.,

11 Leonard Walen, 3

5 Wonson Bros., 3

9 William C. Wonson \& Co., 5

2 Michael Walen \& Son, 8

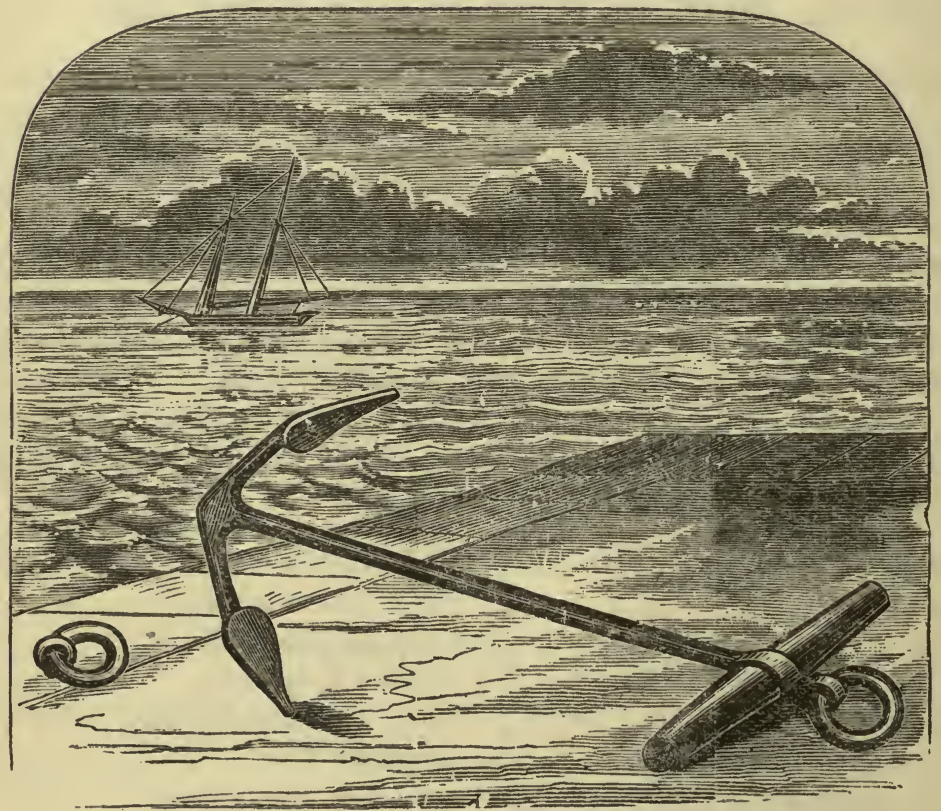




\section{do I

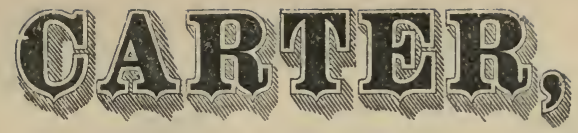

MANUFACTURER OF

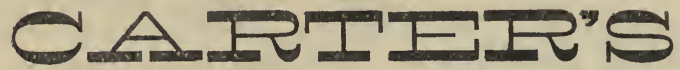

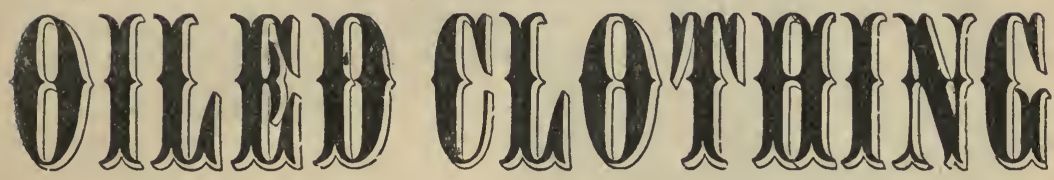

Sou' Westers,

Grand Bank Hats,

Beverly Hats,

Carter's Home-Made Drawers, SHIRTS, JUMPERS, OVERALLS, \&C.

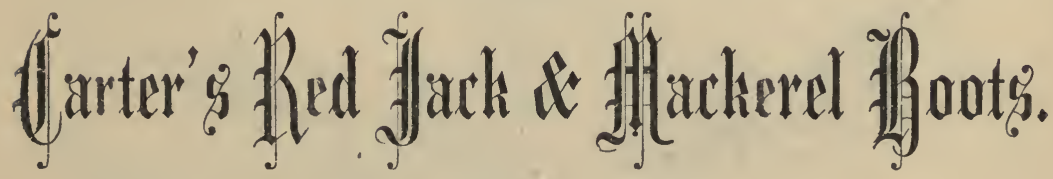
ALSO, WHOLESALE AND RETAIL DEALER IN

FISHERMEN'S OUTFITS, OF EVERY DESCRIPTION.

Principal Manufactory at BEVERLY, Mass. BRANCH STORE AT

GLOUCESTER, Mass., cor. Rogers and Duncan Streets. JOSEPH H, ROWE, Manager. 


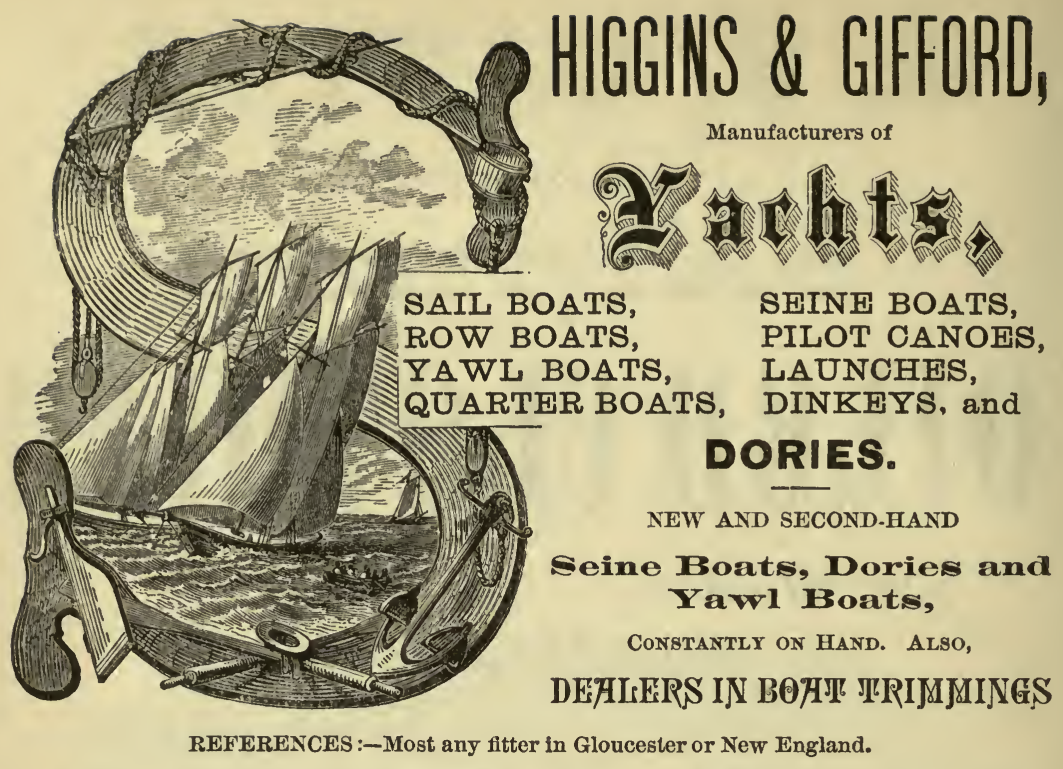

P. O. Box, No. 130, GLOUCESTer, Mass. Send for Price List.

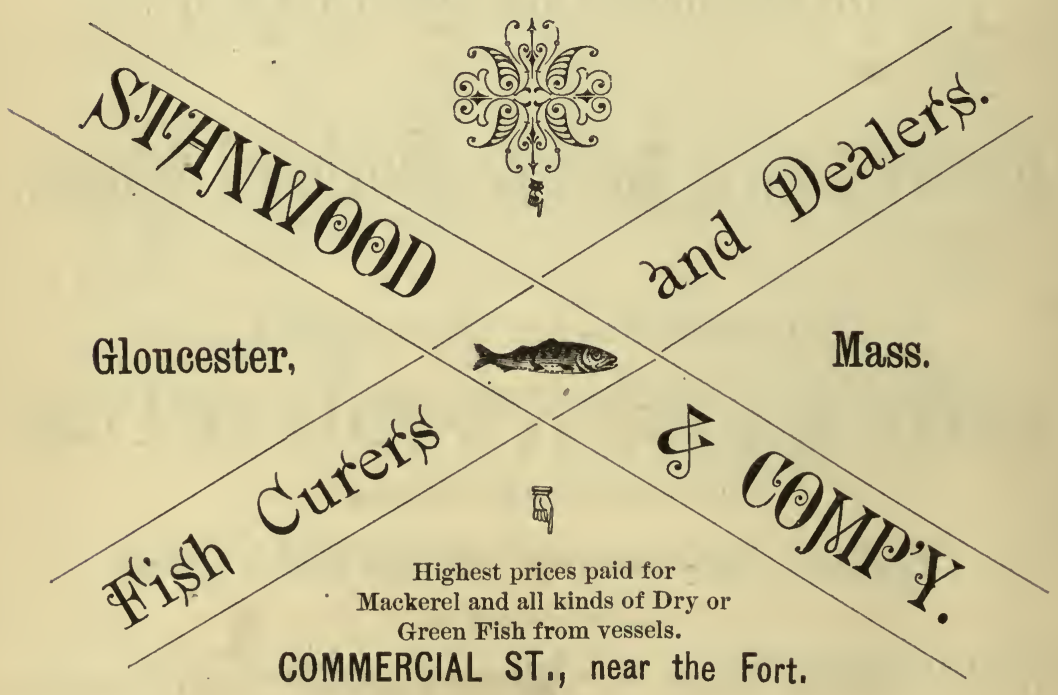




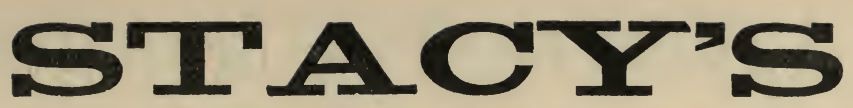

\section{FIRST-CIASS}

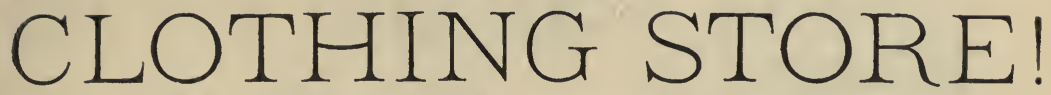

The largest and best selected stock of

FINE HATS and GENTS' FURNISHINGS IN TYIE OITY.

- A GOOD ASSORTMENT OF

Custom and Ready-Made Clothing Antrars ox masp.

Newest Styles, Popular Prices.

No. $16 \dot{8}$ Main St., - - Gloucester.

A AROIT BIETTIT'S

Billiard Parlors,

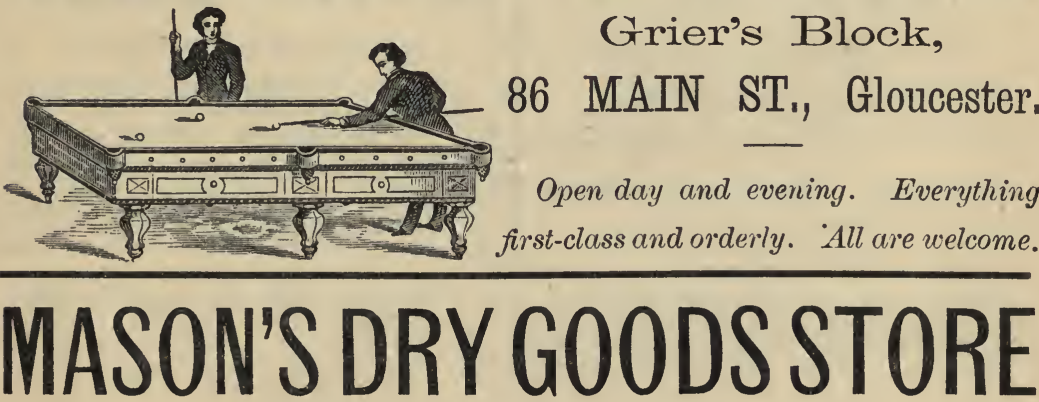

IVo. 311 MIain Street,

Is the place for BARGAINS.

Full stock of Goods in the various departments, and the lowest prices of any store in the city. Call and prove this assertion.

C. A. MASON, Proprietor. 


\section{SAMUEL LANE \& BROTHER,}

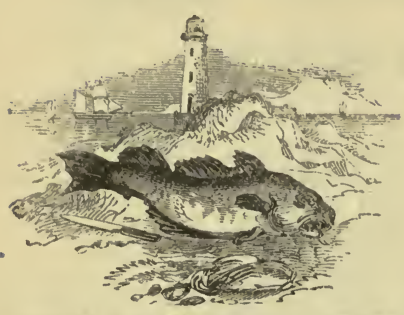

Producers and Wholesale Dealers in

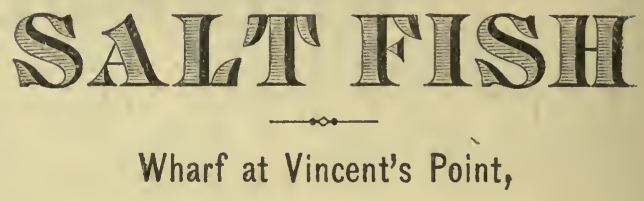

GIOUCESTER, MLAS.

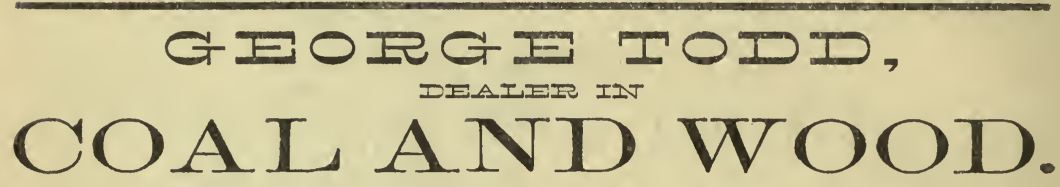

Locust Mt., Suffolk, Lorberry and Lincoln of Lykens Valley Coals,

\section{${ }_{6}$ SOLE AGENTS FOR}

\section{Breed's Chemical Compound. HFRD HND SOHT WOOD PREPHRED.}

393 MAIN STREET,

M. HI. PERIKINS,

327 Main St., Gloucester.

Drugs and Chemicals TOILET AND FANCY ARTICLES,

Patent Medicines, \&c.

Prescriptions Carefully Compounded.

New and Second-Hand Medicine Chests furnished and replenished at short notice.

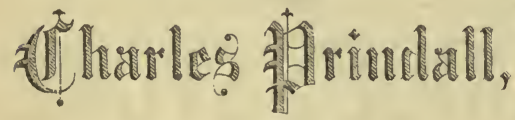
$\because$ SHILMXHKRR, $\%$

GLOUCESTER, MASS.

$$
-0050500
$$

Sails made to order and satisfaction guaranteed.

Gloucester, Mass.

\section{B. JACKMAN \& CO.,} MANUFACTURERS OF

(6)

Best Quality, All Sizes.

A specialty of Tarred Lines of the various sizes required for sea flshing.

LINE-WALK AND FACTORY AT

Newburyport, Mass.

Moses B. JACKMAN, LEONARD A. BURNHAM, Newburyport.

Gloucester.

\section{Chas. H. Boynton,}

DEAIEIE INT

Wood and Coal

Gloucester, Mass.

Office Rear Cape Ann Savings Bank. 


\section{N. BOYNTON \& CO.}

$87 \& 89$ Commercial Street, BOSTON,

MANUFACTURERS OF

COTTON + DUCK!

EUSSEI工 MIIILS,

DEUID MIIIIS,

UIITED STAIES, Yacht, $8 \mathrm{oz} .10 \mathrm{oz} .12 \mathrm{oz}$. EXIEA INAVI, “. . . .

SOLE AGENTS FOR THE

N. E. BUNTING COMPANY,

AND IMPORTERS OF

HOTH'S RUSSIA BOLTROPE.

WM. COOS, JR., NKISS Z SEINES,

Tarred and Repaired. OVER CALL'S SPAR SHOP, VINCENT SPRING,

Rear John Pew of Sons, GludCester, MAss.

NETS, SEINES, TWINE and FISHING NETTINGS, of every description, furnished to order. ALL WORK GUARANTEEU.

\section{Joseph Simpson,}

MANUFACTURER OF

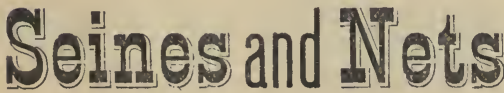

OF ALI DESCRIPTIONS.

ACORRING and REPAIRING done in the best manner.

PARKHURST'S WHARF, Foot of Duncan St., P. O. Box 702 .

GLOUCESTER, MASS.
BOSTON \& GLOUCESTEP

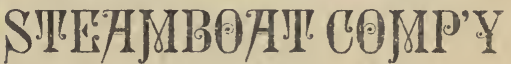

For Freight and Passengers, Making Connections with alb Railroad and Steamship Lines out of Boston.

Through Rates and Bills of Lading given.

Leaves Boston Daily (Sundays excepted) at 2 P. M. and 10.15 A. M. Leaves Gloucester Daily at 3 and 7 A. M.

ADEOIT COFEII, Agent, Gloucester, Mass.

ㅍ. S. MREICCIIANI, Agent, Central Wharf, Buston, Mass.

AISHERMEN: YOU CAN FIND

\section{PRubber DBoots,}

The Cenuine Annisquam Boot,

And all other styles for sea or shore wear. Pri ces alivays the LOWEST.

ACS REPAIRING done at short notice. Call and see your old shipmate,

\section{JAMES A. DAVID,}

45 Main St., Foot of Short. 

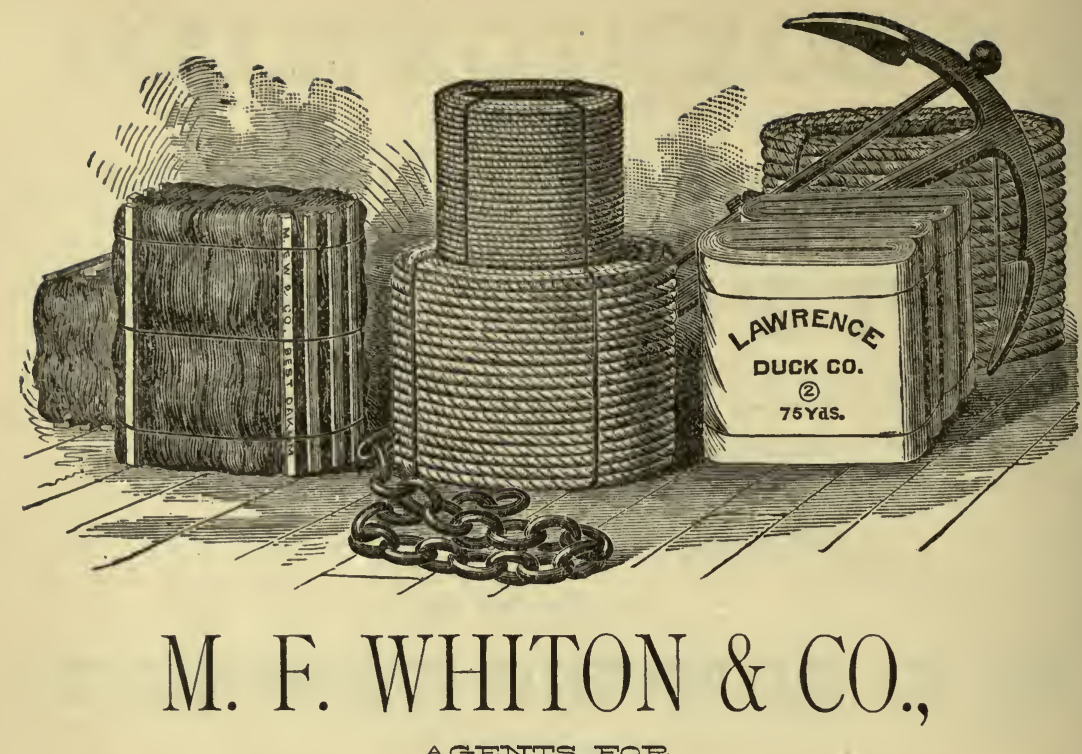

agamers zoom

\section{HINGHAM CORDAGE COMP'Y $-A$ SrD -}

\section{LAWRENCE MILLS COTTON DUCK.}

DEATIES INT

Wire Rope, Chains, Anchors, Bolt Rope, Oakum, Bunting, \&C. Cables a Specialty. 31 \& 33 COMIMIEFOIAI ST., DAVID WIIITON. M. F. WIIITOA. - $\quad$ BOSTOI. The Fishermen's Memorial \& Record Book, A COMPANION VOLUme To "THE FISHERMEN'S OWN BOOK,"

Gives you interesting facts relative to the fisheries. How fish are caught, and where they are caught, olden time and modern time fishing, OFF HAND SKETCHES, BIG TKIPS, STATISTICS OF The Fisheries, TAles of Narrow Escapes, Fearful Gales, Maritine Poetry, and other matters of interest concerning this important industry. Very handsomely illustrated with original engravings. Price $\$ 1.00$ in Paper Covers; $\$ 1.50$ finely bound in Cloth. Sent anywhere on receipt of price. Agents wanted to whom exclusive territory will be given. Liberal commissions. Write for particulars.

PROCTER BROS., Publishers, Advertiser Office, Gloucester, Mass. 
WM. R. CALL, House and Sign Painter Graining, Paper Hanging, Kalsomining, Whitewashing, \&c. ALSO DEALER IN

Room Paper, Borders and Curtain Goods,

42 Washington Street, Corner of Granite, GLOUCESTER, MHSS.
GRIFFIN, COOK \& C0., PAINTING, GRAINING, Coloring, Glazing, Paper Hanging.

House and Vessel work promptly attended to.

SASHES and BLINDS constantly on hand. Sign Painting and Decorating a Specialty . 257 Main St., Glougester. Thaddeus Griffin, H. A. Cook, E. L. Cook.

\section{H. L. FEARING \& CO.,}

AGENTS OF

New Bedford Cordage Company,
Warpington Wire Rope Works

OF LIVERPOOL, England.

Proprietors of STANDARD CHAIN CABLE WORKs,

91 \& 93 Commercial Street, and 33 Mercantile Street, BOSTON.

GEO. E. HALL,

SIGN AND ORNAMENTAL

PAINTEE.

Signs and Show Cards of all descriptions, Gilding, Wayside Advertising, Orna-

menting, and Furniture Painting done with neatness, cheapness and dispatch.

Cor. Ohestnut \& Main Sts., over Perry's Picture Store,

Glorzcester, - Mrass. ALL ORDERS RECEIVE PROMPT ATTENTION AT SHOP, ENTRANCE ON CHESTNUT ST.

JOHN S. CARTER, - DEALER IN -

\section{Beef.Pork, Mutton,}

HAM, POULTRY,

Vegetables, Butter, Cheese, Lard, Canned Goods, \&c.,

A few doors east of Atlantic House,
Joseph C. Shepherd, - DEALER IN -

\section{BEEF, PORK, MUTTON,}

Ham, Poultry, Vegetables, \&c.

BUTTER, CHEESE, LARD, EGGS, \&c.

Nos. 2 and 4 Main Street,

GLOUCESTER, MASS.

\section{JAS. CUNNINGHAM,} HOISE, SHIP \& SIGI PAINTER, DEAIIEZ INT

PAINTS, OILS, PURE COPPER PAINT GLASS AND PUTTY.

Special attention paid to GRAINING in all colors.

Orders for Paper Hanging, Whitewashing. Kalsomining and Glazing promptly attended to.

SHOP AT CITY LANDING, COMMERCIAL ST. GLOUGESTER, = = MASS. 


\section{ACHIM JOHNSON,}

-

\section{JOB JOHINSON \& SON,}

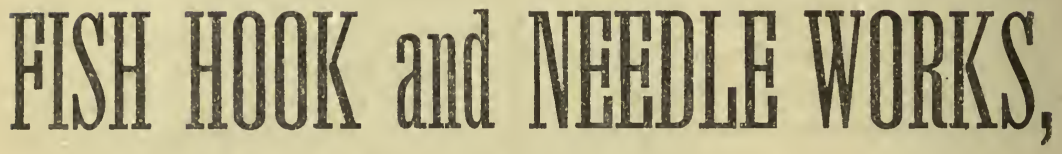

Cor. Myrtle and Bedford Aves, Brcoklyn, N. Y.

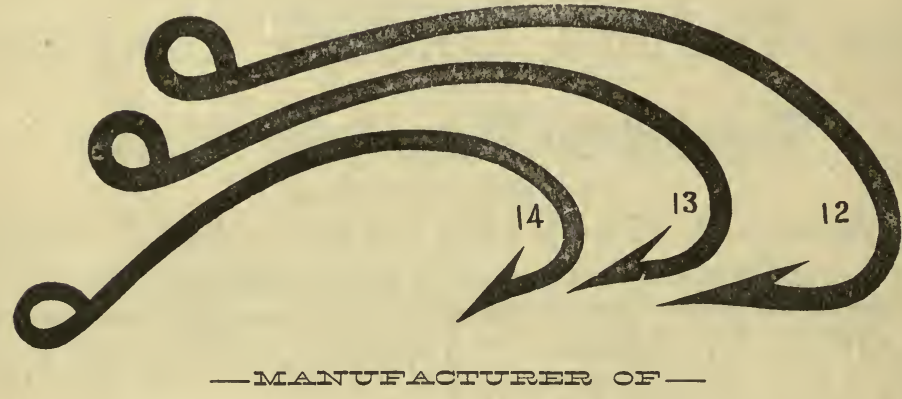

Best Cast Steel Wire, General Hardware, A.TI

Different Kinds of Patent, and all other descriptions of Fish Hooks, Sail Needles, Pack and Bag Needles, Mattress Needles,

Upholsterers' Needles, Surgeons' Needles, Spaying

Needles, Scarf Needles, Dissecting Needles, Dissecting Hooks, Plain and Swiveled Sail

Hooks, Sailors' \& S'ail-Makers' Palms.

Straight Rod or Tortional Door Springs. Automatic Gate Hardware, Burglar Proof Blind and Shutter Fastenings, The Universal Clothes

Line Holder, and all descriptions of Steel Wire Goods, Machinery, Springs, etc., etc.

N. B.-Particular Attention paid to Tempering and Finishing all kinds of Steel Wire Goods. 


\section{AOFIIMI JOFINTSOITS}

GREAT AMERICAN AUTOMATIC

\section{GATE HARDWARE,}

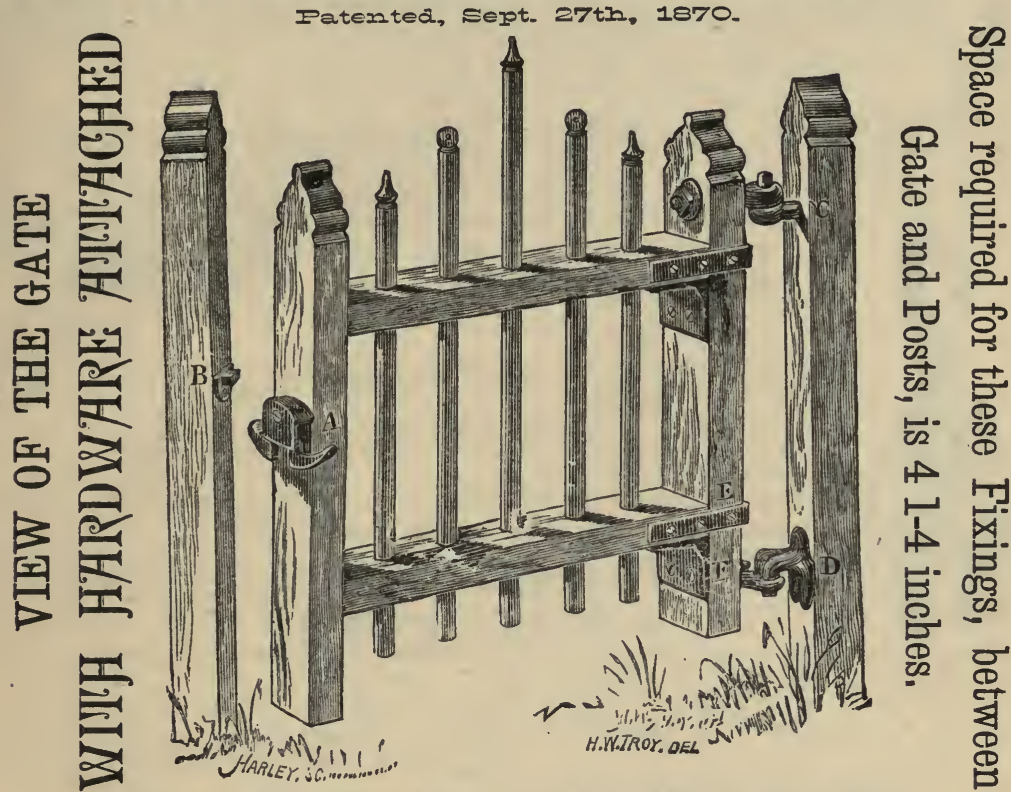

THIS AUTOMATIC GATE HARDWARE,

While marvelously ingenious in construction, is hardly possible to get out of repair. If the gate sags by frost or otherwise, the owner can adjust or correct it by screwing the upper Hinge into the Post. It admits the Gate to swing either or both ways - is sure to close the Gate-and the Latch sure to fasten itself. Is made for both Iron and Wood Gates.

To GATE MAKERS and GATE USERS, look at the article and judge for yourselves.

Their application to use is so simple, that a comparative Child may apply them.

The entire Hardware for the use of the Gate, embracing this Patent A UTOM ATIC GATE LATCH AND HINGES, are packed all together, in a strong paper box, with a circular attached thereto, explaining the whole matter of their application and use-then six of the above boxes are placed in a large box which is properly labeled and marked, and so sold to the Market, in boxes of half dozen full sets of Gate Hareware, with screws complete.

SOLD AT ALL HARDWARE STORES. 
We are prepared to furnish Cornet Players with instruments of the BEST FOREIGN and A MERICAN MANUFACTURE, which have veen pronounced by first-class artists to be the best and most perfect instruments manufactured.

This is a branch of the world-renowned house of OLIVER DITSON CO., where special bargains in MUSICAL INSTRUMENTS OF ALL KINDS and makes, are eoustant ly lieing offered. All our instruments are MADE ESPECIALLY FOR OUR TRADE, by skilled workmen, have been thoroughly tested, AND ARE WARRANTED as first-class in every respect. We always keep in stock a complete assortment of BAND AND ORCHES. TRAL INSTruneNTS, Guitars, Music Boxes, Violins, Banjos, Sheet Music and Music Books, and general Musical Merchandise. Send for Illustrated Catalogue to

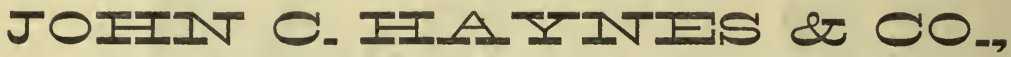

33 Oourt Street, (directly opposite Court House,) BOSTON, Mass.

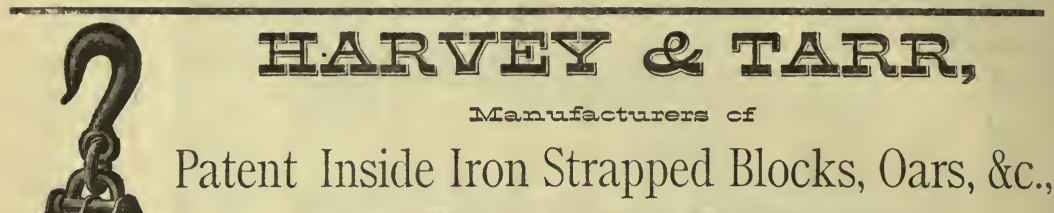
Dealers in WOODEN AND IRON SHIP CHANDLERY.

Steam Factory, Duncan Street, Between Custom House and Marine Railways.

Oarving and Gilding, and Repairing Blocks of all kinds

PEOMIPIIT ATIPNTDED TO.

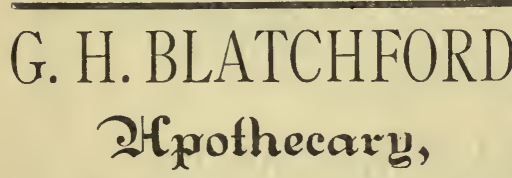

216 MAIN ST., CORNER CHESTNUT,

CLOUCESTER, MASS.

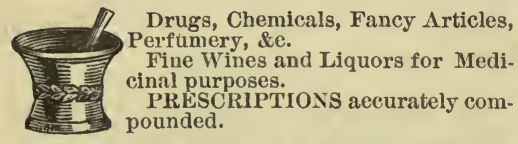

ADDISON WITHAM, FIGGER.

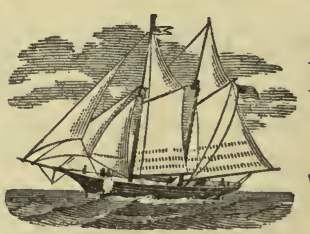

LOFT AT

BURNIIIAII BROS.

RAILWAY,

Water St., Gloucester,

$$
\text { MASS. }
$$

All Work Warranted.

Satisfaction Guaranteed.

\section{Howard's
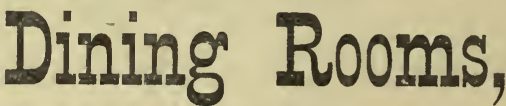 \\ No. 55 Main St., Gloucester, Mass.,}

Is the place for a good meal at any hour of the day or evening. The room over the Dining Establishment has been fitted up as
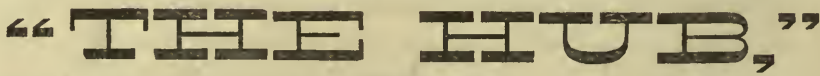

Where all are invited to spend a social hour. Fishermen are cordially invited to visit "THE HUB," and all will be welcome.

GEO. W. HOWARD, - - Proprietor. 
The Oldest llardware Store in the City! 76 MHIN ST!REET.

\section{CYRES ST0RY, DEAIEF INT}

\section{HA ADW A TRE,}

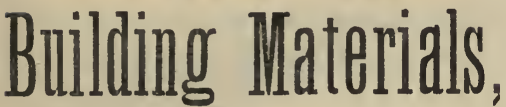

Dry and Tarred Sheathing Paper,

\section{Carpenters' Tools,}

Nails, Brushes, Cutlery, Rubber Mroulding, Garden and Farming Tools, etc.

76 Main Street,

Gloucester, - Mass.

GEO. Is. FEFRS,

SAIL MAKER

And Ship Chandler.

Hemp, Manila and Wire Cordage of all Kinds, constantly on hand.

Also FLAGS and FLIES.

Loft on Duncan Street, GLOUGESTEER, MASS,
GEORGE STLELE,

\section{Insurance Agent AND BROKER,}

Will take risks in the BOSTON MARINE INSURANCE COMPANY,

NORTH BRITISH and MERCANTILE, of London and Edinburgh,

CITY of LONDON FIRE INSURANCE COMPANY, of London, England, (Limited,)

METROPOLE INSURANCE COMPANY, of Paris,

And the DORCHESTER MUTUAL FIRE IN SURANCE COMPANY.

Office in Rooms of GLOUCESTER MUTUAL FISHING INSURANCE CO.,

Opp. the Post Office, Main Street,

Gloucester, - Mass.

All wishing Insurance of any kind are invited to call and learn rates.

\section{On Georges in a Storm!}

\section{This BEAUTIFUL PAINTING}

Has been Photographed, and coples may be obtained of Procter Brothers. It is a fine picture, showing two schooners riding at anchor and another jogging under a double-reefed foresail. Just suck a picture as everybody wants. Copyright secured according to law.

Send 75 cents to

PROCTER BROS., , , Gloucester, Mass., and receive by return mail one of the above pictures.

\section{RANGES and STOVES.}

Pallas Ieanges are all the Go! 100,000 ALREADY SOLD.

I have a large assortment of the best Ranges and Stoves in the Market, and think I can suit all in want of anything in this line. I have now in store,

Pallas, Welcome, Revere, Hudson, Lyra, Morden, Our Choice, Supreme, Concord, Temple and Active Ranges,

at prices ranging from $\$ 15$ to $\$ 60$; and a choice variety of PARLOR STOVES from $\$ 5$ to $\$ 35$. I have also on hand 25 Second-hand PARLOR CoOKING STOVEs, which will be sold very cheap. A full assortment of CROCKERY WARE selling cheap. Call and see my stock before purchasing elsewhere.

A. F. HARVEY, 59 Washington St., Gloucester. 

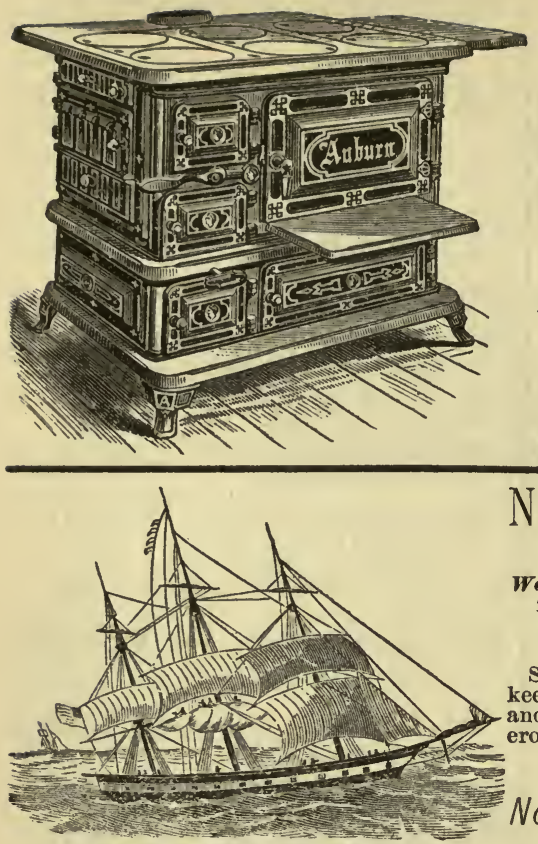

ChRESTEN nelson, Prop.

\section{THOMAS RENTON,}

-DEALER IN-

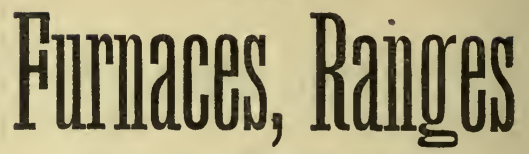

And STOVES.

A good assortment of TIN WARE, PUMPS, and SINKS of all sizes.

NEXT DOOR TO POST OFHCE, EAST GLOUCESTER.

Ac5 Low Prices, Cash Sales, First-class Goods

Nelson's Pat. Duck Preserver

(PAI. JAIT. 7, 1873.)

Warranted to protect Ships' Sails, Awnings, Tents, and all kinds of Hemp and Cotton Canvas from Mildew and Decay.

SAILS, \&c., saturated in this PRESERVER, will keep free from mildew and mould till worn out, and remain white as when new, as shown by numerous Testimonials, after a test of two years.

MANUFACTURED AT

No. 307 Main St., Gloucester, Mass. SEND FOR CIRCULAR.

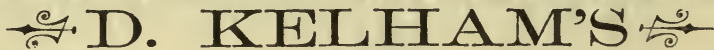

\section{Furniture}

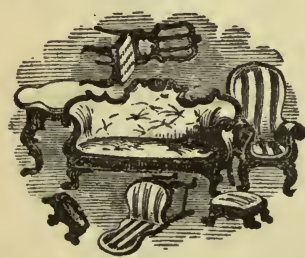

Nos, 139 FRIEND \& 46 CANAL STREETS, BO

You can always find a full assortment of the latest styles of Furniture at fair prices. When in Boston please give me a call.

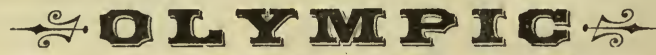

\section{BILLIARD PARLOR,}

FITZ E. MCINTOSH, - PROPRIETOR.

THE above Parlor is fitted up in a neat style, and parties wishing to play a
cosy game of Billiards are invited to eall. The best of order preserved, and
everything first-class, including Bailey's New Patent Cushion Tables. 'Tibbets' New Building,

96 Main street, - Gloucester, Mass. 


\section{Trusses \& Supporters,}

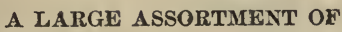

\section{Hard Rubber \& Leather Trusses,}

Made by the best manufacturers and of the best materials.

My experience for over twenty years in this line of business warrants me in garanteeing to give $A S$ PERFECT A FITTING TRUSS as can be procured in Boston or New York, and I am selling them at about ONE-HALF THE $P R I C E$ usually charged for such goods.

Price from $\$ 1.00$ to $\$ 6.00$, and a perfect fit warranted in every case. The money returned for every truss that is not satis. factory. Those needing goods of this kind will find it for their interest to give me a call. I also make a specialty of

Supporters, Belts, Elastic Stockings, Suspensory Bandages \& Rubber Goods.

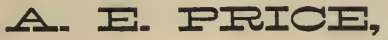

Cor. MAIN \& IIANCOCK Sts., Gloucester, Mass.

\section{JAMES DAVIS, JUSTICE of the PEACE, NOTARY PUBLIC,}

AUOTIOINEI, - AND -

CONVEYANCER.

AG-PROBATE BUSINESS ATTENDED TO. BERGENGREN'S BLOCK,

132 Main St., - Gloucester.

\section{F. DOEBLE,}

Kanufactures of and Deales in all kinds of

Domestic \& Imported CIGARS,

Tobacco, Pipes, dec.

Largest Stock, Lowest
Prices.

No. 230 MAIN STREET, GLOUCESTER, MASS.

\section{PHCENIX BILLIARD PARLOR}

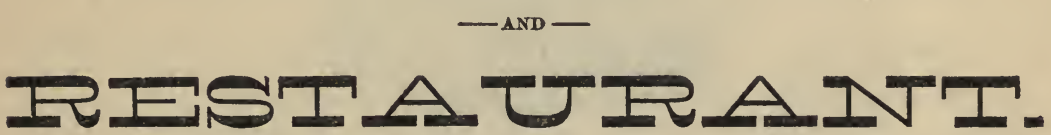

\section{ROBERT BROWN, Proprietor,}

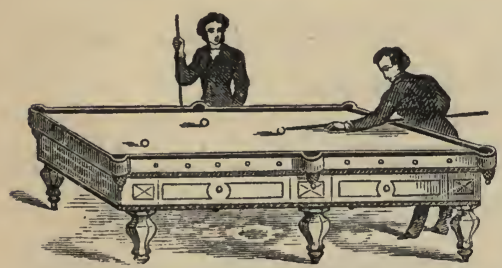

Takes pleasure in announcing that the above establishment, near the head of Duncan street, in the new brick building, is now open to the pab. lic, and is fitted up in the best style with all the modern convenlences, lighted with gas throughout, and fully equal to any in the country.

There are eight of Bailey's Patent Billiard Tables, four in the upper hall and four in the lower, with all the late Improvements, and persons wishing to enjoy a game of billiards in good company, and where courtesy and good order is maintained, will find this the place. Everything done for the pleasure and convenience of its patrons. In connection is a First-Class RESTAURANT, where anything desired on the Bill of Fare, which includes all the good things, may be obtained at short notice, cooked in excellent style, and served on either floor.

Fishermen and landsmen will find this a cozy retreat to while away an evening or any spare hours of the day at their disposal, in good company. Come in and inspect the premises. All will be welcome. 


\section{IM* HILTON,}

Teaming and Boarding Stable.
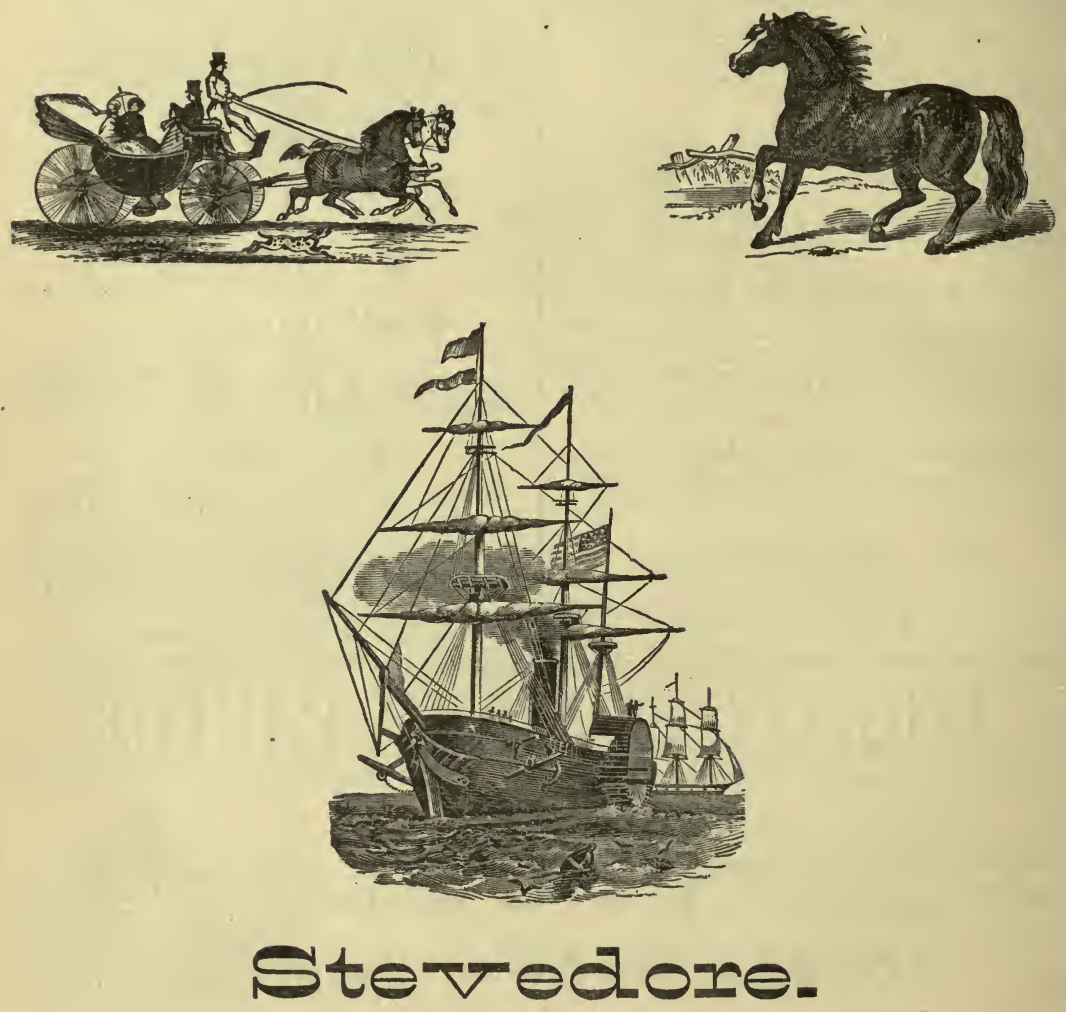

All kinds of Heavy and Light Trucking and Teaming PROMPTLY ATTENDED TOO,

Orders for Hauling Fish or Ballast entrusted to me will meet with prompt personal attention.

Vessels Discharged and Satisfaction Guaranteed.

$$
\text { OFFICES: }
$$

Rear 152 Main Street, and Main cor. of Pearce St.,

Gloucester, Mass. 


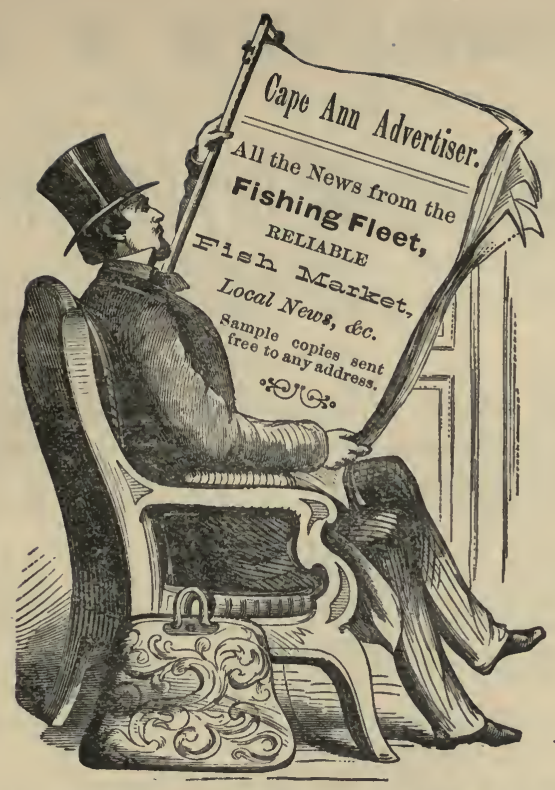

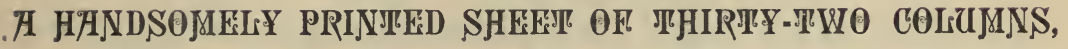

IUTIISIIED EVEIEI IEIDAYI MIOINTING.

Each issue has all the Local News of Cape $\Lambda n n$, together with all the Fishing Items, a reliable Fish Market, good Story and cholce Miscellaneous.Reading Matter, making it emphatically

\section{THE PEOPLE'S PAPER.}

\section{The Best Aldvertising Medium om the Cape.}

CIRCULATION, $\mathbf{3 , 8 0 0}$ COPIES. Terms, $\$ 2.65$ per year, which includes postage, strictly in advance. Sent to any part of the country on receipt of price. \$2.50 within Essex County.

Subscribe for it if you wish to perusc a Live Local Newspaper. Address

\section{PROCTER BROTHERS, And Padrorididors, Gloucester, Mass.}
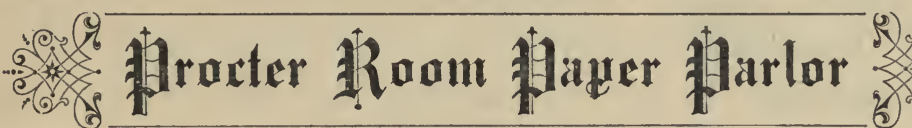
$8 \% \div 0$ $3 x+2$

"Old Corner," 110 Main Street, Gloucester,

tastefully fitted up, with ceiling and walls elegantly decorated, showing the modern style of art in Paper Hanging. This room is flled with the largest stock of

\section{Room Paper, Borders, Decorations, Win- dow Shades and Curtain Goods,}




\section{ANDREWS \& CO.,}

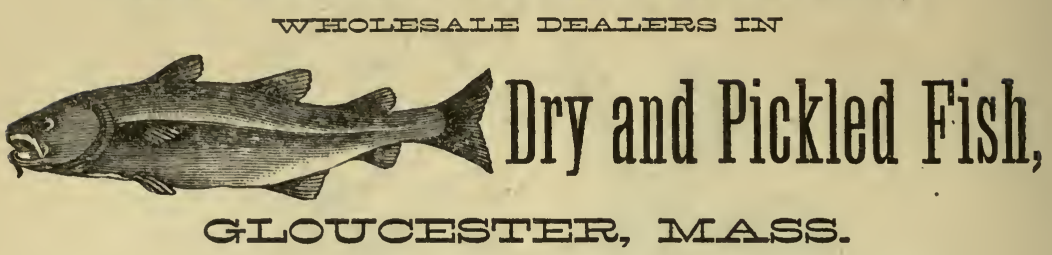

Boneless and Prepared Fish a Specialty

\begin{tabular}{|c|c|}
\hline 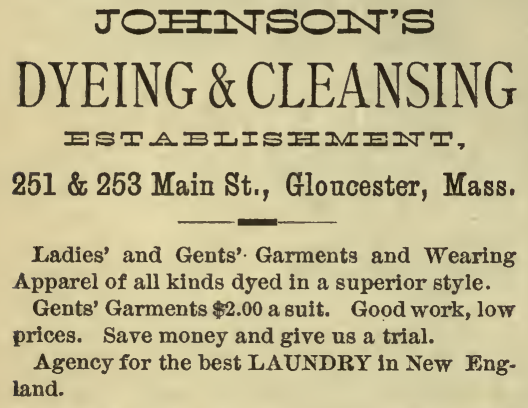 & $\begin{array}{l}\text { Horse shoeing, Carriage } \\
\text { Work and Jobbing } \\
\text { Promptly attended to. } \\
\text { SHOP } 78 \text { WESTERN AVENUE, } \\
\text { GLOUCESTER, MASS. }\end{array}$ \\
\hline
\end{tabular}

\section{TATURABIR BaOTES.}

\section{PROCTER BROTHERS, Gloucester, Mass.}

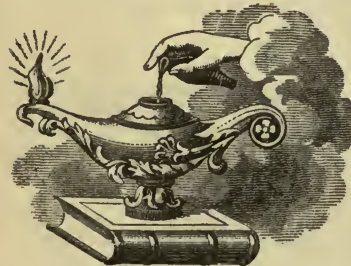

HISTORY OF GLOUCESTER. By Hon. John J. Babson, $\$ 10.00$.

GLOUCESTER DIRECTORY. \$2.00.

FISHERMEN'S OWN BOOK. Paper, $\$ 1.00$; Cloth, \$1.50.

FISHERMEN'S MEMORIAL AND RECORD BOOK. Paper, 50 cts. ; Cloth, $\$ 1.00$.

THE FISHERIES OF GLOUCESTER FROM

1623 TO 1876. Paper, 50 cts. ; Cloth, 75 cts.

FISHERMEN'S BALLADS, or,' Songs of the Sea. 50 cts.

NORA RAY, THE CHILD MEDIUM. Paper, 50 cts.

GEORGES' FISHING SCHOONER IN A STORM. Large Photograph ;

75 cts.

MAP OF GLOUCESTER AND CAPE ANN. 50 cts.

STEREOSCOPIC VIEWS OF THE ROMANTIC SCENERY OF CAPE ANN. 1000 subjects. $20 \mathrm{cts}$. each ; $\$ 2.00$ per doz. Send for Catalogue.

All the above sent by Mail, to any part of the World.

FRANCIS PROCTER.

GEORGE H. PROCTER. 


\section{AUSIINT B. BIEAT,}

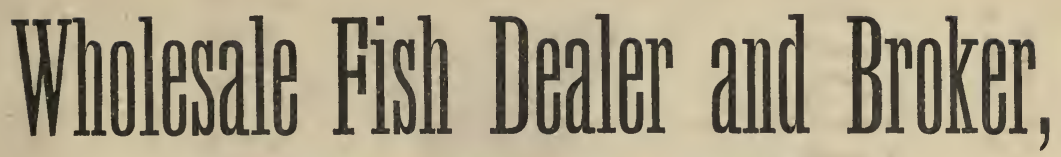

GIOUCESTER, MISS.

Office and Wharf, - Rogers Street.

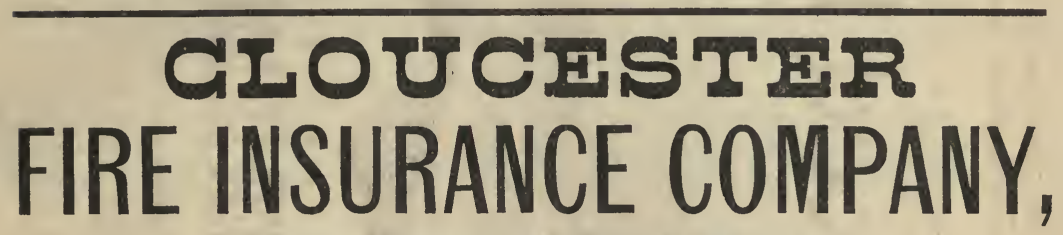

First National Bank Block,

OPP. POST OFFICE, - - MAIN ST,, GLOUCESTER.

Fire and Marine Risks effected at lowest market rates.

ROBERT R. FEARS, President.

JOHN CUNNINGHAM, Sec.

\section{CLARK \& PRESSON,}

PACKERS \& WHOLESALE DEALERS IN

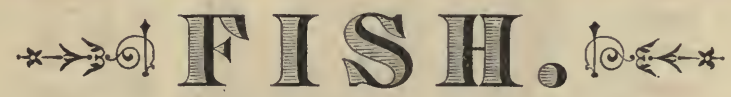

21 ROGERS STREET,

GIOUCESIER, - - MIASS.

WILLIAM H, CROSS,

Sailmaker and Ship Chandler,

Constantly on hand a full assortment of

CORDAGE USED IN THE FISHERIES

\section{- COMPRISIYG -}

Hoth's Best Russia Hemp Bolt

Rope for Purse Lines, Bunt-

ing, Flags, Flys, \&c., at

Tarr's Wharf, Rocky Neck, East Gloucester.
Moses Merlett, Rigger \& Mast Setter

Loft at Lemuel Friend's Wharf, Vrncent Point, Near Sam'l Lane \& Bro's.

Tarring Rigging and Planing Masts done at short notice.

Second-hand Rigging and Red Stock of all kinds. Stock furnished if required.

Good warranted work and low prices. 


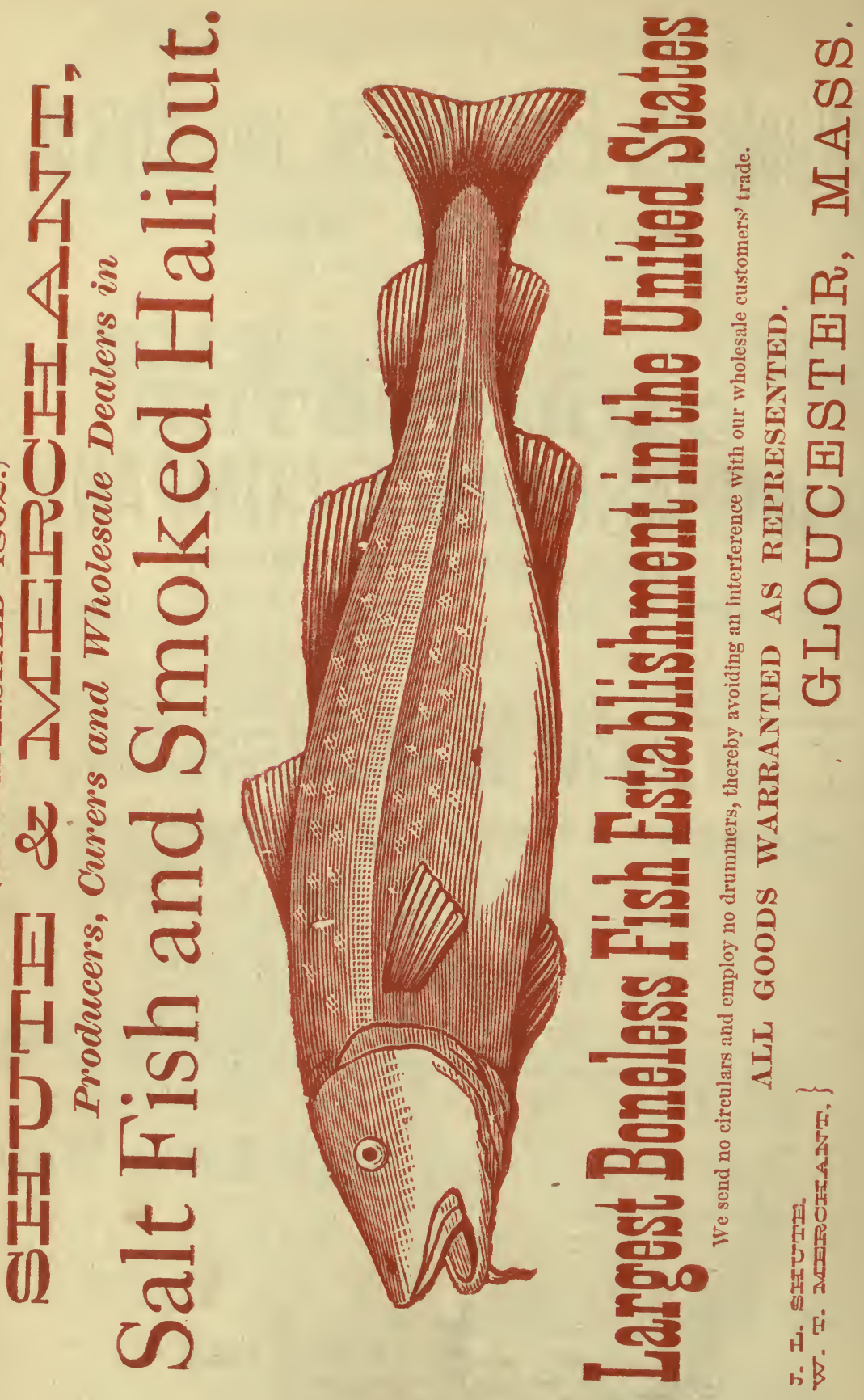


EWHIS II. HEROHANI,

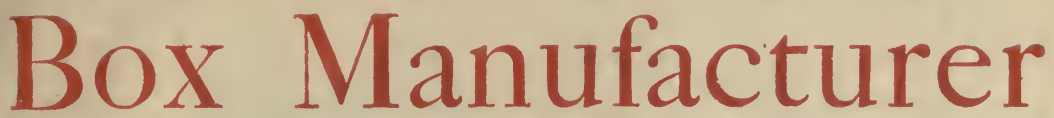

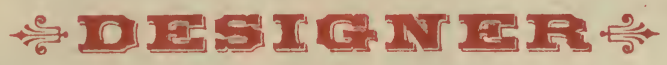
$\longrightarrow$ AND

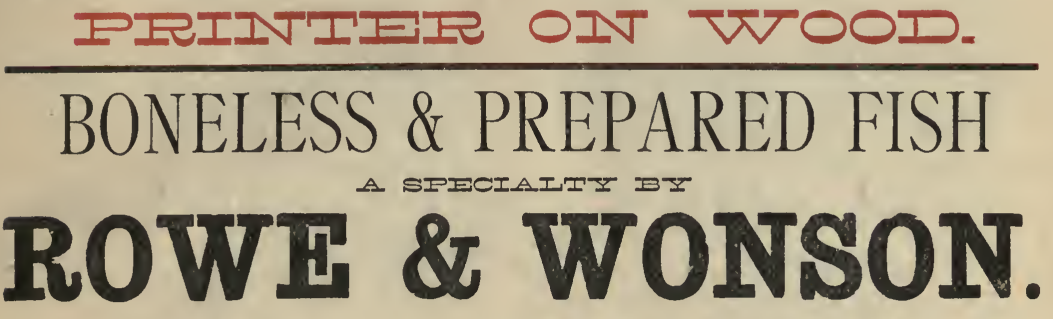

Also, Dealers in and Curers of Dry and Pickled Fish. Every variety of Fish handled
in their season.

WALTER L. ROWE.

ERNEST C. WONSON.

EAST GLOUCESTER, Mass.
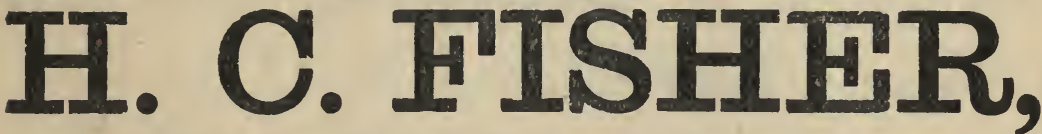

Commission Merchant in Codfish, Mackerel, Oil, \&C., 42 WATER ST., NEW YORZ.

E. L. ROWE, SAIIMAIERR AND DEATER IN

Duck and Cordage. Hoth's Best Russia Hemp Bolt Rope For PURSE LINES; also, BUNTING, FLAGS, and SIGNALS, for sale at

33 WHARF ST., foot of Water.

AG-TENTS, AWNINGS, WAGON COVERS and WINDOW SHADES made to order.

\section{GEO. MERCHANT, Jr.,}

Net \& Seine Repairer,

SHUTE \& MERCHANT'S WHARF,

GLOUCESTER, Mass.

Nets, Seines, Twine and Fishing Nettings of every description, furnished to order.

Parties wishing Nets and Seines will please give the longest notice possibie.

Agent for \#. \$. Willard's Mackerel Pockot.

Nets stored in winter FREE OF CHARGE.
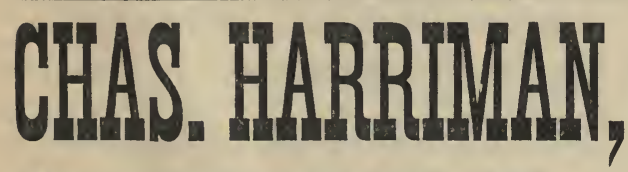

New York Office, 165 MAIDEN LANE.
WHOLESALE Fish Dealer, GLOUCESTER, Mass. 

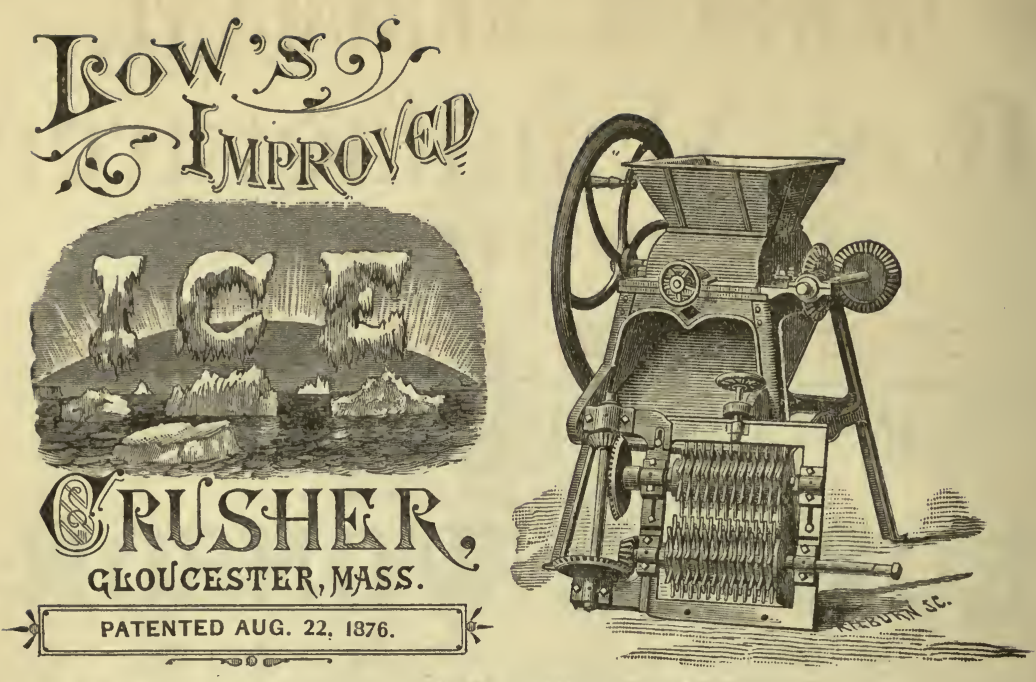

\section{Washington St. Bottling Works.}

JAMES H. JOYCE, Proprietor, 39 Washington Street, GLOUCESTER, Mass.

Manufacturer of SODA and MINERAL WATERS, GINGER ALE, TONIC BEER, \&C. Bottler of ALE, LAGER BEER, CIDER and PORTER.

\section{Fishermen's Ballads}

\section{And SONGS OF THE SEA.}

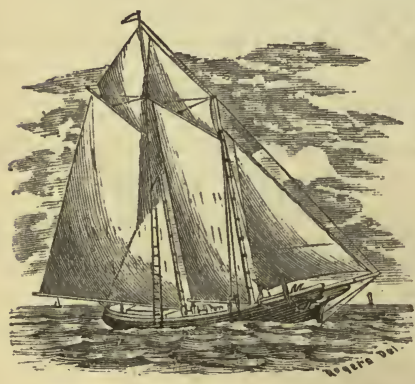

A book of 184 pages, containing choice Ballads and Sea Songs, many of which were written expressly for the book by the Fishermen themselves. It has the real salt water flavor all through, and is just the book to have on board the vessel or in a person's pocket, to while away the leisure hours.

\section{PRICE 50 CENTS.}

Very handsomely illustrated. For sale by the publishers,

PROCTER BROS., Gloucester, Mass. Mailed anywhere on receipt of price. Postage stamps taken. 


\section{E. C. WTIIEY,}

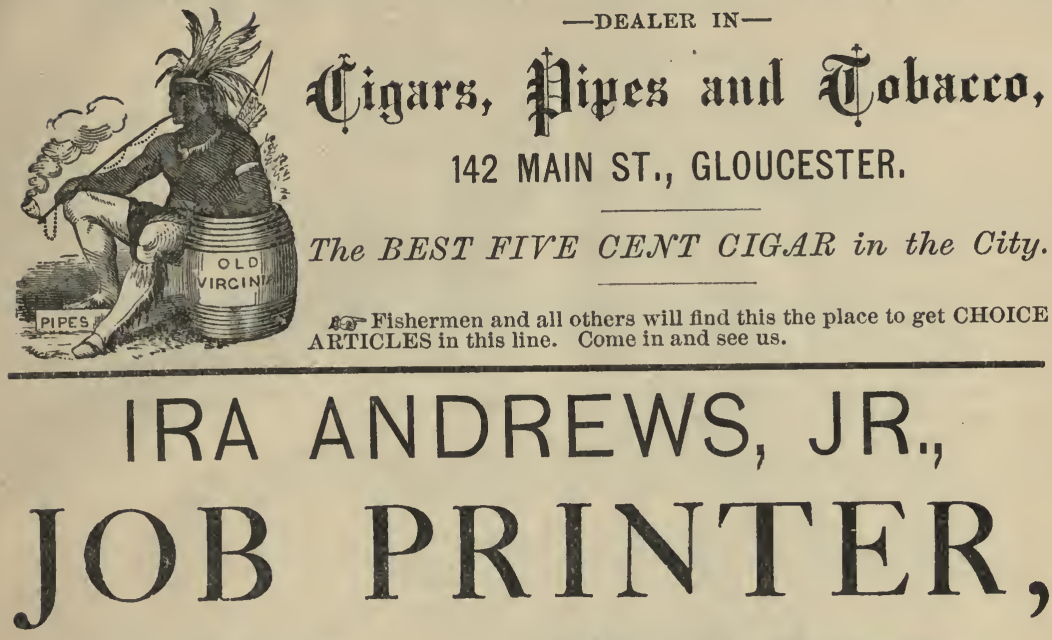

Tappan Block, - - 114 Main St., Gloucester.

CONTHEOTED WITII IEIIPIIOIVE.

\section{G. W. PLUMER, ShipBroker, \&c.,}

GLOUCESTER, MASS.

Also in Boston, 214 State St.

VESSELS of all descriptions Bought, Sold and Chartered.

AC- FISH Bought and Sold on Commission.
F. T. Hall \& Son,

\section{Boot\& Shoe Dealer's,}

282 Main St., Gloucester.

Constantly on hand a full assortment of FirstClass Goods at Low Cash Prices.

RUBBER BOOTS A SPECIALTY.

\section{House Lots on Bellevue Heights.}

Young men or any one desiring to make a safe investment, cannot do better than to look over the

\section{CMOICE MOUSE IOTS}

delightfully situated on Bellevue, Beacon, Conant, Blynman and Centennial avenues, and thus secure good homesteads. Best location, best neighborhood, best water view in the city; within ten minutes walk of the post office, schools, churches, ete.

Interview the subscribers, and they will tell you all about them.

PROCTER BROTHERS. 


\section{L. WETHERELL, Druggist \& Chemist.}

ESIAAIIISITED INT 1860.

The most Reliable PHARMACIST in Essex County. Employs none but Efficient and Courteous Assistants.

All Pharmaceutical Preparations manufactured from the best materials, and in strict accordance with the revised Pharmacopocias, and standard works. Family Medicines and compounding Physicians' Prescriptions a specialty. One of the largest Proprietary Manufacturers in the United States of America. So, if you are desirous of using Proprietary Medicines, be sure to use none but are put up by, and have the signature of M. L. WETHERELL to the same.

Use WETHERELL'S WINE OF CALISAYA BARK to strengthen and tone up the system.

Use WETHERELL'S SARSAPARILLA AND IRON to purify and enrich the blood.

Use WETHERELL'S.BUCHU AND HOPS for all diseases of the kidneys and urinary organs in male or female.

Use WETHERELL'S ROSE LOTION for all cutaneous diseases, and all eruptions whatever that require a soothing and pleasant wash.

Use WETHERELL'S DANDELION AND MANDRAKE LIVER PILLS for chronic affections of the liver and bowels, constipation in all its forms, headache, giddiness, dyspepsia, biliousness, \&c. Be sure to buy a bottle of these pills, and you will use no other. None genuine unless signed M. I. Wetherell.

If you want the genuine BED-BUG POWDER, be sure to procure it at M. I. Wetherell's, 178 Main St., as all other kinds are worthless imitations of the genuine article, which is imported by M. L. Wetherell from Trleste, Austria. Every bottle warranted.

Use WETHERELL'S EUREKA LINIMENT for rheumatics, sprains, bruises, fish bone sores, colds, colic pains, or eramps in the stomach, and for pingents (caused generally by the oil jacket chafing the wrist), etc. It is the strongest liniment made.

Try WETHERELL'S EXTRACT JAMAICA GINGER ROOT, mannfactured from the pure Jamaica Ginger Root. It is one-third stronger than any other ginger in the market. It is guaranteed to contain all the medicinal qualities of that drug in a concentrated form. Be sure that you procure none but M. L. Wetherell's, and take no other.

WETHERELL'S EXTRACT OF WITCH HAZEL, or HAMAMELIS, is the people's remedy or balm for every wound. It is a most eflicacious remedy for catarrh or cold in the head, burns, bruises, piles, sore eyes, all humors of the scalp, and wounds of every description.

The best plaster ever offered to the public is WETHERELL'S BUCHU and HOPS STRENGTH. ENING PLASTER, manufactured by M. L. Wetherell, at 178 Main St. Every plaster is made of the best materials, selected by him, is freshly made, and thus none of the virtues of the ingredients are lost. Every plaster contains the valuable medicinal qualities of Buchu and Hops, carefully combined, so that for a lame back, weak back, pain in the side, or pain across the kidneys, in the loins, across the chest, weak kidneys, contusions, bruises, etc., and as a general strengthening plaster, it has no equal. Use Wetherell's Buchu and Hops Strengthenlng Plasters, and be convinced they are the best plaster in the market.

Use WETHERELL'S TOOTHACHE DROPS. Cure in one minute. Try them.

Use WETHERELL'S PURE COD LIVER OIL, with PHOSPHATE OF LIME.

Use WETHERELL'S COLD.PRESSED COD LIVER OIL. This oil is made from fresh, healthy livers, and is guarantecd to be the best in the market.

Use WETHEREIL'S HORSE POWDERS for horse ail, hide bound, heaves, bots, etc.

Try WETHERELL'S WINE OF BEEF AND IRON, prepared from fresh beef, lron and sherry wine. It is carefully prepared, and for children, delicate persons, nervous and fastidious patients, it will be found very estimable.

Use WETHERELL'S COMPOUND SYRUP OF HYPOPHOSPHITES, made from the formula of Dr. Churchill, of Paris, for the prevention and cure of consumption.

Use WETHERELL'S SALVE for gurry sores, salt rheum, burns, ringworms and old sores.

Try IVETHERELL'S CHLORATE POTASSA LOZENGES for Diphtheria, Croup, Coughs, Colds and Hoarseness.

Try IVETHERELL'S ROLL SALVE for corns, cuts, cracked hands and gurry sores.

WETHERELL'S FLAXSEED COUGI SYRUP is the best for coughs, colds on the lungs, bronchitis, hoarseness and spitting of blood.

WETHERELL'S NEW WHITE ROSE COLOGNE-superb, fragrant and lasting. As a toilet article it has no superior.

Use WETHERELL'S CELEBRATED EYE WATER, for the relief of inflamed and sore eyes.

Use WETHERELL'S HOOF OINTMENT for scratches, thrush, quarter cracks, hard and brittle hoofs.

Use WETHERELL'S COMPOUND SYRUP OF BLACKBERRY ROOT, a sure cure for cholera morbus, dyscntery, diarrhœa, colic, cramps, and summer complaints of children. This has been found to be a very bencficial medicine. A large stock constantly on hand.

Try WETHERELL'S CAMPHORATED SAPONACEOUS DENTRIFICE for beautifying the tceth and cleansing the guins. It is a very pleasant dentrifice, entirely harmless to the teeth, in. stantly rendering them pearl white and glassy smooth. 


\section{$+x$}

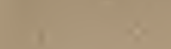

1

$n^{2}+x^{2}$

+ $x$

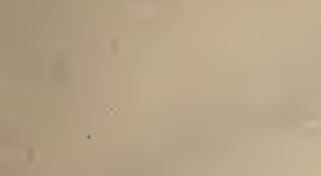

$n^{2}$

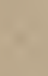

$+$

$-$

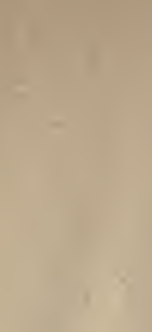

I

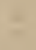

$$
1
$$
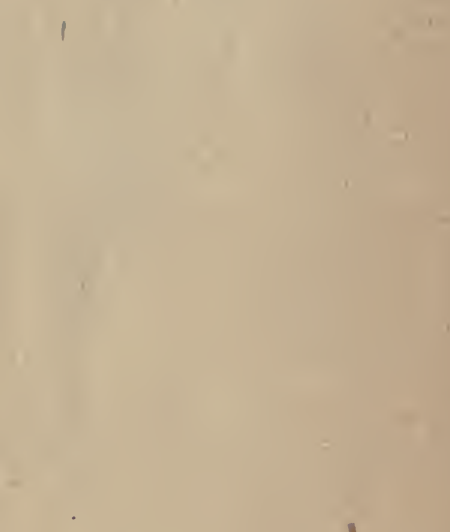

$\sqrt{2}$<smiles>CC</smiles>

8

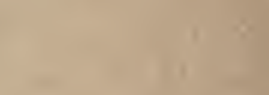

10

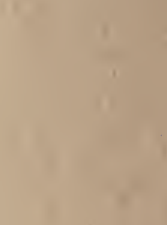

$-$

F 


\section{GENERAL LIBRARY}

UNIVERSITY OF CALIFORNIA-BERKELEY

RETURN TO DESK FROM WHICH BORROWED

This book is due on the last date stamped below, or on the date to which renewed.

Renewed books are subject to immediate recall.

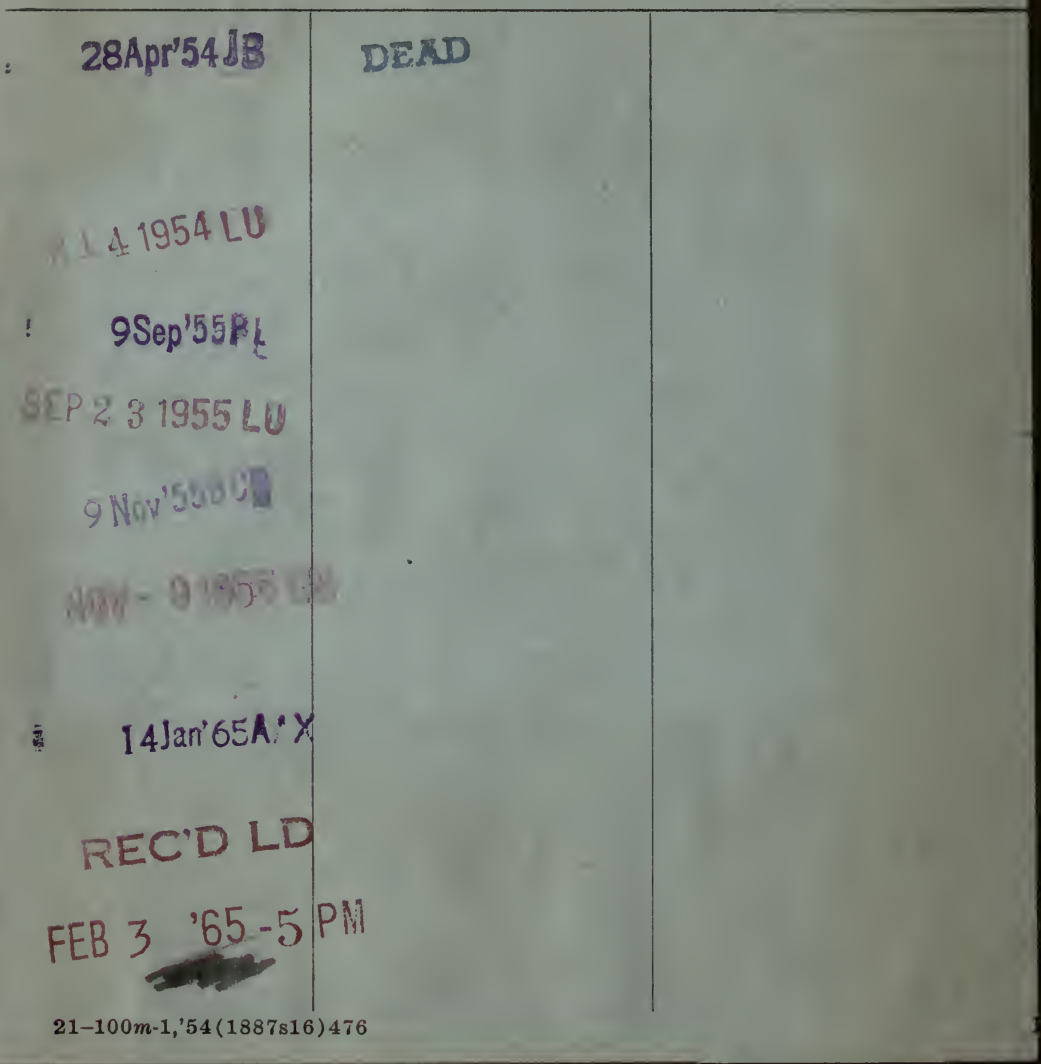




\section{LIBRARY USE}

RETURN TO DESK FROM WHICH BORROWED

\section{LOAN DEPT.}

THIS BOOK IS DUE BEFORE CLOSING TIME ON LAST DATE STAMPED BELOW

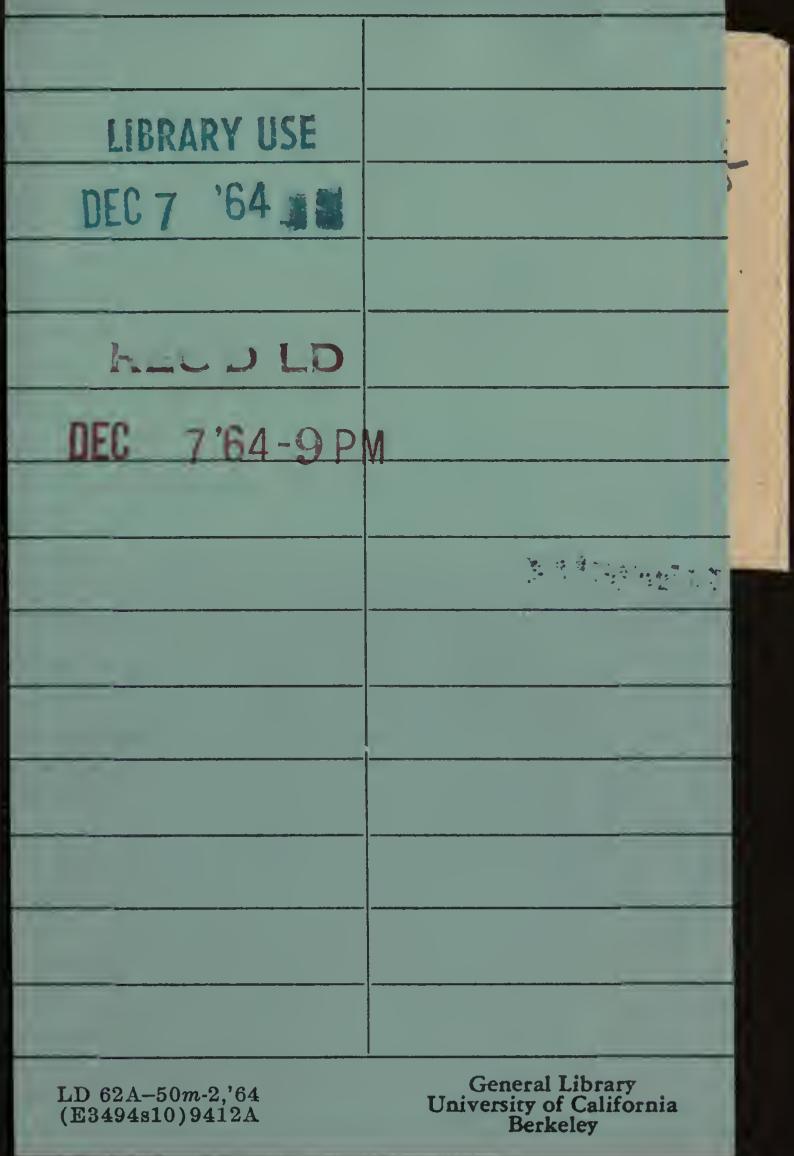




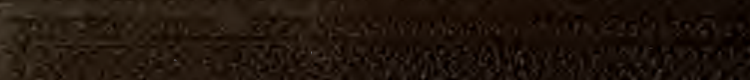

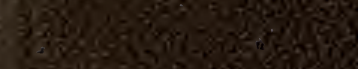

Q7.

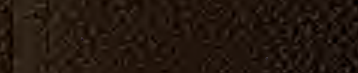

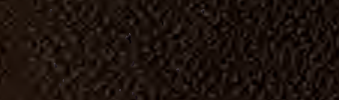

Q6.3.5.

wis

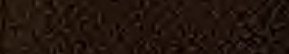

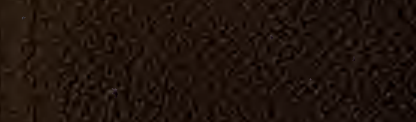

toris 